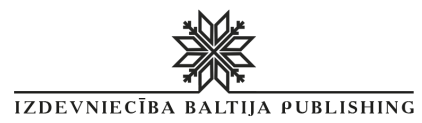

\title{
RELEVANT ISSUES \\ OF DEVELOPMENT AND MODERNIZATION OF THE MODERN SCIENCE: \\ THE EXPERIENCE OF COUNTRIES \\ OF EASTERN EUROPE \\ AND PROSPECTS OF UKRAINE
}

Monograph

Riga, Latvia

2018 
UDC 001(4-11)(082)

Re 513

Title: Relevant issues of development and modernization of the modern science: the experience of countries of Eastern Europe and prospects of Ukraine

Subtitle: Monograph

Scientific editor and project director: Anita Jankovska

Authors: Bilushchak Tetiana, Myna Zhanna, Bondarchuk Viktor, Vasilenko Tetyana, Milostiviy Roman, Kalinichenko Olena, Vilchynska Lydmila, Horodyska Olesia, Hbur Zoriana, Gotsulyak Volodymyr, Levchenko Andrey, Gapchenko Elena, Gulyaeva Tatiana, Kvasnikov Volodymyr, Dudnik Andriy, Bondarenko Yuri, Koltun Viktoriia, Kulyk Maksym, Shokalo Natalia, Kurilyak Valentina, Himicheva Anna, Lapkina Inna, Malaksiano Mykola, Moiseienko Tetiana, Torianyk Inna, Kazmirchuk Viktor, Morozik Alina, Vasylenko Lyudmila, Pylypenko Lilia, Bilan Serhii, Ruda Mariya, Taras Ulyana, Savchenko Larysa, Savchenko Karyna, Sorokina Svetlana, Akmen Vyktorya, Trembus Iryna, Halysh Vita, Foka Mariia, Shevchuk Valentin, Fedorenko Mikhail

Publisher: SIA "Izdevnieciba "Baltija Publishing", Valdeku iela 62-156, Riga, LV-1058

Available from: http://www.baltijapublishing.lv/index.php/all-science

Year of issue: 2018

All rights reserved. No part of this book may be reprinted or reproduced or utilized in any form or by any electronic, mechanical, or other means, now known or hereafter invented, including photocopying and recording, or in any information storage or retrieval system, without permission in writing from the publisher and autor.

Relevant issues of development and modernization of the modern science: the experience of countries of Eastern Europe and prospects of Ukraine: monograph / edited by authors. - Riga, Latvia : "Baltija Publishing", 2018. - 434 p.

ISBN: 978-9934-571-26-8

DOI: https://doi.org/10.30525/978-9934-571-26-8

The monograph studies issues of development and modernization of contemporary science, taking into account the experience of countries of Eastern Europe and prospects of Ukraine. General issues of political sciences, public administration, history, culturology, biological, chemical, engineering, agricultural sciences, and so on, are considered. The publication is designed for scientists, lecturers, postgraduate students, students, as well as for the general reader.

C) Publishing House "Baltija Publishing", 2018

(C) Authors of the articles, 2018 


\section{Table of Contents}

Bilushchak Tetiana, Myna Zhanna

INNOVATION MANAGEMENT IN THE HIGHER EDUCATION SYSTEM WITH INTEGRATION OF ISO 9000 FAMILY OF INTERNATIONAL STANDARDS AND INTERNATIONAL STANDARDS IN THE FIELD OF ARCHIVAL ACTIVITY, RECORDS MANAGEMENT.

Bondarchuk Viktor

CREATIVE BIOGRAPHY IN THE COORDINATES OF THE HUMANITIES: HISTORIOGRAPHY AND RESEARCH METHODS.

Vasilenko Tetyana, Milostiviy Roman, Kalinichenko Olena

INFLUENCE OF HIGH TEMPERATURE ON DAIRY PRODUCTIVITY

OF UKRAINIAN SCHWYZ

Vilchynska Lydmila, Horodyska Olesia

BUCKWHEAT SELECTION IN SOUTH WESTERN

FOREST STEPPE CONDITIONS OF UKRAINE

Hbur Zoriana

HYBRID WAR AND ITS IMPACT ON ECONOMIC

SECURITY GOVERNMENT.

Gotsulyak Volodymyr, Levchenko Andrey, Gapchenko Elena

INTER-DIAGNOSTIC APPROACHES IN POST-ADVOCACY SCIENCE:

POSSIBILITIES OF SELF-REFLECTION IN POLITICAL DISCOURSE.

\section{Gulyaeva Tatiana}

STUDY OF THE INFLUENCE OF EXTERNAL PRESSURE AND SINTERING TEMPERATURE ON THE STRUCTURE AND PROPERTIES OF THE SYSTEM ND-FE-C,B

Kvasnikov Volodymyr, Dudnik Andriy, Bondarenko Yuri

RELEVANCE ANALYSIS OF MEASUREMENT MECHANICAL

QUANTITIES IN THE COMPOSITION OF THE NETWORK

"INTERNET OF THINGS" AND SYSTEMS OF PROFESSIONAL

COOPERATION DURING METROLOGICAL STUDIES

\section{Koltun Viktoriia}

COMPLEXITY AS THE IMMUNENTAL PROPERTIES

OF LOCAL SELF-GOVERNANCE PHENOMENON. 
Kulyk Maksym, Shokalo Natalia

IMPACT OF PLANT BIOMETRIC CHARACTERISTICS

ON SEED PRODUCTIVITY OF CASTOR-OIL PLANT

AND SWITCHGRASS DEPENDING UPON WEATHER CONDITIONS

OF THE VEGETATION PERIOD IN THE FOREST-STEPPE OF UKRAINE . . 182

Kurilyak Valentina, Himicheva Anna

STATISTICAL REASONING FOR THE APPLICATION

OF QUALIMETRY METHODS TO SPEED-LOAD MATERIALS.

Lapkina Inna, Malaksiano Mykola

OPTIMAL REPLACEMENT SCHEDULING FOR EQUIPMENT

TAKING INTO ACCOUNT THE UNSTABLE LOADING LEVEL

Moiseienko Tetiana, Torianyk Inna, Kazmirchuk Viktor

HOP-PLANT DRUG USING ON TREATMENT

OF THE COMPLICATE ACNE FORMS

Morozik Alina, Vasylenko Lyudmila

MODERNIZATION HOUSING TERRITORIES OF UKRAINE'S

MILITARY CITIES. BACKGROUND AND CONCEPT

Pylypenko Lilia, Bilan Serhii

NATIONAL LIBERATION MOVEMENT IN WESTERN UKRAINE

IN THE INTERWAR PERIOD (1918-1939).

Ruda Mariya, Taras Ulyana

THE CYBER PHYSICAL PRINCIPLE MANAGEMENT

OF CAPRICIOUSNESS OF LANDSCAPE COMPLEXES.

Savchenko Larysa, Savchenko Karyna

COMPREHENSIVE PEDAGOGICAL DIAGNOSIS

OF THE QUALITY OF THE TRAINING OF FUTURE TEACHERS.

Sorokina Svetlana, Akmen Vyktorya

ELABORATION OF THE METHOD OF OBTAINING THE PRODUCTS

FOR THE CULTIVATION OF FLOWER PRODUCTION

WITH ANTIMICROBIAL COVERING

Trembus Iryna, Halysh Vita

ORGANOSOLV PULPING OF WHEAT STRAW.

Foka Mariia

SUBTEXT OF A FICTIONAL WORK AS A LITERARY PROBLEM. 
Shevchuk Valentin, Fedorenko Mikhail

ORGANIZATIONAL STRUCTURE

OF THE CHURCH OF THE ADVISERS OF THE DAY

TO THE HISTORICAL RETROSPECTIVE. 



\section{INNOVATION MANAGEMENT IN THE HIGHER EDUCATION \\ SYSTEM WITH INTEGRATION OF ISO 9000 FAMILY \\ OF INTERNATIONAL STANDARDS AND INTERNATIONAL \\ STANDARDS IN THE FIELD OF ARCHIVAL ACTIVITY, RECORDS MANAGEMENT}

\section{Bilushchak Tetiana ${ }^{1}$ \\ Myna Zhanna ${ }^{2}$}

DOI: http://dx.doi.org/10.30525/978-9934-571-26-8_1

Abstract. A higher education institution, as a social institution, is responsible for the quality of educational services. Ukraine is on the path to reforming the educational sector. It is important to envisage fundamental changes not only in the structure and content of education, but also in improving the system of a higher educational institution management.

The purpose of this article is to show innovations in the education management system with the integration of ISO 9000 family of international standards and international standards in the field of archival activity, records management.

The methodological basis of the research form the principles of scientificity, systematicity and objectivity. The general scientific methods (of analysis, synthesis, comparative, systematization, generalization) have been used when writing the paper. The material has been presented according to the thematic principle. Comparative, typological and functional methods have been used for a comprehensive research of the topic.

The subject of the study is the introduction of innovative management in higher school on the basis of ISO 900 family of international standards and international standards in the field of archival activity, records management.

The paper stresses that we need to direct the activity of higher educational establishments in accordance with quality standards, to motivate the faculty staff to innovative professional activities, to apply up-to-date methods of educational management, to competently communicate with subjects

\footnotetext{
${ }^{1}$ Ph.D., Assistant Lecturer of Social Communication and Information Activities Department, Lviv Polytechnic National University, Ukraine

${ }^{2} \mathrm{Ph} . \mathrm{D}$., Senior Lecturer of Social Communication and Information Activities Department, Lviv Polytechnic National University, Ukraine

(C) Bilushchak Tetiana, Myna Zhanna
} 
and objects of management. The relevance of professional growth, skills and competencies of the manager, as well as skills to stimulate creative and search activities have been emphasized. Thus, the authors of the article suggest that innovation management in education is an art of management. The modern manager is, before everything else, an effective innovative leader with systemic fresh thinking on the issues of internal communication, has high human qualities, is able to carry out marketing research and forecast the development of events. It follows therefrom that in the process of innovation management with the integration of ISO 9000 family of international standards and international standards in the field of archival activity, records management, the higher education manager consistently and purposefully introduces new technologies for business career management, and thus provides for optimal and effective activity of higher education institution. The article shows that innovation management in education creates an edu-cational environment that functions efficiently and meets the current dictates of times, and is also attractive (and this is extremely important today) for the potential consumer of educational services. While proving their postulates, the authors of the paper, show that it is absolutely impossible to manage education today, if not all its components are considered - innovative methodological base, personnel, pedagogical management, finance, the process of studying through the interaction of disciplines, well-established document communication (since any process, means of information sharing, making managerial decisions is impossible without being recorded on paper or electronic media). It has been suggested to use the state standards to manage document processes the Lviv Polytechnic National University. These standards were modified on the basis of international ones, such as DSTU 4423-1:2005 "Information and documentation. Records management. Part 1: Key provisions (ISO 15489-1: 2001, MOD) and DSTU 4423-2:2005 "Information and documentation. Records management. Part 2: Guidelines (ISO/TR 15489-2:2001, MOD). Documentation management is considered in the international standard as a part of the quality management system based on the requirements of ISO 9001 (Quality Management System).

Thus, innovation management in the higher education system with integration of ISO 9000 family of standards and international standards in the field of archival activity, records management provides for the provision of qualitative content of educational programs and qualifications of 
the academic staff, effectiveness and efficiency of joint efforts of the staff, determination of incentives and development of the performance evaluation system, development of the personnel policy, personal responsibility, creation of conditions for fruitful work, effective use of resources, formation of records management on the basis of standards, creation of an efficient information retrieval archival system.

\section{Introduction}

Relevance of the topic. The established methods that provide high quality of studies require a thorough analysis and review today. The essence and methods of modern higher education should contribute, first of all, to the disclosure of creative potential of an individual. The strategy for the development of higher education should become the impetus for Ukraine's economic growth. These goals can only be realized, of course, if advanced information technologies are implemented.

A graduate must be competitive in the globalized labor market. Therefore, education should be innovative. The graduate must be ready to "challenges of time" and be free to make decisions in a changing environment of various factors, using knowledge and skills he/she gained, quickly adapt to scientific and technical progress. Therefore, the quality of education in a broad sense has to be decisive and provide the necessary level of training of specialists, capable of effective professional activities. What is more, we should not forget that higher education will be of higher quality and more perfect, and will contribute to personal development in the humanistic approach. This is extremely important. Ethical principles, and actually environmental ones, should be of top priority.

A higher education institution, using a variety of organizational, methodological, and technological factors, must have an effective management system of future specialists training. M.M. Levshyn, S.A. Svizhevska emphasize that "One of the significant obstacles to wide introduction of quality management systems in higher education institutions of Ukraine is the lack of theoretical and practical developments in this area. Consequently, unlike foreign practice, where the introduction of quality management systems at universities is quite common, only some universities in Ukraine begin addressing this issue" [6, p. 50]. Hence, therefrom follows the urgency of creating innovative foundations for the development of quality management systems of higher education institutions based on the prin- 
ciples of general quality management and the requirements of international standards of ISO 9000 family.

The purpose of the article is to analyze the innovations of educational man-agement and strengthen the competitive positions in the European educational market through the integration of international standards of innovation management, records management and in the field of archival activity.

Tasks required to achieve the goal: to conduct an analytical review of scien-tific papers describing the materials of application of ISO 9000 family of international standards; to show the importance and expediency of innovations in the education management system with the integration of international standards of ISO 9000 family and international standards in the field of archival activity, records management, to analyze ISO 9000 family of international standards and international standards in the field of archival activity, records management to make suggestions for improvement of functioning of the Lviv Polytechnic National University; to determine the expediency and make suggestions based on the standards on automation of the archival unit operation and records management at the Lviv Polytechnic National University.

Research methods. The methodological basis of the research form the principles of scientificity, systematicity and objectivity. The general scientific methods (of analysis, synthesis, comparative, systematization, generalization) have been used while writing the paper. The material has been presented according to the thematic principle. Comparative, typological and functional methods have been used for a comprehensive research of the topic.

The theoretical and practical results of implementing the standards of records management and in the field of archival activity have been studied using the methods of analysis and synthesis.

The method of analysis has been used for a detailed study of standards applied in records management and in the field of archival activity, which made it possible, in particular, to study scientific viewpoints on the need for implementation. The method of synthesis made it possible to distinguish the types and the system of standards of records management and in the field of archival activity.

Analysis of sources. In addition to the aforementioned authors, the following domestic scientists deal with the issue of creating theoretical, meth- 
odological, regulatory and informational principles for the development of quality management systems of higher education institutions on the basis of principles of general quality management and requirements of international ISO 9000:2000 standards: T. Finikov, S. Laptiev, L. Vitkin, S. Piddubna, H. Khimicheva, K. Metashkin, O. Volkov, M. Shapoval. Thus, L. Vitkin, S. Laptiev, T. Finikov, S. Piddubna considered the main principles and approaches of modern quality management in the manual "Development of Quality Management System of Higher Education Institutions". The recommendations for the development of implementation and support of the quality management system in higher education institutions have been provided. A number of innovations in the field of quality of higher education have been suggested.

The issues of standardization development in the field of archival activity and records management are the subject of analysis of many scientists, both Ukrainian and foreign ones. In the publications of such Ukrainian scholars as I. Antonenko, V. Bezdrabko, H. Bespianska, L. Greenberg, V. Dobrovolska, L. Drahomirova, O. Zahoretska, L. Kyseliova, M. Komova, S. Lytvynska, P. Marchenko, I. Matiash, O. Tur, S. Kharchenko, N. Khrystova, A. Shurubura, et al., a wide range of issues related to the creation and functioning of standards in this area have been raised. However, there are not enough generalizing works today elaborating on the issues of introduction of innovation management in the system of higher education institutions with the integration of ISO 9000 international standards and the use of standards with the help of automation of the archival unit operation and records management in higher education institutions taking into account its specificity.

\section{The main tasks of innovation management in the system of higher education}

Analyzing innovation management in the system of domestic higher education using ISO international quality standards, we cannot but mention the principles of Edward Deming, which are and remain relevant due to their universality. By following these principles, one firstly needs to understand that awareness of the goals and their successful attaining is important. You need a clear action plan and a developed action strategy to achieve the goals. The main means to achieve the goals and the key function of management should be the quality management in higher education. Employees of higher education institutions need to keep up with the times and accept 
challenges, first of all, the challenges of quality improvement. Let us pay the attention to the third Deming's principle - the quality audit since it is too important. And here it is not about looking for drawbacks in work, but understanding the audit as being aimed at improving the processes in educational activities and search for the right decisions. All work should be aimed at ensuring initial quality, and this principle must be followed at all stages of work. At the same time, it is necessary to continuously improve your pedagogical and scientific excellence.

Today, the competition for quantitative indicators in scientific and pedagogical activity is a big problem. There should be effective competition instead, aimed at quality, but not quantitative indicators. At the same time, experiments, innovative ideas, creative approaches with every possible support of leadership should be supported in every possible way. The managers' task is to develop methods for improving quality. It is important to develop educational programs, programs of retraining and advanced training, attracting leading specialists.

The task of managers is to develop methods for improving quality. Problems should grow into tasks, creative solutions, quality changes in education should be welcomed, break the innovative level of development. Consultations and organizational assistance in searching for and making tricky decisions should influence the improvement of quality of educational process. What is important is the ability to find compromise solutions, prompt resolution of all existing problems, analytical forecasting; feedback; promising outlook; attention to personnel; legal priority and legality; financial and economic rationality. The theoretical understanding and practical application of the latest achievements of international management (up-to-date principles, methods, techniques, strategies, structures, controlling mechanism at the level of international standards) is extremely important because it will facilitate rapid accession into the global economic community as an equal partner.

The experience of introducing QMS in higher education institutions points to its advantages, namely:

- improving labor efficiency;

- cost optimization;

- improving the quality of training of future specialists;

- foreign cooperation, participation in tenders for conducting research work; 
- certification and recognition procedure in the domestic and foreign markets.

By analyzing the content of DSTU ISO 9001:2000 [4] standard in accordance with its application at universities, the authors of the manual "Development of Quality Management System of Higher Education Institutions" [3, p. 179] suggest the following model of QMS of the higher education institution, which serves as a guideline (fig. 1).

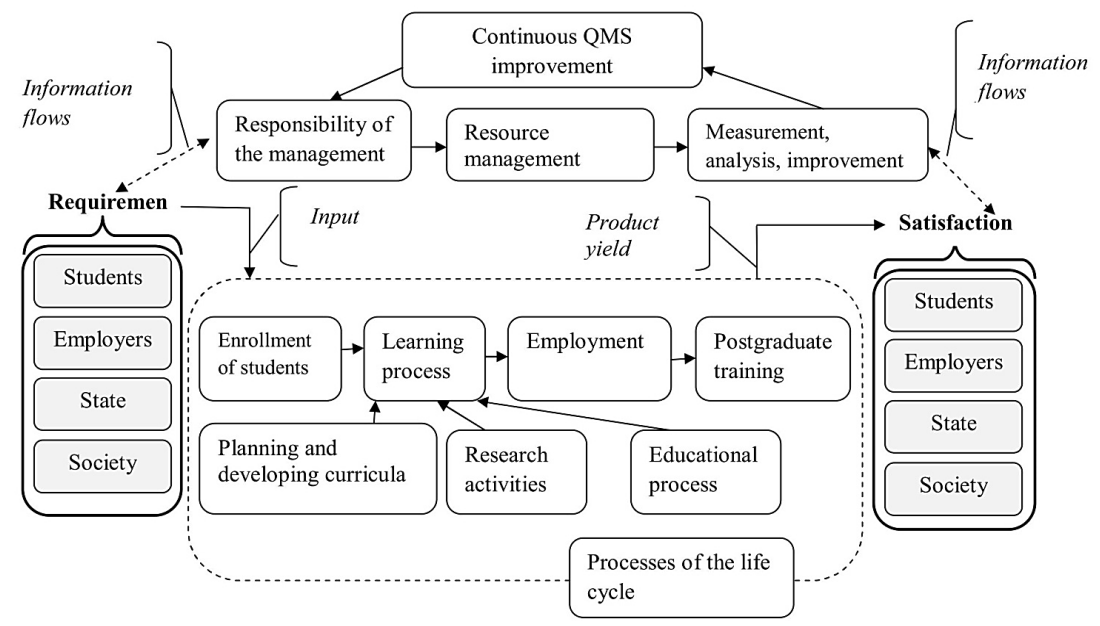

Fig. 1. QMS model in Universities

It is proposed to apply an algorithm of the university activity, comprising: identifying a certain system of processes necessary for quality management, defining relationships, cooperation, consistency in the system of processes, identifying key processes from the perspective of strategic plans and objectives; searching for an employee ready to take responsibility for the process, giving him adequate powers, i.e. appointment of the process owner; determination of the process customer or consumer and description of the process outputs, that is, the requirements for the quality of the results of its functioning; determination of the process suppliers and requirements for input elements of the process, that is, resources; determination of the criteria for effective management of this process and selection of methodological support for measurements of these criteria; planning processes of quality and effective process indicators measurement; description of the 
process as a flowchart with the account of the process management system; determination of outgoing and incoming documents according to the stages of the process; provision of information flows necessary for effective process management and monitoring; conducting regular monitoring and analysis of data relating to the process; systematic implementation of corrective and preventive actions aimed at attainment of the process goals; determination of the procedure for making changes in the process [3, p. 179].

In turn, university's management, in accordance with the proposed model, should provide the necessary resources. First of all, these are human resources (faculty and other staff). What is more - premises, equipment (laboratories, computer network, library stock, compliance with sanitary and technical standards, etc.) [3, p. 179].

Thus, the high quality of the university activities as a whole will determine both the improvement of the very processes and the system in general through the effective management of each key process and through their interaction. In this case, management should be carried out through the control of the indicators that characterize them.

It should be emphasized that DSTU ISO 9001-2001. Quality management systems. Requirements and DSTU ISO 9004-2001. Quality management systems. Guidelines for performance improvements act as compatible with each other. The second of these standards is rather broad and goes beyond the requirements of the first one. Therefore, it is recommended to use the second standard as well for the higher education institution, where the quality management system is implemented in accordance with the requirements of the first standard in order to maintain efficiency and ensure further improvement.

\section{Analytical abilities of the education manager}

The education manager carries out continuous analysis and processing of information and makes the corresponding decisions on that basis. Therefore, he/she must have analytical skills. It is important to make realistic forecasts based on a comprehensive analysis of real situations and the construction of specific models of functioning of pedagogical process or the educational institution in general. Therefore, helshe must possess such business qualities as professional skills; initiativity; good organization (rational use of time, workplace arrangement); responsibility; diplomacy, ability to maintain professional secrecy (use only actual, strictly verified information, 
not to disclose secret information, as well as information that is truthful, but may harm the organization or individual employees if disclosed; keep documents properly).

Analytical forecasting is carried out on the basis of processing of information about personnel, financial and economic, as well as material and technical capabilities of the educational institution, the psychology of performers, stereotypes of their thinking in solving the matters of principal, about deadlines, ways of adjusting and criteria for the quality of actions and tasks performance. The "access mode" term is used to define legal aspects $[7$, p. 22].

\section{Responsibility of the higher education institution management and factors influencing the quality of training in comparison with TQM principles, EFQM criteria and requirements of the international ISO 9001 standard}

Analyzing the content of DSTU ISO 9001-2001 standard. Quality management systems. Requirements and the issues of innovation management, we will consider section 5 "Responsibility of management". Senior management, being in charge of the work on the QMS implementation, should organize work based on the strategic plan. The medium-term development plan is suggested for 3-5 years and the long-term one - for 7-10 years.

There should be a quality coordination council. The Department for ensuring functioning of the quality management system functions at the Lviv Polytechnic National University. The main tasks of the Department for implementing the University's quality assurance policy of educational services is the practical implementation of the plan for QMS implementation at the University, the development of proposals, draft documents for the rector and the Academic Council to improve the regulatory framework of the organization of the educational-bringing-up process and the University's quality management system. Moreover, participation in the development and improvement of the following techniques: rating assignment to the University chairs; rating assessment of the activities of academic staff of the University; monitoring the quality of University's specialists training, etc. The main tasks also include the collection, analysis and generalization of information on the quality of educational services at the University.

Inspections of the organization of educational-bringing-up process and the state of affairs in the structural subdivisions of the University took place 
under a separate rector's order. The tasks also include the analysis of performance and results of students training and the work of the State Examination Commissions; checking the chairs' readiness for the new academic year; analysis of the results of the rating assessment of performance of academic employees of the University; planning and registration of methodological editions of the University and issuance of quality certificates; organization of control of residual knowledge of students; organization of works on rating of the university chairs; organization of work on conducting the first and the second rounds of All-Ukrainian student competitions and competitions of qualifying papers, collecting and processing reports on the results of their conduct.

The state and improvement of the QMS should be regularly considered at the Academic Council of higher education institutions, academic councils of the institutes (faculties), meetings of the chairs. Materials about the quality of student training, consumer feedback (students, employers, NGOs, representatives of governmental bodies) should be disseminated through the internal computer network of the university and its printed media [3, p. 184].

The list of factors, presented in Figure 2, that influence the quality of training in comparison with TQM principles (Total Quality Management), EFQM criteria (European Foundation for Quality Management) and the requirements of the international ISO 9001 standard (International Organization for Standardization) [6, p.53] gives grounds to conclude that these factors are fully integrated into the common TQM ideology, which they are based on.

Creation of scientifically grounded methodological approaches to assessing the quality of students training, the universities' performance, development, implementation and monitoring of a professionally oriented quality management system (QMS) of higher educational establishments, its regulatory and computer support require the development of a conceptual model of the quality of university students' training based on TQM principles, and derivation of the formula for assessing the university's performance; construction of the QMS model of the higher education institution and monitoring system using a process approach; studying the impact of the quality of students' training on the competitiveness of universities, in particular, the multifactor model of student admission and the model of academic progress; development of recommendations on the implementation 


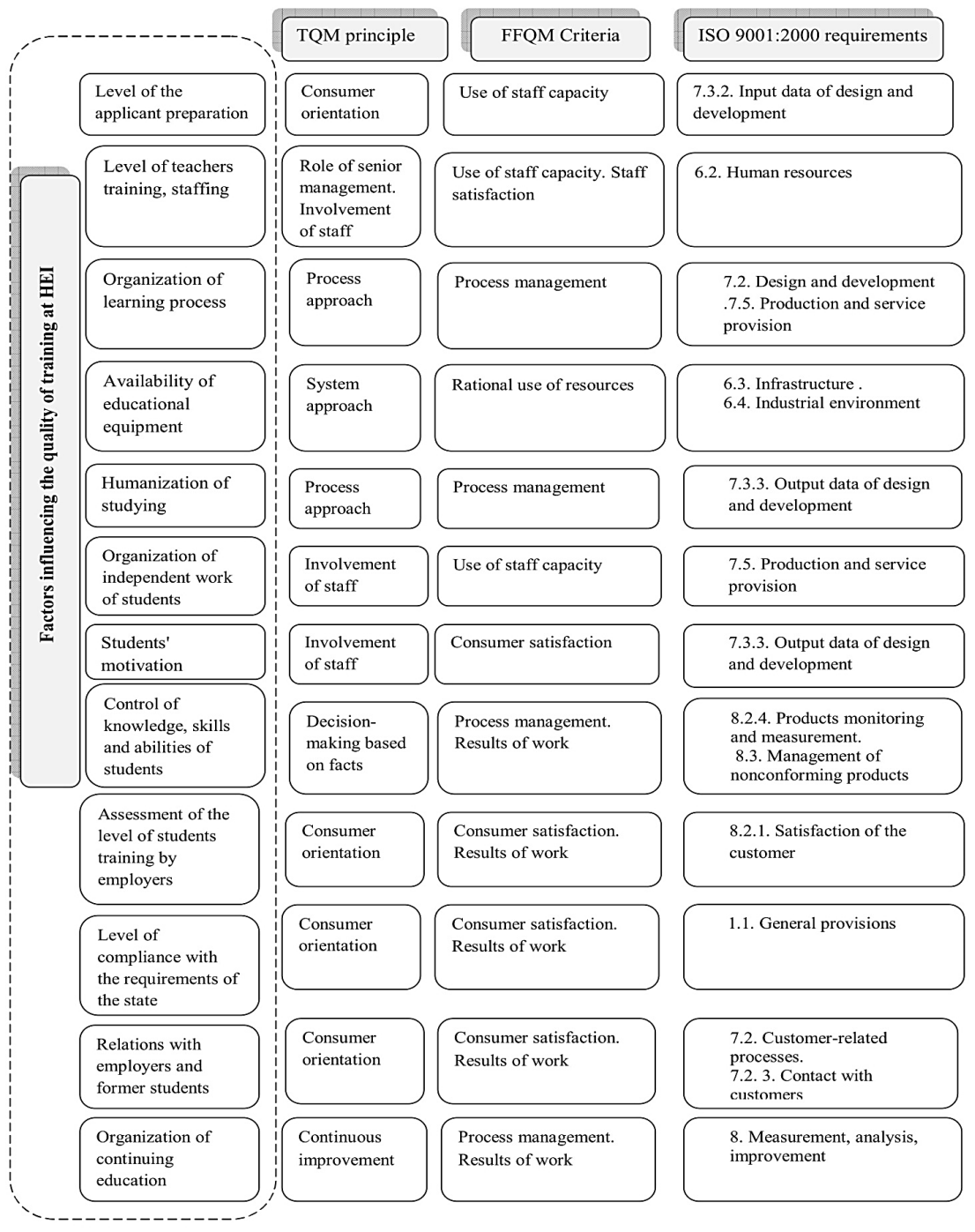

Fig. 2. A comparative table of the list of factors influencing the quality of training in comparison with TQM principles, EFQM criteria and the requirements of the international ISO 9001 standard 
of QMS of higher education institutions using the methodology of project management; application of the method of the quality function structuring for the development of a set of regulatory documents of higher education institution QMS; development of the modular process-oriented information system for the maintenance of the University's QMS with the use of programming and databases; approbation of the created documentation, methodological and program developments on the basis of selected universities $[6$, p. 53].

\section{Improvement of functioning of the electronic document flow system in accordance with the requirements of state standards}

The development and existence of society depends on social and communicative activities. The social communication channel is provided through document communication. That is, any processes, mediums of exchange, and adoption of managerial decisions is impossible without being recorded on a paper or electronic medium. Taking into account the prospects of Ukraine's activities in the European collaboration market, development of the documentation field requires consideration of the world's practical experience and integration of international standardization and unification of information processes.

Ukrainian higher education institutions (HEIs) should work to not only provide high-quality content of educational programs and qualifications of the faculty staff, but also pay attention to the formation of standards-based documentation management for successful work and cooperation with European educational institutions [2, p. 27; 5, p. 31].

A set of international standards on compliance with harmonization in Ukraine in the field of archival activity and records management will allow organizing work with document information in an educational institution in a more efficient way. In records management at the Lviv Polytechnic National University it is suggested using state standards, which were modified on the basis of such international standards as DSTU 4423-1:2005 "Information and documentation. Records management. Part 1: Key provisions (ISO 15489-1: 2001, MOD) [9] and DSTU 4423-2:2005 "Information and documentation. Records management. Part 2: Guidelines (ISO/TR 15489-2:2001, MOD) [10]. The international standard considers the documentation management as a part of quality management system based on the requirements of ISO 9001 standard (Quality Management System). The 
national version of DSTU 4423: 2005, which has been modified on the basis of the international standard ISO 15489, includes recommendations for an optimal records management methodology, which is intended for experts in the field of document management, and experts in other fields of activity. In particular, this standard can be used by developers of new information programs and systems to ensure compliance of these programs and systems with the requirements for records management.

The standard deals with the management of documents of all kinds and on all carriers created or received by an organization in the course of its activities, as well as by individuals who must create and use documents.

There is a department at the Lviv Polytechnic National University for implementation and maintenance of electronic document flow systems, which uses the document flow management system of modern ECM and BPM solution base on Alfresco platform. The following criteria became decisive in selection of this system functioning at the University: open source; state-of-the-art technological solutions; support of the most common file formats; advanced possibilities of business process modeling; multilevel system for access control to information [8, p. 192].

According to section "Documentation processes and their control" of DSTU 4423-2:2005 "Information and documentation. Records management. Part 2: Guidelines" to make Alfresco system function effectively, it should be based on these advisory requirements. According to the standard, it is suggested to include service documents in the electronic documentation system that require configuration, which would remind of filling out the fields necessary for metadata, or a configuration that would automatically create such metadata.

We also offer to improve the classification of areas of business activities in accordance with the standard. A system of classification associated with business functions can provide a systematized structure for records management. The fully developed form of classification reflects the functions, areas of activity and operations of the higher education institution. Such reflection can be used to develop a scheme for classification of service documents and thesaurus, rules for providing headings to documents and their indexing, determining the deadlines for storage of documents and classification of access at higher education institution. Such a classification system will give a tool to the Lviv Polytechnic National University to organize, describe and logically combine its service documents; com- 
bine and divide interdisciplinary documents, both internal and external for an organization, and, if necessary, provide improved access, search, use and classification of their service records. Supported by such tools as vocabulary control, the classification system ensures unification in providing headings to service documents and their descriptions, which facilitates searching for and using service documents. The scheme of classification of the areas of activity of the institution can be developed using the methodology described in section "Strategy, development and implementation" based on stage A "Preliminary study" and stage B "Business activity analysis".

The developer of the classification systems should observe the following provisions:

a) Vocabulary of the system should be based on its business functions and areas of activity, and not on the names of the organization divisions;

b) The systems are specific to each organization and provide a consistent and standardized way of communication across organizational units using the same information to perform interrelated functions;

c) They are hierarchical, they should proceed from the most general to the most specific concept, that is, from the general function to the specific action;

d) They contain precise terms used in the organization;

e) They contain large groups and subgroups that cover all business functions and areas of activities to be documented;

f) They contain separate groups;

g) They are developed in consultation with the authors of service documents;

h) They reflect changes that are made to ensure that the scheme meets up-to-date requirements and reflects changes in the functions and areas of activities of the organization [10, p. 9].

The most effective way to determine, which service documents should be attached to the documentation systems and how long they should be stored, is when it is systematically done in accordance with the laws and instructions. The means for making such decisions may include instructions identifying service records to be destroyed or included in the documentation system, formally accepted lists of classes of documents, storage periods and appropriate actions on transfer of service records to the archive or their withdrawal for destruction, which are subject to approval by the 
external competent authority - the file register. In electronic documentation systems, documents attaching and storing is considered at the initial stage of system development.

Service documents are added to the electronic documentation systems as a result of a well-developed process, which is a registration according to its tasks and objectives. Information about the people involved in the operation, the activities performed and the service records that are the result of this activity, can be recorded with varying degrees of specification. The level of required specification depends on the needs of the activity and the scope of use of the service document. Example:

a) service records with respect to one person can be grouped into simple systems using the minimum search-based information, in particular, into such systems as personal, referential case file with copies of instructions and laws;

b) service records that are never used outside of one unit require documentation of details only that are sufficiently understandable within the unit;

c) service records that go beyond a particular unit require more information that identifies this unit and the involved performance in the context of the entire organization activity;

d) service records created in the public domain, such as World Wide Web, require more information in accordance with the context, since it can be predicted that users will consider a document with a different understanding of operations in the context of which it was created [10, p. 21].

\section{Automation of archival activity on the basis of integration of international standards}

One of the main structures of the system of social communication is archives, including archives of structural units of HEIs. One of the first and priority tasks of the archives of structural subdivisions of universities is not only the storage of documents, but also the active use of archival information in solving socially important tasks - verification of personal data. Strengthening the requirements for the level of informatization and dissemination of the processes of European integration determine the leading role of the HEI's archival units, which ensure the implementation of state policy in the archival sector, organize the formation and storage of information resources. 
The main tasks of the university archive as a subject of educational activity are the organization of the records use, issuance of archival certificates, copies, extracts to legal entities and citizens in accordance with the established procedure, creation and improvement of the reference tool for access to archival documents. One of the problems of the archive functioning of the structural unit of Lviv Polytechnic National University is a large number of information queries daily, which is about 100 . Since the search for information is carried out through paper media, which significantly complicates and slows down the work of the employee, it is proposed to change the manual search technology for electronic one using the information retrieval system.

In order to establish common requirements for the definition of the quality of service provision, enterprises, institutions, local governments, archival information, extracts and copies to fulfill the biographical and factual requests by the archival departments of the higher educational institutions are implementing a management system quality. The regulatory framework for the creation of such systems is the international standard ISO 9001-2008, "Quality Management Systems" [4]. The process of providing archival references, excerpts, copies includes:

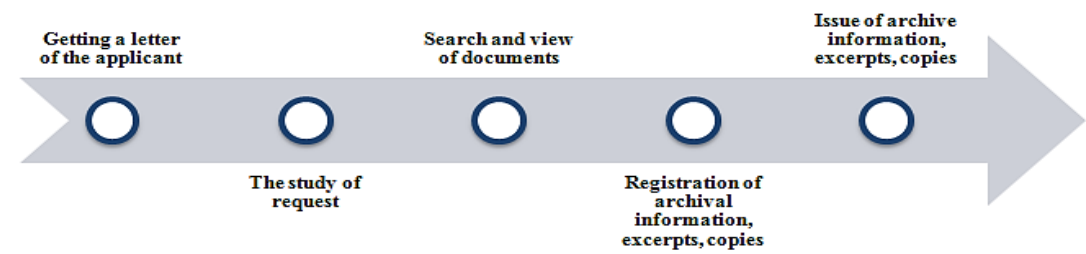

The prerogative of the information retrieval archive system is that it enriches the prospects for the user in the work of an array of archival information as a means of using the relevant databases in the structural department of the university, which allows only limited access to documents. Thus, the information retrieval archive system will allow:

- to search for a person (surname, name, last name, year of birth or period of work and study), regardless of place of his stay in the past,

- search for a person in all documents,

- search for object,

- to organize the geographical and chronological filter of documents;

- automatic filling of the template of the document for extraction from the archive. 
Information search system in (ISS) the form of a database is created:

1. In order to improve the conditions of citizens' servicing;

2. Improving the efficiency of work is the speed of service, the convenience of finding information, eliminating barriers to obtaining services through a human factor (corruption, bureaucracy, physical overload, etc.);

3. Storing of archival documents.

In order to organize the activities of the colleges of higher educational institutions, it is necessary to adapt the ISS to the needs of the archival industry in accordance with the international standard ISAD (G): 1999 "General international standard archival description". Consider the construction of an ISS conforming to the international standard ISAD $(\mathrm{G})$. The elements of the description of the document must contain the following blocks, which are shown in Fig. 3.

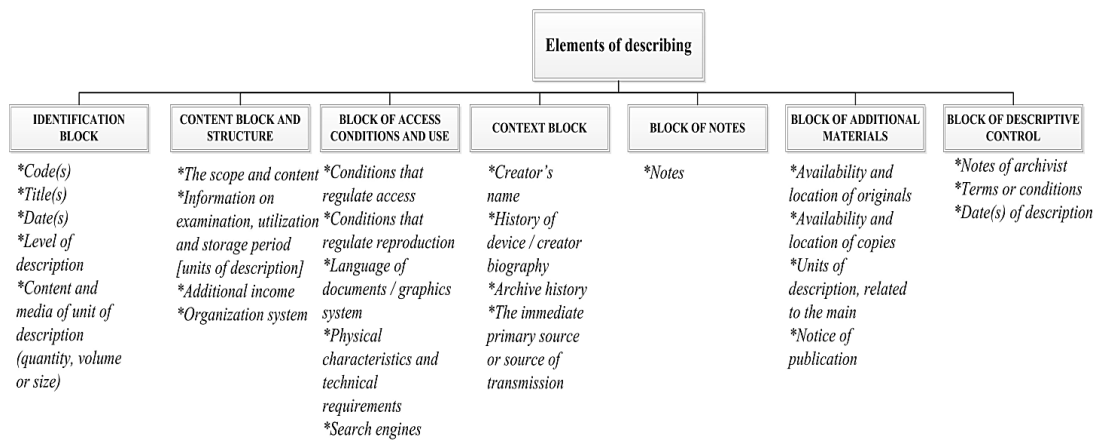

Fig. 3. Schematic representation of the elements of the description according to the international standard ISAD (G): 1999 and their blocks.

The development of an information retrieval system facilitates the laborious and routine work of the search problem and will be implemented as a means of reliable data storage, which makes it convenient and quick to find the necessary information [1, p. 202]. It is also proposed for the final stage of processing the results of the request for the archival information found to automatically fill this information in a template form in the database for issuing documents (Fig. 4).

Consequently, as a result of the analysis of the problem of finding large volumes of document and information arrays in the archive department of higher educational institutions, the Lviv Polytechnic National University it 
was proposed to implement an information retrieval system in the form of a database.

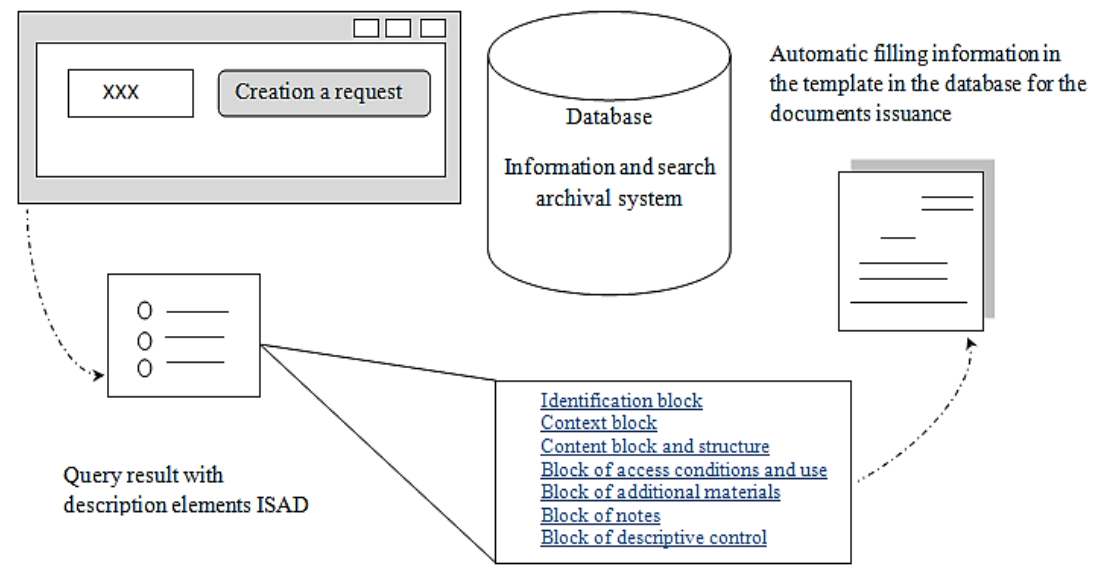

\section{Fig. 4. Schematic representation of the execution of the request in the Archival Information Retrieval System}

This search archival system must conform to the International Standard for Archival Descriptions ISAD (G). Thus, the information retrieval archive system, which is able to accumulate information and outputs of it on multidimensional requests, will allow the employees of the department of higher education to increase the efficiency of the implementation of requests for verification of personal data of graduates and university employees.

\section{Conclusion}

Thus, innovation management in the higher education system with the integration of ISO 9000 family of international standards and international standards in the field of archival activity, records management should include the following components: innovative methodological base, personnel, pedagogical management, finance, the process of studying through the interaction of disciplines, well-established document communication (since any process, means of information sharing, making managerial decisions is impossible without being recorded on paper or electronic media). On the example of records management, namely, the electronic document flow system at the Lviv Polytechnic National University, for successful 
functioning of the system and competitiveness in the European market, it is suggested to make proposals to use state standards that have been modified on the basis of international ones: DSTU 4423-1:2005 "Information and documentation. Records management. Part 1: Key provisions (ISO 15489-1: 2001, MOD) and DSTU 4423-2:2005 "Information and documentation. Records management. Part 2: Guidelines (ISO/TR 15489-2:2001, MOD). Documentation management is considered in the international standard as a part of quality management system based on the requirements of ISO 9001 (Quality Management System). It has been also suggested changing the manual search technology to the electronic one at the Lviv Polytechnic National University's archival unit by using the information retrieval system in the form of a database, which should be designed to comply with the International Standard for Archival Descriptions ISAD (G). The designed information retrieval archival system, taking into account the international standard of archival description ISAD (G), will allow the archival unit of the Lviv Polytechnic National University to apply international rules and technologies that will be clear to all when entering the European information space.

Innovation management in the higher education system with integration of ISO 9000 family of standards and international standards in the field of archival activity, records management provides for the provision of qualitative content of educational programs and qualifications of the academic staff, effectiveness and efficiency of joint efforts of the staff, determination of incentives and development of the performance evaluation system, development of the personnel policy, personal responsibility, creation of conditions for fruitful work, effective use of resources, formation of records management on the basis of standards, creation of an efficient information retrieval archival system.

\section{References:}

1. Bilushchak T., Myna Zh., Yarka U., Peleshchyshyn O. (2017) Integration processes in the archival section of Lviv Polytechnic National University. Proceedings of the XI' International Scientific and Technical Conference "Computer Sciences and Information Technologies" (Ukraine, Lviv, September 05-08 2017), Lviv: Lviv Polytechnic Publishing House pp. 200-203.

2. Bilushchak T., Komova M., Peleshchyshyn A. (2016) Poniattievoterminolohichnyi aparat keruvannia dokumentatsiinymy protsesamy [Conceptualterminological apparatus for managing documentation processes] Proceedings of the IX Mizhnarodnoho naukovo-teoretychnoho seminaru "Terminolohiia doku- 
mentoznavstva ta sumizhnykh haluzei znan" (Ukraine, Kyiv, June), Kyiv:Chetverta khvylia, pp. 27-33.

3. Vitkin L.M., Laptiev S.M., Finikov T.V. (2009) Pobudova system upravlinnia yakistiu vyshchykh navchalnykh zakladiv [Building quality management systems of higher education institutions]. Kyiv: Taksona. (in Ukrainian).

4. DP NDI "Systema" (2009) Systemy upravlinnia yakistiu. Vymohy: DSTU ISO 9001:2009 (ISO 9001:2008, IDT), Kyiv: Derzhspozhyvstandart Ukrainy.

5. Komova M.V., Peleshchyshyn A.M., Bilushchak T.M. (2013) Keruvannia dokumentatsiinymy protsesamy [Records management]. Lviv: V-vo Lvivskoi politekhniky. (in Ukrainian).

6. Levshyn M.M. Svizhevsjka S.A. (2012) Neobkhidnistj vykorystannja mizhnarodnykh standartiv jakosti ISO u praktyci vyshhykh navchaljnykh zakladiv Ukrajiny. Stan vprovadzhennja innovacijnogho menedzhmentu [The need to use international ISO standards in the practice of higher education institutions in Ukraine. The state of implementation of innovation management in the national system of higher education]. Proceedings of the Upravlinnja jakistju pidghotovky kadriv z vyshhoju osvitoju cherez udoskonalennja procedur licenzuvannja, akredytaciji ta rejtynghuvannja (Ukraine, Dnipropetrovsk, March 15-16, 2012) (eds. Salov V.O., Pysjmenkova T.O., Svizhevsjka S.A., Sobolj V.S), Dnipropetrovsk : Nacionaljnyj ghirnychyj universytet, pp. 50-54.

7. Myna Zh.V. (2016) Analityko-syntetychne opracjuvannja informaciji [Analytical and synthetic processing of information]. Lviv: Publishing House of Lviv Polytechnic. (in Ukrainian).

8. Peleshchyshyn O., Zhezhnych P. (2016) Systema slabostrukturovanoho dokumentoobihu Lvivskoi politekhniky na bazi platformy Alfresco [System of weakly structured workflow of Lviv Polytechnic on the basis of Alfresco platform]. Proceedings of the VIII ${ }^{\text {th }}$ Innovatsiini kompiuterni tekhnolohii $u$ vyshchii shkoli (Ukraine, Lviv, November 22-24, 2016), Lviv: Vydavnytstvo Naukovoho tovarystva im. Shevchenka, pp. 190-194.

9. UNDIASD Derzhkomarkhivu Ukrainy (2007) Informatsiia ta dokumentatsiia. Keruvannia dokumentatsiinymy protsesamy. Ch. 1: Osnovni polozhennia (ISO 15489-1:2001, MOD): ДСТУ 4423-1:2005 [DSTU 4423-1:2005 "Information and documentation. Records management. Part 1: Key provisions (ISO 15489-1: 2001, MOD)], Kyiv: Derzhspozhyvstandart Ukrainy.

10. UNDIASD Derzhkomarkhivu Ukrainy (2007) Informatsiia ta dokumentatsiia. Keruvannia dokumentatsiinymy protsesamy. Ch. 2: Nastanovy (ISO/TR 15489-2:2001, MOD): ДСТУ 4423-2:2005, [DSTU 4423-2:2005 "Information and documentation. Records management. Part 2: Guidelines (ISO/TR 15489-2:2001, MOD)], Kyiv: Derzhspozhyvstandart Ukrainy. 
CREATIVE BIOGRAPHY IN THE COORDINATES

OF THE HUMANITIES: HISTORIOGRAPHY

AND RESEARCH METHODS

\section{ТВОРЧА БІОГРАФІЯ В КООРДИНАТАХ \\ СУЧАСНОЇ ГУМАНІТАРИСТИКИ: \\ ІСТОРІОГРАФІЯ ТА МЕТОДИ ДОСЛІДЖЕННЯ}

\section{Bondarchuk Viktor ${ }^{1}$}

DOI: http://dx.doi.org/10.30525/978-9934-571-26-8_2

Abstract. The essence of creative biography as a concept in the context of culturological discourse is revealed. Appealing, both to the rational-polemical substantiation and to the simplistic conclusions, the constant, the invariable component of scientific intentions, is absolutely crystallized a person who, by dividing it into the general texture of the cultural space, breaking his principles and essence, becomes the object of study, outlining the subject of the research and formulating the appropriate tools for processing. In complex interdisciplinary dialogue, where the research methods undergo constant division, changing the position of the leading on the secondary, moving the focus of research, and emphasizing the attention of scientists on its various vectors, biographism (biographical method) remains unchanged and uncontested, which, comprehending possible lines of intersection of sociology, psychology, philosophy, art studies, and cultural studies maintains and localises the epicenter of all scientific intentions - a creative personality.

The purpose of the work. Investigation of creative biography in the context of its historical formation, social adaptation and creative comprehension. Study of biography as a form of knowledge of the essence of phenomena with further consolidation in the coordinates of cultural discourse.

The methodology of the research is to apply historical and culturological methods, which makes it possible to analyze the creative biography in the context of interdisciplinary relationships.

\footnotetext{
${ }^{1}$ Associate Professor, Candidate of Art,

Tchaikovsky National Music Academy of Ukraine, Ukraine

(C) Bondarchuk Viktor
} 
The scientific novelty of the work is to broaden ideas about the creation of a creative biography in the coordinates of art and cultural discourse. The current state of the study of personality, its creative, scientific biography, makes the scientists and researchers think about the problem of finding and rational substantiation of methodological approaches, their synthesis and differentiation for the sole purpose - to fully comprehend the life and creative way of man, to outline all the points of its accomplishment in the space of socio-cultural dynamics of reality. Cultural discourse clearly defines the subject of research - the vital and creative way of the individual, who, in the context of his own processual temporal organization, demonstrates human life's realities in the projection of relevant text materials and other informative media, which forms the source base in the form of its invaluable heritage. It is the material elements of a complex multilevel human model that give as clear orientations of the individual in the space of his psycho-physical evolution, and tracking the communication of the individual in a dynamic socio-cultural dialogue. By synthesizing these two aspects of analytical intelligence, we are able to fully comprehend the problem of social adaptation of a person and to identify the stimulating aspects of its creative principle, at the intersection of which a person acquires the status of a creative person whose essence is determined by the continuum as artistic progression and psycho-physiological aspects of its evolution. Taking into account the discussions that are caused by the problems of biography and its source, the current state of philosophical, sociological, psychological, art criticism and cultural space is at the stage of a permanent rethinking of phenomena, their essence, which leads to the formation of new, sometimes dangerous, conclusions that are an important structuring element of history, science, art. The measurements of the present, the sensations of the ripple of time and reality, push us into reflection, the epicenter of which is a new understanding of reality, which more and more often leaves aside the empirical models of world outlook, world perception, place and role in it of man and personality. The accents of postmodernism form the strategies of thought of each of us, when the sense of time realities changes its coordinates every day, every moment, and feel the progress of the present becomes more difficult and harder. The modern creative personality is the projection of virtual mechanisms that work according to their own laws and strategies, bypassing the formatting of the empirical modeling of human development vectors, their symbols and ideals. The creative personality of 
the present is formed in the range of a powerful information space, which depresses the genetically intertwined ideological human models. Formulating, and simultaneously destroying the feeling of reality, rising to the pedestal of recognition and simultaneously falling into the abyss of internal devastation, the person is established in the space of the present, covered by fictitious names, non-existent photographic images, false and fictitious life history. Blogs, instagrams, sites are the continuum where anyone can find their recognition, become a leader, masking eloquent slogans and slang. When studying the personality biography, the main thing remains to avoid simplification, when a significant part of his creative, or scientific, social, intellectual manifestation is lost and remains beyond the contextual limits.

\section{1. Вступ}

Інтенції сучасної гуманітаристики представлені чітко структурованим і послідовним вивченням соціальної сфери, іiі організації та систематизації в контексті культурно-історичних чинників, динамічно формуючи універсалії культури, освіти, науки. Саме культура, у всій іiі багатогранній і самобутній природі генерує світоглядну картину відповідного етносу, уніфікуючи його емпіричні надбання в контексті сучасних теоретико-методологічних вимог. Культура - це завжди чітко структурована і циклічно зумовлена послідовність, сутність якої відображена її історичним досвідом з обов'язковим формуванням стратегії подальшого розвитку та моделюванням цілісної картини світу, у якій важливим структуротворчим елементом залишається особистість у всіх проявах її художньої рефлексії, творчості та мистецьких здобутках.

Транслюючи наукові напрацювання сучасної гуманітаристики, кристалізується стійка основа, тло, відкриваючи широкий простір у пізнання особистості, іï внутрішнього світу, вподобань та інтересів. Виокремлення суб' єктивно-особистісного зі сфери узагальнено-об' єктивного дає можливість пізнати індивідуально-особистісну сутність людини, враховуючи чинники зовнішнього впливу та можливі асимілятивні тенденції. У контексті обраної проблеми дослідження прослідковується чітке відшарування суб'єктивної культури - категорії, що, виокремившись зі структури її об'єктивної основи, формує чіткий предмет дослідження - особистість, яка будучи її невід'ємною частиною, здобуває нові характеристики, властивості, особливості, сутнісні 
основи. Саме у процесі акультурації особистості, суб'єктивна культура виступає у формі конкретної програми іiі життєдіяльності, стимулюючи до логічної і послідовної адаптації, становлення та самоактуалізації у динамічній соціо-комунікативній сфері.

Досліджуючи феномен творчої особистості, гуманітаристика ставить чітке завдання - уникнути численних теоретично-аналітичних спекуляцій, зберігаючи базові положення у методах та підходах до вивчення творчих біографій видатних постатей культурно-мистецького простору.

\section{2. Виклад основного матеріалу}

Потужна традиція біографізму, яка знайшла своє відображення у наукових поступах соціології, філософії, естетики, акмеології, стимулює до раціонального узагальнення - творча біографія проектує неповторну, самобутню особистість, яка, будучи вмонтованою в контекст соціокультурної динаміки, формує розгалужений простір дослідження, що знаходиться на перетині окремих міждисциплінарних концептуальних векторів, узагальнюючим механізмом яких $є$ історія та культурологія передусім. Творча біографія - це історико-культурологічне, історико-мистецтвознавче та історико-психологічне дослідження, тому ми розглядаємо творчу особистість як феномен історії та культури, який, сформувавшись на синтетичних моделях міждисциплінарного дискурсу гуманітарних наук, дає можливість парадигмально сприймати та аналізувати лінію загального розвитку як усього людства, так і окремої особистості, не залишаючи поза увагою момент включення іï у дискурс філософії, соціології, історії. Творча біографія - це культурологічне дослідження - оповідь, побудоване не за принципом хронологічного нанизування, де кожний крок біографії Майстра працює як чергова фаза творчого сходження, піднесення, в яких прокреслюється єдність, цільність, що вирізняє особистості між інших постатей, індивідуальностей; творча біографія - це життєвий і творчий шлях митця, зумовлений культурно-історичними і особистісними чинниками і відтвореними у його художній творчості.

Сутність творчої біографії не достатньо розкрита в сучасній науці. Проблема творчої біографії реальної конкретної особистості передбачає дослідження різних галузей гуманітарного знання та видів художньої творчості. Вивчаючи біографії Митців, ми поринаємо у сферу 
творчого процесу, у контекст, який виражений сукупністю факторів поза текстової реальності, що безпосередньо чи опосередковано впливають на його подальший розвиток. Ця проблема передбачає вивчення не лише результату праці художника, але й самого акту творчості у всій його виключній складності, у найрізноманітніших його зв'язках $з$ дійсністю, у множині відтінків сприйняття Художником життя, дійсності й в опосередкуванні зв'язку Митця і світу. Коло проблем, пов'язаних з вивченням творчої біографії, як ми бачимо, надзвичайно різноманітний. Ця проблема є плідною не лише для окремого дослідження життя й творчості того чи іншого Митця, але й для висновків більш широкого характеру, в яких можуть бути поставлені надважливі питання загальної теорії культури, зокрема, й художньої. Проблема дослідження творчої біографії - одна з окремих напрямів дослідження теорії культури - пов'язана 3 кардинальними поняттями теорії та психології творчості та сприйняття, теорії пізнання у дуже широкому, що виходить далеко за межі власне мистецтва, сенсі. Мова йде про спорідненість і певну адекватність творчих імпульсів, мотивів, спонукань та остаточних результатів творчості Художника, що ставить перед культурологічною наукою кардинальні проблеми загальної теорії художньої культури, мистецтва й теорії творчості. Ми будемо говорити про творчу біографію Майстра - добре знайомого, а, можливо, й зовсім незнайомого. Спробуємо уявити за цим людську долю, Людину, уявити і зрозуміти час - минулий, теперішній, можливо, майбутній. Відтак через біографіку великих митців ми замислюємося й пізнаємо не тільки їх життєвий і творчий шлях, а й досліджуємо та аналізуємо картину світу, відображену у їх творчості, художніх здобутках.

\section{3. Дослідження творчої біографії в контексті} міждисциплінарного аналізу: історіографія питання

Проблема творчої біографії гостро і динамічно підіймається у гуманітарній сфері, вказуючи на рівень їі актуальності та осмисленості. Відтак, у координатах біографічної розвідки кристалізується простір численних філософських висновків, концепцій та узагальнень. Від античних мислителів (Теофраста, Вергілія, Марка Аврелія) крізь призму життєписів Дж.Вазарі, Мікеланджело Буонарроті, Леонардо да Вінчі, думки Б. Паскаля, С. Монтеньо, роздуми С. Пачекко, Д. Дідро, до узагальнень Е. Канта, Г. Гегеля, А. Шопенгауера та тенденцій сучас- 
ної філософської думки Л. Левчук, Т. Гуменюк, В. Менжуліна, О. Болдачева $[1 ; 5 ; 6 ; 7 ; 8]$.

У здобутках мистецтвознавців кристалізується потужна складова біографічного жанру. Дослідження Ю. Станішевського, В. Рожка, М. Черкашиної-Губаренко, С. Тишка, Ю. Зільбермана, В. Реді формують ціннісно-орієнтаційну концепцію наукового напряму - біографістики, що дає можливість вивчення не тільки творчості Митця, а й соціокультурного середовища, його контекстуального простору $[16 ; 17 ; 18 ; 20]$.

Плідну і методологічно-значиму основу, що стимулює до вивчення творчої біографії особистості, пізнання іiї внутрішнього світу, створила сучасна біографістика, яка чітко структурувала механізми аналізу життєвого і творчого шляху особистості, вказала на іiі базові положення та закономірності. Внесок І. Бєлєнького, А. Валевського, Г. Винокура, В. Климчук, Н. Дічек, Т. Смельянової, Л. Ільчук, Н. Логінової, С. Ляшко, А. Петриної, В. Попика, Т. Попової, М. Поповича канонізував і узагальнив біографістику як потенційну і виважену у власних наукових переконаннях науку $[2 ; 6 ; 11 ; 12 ; 13 ; 14]$.

3 нашого погляду, подальший розвиток біографічного методу в просторі української культурологічної думки потребує подальшого фахового осмислення самого процесу становлення й утвердження біографічного підходу як форми вивчення і пізнання не тільки творчої біографії Митця, а й соціокультурного середовища, його контекстуального простору з метою об'єктивного висвітлення маловідомих і недосліджених аспектів вітчизняного культурно-мистецького простору.

Біографічний метод дослідження стає предтечею численних наукових теоретично-аналітичних спекуляцій в галузі гуманітаристики, він імпульсивно впроваджує нові механізми пізнання соціуму, його наративно-історичних засад, розсікаючи ціннісно-орієнтаційні виміри сучасності, змінюючи базові положення у методах та підходах до вивчення проблеми.

Біографістика у структурі свого хронологічного становлення представлена відповідним категоріальним та понятійним апаратом, зокрема:

- в Античності - це досвід емпіричного моделювання дійсності, коли кристалізується літературно-жанрова сутність біографії, завдання якої полягало у відтворенні життєвого циклу людини в контексті соціокультурної динаміки; 
- у Середньовіччі вона представлена символікою християнських оповідей, які вмонтовують людину у річище протистояння внутрішнього і зовнішнього, формуючи новий тип описання життєвого шляху особистості - агіографію, контури якої закріплені жанровими координатами життєвої літератури [11];

- у Відродженні через біографію Митця особистість набуває статусу Творця, що вказує на соціальне визнання його інтелекту і визнання загально-особистісної зрілості. Людина Відродження стверджує красу реального буття й пізнає саму себе. Пізнає й стверджує і себе, і свої стосунки зі світом, й світ своїх почуттів й думок, і саме цим, зрештою, возвеличує людську творчу особистість;

- у класичних інтенціях автобіографічні оповіді перетворюються на спосіб глибинного самопізнання людини, символізуючи початок нового етапу розвитку жанру, епіцентром якого постає індивідуальність, що належить не лише собі самій, а, передусім, ідеям та прагненням свого часу, і навіть цілій епосі. В основі дослідження - історизм, достовірність і перевіреність фактів;

- в епоху Романтизму, формується чітку структурованість біографії як жанру, крізь призму якої відбувається пізнання, розуміння об'єктивної дійсності, процесів, які формують структуру мистецького простору, його змісту та наповнення. Творча особистість піддає перманентному переосмисленню власні онтологічні реалії, наповнює життя смисловими категоріями, в основі яких прагнення до взаємодії 3 потужним генетичним досвідом творчості та самореалізації в ньому. Мистецтво романтизму сприймається як засіб перетворення дійсності, життєтворчість, коли людина перебуває у пошуку того невидимого шляху, який виведе ії з оточення реальності, безнадії [16];

- у механізмах наукового вивчення XIX століття, динамічно формується біографіка як сукупність філософсько-методологічних, історіографічних, історико-культурних та рецептурних знань і уявлень про окремі біографічні жанри, про значення, завдання i можливості біографічного мислення і пізнання, про методи біографічної реконструкції виокремлюючи статус таких категорій як «індивідуальність» та «особистість». Народжується інша особистість 3 новим відчуттям динаміки часу, в якому вона представлена елементом складної системи, сформованої континуумом творчих пошуків та життєвих реалій; 
- у розгалуженому науковому дискурсі XX століття, біографіка змінює власні ключові орієнтири і стимулює до формування похідних семантичних структур таких як: «біографічний жанр», «біографічна література», «біографічний метод», «мистецтво біографії». Мистецький простір наповнюється внутрішньою суперечливістю та протистоянням людини часовим реаліям. Інтуїтивний спосіб осягнення світу, індивідуалізм, зосередження автора на особистісному «Я», героя, читача, заперечення залежності характеру й учинків героя лише від зовнішніх умов його життя, посилена увага до психологізму, позасвідомих сфер душі, внутрішньої боротьби роздвоєного людського «Я»це ознаки, яких набуває особистість у контексті активного діалогу зі світом, дійсністю;

- i вже у реаліях XXI століття біографістика тяжіє до документально достовірного осягнення реальної конкретної людини, iї життєвого шляху і творчості,представляючи біографію як явище культури, сутність якого залишає осторонь лінійний життєпис (буттєва біографія) і акцентує увагу на реконструкції цілісності особистості в контексті iї творчих досягнень, звершень, поступів. Сучасна творча особистість - це проекція віртуальних механізмів, які працюють за власними законами і стратегіями, оминаючи форматні до нині засади емпіричного моделювання людських векторів розвитку, їх символів та ідеалів [8].

Творча особистість сьогодення формується у діапазоні безмежного інформаційного простору, що розгерметизовує генетично-заангажовані світоглядні моделі людини. Формуючи і одночасно руйнуючи відчуття реальності, піднімаючись на п'єдестал визнання і водночас падаючи у прірву внутрішнього спустошення, особистість утверджується у просторі сучасності, прикриваючись вигаданими іменами, неіснуючими фотозображеннями, фальшивою і вигаданою життєвою історією. Блоги, інстаграми, сайти - це той континуум, де будь-хто може віднайти своє визнання, стати лідером, маскуючись красномовними гаслами та сленгами. Саме в реаліях XXI століття особистість набуває статусу суб'єкта культури, помітно розширюючи коло питань, пов'язаних з дослідженням проблеми людини, їі місця в реаліях сьогоденної гуманітаристики [5].

Апелюючи до проблеми творчої особистості, дослідження ії життєвого шляху, що обумовлений динамікою соціальних та культурних 
змін, ми маємо можливість відслідкувати чіткий механізм ії адаптації, акультурації, самоактуалізації, послідовного становлення та звершення у складному комунікативному просторі. Саме крізь призму біографістики, біографічного методу дослідження сучасна наукова думка вдається до реставрації прихованих раніше і маловивчених аспектів людини, особистості, митця, рефлексія яких обумовлена систематизованими емпіричними надбаннями, їх осмисленням 3 подальшим включенням у вимір прогресивної теоретичної концепції. У такому контекстуальному просторі сучасної гуманітаристики прослідковуються ключові параметри зміни поняттєвого апарату психології, соціології, культурології,мистецтвознавства підтвердженням чого є розширення семантичних кордонів деяких означень та понять. Йдеться про проблему особистості, розкриття сутності поняття шляхом включення іiї у складний міждисциплінарний дискурс, відслідковуючи динаміку його смислового наповнення в контексті хронологічної систематизації. Від античної моделі людини до індивідуальності, від індивідуальності до особистості, від особистості до суб'єкта культури - саме в такій послідовності відбувається спроба пізнати внутрішній світ людини, руйнуючи однотипність та одноманітність ії вивчення та трактування. Сучасна культурологія виходить далеко за межі усталених і канонізованих довідниками постулатів, де вектори особистості окреслювалися iï соціальним позиціюванням, суспільною ідентифікацією, розглядаючи особистість як соціальний тип, сутність якого детермінована соціально-культурними факторами.

\section{4. Вивчення феномену особистості в контексті антропологічної концепції}

Локалізуючи феномен Митця, сучасна гуманітаристика помітно розширила науковий тезаурус, структуруючи його синонімічну послідовність, що виражена такими поняттями як: Майстер, Художник, Митець, рефлексивний Художник, стимулюючи до перманентного переосмислення категоріального апарату не тільки культурології, а й філософії, соціології, психології, мистецтвознавства, акмеології, біографістики. Незважаючи на розлогий поняттєвий ряд, структурним елементом даного наукового пошуку і обгрунтування залишається, насамперед, людина, індивідуальність, творча особистість, етимологічні засади якої детерміновані проблемою ідентифікації іiї сутності, 
закріпленої в динамічному поліконтекстуальному просторі наукового дискурсу. Оперуючи аксіомами гуманітаристики, які вкарбували у простір наукових обгрунтувань механізми антропології, сучасна наукова думка формує новий гносеологічний вектор онтологічної проблеми особистості, локалізуючи іï у простір новітньої наукової парадигми XXI століття. Її інтенції представлені моделями:

- філософської антропології, в якій відбувається дослідження духовного осереддя людини, основних феноменів ії буття, таких як: душа і тіло, життя і смерть, праця і гра;

- концепціями креативної антропології, предметом якої є механізми естетичної самореалізації особистості, суб'єктивний ментальний досвід, процеси втілення художнього потенціалу у послідовні вікові фази людини;

- засадами біологічної антропології, що піддає аналізу людину у статусі біологічного феномену, розглядаючи взаємозв'язок ії тілесного і художнього буття з акцентом на біологічні нахили;

- положеннями психологічної антропології, сутність якої сформована вивченням розвитку психіки індивіда від дитинства до старості;

- постулатами культурної антропології, які дають можливість дослідження духовних феноменів людського буття у просторі різних часових епох [15].

Об’єктом дослідження культурної антропології є не суспільство як таке, а людина як творець певно го суспільства і культури. Культурна антропологія наголошує на історичному процесі взаємовідносин людини та культури, адаптації людини до навколишнього культурного середовища, становленні духовного світу особистості, втіленні творчих потенціалів в діяльності та їі результатах. Діалог між діалектичною єдністю людини та культурним середовищем зумовлений сутністю творчої особистості, яка має можливість максимально реалізувати себе у творчій мистецькій діяльності, спрямованій на пізнання і перетворення дійсності.

Головна теза антропологічної науки представлена у вигляді єдиної ідеї людини і якій формується ії перформативність - як спосіб самопредставлення, самовиявлення, самозасвідчення [7, с. 7]. Як зазначає О. Левченко: «На рівень свідомості людини виходить відчуття, що світ заповнений не так і не тим, та виникає гостра потреба пошуку порожнього простору, який треба заповнити так і тим» [7, с. 19]. Інтен- 
ції біографістики, зумовлені таким антропоцентричним моделюванням дійсності, ідентифікують творчу особистість як феномен, який у координатах просторово-часового континуума представлений універсальним механізмом формування ціннісно-орієнтаційної концепції соціуму, його світоглядної моделі, онтологічних засад.

Сформулювати визначення особистості на вістрі сучасних наукових поглядів стає все складніше, оскільки ії смислова природа активно розпорошується в контексті перманентної зміни інструментарію пізнання її сутності.

Досліджуючи феномен особистості, ми апелюємо до вже відомих форм пізнання дійсності, які означив у своїй «Феноменології духу» і ввів до наукового вжитку ще Г.Ф. Гегель. Виділяючи: релігійну (яка представлена у формі людських фантазій); образну (коли почуття передаються в образах); пізнання дійсності, яке виражене в поняттях, ми закріплюємо проблему вивчення сутності особистості в координати системного підходу до проблеми, оскільки саме системність акцентує увагу на взаємозв'язку та взаємодії між елементами [4]. Дотримання принципу системності у дослідженні особистості є беззаперечним, оскільки дає можливість сформувати цілісність, об'єктивність, структурність, мотиваційність у вирішенні проблеми. Закріплюючи проблему в координати системного аналізу, у вигляді алгоритму: тезис - антитезис - синтезис, ми формуємо картину цілісного і послідовного аналізу. Власне такий підхід і розкриває основу діалектичного виміру у вивченні особистості, коли одне поняття шляхом логічного обгрунтування переходить в інше, і не тільки переходить, а й стає його невід'ємною частиною, без якого вже не існую, більше того - навіть не $є$ мислимим. Соціум, є особливим видом соціальної системності, у якій прослідковується об'єктивна форма існування особистості, локалізація якої із сфери загального розуміння стає за умови формування системи стійких ознак, які, власне є ідентифікуючим їі елементом як окремої категоріальної одиниці.

Головна властивість особливість - створювати навколо себе художній світ. Та як зазначає В. Климчук, у такому випадку: «Акценти наукових висновків зміщуються із вивчення сутності «Я» та «особистості» на вивчення способів їх дискурсивного конструювання. Особистість перестає бути іменником, і стає дієсловом; перестає бути явищем, i стає процесом» [6, с. 72]. Тому напрошується висновок, що особи- 


\section{Bondarchuk Viktor}

стість - це явище процесуальне, ширше - темпоральне, i лише закріпивши його в координати просторово-часової організації, ми маємо можливість їі об'єктивного аналізу, розкривши всі рівні як соціальної так і культурної ідентифікації.

Якщо ж розглядати особистість в контексті формального, аналізу, ми отримуємо, скоріше, ілюзію у якій частково відзеркалено лише окремі елементи їі структури. Вивчати проблему особистості в контексті розуміння іï як реальності стає неможливим, оскільки реальність як суб'єктивна категорія - це те, що дане нам у сприйнятті, а об'єктивна - те, що не залежить від того, сприймаємо ми іï чи ні. Така інтенція наштовхує до певного висновку, що реальність - це галюцинація в яку ми віримо, а від так людина залишається єдиним створінням, здатним сприйняти закон становлення реальності й - більше - відтворити його в процесі, художній творчості. Розмежування реальності та ілюзії, закріплене в координати гносеологічного принципу, відкриває новий погляд на проблему особистості, розкриття її сутності та ідентичності. У такому контексті людина, особистість - це реальність, яка фіксує у своїй творчості, власній творчій біографії реалії об'єктивної дійсності, у вигляді художньої творчості, вираженої ii мистецькими здобутками.

За час свого розвитку сучасна гуманітаристика виробила важливу специфічну властивість - здатність до теоретичного вирішення багатьох актуальних проблем. Статус «людини культури», для якої природність культурних реалій $\epsilon$ органічною властивістю, веде до подолання сучасної культурно-антропологічної кризи. Діяльне, перетворювальне начало у цьому процесі пов'язано 3 можливостями персоналізму у сфері професійного росту індивіда. Аура професії, эiі досягнення, реакція на професійну діяльність збоку суспільства, критерії та рівні професіоналізму входять у культурологічне розуміння цього важливого аспекту багатовимірного поняття особистості. Сюди також належать й інші поняття: життєвий успіх, здатність до осяяння, сучасне визначення якості розуму, характеру і душі, моральне здоров'я, світ нових емоцій, субстанціональне почуття Батьківщини, самостійність і внутрішня свобода індивіда.

У соціокультурному розумінні становлення та розвиток особистості виявляється як багатоетапний процес залучення людини у соціум i культуру, тобто у соціокультурні інститути, середовище, різноманітні 
види культурної діяльності, що сприяють соціалізації, інкультурації та самореалізації особистості [13]. Людинотворча природа культури, властивість відтворювати людину в усій ii цілісності і всебічності є ї найважливішою особливістю. У процесі інтеріоризації культурних цінностей, явищ, феноменів розкривається й виявляється творчий потенціал особистості. При цьому людина набуває здатності долати диктат вибору, створювати конструктивну альтернативу самому вибору, тобто брати участь у надситуативній діï, що забезпечує оволодіння «живими точками росту культури», а також формами духовно-практичного досвіду людства, які саморозвиваються й самовідтворюються.

На особистісному рівні розвиток культури можна уявити у єдності опанування попередньої культури й створення нових культурних цінностей. Однак, створюване людьми предметне багатство є лише зовнішньою формою культури. Його справжнім змістом виявляється розвиток сутнісних сил самої людини, представленої в культурі як самостворюваної, саморозвивальної істоти. В культурі, отже, знаходить віддзеркалення вся сукупність потреб, здібностей, відношень, сил і т.д людини. Проектний, створювальний, діяльний бік в цьому процесі є провідним.

Базовою функцією культури є функція людинотворча. Визначення сутнісного базису феномену культури підкреслює, що через культури розвивається надприродна, позабіологічна складова людини, названа ii внутрішнім світом, душею, “Еgo”. Історично-осяжний процес еволюції людини демонструє, що основний його рух пов'язаний з визріванням саме внутрішньої складової людської сутності. Саме тут - у внутрішньому світі людини - закорінена їі здатність до пізнання світу й перетворення його. Перше відбувається завдяки суб'єктивній духовній здатності людини до подолання меж відомого i пізнаного, до постійного трансцендентування до вищих можливостей й ідеалів, що й постає рушієм антропогенної еволюції. Друге пов’язано з культуротворчою діяльністю людини, коли нові ідеали і цінності втілюються у земні усталені форми взаємодії, вступають у суперечність або доповнюють вже існуюче. I те і інше (пізнання світу та перетворення його) має потребу у чіткому ціннісному підгрунті й систематизації, утвердити й здійснити які здатен тільки сам суб’єкт у процесі свого духовного визрівання. Таким чином, людинотворча функція культури як вирощування, виховання, культивування внутрішнього світу людини 
онтологізує в сучасності духовну проблематику, пред'являє в якості насущної необхідності дослідження феномену духовності як атрибутивної властивості людської сутності й актуалізує значимість суб'єктивного та індивідуального.

Дослідження феномену творчої біографії у культурологічному вимірі пов'язано з тим, що науки про культуру з їх індивідуалізуючим методом мають цікавитися, у першу чергу, індивідуальним і неповторним в культурі. Індивідуальне в культурі, їі власне людський зміст постає головною метою біографічних досліджень, а інтерес до індивідуального - показником стану біографічної свідомості епохи.

Парадигми біографічної свідомості: агіографічна, героїко-міфологічна, наративна та ін., так чи інакше прив'язані до культурних універсалій. Індивідуальне існування завжди вплетене у культурний контекст. «Культурно-історичний контекст» так само значимий для біографії-життєрозуміння, як «історичне тло» для біографії-життєопису (життєоповіді); він вказує на приналежність біографії, що розглядається як текст культури своєму часові. Для різних епох і для різних культур характерні свої категорії осмислення й оформлення біографії. Однак, дослідники неминуче звертаються до понять «образ людини в культурі епохи», «смисл життя», «культурний код» [14].

Біографія як культуно-історична проблема передбачає предметом дослідження вважати історію індивідуального життя особистості у єдності всіх тих ознак, з яким вона дана в історії культури. Особисте життя й, безперечно, особисте творче життя майстра, постає своєрідною самостійною культурною формою. У ході вивчення біографії особистості слід брати до уваги рецепцію. Масштаби рецепції творчості та творчої діяльності особистості завжди є вражаючими. Рецепції мають тенденцію вибирати із загальної картини ту точку зору, яка найбільш значуща або для дослідника, або для певного часу. Так, ім'я особистості існує в постійному рецептивному русі, в якому відтворюється різноманітність їі діяльності і особистого творчого життя.

Творча біографіка як науковий жанр дослідження взаємовідносин митця і сучасного йому суспільства розвивається, як правило, по одному з двох шляхів, крайніми точками яких є або поступове забуття, або піднесення на п’єдестал. Проходячи по другому шляху, великий митець як «яскравий представник свого часу» поступово стає культурним героєм, культурною константою, зрештою, класиком. Класик 
існує відразу у трьох часах: у минулому як історичний персонаж, у майбутньому як ідеал та сподівання, прагнення розвитку, й в актуальній сучасності, де класику доводиться відповідати на повсякденні запити і претензії й підтримувати своїм «мідним» чи то «мармуровим» авторитетом, незалежно, хто того потребує. Таким чином, класик завжди $є$ «вічним сучасником» й «спільним однодумцем». Класик завжди задовольняє й відповідає горизонту (обрію) очікувань. Очевидною є нескінченна варіабельність Майстра, і кожний новий крок у дослідженні його постаті, яким би переконливим і точним він не здавався сьогодні, це лише нова, чергова, але ніяк не остання сторінка його «посмертної біографії». Класик-монумент є обов'язковим компонентом культури, але у кожній новій культурній ситуації цей феномен необхідно актуалізувати - і навіть ширше - опанувати.

Останнім часом у світовій та вітчизняній науковій (і не лише) літературі значно виріс інтерес до історико-біографічного жанру. Слід відзначити у біографічному потоці саме творчу біографію. При створенні наукових життєписів видатних майстрів автора очікує множина проблем, від вирішення яких залежить досконалість розвідки, іiї наукова значущість: це і певний рівень художньо-культурної адекватності, співмірності особистості автора та досліджуваної індивідуальності. Йдеться про осягнення творчої лабораторії митця, або - чи можливе осмислення генія. Підсилює складність чинник міфологізації, адже в монументальних рисах почасти втрачається людяність, справжня природа видатних діячів, їх земний масштаб. Водночас існує загроза певного заниження видатної персони, пов'язана з невиправданим спрощенням, схематизацією та користуванням усталеними штампами та ін. Тож робота з архівами, вивчення всіх попередніх досліджень, абсолютне занурення у творче життя Генія - це той шлях, який допомагає автору відтворити унікальну знакову культурну індивідуальність.

Проблема творчої біографіки безпосередньо стикається 3 проблемою соціальної місії творця. Це питання є неоднозначним за самою його постановкою, а тим більше за діапазоном відповідей. Епоха Модерну поставила його достатньо гостро, окресливши простір можливостей творчої особистості заявлять про себе у світі. На межі XIX-XX століть концепція художника у вежі зі слонової кістки та активного залучення у соціально-політичну діяльність, як полярні за своєю сутністю позиції, набули не стільки теоретичний скільки прак- 
тично-прикладний характер. Цілком виправдано спиратися на те, що при всій ексклюзивності прагнення творця виразити істину, що ставить його поза залежністю від чужих впливів, він завжди має потребу в іншому й звертається до світу з надією бути почутим, зрозумілим, тобто визнаним. У відповідності з цією настановою, крім громадянської позиції творця, питання достатньо суперечливого, актуалізується соціальна зумовленість його зв'язку зі світом у момент презентації своєї творчості публіці. Саме цей контекст зумовлює можливість дій-вчинків творчої особистості, взяті у бахтінському модусі діяльності «всім своїм життям». Творчість як свобода самовираження суть вчинок. Смисловий зміст творчості-вчинку й конкретна історичність його здійснення єдині й неподільні в оцінці його як відповідального вчинку. Ця відповідальність творця за здійснення вчинку у певному місці і у певний час, - це відповідальність за те, що, крім нього цього зробити ніхто не може. Демонструючи світові цінності й відстоюючи їх, творець вступає у відкрите співбуття.

\section{5. Висновки}

Закріплюючи проблему вивчення творчої біографії в динамічний міждисциплінарний контекст, сучасна гуманітаристика стимулює до формування потужного інструментарію дослідження особистості, який активно впроваджується у методах психології, соціології, філософiї, біографістиці, культурології та мистецтвознавстві. Виокремлюючи категорію суб'єктивної культури, консолідується механізм вивчення творчої біографії Митця з обов'язковим закріпленням іiї у широкий полі контекстуальний простір сучасної гуманітаристики. Саме в таких координатах і стає можливим вивчення не тільки результатів художньої діяльності особистості, а й зануритись у сферу самого акту творчості, як результату рефлексії Митцем дійсності, у всій іiї складності та неоднозначності.

Проблема вивчення творчої біографії в координатах міждисциплінарного аналізу слугує кристалізації чіткої структури іiі пізнання біографічного методу дослідження, який в контексті історичного становлення зумовив структурування відповідного категоріального та поняттєвого апарату. Проводячи аналітичний зріз від Античності до наукових узагальнень XXI століття, формується простір, в якому стає можливим проаналізувати всі властивості особистості в динаміці іiі 
хронологічного становлення та розвитку. Від пересічної людини, до індивідуальності, особистості і, до особистості як суб'єкта культури саме в таких координатах прослідковується тривалий шлях акультурації і соціалізації людини, з можливістю ï системного вивчення та пізнання.

Творча особистість стає епіцентром наукової думки, формуючи основні вектори антропологічної філософії, психології та культурології. Головне місце посідають проблеми дослідження духовних феноменів буття людини, розглядаючи взаємозв'язок тілесного і художнього, механізми естетичної самореалізації особистості, процеси втілення іii художнього потенціалу у сфері комунікативного простору.

За результатами дослідження сформульовано визначення основних характеристик творчої особистості, iї функцій та властивостей. 3 урахуванням результатів наукової розвідки кристалізовано визначення творчої біографії особистості в контексті культурологічних та мистецтвознавчих узагальнень.

На сьогодні проблема вивчення творчих біографій є актуальним i вкрай важливим питанням. Досліджуючи творчі біографії Митців, ми заповнюємо прогалини не тільки в національній культурно-історичній спадщині, а й формуємо нову картину комунікативної моделі численних етнічних культур.

\section{Список літератури:}

1. Аврелий Марк. Наедине с собой: Кн. 2. Абзац 17. URL: https://psylib.org.ua/books/avrel01/txt01.htm (дата обращения: 12.07.2017).

2. Беленький И. Л. Биография и биографика в отечественной культурно-исторической традиции // История через личность: историческая биография сегодня. Москва: Вестник МГУКИ, 2005. С. 37-54.

3. Вергилий М. П. Георгики // Вергилий М. П. Георгики. Москва: Эксмо, 2007. C. $10-40$.

4. Гегель Г.В.Ф. Феноменология духа. М.: Наука. - 2000. -495 с.

5. Гуменюк Т.К. Продовження глінкініани : стиль автора у просторі сучасного наукового мислення (Тышко С.В. Странствия Глинки. Комментарии к «Запискам»: в 4-х ч. - Ч. 4: Кавказ. Киев: ЛАТ. 2015. 234 с.) // Часопис Національної музичної академії України імені П. І. Чайковського. 2015. № 3 (28). C. $150-156$.

6. Климчук В. О., Мойсієнко Я. В. Життєвий шлях творчої особистості: принципи біографічного дослідження за допомогою сценарного аналізу Е. Берна // Соціальна психологія. 2007. № 6. С. 32-44.

7. Левченко О.Г. Театр у системі філософської антропології: монографія/ Олена Левченко; Нац. Цент театр. мист. ім. Леся Курбаса. - К., 2012. - 296 с. 


\section{Bondarchuk Viktor}

8. Левчук Л. Т. Проблема художньої творчості в контексті сучасної естетичної теорії: процес концептуалізації // Гуманітарний часопис. 2014. № 3. C. 9-16.

9. Монтень М. Опыты: в 2 кн. / пер. А. С. Бобовича и др. Кн. 1. Москва: Голос, 1992.

10. Пачеко С. Отрывки из книги «Искусство живописи, ее древность ы величие». Мастера искусства об искусстве. Избранные отрывки из писем, дневников, речей и трактатов: в 4 т. / под общ. ред. Д. Аркина и Б. Терновца. Москва; Ленинград: Изогиз, 1936-1939. Т. 1: Ренессанс и (XV-XVIII вв.) / ред А. Губер, А. Сидоров; вводн. ст. Л. Пинского. Москва; Ленинград: Изогиз, 1936. C. 396-438.

11. Петрина А. Б. Научная биография в российской культурной и интеллектуальной традиции: поиск новой модели: дис. ... канд. исторических наук: спец. 24.00.01 Теория и история культуры / Омский гос. Ун-т путей сообщ. Омск, 2009. 182 с.

12. Попик В. І. Світоглядні засади розвитку української біографістики та формування національних ресурсів біографічної інформації XX століття // Українська біографістика: зб. наук. пр. Ін-ту біогр. дослідж. Київ, 2008. Вип. 4. С. 8-40.

13. Попова Т. Н. Жизнеописание ученого-историка на перекрестке историографических традиций: теория, методология, практика // Ейдос. Альманах теорії та історії історичної науки. Київ, 2015. № 8. С. 15-40.

14. Попова Т. Н. Историография в человеческом измерении // Історіографічні дослідження в Україні. 2012. Вип. 22. С. 265-292.

15. Попович О. В. Біографія як феномен культури // Гуманітарний часопис. 2011. № 2. C. $96-103$.

16. Редя В. Я. Музично-критична діяльність П. І. Чайковського // Мистецтвознавчі записки: зб. наук. пр. / Нац. акад. кер. кадрів культ. і мистецтв. Київ, 2010. Вип. 18. С. 3-9.

17. Рожок В. І. Стефан Турчак / переднє сл. Б. Олійника. Київ: Либідь, 2013. 248 с.; іл.

18. Станішевський Ю. О. Дмитро Гнатюк. Київ: Муз. Україна, 1991. $167 \mathrm{c}$.

19. Теофраст. Характеристики // Электронная библиотека royallib.com. URL: royallib.com/book/teofrast/harakteristiki.htm (дата обращения: 12.07.2017).

20. Тышко С.В., Мамаев С.Г. Странствия Глинки. Комментарий к «Запискам». Часть II. Глинка в Гермаании или Апология романтического сознания. Киев. ТОВ «Задруга». 2002. 508 с.

\section{References:}

1. Aurelius Mark. Nayedine s soboy. [Private with you]. Available at: https://psylib.org.ua/books/avrel01/txt01.htm.

2. Belenky I. (2005). Biografiya i biografiya v otechestvennoy kul'turno-istoricheskoy traditsii. [Biography and biography in the national cultural-historical tradition]. Moscow: Vestnik. Pp. 37-54.

3. Vergil M. (2007). Georgiki. [Georgiques]. Moscow: Exmo. P. 10-40. 


\section{Creative biography in the coordinates of the humanities: historiography...}

4. Hegel G. (2000). Fenomenolohyya dukha [Phenomenology of the spirit]. Moscow, P. 495.

5. Gumenyuk T.K. (2015). Prodovzhennya hlinkiniany : styl avtora u prostori suchasnoho naukovoho myslennya [Continuation of glinkiniyan: author's style in the space of modern scientific thinking]. Kyiv, P. 150-156.

6. Klimchuk V.O. (2007). Klymchuk V. O., Moysiyenko YA. V. Zhyttyevyy shlyakh tvorchoyi osobystosti: pryntsypy biohrafichnoho [Moysienko Ya.V. The Life Path of the Creative Personality: Principles of Biographical Research Using the Scenario Analysis of E. Bern]. Kyiv, P. 32-44.

7. Levchenko O.G. (2012). Teatr u systemi filosofs'koyi antropolohiyi: monohrafiya [Theater in the system of philosophical anthropology]. Kyiv, P. 296.

8. Levchuk L.T. (2014) Problema khudozhn'oyi tvorchosti v konteksti suchasnoyi estetychnoyi teoriyi: protses kontseptualizatsiyi [The problem of artistic creation in the context of modern aesthetic theory: the process of conceptualization]. Kyiv, P.9-16.

9. Monten M. (1992). Monten M.( 1992). Opyty. [Experiences]. Moscow: Voice.

10. Pacheco S. (1936-1939). Otryvki iz knigi "Iskusstvo zhivopisi, yeye drevnost' y velichiye". Mastera iskusstva ob iskusstve. Izbrannyye otryvki iz pisem, dnevnikov, rechey i traktatov. [Excerpts from the book "The Art of Painting, Its Antiquity is Greatness." Masters of Art on Art. Selected excerpts from letters, diaries, speeches and treatises]. Moscow; Leningrad: Izogiz, P. 396 - 438.

11. Petrina A. (2009). Nauchnaya biografiya v rossiyskoy kul'turnoy i intellektual'noy traditsii: poisk novoy modeli. [Scientific biography in the Russian cultural and intellectual tradition: the search for a new model]. Omsk $182 \mathrm{p}$.

12. Popyk V. (2008). Svitohlyadni zasady rozvytku ukrayinskoyi biohrafistyky ta formuvannya natsionalnykh resursiv biohrafichnoyi informatsiyi KHKH stolittya. [World-view principles of the development of Ukrainian biography and formation of national resources of biographical information of the twentieth century]. Kyiv. 8-40.

13. Popova T. (2015). Zhizneopisaniye uchenogo-istorika na perekrestke istoriograficheskikh traditsiy: teoriya, metodologiya, praktika. [Biography of the historian at the crossroads of historiographic traditions: theory, methodology, practice]. Kiev. P. 15-40.

14. Popova T. (2012). Istoriografiya v chelovecheskom izmerenii. [Historiography in the Human Dimension]. Kyiv. P. 265-292.

15. Popovich O. (2011). Biohrafiya yak fenomen kultury. [Biography as a Culture Phenomenon]. Kyiv. P. 96-103.

16. Reda V. (2010). Muzychno-krytychna diyalnist P. I. Chaykovskoho. [The musical-critical activity of Pyotr Tchaikovsky]. Kiev. P. 3-9.

17. Roshok V. (2013). Stefan Turchak [Stefan Turchak]. Kiev, 248 P.

18. Stanishevsky Y. (1991). Dmytro Hnatyuk [Dmytro Hnatyuk]. Kiev, 167 P.

19. Theophrastus. Characteristics. Available at: royallib.com/book/teofrast/ harakteristiki.htm.

20. Tyshko S., Mamaev S. Stranstviya Glinki [Glinka's Wanderings]. Kiev, 508 P. 


\title{
INFLUENCE OF HIGH TEMPERATURE ON DAIRY PRODUCTIVITY OF UKRAINIAN SCHWYZ
}

\author{
Vasilenko Tetyana ${ }^{1}$ \\ Milostiviy Roman ${ }^{2}$ \\ Kalinichenko Olena ${ }^{3}$
}

DOI: http://dx.doi.org/10.30525/978-9934-571-26-8_3

Abstract. In monitoring studies of recent years, global warming is reported. This is a significant problem for dairy farming in much of Europe, especially in the central and southern regions, as reported by numerous studies. Dairy cattle highly productive are extremely sensitive to hot temperatures; their consequence is health problems, a significant reduction in milk yield and milk quality. Unfortunately, heat stress remains an unrecognized problem for domestic cattle breeding, although the financial losses from its harmful influence in European are quite substantial. The aim of our work was to study the effect of high temperatures on milk yield of cows of Ukrainian Schwitz on one of the complexes of high-tech milk production. At the beginning of the research, we decided to test the hypothesis of increasing hot air temperatures in the warm period of the year compared with the long-term data. Then we studied how the milk of Schwitz breed varies during the hot season, depending on the magnitude of the maximum temperature values. According to the results of the study, it can be noted that the air temperature during the warm period of 2017 tended to increase $\left(+0.6^{\circ} \mathrm{C}\right)$ in comparison with the long-term data. In August, the air temperature significantly exceeded the long-term data by $+3{ }^{\circ} \mathrm{C}(\mathrm{td}=2.89, \mathrm{P}<0.05)$. The obtained results testify that in the conditions of the central region of Ukraine in the warm period of the year the probability of occurrence of heat stress in dairy cows is high. In the warm season of 2017, the period during which THI exceeded the comfortable value for dairy cows was 100 days. At the same time, a decrease in productivity per cow in the hot season may

\footnotetext{
${ }^{1}$ Candidate of Agricultural Sciences, Associate Professor,

Dnepropetrovsk State Agrarian-Economic University, Ukraine

${ }^{2}$ Candidate of Veterinary Sciences, Associate Professor,

Dnepropetrovsk State Agrarian-Economic University, Ukraine

${ }^{3}$ Candidate of Agricultural Sciences, Associate Professor,

Dnepropetrovsk State Agrarian-Economic University, Ukraine
} 
amount to $146 \mathrm{~kg}$ of milk, and the loss may reach 39.5 EUR / cow. To prevent heat stress in conditions of year-round maintenance of dairy cattle, it is advisable to use active ventilation systems with humidification of air. The relationship between the temperature and milk yield of cows is revealed by an average degree of reliability $(\mathrm{r}=-0.45, \mathrm{P}<0.05)$. Compared with the most favorable external conditions in May, the cows' milk yield decreased in June by $3.0 \%$, the yield of milk fat by $5.2 \%$, the milk protein content by $3.4 \%(\mathrm{P}<0.001)$. In July and August, the cows' milk yield decreased by 4.6 and $5.5 \%(\mathrm{P}<0.001)$, the yield of milk fat decreased by 3.1 and $7.3 \%$ $(\mathrm{P}<0.01-0.001)$, the yield of milk protein 3.4 and $5.7 \%(\mathrm{P}<0.001)$. Thus, high temperatures during the summer period contributed to a decrease in milk yield and the main components of milk of the Ukrainian Schwitz, which can lead to tangible financial losses.

\section{Introduction}

In monitoring studies of recent years, global warming is reported. This is a significant problem for dairy farming in much of Europe, especially in the central and southern regions, as reported by numerous studies. According to experts [17, p. 18], for the EU countries the problem of heat stress is quite relevant. In the summer, losses in the dairy sector can be about $3 \mathrm{~kg}$ of milk per cow per day. In the southern regions of Europe (Spain, Italy and southern France) cattle are exposed to heat stress for most of the day (13-18 hours), losing up to $5.5 \mathrm{~kg}$ of milk per cow per day. And even in the northern regions of Europe (Switzerland, Czech Republic and Poland), dairy cows can be exposed to heat stress from 6 to 10 hours a day. A sharp increase in the temperature of the environment in Eastern Europe leads to an increase in cases of abnormal heat during the summer time (the duration of the stress period may be 30 to 60 days), which leads to a deterioration in the conditions of animals and financial losses in dairy cattle. Dairy cattle highly productive are extremely sensitive to hot temperatures; their consequence is health problems $[7, \mathrm{p} .260$; 9, p. 37], a significant reduction in milk yield and milk quality [12, p. 1]. Unfortunately, heat stress remains an unrecognized problem for domestic cattle breeding, although the financial losses from its harmful influence in European countries are estimated at an average of more than 400 euro per cow per year [17, p. 18]. Previous studies [14, p. 229] indicate a high probability of occurrence of thermal stress in cows in the conditions of 
high temperatures in the central part of Ukraine and significant economic losses in dairy cattle breeding [20, p. 128].

The aim of this work was to study the influence of high temperatures in summer on the productivity of cow's of the Schwitz, in conditions of keeping in stalls all year round with a paddocks in the large dairy complex.

\section{Materials and Methods}

Long-term data, as well as the dynamics of air temperatures in the warm period of 2017 (from May to September inclusive) at the location of the dairy complex (where the animals are kept in light barns) were taken into account by analyzing the materials of the weather report archive (www. accuweather.com). The yield of cows was assessed using the herd management system "Dairy Comp 305«. The average amount of milk received per day, the yield of milk fat and protein per herd of cows was taken into account throughout the study period. To process the data obtained and to evaluate the reliability of the indicators, the software Statistica 10 was used. In order to assess the likelihood of occurrence of heat stress, during the warm period of 2017, every day at different times of the day (four times), the air temperature and relative humidity were measured. The temperature-humidity index was determined by the conventional method (Kibler, 1964):

$$
T H I=1.8 \times T-(1-R H / 100) \times(T-14.3)+32 \text {, where }
$$

THI is the temperature-humidity index

$T$ is the ambient temperature $\left({ }^{\circ} \mathrm{C}\right)$;

$R H$ is the relative humidity of air (\%).

\section{Influence of high temperature on dairy productivity}

It was found that the average temperature during the warm period of the year from May to September $2017\left(26.4^{\circ} \mathrm{C}\right)$, slightly increased $\left(0.6^{\circ} \mathrm{C}\right)$, compared with the long-term data, but did not have significant differences $(\mathrm{td}=1.07 ; \mathrm{P}>0.05)$. However, in August this year was hotter than the longterm data. The air temperature exceeded the average values by $3.0^{\circ} \mathrm{C}$ $(\mathrm{td}=2.89, \mathrm{P}<0.001)$, and in certain periods of this month the excess of the multi-year maximum was $8.0^{\circ} \mathrm{C}$. Unusually hot was September, the difference between long-term data and temperature in certain periods this month was $10-13{ }^{\circ} \mathrm{C}$, at the highest temperatures up to $35^{\circ} \mathrm{C}$, which is not very typical for this time of year (Figure 1). 


\section{Influence of high temperature on dairy productivity of Ukrainian schwyz...}

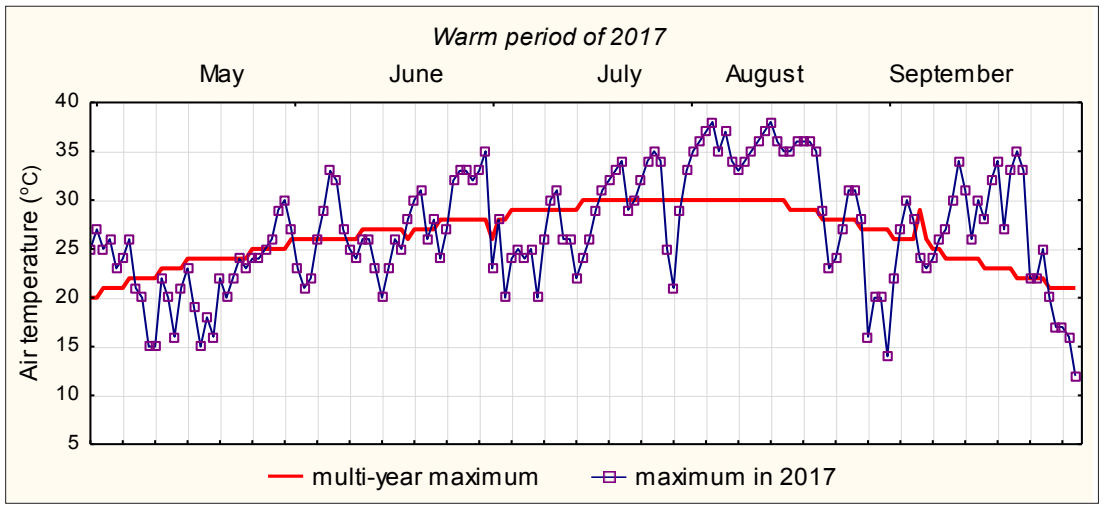

Fig. 1. Dynamics of maximum temperatures during the period from May to September

Analysis of the state of the air environment and the level of productivity of animals in the hot period indicates a significant dependence of the daily milk yield on the temperature of the air, between which the average degree of negative correlation $(\mathrm{r}=-0.45 ; \mathrm{P}<0.05)$ was detected. As can be seen from the data (Figure 2), periods of growth of external temperatures were accompanied by a significant decrease in the daily milk yield in cows.

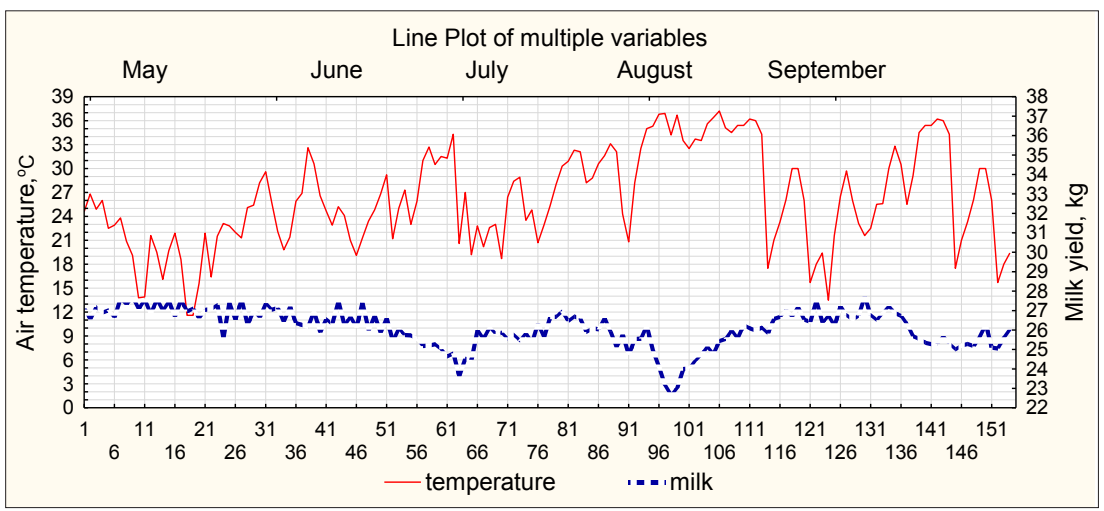

Fig. 2. Dependence of daily milk yield on external temperatures during the hot season 
We found that the most favorable temperature conditions for the manifestation of milk productivity in cows were in May. This month, with an average air temperature of $14.7^{\circ} \mathrm{C}$, the average yield of milk in a herd of cows averaged $27.1 \mathrm{~kg}$ per day. We compared how high temperatures in the summer affected this figure in the future. In June, the average air temperature increased by $5^{\circ} \mathrm{C}$ and amounted to $19.7^{\circ} \mathrm{C}$. This resulted in a decrease in milk yield of cows by $3.0 \%(\mathrm{P}<0.001)$. The yield of milk fat decreased by $5.2 \%(\mathrm{P}<0.001)$. The rise in temperature was also reflected in the yield of milk protein, the amount of which decreased by $3.4 \%(\mathrm{P}<0.001)$. Thus, the content of these indicators in June decreased by $850 ; 50$ and $30 \mathrm{~g}$ respectively (Figure 3).

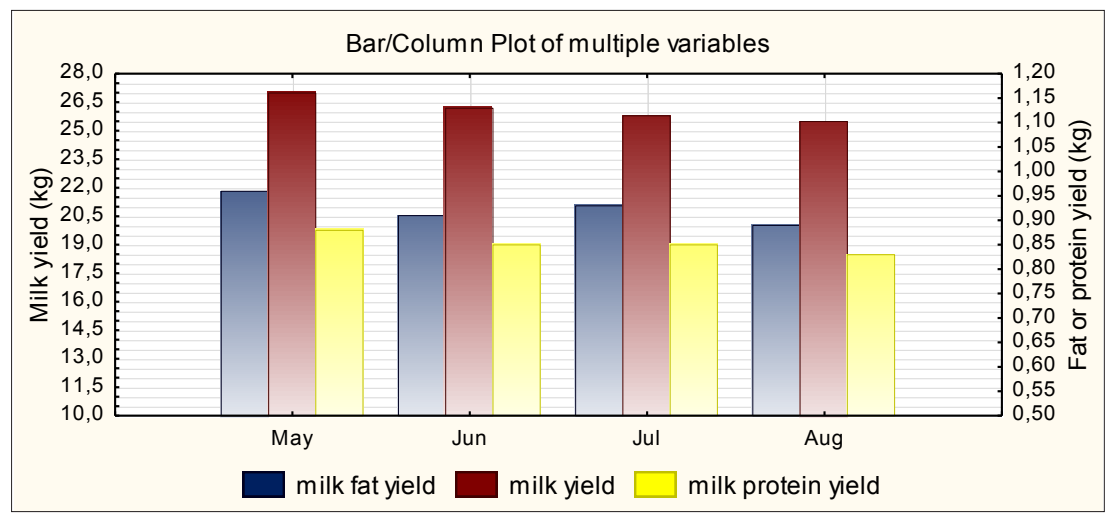

Fig. 3. Dynamics of milk production productivity in the heat of the year 2017

In July, the average air temperature was $20.7^{\circ} \mathrm{C}$, that is, it increased by $6.0^{\circ} \mathrm{C}$ compared to May. This led to a decrease in milk yield by $4.6 \%$ $(\mathrm{P}<0.001)$, milk fat yield by $3.1(\mathrm{P}<0.01)$ and milk protein yield by 3.4 ( $\mathrm{P}$ $<0.001$ ), or by $1390 ; 30$ and $30 \mathrm{~g}$ respectively.

August was the hottest month of summer. The average temperature was at $23.4^{\circ} \mathrm{C}$. Its increase of $9.2^{\circ} \mathrm{C}$ compared to May, led to a decrease in milk yield of cows by $5.5 \%(\mathrm{P}<0.001)$, milk fat yield by $7.3 \%(\mathrm{P}<0.001)$ and protein yield by $5.7 \%(\mathrm{P}<0.001)$ or $1540 ; 70$ and $50 \mathrm{~g}$ respectively. It should be noted that the monthly fluctuations in fat and protein content in milk (\%) were not reliable. 


\section{Heat stress in dairy cows and its economic consequences}

Hot temperatures and, in particular, heat stress, affect the health of animals through direct or indirect effects on physiology, metabolism, hormonal and immune system $[8$, p. $86 ; 18$, p. $96 ; 13$, p. 366]. The decline in productivity in dairy cows is associated, first of all, with a decrease in food intake and changes in the digestive tract [1, p. 311; 4, p. 4939].

The materials obtained about the decrease in the yield of milk and its components in cows under the influence of high temperatures are consonant with the results of other researchers. It is reported [3, p. 479] on the reduction of dry matter intake of feed (by $9.6 \%$ ) and decrease in milk yield (by $21 \%$ ) with a rise in temperature-humidity index (THI) from 68 to 78 . The increase in THI per unit over 69 was the reason reduction of milk yield in cows by $0.41 \mathrm{~kg}$ [19, p. 759]. It is enough four hours of finding cows in conditions of moderate heat stress for the loss of $1 \mathrm{~kg}$ of milk per day $[5$, p. 5]. High temperature and humidity not only caused the decrease in milk yield in cows, but also helped to reduce the yield of fat and milk protein by 39.7 and $16.9 \%$ [11, p. 59].

At high air temperatures, the temperature-humidity index (THI) is a common indicator of the assessment of heat stress (Kibler, 1964). To ensure comfortable conditions for animals, the THI value should be below 68 . THI at 68-71 corresponds to low stress, $72-79$ to moderate stress, 80 to 89 to severe stress and 90 to 99 to very high stress [17, p. 18].

We have studied the possibility of occurrence of heat stress in animals during the hot season of 2017 (from May to September). It is established (Table 1) that the value of the THI indicator directly depended on the temperature regime of the ambient air $(\mathrm{r}=0.98, \mathrm{P}>0.95)$.

Table 1

Average parameters of the temperature-humidity regime of the environment in the warm period of 2017

\begin{tabular}{lcccccc}
\hline \multicolumn{1}{c}{ Month } & \multicolumn{2}{c}{ Temperature of air, ${ }^{\circ} \mathbf{C}$} & \multicolumn{2}{c}{ Humidity of air, $\%$} & \multicolumn{2}{c}{ THI } \\
\hline & $\mathrm{M}$ & $\mathrm{m}$ & $\mathrm{M}$ & $\mathrm{m}$ & $\mathrm{M}$ & $\mathrm{m}$ \\
\hline May & 14.7 & 0.51 & 62.0 & 1.83 & 57.5 & 0.68 \\
\hline June & 19.7 & 0.47 & 60.9 & 1.65 & 64.9 & 0.58 \\
\hline July & 20.7 & 0.49 & 66.2 & 1.70 & 66.3 & 0.59 \\
\hline August & 23.4 & 0.60 & 53.0 & 1.90 & 68.8 & 0.65 \\
\hline September & 19.9 & 0.54 & 59.6 & 2.01 & 64.4 & 0.60 \\
\hline
\end{tabular}


As can be seen from the data presented, the average THI in August corresponded to the level of low stress. However, during the hot period of the day, throughout the warm period of the year taken for evaluation (May-September), the animals could be in a state of thermal stress of one or another force. So, in May, the value of THI in which dairy cattle could be in a state of heat stress was 5 days, including 3 days corresponding to a small stress and 2 days to moderate stress.

In June the value of THI in which dairy cattle could be in a state of heat stress was 25 days, of which 12 days corresponded to a low stress and 12 days to a moderate stress.

In July the value of THI during the period of maximum temperature rise, during the day at which dairy cattle could be in a state of heat stress was 22 days. However, the degree of manifestation of a possible stress reaction increased. During this period, the animals could be in a state of thermal stress of strong action (THI> 80) one day; 18 days corresponded to mild stress and only 3 days - a state of low stress.

The hottest was August 2017 (Figure 4). The number of days when dairy cattle could experience the heat stress of a strong effect was 7 days, moderate -17 and only 2 days a little stress. In this case, the THI value exceeding the comfort zone of the animals (68) this month was observed for 26 days.

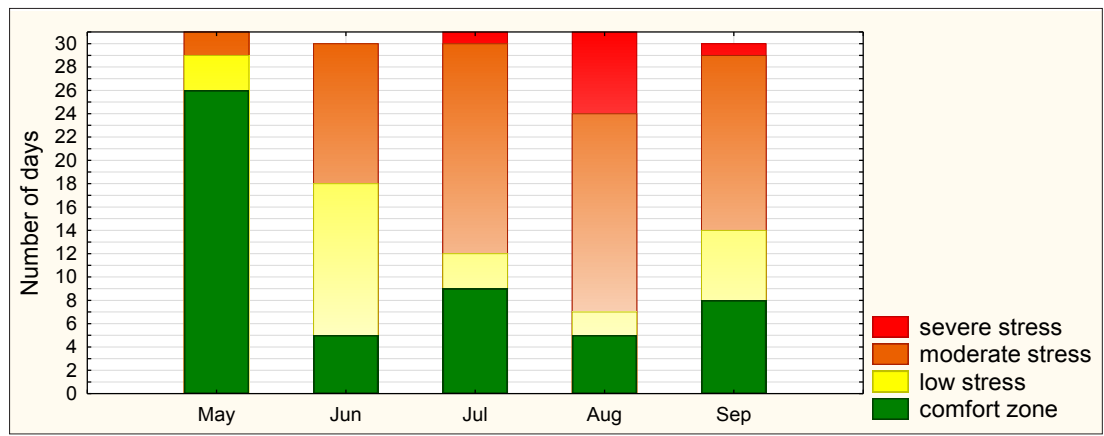

Fig. 4. Probability of heat stress in dairy cattle

Despite the long-term trend of temperature decrease, September, the year 2017 was characterized by significant maximum daily temperatures, the highest of which was raised to $+33 \ldots+35^{\circ} \mathrm{C}$ and higher. 
At the same time, the THI value, in which animals could be exposed to severe heat stress, was recorded for 1 day, moderate stress of 15 days and a slight stress of 6 days. In general, the number of days exceeding the conditions of comfort for animals in September was 22 days.

Thus, the index THI, which exceeded the value of comfort for dairy cows in the warm period in 2017 (from May to September inclusive), recorded over 100 days. This amounted to approximately $35 \%$ of the warm period of the year. Of these, 73 days were recorded during the hot summer period.

To prevent the effects of high temperatures in the barns of the dairy complex, active ventilation is used using the longitudinal arrangement of the fans. However, their independent use (without air humidification) proved to be insufficiently effective. As a consequence, for the period from June to September 2017 inclusive, losses per cow amounted to $146 \mathrm{~kg}$ of milk. Given the average price of milk sales in Ukraine (in terms of euro at the rate of the National Bank), as a result of high temperatures in the hot season of 2017 , the company incurred a loss in the dairy herd at a rate of 37.5 thousand $€$, or $39.5 €$ per 1 cow.

\section{Technical solutions for preventing heat stress}

Modification of the air environment of premises in hot weather usually consists of keeping dairy cows under shady canopies with ventilation-turbine blowing and spraying. In the results published in 1988 [23, p. 809], it was shown that the combination of wetting and forced ventilation can reduce the daily increase in rectal temperature by $0.3^{\circ} \mathrm{C}$ and increase the milk yield of cows by $3.6 \mathrm{~kg}$ per day. It is reported [22, p. 74] that the contents of cows in stalls throughout the year, the parameters of the air environment in the "cold" barn of the frame type were approximated as much as possible to the conditions of the environment. An increase in the external temperature from 19.6 to $33.0^{\circ} \mathrm{C}$, led to an increase in the indoors temperature from 20.4 to $28.5^{\circ} \mathrm{C}$. At the same time [15, p. 291] the use of the active ventilation and spraying system in the barn during the heat, prevented the rectal temperature increase in the cows by $0.4^{\circ} \mathrm{C}$ and promoted a decrease in respiration rate by 8 times / $\mathrm{min}$.

The proposed technical solution [16, p. 13] allows us to regulate the temperature regime and maintain the relative humidity of air in the cattle-breeding premises. This is achieved by creating a water mist from small droplets with a normalized supply of water to the animal zone, and adjust- 
ing the time between humidification cycles. A distinctive feature of this device is that the nozzles are placed on a horizontal bar with the possibility of changing their height above the floor with brackets. They are equipped with electromagnetic valves with an automatic control unit for their operation. Using this device can be effective in the premises for animals of different age and height.

The device (Figure 5) consists of a circulating water circuit (1), a spray unit (2) with injectors (3), which is equipped with solenoid valves (not shown) and control brackets (4), which are mounted on vertical posts (5) in the corresponding position above the floor surface. The regulation of the water supply and its quantity, as well as the time between humidification cycles, is carried out with the help of the automatic control unit (6).

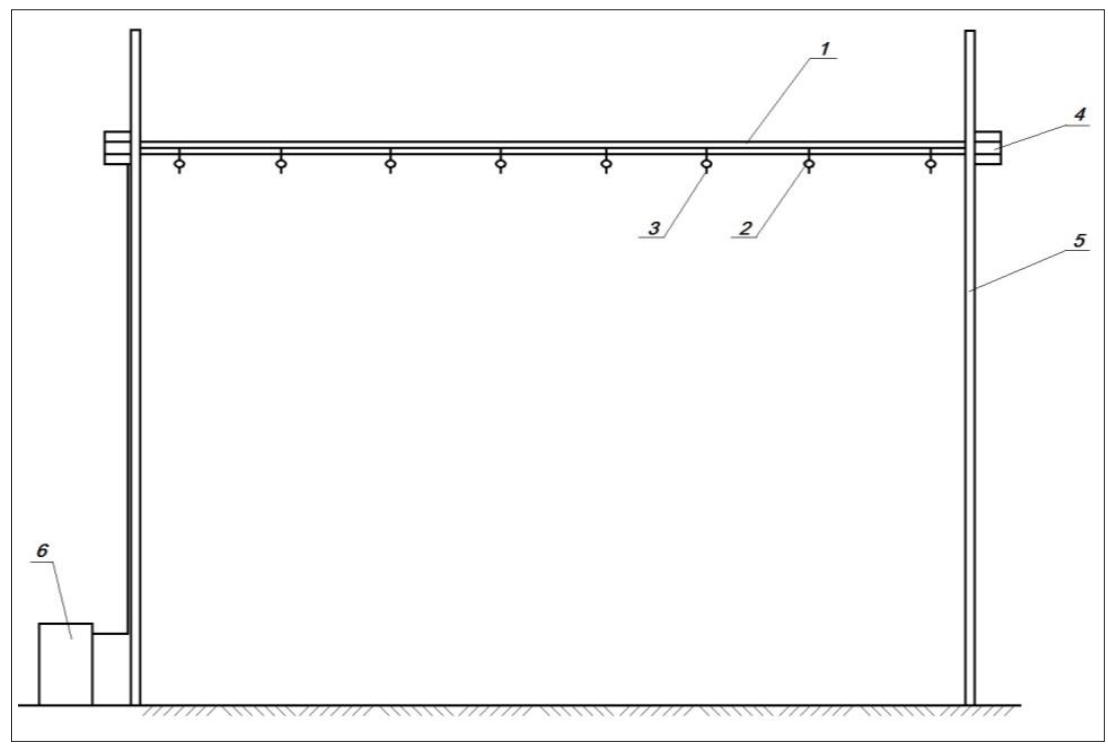

Fig. 5. An apparatus for humidifying and cooling air into the livestock house

The device operates as follows. In hot periods of animal maintenance, when there is a need to reduce the temperature of the air, adjust the height of the brackets (4) above the floor. Water from the main line is fed to the circulation circuit (1), spray units (2). Electro-magnetic valves started or 
stop the flow of water to the injectors (3) using the automatic control unit (6). When high-pressure water exits, a micro drop mist is formed from the nozzles (droplet sizes of up to 30 microns), which eliminates the risk of wetting the litter material. Due to the evaporation of parts of the water, the cattle-breeding premises are roughly cooled to $4 \ldots 10^{\circ} \mathrm{C}$. There is also the possibility of using a set of equipment for disinfection of large-sized premises of an industrial complex [21, p. 60].

Thus, the technical solutions proposed by the staff of the Dnepropetrovsk State Agrarian and Economic University can be effectively used to maintain the health of the dairy herd of cows and prolong their productive longevity in industrial technology.

\section{Conclusions}

1. High temperatures during the summer period contributed to a decrease in milk yield and the main components of milk of the Ukrainian Schwitz. Therefore, to prevent the harmful effects of high temperatures on animals in conditions of year-round maintenance in barns of lightweight construction, it is advisable to use active ventilation systems with air humidification.

2. The THI indicator, which exceeded the comfortable value for dairy cows in the warm period of 2017 (May-September) was recorded for 100 days. As a result of high temperatures in the hot season of 2017, the loss for the dairy herd amounted to 37.5 thousand EUR, or 39.5 EUR per 1 cow.

3. The technical solutions proposed by the staff of the Dnepropetrovsk State Agrarian and Economic University can be effectively used to maintain the health of the dairy herd of cows and prolong their productive longevity in industrial technology.

\section{References:}

1. Baumgard, L. H., \& Rhoads, R. P. (2013). Effects of Heat Stress on Postabsorptive Metabolism and Energetics. Annual Review of Animal Biosciences, 1(1), 311-337. doi:10.1146/annurev-animal-031412-103644.

2. Bernabucci, U., Ronchi, B., Lacetera, N., \& Nardone, A. (2002). Markers of Oxidative Status in Plasma and Erythrocytes of Transition Dairy Cows During Hot Season. Journal of Dairy Science, 85(9), 2173-2179. doi:10.3168/jds. s0022-0302(02)74296-3.

3. Bouraoui, R., Lahmar, M., Majdoub, A., Djemali, M., \& Belyea, R. (2002). The relationship of temperature-humidity index with milk production of dairy cows in a Mediterranean climate. Animal Research, 51 (6), 479-491. doi:10.1051/animres:2002036. 
4. Bravo, D. M., \& Wall, E. H. (2016). The rumen and beyond: Nutritional physiology of the modern dairy cow 1. Journal of Dairy Science, 99(6), 4939-4940. doi:10.3168/jds.2015-10191.

5. Burjakov, N.P., M.A. Burjakova, \& D.E. Aleshyn (2016). Teplovoj stress y osobennosty kormlenyja molochnogo skota Rossyjskyj veterynarnыj zhurnal, 3, 5-13 (in Russian).

6. Caso, J., Leza, J., \& Menchen, L. (2008). The Effects of Physical and Psychological Stress on the Gastrointestinal Tract: Lessons from Animal Models. Current Molecular Medicine, 8 (4), 299-312. doi:10.2174/156652408784533751.

7. Das, R., Sailo, L., Verma, N., Bharti, P., Saikia, J., Imtiwati, \& Kumar, R. (2016). Impact of heat stress on health and performance of dairy animals: A review. Veterinary World, 9 (3), 260-268. doi:10.14202/vetworld.2016.260-268.

8. Do Amaral, B. C., Connor, E. E., Tao, S., Hayen, M. J., Bubolz, J. W., \& Dahl, G. E. (2011). Heat stress abatement during the dry period influences metabolic gene expression and improves immune status in the transition period of dairy cows. Journal of Dairy Science, 94 (1), 86-96. doi:10.3168/jds.2009-3004.

9. Fournel, S., Ouellet, V., \& Charbonneau, É. (2017). Practices for Alleviating Heat Stress of Dairy Cows in Humid Continental Climates: A Literature Review. Animals, 7(12), 37. doi:10.3390/ani7050037.

10. Halliwell, B. (2012). Free radicals and antioxidants: updating a personal view. Nutrition Reviews, 70 (5), 257-265. doi:10.1111/j.1753-4887.2012.00476.x.

11. Kadzere, C.., Murphy, M.., Silanikove, N., \& Maltz, E. (2002). Heat stress in lactating dairy cows: a review. Livestock Production Science, 77 (1), 59-91. doi:10.1016/s0301-6226(01)00330-x.

12. Liu, Z., Ezernieks, V., Wang, J., Arachchillage, N. W., Garner, J. B., Wales, W. J., ... Rochfort, S. (2017). Heat Stress in Dairy Cattle Alters Lipid Composition of Milk. Scientific Reports, 7(1). doi:10.1038/s41598-017-01120-9.

13. López-Gatius, F., \& Hunter, R. (2017). Clinical relevance of pre-ovulatory follicular temperature in heat-stressed lactating dairy cows. Reproduction in Domestic Animals, 52 (3), 366-370. doi:10.1111/rda.12916.

14. Milostivyj R.V., Vasilenko T.O., Vysokos N.P., Kalinichenko A.A., \& Milostivaja D.F. (2017). Ocenka verojatnosti razvitija teplovogo stressa u vysokoproduktivnyh korov v uslovijah centra Ukrainy. Materialy mezhdunarodnoj nauchno-prakticheskoj konferencii "Prodovol'stvennaja bezopasnost': ot zavisimosti k samostojatel'nosti" (12-13 dekabrja). Smolensk, 229-237 (in Russian).

15. Milostivyj, R.V., Visokos, N.P., Priluckaja, E.V. \& Tihonenko, V.A. (2016). Meroprijatija po stabilizacii mikroklimata $\mathrm{v}$ zhivotnovodcheskih pomeshhenijah $\mathrm{v}$ zharkih pogodnyh uslovijah. Prioritetnye i innovacionnye tehnologii v zhivotnovodstve - osnova modernizacii agropromyshlennogo kompleksa Rossii: Sb. nauch. statej. - Stavropol', 291-295 (in Russian).

16. Pugach, A.M., Visokos, M.P., Milostivij, R.V., Tjupina, N.V. \& Kalinichenko, A.O. (2016). Patent na korisnu model' № 108437, MPK F24F 6/12 "Pristrij dlja zvolozhennja ta oholodzhennja povitrja v tvarinnic'komu primishhenni"; Zajavl. 26.02.16. Opubl. 11.07.2016. Bjul. № 13 (in Ukrainian).

17. Pyron, O., \& Y. Malynyn (2015). Nuzhno ly predotvrashhat' teplovoj stress u dojnыh korov? Эffektyvnoe zhyvotnovodstvo, 3-4 (113), 18-20 (in Russian). 


\section{Influence of high temperature on dairy productivity of Ukrainian schwyz...}

18. Rashid, M., Hossain, M., Azad, M., \& Hashem, M. (2013). Long term cyclic heat stress influences physiological responses and blood characteristics in indigenous sheep. Bangladesh Journal of Animal Science, 42(2). doi:10.3329/bjas. v42i2.18486.

19. Spiers, D. E., Spain, J. N., Sampson, J. D., \& Rhoads, R. P. (2004). Use of physiological parameters to predict milk yield and feed intake in heat-stressed dairy cows. Journal of Thermal Biology, 29(7-8), 759-764. doi:10.1016/j.jtherbio.2004.08.051.

20. Vasilenko T., Milostiviy R., Kalinichenko A., Milostiva D. (2018). Heat stress in dairy cows in the central part of Ukraine and its economic consequences. Social and economic aspects of sustainable development of regions. Monograph. Opole, 128-135.

21. Vysokos M.P., Milostiviy R.V., Kalinichenko O.O., Tikhonenko V.A., Sanzhara R.A. (2017). Technical support of aerosol processing for large groups of animals under the conditions of the industrial complex. Science and Technology Bulletin of SRC for Biosafety and Environmental Control of AIC, 5 (1), 60-64.

22. Vysokos, M.P., Milostiviy, R.V., Typina, N.V., \& Kalinichenko, A.O. (2015). Zoogigijenichna ocinka umov utrymannja molochnogo gurtu golshtyns'koi' hudoby za parametramy mikroklimatu monobloku korivnyka v regioni Prydniprov'ja. Naukovo-tehnichnyj bjuleten' NDC biobezpeky ta ekologichnogo kontrolju resursiv APK, 3(4), 74-78 (in Ukrainian).

23. Wolfenson, D., Flamenbaum, I., \& Berman, A. (1988). Dry Period Heat Stress Relief Effects on Prepartum Progesterone, Calf Birth Weight, and Milk Production. Journal of Dairy Science, 71(3), 809-818. doi:10.3168/jds.s0022-0302(88)79621-6. 


\section{BUCKWHEAT SELECTION IN SOUTH WESTERN FOREST STEPPE CONDITIONS OF UKRAINE}

\section{Vilchynska Lydmila ${ }^{1}$ \\ Horodyska Olesia ${ }^{2}$}

DOI: http://dx.doi.org/10.30525/978-9934-571-26-8_4

Abstract. The research subject is the buckwheat breeding process in the direction of creating a source material on crop yield and grain quality technological indicators, and by early maturity signs, drought resistance and other economically important features adapted to the southwestern forest-steppe conditions of Ukraine.

The research purpose: on the collection basis of the global gene pool of buckwheat Fagopyrum Mill, to create a new source material on crop yield and technological indicators of grain quality, and early maturity signs and drought resistance, adapted to the southwestern forest-steppe conditions of Ukraine.

Methodology: the metameric features usage of the stalk structure of buckwheat plants is proved and the relationship between the fruiting and branching areas of the shoot for the rapid assessment of promising material on the early maturity basis is established. Donors have been identified for breeding programs on the early maturity basis: Kazanka, Mriia, Veselka, Mih, Solianska, Smuhlianka, Zhniaiarka, № 4013.

The germination method efficiency of buckwheat grains in osmotic solutions has been established to determine its drought resistance. Donors to source material creation on the drought resistance basis are varieties: Kazanka, Mriia, Veselka, Skorostyhla 86, Smuglianka, Kazanka, Alonushka, Veselka.

A buckwheat variety model adapted to the southwestern Forest-Steppe conditions has been developed, an established advantage for the main economically valuable indicators of the newly created varietal samples 7/07.

Created early and drought-resistant buckwheat numbers $(7 / 06,22 / 06$, $23 / 06,24 / 06,25 / 06,4 / 07,5 / 07,6 / 07,15 / 07,16 / 07,33 / 03,219 / 02)$ are

\footnotetext{
${ }^{1} \mathrm{PhD}$ in Agriculture,

Associate Professor of Plant Growing, Selection and Seed Production Department,

Podilskyi State Agrarian and Engineering University, Ukraine

${ }^{2} \mathrm{PhD}$ in Agriculture,

Assistant of Agrochemistry, Chemical and General Biological Disciplines Department,

Podilskyi State Agrarian and Engineering University, Ukraine
} 
characterized in comparison with the standard by high yield and quality of grain, the best economic indicators and are used in breeding programs of the Scientific Research Institute of Crops Research Institute of Podilskyi State Agrarian Engineering University. They were transferred to the National Center of Plant Production Institute nd. a V.Ya. Yuryev of NAAS of Ukraine (NCPPI NAASU) and the Plant Variety Expertise Ukrainian Institute of Plant Varieties Examination (buckwheat of edible Kamianchanka date of submission 18.03. 2016 application № 16008001).

Received author's certificates for buckwheat edible: Malynka, Perlyna Podillia, Kvitneva; The certificate on drought-resistant, like buckwheat sample 7/07, issued by NCPPI NAASU.

\section{Introduction}

One of the most important tasks of modern buckwheat breeding is the source material creation with yield and resistance high level to unfavorable environmental factors, particularly in the context of global warming and its aridity. However, until recently, theoretical studies and directed selection of buckwheat for its early ripeness and drought resistance have not received due attention. Therefore, the study of the existing gene pool from the world collection of buckwheat Fagopyrum Mill, the regularities identification in the formation and inheritance of signs of its early maturity, drought resistance, the creation of a new selection-valuable material adapted to the Forest-Steppe conditions of Ukraine, is an actual task of modern breeding [2, pp. 86-98; 3, pp. 38-42; 5, pp. 136-137; 23, pp. 27-29; 27, pp. 9-10; 34,36 , pp. 20-22; 37, pp. 32-33].

The novelty of topic. For the first time in the southwestern forest-steppe conditions of Ukraine, the morphological characteristics variability of buckwheat plants was revealed, main elements correlation links of seed production were established, namely: the number of inflorescences on the plant with the number of grains and the grain mass from the plant and the height of plants. The genotype-environment interactions and the inheritance rates of plant heights, the number of inflorescences, the amount and mass of grain from the plant, the mass of 1000 grains were studied. The index ratio of morphological indices is determined, which characterizes the early maturity of the variety or the buckwheat form.

The buckwheat varieties model parameters, adapted to the conditions of the southwestern Forest-Steppe were determined for the first time by 


\section{Vilchynska Lydmila, Horodyska Olesia}

the main economic indicators. The express estimation peculiarities of the drought resistance level of buckwheat by the germination method of grains in osmotic solutions are revealed.

A new selection material has been created 33/03, 28/03, 94/01, 219/02, 101/01, 91/01, 83/01, 172/01, 150/01, 89/01, 96/01, 7/06 22/06, 23/06, 24/06, 25/06, 5/07, 7/07, 8/07, 15/07, 24/07, 26/07, which are donors of precocity, drought resistance, increased productivity and the quality of buckwheat seeds [6, pp. 14-19; 18, pp. 207-210].

Practical significance of the obtained results. The new source material (7/07, 8/07, 24/06, 5/07, 15/07, 24/07, 26/07, 19/06) is used in the selection programs of scientific research institutions: the Yaltushkivskii experimental station of the Institute of Bioenergetic cultures and sugar beet NAAN, Ustymivskii experimental station of plant selection named after. V.Ya. Yur'eva NAAN, Subsidiary enterprise pilot farm "Podilske", Ternopil Experimental Station IKHSP NAAN, VP NUBiP of Ukraine, "Zalishchyky Agrarian College named after. E. Khraplyvyi ». Prospective numbers of hybrid origin 7/06, 22/06, 23/06, 24/06, 25/06, 4/07, 5/07, 6/07, 7/07, 15/07 and 16/07 are used in selective programs of the Scientific Research Institute of Crops of Podilskyi State Agrarian and Engineering University, and the best of them 7/07 $($ Kazanka $\times$ Smuhlianka $) \times$ Smuhlianka, 24/07 $\mathrm{SC}_{2} \mathrm{~F}_{4}$ Roksolana $\times$ Kazanka - transferred to the State variety testing as new varieties quality.

The scientific research relevance. The researches were carried out by the authors, they are constituent parts of the state budget subject of the Research Institute of Crops by the registration number 01001U003326, 0107U011751 on the topics: "Selection for high and stable productivity of buckwheat varieties adapted to changing conditions of cultivation and development of energy-saving technologies for their cultivation and harvesting for conditions of the southwestern region of Ukraine" and "Selection and creation of highly productive buckwheat varieties for spring and summer sowingi, the development of technologies their groving conditions for south-western region of Ukraine".

The research purpose: using the global gene pool collection of buckwheat Fagopyrum Mill to create a new source material by hybridization with high yield and technological indicators of grain quality and on the signs of precocity and drought resistance, adapted to the southwestern Forest-Steppe conditions of Ukraine.

To achieve this goal, the following tasks were accomplished: 
- to investigate and characterize the various varieties of buckwheat from the collection of buckwheat Fagopyrum Mill, to select the optimal output forms;

- to conduct simple and repeated crosses and get hybrids of buckwheat $\mathrm{F}_{0}, \mathrm{~F}_{1}, \mathrm{~F}_{2}$;

- establish, on the comparative assessment basis, the economically important indicators of buckwheat grains (early maturity and drought resistance, vegetation period, productivity and technological indicators of grain quality);

- determine the coefficients of inheritance and variation, the phenotypic dominance degree of buckwheat hybrids that are different in terms of output forms;

- to test new varieties of buckwheat in production, to give an economic assessment of their cultivation.

Research conditions: Field research was carried out in the selection crop rotation of the Research Institute of Crops Scientific Research Institute named after. A.S. Alekseeva Podilskyi State Agrarian and Engineering University (SRICC PDATU) and farms and research institutions of Khmelnytskyi, Chernivtsi, Ternopil and Poltava regions for the period 2006-2017.

The soil cover of the experimental field in the overwhelming majority is represented by low-humus, weakly moisture-bearing chernozem. The main groundwater-bearing rock is the carbonate forest and loess-like loam [7, 8].

Methodology. The material for the studies was selected from the collection of the world gene pool RICC PDATU, from which 27 buckwheat varieties Fagopyrum esculentum Moench of different eco-geographical origin, 20 hybrid combinations and 93 hybrids of the first and second saturating crossings were used. The material was studied according to the scheme of the selection process in the selection, control nurseries, as well as the previous and competitive variety testing.

During the hybridization, the heterostylium phenomenon was used: at the beginning of flowering, the defects of plants D (pre-nostalgia) - the type of flowers in the maternal $(+)$ and $\mathrm{K}$ (short-stemmed) - type in the parental (ठ) forms were carried out. In this case, reciprocal crosses were carried out. Simple and complex reverse impregnating crosses were made between the selected numbers from the gene pool collection of the buckwheat genus Fagopyrum Mill and the selection varieties SRICC PDATU [29].

In the breeding seedbed, the numbers were sown for two with four rows areas with a registration area of 1.35 to $2.7 \mathrm{~m}^{2}$. The best hybrid numbers from this seedbed were studied in a control nursery with a registration area of 
$5 \mathrm{~m}^{2}$ in three repetitions. The standard in these nurseries was sown after the corresponding group of hybrids (of the same origin) or through 10 numbers.

Prospective hybrid numbers were studied at the sites of the previous (PS) and competitive (KS) strain tests with a sowing area of $31.5 \mathrm{~m}^{2}$ and accounting of $25 \mathrm{~m}^{2}$ in three (PS) and four (KS) repetitions [29].

The standard in all seedbed is Victoria, which is listed in the Register of Plant Varieties of Ukraine [20].

Bookmarks of experiments, material evaluation, analysis of plants, yield and grain quality were carried out in accordance with the generally accepted methodology of state variety testing. The material was studied under conditions of screen isolation created with the help of the buckwheat tetraploid form. The isolation technique proposed by E.D. Nettevych and M.V. Fesenko and improved by A.S. Alekseeva. The width of the screen bands was $10.8 \mathrm{~m}$ [33, pp. 41-45; 1, pp. 124-141].

Seeding method - wide-row with a row spacing of $45 \mathrm{~cm}$, a cassette seeder SKS-6-10, sowing was carried out on May 12-27.

The following observations, accountings, analyzes and calculations were carried out in the experiments.

1. Phenological observations were carried out according to the State variety testing method with phases fixation of full shoots, budding, flowering, ripening and maturation of $75 \%$ of the fruits. The duration of the vegetative and interphase periods was determined by counting the number of days.

2. The influence of weather conditions on the growth and buckwheat development was analyzed according to the Kamianets-Podilskyi meteorological post.

3. The density of planting was taken into account in the selected areas at the beginning and at the growing season end according to the method developed by V.F. Moiseichenko and V.A. Yeshchenko (1994) [30].

4. The harvest was recorded in a continuous method. The threshing was carried out by the "Sampo-135» combine. The yield was taken into account at $100 \%$ purity and standard moisture. The yield data were processed by the variance analysis method. B.A. Dospekhovym (1985) [22].

5. Analysis of the structure of plants was carried out according to the following parameters: plant height, cm; number of branches, pcs., incl. first order; all: the number of nodes, pcs.; on the main stem; node 1: branching and inflorescence; the number of inflorescences, grains, the grain mass from 
the plant and the mass of 1000 grains. The data obtained are analyzed by the variational statistics method [28].

6. The buckwheat grains quality was determined by such indicators (technological): the mass of 1000 grains, leveling, arillus and nature. The processing of grain quality data was carried out by the method of variance analysis. Analysis of the chemical composition of the grain for the content of trace elements, mycotoxins, pesticides and radionuclides was carried out in the state institution Khmelnytskyi Regional state design and technology center for soil fertility protection and product quality.

7. Buckwheat drought resistance in laboratory conditions was determined by germination of seeds in an osmotic solution of sucrose according to the method proposed by N.N. Kozhushko (1982). The drought resistance (P) indicator was determined by the ratio of the grains sprouting number in a sucrose solution with a concentration of $13.9 \%$, to grains germinating with water [26].

8 . The coefficients of heritability and indicators of the phenotypic dominance degree were determined by the methods described in such literary sources: Zhuchenko A.A. (1980), Griffing B. (1956) [19, pp. 463-493; 25 , pp. 18-20; 28].

\section{The main content of the reserch main results of buckwheat selection}

Buckwheat for Ukrainian has been long traditional national cereal crop, but its homeland is considered Tibet and the highlands of southern China, from where it gradually spread across the planet. So, in 2017 in comparison with 2000 the area of buckwheat field decreased by 3.5 times. But the total grain production decreased only 2.7 times, which indicates an increase in cultivation productivity. The main institutions engaged in breeding buckwheat in our country and whose varieties are included in the "State Register of Plant Varieties Suitable for Distribution in Ukraine" in 2014-2017, include [21]:

- National Science Center "Institute of Agriculture of the National Academy of Agrarian Sciences" (Chabany, Kyiv-Sviatoshinskyi district, Kyiv region), which owns such varieties as: Antharia, Lileia, Nadiina, Olha, Oranta, Ruta, Syn-3/02 Ukrainka, Malva [32]; and TzOV NV MP “Antariia", which is a co-owner of the varieties Syn-3/02, Oranta, Anthariia and owner of the varieties Sofiia and Volia [35];

- The Agriculture Institute of the Northeast of National Academy of Agrarian Sciences of Ukraine (v. Sad, Sumy district, Sumy region) owns 
the following buckwheat varieties listed in the State Register: Ivanna, Krupynka, Selianochka, Slobozhanka, Sumchanka, Yuvileina 100, Yaroslavna [24];

- Scientific Research Institute of Crops named by Alekseeva O.S. Podilskyi State Agrarian and Engineering University (Kamianets-Podilskyi, Khmelnytskyi Region), which owns such buckwheat varieties as Elena, Zelenokvitkova 90, Kara-Dah [31]. Also, the Podilskyi State Agrarian Engineering University together with the Institute of Rice of National Academy of Agrarian Sciences of Ukraine (Antonivka village, Skadovskyi district, Kherson region) is co-owner of the buckwheat grade Stepova [31].

Based on the analysis of data from literature sources of domestic and foreign authors, the buckwheat role in agriculture, the methods for creating a new source material, and the varieties that they obtained are highlighted. The influence of individual factors and characteristics on the vegetative period duration, productivity and yield of buckwheat plants was determined. Proceeding from the analysis, the necessity of buckwheat breeding for early maturity and drought resistance has been established, the conducting research main directions on creating varieties and hybrids with high yield and grain quality adapted to the southwestern Forest-Steppe conditions of Ukraine have been outlined [2, pp. 86-98; 3, pp. 38-42; 5, pp. 136-137; 6, pp. 14-19; 14, pp. 20-21; 18, pp. 207-210; 23, pp. 27-29; $34 ; 36$, pp. 20-22; 37, pp. 32-35].

\section{Buckweat selection on early ripeness and drought resistance}

The use of index indicators to evaluate new material on the basis of early maturity. The vegetation period of buckwheat varieties largely depends on the morphological indices characterizing the shoot bearing zone (ZBP) and shoot branch zone (ZBZ) on the plant. It is established that by using the ratio of indicators, that is, their indexation, it is possible to determine, by an indirect way, the early ripeness of a variety or form. If the ratio of the ZBP indices in the $\mathrm{ZBZ}$ is less than 1, then the plant is probably late-ripening [3, pp. 38-42; 4, pp. 98; 6, pp. 14-19; 15, pp. 33-39].

We conducted a biometric analysis and the main morphological indicators in both the selected parent varieties and the new breeding material. Based on the main morphological features directly related to precocity, the relationship between the fruiting zones and the branching zone of the shoot was determined (Table 1). 
Over the research years, the average number of vegetative nodes in the branching zone of the shoot varied within 4.8 pieces. (Solianska $\times$ Mih) $\times$ Mih; 4.9 pcs. (Veselka $\times$ Alenushka) to 5.9 pcs. (Smuhlianka $\times$ № 4013) $\times$ № 4013. The average number of vegetative nodes on the plant varied within the limits of $11,2-14,1$ pcs. In all hybrid combinations, the ratio between the fruiting and branching branches of the shoot was observed to be greater than one [15, pp. 33-39].

Table 1

Value of ZBP / ZBZ in the best hybrid combinations of buckwheat

\begin{tabular}{|l|c|c|c|}
\hline \multirow{2}{*}{\multicolumn{1}{c|}{ Grade, hybrid }} & \multicolumn{2}{|c|}{$\begin{array}{c}\text { Average number of } \\
\text { nodes, pes }\end{array}$} & \multirow{2}{*}{$\begin{array}{c}\text { Correlat } \\
\text { ZPP/ZBP }\end{array}$} \\
\cline { 2 - 3 } & ZBP & on the plant & \\
\hline Victoriia - St. & 5,8 & 11,4 & 0,97 \\
\hline Skorostyhla 86 $\times$ Solianska & 6,2 & 13,4 & 1,16 \\
\hline$($ Solianska $\times$ Skorostyhla 86$) \times$ Skorostyhla 86 & 6,7 & 13,6 & 1,03 \\
\hline$($ Solianska $\times$ Zhniaiarka) $\times$ Zhniaiarka & 5,5 & 12,2 & 1,22 \\
\hline$($ Smuhlianka $\times$ № 4013) $\times$ № 4013 & 5,9 & 13,6 & 1,31 \\
\hline$($ Mih $\times$ № 4013) & 5,3 & 13,4 & 1,53 \\
\hline Solianska $\times$ Mih) $\times$ Mih & 4,8 & 11,8 & 1,46 \\
\hline (Mih $\times$ Solianska $\times$ Solianska & 5,1 & 14,1 & 1,77 \\
\hline Veselka $\times$ Alonushka & 4,9 & 11,2 & 1,29 \\
\hline
\end{tabular}

Rather high from 1,22-1,77 is the ratio in combinations (Mih $\times$ № 4013), $($ Mih $\times$ Solianska $) \times$ Solianska, $($ Solianska $\times$ Zhniaiarka $) \times$ Zhniaiarka, $($ Smuhlianka $\times$ № 4013) $\times$ № 4013, (Veselka $\times$ Alenushka). This indicates that the new source material on the early maturity basis prevails the original parental forms and can be used in breeding programs as a donor of precocity [9, pp. 91-92].

Express assessment of breeding material for drought resistance.

It has been practically proved that the accuracy of the investigation increases when several estimates give the identical result. In parallel with eye measure assessment in the field, we previously conducted a laboratory assessment of the selection material on the basis of drought resistance by germinating buckwheat seeds in an osmotic solution of sucrose [16, pp. 207-214; 18, pp. 207-210; 27, pp. 9-10].

As a result of the conducted studies it was established that the hybrid combinations obtained from the crossing of varieties Kazanka and Smuhlianka were characterized by high drought resistance (P) 41.2-53.0\%. 
Combinations Smuhlianka $\times$ Kazanka and Kazanka $\times$ Smuhlianka, obtained from the first saturating crossing $\left(\mathrm{SC}_{1}\right)$ for the research years, had relatively high rates of drought resistance $-40.3-47 \%$. This is explained by the fact that the share of parental forms is $1 / 2$ and this attribute was controlled by the action of polymer genes of the Kazanka variety, which indicates its heterozygous conditionality (50.2-30.8\%). In hybrid combinations $($ Smuhlianka $\times$ Kazanka) $\times$ Kazanka and (Kazanka $\times$ Smuhlianka) Smuhlianka received from $\mathrm{SC}_{2}$ in 2007 , the sign was controlled by the combined effect of heterozygotes, from which high drought resistance values $-50.5-47.3 \%$. Under the unfavorable weather conditions influence, the recessive genes of Smuhlianka variety manifested itself, as evidenced by the average indices of this feature [9, pp. 91-92; 16, pp. 207-214; 18, pp. 207-210; 27, pp. 9-10].

The results of the selection material evaluation using the seed germination method in osmotic solutions make it possible to more fully distribute the parental forms and the new buckwheat selection material on the drought resistance basis.

\section{Evaluation of material in kennels breeding process}

The vegetation period of the studied hybrid numbers. We conducted a study of the duration inheritance of the vegetative and interphase periods in the hybrid combinations studied from $\mathrm{SC}_{1}$ and $\mathrm{SC}_{2}$ Inheritance of the vegetation duration in buckwheat hybrids from the first and second saturating crossings was studied for two periods: vegetative (shoots - flowering) and generative (flowering - maturation).

The inheritance nature of the periods studied in the hybrids was significantly different. As a result of the vegetative period inheritance in the buckwheat hybrids from $\mathrm{SC}_{1}$ and $\mathrm{SC}_{2}$, the overwhelming majority of hybrids in 2008 had an intermediate inheritance of $50 \%$. And in the hybrids of $\mathrm{SC}_{1} \mathrm{~F}_{1}$ and $\mathrm{SC}_{1} \mathrm{~F}_{2}$, a tendency to early maturity dominance was observed, namely: $59-64.2 \%$ of hybrids evaded the early ripening parent varieties or reached their level. The number of hybrids bloomed in time, close to late-maturing parental varieties, was smaller (Table 2) [5, pp. 136-137; 9, pp. 91-92; 16, pp. 207-214; 18, pp. 207-210].

The behavior of hybrids about the duration of the generative period was somewhat different. Most of the hybrids $\mathrm{SC}_{1} \mathrm{~F}_{1}$ and $\mathrm{SC}_{1} \mathrm{~F}_{2}$ over the duration of the exceeded period the original parental forms, their num- 
ber was $48.7-70 \%$ of the total number in the experiments [6, pp. 14-19; 10, pp. 12-13; 17, pp. 69-77].

Table 2

Inheritance of the duration of vegetative and interphase periods in buckwheat hybrids from the first and second saturating crosses

\begin{tabular}{|c|c|c|c|c|c|}
\hline \multirow{3}{*}{ Hybridization } & \multirow{3}{*}{ Years } & \multirow{3}{*}{$\begin{array}{c}\text { Number of } \\
\text { hybrids in the } \\
\text { experiment, pcs }\end{array}$} & \multicolumn{3}{|c|}{$\begin{array}{l}\text { Distribution of hybrids by type } \\
\text { of inheritance (in } \% \text { of total) }\end{array}$} \\
\hline & & & \multirow{2}{*}{$\begin{array}{l}\text { intermediate } \\
\text { manifestation } \\
\text { (IM) }\end{array}$} & \multicolumn{2}{|c|}{$\begin{array}{l}\text { the dominance } \\
\text { of high rates }\end{array}$} \\
\hline & & & & $\begin{array}{l}\text { positive } \\
\text { dominance } \\
\text { (PD) }\end{array}$ & $\begin{array}{c}\text { positive } \\
\text { dominance } \\
\text { (PND) }\end{array}$ \\
\hline \multicolumn{6}{|c|}{ Vegetative period } \\
\hline $\mathrm{SC}_{1} \mathrm{~F}_{1}$ & 2007 & 39 & 41 & 41 & 18 \\
\hline $\mathrm{SC}_{1} \mathrm{~F}_{2}$ & 2008 & 14 & 35,8 & 42,7 & 21,5 \\
\hline $\mathrm{SC}_{2} \mathrm{~F}_{1}$ & 2008 & 20 & 50 & 40 & 10 \\
\hline \multicolumn{6}{|c|}{ Generational period } \\
\hline $\mathrm{SC}_{1} \mathrm{~F}_{1}$ & 2007 & 39 & 12,8 & 38,5 & 48,7 \\
\hline $\mathrm{SC}_{1} \mathrm{~F}_{2}$ & 2008 & 14 & 21,5 & 42,7 & 35,8 \\
\hline $\mathrm{SC}_{2} \mathrm{~F}_{1}$ & 2008 & 20 & - & 30 & 70 \\
\hline \multicolumn{6}{|c|}{ Vegetation period } \\
\hline $\mathrm{SC}_{1} \mathrm{~F}_{1}$ & 2007 & 39 & 30,8 & 41 & 28,2 \\
\hline $\mathrm{SC}_{1} \mathrm{~F}_{2}$ & 2008 & 14 & 42,9 & 14,2 & 42,9 \\
\hline $\mathrm{SC}_{2} \mathrm{~F}_{1}$ & 2008 & 20 & 30 & 40 & 30 \\
\hline
\end{tabular}

As the research result, it was found that the total duration of the growing season in hybrids decreased due to the generative period reduction, a greater number of hybrids bent toward the early ripening parent varieties. The number of hybrids that approached late-maturing parental forms was insignificant and amounted to $30 \%$ of the total.

So, according to the growing season duration, it is better to have hybrid combinations (Skorostyhla $86 \times$ Solianska) Solianska $($ Mih $\times$ № 4013) No. 4013, (№ $4013 \times$ Mih) which could be used in breeding programs on the basis of early maturity.

We established a correlation between the main morphological indicators of varieties, the buckwheat family collection samples and the new selection material obtained on their basis. 
A very weak correlation was noted between the height of plants and the number of all branches (027-0.30), the node of the first branching and inflorescence (0.03-0.1). The average correlation was observed between the height of plants and the grain mass from the plant (0.37-0.43), the mass of 1000 grains (0.31-0.35), the number of grains (0.35-042), the branches of the first order (035-0.38). A high correlation was observed between plant height and the number of inflorescences (0.7-0.77), nodes of all (0.6-0.7), nodes on the main stem (0.8-0.87) [13, pp. 68-75] (Table 3).

Table 3

Yield and technological indicators of grain quality of the best hybrid numbers of the breeding seedbed

\begin{tabular}{|c|c|c|c|c|c|c|}
\hline \multirow[b]{2}{*}{$\begin{array}{l}\text { Selection } \\
\text { number }\end{array}$} & \multirow[b]{2}{*}{ Origin } & \multicolumn{2}{|c|}{ Yield, } & \multicolumn{3}{|c|}{$\begin{array}{l}\text { Technological indicators } \\
\text { of grain quality }\end{array}$} \\
\hline & & $\mathbf{g} / \mathbf{m}^{2}$ & \pm to $\mathrm{St}$. & 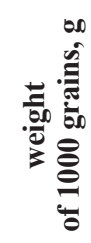 & 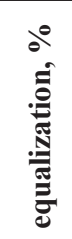 & 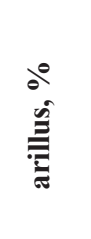 \\
\hline & Victoriia-Standart (St.) & 146,9 & - & 26,9 & 88,2 & 21,9 \\
\hline $33 / 03$ & Ukrainka $\times$ № 4013 & 298,0 & 151,1 & 21,9 & 68,2 & 20,9 \\
\hline $219 / 02$ & № $4013 \times$ Roksolana & 269,0 & 122,1 & 26,9 & 82,6 & 21,9 \\
\hline $94 / 01$ & $\begin{array}{l}\mathrm{F}_{3}[(\text { Veselka } \times \text { Victoriia }) \times \\
\times \text { Victoriia }]\end{array}$ & 285,0 & 138,1 & 26,5 & 76,4 & 22,3 \\
\hline $7 / 06$ & № $4013 \times$ Mih & 171,1 & 24,2 & 27,7 & 92,4 & 21,7 \\
\hline $22 / 06$ & Skorostyhla $86 \times № ~ 4013$ & 213,0 & 66,1 & 29,2 & 74,4 & 21,7 \\
\hline $24 / 06$ & Alenushka $\times$ Veselka & 268,6 & 121,7 & 26,3 & 88,4 & 21,5 \\
\hline $25 / 06$ & Veselka $\times$ Alenushka & 263,3 & 116,4 & 33,7 & 89,7 & 23,5 \\
\hline $15 / 07$ & $\begin{array}{l}(\text { Alenushka } \times \text { Veselka }) \times \\
\times \text { Veselka }\end{array}$ & 245,9 & 99,0 & 28,5 & 94,8 & 22,1 \\
\hline $16 / 07$ & $\begin{array}{l}(\text { Veselka } \times \text { Alenushka }) \times \\
\times \text { Alenushka }\end{array}$ & 257,8 & 119,9 & 32,8 & 88,8 & 23,3 \\
\hline $5 / 07$ & $\begin{array}{l}(\text { Zhniaiarka } \times \text { Solianska }) \times \\
\times \text { Solianska }\end{array}$ & 295,9 & 149,0 & 31,6 & 92,8 & 23,9 \\
\hline $6 / 07$ & $\begin{array}{l}(\text { Solianska } \times \text { Zhniaiarka }) \times \\
\times \text { Zhniaiarka }\end{array}$ & 325,6 & 178,7 & 31,4 & 94,0 & 23,1 \\
\hline $7 / 07$ & $\begin{array}{l}(\text { Kazanka } \times \text { Smuhlianka }) \times \\
\times \text { Smuhlianka }\end{array}$ & 250,4 & 103,5 & 30,7 & 92,0 & 22,5 \\
\hline
\end{tabular}


Yield and technological indicators of grain quality of the best numbers of the seedbed breeding. The criteria for assessing the source material in the breeding seedbed were the yield and grain quality.

Better performance were the numbers of $\mathrm{SC}_{1} \mathrm{~F}_{1}$ 7/06 №. $4013 \times$ Mih, 24/06 Alonushka $\times$ Veselka, 25/06 Veselka $\times$ Alenushka, they exceeded the grade-standard by $24.2-121.7 \mathrm{~g} / \mathrm{m}^{2}$ and are characterized by improved technological quality indicators grain, in particular the grain leveling is higher than the standard by $0.2-5.8 \%$, the mass of 1000 grains is $0.8-6.8 \mathrm{~g}$.

Analyzing the harvest and technological indicators of grain quality, it should be noted that the high numbers had breeding numbers 33/03 Ukrainka $\times$ № 4013, 219/02 № $4013 \times$ Roksolana, 94/01 $\mathrm{F}_{3}[$ (Veselka $\times$ Victoria $) \times$ Victoria], $\mathrm{HC}_{2} \mathrm{~F}_{1}$ 6/07 (Solianska $\times$ Zhniaiarka) $\times$ Zhniaiarka, 4/07 (№ $4013 \times$ Mih) $\times$ Mih, 15/07 (Alonushka $\times$ Veselka) $\times$ Veselka, 16/07 (Veselka $\times$ Alonushka) $\times$ Alonushka, which exceed the standard Victoria on productivity by $31.1-178.7 \mathrm{~g} / \mathrm{m}^{2}$, the leveling off is $0.6-5.8 \%$, the weight of 1000 grains is $1.6-5.9 \mathrm{~g}$, the plavness is $0.2-2 \%$.

Estimation of perspective numbers in the seedbed control. The yield of the samples and the standard variety in the seedbed control varied between 1.34-1.58 $\mathrm{t} / \mathrm{ha}$. The duration of interphase and vegetation period was reduced to 75-90 days compared to the standard.

Hybrid numbers of the seedbed control of 2008 were characterized by a long vegetation period. The beginning of flowering passed on the 23-25th day from sowing, the fruiting of fruits - on the 30-35th day from flowering, ripening - on the thirtieth day from the ripening. Most of the breeding numbers significantly exceeded the Victoria variety in terms of grain quality indicators [16, pp. 207-214] (Table 4).

For the growing season duration, the new selection material was characterized by its reduction in comparison with the Victoria Standard for 7-17 days. Shorter period of the growing season had breeding numbers 24/06, 2/07, 4/07, 7/07, 8/07.

It should be noted that the weather conditions of 2009 were more favorable for the buckwheat plants crop formation. The higher yield and improved technological parameters of grain quality compared to the standard variety Victoria had breeding numbers 6/07, 2/07, 7/07, 16/07, 4/07, 8/07 [15, pp. 33-39].

Preliminary and competitive testing of the best buckwheat numbers. During 2009-2011 years there was a study of prospective numbers selected from the control nursery in the previous (PS) and competitive (KS) strain 


\section{Yield and grain quality of the best buckwheat numbers of the seedbed control}

\begin{tabular}{|c|c|c|c|c|c|c|c|}
\hline \multirow[b]{2}{*}{$\begin{array}{c}\text { Selection } \\
\text { number }\end{array}$} & \multirow[b]{2}{*}{ Origin } & \multirow[b]{2}{*}{$\begin{array}{c}\text { Vegetation } \\
\text { period, } \\
\text { days }\end{array}$} & \multicolumn{2}{|c|}{$\begin{array}{c}\text { Yield } \\
\text { capacity, }\end{array}$} & \multicolumn{3}{|c|}{$\begin{array}{c}\text { Grain Quality } \\
\text { Indicators }\end{array}$} \\
\hline & & & t/ha & \pm to $\mathrm{St}$. & 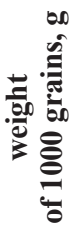 & & 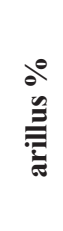 \\
\hline St. & Victoriia-Standart (St.) & 90 & 1,34 & - & 26,1 & 76,5 & 21,9 \\
\hline $4 / 07$ & $($ № $4013 \times$ Mih $) \times$ Mih & 75 & 1,57 & 0,23 & 28,4 & 85,3 & 22,7 \\
\hline $33 / 03$ & Ukrainka $\times$ № 4013 & 94 & 2,77 & 1,43 & 23,0 & 88,6 & 20,9 \\
\hline $219 / 02$ & № $4013 \times$ Roksolana & 94 & 2,18 & 0,84 & 24,6 & 91,0 & 21,3 \\
\hline $2 / 07$ & $($ Solianska $\times$ Mih $) \times$ Mih & 75 & 1,51 & 0,17 & 30,9 & 91,5 & 21,9 \\
\hline $8 / 07$ & $\begin{array}{l}(\text { Smuhlianka } \times \text { Kazanka }) \times \\
\times \text { Kazanka }\end{array}$ & 77 & 1,55 & 0,21 & 29,4 & 90,6 & 21,9 \\
\hline 7/07 & $\begin{array}{l}(\text { Kazanka } \times \text { Smuhlianka }) \times \\
\times \text { Smuhlianka }\end{array}$ & 77 & 1,7 & 0,36 & 30,3 & 92,7 & 22,1 \\
\hline $25 / 06$ & Veselka $\times$ Alonushka & 78 & 1,50 & 0,16 & 30,1 & 89,7 & 22,1 \\
\hline $15 / 07$ & $\begin{array}{l}\text { Альонушка } \times \text { Veselka) } \times \\
\times \text { Veselka }\end{array}$ & 80 & 1,50 & 0,16 & 30,1 & 91,4 & 22,7 \\
\hline $16 / 07$ & $\begin{array}{l}\text { Veselka } \times \text { Alonushka) } \times \\
\times \text { Alonushka }\end{array}$ & 80 & 1,54 & 0,20 & 30,5 & 90,7 & 22,5 \\
\hline $5 / 07$ & $\begin{array}{l}(\text { Zhniaiarka } \times \text { Solianska }) \times \\
\times \text { Solianska }\end{array}$ & 83 & 1,52 & 0,18 & 30,7 & 91,5 & 21,9 \\
\hline $6 / 07$ & $\begin{array}{l}\text { Solianska } \times \text { Zhniaiarka) } \times \\
\times \text { Zhniaiarka }\end{array}$ & 82 & 1,58 & 0,24 & 31,7 & 93,6 & 23,1 \\
\hline & $\mathrm{SSD}_{05}$ & & & 0,14 & & & \\
\hline
\end{tabular}

testing. The main part of them was made up of hybrid material obtained in previous years from crossing varieties of Kazanka, Roksolana, №. 4013, Mih, Veselka, Alenushka, Solianska. In addition to grain quality productivity and technological indicators, these seedbedi determined the survival rate of plants [11, pp. 22; 12, pp. 137-144].

In the PS, ten numbers were observed, their field germination and plant survival varied within $97.9-99.3 \%$.

The overwhelming majority of PS numbers during the research years had approximately the same percent survival of plants - 98.3-98.9 (№ 15/07, 
$8 / 07,2 / 07,8 / 07$ ). Survival in plant numbers 7/07, 2/07, 8/07, 4/07 was observed in comparison with the standard variety.

The lowest percentage of 97.9 plant survival was in breeding number 6/07 (Solianska $\times$ Zhniaiarka) $\times$ Zhniaiarka, and also in numbers $15 / 07($ Veselka $\times$ Alenushka $) \times$ Alenushka $-98.1 \%$. According to the vegetation period,duration it should be noted that the long growing season compared with the standard had breeding numbers 6/07, 2/07, 7/07, 15/07, formed from saturating crosses of varieties Kazanka, Veselka, Alonushka, Smuhlianka, Mih, Solianska. The remaining numbers had the same growing season as the standard. This is explained by the presence in the genotype of hybrids obtained from saturating crossings, the early-ripening variety Kazanka, previously selected from the buckwheat family collection and brought to cross.

Yields of the studied numbers ranged from 1.52-1.96 t/ha, and from the standard $-1.52 \mathrm{t} / \mathrm{ha}$.

For the yield in the PS, Victoria's grade standard was exceeded by 0.20-0.44 t/ha numbers: 7/07 (Kazanka $\times$ Smuhlianka) $\times$ Smuhlianka; 8/07 $($ Smuhlianka $\times$ Kazanka $) \times$ Kazanka; 2/07 (Solianska $\times$ Mih $) \times$ Mih; 4/07 (No. $4013 \times$ Mih) $\times$ Mih; 6/07 (Solianska $\times$ Zhniaiarka $) \times$ Zhniaiarka, (№ $4013 \times$ Ukrainka).

All the investigated breeding numbers were characterized by high technological quality indicators of grain quality - 1000 grains, equalization in comparison with the standard. Due to the higher mass of 1000 grains and evenness, the yield of cereals also increased.

The overwhelming majority of breeding numbers had the high percentage of pluvness and only in numbers $2 / 07$ (Solianska $\times$ Mih) $\times$ Mih this figure was almost at the standard level.

In the competitive variety testing, the numbers obtained by the methods of simple and reverse saturating crossings were studied. The field germination and survival rate of buckwheat plants of the breeding selection numbers in the SC varied within 95.1-99.4\%. Higher in comparison with the standard variety Victoria, the germination capacity, the survival rate of plants and the shorter vegetation period had the numbers 219/02 (№. $4013 \times$ Roksolana), 26 (Kazanka $\times$ Smuhlianka $) \times$ Smuhlianka, $24($ Smuhlianka $\times$ Kazanka) $\times$ Kazanka. Below the standard, field germination and survival of plants had breeding numbers 21 (Solianska $\times$ Zhniaiarka) $\times$ Zhnjarka and 20 (№ $4013 \times$ Mih) $\times$ Mih - by 3.8 and 1.2\%, respectively. In these 
breeding numbers for 1-2 days, the vegetation period was extended in comparison with the standard [11, pp. 22; 12, pp. 137-144].

The yield of selection numbers of the competitive test ranged from 1.64-2.73 t/ha at $1.69 \mathrm{t} / \mathrm{ha}$ to the standard. The best numbers of KS is № 24 (Smuhlianka $\times$ Kazanka $) \times$ Kazanka, № $22($ Solianska $\times$ Mih $) \times$ Mih, № $26($ Kazanka $\times$ Smuhlianka $) \times$ Smuhlianka, 33 (№ $4013 \times$ Ukrainka), obtained from simple saturating crossings, characterized by high in comparison with the standard yield by 0,46-1,04 t/ha and improved technological indicators of grain quality, in particular above the mass of 1000 grains (by 3.7-5.4 g) and equalization (by 11.3-17,4\%) (Table 5).

Таблиця 5

Yield and technological indicators of grain quality of promising buckwheat numbers in competitive variety testing

\begin{tabular}{|c|c|c|c|c|c|c|}
\hline \multirow[b]{2}{*}{$\begin{array}{c}\text { Selection } \\
\text { number }\end{array}$} & \multirow[b]{2}{*}{ Origin } & \multicolumn{2}{|c|}{$\begin{array}{c}\text { Crop } \\
\text { capacity, }\end{array}$} & \multicolumn{3}{|c|}{$\begin{array}{l}\text { Grain Quality } \\
\text { Indicators }\end{array}$} \\
\hline & & t/ha & $\begin{array}{c} \pm \text { to } \\
\text { St.t/ha }\end{array}$ & 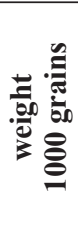 & 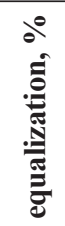 & 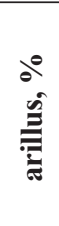 \\
\hline 25 & Victoriia --Standart (St.) & 1,69 & - & 26,0 & 75,4 & 21,7 \\
\hline 33 & (№ $4013 \times$ Ukrainka) & 2,73 & 1,04 & 22,4 & 88,0 & 21,3 \\
\hline 22 & $($ Solianska $\times$ Mih $) \times$ Mih & 2,15 & 0,46 & 29,7 & 86,7 & 23,1 \\
\hline 24 & Smuhlianka $\times$ Kazanka) $\times$ Kazanka & 2,73 & 1,04 & 31,4 & 90,5 & 22,1 \\
\hline 26 & $($ Kazanka $\times$ Smuhlianka $) \times$ Smuhlianka & 2,57 & 0,88 & 30,9 & 92,8 & 22,5 \\
\hline & $\mathrm{SSD}_{\mathrm{Nos}}=$ & & 0,15 & & & \\
\hline
\end{tabular}

Development of buckwheat breed model. Based on the generalization of previous studies and our own results on the creation of selection material, we developed a buckwheat varieties model adapted to the conditions of the southwestern Forest-Steppe. The model is comparatively based on the main economically valuable indicators of the most promising hybrid number 7/07 [18, pp. 207-210] (Table 6).

In comparison with the model the prospective hybrid number is characterized by an average period of vegetation, higher yields, high technological indicators of grain quality (plaviness, flattening, weight of 1000 grains, grain 
nature). According to the chemical composition (protein, fat, starch, fiber content), the seeds of the new variety are at the level of the model (control).

Table 6

Characteristic of the model and new buckwheat variety

\begin{tabular}{|l|c|c|}
\hline \multicolumn{1}{|c|}{ Indexes } & Model & Variety $\mathbf{7 / 0 7}$ \\
\hline Vegetation period, days & $70-90$ & 89 \\
\hline Yield, t/ha & 2,5 & 2,73 \\
\hline $\begin{array}{l}\text { Technological indicators of grain quality: } \\
\text { - weight of 1000 grains, g }\end{array}$ & 28,0 & 31,4 \\
\hline - arillus, \% & $20,1-24,9$ & 22,1 \\
\hline - equalization, \% & $60-90$ & 90,5 \\
\hline - Nature of grain, g/1 & $650-680$ & 665 \\
\hline Content, \%: & & \\
\hline - albumen & $12-14$ & 12,02 \\
\hline - fats & $2-4$ & 2,01 \\
\hline - amylum & 85 & 85 \\
\hline - cellulose & $10-12$ & 11,4 \\
\hline
\end{tabular}

Newly created variety $7 / 07$ is also characterized by improved biochemical indicators, in particular, the content of BEP, the mass fraction of phosphorus, calcium. Approximately the same high economic values had a hybrid sample № 8/07.

\section{We received protection documents for buckwheat varieties:}

1. A. s. with. the plant variety № 09029 Buckwheat edible Malynka / Alekseeva A.S., Vilchinska L.A., Malyna N.N., Ivashchuk P.V.; Application 05002004 (entered in the State Register of Plant Varieties from 2007).

2.A. s. with the plant variety № 110265 Buckwheat edible April/Vilchinska L.A., Malyna N.N., Ivashchuk P.V.; Application 06002001 (entered in the State Register of Plant Varieties, suitable for distribution in Ukraine since 2010).

3. A. s. with the plant variety № 110266 Buckwheat edible Perlyna Podillia / Vilchinska L.A., Malyna N.N., Ivashchuk P.V.; Application 06002002 (entered in the State Register of Plant Varieties from 2011).

4. Certificate of gene pool sample registration of plants in Ukraine № 1300 buckwheat edible population 7/07 dated 26.04. 2013 U.S. Patent No. 0102196. 
In 2016 we transferred to the State variety test the new buckwheat variety edible Kamianchanka (Application No. 16008001 dated 18.03.2016). Based on the preliminary testing results of the new variety in the institutions of the State Expertise, this grade exceeds the average yield of varieties that have passed state registration for the previous five years in the Forest-Steppe zone. The analysis of the field research results on the difference, uniformity and stability (DUS) of this variety in 2017 showed that its uniformity is within the limits of the norm boders.

\section{Testing perspective buckweat numbers in production}

The competitive variety testing perspective numbers were tested in the farms of Khmelnytskyi region - "Myrne", closed joint-stock company, the "Perlyna Podillia" Research and Production Agrofirm, peasant farm enterprise "Zolotoy Kolos", peasant farm enterprise "Lubystoc".

According to the production test results of the numbers obtained by hybridization from the crossing of varieties Kazanka, Roksolana, № 4013, the highest yields and the grain quality best technological indicators had such combinations: (№. $4013 \times$ Ukrainka), (№ $4013 \times$ Roksolana), $($ № $4013 \times$ Kazanka), $($ Kazanka $\times$ Smuglyanka $) \times$ Smuglianka, $($ Smuglianka $\times$ Kazanka $) \times$ Kazanka. Their yield exceeded the Victoria Standard grade by $0.5-1.04 \mathrm{t} / \mathrm{ha}$.

\section{Conclusions}

The article presents theoretical generalization and a new solution to the scientific problem, which consists in creating a new source material in the buckwheat selection by hybridization using buckwheat family samples for yield and technological indicators of grain quality and early maturity signs and drought resistance. Sources of economically useful traits with stable expression are singled out. Genotype-environmental interactions between the plant genotype and the changing conditions of different research years have been studied.

1. It is established variability of morphological characters and the correlation between them in buckwheat plants during cultivation in the southwestern forest-steppe conditions of Ukraine. The boundaries of variation in plant height were $14.5-29.6 \%$, the number of branches of the first order was 29.8-77.9; inflorescence - 47,9-104,1; grains - 60.5-103.6; mass of grain from the plant $-62.5-120.6$; with a mass of 1000 grains $-14.2-31.8 \%$. The 
correlation between the seed productivity main element - the number of inflorescences on the plant - amounted to the number of grains $0.37-0.83 \%$, the grain mass from the plant $-035-0.82 \%$, the plant height $-0.38-0.77 \%$.

2 . It is established that the buckwheat plant precocity depends on the following morphological indices: the first branch node, the first inflorescence node, the average number of vegetative nodes on the plant, the plant height, the nodes on the main stem, the nodes of all, the number of inflorescences and grains. When the ratio of the indices of the fruiting zone to the branching zone of the shoot exceeds 1.0, the vegetative period of buckwheat is, as a rule, reduced.

3. It has been revealed that the varieties can be the sources for obtaining early-ripening forms and varieties in buckwheat breeding: Kazanka, Mriia, Veselka, Mih, Solianska, Smuglianka, Zhniarka, № 4013, selected from the buckwheat family collection.

4. The established efficiency of the rapid assessment of buckwheat breeding material on the drought resistance basis by germination of seeds in osmotic solutions with a sucrose concentration of $13.9 \%$.

5. It is determined that the highest drought resistance in comparison with the parent forms and Victoria variety have hybrid combinations of $515 \mathrm{SC}_{1} \mathrm{~F}_{1}($ Kazanka $\times$ Smuglanka $), 517 \mathrm{SC}_{1} \mathrm{~F}_{1}(($ Kazanka $\times$ Smuhlianka $)$ $\times$ Smuhlianka $), 526 \mathrm{SC}_{1} \mathrm{~F}_{1}(($ Skorostyhla $86 \times$ Solianska $) \times$ Solianska $)$, $535 \mathrm{SC}_{1} \mathrm{~F}_{1}(($ Alonushka $\times$ Veselka $) \times$ Veselka $)$.

6 . Donors create a new source material on the drought resistance basis are the varieties Skorostyhla 86, Smuhlianka, Kazanka, Alonushka, Veselka.

7. The buckwheat numbers $7 / 07,8 / 07,2 / 07,24 / 06$ have a shorter growing period of 5-12 days, a 35.4-47.3\% higher drought tolerance, higher by 0.3-0.7 t/hectare of grain yield compared to standard Victoria variety. The grain of these numbers is characterized by high technological properties, for processing on a cereal, its chemical composition and indicators of food safety meet the regulatory requirements.

8. A model of buckwheat, adapted to the conditions of the southwestern Forest-Steppe, was developed for the main economically valuable indicators. In comparison with the model, grade 7/07 again has a high yield, the best technological parameters of grain quality (weight of 1000 grains, pluvness, alignment, nature), as well as a more balanced biochemical composition.

9. Prospective numbers of hybrid origin are transferred to the National Center for Plant Genetic Resources of Ukraine and are used in the breeding 
programs of the Research Institute of Crops of Podilskyi State Agrarian and Engineering University, and the best of them are 7/07 (Kazanka $\times$ Smuhlianka) $\times$ Smuhlianka, 24/07 $\mathrm{SC}_{2} \mathrm{~F}_{4}$ Roksolana $\times$ Kazanka - are formed to transfer to the state variety testing.

\section{Recommendations for selection practice}

1. Evaluate buckwheat breeding material on the basis of:

- Early maturity by correlation of index morphological indices between fruiting and branching branches, which should be more than one.

- Drought resistance by means of germination of seeds in osmotic solutions of sucrose with a concentration of $13.9 \%$, with an osmotic pressure of $12 \mathrm{~atm}$.

2. To improve the buckwheat grain quality technological parameters as a donor, use the collection sample № 4013 of French selection.

3 . Numbers with economically valuable characteristics $(7 / 06,4 / 07$, $23 / 06,5 / 07,6 / 07,16 / 07,15 / 07,25 / 06,24 / 06,22 / 06)$ used in breeding programs for the creation of more early and buckwheat drought-resistant varieties, with high yield and grain quality.

\section{References:}

1. Alekseeva O. S. (1970) Methody, resultaty i perspective selecziinoi roboty $z$ grechkoi [Methods, results and perspectives of selection work with buckwheat]. Orel: (in Russia).

2. Alekseeva O. S. (2001) Istoria seleczii grechki v Ukraine [History of buckwheat selection in Ukraine]. Kiev: Logos, (in Ukrainian).

3. Balyura V. I. \& Shhagina A. K. (1982) Seleczia grechki na skorostiglost' [Selection of buckwheat for precocity]. Seleczia, cemenovodstvo i technologia viroshyvania grechki [Selection, seed-growing and technology cultivation of buckwheat]. Orel, pp. 38-42.

4. Vilchynska L. A. \& Horodyska O. P. (2008, November) Vpliv skorostiglosti na technologichni pokazniki kachestva zerna grechki [Influence of rapidity on yield and technological parameters of buckwheat grain quality]. Rozvitok naukovich doslidgen 2008: Materialu Chetvertoi Mignarodnya naukovo-praktichnya konferencia [Paper presented at the Development of scientific research 2008: Materials of the Fourth International Scientific and Practical Conference], Poltava: InterGraphics, vol. 8, pp. 98.

5. Vilchynska L. A. \& Horodyska O. P. (2012) Vikoristania kolekzii rody Grechkovi u selekcziunuch programmach NDIKK [Use of the collection of genus Buckwheat in breeding programs RICC PDATU]. Seleczia ta genetika silskogospodarskich roslun: tradizii ta perspiktivi: do 100-richya Selekziuno-geneticheskogo institute - Nazionalnogo zentry nassineznavstva i sortoviivchenia. [Paper presented at the abstracts of the International Scientific Conference. Selection and genetics 


\section{Buckwheat selection in south western forest steppe conditions of Ukraine}

of agricultural plants: traditions and perspectives: to the 100th anniversary of the Selection-Genetic Institute - National Center for Semenology and Sortimental Study], Odessa, pp. 136-137.

6. Vilchynska, L. A. \& orodyska O. P. (2014) Ozinka novogo selekziinogo materialy grechki za oznakoy skorostiglosti [Estimation of new breeding material of buckwheat on the velocity basis]. Chornomorskyi nauchnui gornal accademichnoi nauki [Black sea scientific journal of academic research]. Tbilisi: Georgia, vol. 14, pp. 14-19.

7. Gavrylyuk V. B. Galyschuk V. I. \& Striletskyi O. V. (2010) Grynty Chelnizkoi oblasti. Sychasnui iakisnui stan; zberegenia, vidtvorennia ta polipshenia ih roduchosti [Khmelnytskyi soils. Modern quality condition; preserve, reproduce and improve their fertility]. Kamianets-Podilskyi. (in Ukrainian).

8. Gerenchuk K. I. (1980) Priroda Chelnizkoi oblasti [The nature of Khmelnitsky region]. Lviv: Higher school. (in Ukrainian).

9. Horodyska O. P. \& Vilchynska L. A. (2007) Vliyanie extramalnich usloviu sredy na elementi morfologii rasteniy grechiki [Influence of extreme environmental conditions on elements of the buckwheat plants morphology]. Evropeiska nauka XXI viky - 2007: Materialy II Mignarodnoi nauchno-practicheskoi konferenzii [European Science of the XXI Century-2007: Proceedings of the II International Scientific and Practical Conference]. Dnepropetrovsk: vol. 9, pp. 91-92.

10. Horodyska O. P. (2008) Vplyv nasychyuchich schreshyvan na zminy trivalosti vegetaziunogo periody gibridiv grechki [Influence of saturated crosses to change the duration of the buckwheat hybrids vegetative period]. Naucnay konferenzia: tezy dopovidei Vseukrainskoi nauchno-prakticheskoi konferenzii prisviachenoi 35-richy Naukovo doslidnogo institute krypianich kyltur ta 82-richy z dnia narodgenia vidomogo selekzionera, zasnovnika NDIKK Alekseevoi O. S. [Scientific conference: theses of reports of the All-Ukrainian scientific-practical conference devoted to the 35th anniversary of the Research Institute of Cereal Cultures and the 82nd anniversary of the birth of the famous breeder, the founder of the RICC Alekseeva O. S.]. Kamianets-Podilsky, pp. 12-13.

11. Horodyska O. P. \& Vilchynska L. A. (2008) Urogainiszc ta technologichni pokazniku iakosti zerna hibridiv grechki starshich pokolin' [Yields and technological indicators of grain quality of hybrids of buckwheat elder generations]. Problemu pidvushenia adaptyvnogo potenzialy systemu rosliniztva $v$ zviazky zi zminamy klimaty: tezy dopovidei Mignarodnoi nauchno-prakticheskoi konferenzii [Problems of increasing the adaptive potential of the system of plant growing due to climate change: abstracts of the reports of the International scientific and practical conference]. Bila Tserkva, pp. 22.

12. Horodyska O. P. \& Vilchinskaya L. A. (2008) Stypin fenopypovogo dominyvania y hibridiv grechki starshych pokolin [Degree of phenotypic domination in buckwheat hybrids of older generations]. Selekzia i nasinnuztvo: migvidomchyi tematychnyi naucnyi zbirnuk [Selection and seed production: interagency thematic scientific collection]. Kharkiv: vol. 96, pp. 137-144.

13. Horodyska O. P., Vilchinskaya L. A. (2009) Koefizienty yspadcuvania i variazii okremich morfolochnuch pokaznukiv hibridiv grechki [Coefficients of inheritance and variation of individual morphological indices of buckwheat hybrids]. 
Zbirnik nauchnich praz' Podilskogo dergavnogo agrarno-technichnogo universitety [Collection of scientific works of the Podilskyi State Agrarian and engineering university]. Kamianets-Podilskyi: vol. 17, pp. 68-75.

14. Horodyska O. P. \& Vilchynska L. A. (2009) Vpluv trivalosti vegetazijnogo periody na urogaini ta technologichni pokaznuki iakosti zerna grechki [Influence of the growing season duration on yield and technological indicators of grain buckwheat quality]. Tezy Naukovo-teoretychnoi konferenzii professorsko-a vikladazkogo sklady ta naukovziv, prisviachenoi 90-richy vid dna zasnuvania universitety [Theses of the Scientific-Theoretical Conference of the Faculty and Researchers, dedicated to the 90th anniversary of the University's foundation]. KamianetsPodilskyi, pp. 20-21.

15. Horodyska O. P. \& Vilchynska L. A. (2009) Vpluv nasychyuchich schreshyvan' na skorostiglost', uragainost' ta technologichny pokazniky iakosti zerna grechki [Influence of saturated crossings on speediness, yield and technological parameters of buckwheat grain quality]. Agrobiologia: zbirnik naukovich praz' [Agrobiology: a collection of scientific works]. Bila Tserkva: vol. 1(64), pp. 33-39.

16. Horodyska O. P. \& Vilchynska L. A. (2010) Ozinka selekziinogo materialy grechki za oznakou posychstijkosti [Evaluation of breeding material of buckwheat on the drought resistance basis]. Visnik Lvivskogo Natscionalnjgo Agrarnogo Univesitety: Agronomia [Bulletin of Lviv National Agrarian University: Agronomy]. Lviv: Lviv National Agrarian University, no. 14(2), pp. 207-214.

17. Horodyska O. P. (2012) Vlianie prodolgitelnosti vegetazionogo perioda i nasyshaushich screshyvanyi na prodyktivnost' $i$ technologichni pokozately kachestva zerna grechki [Influence of the vegetation period duration and saturating crosses on productivity and technological indicators of buckwheat grain quality]. Innovazii $v$ nauke: materialy XV Megdynarodnoi zaochnoi nauchno-prakticheskoi konferenzii [Innovations in Science: materials of the XV International Correspondence Scientific and Practical Conference]. Novosibirsk: SibAK, pp. 69-77.

18. Vilchynska L. A. \& Horodyska O. P. (2013) Ischodnyi material v selekzii grechki na zasychoystojchivist' [The initial material in the selection of buckwheat for drought resistance]. Problemy i perspektivy innovazijnogo razvitia mirovogo selskocho hozaijstva [Problems and prospects of innovative development of world agriculture]. Saratov: pp. 207-210.

19. Griffing, B. (1956) [Concept of General and specific combining ability in relation to diallel crossing system]. [Austr. J. Biol. Sci], vol.9, pp. 463-493.

20. Dergavnyi reestr sortiv roslyn, pridatnych dlya poshyrenya v Ukraine na $2017 \mathrm{r}$ [State register of plant varieties, suitable for distribution in Ukraine]. Elekrotronik resurs [Electronic resource]. Available at: (http://www.minagro.gov.ua/ rating/files/r3.pdf), (accessed March 02, 2018)).

21. Dergavna slygba statistika Ukraine. Roslynuztvo Ukraine (2017). [State Statistics Service of Ukraine. Plant Growing of Ukraine]. Elekrotronik resurs [Electronic resource]. - Available at: (http://www.ukrstat.gov.ua), (ccessed March 02, 2018)).

22. Dospexov B. A. (1985) Metodika polovogo opyta (z osnovamy statisticheskoi obrabotki resullatov issledovaniu [Methodology of field experience (with the basics of statistical processing of research results)]. Moscov: Agropromizdat, (in Ukrainian). 


\section{Buckwheat selection in south western forest steppe conditions of Ukraine}

23. Dzhulai N. P. \& Lakhtionova S. O. (2013) Zariza kryp (grechka) [Queen of Greens (Buckwheat)]. Sychasni agrarni technologii [Modern agrarian technologies]. No 8, pp. 27-29.

24. Instityte silskogo hospodarstva Pivnicnogo Schody Natchionalnoi akademii agrarnych nauk Ukraine (2018) [Institute of Agriculture of the North East of National Academy of Agrarian Sciences of Ukraine]. Elekrotronik resurs [Electronic resource]. - Available at: (http://isgps.pp.ua), (accessed March 02, 2018)).

25. Zhuchenko A. A. (2000) Adaptivne semenovodsvo [Adaptive seed production]. Visnuk semenovodsva $v$ SNG [Bulletin of Seed Growing in the SNG]. No 2, pp. $18-20$.

26. Kozhushko N. N. \& Volkova A. M. (1982) Metodichni ykazania. Opredelenie otnositelnoi zasychystojchivosti i garostoikosti obrazcsov zernovich kyltur (psheniza, yachmin') sposobom proroshyvania semyan $v$ rastvorach sacharozu $i$ posle progrevania [Methodical instructions. Determination of relative drought tolerance and heat resistance of grain crops samples (wheat, barley) by seed germination in sucrose solutions and after heating]. Leninhrad, (in Russian).

27. Lakhanov A. P. (1992) Ob ozenke grechyki na zascuchystoichivost' [On the evaluation of buckwheat for drought resistance]. Selekzia i semenovodstvo [Selection and seed-growing], pp. 9-10.

28. Mazer K., \& Jinks J. (1985) Biometrichna henetica [Biometric Genetics]. Moscow: Mir, (in Russian).

29. Volkodav V. V. (Ed.). (2001) Metodika Dergavnogo sortoviprobyvanya silskohospodarskich kyltur (zernovi, krypyani ta zernobobovi kylture) [Technique of the State variety testing of agricultural crops (cereals, grains and legumes)]. Kyiv, (in Ukrainian).

30. Moiseichenko V.F., \& Eshchenko V.O. (1994) Osnovy naukovych doslidjen $v$ agronomii [Fundamentals of Scientific Research in Agronomy]. Kyiv: Higher school, (in Ukrainian).

31. Naukovo-doslidnyu instityte krypyanich kyltur im. Alekseevoi O. S. Podilskogo derjavnogo agrarno technichnogo universitety (2018) [Research Institute of Cereal Crops them. Alekseeva O.S. Podilskyi State Agrarian and Engineering University]. Elekrotronik resurs [Electronic resource]. - Available at: (http://www.pdatu.edu.ua/research-institute-cereals-them-oalekseyevoyi.html), (accessed March 02, 2018)).

32. Nazionalnyu naukoviy zentr "Instityte zemlerobstva Nazionalnoi akademii agrarnuch nauk Ukraine" (2018) [National Scientific Center "Institute of Agriculture of the National Academy of Agrarian Sciences of Ukraine"]. Elekrotronik resurs [Electronic resource]. - Available at: (http:// zemlerobstvo.com/?page_id=398/), (accessed March 02, 2018)).

33. Nettevych E. D. \& Fesenko N. V. (1964) Biologichnyi metod izolyazii obyknovennoi grechki [Biological method of isolation of common buckwheat]. Sekekzia i semenovodstvo [Selection and seed-growing]. No. 2, pp. 41-45.

34. Taranenko L. K. \& Yatsyshen O. L. (2014) Prinzipy, metody i dosagnenya selekzii grechki (Fagopyrum esculentum Moench): monografia [Principles, methods and achievements of buckwheat selection (Fagopyrum esculentum Moench): monograph]. Vinnytsia: LLC Nilan LTD, (in Ukrainian). 
35. TzOV NV MP “Antaria” (2018) [TzOV NV MP “Antariia”]. Elekrotronik resurs [Electronic resource]. - Available at: (http:/antaria.com.ua/en/catalog/ grupa/20), (accessed March 02, 2018)).

36. Fesenko N. V., Koblev S. Yu, \& Martinenko G. E. (1992) Metod sozdania vysokoyrojainich sortov grechki [Method of creating high-yield buckwheat varieties]. Sekekzia i semenovodstvo [Selection and Seed Growing]. No 6, pp. 20-22.

37. Shuvar Ivan. (2011, March) Vona vratye [She will rescue]. Agrobizness sogodni. Gazeta pidpreemziv APK [Agrobusiness today. The newspaper of entrepreneurs APK]. No 6 (205), pp. 32-35. 


\section{HYBRID WAR AND ITS IMPACT \\ ON ECONOMIC SECURITY GOVERNMENT}

\section{ГІБРИДНА ВІЙНА ТА ЇЇ ВПЛИВ \\ НА ДЕРЖАВНЕ УПРАВЛІННЯ ЕКОНОМІЧНОЮ БЕЗПЕКОЮ}

\section{Hbur Zoriana ${ }^{1}$}

DOI: http://dx.doi.org/10.30525/978-9934-571-26-8_5

Abstract. The article defines the difference between traditional and nontraditional warfare. The essence of the concept of "hybrid war", as one of the types of informal and / or non-traditional warfare from the standpoint of various scholars, politicians and other statesmen, is described. As a result, the actual definition is proposed: a hybrid war - a set of tools and tools used by the enemy, which includes not only and not only nuclear, biological, chemical weapons, but a complex of information, high-tech, cybernetic means of influence, psychological pressure to achieve political goals. The basic forms of the hybrid war have been found out. The classification of types of weapons used in hybrid warfare is described, as well as its influence on modern processes of European integration is clarified.

A number of scholars and political figures paid attention to this issue, among them: R. Arzumanyan [1], O. Vasilenko [2], O. Galak [3], V. Horbulin [4; 5], A. Demidov [6], E. Magda [7], Malsky [8], V. Pobordsky [9], L. Savin [10] and others.

The purpose of this article is to reveal the essence of the hybrid war and determine its impact on state governance of economic security.

\section{1. Ветуп}

Забезпечення воєнної безпеки - це одне з найважливіших завдань, яке стоїть перед державою і є складовою національної безпеки. Для виконання даного завдання здійснюються складні політичні, економічні, військові та інші заходи. Головна роль належить політичним заходам, які спрямовані на формування сприятливих умов для функ-

\footnotetext{
${ }^{1} \mathrm{PhD}$ in Public Administration, Postdoctoral Student, National Academy of Public Administration under the President of Ukraine, Ukraine

(C) Hbur Zoriana
} 


\section{Hbur Zoriana}

ціонування суспільства всередині країни та поза ії межами, особлива увага приділяється зміцненню міжнародного визнання держави та недопущення поточних та можливих конфліктів. Важливо підкреслити, що будь-які заходи будуть ефективними лише у випадку сполучення їх з оборонними діями, що спрямовані на стримування можливих агресорів та блокування їх спроб порушити цілісність країни.

Дослідженню цього питання приділяли свою увагу ряд науковців та політичних діячів, серед них: Р. Арзуманян [1], О. Василенко [2], О. Галака [3], В. Горбулін [4; 5], А. Демидов [6], С. Магда [7], Мальський [8], В. Предборський [9], Л. Савин [10] та інші.

Метою цієї статті є розкриття сутності гібридної війни та визначення ïï впливу на державне управління економічною безпекою.

\section{2. Поняття та суть «гібридної війни» \\ у зарубіжній та вітчизняній літературі}

Специфіка збройних протистоянь, місце та значення військового аспекту у державному управлінні залежить від рівня економічного розвитку та технологічної складової. У процесі ускладнення воєнної зброї та техніки, який відбувається паралельно з вдосконаленням інших суспільних процесів та громадської свідомості, породжуються властиві даному розвитку методи воєнного протистояння.

Формальною війною вважається зіткнення збройних сил однієї держави зі збройними силами іншої. Таке зіткнення супроводжується формальним актом оголошення війни. Неформальні війни - це збройні конфлікти, в яких принаймні одна або обидві сторони є недержавними утвореннями. Нові загрози, що виникли після закінчення холодної війни, призвели до виникнення феномену сірої зони, тобто до комбінації війни і воєнних дій з організованою злочинністю (наприклад, конфлікту у Республіці Ічкерія). Формальні війни можуть набувати традиційної та нетрадиційної форм. Традиційні війни - це воєнні дії регулярних збройних сил однієї країни проти регулярних і нерегулярних збройних сил (партизанські війни) іншої країни із застосуванням звичайних засобів збройної боротьби. Традиційні війни - контактні, їх подальший розвиток пов'язаний з розробленням нових способів і засобів збройної боротьби. У поєднанні $з$ новітніми інформаційними технологіями вони породжують такі форми, як мережеві та мережо-центричні війни [2, с. 20-22]. 


\section{Hybrid war and its impact on economic security government}

Нетрадиційні війни - це зіткнення регулярних збройних сил країни з іррегулярними формуваннями, угрупованнями, загонами, які не визнають норм і правил ведення воєнних дій. Формальні та неформальні воєнні конфлікти можуть бути симетричними й асиметричними.

Асиметричний конфлікт відбувається за участю суб'єктів, що якісно відрізняються стосовно силового потенціалу й принципів організації та управління. Навіть без переходу до воєнної фази асиметричний конфлікт має ряд специфічних ознак, які є наслідком обмеженого арсеналу засобів для слабших учасників. В асиметричних відносинах сильний партнер зазвичай не потребує застосування додаткових силових заходів для нав'язування власної волі. Тому конфлікт часто відбувається в латентному вигляді, лише епізодично переходячи в збройну фазу у формі жорстоких і на перший погляд ірраціональних дій, зокрема терористичних актів. Такі дії є тим засобом з обмеженого арсеналу, за допомогою якого слабший партнер впливає (і потенційно перемагає) на сильнішого [3, с. 24-26].

У сучасних умовах формується новий вид загрози державній цілісності під назвою «гібридна війна». Для більш глибокого розуміння іiі впливу на державне управління економічною безпекою слід розглянути основні підходи до визначення даного поняття.

Автором цієї концепції є Френк Г. Хоффман, колишній офіцер морської піхоти, науковий співробітник міністерства оборони США. Це великий теоретик в галузі збройних конфліктів та військово-політичної стратегії. Автор зазначає, що конфлікти будуть мультимодальними (тобто такими, що ведуться різними способами) та багатоваріантними, що не входять в межі простої конструкції ведення збройного конфлікту чи війни. За Г. Хоффманом майбутні загрози можуть в більшій мірі бути охарактеризованими як гібридне співвідношення традиційних та нерегулярних стратегій і тактик, це децентралізоване планування та виконання, участь недержавних акторів з використанням одночасно простих та складних технологій [11].

Сьогодні ж існують різні варіанти визначення сутності гібридної війни [1, с. 22-39]:

1) військова стратегія, яка поєднує звичайну війну, малу війну та кібервійну;

2) атака з використанням ядерної, біологічної, хімічної зброї, саморобних знарядь для терористичних атак та інформаційного тиску; 


\section{Hbur Zoriana}

3) складна та гнучка динаміка бойового простору (battlespace), яка передбачає швидку реакцію та адаптацію учасників протистояння;

4) сучасний вид партизанської війни, яка поєднує сучасні технології та методи мобілізації (Біл Неметт, підполковник Корпусу морської піхоти США);

5) основний метод у асиметричній війні, яка ведеться на трьох умовних фронтах - серед населення конфліктної зони, тилового населення та міжнародної спільноти (полковник Армії США Джек МакКуен);

6) Франк Хоффман визначає гібридну війну у вигляді будь-яких дій ворога, який швидко та гнучко використовує найрізноманітніші комбінації дозволеної зброї, партизанську війну, тероризм, злочини на полі бою, і все для досягнення політичних цілей.

У свою чергу Є. Магда [7] зауважує, що гібридну війну можна у найзагальніших рисах визначити як сукупність заздалегідь підготовлених і оперативно реалізованих дій військового, дипломатичного, економічного, інформаційного характеру, спрямованих на досягнення стратегічних цілей. До складових гібридної війни відносяться традиційні та нестандартні загрози, тероризм, підривні дії, коли використовуються новітні чи нешаблонні технології для протидії перевазі супротивника у військовій силі.

Науковець М. Айшервуд пропонує наступне трактування «гібридної війни» - це війна, що стирає різницю між чисто конвенційною та типово нерегулярною війною [10].

Проаналізувавші деякі підходи та визначення різних науковців та державних діячів, можемо запропонувати власне визначення. Отже, гібридна війна - сукупність засобів та інструментів, які використовуються противником, до складу яких входить не тільки і не стільки ядерна, біологічна, хімічна зброя, а комплекс інформаційних, високотехнологічних, кібернетичних засобів впливу, психологічний тиск 3 метою досягнення політичних цілей.

На переконання В. Передборського, гібридна війна 3 визначним синергетичним ефектом є проявом визначає синкретизму, змішування, які мають такі основні форми [9]:

- форми організації сил, використання засобів війни - за критерієм масштабу використання збройних сил - використання великомасштабних та невеликих, мобільних підрозділів 3 високотехнологічною зброєю, системами зв'язку, інформаційною технікою; 
- форми організації сил - за критерієм відношення до офіційної влади - державних та парамілітарних (партизанських), добровольчих підрозділів збройних сил. Україні (як і Росіі) завжди було характерним широке застосування, окрім державних військових формувань, партизанських, добровольчих, інших парамілітарних підрозділів. За сучасних умов значення невеликих мобільних військових угрупувань, у тому числі альтернативних до держави, з функцією виконання диверсійно-розвідувальних, штурмових, терористичних, інших спеціальних завдань різко зростає;

- принципово змінюється значення синкретичних засобів (функцій) колишнього забезпечення основної ударної функції військ - відбувається синергетичне посилення, застосування кібернетичних, пропагандистських, медійних, інформаційних, психологічних, космічних засобів, переведення їх у сегмент основних функцій війни;

- посилення синергетично-синкретичних засобів ведення війни засобами іiі ресурсного забезпечення - дипломатичного, економічного, торгівельного, фінансового, корупційного, енергетичного тощо; синхронізація їх застосування у складі інших засобів військової політики щодо інших основних засобів війни.

У таких конфліктах противники (держави; групи, що фінансуються державами, або суб'єкти, які самі фінансують свою діяльність) будуть мати доступ до сучасного воєнного потенціалу, що включає зашифровані командні системи, переносні ракети класу «земля-повітря» та інші сучасні смертоносні системи; а також - підтримувати організації затяжних партизанських дій, в яких застосовуються засідки, саморобні вибухові пристрої та вбивства [11].

Коли справа дійде до політичних цілей, гібридні війни, скоріш за все, матимуть вигляд нерегулярної війни, де ії учасники робитимуть спроби та намагатимуться підірвати легітимність та авторитет керуючого режиму. Це вимагатиме від збройних сил держави допомоги, щоб закріпити здатність держави забезпечувати соціальні, економічні та політичні потреби свого народу [11].

У цьому контексті М. Айшервуд також зазначає, що потенційно гібридну війну сьогодні можуть вести багато конфліктуючих держав. Він пояснює, що складний характер гібридної війни вимагає від воєначальників та цивільних лідерів розуміння свого операційного оточення або відчуття бойового простору. Гібридний противник може 


\section{Hbur Zoriana}

приховуватися поміж цивільного населення, бути не схожим на типового ворога та використовувати «електронний притулок», створений глобальним телекомунікаційним ринком [10].

Відмінність гібридної війни полягає у тому, що противним замається декількома фазами воєнних дій одночасно і тим самим потребує зовсім інші вимоги до реакції збройних сил. А. Демидов [6] також поділяє цю думку.

На думку В. П. Горбуліна, кожен конкретний елемент «гібридної війни» не новий по суті й використовувався майже в усіх війнах минулого, але унікальними є узгодженість і взаємозв'язок цих елементів, динамічність та гнучкість їх застосування, а також зростання ваги інформаційного чинника. Причому інформаційний чинник в окремих випадках стає самостійним складником і виявляється не менш важливим, ніж військовий [4].

3 огляду на це Л. Савин пропонує класифікацію видів зброї, яка використовуються у таких умовах [10]:

1.Модельно організаційна - зброя, що грунтується на особових базах даних політиків, державних службовців, бізнесменів, псевдо- та ксеноліти країни противника. Ці бази збирають за допомогою різних міжнародних організацій, благодійних фондів, радників, політологів та інших підготовлених служб. У цих базах даних міститься інформація про рахунки з-за кордону, а також компрометуюча інформація. Основні бази даних використовуються для залякування і розкладання політичної та державної еліти для формування кола підтримки та запобіганню супротиву.

2. Інформаційна зброя має таку класифікацію за ознаками:

- за якістю інформації;

- за носієм інформації;

За якістю інформаційна зброя класифікується:

- концептуальна-методологічна - це формування глобальної політики, що спрямовується на різні народи з метою створення якогось конкретного спланованого виміру розвитку історичних подій.

- хронологічна зброя - інформація хронологічного плану - є послідовність фактів на явищ. дає можливість розглядати всі явища історичного процесу та прогнозувати вектори майбутньої політики.

- факторологічна зброя - це ідеологія, релігія, технології. саме ці види зброї дають можливість підпорядкувати собі противника 


\section{Hybrid war and its impact on economic security government}

3. Матеріальна зброя поділяється на:

- економічну зброю - включає засоби економічної боротьби 3 дезорганізацією структур противника і подальше їх поглинання. Сюди входить контроль фінансово-кредитної системи країни та контрольна іншими економічними системами держави, борговими зобов'язаннями розподілом коштів, повернення фінансів в державу, прибутковість державного сектору в економіці, іiі частка.

- зброю геноциду - включає етнічний геноцид, наркотичний, алкогольний, інформаційно-економічний та інший;

- звичайна зброя фізичного знищення.

Як підкреслює В. Гобулін, що нинішня безпекова криза вирізняється тим, що розгортається за умов глобалізації, тобто кардинального підвищення ступеня взаємної залежності суб'єктів міжнародної політики, а це вимагає підвищення рівня відповідальності учасників системи міжнародних відносин. Нехтування міжнародними зобов'язаннями, зокрема 3 боку впливових світових держав та їх об'єднань, призводить до небезпечних наслідків на регіональному та глобальному рівнях $[5$, с. 46$]$.

Головною загрозою економічній безпеці України є агресія з боку Російської Федерації, яка змушує українців приймати рішення про обрання колективної системи безпеки через Організацію Північноатлантичного договору (НАТО) та Європейський Союз, наслідуючи досвід більшості країн пострадянського режиму.

Влучною є думка М. Мальського, який стверджує, що вона «... підірвала ідею побудови системи загальноєвропейської безпеки, а також звела нанівець одне з головних досягнень, покладене у фундамент ОБСЄ, - Гельсінський заключний акт, в якому задекларовано такі міжнародні принципи, як повага до суверенітету, відмова від використання сили або погрози силою, визнання непорушності кордонів та територіальної цілісності держав, мирне врегулювання суперечностей, невтручання у внутрішні справи, повага до прав і свобод людини, рівноправ'я країн та право народів розпоряджатися власною долею, співробітництво між державами, дотримання зобов'язань згідно з міжнародним правом» [8, с. 45].

Сучасні умови міжнародного середовища характеризуються процесам и глобалізації, розвитком економіки та міжнародних норм права, зростанням рівня науково-технічного прогресу та інноваційних техно- 


\section{Hbur Zoriana}

логій. Однак на заваді загальносвітовому благополуччю постало нове явище «гібридна війна». Сутність проблеми полягає у розкритті сутності даного поняття у контексті сучасних реалій ведення війни, що відбувається поза межами, що окреслені у конвекційно-закріплених стандартах та правилах. Дослідження даного питання є актуальним у зв'язку з тим, що проблема «гібридної війни» піднімається не лише у наукових колах, а й на різних рівнях державного управління, юридичних структур з метою забезпечення безпечних умов функціонування всіх сфер державного функціонування.

Сучасний стан розвитку світового господарства характеризується розповсюдженням різнопланових форм гібридних війн. Дана ідея не $є$ новою, оскільки у військовій історії існує немало прикладів нетрадиційних війн, в яких використовувалася нелінійна тактика та нерегулярні збройні формування, які є прадавніми формами даного виду протистояння.

Зазвичай гібридні форми війни не є суто воєнним протистоянням, а включають економічні, психологічні та партизанські засоби нападу. Структура та величина впливу цих компонентів, міра їх використання у певному протистоянні залежать від поточного рівня розвитку економіки та технологій.

Загальновідомо, що війни та збройні конфлікти $є$ просторово-часовими процесами, в основі яких лежать найрізноманітніші суперечності, а також використання різномасштабних військових формувань на певних територіях для досягнення певних цілей. Гібридні сили успішно використовують технологічно передові системи таким чином, що вони працюють на межі можливостей. Тому гібридні збройні сили мають перевагу над традиційною армією, яка діє суворо в рамках уставу. Загалом, гібридна загроза відзначається тим, що стирає традиційні уявлення та практики війни [2].

Як зауважує В. Предборський, необхідність модернізації вітчизняного суспільства часто обмежується копіюванням досвіду вестернізації, чи удосконаленням радянської моделі реформування, що призводить лише до зростання численних загроз національній безпеці, серед яких одне з головних місць належить феномену синергетичної системи управлінських криз, активованих як зовнішніми, так і внутрішніми чинниками. Процеси кризового інвазійного тиску захопили не тільки соціально-економічні, а й інші суспільні процеси, зокрема 


\section{Hybrid war and its impact on economic security government}

військові, перетворивши їх на систему модифікованого кризового механізму функціонування суспільства. У зв'язку з цим реформування у будь-якій сфері життя і діяльності (політичній, соціальній, економічній, військовій, організаційній, правовій) у сучасному вітчизняному суспільстві має спиратися на загальні закономірності адекватного реформування [5].

Існує загалом два підходи до розуміння сутності війни. Перший, пов'язаний з традицією Карла фон Клаузевіца, визначає війну як організоване насильство, що має на меті досягнення соціальних та політичних цілей. Цей підхід дистанціюється від моральних, правових, етичних аспектів війни, або сприймає їх через призму військово-політичних інтересів. Другий підхід виходить із праць Цицерона, який твердив, що війна - це правова ситуація та умови, яке легітимізують насильство та визначають його допустимі межі. Таким чином вводиться поняття «мирний стан» та «військовий стан», залежно від того чи $€$ насильство легітимним. Розрізнення мирного та військового стану $\epsilon$ критично необхідною річчю. Війна створює принципово іншу реальність, формує власне розуміння моральної, етичної, правової норми, яке потребує визначення засобами військового права. Поки правове поле залишається невизначеним, ми не можемо говорити про організоване ведення бойових дій, а насилля може стати неконтрольованим, що тим не менш, не означатиме війни [1, с. 39].

Відповідно, саме ці особливості і є основною загрозою гібридної війни. В умовах війни зазвичай складно чітко визначити, хто $є$ суперником у конкретному протистоянні, а також визначити джерело впливу правових, етичних та моральних фреймів.

\section{3. Актуальні гібридні загрози економічній безпеці України та досвід протидії гібридним загрозам в Польщі}

Незважаючи на вже триваючу четвертий рік гібридну війну Росії проти України, низка гібридних загроз з 2014 року залишаються актуальними і на сьогодні, створюючи небезпеку дестабілізації й ослаблення нашої держави, порушення фундаментальних прав і свобод, зниження рівня життя та власне і самого мирного існування громадян України.

Для ідентифікації гібридних загроз слід розмежувати поняття «виклик», «ризик», «небезпека», «загроза», «надзвичайна ситуація», 


\section{Hbur Zoriana}

які є базовими в теорії «безпеки». Часто деякі з них ототожнюються і вживаються як синоніми, що не завжди відповідає реальному стану речей.

У цьому контексті варто навести визначення поняття «гібридна загроза» - це будь-який противник, який одночасно та адаптовано використовує співвідношення звичайного озброєння, нерегулярну тактику, тероризм та злочинну поведінку в зоні бойових дій для досягнення своїх політичних цілей [9].

Гібридні загрози включають в себе коло різних режимів ведення війни, що відносить до себе стандартне озброєння, нерегулярні тактики і формування, терористичні акти (в тому числі і насилля та примус) і кримінальний безлад. На сьогоднішній час цей термін має три гілки. Гібридність може відноситися, перш за все, до військової ситуації та умовам; по-друге, до стратегії та тактики противника; по-третє, до типу сил, які держава повинна створювати та підтримувати [9].

Розмірковуючи про виникнення воєнних загроз, слід визначити основні джерела і чинники воєнної небезпеки України в сучасних умовах. Як зауважує I. Руснак, існуючі джерела воєнної небезпеки для України за походженням можна поділити на зовнішні та внутрішні. До основних зовнішніх джерел належать [6]:

- наявність територіальних претензій до України;

- зацікавленість у зміні зовнішнього та внутрішнього політичного курсу України на свою користь;

- прагнення до зменшення політичної, економічної, воєнної ваги України в інтересах свого домінування в регіоні;

- ведення проти нашої держави ворожої пропаганди, підтримка дій сепаратистських сил в Україні, сприяння розпалюванню міжетнічних та міжконфесійних протиріч;

- зацікавленість у встановленні контролю над стратегічними об'єктами та комунікаціями України;

- наявність поблизу кордонів України значних угруповань військ.

Актуальність наведених джерел набувають особливого значення 3 огляду на інші об'єктивні чинники, які походять із сусідніх держав. До таких чинників можна віднести [6]:

- внутрішня економічна й соціально-політична нестабільність;

- недостатня правова врегульованість міждержавних відносин 3 Україною. 
- наявність потужного воєнного потенціалу в поєднанні з перманентним зростанням воєнних витрат.

Характер сучасних та майбутніх війн визначається тенденціями розвитку форм та способів ведення збройної боротьби. Серед них варто відзначити [2]:

1.Зростання значення стратегічного неядерного стримування супротивника шляхом масового оснащення військ новітніми засобами збройної боротьби для ведення неядерних, неконтактних (дистанційних) бойових дій;

2.Підвищення ролі динамічності та маневреності в діях військ на розрізнених напрямках з широким застосуванням сил швидкого реагування, аеромобільних військ і військ спеціального призначення;

3. Розширення простору та масштабів збройної боротьби, перенесення бойових дій із землі і поверхні морів у повітря, під воду та у космос. Одночасне вогневе та електронне ураження військ, об'єктів тилу, економіки, комунікацій на всій території супротивника;

4.Зростання ролі протиборства в інформаційній сфері та використання новітніх інформаційних технологій;

5.Боротьба 3 міжнародним тероризмом, створення експедиційних сил для проведення миротворчих і антитерористичних операцій.

Що стосується міжнародного досвіду, то в СС доволі чітко ідентифікували «гібридні загрози» та визначали заходи протидії. Була розроблена низка документів, включаючи Глобальну стратегію $\mathrm{EC}$, Спільний рамковий документ 3 протидії гібридним загрозам (06.04.2016 р.) [7] і Спільна доповідь Свропейському парламенту і Європейській Раді з його імплементації (19.07.2017р.) [8], Оперативний протокол $\mathrm{EC} 3$ протидії гібридним загрозам "EU Playbook" (05.07.2016 р.), Спільний робочий документ «Східне партнерство 20 очікуваних досягнень до 2020 року: фокусуючись на головних пріоритетах та реальних результатах» (15.12.2016 р.), доповідь Свропейського парламенту «Протидія гібридним загрозам: Співпраця ЄС-НАТО» (березень 2017 р.)

В СС класифікують сфери протидії таким загрозам: інформаційна сфера, енергетика, транспорт та інфраструктура, космос, військова сфера, охорона здоров'я і продовольча безпека, кібер-простір, фінансова сфера, промисловість, громадський або суспільний вимір. Слід зазначити, що в ЄС досить серйозно підійшли до виявлення гібрид- 


\section{Hbur Zoriana}

них загроз і ще минулого року запропонували створити Центр аналізу гібридних загроз ЄC (EU Hybrid Fusion Cell) в рамках Розвідувального і ситуативного центру СС (EU Intelligence and Situation Centre, EU INTCEN) Свропейської служби зовнішньої дії. Саме на цю нову структуру, яка у травні 2017 року набула повної оперативної здатності, і покладається завдання збору, аналізу і доведення відкритої та закритої інформації стосовно індикаторів та попереджень про гібридні загрози. Цей Центр підводить гібридні загрози під єдиний європейський знаменник та доводить відомості про них, у тому числі й у формі «Гібридного Бюлетеня» (Hybrid Bulletin), до інституцій ЄС і країн-членів Свросоюзу [4].

В Україні ж під загрозою виявились практично усі сфери суспільного життя - економіка, політика, культура пам'яті та інформаційного споживання, навіть ідентичність. Слабка диверсифікація ринків збуту української продукції, прив'язаність до російського ринку базових секторів вітчизняного господарства, відсутність альтернативних джерел постачання ресурсів - усе це перетворилося на питання національної безпеки. Промисловість, інфраструктура залишаються енерговитратними й малоефективними. Відсутність адекватної інформаційної та культурної політики спричинила культурну окупацію свідомості значної частини громадян. Зусиллями пропаганди була нав'язана штучна проблема дискримінації російськомовного населення, страх перед ефемерною загрозою «бандерівщини». Український інформаційний простір без належного російськомовного й англомовного контенту виявився замкненим, неконкурентним, не готовим донести українську позицію до світової спільноти [2].

Дослідник В. Мартинюк пропонує наступну класифікацію гібридних загроз економічній безпеці Україні та суспільству на сучасному етапі [4]:

1) у військовій сфері:

- діяльність незаконних збройних формувань на території України, що спрямована на дестабілізацію внутрішньої соціально-політичної ситуації в Україні, порушення функціонування органів державної влади, органів місцевого самоврядування та блокування важливих об'єктів промисловості й інфраструктури;

- діяльність диверсійно-розвідувальних груп агресора під маскою українських силовиків з метою дискредитації останніх; 
- нелегальне розповсюдження (торгівля) зброєю, що призводить до неконтрольованого володіння зброєю населенням країни та можливостей іï придбання;

- цілеспрямовані заходи дискредитації збройних сил України та інших військових формувань і силових структур;

2) у правоохоронній сфері:

- використання компромату на представників правоохоронної системи не для усунення їх від роботи, а для просування необхідних для зацікавленої сторони рішень;

- фізичне усунення активно діючих співробітників правоохоронних органів;

- використання зовнішнього впливу на злочинні елементи для розхитування ситуації в Україні;

3) в інформаційній сфері:

- відкрите і приховане використання демократичних норм та процедур країн $С С$, а також США й інших країн-партнерів для інформаційної дискредитації України та іiї спроб формувати міжнародну підтримку протидії російській агресії;

- політичні та лобістські заходи на Заході, які використовуються Росією для формування сумніву у правильності позиції країн ЄС щодо продовження санкційного впливу на Кремль, а також для легітимації анексії Криму;

- використання українських телевізійних каналів та інших медіа для трансляції проросійських наративів у дозованому вигляді чи під опозиційними гаслами;

- поширення інформаційних продуктів з використанням регіональної, етнонаціональної, мовної та іншої партикулярної ідентичності серед громадян України для формування ліній розколу в суспільстві, нав'язування відчуття дискримінації та незахищеності, підготовки соціальної бази для протестів та провокацій;

4) у кібер-сфері:

- збереження присутності російських банків в Україні, які продовжують контролювати значну частину фінансів бізнесу і громадян;

- контроль над важливими економічними активами в Україні, зокрема в енергетичному секторі (обленерго, облгаз), з боку російських або проросійськи налаштованих власників, що робить можливим тихі диверсії (саботаж, умовні аварії і простої), впровадження 


\section{Hbur Zoriana}

шкідливого програмного забезпечення для подальших кібер-атак, руйнування стратегічних підприємств;

- зовнішній економічний вплив на діяльність крупних підприємств, що створює передумови для впливу на великі робітничі колективи та маніпулювання (шахтарські протести);

5) у сфері прав людини, національних меншин:

- експлуатація зовнішнім суб'єктом тематики «захисту прав національних меншин», «порушення прав в сфері мовної політики», «прояву дискримінації за національною ознакою» задля досягнення власних цілей;

- використання питань мовної політики для дестабілізації ситуації в крані;

- інспіровані ззовні ущемлення прав національних меншин з метою розпалювання міжетнічної ворожнечі, стимулювання проявів сепаратизму і дестабілізації ситуації тощо.

Як наголошують аналітики, гібридні загрози також концентруються у невійськовій сфері. До основних транснаціональних загроз для України, що активно експлуатуються у гібридній війні, на сучасному етапі можна віднести [3]:

- наявність сепаратистських тенденцій в окремих прикордонних районах: на додачу до тимчасово окупованих Криму та частини території Донбасу спостерігаємо непевність на Закарпатті (русинський сепаратизм); наявність подвійних паспортів у мешканців Буковини, Закарпаття, прикордонних територій з Московською Федерацією, що дають змогу використовувати карту «захисту своїх громадян»;

- відсутність ефективних механізмів забезпечення законності, правопорядку, боротьби зі злочинністю, особливо ії організованими формами і тероризмом; як результат маємо неконтрольоване проникнення диверсійних груп та груп провокаторів на територію України;

- неконтрольований відплив за межі України матеріальних і фінансових ресурсів, передусім із непідконтрольних територій;

- безпідставна міграція (коли мешканці непідконтрольних територій приїжджають в Україну за пенсіями та виплатами і повертаючись назад підтримують окупацію України Москвою) та криміналізація суспільства.

Така різноманітність слабких місць у контексті гібридних загроз дозволяє зробити висновок про те, що дане питання залишається акту- 


\section{Hybrid war and its impact on economic security government}

альним і сьогодні, що в свою чергу створює небезпеку дестабілізаційних процесів та ослаблення України шляхом порушення системи прав і свобод громадян, зниження рівня їхнього життя та мирного існування.

Таким чином, ми бачимо, що в умовах «гібридної» війни на передній план виходять проблеми насильницького розв'язання конфліктів, що характеризується високою інтенсивністю і широким застосуванням методів прямої агресії, а також здатністю залучати у свою сферу і заражати все нових людей, руйнуючи історично сформовану систему державної стабільності i, отже, безпеку. Що б перемогти у «гібридній» війні треба мати найсучасніші збройні сили, силові структури, що здатні до проведення антитерористичної боротьби, удосконалені та захищені засобі інформаційної боротьби.

Тематика війни гібридного типу стала опрацьовуватись в Польщі після доволі швидкого усвідомлення того, що чинить Росія проти України, починаючи з 2014 року. Спочатку польська стривоженість була обумовлена неясністю подальших намірів Росії в Європі та агресивних дій проти Польщі, сусідніх країн Балтії, а також НАТО та СС, які РФ ідентифікує як не дружні до неї західні альянси. 3 часом в Польщі дійшли висновку, що потенційні гібридна агресія Росії проти Польщі за українським зразком малоймовірна. Польське суспільство досить монолітне. Основну ставку в протидії гібридним загрозам Польща робить на багатосторонню взаємодію в рамках НАТО та ЄС. Варшава також проводить активно лінію співпраці обох альянсів за для їх взаємного посилення за принципом «у двох краще ніж самому».

\section{4. Методологія дослідження}

Методологічну основу статті становлять загальнонаукові прийоми дослідження і методи, що грунтуються на сучасних наукових засадах управлінської, юридичної і споріднених із ними наук.

У роботі використано такі методи:

- системний підхід - для дослідження і формулювання поняття гібридна війна, гібридні загрози та вплив на економічну безпеку України;

- метод аналізу і синтезу - для аналізу та опису динаміки загроз в різних регіонах нашої країни у 2016-2017 рр.;

- логічний метод - для дослідження еволюції постановки проблеми й наступності іï вирішення, для встановлення зв'язків між суспільними явищами та подіями. 


\section{Hbur Zoriana}

\section{5. Пошуки}

На сьогоднішній день приймаються рішення щодо долі України в Європі, тому наша держава повинна не тільки сформувати безпечне середовище, а й зробити внесок у колективну безпеку Європи. Загальновідомо, що євро інтеграційні процеси та налагодження євроатлантичної співпраці пов'язане з безліччю ризиків. Тому обраний курс України на європейську інтеграцію, яка є невід'ємною складовою євроатлантичного простору, зумовлює необхідність розвитку нових суспільно-політичних моделей держави, розробки відповідних стратегій розвитку економічної системи України, а особливо, військово-промислової складової.

Отже, об'єктивні закономірності вітчизняних суспільних процесів, їх модернізації призводять до значного поширення та піднесення ролі синкретичних, нероздільних, гібридних трендів, у тому числі у військовій справі. Використання гібридних суспільних форм, гібридних засобів війни здатне забезпечити дифузійне врощення цих інструментів у процеси модернізації, принципово підсиливши свій вирішальний вплив на іï якість, зробити їх у певній мірі захищеними, непомітними для дії традиційних небезпек їх функціонуванню, військових засобів виявлення, ідентифікації та протидії, забезпечує появу нової якості використання гібридних форм як інституційної матриці з якісно новими можливостями - своєрідних соціальних технологій «стелс», яку нездатна уразити традиційна зброя інституційного, соціального та військового призначення.

\section{6. Висновки з дослідження}

Практично весь час, починаючи 31991 року, Україна не приділяла належної уваги зміцненню власної безпеки, вважаючи що їі оточення $\epsilon$ потенційно дружнім і не несе серйозних загроз безпеці держави i суспільства. Рік у рік система безпеки України послаблювалась, що виражалось не лише в нездатності Збройних Сил виконувати свої завдання за призначенням, але й ослабленні державної системи вцілому та іiї окремих безпекових компонентів зокрема економічної безпеки.

Як висновок з усього викладеного вище варто узагальнено зазначити гібридні загрози економічній та національній безпеці України які залишаються актуальними і сьогодні. 
На національному, загальнодержавному рівні:

- політична війна в українському середовищі правлячої політичної групи, що стимулюється ззовні агресором через внутрішньо-українську агентуру впливу;

- неефективність парламенту, що не відповідає визначеній Конституцією України парламентсько-президентській моделі;

- незадовільний професійний рівень державної служби України;

- PR-активність влади замість предметної діяльності;

- корупційна діяльність у всіх секторах економіки і навіть в тих які покликані упереджувати та боротись з корупцією;

- комбіновані дії комплексного характеру з метою нарощування протестного потенціалу суспільства проти неефективної влади;

- використання українських телевізійних каналів та інших медіа для трансляції проросійських наративів у дозованому вигляді чи під опозиційними гаслами.

В економічній сфері:

- збереження присутності російських банків в Україні, які продовжують контролювати значну частину фінансів бізнесу і громадян;

- контроль над важливими економічними активами в Україні;

- впровадження на підприємствах державного значення програмного забезпечення для подальших кібер-атак;

- руйнування стратегічних підприємств;

- зовнішній економічний вплив на діяльність крупних підприємств.

\section{Список літератури:}

1. Арзуманян Р.В. Определение войны в 21 веке. Обзор XXI ежегодной конференции по стратегии Института стратегических исследований Армейского военного колледжа, 6-8 апреля 2010 / Р.В. Арзумян. - Ереван, 2011. -60 c.

2. Василенко О.В. Основні світові тенденції розвитку озброєння та військової техніки для ведення війн у майбутньому / О.В. Василенко // Наука і оборона. - 2009. - № 4. - С. 18-22.

3. Галака О. М., Ільяшов О. А., Павлюк Ю. М. Основні тенденції розвитку та ймовірні форми воєн і збройних конфліктів майбутнього / О. М. Галака, О. А. Ільяшов, Ю. М. Павлюк // Наука і оборона. - 2007. - № 4. - С. 10-15.

4. Горбулін В. П. «Гібридна війна» як ключовий інструмент російської геостратегії реваншу / В. П. Горбулін // Стратегічні пріоритети. - 2014. № 4. - C. 5 . 


\section{Hbur Zoriana}

5. Горбулін В.П. Донбас і Крим: ціна повернення: монографія / за заг. ред. В.П. Горбуліна, О.С. Власюка, Є.М. Лібанової, О.М. Ляшенко. - К.: НІС, $2015-474$ c.

6. Демидов А.В. Управляемый хаос. Стратегия Росии № 5, май 2015 - Електронний ресурс / Режим доступу: http://sr.fondedin.ru/new/ fullnews.php? subaction=showfull \&id=1430428108\&archive $=1430773984 \&$ st art from $=\& u c a t=14 \&$

7. Магда Є.М. Гібридна війна: сутність і структура феномену / Є. Магда // Міжнародні відносини: Серія «Політичні науки». - 2014. - № 4.

8. Мальський М.3. Транскордонна безпека: політико-правовий, соціально- економічний, гуманітарний та екологічний вимір. Збірник матеріалів Міжнародної науково-практичної конференції, Львів, 21 квітня 2017 року / Упорядники: М. 3. Мальський, О. С. Кучик, Р. В. Вовк. - Львів: Факультет міжнародних відносин, 2017. - 96 с.

9. Предборський В. А. «Гібридна» війна як відбиття закономірностей розвитку суспільства незавершеної модернізації / В. А. Предборський // Формування ринкових відносин в Україні. - 2014. - № 10. - С. 13-18.

10. Савин Л. Гибридная война. / Информационно-аналитический портал Геополитика. 27янв. 2015 - Електронний ресурс / Режим доступу: http:// geopolitica.ru/article/gibridnaya-voyna\#.VazC1qTtmko

11. Major Shane R. Reeves, Major Robert E. Barnsby The New Griffin of War. Hybrid International Armed Conflicts // Academic joutnal article "Harvard International Review" 2013. - Електронний ресурс / Режим доступу: https:// www.questia.com/library/journal/1G1-316203914/the-new-griffin-of-war-hybridinternational-armed

\section{References:}

1. Arzumanian R.V. (2011), Opredelenye vojny v 21 veke. Obzor XXI ezhehodnoj konferentsyy po stratehyy Ynstytuta stratehycheskykh yssledovanyj Armejskoho voennoho kolledzha [The definition of war in the 21 st century], Yerevan, Armenia.

2. Vasylenko O.V. (2009), "The main world trends in the development of weapons and military equipment for future wars", Nauka i oborona, no. 4, pp. $18-22$.

3. Halaka O. M., Il'iachov O. A., Pavliuk Iu. M. (2007), "The main trends of development and probable forms of wars and armed conflicts of the future", Nauka i oborona, no. 4, pp. 10-15.

4. Horbulin V. P. (2014), "Hybrid War; as a key tool of Russian geostrategy of revenge", Stratehichni priorytety, no. 4, pp. 5.

5. Horbulin V. P. (2015), Donbas i Krym: tsina povernennia: [Donbass and Crimea: returning price], NIS, Kyiv, Ukraine.

6. Demydov A.V. (2015), "Controlled chaos", Stratehyia Rosyy, no. 5, available at: http://sr.fondedin.ru/new/fullnews.php?subaction=showfull\&id= $1430428108 \&$ archive $=1430773984 \&$ start from $=$ \&ucat $=14 \&$.

7. Mahda Ie. M. (2014), "Hybrid war: the essence and structure of the phenomenon", Mizhnarodni vidnosyny, no. 4. 
8. Mal's'kyj M.Z. (2017), "Cross-border security: political, legal, socioeconomic, humanitarian and environmental dimensions.", Zbirnyk materialiv Mizhnarodnoi naukovo-praktychnoi konferentsii, $96 \mathrm{p}$.

9. Predbors'kyj V. A. (2014), "Hybrid war as a reflection of the laws of development of a society of incomplete modernization", Formuvannia rynkovykh vidnosyn v Ukraini, no. 10, pp. 13-18.

10. Savyn L. (2015), "Hybrid war", Informatsyonno-analytycheskyj portal Heopolytyka, available at: http:// geopolitica.ru/article/gibridnaya-voyna\#.VazC1 qTtmko.

11. Major Shane R. Reeves, Major Robert E. Barnsby (2015) "The New Griffin of War. Hybrid International Armed Conflicts, Academic joutnal article "Harvard International Review", available at: https://www.questia.com/library/ journal/1G1-316203914/the-new-griffin-of-war-hybrid-international-armed. 
INTER-DIAGNOSTIC APPROACHES

IN POST-ADVOCACY SCIENCE: POSSIBILITIES

OF SELF-REFLECTION IN POLITICAL DISCOURSE

\title{
МІЖДИСЦИПЛІНАРНІ ПІДХОДИ \\ В ПОСТНЕКЛАСИЧНІЙ НАУЦІ: МОЖЛИВОСТІ \\ САМОРЕФЛЕКСІЇ В ПОЛІТОЛОГІЧНОМУ ДИСКУРСІ
}

\section{Gotsulyak Volodymyr ${ }^{1}$ \\ Levchenko Andrey ${ }^{2}$ \\ Gapchenko Elena ${ }^{3}$}

DOI: http://dx.doi.org/10.30525/978-9934-571-26-8_6

\begin{abstract}
Modern post-classical science is experiencing a time of rapid development, that is enriching its methodological potential by developing interdisciplinary approaches and outlining new areas of research, the subject of which are complex human-dimensional systems. Interdisciplinary opens up new perspectives for understanding the Ukrainian political reality as a space of the state actions, various political forces, political institutions, activities, power systems, organizational interactions, political values, and norms.

The system and the integrity of Ukrainian political reality study are achieved through the use of the cognitive potential of various scientific disciplines that deal with the problem in various aspects - history, law, political history, philosophy, cultural studies, and political philosophy.

The purpose of this study is to understand the cognitive capabilities and benefits of an interdisciplinary approach in the analysis of Ukrainian political reality in terms of modern post-classical science. However, the task of outlining the political science discourse features as a political reality in the field of social and cultural constructions of various forms of human experience is also important.
\end{abstract}

\footnotetext{
${ }^{1}$ Candidate of Political Science, Associate Professor,

Khmelnytsky National University, Ukraine

${ }^{2}$ Candidate in Philosophy Sciences, Associate Professor,

Khmelnytsky National University, Ukraine

${ }^{3}$ Candidate of Pedagogical Sciences, Associate Professor,

Khmelnytsky National University, Ukraine
} 
Because of the research, the following conclusions were made:

1 The study of complex, multifaceted and multidimensional phenomena, one of which is the Ukrainian political reality, is programmed by the researcher and is using those methodologies and knowledge that characterize post-classical science. One of these methodologies, the object of which is self-developing and self-organizing systems, offers synergy.

Using categories of synergetic thinking (nonlinearity, dissipation, bifurcation, and fluctuation) allows us to perceive the ambiguity and complexity of political reality, to outline the degree of human subjectivity in social and political processes.

2 In post-classical science, clear emphasis is put on the possibilities of combining the benefits of theoretical knowledge and reflexive scientific thinking and the possibilities of a historical approach to the study of important problems of social and political life.

Historical reconstruction from the standpoint of post-classical science is an essential element of research and an important prerequisite for achieving the complete knowledge of the investigated reality. The combination of theoretical and concrete historical knowledge opens up great opportunities for sustainable conceptual schemes restructuring that have developed in political science and expands the scope of scientific research.

3 Despite the fact that various forms of inappropriate knowledge (in particular, historical memory and political myth) cannot give an objective picture of the past, they form an integral part of the notions about it. Post-classical science in a new way understands the status of scientific knowledge: it is only an approximation to the truth; therefore, it contains a large fraction of errors. Increasingly important is scenario thinking, which involves a multivariate path of evolution and nonlinear dynamics of the complex systems. The analysis of political knowledge today includes various historical, sociological and cultural factors.

The totality of ideas about the Ukrainian past, the spiritual and political experience of a certain history of a person are focused on historical memory. Historical memory has one universal advantage over reliable knowledge: it contains impulses and motives for preserving national identity and the establishment of a national idea.

A glance in the past is accompanied by an understanding of contemporary and outlining the ways of progress in the future. Therefore, a change in the research emphasis in political science is fully justified. They relate not 
only to the achievement of specific knowledge but also to the historical, cultural and political tasks that are prioritized for a modern Ukrainian person.

For modern post-classical science, methodological pluralism, awareness of the limitations and one-sidedness of any methodology is characteristic, a multilevel concept of methodological theory and new strategies for scientific research are formed.

\section{1. Вступ}

Сучасна постнекласична наука переживає час стрімкого розвитку, збагачення свого методологічного потенціалу розробкою міждисциплінарних підходів і окресленням нових напрямів дослідження, предметом яких стають складні людиновимірні системи. Міждисциплінарність відкриває нові перспективи в осмисленні української політичної реальності як простору дії держави, різних політичних сил, політичних інститутів, діяльності, систем влади, організаційних взаємодій, політичних цінностей і норм тощо. Науково виправданою стає саморефлексія, прагнення осмислити попередній культурний та політичний досвід діяльності української людини в історії і зробити спробу спрогнозувати можливості подальшого розвитку. Дисциплінарна роздробленість попередньої науки (предметна, методологічна) змінюється трансдисциплінарними модернізаціями.

Системність і цілісність вивчення української політичної реальності досягається через використання пізнавального потенціалу різних наукових дисциплін, які розглядають досліджувану проблему в тих чи інших аспектах - історії, права, політичної історії, філософії, культурології, політичної філософії. Це є загальною тенденцією розвитку сучасної науки, а також свідченням посилення й інтенсифікації зв'язків між різними дисциплінами й зростання значущості міждисциплінарних досліджень у гуманітарному та політологічному дискурсі. Все більшу роль починають відігравати великі комплексні програми і проблемно орієнтовані міждисциплінарні дослідження.

Метою даного дослідження є осмислення пізнавальних можливостей і переваг міждисциплінарного підходу в аналізі української політичної реальності з погляду сучасної постнекласичної науки. Важливим також постає завдання окреслення особливостей політологічного дискурсу щодо політичної реальності як поля соціального і культурного конструювання різних форм людського досвіду. 


\section{2. Синергетична методологія в політичній науці}

Науковий дискурс щодо змісту, специфіки і основних напрямів розвитку політичної науки в Україні потребує усвідомлення значущості використання різних пізнавальних підходів у дослідженні, ідеї міждисциплінарності як вимоги постнекласичної науки, відходу від усталених стереотипів, спрощень, міфів про українську історію та культуру.

Сучасна практика наукових досліджень свідчить якраз про пріоритетність тих напрямів, які виникають на стикові різних дисциплін [17, с. 389]. Міждисциплінарні зв'язки і взаємодії змінюють вигляд політичної науки, роблять їі багатшою на конкретні факти, з одного боку, а з іншого, посилюють рівень ії теоретичності. Перспективність таких досліджень визначається, передусім, використанням методологічного потенціалу наук, об’єктом яких є багатовимірний світ людини, iii діяльності, людської історії, історії суспільно-політичних ідей в соціокультурному контексті. Міждисциплінарні дослідження і сучасний синтез різних наук сприяють окресленню принципово нових тем, аспектів, нових акцентів у, здавалося б, традиційній проблематиці української політичної науки. Йдеться, зокрема, про витоки української державності, формування української політичної ідентичності, про ідею національної єдності українського етносу тощо.

Сучасна методологія політологічного дослідження не зосереджена виключно на використанні класичних методів - інституціонального аналізу, системного, структурно-функціонального підходів тощо. Нова постнекласична картина світу, що характеризується стратегічною нестабільністю, нелінійністю, віртуальністю і конфліктністю, передбачає нестандартне політичне мислення, розраховане на пізнання багатовимірних і пластичних складних об'єктів. Головною проблемою постнекласичної методології стає пошук нових механізмів дослідження процесу самоорганізації складних, нелінійних, стохастичних процесів [6, с. 243-245].

Одним 3 найважливіших і найперспективніших методів дослідження сучасної політичної науки є синергетичний підхід. Синергетичні уявлення $є$ необхідним елементом арсеналу дослідження політичної реальності як складноорганізованої і нелінійної системи, а завдяки пізнавальним можливостям синергетичного підходу досягається цілісне знання про дуже непрості й неоднозначні періоди в роз- 
витку української історії. Українська політична реальність завжди формувалася різними соціальними й політичними силами, втілювала їхні часто антагоністичні уявлення про Україну і світ української людини, відображала протилежні політичні тенденції й культурно-національні орієнтації свого часу.

Саморефлексія в політичній науці спрямована на реконструкцію картини політичного світу, яка творилася не лише політичною діяльністю, але й системою цінностей, формами ментальності, зразками культурної діяльності. Тому при аналізі політичної реальності слід приймати до уваги всю різноманітність як політичних, так і неполітичних факторів - соціальних, релігійних, географічних, культурних, які в своїй цілісності свідчили про саморозвиток і самоорганізацію українського суспільства.

Головним елементом політичної реальності визнається людина з іiі особистісними, психологічними, антропологічними, культурними та іншими особливостями, а отже, і тими соціальними нормами і політичними правилами, якими вона оперує. В цьому випадку можна говорити про цілісну систему реальності. На думку Л. Бевзенко, здатність такого середовища до саморганізаційних ефектів гарантує виникнення стійких форм узгодженої, упорядкованої поведінки, в яких можуть виділятися регулярні правила. Умовою самоорганізації в таких середовищах і є нелінійність [2, с. 545].

Синергетичний підхід до наукового дослідження породжує нові смисли багатьох звичних для класичного погляду понять, зокрема, таких як ціле, частина, закон, причина, детермінованість. Синергетика використовує й інші категорії для осмислення феноменів складності, самостановлення, саморозвитку і самоорганізації. Український філософ Ірина Добронравова пише у цьому зв'язку, що самоорганізація може бути визначена як виникнення(становлення) нового цілого, утвореного складною, але узгодженою поведінкою елементів середовища. Цілісність, що характеризується наявністю параметра порядку, зберігає своє значення на всіх фазах здійснення процесу самоорганізації [8, с. 7]. Нелінійність середовища при цьому може розглядатись як основа самоорганізації.

Під впливом синергетики відбуваються суттєві зрушення у сучасній політичній науці, у виробленні нового погляду на зміст процесів, що відбуваються у різних сферах людської активності, соціальній та 
політичній практиках відповідної історичної доби. Крім того, вона дає можливість побачити всю неоднозначність соціальної та політичної історії, з'ясувати міру людської суб'єктивності у суспільних і політичних процесах.

Синергетика, тобто теорія систем, що самоорганізується, є однією 3 найважливіших парадигм сучасної науки, яка грунтується на ідеях системності та цілісності світу. Це наука про те, як спільна дія елементів нелінійного середовища породжує нові структури, тобто як відбувається самоорганізація, становлення порядку з хаосу [15; 20]. Синергетика висунула нову загальну концепцію самоорганізації і тим самим сформулювала їі загальні принципи, які можуть використовуватися в різних галузях дослідження, в тому числі й політологічному.

Ідеї та принципи синергетики здебільшого використовуються при вивченні можливостей спільної діяльності, соціальних переваг узгоджених дій людей для досягнення спільних цілей, а також при дослідженні самоорганізаційних процесів у періоди нестабільності, соціальних і політичних змін.

Згідно з теорією самоорганізації нові форми організації виступають результатом ускладнення різних процесів у рамках соціального й політичного цілого, росту різноманітності елементів, різноспрямованості зв'язків зі світом. Здатність нестабільних утворень до самоорганізації свідчить про те, що вони не є пасивним об'єктом людської діяльності, а володіють певною свободою і втілюють у собі різні вияви людської активності.

В неоднозначні, кризові, а то й трагічні моменти української історії саме людина, реалізуючи свою активність, поставала важливим суб'єктом творення політичної реальності, сприяла реалізації інтеграційних процесів в українському суспільстві, через різні форми соціальних зв'язків і комунікацій утверджувала протилежні офіційним державним і політичним структурам форми самоорганізації свого життя.

Механізми самоорганізації є дієвим механізмом вирішення проблем в умовах, коли відсутнє порозуміння між основними учасниками суспільно-політичних процесів, не досягнуто єдине загальноприйняте бачення загальної перспективи політичного розвитку. Саме тоді, коли існуюча соціальна система входить у фазу кризи, порушення рівноваги, втрачає здатність обмінюватися з навколишнім середовищем речовиною, енергією та інформацією, самоорганізація здатна забезпе- 
чити як внутрішню стабільність людських спільнот, так і їх динаміку, здатність до саморозвитку.

В різні історичні часи в Україні формувався такий соціокультурний і політичний простір, для якого досягнення національної та культурної цілісності, стало нагальною потребою. Це стосується, зокрема, доби домодерної і модерної України, часу Руїни в період Гетьманщини, періоду національно-визвольних змагань XX ст., сучасної української історії. Загальний висновок, який можна зробити щодо вирішення соціальних і політичних протиріч - цілком у дусі синергетитичних уявлень: дезорганізації соціуму можна уникнути, забезпечивши узгодженість, згоду в діях загальнонаціональних сил. Якщо такої узгодженості в суспільстві не спостерігається, а соціальні й політичні зміни виходять за межі традиції, можуть відбуватися різні конфлікти і потрясіння (війни, протистояння, повстання тощо). Важливим у цьому контексті є збереження культурної основи суспільних і політичних перетворень, оскільки без неї втрачається важливий елемент загальної суспільної і людської цілісності.

На відміну від прийнятого тривалий час у науці редукціонізму (зведення складних процесів до аналізу окремих його елементів) синергетична парадигма в сучасному політологічному дослідженні враховує дію та значення всіх параметрів і факторів, завдяки яким українська політична реальність постає як самостійний феномен, дослідження якого вимагає врахування і якомога повнішого використання ідей синергетики. Найбільш суттєвими соціокультурними параметрами, які найбільше впливали і впливають на політичну картину українського світу є цінності, традиції, український менталітет, соціокультурна ідентичність, моральні імперативи. Окрема роль у політологічному дослідженні повинна відводитися духовним факторам, які особливим чином втілюють зміст людського буття на певному історичному етапі розвитку і значною мірою виражають зміст національної ідеї.

Висновок. Таким чином, вивчення складних, багатогранних і багатовимірних феноменів, одним 3 яких є українська політична реальність, програмує дослідника на використання тих методологій і знань, які характеризують постнекласичну науку. Одну з таких методологій, об’єктом яких є системи, що саморозвиваються і самоорганізуються, пропонує синергетика.

Синергетична парадигма або концепція самоорганізації нелінійних систем містить у собі великі евристичні можливості для осмис- 
лення причин і факторів, що впливають на формування політичної реальності, способів існування різних політичних феноменів в істоpiï. Використання категорій синергетичного мислення (нелінійність, дисипативність, біфуркація, флуктуація тощо) дозволяє сприймати неоднозначність і складність політичної реальності, окреслювати міру людської суб'єктивності у суспільних і політичних процесах.

\section{3. Політична наука і дослідження історії}

Осмислення складних інтегральних проблем, що потрапляють у поле зору політичної науки, потребує поєднання теоретичного аналізу, філософської рефлексії із використанням можливостей історичного пізнання. Суто методологічний, теоретичний проект у дослідженні політичної реальності виявляється недостатнім і неможливим. А всі спроби саморефлексії щодо змісту політичної реальності виявляються досить обмеженими без врахування історико-культурного контексту ii творення і розвитку, без вивчення реального процесу формування загальнолюдських і політико-правових цінностей, зрештою, без розуміння самої історії як свого роду реальності, наповненої діями, активністю, думками, ідеями, переконаннями людей певної епохи.

Концентруючи свою увагу на вивченні специфіки української політичної реальності, слід брати до уваги історичні події, обставини, факти, що впливали на розвиток уявлень про державу, правові відносини, національну єдність, національну ідентичність тощо. Головна увага повинна зосереджуватися на поясненні логіки дій людей минулого та факторів, що ії обумовлювали [7].

В сучасній політичній науці посилюється інтерес до вивчення національних історій. В Україні національна історія нового типу була започаткована в домодерний час - на початку XVIII ст. Самійлом Величком i Григорієм Грабянкою [26, с. 28]. Особливим способом рефлексії щодо розуміння специфіки української національної історії $\epsilon$ фіксування іiі відмінностей, з одного боку, від метаісторії, а з іншого, від інших національних історій, зокрема, польської чи російської.

Необхідним кроком у політологічному дослідженні постає філософська рефлексія історії, особливо, коли йдеться про визначення людиною свого місця у світі, у цілісності зв'язків і залежностей, які характеризують ту чи іншу історичну реальність. 
У науках про суспільство історію найчастіше розуміють як соціальну дійсність, що вже минула, події минулого суспільного життя. Вважається, що люди та їх справи стають історією, віддаляючись від сучасності в часі, відходячи в минуле, залишаючи після себе слід у пам'яті поколінь. При цьому історією називають не лише минуле життя людей в часі, але й знання про це життя. Це та область людського пізнання, яка встановлює, класифікує та інтерпретує свідчення про те, що відбувалося 3 людьми на довгому й важкому шляху розвитку суспільства.

Історія - це складний, багатовимірний, багатофакторний процес $\mathrm{i}$ не зводиться лише до емпіричної, хронологічної послідовності явищ, подій, фактів. Тут йдеться про становлення, розвиток і зміну стійких структур духовної, практичної, політичної діяльності суспільства, а також про формування ідей, уявлень та поглядів людей в категоріях історичного часу.

Під історією не слід розуміти також набір абстрактних характеристик історичного процесу, яким, як правило, оперує теоретичне знання про світ і людину. В історії людина виступає як актуальна сутність, як носій «роду», тієї реально існуючої спільноти всіх людей, яка і робить ï суб'єктом історії. Завдяки такому підходу історія не є випадковою сукупністю локальних цивілізацій і культур, а єдиним i цілісним процесом.

Отже, історія постає як реальне життя людей, їх спільна діяльність, що проявляється в багатьох взаємозв'язаних подіях у певному історичному час і певному місці. Відомий англійський історик Робін Колінгвуд у 20-х роках XX ст. писав, що історія вивчає дії людей, що відбулися в минулому [10, с. 446]. Послідовним у своєму розумінні історії був також один $з$ найвидатніших істориків XX ст., представник французької школи «Анналів» Марк Блок, який вважав, що історія це зустріч людей у віках. «Інколи кажуть, що історія - це наука про минуле. На мій погляд, це неправильно... Предметом історії є людина. Скажімо точніше - люди» [3, с. 17].

Досліджуючи українську політичну реальність, слід обов'язково враховувати специфіку української історії, всі вияви діяльності української людини в історії. Такий методологічний підхід цілком співзвучний висновкам видатних представників французької історичної школи «Анналів». Якщо історія є реальним життям людей, і вклю- 
чає в себе унікальні події з неповторним соціокультурним обличчям, і загальне в розвитку суспільства, і відтворює цілком звичайні «структури повсякденності» [5, с. 124], то всю сукупність ії проявів, всю минулу діяльність людей слід розглядати через проекцію ідей та уявлень відповідної історичної епохи, оскільки кожна епоха витворює свій власний ментальний Всесвіт, свої власні уявлення про минуле, застосовуючи інакші методи інтелектуального пошуку. Відновлення, реконструкція історії, - пише Л. Февр, - відбувається на основі людяності. Історія - це наука про людину, про минуле людства, адже ідеї не існують незалежно від людей, які їх творять чи сповідують Вона (історія) використовує факти, але це - факти людського життя. Історія, звісно, використовує тексти, але це - людські тексти. Самі слова, які їі складають, насичені людською суттю [19, с. 16-19].

Таким чином, людина концентрує в собі все багатство історичного буття, вона є центром історії, прагне усвідомити своє місце в історії. Пізнання людини і всіх виявів іiі життя скрізь призму історії є обов'язковою умовою не тільки історичної науки, але й всіх інших - політології, юриспруденції, соціальної науки, психології тощо. Історія невід'ємна частина простору всіх гуманітарних наук. Вона створює передумови для розуміння складних проблем сучасної людини.

Цілком обгрунтованим може вважатися підхід, згідно з яким історія - це, передусім, пізнання людини і їі життєдіяльності в історії, це наука про людей у часі, це «діалог сучасності з минулим», «різноманітний досвід людства, зустріч людей у віках» [3, с. 79]. А пізнання суспільства - це пізнання життєвих ціннісних орієнтацій, форм мислення, змісту свідомості людини, що утверджує і реалізує себе в різних формах соціальності, культурної та політичної діяльності.

Важливе значення для політологічного дослідження мають темпоральні характеристики. Ф. Бродель писав, що минуле присутнє в теперішньому у вигляді історичних систем, блоків, що мають різну тривалість. Тому будь-яка «сучасність» включає в себе «різні рухи, різні ритми»: «сьогодні» почалось одночасно «вчора», «позавчора» $\mathrm{i}$ «деколи». Абсолютизація «короткочасної історичної перспективи», на думку Ф. Броделя, приводить до простої «каталогізації» подій. Тому вивчати слід «довготривалі структури» - економіку, суспільні інститути, світогляд, духовні утворення, які є стійкими утвореннями для життя людей і функціонують протягом історичного часу [5, с. 128]. 
Виділення «довготривалих структур» дозволяє пізнавати соціокультурну й політичну реальність як сукупність різних структур, кожна з яких, хоча і має тільки їй притаманний час існування, разом 3 іншими утворює складну і суперечливу єдність. Держава, суспільні й політичні інститути, етнічні спільноти - це ті структури, які складають зміст людської історії на певному відрізку історичного часу. Політичні ідеї, політичні погляди й політичні події є необхідно частиною діяльності таких структур.

У рамках певних часових структур проявляється своєрідність і неповторність людського буття, особливості функціонування різних соціальних і політичних феноменів. Сама людина, іiі мислення, ментальність, суспільні інститути, які впливають на характер діяльності людини в певну історичну епоху не можуть бути зрозумілими поза обставинами місця та історичного часу. Повною мірою це стосується і вивчення української політичної реальності в різних ії̈ проявах, а також соціального, духовного й політичного досвіду української людини і української суспільності.

Таким чином, досліджуючи українську політичну реальність, слід обов'язково враховувати специфіку української історії, всі вияви діяльності української людини в історії. Якщо історія є реальним життям людей, включає в себе унікальні події з неповторним соціокультурним обличчям, загальне в розвитку суспільства і відтворює цілком звичайні «структури повсякденності», то всю сукупність іiі проявів, всю минулу діяльність людей слід розглядати через проекцію ідей та уявлень відповідної історичної епохи.

Виходячи з таких методологічних передумов, політологічна наука ставить перед собою, крім іншого, завдання історичної реконструкції соціального і духовного світу людей тієї чи іншої епохи, спираючись не тільки на вивчення соціально-економічних факторів, які обумовлюють спосіб життя людей, але і на дослідження колективних психічних станів, специфіки ментальності, стилю життя і стилю мислення. А політична реальність постає як сукупність дій людини, форм політичного мислення, культурних імпульсів, способів міжлюдської взаємодії.

Отже, знання лише законів суспільного буття не дає повного пояснення змісту історичних процесів, розуміння обставин й мотивів, що впливають на політичні дії та вчинки. Політологічний науковий 
дискурс включає в себе аналіз історичних подій, національної унікальності різних форм індивідуального життя, соціальних зв'язків, що характеризують українське суспільство на певному історичному етапі розвитку, вивчення інституціональних вимірів буття української спільноти із врахуванням специфіки історичного часу та історичного простору.

Здійснюючи політологічне дослідження, слід також враховувати, що активну, діяльну людину, яка творила світ і себе за власними уявленнями, переконаннями, ціннісними установками, створило культурне буття. Саме тому політична історія набуває своєрідного антропологічного виміру. Політичні координати людського буття вивчає політична антропологія. Основними її темами є ідентифікація людиною себе в системі певної владної моделі, сприйняття влади та владних інститутів, уявлення про стосунки людини і влади тощо [11].

Специфічною пізнавальною процедурою, що використовується постнекласичною наукою в дослідженні різних соціальних і політичних об'єктів, є історична реконструкція. Механізми історичної реконструкції зводяться до спеціальної роботи опису різноманітних форм людського досвіду, спираючись на який, соціальна, історична чи політологічна наука вибудовують свої теорії і концепції. Тому реконструкції - це підстава для побудови різних теоретичних конструктів і узагальнень. Водночас реконструкції $є$ способом проникнення в зміст соціокультурної і політичної реальності, методом відтворення в науці структур людського буття.

Кожна історична реконструкція часто сприймається як чисто ідеографічне знання. Проте це відбувається лише зовні. В. Стьопін наголошує: «Насправді, в ній ідеографічні і номотетичні елементи об’єднуються особливим чином, що виявляє певну логіку пізнання» [17, с. 41]. Завдяки механізмам історичної реконструкції в матеріалах історичного опису дається теоретичне бачення тієї чи іншої проблеми і відкривається шлях до побудови різних теоретичних конструктів.

Історичні реконструкції можна інтерпретувати як особливу теоретичну модель того чи іншого унікального історичного процесу. Теоретичні конструкти, що використовуються в реконструкціях, не відділені від фактів, а поєднані з ними. Вони вибудовують факти згідно $з$ певною логікою історичного розвитку. Теоретичні конструкти онтологізуються, приписуються реальності й представляють історичний процес, 
що реконструюється, як саму реальну історію, а не як одну з ії моделей. Ця особливість історичних реконструкцій часто приводить до неправомірного ототожнення їх з емпіричним описом. Водночас один $і$ той же набір фактів і той же фрагмент історії може бути представлений в різних реконструкціях. Тоді кожна 3 них виступає як окрема теоретична модель, що претендує на опис, розуміння і пояснення історичної реальності [17, с. 302].

У процесі реконструкції тих чи інших елементів політичної історії відбувається розуміння відповідного типу культури, культурної традиції. В такому випадку на перший план виходять процедури розуміння, руху (герменевтичне коло), коли розуміння багаторазово переходить від частини до цілого, а потім від цілого до частини, пізнаючи особливості іншої культурної традиції.

Історична реконструкція дозволяє проникнути в зміст політичної реальності, зрозуміти людину, що проявляє свою активність в різних формах політичної дії, відтворити картину соціального та політичного буття. Як пише англійський історик Д. Тош, історична ретроспекція, тобто наше положення у часі відносно об'єкта дослідження дозволяє нам осмислити минуле - виділити передумови, про які сучасники навіть не підозрювали, і розгледіти справжні, а не бажані з погляду учасників подій наслідки [18, с. 169].

Акцентуючи увагу на можливостях історичної реконструкції чи ширше -історичної методології в політологічному дослідженні, слід усвідомлювати евристичну цінність принципу єдності теоретичного та історичного в науковому пізнанні. Використання його відкриває шлях до осягнення того чи іншого політичного феномена українського життя не через пізнання загального чи деяких закономірностей суспільно-політичного розвитку в «чистому» вигляді, а через вивчення конкретних виявів загального в тих чи інших історичних умовах. Процес суспільного, політичного та культурного розвитку і узагальнене уявлення про нього відтворюється, таким чином, з урахуванням конкретних історичних обставин, подій, фактів, специфіки історичної ситуації тощо.

Таким чином, пізнання політичної реальності не обмежується фактографічною реконструкцією подій, воно мусить піти далі простої історичної хроніки і зосередитися на осмисленні суті тих процесів (соціальних, політичних, духовних), які відбуваються в історії. 
Опис історичних фактів повинен доповнюватися їх поясненням шляхом проникнення в духовний світ людини. Інтерес дослідника часто сконцентрований на пізнанні одиничного, конкретного, на поясненні унікальних, неповторних суспільних і політичних явищ. Але за цим одиничним завжди проглядається загальне - сутність політичних процесів і дій.

Безперечно, дослідження таких складних феноменів українського життя, як українська політична реальність грунтується на використанні пізнавальних можливостей людського розуму, наукової раціональності, що надає можливість чітко окреслювати проблему й аналізувати іiі, використовуючи категоріальний апарат різних наук, суміжних 3 політичною наукою, передусім, філософії. Але при цьому не відкидається також значення нераціональних засобів пізнання - уявлення, фантазії, літературної творчості тощо.

Переваги теоретичного пізнання української політичної реальності проявляються в умінні критично осмислювати засади політичного життя, механізми, передумови, ціннісні орієнтири політичних дій людини, зіставляти їх із загальними моральними, соціокультурними нормами людської діяльності, оцінювати ідеальні проекти перебудови українського життя, аналізувати процеси формування ідентичності української нації тощо. Особливо важливими постає знання норм християнської моралі та усвідомлення їх значення в досягненні ідеалу людського співжиття в політичній думці України, у формулюванні програм перебудови українського суспільства на засадах християнської любові і братерства, представленого в християнських утопіях. Не менш важливим питанням $є$ усвідомлення значущості комунікативних зв'язків, міжособистісного спілкування як форми соціальної взаємодії в національному середовищі. В цілому йдеться про формування загальної картини українського життя, політичної культури й політичної реальності в цілому.

Отже, сучасне політологічне дослідження не обмежується теоретико-пізнавальними, логіко-дискурсивними моментами. Воно передбачає використання не тільки наукових, логічних, раціональних шляхів пізнання політичної реальності України, але й врахування численних факторів соціокультурного та історичного характеру, особливостей індивідуальної та колективної психіки, особистісних установок, моральних нормам, релігійних почуттів, інтересів, мотивів. 
Водночас, як відзначають дослідники, лише історичний наратив, історичний опис тих чи інших подій чи фактів, ніколи не замінить потреби осягнення логіки історичного процесу, розуміння сутності тих чи інших феноменів духовного чи політичного життя, що дається на рівні теоретичного, філософського аналізу. Тобто в історії і через історію відбувається своєрідна персоналізація людських смислів [14].

Висновок. Таким чином, у постнекласичній науці розставляються чіткі акценти щодо можливостей поєднання переваг теоретичного пізнання і рефлексивного наукового мислення і можливостей історичного підходу до вивчення важливих проблем суспільного і політичного життя.

Історична реконструкція з погляду постнекласичної науки є необхідними елементом дослідження і важливою передумовою досягнення найбільш повного знання про досліджувану реальність. Поєднання теоретичного та конкретно-історичного знання відкриває великі можливості для перебудови стійких концептуальних схем, що склалися в політологічній науці і розширює рамки наукового дослідження.

Цілісне вивчення феномену української політичної реальності включає в себе розуміння історико-культурного контексту іiі творення та розвитку, розгляд іiі особливостей у зв'язку з аналізом людської діяльності в певну історичну епоху, з виявами соціально-політичної активності в реаліях українського життя.

Пізнання української політичної історії не зводиться до побудови якоїсь іiі єдиної схеми, моделі чи варіанту. Складна інтегральна проблема припускає багатоваріантність шляхів іiі дослідження, використання досягнень різних наук, відходу від усталених пізнавальних принципів і методів.

\section{4. Політична наука і феномен історичної пам'яті}

Головне завдання політичної науки полягає в досягненні найбільш повного і цілісного знання про ту чи іншу політичну реальність, політичні явища, процеси, політичну культуру тощо. Особливістю постнекласичної науки, як відомо, є спрямованість їі на вивчення складних об'єктів дослідження, які потребують використання міждисциплінарних комплексних підходів і програм, у яких беруть участь фахівці $з$ різних галузей знань. Усе це призводить до взаємодії різних методів, норм та ідеалів пізнання. 
На основі синтезу різних підходів теоретичного аналізу з конкретними прийомами історичного дослідження таке інтегральне знання досягається. Однак на шляху до нього стоять численні стереотипи свідомості, неприйнятні у науковому дослідженні схеми, ненаукові підходи, псевдонаукові твердження і висновки.

Дуже часто важливі та актуальні проблеми, що стосуються вивчення особливостей українського національного буття і специфіки української політичної реальності, ставляться на рівні буденної свідомості та масової культури без належного світоглядного, філософського, теоретичного обгрунтування і пояснення, без спирання на факти. Водночас, існують такі аспекти людського досвіду, які не можна виразити суто науковим способом. Вони мають свою соціокультурну цінність і можуть бути представлені літературними чи поетичними образами, зразками утопічного мислення тощо. Різні знання і практики завжди були в культурі, але вони не завжди можуть вивчатися суто науковими методами. Проте за будь яких обставин слід визнати домінантну цінність наукової раціональності та іiі вплив на всі форми культури $[17$, с. 315$]$.

Однісю з важливих передумов проникнення в минуле, в різні смисли культурної та політичної реальності є звернення до історичної пам'яті як моделі вирішення сучасних проблем. При цьому, з погляду постнекласичної науки, оперуючи поняттям історичної пам'яті, неприпустимим є використання різних міфів, стереотипних уявлень масової свідомості як основи для пізнання минулого. Разом з тим, український філософ Л. Бевзенко вважає, що різні ігрові, міфологічні колективні утворення часто виступають основними маніфестаціями нелінійної природи соціальних систем [2, с. 539].

Політична наука оперує поняттями історичної пам'яті та політичного міфу для ретроспективного погляду в минуле і конструювання на основі цього проектів майбутнього національного розвитку.

Звертаючись до історичної пам'яті, вдається реконструювати сукупність ідей та уявлень певної історичної доби як певну цілісність, зрозуміти шляхи і механізми самоідентифікації особистості зі своєю національною спільнотою.

Уявлення про минуле або історична свідомість давно перебувають у полі дослідницьких інтересів істориків, політологів, соціологів. Незважаючи на цілком очевидну історичну «спрямованість» цієї теми, вона 
вимагає комплексного, міждисциплінарного осмислення. Історична наука і професійна діяльність істориків не дають виключно повного знання про минуле, про історичну реальність. Як писав Й. Гейзінга, історичне знання ніколи не може бути чимось більшим, ніж пам'ять, звідки можуть бути викликані ті чи інші образи [22]. В сучасній науці поряд 3 традиційною історіографією з'являються праці, в яких аналізується розвиток історичних уявлень і поглядів (те, що називається історичною свідомістю) в контексті культурного та інтелектуального розвитку людини певної історичної доби [23, с. 219].

Очевидною також є зміна концептуальних акцентів у дослідженні національного минулого, політичної історії та національної культури. Зокрема, наголошується, що пізнання минулого - це не стільки буквальне відтворення фактів, подій тощо, а скоріше конструювання минулого 3 позицій сьогоднішніх цілей дослідження і наші сьогоднішні репрезентації минулого [14].

В ідеологізованій версії такої позиції конструкція минулого є об’єктом маніпуляцій і виступає однією 3 форм «владного дискурсу», за допомогою якого масам нав'язується образ минулого (так само, як і теперішнього і майбутнього), вигідного інтелектуальним і політичним елітам [16, с. 31].

Групові політичні інтереси значною мірою визначають сьогодні проекти партикулярного образу минулого, що мають цілком конкретного реципієнта і конкретне призначення. Тому в такому середовищі переважає акцентування на тих чи інших подіях минулого, пов'язаних 3 формуванням певної соціальної чи політичної групи та їі сьогоднішніми завданнями. У свою чергу, політичні опоненти створюють у своїх цілях свій альтернативний образ минулого, в якому розставляються інші акценти у трактуванні реальності.

Крім того, як відзначає один з найяскравіших дослідників історичної пам'яті, німецький історик Я. Ассман, однією з важливих причин звернення в сучасному суспільстві до теми знань про минуле, стало усвідомлення того факту, що покоління очевидців важких злочинів в анналах людської історії поступово відходить із життя [1, с. 11].

Звернення політологічної науки до проблем історичної пам'яті зачіпає проблеми функціонування масової свідомості: масові уявлення про минуле суттєво відрізняються від тих, про які пишуть професіонали. В сучасному суспільстві історія як наукове знання не завжди 
виступає в ролі каркасу історичної свідомості чи масових уявлень про минуле. 3'ясувалося, що трансформація наукового знання в соціальні, масові уявлення - це складний процес, а масові уявлення про минуле дуже відрізняються від професійних [16, с. 34]. Це стосується і європейського, і українського минулого, всіх інших уявлень про минуле різних країн (наприклад, у німецькій масовій свідомості події, пов’язані з нацизмом, інтерпретуються не так, як у офіційних виданнях. Існує інша, «мовчазна» історія нацистського минулого, яку воліють не згадувати пересічні німці).

Поняття «пам'ять» $є$ досить дискусійним у науковій літературі, незважаючи на його широке використання. Однією з головних причин його появи в політологічній науці стала підвищена і цілком виправдана увага до спогадів учасників і жертв великих трагедій XX ст. Другої світової війни, Голокосту, Голодомору, політичних геноцидів. Але згодом цей термін став поширюватися на різні аспекти соціальних уявлень про минуле. Великий інтерес викликали дослідження французького вченого М. Хальбвакса (учень Е. Дюркгейма) про колективну пам'ять. Він писав, що соціальне середовище обмежує і упорядковує спогади в просторі та часі, виступає джерелом як самих спогадів, так і понять, в яких вони фіксуються. Навіть особисті спогади мають соціальний вимір і $є$ складними образами, які виникають тільки через комунікацію і способи взаємодії в рамках соціальних груп [21].

Однак, як відзначає Я. Асманн, Хальбвакс не обмежився аналізом соціальних рамок пам'яті, а вважав колектив суб'єктом пам'яті і спогадів, створивши поняття «групова пам'ять» $\mathrm{i}$ «пам'ять нації», в яких поняття пам'яті перетворюється в метафору [1, с. 37].

Слід відзначити, що в політичній науці досвід наділення соціальних спільнот і колективів антропоморфними характеристиками існував ще з XVIII ст. У творах Монтеск'є - це поняття «дух народу», «душа народу», «характер народу». Активно використовували подібні характеристики філософи-романтики. В українській політичній науці також зустрічаються приблизно такі самі антропоморфізовані поняття, як і в європейській.

Історична пам'ять інтерпретується дослідниками як спосіб збереження і трансляції минулого в епоху втрати традиції, як індивідуальна пам'ять про минуле, як частина соціального знання, існуючого вже в примітивних суспільствах, як колективна пам'ять про минуле, якщо 
мається на увазі соціальна група і як соціальна пам'ять, коли йдеться про суспільство, як ідеологізована історія, що зв'язана з виникненням держави. Історична пам'ять також виступає синонімом історичної свідомості $[13 ; 16]$.

В цілому під історичною пам'яттю розуміється сукупність уявлень про минуле тієї чи іншої спільноти, міфи, суб'єктивні рефлексії про події минулого, що передаються з покоління в покоління. Через механізми історичної пам'яті забезпечується передача різних форм людського досвіду, який сформувався в історії та існує в різних культурних формах (усній традиції, мемуарах, пам'ятках,переказах, художній літературі, письмових свідченнях учасників різних історичних подій).

Історична пам'ять $є$ втіленням і продуктом свідомості людей певного суспільства, їхнього індивідуального досвіду в історії, при цьому вона обмежена в історичному часі. Як пише Л. Нагорна, «коли говорять про соціальну, етнічну, конфесійну чи якусь іншу пам'ять, мають на увазі радше різновиди колективної обумовленості пам'яті, які, кожен по-своєму, фільтрують індивідуальний досвід» [13, с. 22].

Історична пам'ять вкорінена в духовний, соціальний, політичний досвід людини і проявляється у звичках, культурі, ставленні до інших народів, у політичних преференціях, механізмах самоідентифікації. Можна стверджувати, що історична пам'ять - це фундамент національної ідентичності. Завдяки спільному образові минулого, що існує в свідомості окремої особистості і народу в цілому, ми ототожнюємо себе $з$ діями, вчинками, перемогами і поразками попередніх поколінь, з героїчним минулим, зі знаковими для українського народу місцями пам'яті, $з$ досягненнями культури тощо [26].

Для набуття тією чи іншою спільнотою ідентичності потрібно загальне розуміння подій і досвіду, які й, по суті, формують цю групу. В одних випадках це включає загальноприйняті уявлення про спільне походження цієї групи, в інших - акцент робиться на яскравих переломних етапах і моментах символічного характеру, які допомагають сформувати групі уявлення про себе, усвідомити свої цілі та прагнення. Але в цілому ці процеси характеризують процес становлення національної свідомості нації. I в обох випадках це властиво українській політичній свідомості, яка формувала уявлення про національну й культурну ідентичність українців. 
На думку Д. Тоша, історична пам'ять служить нам і як база даних, i як засіб осмислення життя. Неможливо зрозуміти конкретну ситуацію без відчуття того, як вона вписується в розвиток подій, і не задумуватися, чи відбувалося щось подібне раніше. Будь-яке суспільство володіє колективною пам'яттю, сховищем досвіду, що дозволяє виробити почуття ідентичності і оцінити напрям свого розвитку [18, с. 24]. Політичні судження і політична думка будь якої історичної епохи пронизані відчуттям належності до історії й включенням пам'яті про своїх героїв в осмисленні сучасних їм реалій.

Слід пам'ятати також про серйозний «ефект викривлення» як рису історичної (соціальної) пам'яті. Йдеться, передусім, про повагу до традицій. Таку повагу до традицій часто плутають 3 «відчуттям історії», оскільки воно передбачає прив'язаність до минулого і прагнення зберігати йому відданість. Однак, як відзначають дослідники, при зверненні до традицій історичний підхід існує лише в невеликій мірі [18, с. 22]. Повага до традицій відіграла свою роль у згуртуванні суспільства, але некритичне ставлення до них стає контрпродуктивним, оскільки воно не звертає належної уваги на історичні зміни, що відбуваються.

В період становлення національних ідентичностей і етносів (як це було притаманно українській домодерній i модерній історії), сподівання на власну державність вимагали історичного обгрунтування - спогадів про славне минуле, яке існує «з незапам'ятних часів» чи пошук спільних образ, тобто традицій, які були здатні підтримати дух нації. Таким шляхом може відбуватися легітимація минулого.

Однак беззастережна відданість традиціям, замовчування відмінностей і змін заради зміцнення національної ідентичності $є$ підгрунтям націоналізму. Грубим викривленням історичної свідомості є також традиціоналізм, оскільки він виключає важливе поняття розвитку в часі (а також ностальгію, як і віру в історичний прогрес, безпідставний оптимізм).

Таким чином, традиції, ностальгія за минулим (за кращими часами) i прогрес є базовими складовими історичної пам'яті. Кожна 3 них по-своєму відгукується на глибоку психологічну потребу в захисті вони обіцяють або відсутність змін, або зміни до кращого, або душевно більш близьке [18, с. 27]. При цьому може недооцінюватися все інше критичний розум, визнання мінливості світу, історичність поглядів на 
реальність, історична свідомість. Необхідно враховувати й те, що зміст історичної пам'яті змінюється залежно від контексту та пріоритетів.

Історію та історичну пам'ять деколи важко відділити одну від одної. Але професійне дослідження в галузі політичної історії, що грунтується на аналізі фактів та подій, завжди відрізняється від історичної пам’яті.

Апелюючи до простору пам'яті, ми отримуємо можливість пізнання історичної та політичної реальності як зосередження соціальних i політичних дій, людських смислів, культурних значень, що існували в свідомості. На думку А. Асмана і М. Хальбвакса, пам'ять є носієм соціально сконструйованого минулого [1;21]. Ця позиція перегукується 3 думкою Ю. Лотмана про те, що на відміну від історії, завданням якої $\epsilon$ «подати минуле, яким воно було насправді», пам'ять $€$ інструментом мислення в теперішньому, хоча їі змістом є минуле [12, с. 150-399].

Історична пам'ять може стати основою формування національної свідомості. В українській історії цей процес набував форм, схожих 3 тими, що характеризували становлення європейської свідомості. I в Європі, і в Україні це було пов'язано з процесами становлення модерної нації. Проте в Україні спостерігалася своєрідна сакралізація традиції (тобто відчувалася перевага релігійного мислення в історичній свідомості, переважала орієнтація на східнослов'янські, православні зразки духовності), що багато в чому визначало самобутність нашої власної історії і власного історичного шляху.

Щоб зрозуміти суть процесів, які відбувалися в минулій історії, необхідно мати уявлення про те, як той чи інший феномен виник і як розвивався. В цьому сенсі суспільство, звісно, володіє пам'яттю. Однак пам'ять не може бути чимось однозначним і безсумнівним: існують різні форми досвіду про історичне минуле, різні спогади, робляться різні акценти, навіть «згадується» те, чого не було, використовуються різні за ступенем достовірності джерела. Як відзначає Дж. Тош, для колективної пам'яті характерні викривлення, тому в політичному житті вона може бути вибірковою, а деколи абсолютно помилковою. Більш строге витлумачення історичних подій чи феноменів політичного життя передбачає історична свідомість. Іншими словами, мало просто звертатися до минулого; потрібна переконаність у необхідності достовірного уявлення про нього [18, с. 11].

Історична пам'ять не дає точних свідчень про минуле, але створює таку картину минулого, яка служить поясненню і розумінню сього- 
дення і дуже часто це відбувається за рахунок історичної достовірності. Механізми історичної пам'яті найбільш чітко проявляються стосовно тих періодів історії, про які не існує багато точних історичних свідчень, а переважає наратив, опис соціального, культурного досвіду. Але існування історичної пам'яті вказує на універсальну потребу в ній. Будь яке суспільство черпає в історичній пам'яті натхнення силу для утвердження національної ідеї, для згуртування спільноти.

Поряд 3 історичною пам'яттю, $з$ соціально-мотивованими поглядами на минуле, що задовольняють різні політичні і соціальні потреби, в науці функціонує історична свідомість, в якій минуле відтворене в більш строгих формах

Скрізь призму історичної свідомості будь який об'єкт розглядається у зв'язку з конкретно-історичними умовами його існування, в динаміці і розвитку. Прихильники особливого підходу до вивчення iсторії, який з XIX ст. називається історизмом, наголошували, що його фундаментальною передумовою є повага до незалежності минулого, відтворення атмосфери минулого. Найповніше ідеї історизму були представлені в працях німецького історика Леопольда фон Ранке, а також англійського історика Томаса Карлейля. 3 позицій історизму кожна епоха являє собою унікальний вияв людського духу, їй притаманні особлива культура і цінності. Для того щоб зрозуміти іншу епоху, слід враховувати зміни, що відбувалися в умовах життя, менталітеті людей протягом історії. Тому розуміння й реконструкція кожної епохи повинні відбуватися в її власних категоріях, у сприйняття їі власних цінностей і духовних пріоритетів.

Таким чином, історична свідомість означає визнання незалежності минулого і спробу реконструювати його у всій специфіці, зрозуміти його відмінність від сучасності. Результатом цієї програми стало поглиблення відмінностей між елітарним і народним поглядом на минуле [18, с. 21]. Професійний підхід до політологічного дослідження передбачає довготривале заглиблення в першоджерела, свідому відмову від сьогоднішніх уявлень.

Потреба в історичному знанні про своє минуле $є$ абсолютною потребою політичної науки, способом долучення іiі до світу зрозумілих їй цінностей і уявлень. Однак, як писав Й. Гейзінга, сучасний світ, як ніколи, зробив історію знаряддям брехні на рівні державної політики і ніяка східна деспотія в своїх фантастичних «свідченнях» не 
поводилася з історією так, як це робить сучасна держава. Втручання політичної влади в процес формування історичної свідомості часто приводить до іiі деформації. За словами Й. Гейзінги, історична свідомість повинна бути пильною, «щоб не були зведені від імені історії кровожерливі ідоли, які поглинуть культуру» [23].

Метою наукового пізнання минулого є завжди знання про нього. Особливістю історичного й політологічного знання $є$ те, що в них значною мірою є присутня людська суб'єктивність, в ньому є місце емоціям і співпереживанню. А людська думка не стільки відображає, скільки конструює ту реальність, що пізнається. В найбільшій мірі такі риси притаманні саме історичній пам'яті. За своєю суттю пам'ять емоційна, особистісно забарвлена, здатна до містифікацій і міфологізації. Таки риса історичної пам'яті зумовлює можливість різних іiі деформацій, зокрема, зусиллями тих груп і людей, які зацікавлені в деформаціях історії та політичного минулого України.

Виразною властивістю історичної пам'яті є їі міфологічність. Як відзначає Ю. Шаповал, проблеми історичної пам'яті (як і колективної відповідальності) неминуче потрапляють у зону метафоричного моделювання [25, с. 7-11]. Тому слід докладати зусилля до того, щоб тягар міфів не зруйнував засади адекватного сприйняття української історії та української політичної реальності. Звісно, в суспільстві повинна існувати прийнятна для нього система міфів і символів, однак політичний міф не повинен транслювати ті зразки свідомості, які викривляють і деформують знання про українську реальність у минулому.

Політичний міф $\epsilon$ інтегрованою формою політичної свідомості, завдяки якій в колективній пам'яті народу зберігається його соціальний досвід, моральні норми й духовні імперативи розвитку політичних процесів. Це спрощена форма політичної свідомості, в якій знання і розуміння фактів політики заміщується образами, символами, вимислами, легендами і вірою в них. Ю. Шайгородський зауважує, що як символічний засіб інтерпретації політичної реальності, моделювання світу і соціального життя політичний міф $є$ інструментом реалізації конкретних політичних завдань, боротьби за владу, іiі легітимацію тощо [24].

Зміст політичного міфу визначають певні архетипи, міфологізована ідея, стереотип поведінки, мотиваційні потреби, сукупність цінностей. Претендуючи на формування зразків поведінки людини у світі, міф 
завжди апелює до історії, до історичного минулого. М. Еліаде, характеризуючи найважливіші особливості міфу, акцентує увагу на тому, що міф творить типові моделі для всього суспільства. Історія одного людського життя може перетворюватися на зразок, а історичний персонаж на архетип [9].

За багатьма ознаками політичний міф споріднений з класичним архаїчним міфом. Однак на відміну від класичного міфу політичний конкретизується відповідно до актуальної політики, цілеспрямовано поширюється і використовується як ефективний засіб досягнення мети. На рівні масової свідомості міф сприймається як істина.

Політичний міф такий самий давній, як і політика, яку завжди супроводжують міфи про походження влади, про подвиги героїв, про справедливого монарха тощо. Він являє собою невід’ємну частину політичної свідомості. В різні історичні часи основними темами міфів були розповіді про минуле і трактування подій історичного минулого, розповіді про учасників подій, про легендарних героїв. Кожна історична епоха лише добавляє нові, оновлені міфи відповідно до тих історичних завдань, які є пріоритетними для політичної чи релігійної влади в той чи інший період часу.

Парадоксальним чином українська політична реальність потрапляє в фокус сучасного міфотворення, стає об'єктом сучасного політичного міфу. Крім того, численні маніпуляції з фактами української історії, викривлення української свідомості є частиною політичних маніпуляціях сучасної Росії. Як зазначає український історик В. Брехуненко, міфи, які не втомлюється створювати чи удосконалювати сучасна Росія, покривають практично все поле української історії. Більшість 3 них мають «довгу бороду», сягаючи своїми коріннями ідеологічних конструкцій, виплеканими московськими елітами в XVI-XIX ст. Зазнаючи час від часу уточнень та переформулювань, ці міфи мають чітку політичну мету та наполегливо нав'язують спотворений образ минулого України під потрібним для Москви кутом [4, с. 5].

\section{5. Висновок}

Отже, незважаючи на те, що різні форми нераціонального знання (зокрема, історична пам'ять і політичний міф) не можуть дати об'єктивної картини минулого, вони складають невід'ємну частину уявлень про нього. Постнекласична наука по-новому розуміє статус наукового 
знання: воно $є$ тільки наближенням до істини, тому в ньому міститься значна доля помилки. Все більшого значення набуває сценарне мислення, що передбачає багатоваріантність шляхів еволюції та нелінійної динаміки складних систем. В аналіз політичного знання сьогодні включаються різні історичні, соціологічні й культурні фактори.

Сукупність уявлень про українське минуле, духовний і політичний досвід людини певної історичної епохи фокусуються в історичній пам'яті. Історична пам'ять має одну універсальну перевагу над достовірним знанням: у ній зберігаються імпульси і мотиви для збереження національної ідентичності й утвердження національної ідеї.

Погляд у минуле супроводжується розумінням сучасного й окресленням шляхів поступу в майбутнє. Тому цілком обгрунтованою постає зміна дослідницьких акцентів в політичній науці. Вони стосуються не лише досягнення конкретного знання, але й обумовлюються тими історичними, культурними та політичними завданнями, що є пріоритетними для сучасної української людини.

Для сучасної постнекласичної науки характерний методологічний плюралізм, усвідомлення обмеженості та односторонності будь якої однієї методології, формується багаторівнева концепція методологічної теорії та нові стратегії наукового пошуку.

\section{Список літератури:}

1. Ассман Я. Культурная память. Письмо, память о прошлом и политическая идентичность в высоких культурах древности / Я. Ассман. - М.: Языки славянской культуры, 2004. - 368 с.

2. Бевзенко Л.Д. Социальная нелинейность - предпосылки и проявление / Л.Д. Бевзенко // Постнеклассика: философия, наука, культура. - СПб: издательский дом «Мip », 2009. - С. 545-546.

3. Блок М. Апология истории, или ремесло историка / М. Блок; пер. с фр. - Таллин: Ээсти раамат, 1983. - 184 с.

4. Брехуненко В. Війна за свідомість. Російські міфи про Україну та іiі минуле / В. Брехуненко. - К.: Віпол, 2017. - 280 с.

5. Бродель Ф. История и общественные науки. Историческая длительность / Ф. Бродель // Философия и методология истории. Сборник переводов / Под ред. И.С. Кона. - М.: Прогресс, 1977. - С. 115-142.

6. Василенко И.А. Политическая философия: Учеб. пособие / И.А. Василенко. - М.: ИНФРА, 2010. - 320 с.

7. Грицак Я.Й. Нарис історії України: формування модерної української нації XIX-XX століття: навчальний посібник / Я.Й. Грицак. - К.: Генеза, 1996. $-356 \mathrm{c}$. 


\section{Inter-diagnostic approaches in post-advocacy science: possibilities...}

8. Добронравова И.С. Причинность и целостность в синергетических образах мира / И.С. Добронравова // Практична філософія. - 2003. № $1 .-$ C. 6-10.

9. Еліаде М. Священне і мирське. Міфи, сновидіння і містерії. Мефістофель і андрогін. Окультизм, ворожбитство та культурні уподобання / М. Еліаде; пер. 3 нім., фр., англ. Г. Кьорян, В. Сахна). - К.: Основи, 2001. - 592 с.

10. Коллингвуд Р.Дж. Идея истории. Автобиография / Р.Дж. Коллингвуд. -М.: Наука, 1980. - 485 с.

11. Левенець Ю. Теоретико-методологічні засади української суспільнополітичної думки: проблеми становлення та розвитку (друга половина XIX початок ХХ століття) / Левенець Ю. - К.: Стилос, 2001. - 585 с.

12. Лотман Ю. М. Семиосфера. Внутри мыслящих миров // Ю. М. Лотман. Санкт-Петербург: Исскуство-СПБ, 2010. 704 с.

13. Нагорна Л. Історична пам'ять: теорії, дискурси, рефлексії / Л. Нагорна. К.: ІПіЕНД ім. І. Ф. Кураса НАН України,. 2012. - 328 с.

14. Петрук Н.К. Українська духовна культура XVI-XVII ст.: соціальна організація i формування простору національного буття: монографія / Н.К. Петрук. - Хмельницький: [б.в.], 2007. - 288 с.

15. Пригожин И., Стенгерс И. Порядок из хаоса. Новый диалог человека с природой / И. Пригожин, И. Стенгерс. - М.: Прогресс, 1986. - 460 с.

16. Савельева И. М., Полетаев А. В. История и время: в поисках утраченого / И.М. Савельева, А.В. Полетаев. - М.: Языки русской культуры, 1997. $800 \mathrm{c}$.

17. Степин В.С. История и философия науки: Учебник для аспирантов и соискателей ученой степени кандидата наук / В.С. Степин. - М.: Академический Проект; Трикста, 2011. - 423 с.

18. Тош Дж. Стремление к истине: как овладеть мастерством историка / Джон Тош; пер. с англ. М.Л. Коробочкина, ред. В.А. Русев. - М.: Весь Мир, 2000. - 294, [1] c.

19. Февр Л. Бои за историю: сб. ст. / Люсьен Февр; пер. А.А. Бобовича, М.А. Бобовича, Ю.Н. Стефанова. - М.: Наука, 1991. - 629 с.

20. Хакен Г. Синергетика: Иерархия неустойчивостей в самоорганизующихся системах / Г. Хакен. - М.: Мир, 1985. - 419 с.

21. Хальбвакс М. Социальные рамки памяти / М. Хальбвакс; пер. с фр. и вступ. статья С.Н. Зенкина. - М.: Новое издательство, 2007. - 348 с.

22. Хёйзинга, Й. Осень Средневековья: Пер. с нидерланд. / Й. Хёйзинга // Соч.: в 3-х т. - Т. 1 / Вступ. ст. и общ. ред. В.И. Уколовой. - М.: Изд. группа «Прогресс»-«Культура», 1995. - 539 с.

23. Хёйзинга Й. Homo Ludens. Статьи по истории культуры / Й. Хёйзинга; пер. с голл. - М.: Прогресс-Традиция, 1997. - 416 с.

24. Шайгородський Ю. Ж. Політика: взаємодія реальності і міфу / Ю. Ж. Шайгородський. - К. : Знання України, 2009. - 400 с.

25. Шаповал Ю. Політика пам'яті в сучасній Україні / Юрій Шаповал // Громадянська освіта. - 2008. - № 36. - С. 7-11

26. Яковенко Н. М. Вступ до історії / Н. М. Яковенко. - К.: Критика, 2007. $368 \mathrm{c}$. 


\section{References:}

1. Assman Ya. (2004) Kulturnaia pamiat. Pysmo, pamiat o proshlom y polytycheskaia ydentychnost $\mathrm{v}$ vysokykh kulturakh drevnosty [Cultural memory. Letter, memory of the past and political identity in the high cultures of antiquity]. Moscow: Yazyky slavianskoi kulturya. (in Russian)

2. Bevzenko L.D. (2009) Sotsyalnaia nelyneinost - predposylky y proiavlenye [Social nonlinearity-the premise and manifestation]. Postneklassyka: fylosofyia, nauka, kultura [Post-Classics: philosophy, science, culture]. Moscow: yzdatelskyi dom "Mir» pp. 545-546.

3. Blok M. (1983) Apolohyia ystoryy, yly remeslo ystoryka [The apology of history, or the craft of a historian]. Tallyn: Eesty raamat. (in Estonia)

4. Brekhunenko V. (2017) Viina za svidomist. Rosiiski mify pro Ukrainu ta yii mynule [The war for consciousness. Russian myths about Ukraine and its past]. Kyiv: Vipol. (in Ukrainian)

5. Brodel F. (1977) Ystoryia y obshchestvennye nauky. Ystorycheskaia dlytelnost [History and social sciences. Historical Duration]. Fylosofyia y metodolohyia ystoryy [Philosophy and methodology of history]. Moscow: Prohress, pp. 115-142.

6. Vasylenko Y.A. (2010) Polytycheskaia fylosofyia [Political philosophy]. Moscow: YNFRA. (in Russian)

7. Hrytsak Ya.I. (1996) Narys istorii Ukrainy: formuvannia modernoi ukrainskoi natsii XIX-XX stolittia: navchalnyi posibnyk [Essay on the history of Ukraine: the formation of the modern Ukrainian nation of the XIX-XX centuries: a manual]. Kyiv: Heneza. (in Ukrainian)

8. Dobronravova Y.S. (2003) Prychynnost y tselostnost v synerhetycheskykh obrazakh myra [Causality and integrity in synergetic images of the world]. Praktychna filosofiia, no. 1, pp. 6-10.

9. Eliade M. (2001) Sviashchenne i myrske. Mify, snovydinnia i misterii. Mefistofel i androhin. Okultyzm, vorozhbytstvo ta kulturni upodobannia [Sacred and secular. Myths, dreams and mysteries. Mephistopheles and androgynes. Occult, divination and cultural tastes]. Kyiv: Osnovy. (in Ukrainian)

10. Kollynhvud R. Dzh. (1980) Ydeia ystoryy. Avtobyohrafyia [The idea of history. Autobiography]. Moscow: Nauka. (in Russian)

11. Levenets Yu. (2001) Teoretyko-metodolohichni zasady ukrainskoi suspilno-politychnoi dumky: problemy stanovlennia ta rozvytku (druha polovyna XIX - pochatok XX stolittia) [Theoretical and methodological principles of Ukrainian social and political thought: problems of formation and development (the second half of the nineteenth and early twentieth centuries)]. Kyiv: Stylos. (in Ukrainian) (in Ukrainian)

12. Lotman Yu.M. (2010) Semiosphere. Vnutry mysliashchykh myrov [Semiosphere. Inside the thinking worlds]. Sankt-Peterburh: Ysskustvo-SPB. (in Russian)

13. Nahorna L. (2012) Istorychna pamiat: teorii, dyskursy, refleksii [Historical memory: theories, discourses, reflections]. Kyiv: IPiEND im. I. F. Kurasa NAN Ukrainy. (in Ukrainian)

14. Petruk N.K., (2007) Ukrainska dukhovna kultura XVI-XVII st.: sotsialna orhanizatsiia i formuvannia prostoru natsionalnoho buttia [Ukrainian spiritual 
culture of XVI-XVII centuries: social organization and formation of the space of national existence]. Khmelnytskyi. (in Ukrainian)

15. Pryhozhyn Y., Stenhers Y. (1986) Poriadok yz khaosa. Novyi dyaloh cheloveka s pryrodoi [Order out of chaos. A new dialogue between man and nature]. Moscow: Prohress. (in Russian)

16. Saveleva Y.M., Poletaev A.V. (1997) Ystoryia y vremia: v poyskakh utrachenoho [History and time: in search of lost]. Moscow: Yazyky russkoi kultury. (in Russian)

17. Stepyn V.S. (2011) Ystoryia y fylosofyia nauky: Uchebnyk dlia aspyrantov y soyskatelei uchenoi stepeny kandydata nauk [History and Philosophy of Science: A Textbook for PhD Students and Candidates for the Degree of Candidate of Science]. Moscow: Akademycheskyi Proekt Tryksta. (in Russian)

18. Tosh, Dz., 2000. Stremlenye k ystyne: kak ovladet masterstvom ystoryka [The desire for truth: how to master the skill of a historian]. Moscow: Ves Myr. (in Russian)

19. Fevr L., 1991. Boy za ystoryiu [Battles for history]. Moscow: Nauka. (in Russian)

20. Khaken H., 1985. Synerhetyka: Yerarkhyia neustoichyvostei v samoorhanyzuiushchykhsia systemakh [Synergetics: Hierarchy of instability in self-organizing systems]. Moscow: Myr. (in Russian)

21. Khalbvaks M. (2007) Sotsyalnye ramky pamiaty [Social framework of memory]. Moscow: Novoe yzdatelstvo. (in Russian)

22. Kheizynha Y., 1995. Osen Srednevekovia [Autumn of the Middle Ages]. Moscow: Yzdatelskaia hruppa "Prohress" - "Kultura". (in Russian).

23. Khëizynha Y. (1997) Homo Ludens. Staty po ystoryy kultury [Homo Ludens. Articles on the history of culture]. Moscow: Prohress-Tradytsyia. (in Russian)

24. Shaihorodskyi Yu.Zh. (2009) Polityka: vzaiemodiia realnosti i mifu [Politics: the interaction of reality and myth]. Kyiv: Znannia Ukrainy. (in Ukrainian)

25. Shapoval Yu. (2008) Polityka pamiati v suchasnii Ukraini [Memory policy in contemporary Ukraine]. Hromadianska osvita, no. 36, pp. 7-11.

26. Iakovenko N. M. (2007) Vstup do istorii [Introduction to history].Kyiv: Krytyka. (in Ukrainian) 
STUDY OF THE INFLUENCE OF EXTERNAL PRESSURE AND SINTERING TEMPERATURE ON THE STRUCTURE AND PROPERTIES OF THE SYSTEM ND-FE-C,B

\section{Gulyaeva Tatiana ${ }^{1}$}

DOI: http://dx.doi.org/10.30525/978-9934-571-26-8_7

Abstract. Modern industrial production of precision machinery, microelectronics, Aeronautics, rocket science puts high demands on the materials. The main criteria which should characterize the material, high quality, low production cost, minimum material consumption while maintaining the best physical and mechanical properties of products in a production environment. In the global and domestic literature little attention is paid to using one of the thermodynamic parameters of pressure to control the crystallization and sintering of the permanent magnets. Therefore, in this paper applied an integrated approach during the study of the dependence of the coercive force from alloying and heat treatment of hard magnetic alloy $\mathrm{Nd}-\mathrm{Fe}-\mathrm{C}$, received high-speed cooling, sintering the compact under pressure up to $1 \mathrm{GPa}$. In this formulation, the problem of obtaining high coercitive magnets is relevant and timely.

As is known, with increasing temperature, there is thermal expansion of telephone that is, due to the difference of linear expansion coefficients of the materials of the films, molds and bolts you can get more "heat" pressure. For calculations was created analysis model in the program ANSIS. In the design model include: mold, bolts and tapes. The material of the mold and bolts were selected so that the difference in coefficients of linear expansion to create additional pressure on the composite material caused by temperature change.

For modeling were used: the dependence of young's modulus for materials design models, the coefficient of linear expansion $\alpha$ for phase $\mathrm{Nd}_{2} \mathrm{Fe}_{14} \mathrm{C}$. The dependence of the tensile strength, the yield strength of the bolt and the mold temperature. The calculations showed that after temperature of

${ }^{1}$ Candidate of Technical Sciences,

Associate Professor of the Department of Physics,

Zaporizhzhia National Technical University, Ukraine

orcid.org/0000-0002-6408-0463 
$673 \mathrm{~K}$, the values of tensile strength and yield strength for the material of the screws and molds are plummeting. That is, after this temperature begins the process of plastic deformation. In order to account for this phenomenon, you need to build curves of deformation for each calculated temperature.

The greatest elongation, according to the calculations obtained for the film material. The smallest elongation for material of the bolts. For temperatures of $1023 \mathrm{~K}$ and $1173 \mathrm{~K}$ they differ by 4 times. It is due to this it is possible to obtain additional external pressure on the sample in a compressed state in the range of $850 \ldots 900 \mathrm{MPa}$.

For research we used film, that quickly cooled, (scales) alloy composition $\mathrm{Nd}_{20} \mathrm{Fe}_{70} \mathrm{C}_{9,5} \mathrm{~B}_{0,5}$. The films obtained by quenching from the liquid state in the initial state had amorphous or amorphous-crystalline structure. The resulting films (flakes) were placed into the mold and compressed under the press before sintering at a pressure of $0.5 \mathrm{MPa}$. The mold was bolted and placed in a vacuum sintering furnace in a compressed state. Due to the difference in the coefficients of linear expansion of bolts and molds, additional pressure was created on the sample when heated to 0.9GPa. Sintering was conducted at temperatures of $1023 \ldots 1223 \mathrm{~K}$ for 1800 seconds.

The reliability of the obtained scientific results confirmed by the use of modern research equipment (optical microscope OLIMPYS IX-70, X-ray diffractometer Dron-3, a scanning electron microscope JEOL JSM6360LA, magnetometer vicious circle); the error in the reproduction of results is $3 \%$ and $10 \%$.

With the rapid cooling of the melt phase $\mathrm{Nd}_{2} \mathrm{Fe}_{14}(\mathrm{~B}, \mathrm{C})$ kristallizuetsya directly from bypassing liquid equilibrium peritectoid transformation. In the films (scales) alloys $\mathrm{Nd}_{20} \mathrm{Fe}_{70} \mathrm{C}_{9,5} \mathrm{~B}_{0,5}$ in sintering at temperatures of $1123 \ldots 1223 \mathrm{~K}$ of amorphous component kristallizuetsya metastable phase with reduced metastability $\mathrm{Nd}_{2} \mathrm{Fe}_{14} \mathrm{C}$. The external pressure helps to seal the sample and sintering on the limits of the scales. The increase in the sintering temperature in the interval $1023 \ldots 1223 \mathrm{~K}$ increases the coercive force, residual induction and specific magnetic energy of the compact $\left(\mathrm{Hc}=12 \ldots 32 \mathrm{kA} / \mathrm{m}, \mathrm{Br}=0.15 \ldots 0.23 \mathrm{~T}, \mathrm{~W}=0.135 \ldots 0.91 \mathrm{~kJ} / \mathrm{m}^{3}\right.$, respectively $)$.

\section{Introduction}

The basis for the production of high coercitivity permanent magnets are alloys of transition metals $(\mathrm{T})$ with rare earth $(\mathrm{R})$, in which the necessary level of magnetic properties is provided by the formation of intermetal- 
lic compounds of type $\mathrm{RT}_{5}$, and $\mathrm{R}_{2} \mathrm{~T}_{17}, \mathrm{R}_{2} \mathrm{~T}_{14} \mathrm{~B}$. Although SmCo magnets satisfied the demands of modern electrical engineering, but the expensive technology of obtaining of cobalt and the high price limits their practical application. The emergence of materials with high magnetic properties and low cost compared to the SmCo-based alloy system Nd-Fe-B stimulated further research and development in several industrialized countries [1]. To date, developed the technology of fabrication of high performance permanent magnets based on $\mathrm{Nd}_{2} \mathrm{Fe}_{14} \mathrm{C}$ compound, installed precision schematics of heat treatment and methods of alloying the base alloy to achieve the maximum hysteresis properties [2;3].

It is known that to obtain high-quality permanent magnets are promising alloy system $\mathrm{Nd}-\mathrm{Fe}-\mathrm{C}$, because the connection that is formed in the system $\mathrm{Nd}_{2} \mathrm{Fe}_{14} \mathrm{C}$ has a high anisotropy field $(\mathrm{HA}=7,6 \mathrm{MA} / \mathrm{m})$. It should be noted that the phase $\mathrm{Nd}_{2} \mathrm{Fe}_{14} \mathrm{C}$ in the system is formed by peritectoid reaction in the temperature range of $1123 \ldots 1173 \mathrm{~K}$, and the time of complete conversion is more than 20 days [4].

To accelerate the transformation perfectooo resort to the following methods: 1) alloying a small amount of boron (0.5 at. \%) [5]; 2) quenching from the liquid state, which is formed metastable phase $\mathrm{Nd}_{2} \mathrm{Fe}_{14} \mathrm{C}$ along with the $\mathrm{Nd}_{2} \mathrm{Fe}_{17}$ phase. The use of these methods reduces the conversion process to a few tens of minutes [6].

In addition to the search methods of complex alloying, and development of new compounds such as $\mathrm{Nd}_{2} \mathrm{Fe}_{14} \mathrm{C}$, in world and domestic literature little attention is given to the development of new methods of manufacture of permanent magnets, namely using one of the thermodynamic parameters of pressure to control the crystallization and sintering of the permanent magnets. Therefore, in this paper applied an integrated approach during the study of the dependence of the coercive force from alloying and heat treatment of hard magnetic alloy $\mathrm{Nd}-\mathrm{Fe}-\mathrm{C}$, received high-speed cooling, sintering the compact under pressure up to 1 GPA. In this formulation, the problem of obtaining high coercitive magnets is relevant and timely.

\section{Calculation of additional "thermal" pressure}

As is known, with increasing temperature, there is thermal expansion of the bodies. If you take a mold, put inside a bulk material, to seal it and start to heat, when thermal expansion of the material of the mold of bulk material inside it will start to spresovuyetsya. In order to calculate the additional 
"thermal" pressure, it is necessary to simulate the process. This additional "thermal" pressure is due to the difference of coefficients of linear expansion of the materials of the films, molds and bolts. For calculations was created analysis model in the program ANSIS [7]. In the design model include: mold, bolts and tapes. In Fig. 1 presents a computational model is created.
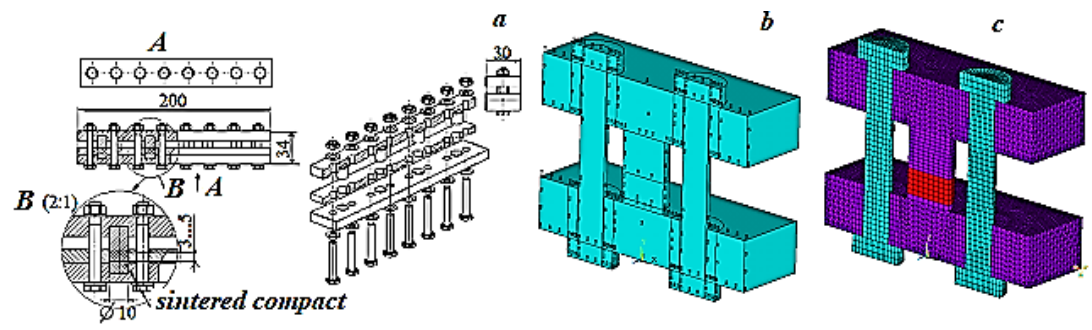

Fig. 1. Design model: a diagram of the mold; b, the geometric model; $\mathbf{c}$ - finite element model

Applied modeling of bolts of a certain force $\mathrm{F}$ depending on the torque $\mathrm{M}$ tightening bolts (forms. 1):

$$
\mathrm{F}=0,8 \mathrm{M}
$$

The films were studied, perceived pressure from parts of the mold together. The interaction of the powder and of the surrounding parts is modeled by contact elements. The result of the calculation is the contact pressure, which depends on the temperature of the installation.

The material of the mold and bolts were selected so that the difference in coefficients of linear expansion to create additional pressure on the material of the compact caused by the change of temperature. In Fig. 2 shows the dependence of temperature coefficient of linear expansion of the $\mathrm{Nd}_{2} \mathrm{Fe}_{14} \mathrm{~B}$ phase for parameters a and $\mathrm{C}$.

In table. 1 presents values of the young's modulus and linear expansion coefficient were used for calculations.

For calculations were used the data graphs (see Fig. 3, 4). In the calculations it was considered that for the material of the CD young's modulus remains almost unchanged, while for the materials of the mold and bolts changes [9-12]. From Fig. 4 shows that after the temperature of $673 \mathrm{~K}$, the values of tensile strength and yield strength for the material of the screws 


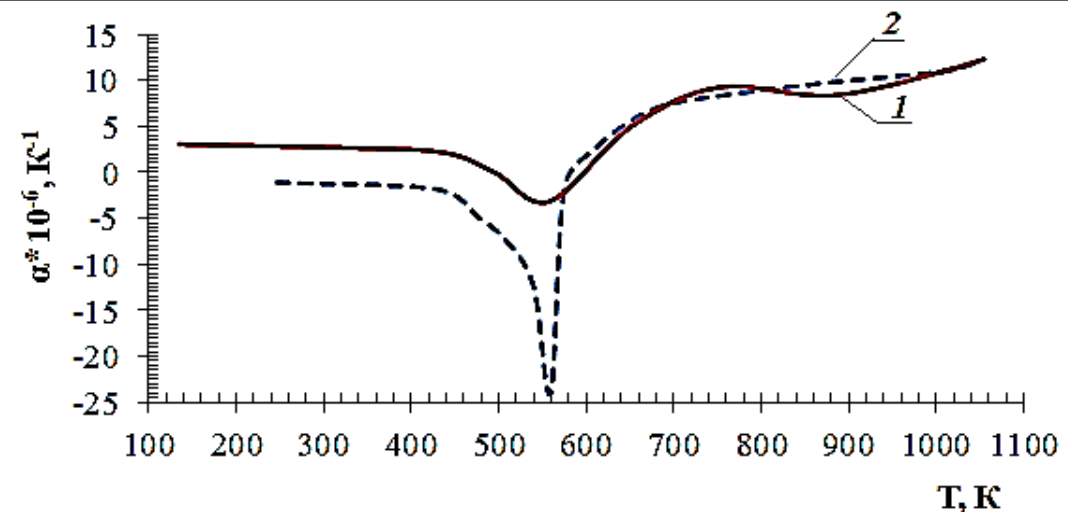

Fig. 2. A graph of the linear expansion coefficient $\alpha$ of the temperature of the $\mathrm{Nd}_{2} \mathrm{Fe}_{14} \mathrm{~B}$ phase: $1-a ; 2-c$ [8]

Table 1

The Values of young's modulus and coefficient of linear expansion for materials that are used for calculations at $\mathrm{T}=293 \mathrm{~K}\left(20^{\circ} \mathrm{C}\right)$

\begin{tabular}{|l|c|c|c|}
\hline The model element & Material & $\begin{array}{c}\text { The Young's } \\
\text { Modulus, } \mathbf{G P a}\end{array}$ & $\begin{array}{c}\text { The coefficient } \\
\text { of linear expansion } \\
\dot{\boldsymbol{\alpha}}^{\bullet} \mathbf{1 0}^{-\mathbf{6}}, \mathbf{K}^{\mathbf{- 1}}\end{array}$ \\
\hline Pres-form & 12X18H10T & 40,9 & 16,4 \\
\hline Bolts & 30ХГСА & 20 & 11,5 \\
\hline Powder & Nd-Fe-B & 150 & 1,66 \\
\hline
\end{tabular}

and molds are plummeting. That is, after this temperature begins the process of plastic deformation. In order to account for this phenomenon, you need to build curves of deformation for each calculated temperature. The total deformation curves shown in Fig. 5.

In order to build these facilitation curves (Fig. 6) you must use the data graph shown in Fig. 43. The angle $\alpha$ is found from the following relationship:

$$
\operatorname{tg} \alpha=\frac{\sigma_{m}}{\varepsilon_{1}}
$$

The angle $\beta$ is as follows:

$$
\operatorname{tg} \beta=\frac{\sigma_{M}-\sigma_{m}}{\varepsilon_{2}-\varepsilon_{1}}
$$




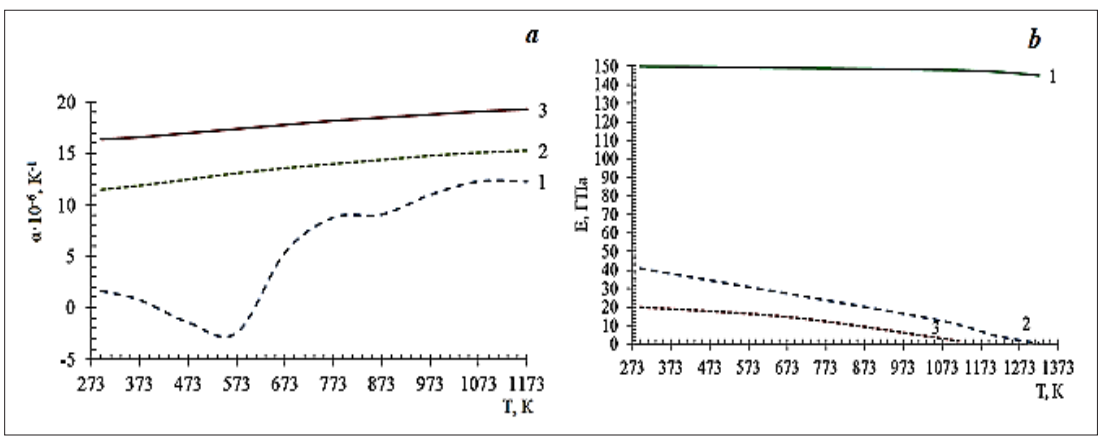

Fig. 3. Graph of relative length (a) and young modulus (b) against temperature for the materials of the bolts and mould:

1 - material films Nd-Fe-B; 2 - bolt material 30KHGSA; 3 - material mold $12 \mathrm{KH} 18 \mathrm{~N} 10 \mathrm{~T}$

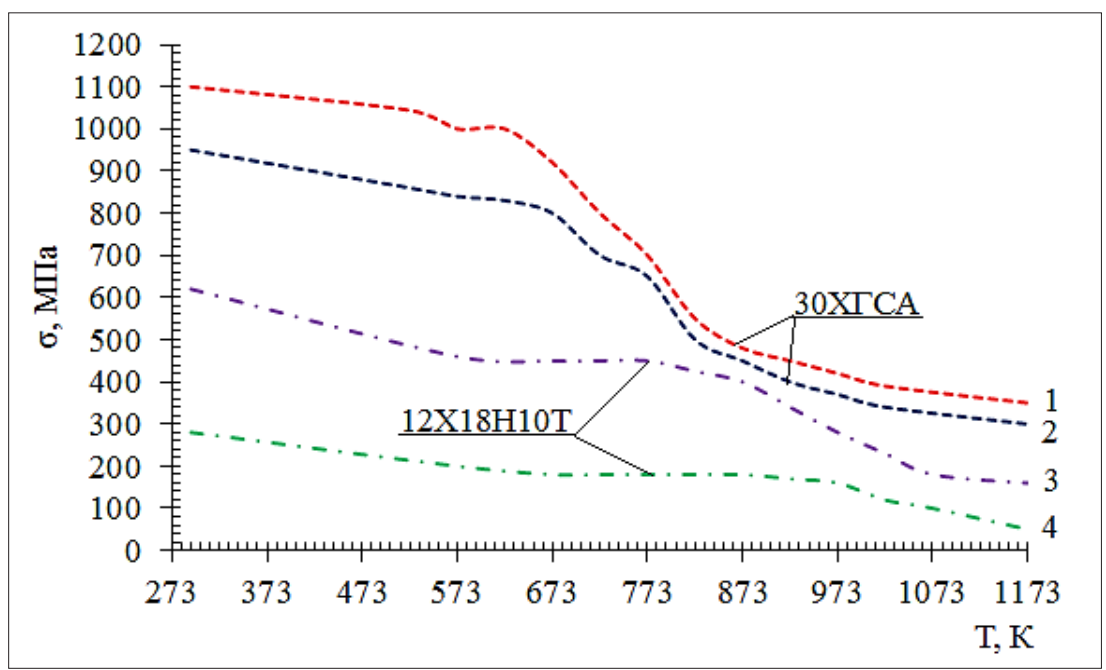

Fig. 4. The dependence of the tensile strength, yield strength on temperature: 1 - tensile strength for bolts; 2 - yield strength for bolts; 3 - tensile strength for the mold; 4 - yield strength for the mold

Thus, in the simulation we used the following simplified deformation curves (Fig. 7). 


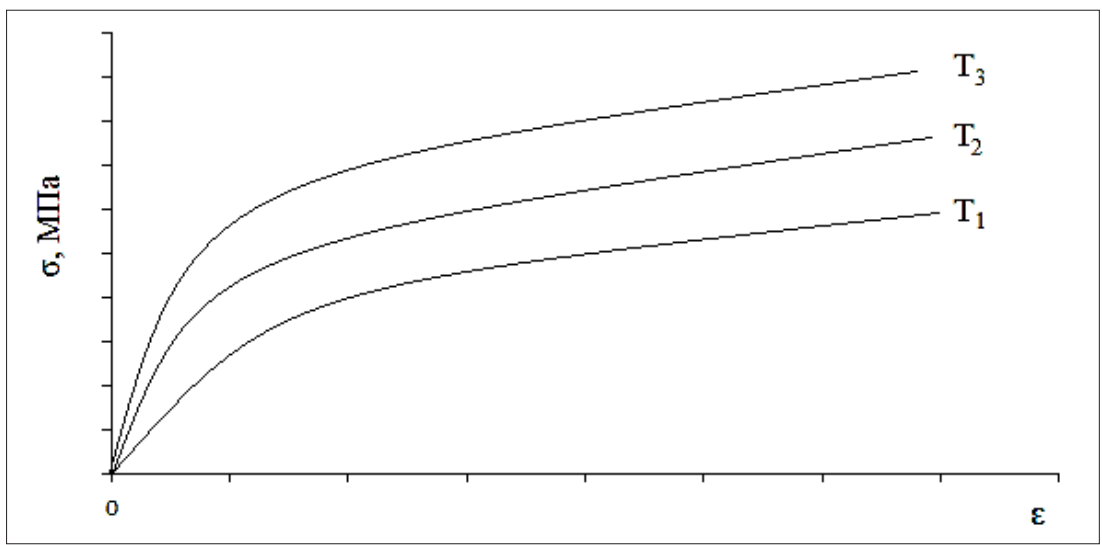

Fig. 5. The General form of curves of deformation at different temperatures: $T_{3}>T_{2}>T_{1}$

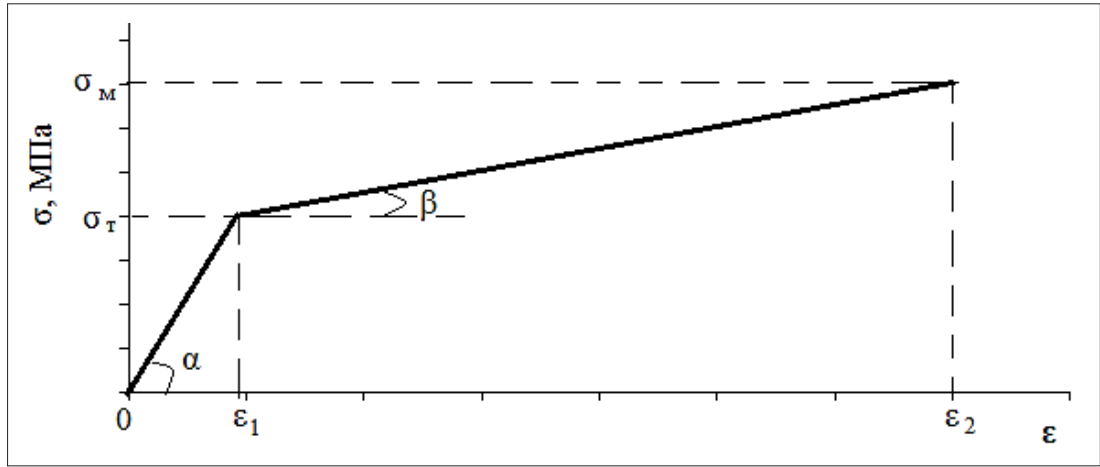

Fig. 6. A simplified theoretical curve deformation

Mechanical stress depends on the deformation in the following way:

$$
\{\sigma\}=[\mathrm{E}]\left\{\varepsilon^{\mathrm{el}}\right\},
$$

where $\{\sigma\}=\left\{\sigma_{\mathrm{x}} \sigma_{\mathrm{y}} \sigma_{\mathrm{z}} \sigma_{\mathrm{xy}} \sigma_{\mathrm{yz}} \sigma_{\mathrm{xz}}\right\}^{\mathrm{T}}$ - vector mehanna in voltage,

[E] - the young's modulus, or elastic stiffness matrix (or stress-strain matrix).

The vector of elastic strain:

$$
\left\{\varepsilon^{\mathrm{el}}\right\}=\{\varepsilon\}-\left\{\varepsilon^{\mathrm{th}}\right\}
$$




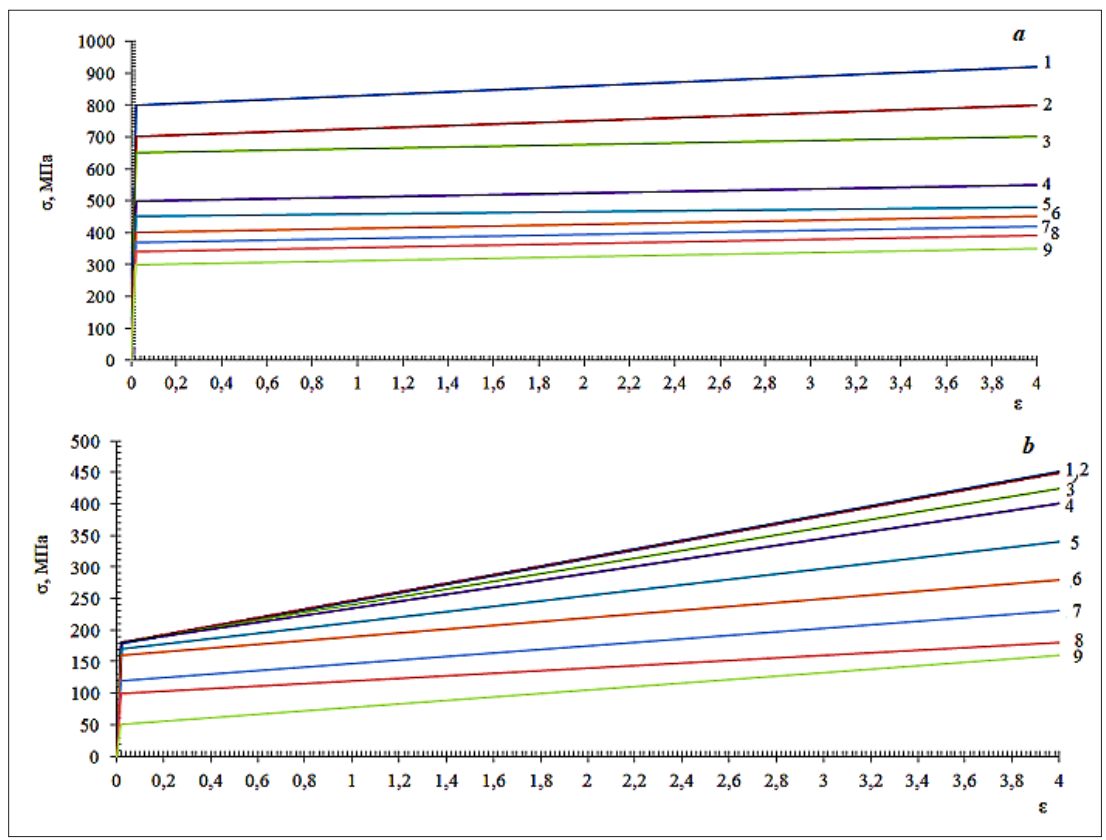

Fig. 7. Deformation curves at different temperatures for the material of the bolts 30KHGSA (a) and for the material of the mold 12KH18N10T (b): 1 - 673K; 2 - 723K; 3 - 773K; 4 - 823K; 5 - 873K; 6 - 923K; 7 - 973K; 8 - 1023K; 9 - 1173K

where $\{\varepsilon\}=\left[\begin{array}{llllll}\varepsilon_{\mathrm{x}} & \varepsilon_{\mathrm{y}} & \varepsilon_{\mathrm{z}} & \varepsilon_{\mathrm{xy}} & \varepsilon_{\mathrm{yz}} & \varepsilon_{\mathrm{xz}}\end{array}\right]^{\mathrm{T}}-$ the total strain vector, $\left\{\varepsilon^{\text {th }}\right\}$ - thermal strain vector.

Sign vector for direct strains and stresses can be represented as follows: the rule of signs for the normal stresses and strains that are used in the program ANSIS, such a tensor is positive, and compression negative, to offset: positive if imposed two additional.

$$
\{\varepsilon\}=\left\{\varepsilon^{\text {th }}\right\}+[\mathrm{E}]^{-1}\{\sigma\}
$$

For three-dimensional vector thermal strain:

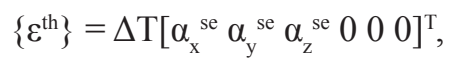

where $\alpha_{\mathrm{x}}^{\text {se }}-$ Jan the coefficient of thermal expansion along the $\mathrm{X}$ axis;

$$
\Delta \mathrm{T}=\mathrm{T}-\mathrm{T}_{\text {ref }} ;
$$


$\mathrm{T}$ - current temperature;

$\mathrm{T}_{\text {ref }}$ - reference (stress-free) temperature.

Elastic matrix is:

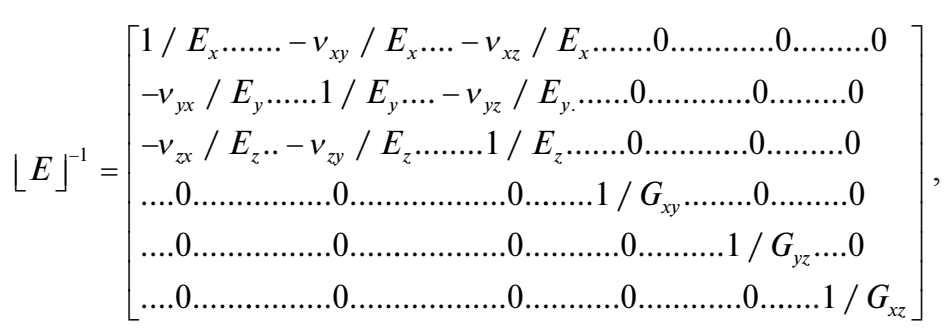

where $\mathrm{E}_{\mathrm{x}}$ - the young's modulus along the $\mathrm{X}$ axis, $\mathrm{G}$ is the shear modulus, $\mu_{\mathrm{xy}}$ - the basic Poisson's ratio,

$\mu_{\mathrm{yx}}$ - the minor Poisson's ratio,

$\sigma_{x y}$ - the module of the tangential mechanical stress in the XY-plane.

For an isotropic material $\left(\mathrm{E}_{\mathrm{x}}=\mathrm{E}_{\mathrm{y}}=\mathrm{E}_{\mathrm{z}}\right)$ and $\left(v_{\mathrm{xy}}=v_{\mathrm{yx}}=v_{\mathrm{xz}}\right)$ there is no difference between the data that is entered. Write down 6 explicit equations:

$$
\begin{gathered}
\varepsilon_{x}=\alpha_{x} \Delta T+\frac{\sigma_{x}}{E_{x}}-\frac{\mu_{x y} \sigma_{y}}{E_{x}}-\frac{\mu_{x z} \sigma_{z}}{E_{x}} \\
\varepsilon_{y}=\alpha_{y} \Delta T-\frac{\mu_{x y} \sigma_{x}}{E_{x}}+\frac{\sigma_{y}}{E_{y}}-\frac{\mu_{y z} \sigma_{z}}{E_{y}} \\
\varepsilon_{z}=\alpha_{z} \Delta T-\frac{\mu_{x z} \sigma_{x}}{E_{x}}-\frac{\mu_{y z} \sigma_{y}}{E_{y}}+\frac{\sigma_{z}}{E_{z}} \\
\varepsilon_{x y}=\frac{\sigma_{x y}}{G_{x y}} \\
\varepsilon_{y z}=\frac{\sigma_{y z}}{G_{y z}} \\
\varepsilon_{x z}=\frac{\sigma_{x z}}{G_{x z}}
\end{gathered}
$$

where $\varepsilon_{\mathrm{x}}$-direct deformation along the $\mathrm{X}$ axis;

$\sigma_{x}$-direct mechanical stress along the $\mathrm{X}$-axis;

$\varepsilon_{\mathrm{xy}}$-shear strain along XY plane;

$\sigma_{x y}$-shear stress along XY plane. 
If the shear modulus $\mathrm{G}_{\mathrm{xy}}, \mathrm{G}_{\mathrm{yx}}$ and $\mathrm{G}_{\mathrm{xz}}$ not introduced for isotropic materials, then they are equal

$$
G_{x y}=G_{y z}=G_{x z}=\frac{E_{x}}{2\left(1+\mu_{x y}\right)}
$$

When solving the above equations we can obtain the following two levels for the main mechanical stress and strain. The equation for determining the main stress:

$$
\sigma_{e}=\frac{1}{2} \sqrt{\left(\sigma_{1}-\sigma_{2}\right)^{2}+\left(\sigma_{2}-\sigma_{3}\right)^{2}+\left(\sigma_{3}-\sigma_{1}\right)^{2}}
$$

Equations for deformation:

$$
\varepsilon_{e}=\frac{1}{2 \cdot(1+\mu)} \cdot \sqrt{\left(\varepsilon_{2}-\varepsilon_{1}\right)^{2}+\left(\varepsilon_{2}-\varepsilon_{3}\right)^{2}+\left(\varepsilon_{3}-\varepsilon_{1}\right)^{2}}
$$

where $\mu$ is the Poisson's ratio for elastic and thermal deformations of the material.

The results of calculations by the formulas 16,17 shown in Fig. 8: distribution of elongation $\Delta \mathrm{l}$ in $\mathrm{mm}$ in the cross section of the mold, bolts and pattern as well as the distribution of the contact load on the sample for temperatures from 293...1073K.

It is seen that with increasing temperature an additional "thermal" pressure initially increases and then gradually decreases and remains almost unchanged. In Fig. 9 shows the dependence of tensile strength, yield stress and "thermal" pressure, temperature, and Fig. 10 - dependence of elongation on temperature.

From Fig. 9 shows that the yield stress for the material of the mold at room temperature lower than the thermal pressure at the same temperature. The maximum thermal pressure $895,8 \mathrm{MPa}$ was obtained for the temperature $673 \mathrm{~K}$. With further increase in temperature the value of thermal pressure decreases slightly and remains at about $850 \ldots 860 \mathrm{MPa}$. This can be explained by the fact that, as for the material of bolts and the material of the mold with the increase of temperature begins the phenomenon of plastic deformation.

From Fig. 10 shows that the greatest elongation, according to the calculations obtained for the film material. The smallest elongation for material of the bolts. For temperatures of $1023 \mathrm{~K}$ and $1173 \mathrm{~K}$ they differ by 4 times. It is due to this it is possible to obtain additional external pressure on the sample in a compressed state in the range of $850 \ldots 900 \mathrm{MPa}$. 

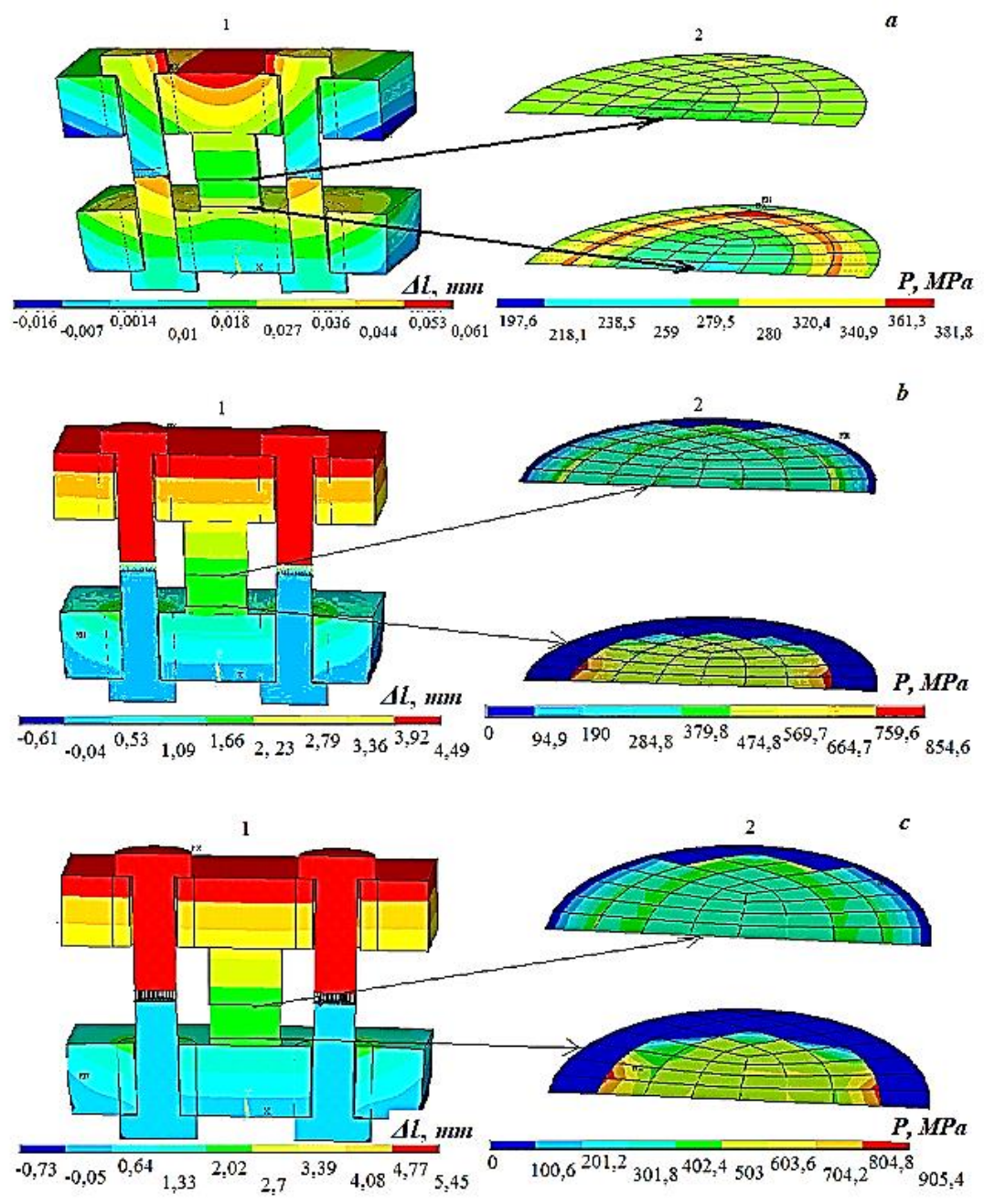

Fig. 8. Distribution diagram widower and contact pressure: 1 - distribution vidaurri in the mold, the bolts, the material of the compact; 2 - distribution of contact pressure at the contact between the punch mold and the material of the $C D$; $a-293 K$ $\left(20^{\circ} \mathrm{C}\right) ; \mathrm{b}-1023$ K $\left(750^{\circ} \mathrm{C}\right) ; \mathrm{c}-1173 \mathrm{~K}\left(900^{\circ} \mathrm{C}\right)$ 


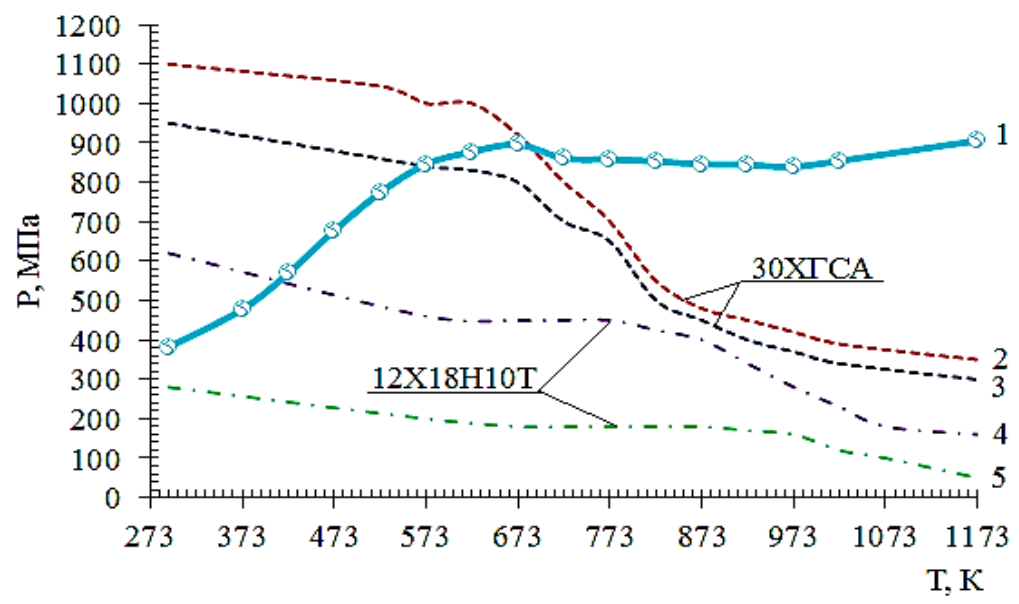

Fig. 9. The dependence of the tensile strength, yield strength and thermal pressure from temperature: 1 - extra pressure; $\mathbf{2}$ - tensile strength for bolts; 3 - yield strength for bolts; 4 - tensile strength for the mold; 5 - yield strength for the mold

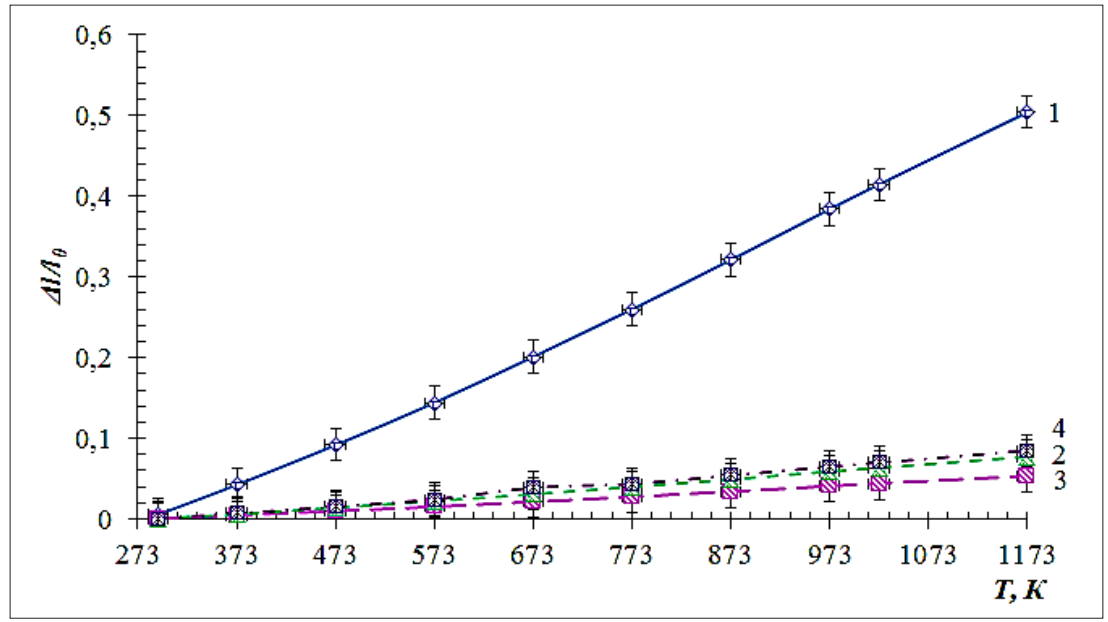

Fig. 10. The dependence of elongation on temperature: 1 - the material of the compact; 2 - material molds; 3 - bolt material; 4 - seredni value 


\section{The influence of external load and sintering temperature on structure, phase composition and magnetic properties of the alloy $\mathrm{Nd}_{20} \mathrm{Fe}_{70} \mathrm{C}_{9,5} \mathrm{~B}_{0,5}$}

To verify the results of mathematical simulation was verified based on phase composition, microstructure and magnetic properties on sintering temperature and external loads. Sintering was carried out for the base alloy composition $\mathrm{Nd}_{20} \mathrm{Fe}_{70} \mathrm{C}_{9,5} \mathrm{~B}_{0,5}$ in the temperature range of $1073 \ldots 1223 \mathrm{~K}$ every $50 \mathrm{~K}$, the initial pressure of $0.5 \mathrm{MPa}$, a sintering time of $1800 \mathrm{sec}$. Annealing occurred at a temperature of $1113 \mathrm{~K}$, the annealing time of $1800 \mathrm{sec}$. The study of structural phase transformations and measurements of magnetic properties were carried out by standard methods.

In Fig.11 shows images of the microstructure of the compacts of base composition after sintering at different temperatures (see Fig. 1 a,c,f,h,m) and after annealing(see Fig. 1 d,b,g,k,n).

As can be seen from the results of metallographic studies of alloys in the structure of the compacts have a multiphase structure. After etching of the sintered alloys were observed components of three types: light grass, dark grass and areas, which after etching have a greenish tinge.

After sintering at a temperature of $1023 \mathrm{~K}$ and $1073 \mathrm{~K}$ (see Fig. $11 \mathrm{a}, \mathrm{C}$ ) it can be seen that the grain is not formed and the structure is fine. After annealing (see Fig. $11 \mathrm{~b}, \mathrm{~d}$ ) the structure is virtually unchanged, grain boundaries are not expressed. Further pawisan sintering temperature of the alloy and the growth of the grains of the main magnetic phase. In the process of growth of grains of the main magnetic phase $\mathrm{Nd}_{2} \mathrm{Fe}_{14} \mathrm{C}$ acquire a regular geometric shape (see Fig. $11 \mathrm{f}, \mathrm{h}, \mathrm{m}$ ). With increasing sintering temperature up to $1223 \mathrm{~K}$ (see Fig. $11 \mathrm{~m}$ ) of grain $\varphi$-phase is the main volume and acquire a rounded shape. Annealing helps to optimize the structure (see Fig. $11 \mathrm{~g}, \mathrm{k}, \mathrm{n}$ ), the main volume is uniform in grain size $\varphi$-phase $\left(\mathrm{Nd}_{2} \mathrm{Fe}_{14} \mathrm{C}\right)$ with a thin clear boundaries, the number of pores and misereor space is minimal. The structure of the $\mathrm{CD}$ as a whole is dispersed, some areas consist of areas of directional solidification grains of the $\varphi$-phase.

Analysis of phase equilibrium diagrams of the system Nd-Fe-C (see Fig. 12) has shown that in the alloys studied composition possible for the next phase: the main phase of magnetic $\mathrm{Nd}_{2} \mathrm{Fe}_{14} \mathrm{C}$, a solid solution of carbon in phase $\mathrm{Nd}_{2} \mathrm{Fe}_{17} \rightarrow \mathrm{Nd}_{2} \mathrm{Fe}_{17} \mathrm{C}_{0,4}$ and enriched in neodymium and carbon carbides. 

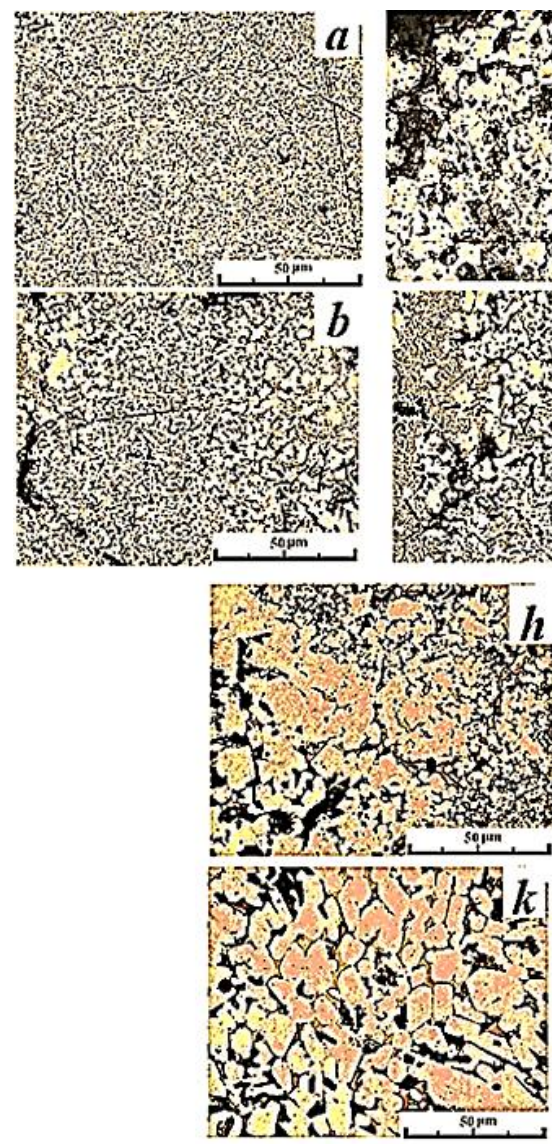
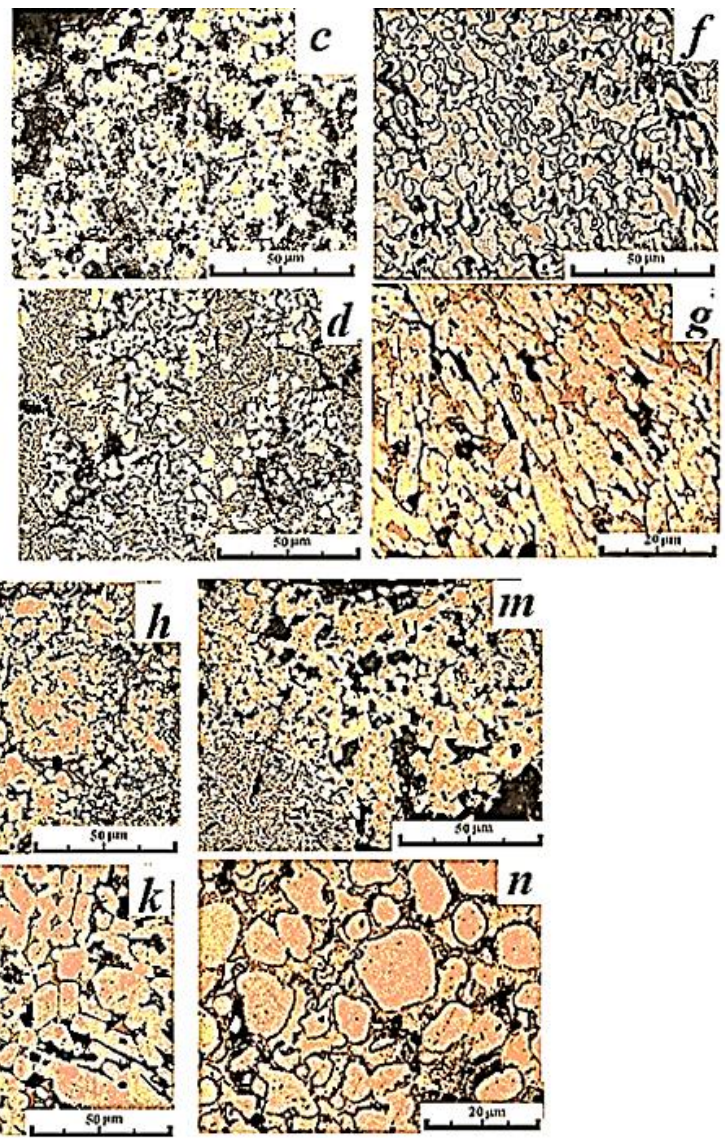

Fig. 11. The microstructure of the compacts sintered from the base alloy $\mathrm{Nd20Fe70C9,5B0,5:} \mathrm{a}-1023 \mathrm{~K}$;

$$
\text { b- } 1073 \mathrm{~K}-1123 \mathrm{~K} \text {; g - } 1173 \mathrm{~K}, \mathrm{q}-1223 \mathrm{~K} \text {. }
$$

$\mathrm{X}$-ray structural analysis of alloys of $\mathrm{Nd}-\mathrm{Fe}-\mathrm{C}$ is complicated by the fact that the angles of diffraction of the main phases $\mathrm{Nd}_{2} \mathrm{Fe}_{14} \mathrm{C}$, $\mathrm{Nd}_{2} \mathrm{Fe}_{17} \mathrm{C}_{0,4}, \mathrm{Nd}_{2} \mathrm{Fe}_{17}$ match. Other phases present in the sintered compacts, due to the low symmetry of its crystal lattices, the large values of their periods, in their majority, have low intensity and overlap. All this complicates the phase analysis, calculation of periods of lattices 


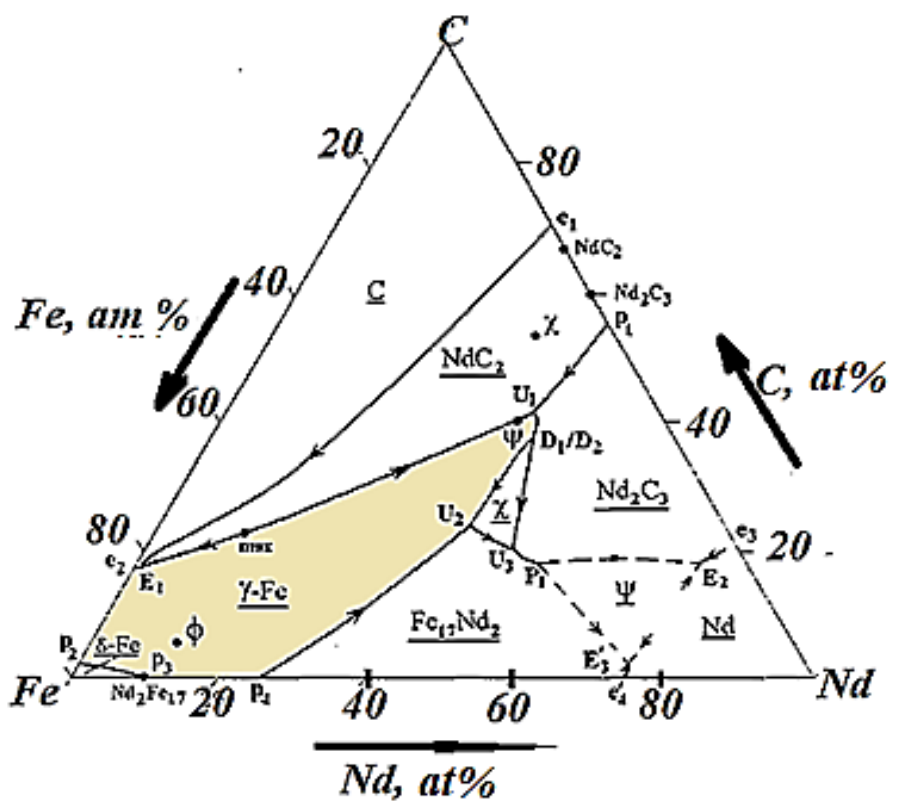

Fig. 12. Projection of the liquidus surface on the plane of the concentration triangle in the system Nd-Fe-C $[13,14]$

of the phases present in the compact, and determine their quantitative relationships.

Analysis and calculation of diffraction patterns showed that the main phase components in the alloy after sintering is tetragonally carbide $\mathrm{Nd}_{2} \mathrm{Fe}_{14} \mathrm{C}$ ( $\varphi$-phase) and a solid solution of carbon in the phase of $\mathrm{Nd}_{2} \mathrm{Fe}_{17} \rightarrow \mathrm{Nd}_{2} \mathrm{Fe}_{17} \mathrm{C}_{\mathrm{x}}$. In addition to these phases in the alloys are double and triple carbides of neodymium. Also, the sintering process changes the phase composition of the alloys. With increasing sintering temperature there is a redistribution of the intensities of diffraction peaks, which is obviously related to the elastic stresses (see Fig. 13).

Data precision measurements of the lattice parameters of the main magnetic phase showed that with increasing sintering temperature there is a growth tetragonality $(c / a) \varphi$-phase in the interval 1,358 ..1,394. Because the composition of the alloys does not match the stoichiometry of the phase $\mathrm{Nd}_{2} \mathrm{Fe}_{14} \mathrm{C}$ and offset in the direction of greater carbon content and neodym- 


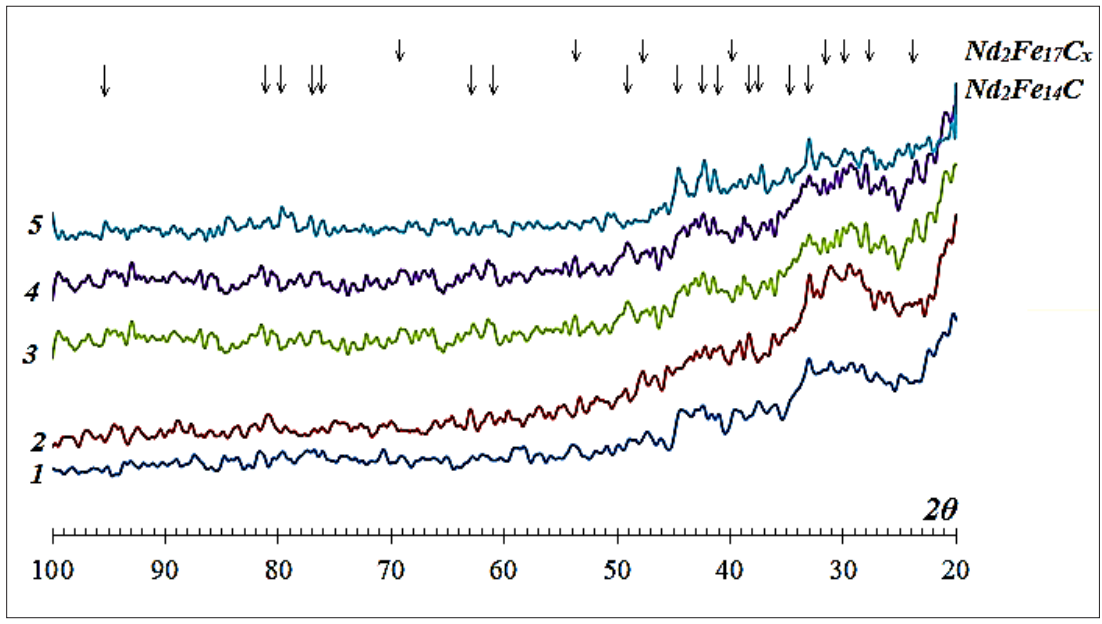

Fig. 13. Diffraction of compacts, sintered from the base alloy

$$
\begin{gathered}
\mathrm{Nd}_{20} \mathrm{Fe}_{70} \mathrm{C}_{9,5} \mathrm{~B}_{0,5}: 1-1023 \mathrm{~K} ; 2-1073 \mathrm{~K} ; 3-1123 \mathrm{~K} ; \\
4-1173 \mathrm{~K}, 5-1223 \mathrm{~K}
\end{gathered}
$$

ium, when cooling after sintering, the formation of a supersaturated solid solution of neodymium and carbon in the $\sigma$-phase. Also in terms of external pressure and in the presence of dramatically increasing the rate of diffusion of alloying elements. Furthermore, the increase tetragonality phase $\mathrm{Nd}_{2} \mathrm{Fe}_{14} \mathrm{C}$ may indicate the allocation of the excess of the neodymium and carbon from the lattice of the main phase, as this is a compression of the lattice along the $\mathrm{C}$ axis and the associated extension along the axis and, due to the "desire" of the structure to balance the change of volume of an elementary lattice.

Despite the fact that carbon is a light element sensitivity of x-ray spectral analysis using a JEOL JSM-6360LA allows it to be detected in the alloy. In Fig. 14 shows the chemical composition of the compacts made from alloy $\mathrm{Nd}_{20} \mathrm{Fe}_{70} \mathrm{C}_{9,5} \mathrm{~B}_{0,5}$ at a temperature of $1173 \mathrm{~K}$ (a) and $1223 \mathrm{~K}$ (b). In the $\mathrm{x}$-ray spectral studies determined that grains of light gray color correspond to the phase $\mathrm{Nd}_{2} \mathrm{Fe}_{14} \mathrm{C}$ (see Fig. 14, points 1,4,6), and grain dark gray phase $\mathrm{Nd}_{2} \mathrm{Fe}_{17}$ (see Fig. 14, points 3,7 ). In addition, miserendino space there are grains enriched in neodymium (see Fig. 14, points 2,5). Also in Fig. 14a shows the distribution of elements on the surface of the 

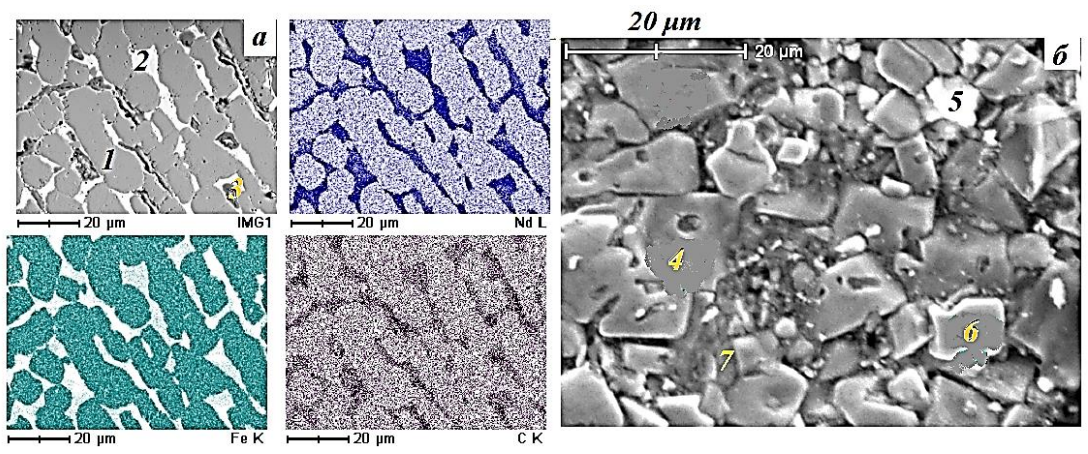

Fig. 14. The chemical composition of the compacts, sintered alloy $\mathrm{Nd}_{20} \mathrm{Fe}_{70} \mathrm{C}_{9,5} \mathrm{~B}_{0,5}$ at a temperature of $1173 \mathrm{~K}$ (a) and $1223 \mathrm{~K}$ (b)

sintered compacts. More content elements correspond to a more saturated color in the pictures.

In General, increasing the sintering temperature up to $1223 \mathrm{~K}$ leads to coarsening of grains of the main magnetic phase, its boundaries become indistinct and blurred. The amount of magnetic phase is increased, its grains are separated by thin layers of paramagnitnyi. At the joints of grains of the main phase are small inclusions of carbides. The dark areas between the grains correspond to the enriched neodymium and carbon hardened during cooling of the melt, and individual defects such as pores. The increase in vacuum at a sintering promotes the formation of a thin and clear boundary grains of the $\varphi$-phase and to reduce the number of carbides and oxides (Fig. 3.7).

Thus, the results showed that increasing sintering temperature peritectoid accelerates the reaction, improves the structure of the compacts. Nearly all compact $\varphi$-is the phase after sintering at a temperature of $1223 \mathrm{~K}$, the grain take the correct form, be homogeneous in size, with thin sharp edges. Although grain boundaries of space, inclusions of paramagnetic carbides and oxides (according to x-ray spectral analysis), the number of grain boundaries and space is minimal.

For rice. 15 the dependence of the specific magnetic energy on the sintering temperature for the compact sintering of base alloy $\mathrm{Nd}_{20} \mathrm{Fe}_{70} \mathrm{C}_{9,5} \mathrm{~B}_{0,5}$. After annealing is presented. Anals loops heterosis for magniv showed that the maximum specific magnetic energy and coercive force of this alloy increased 


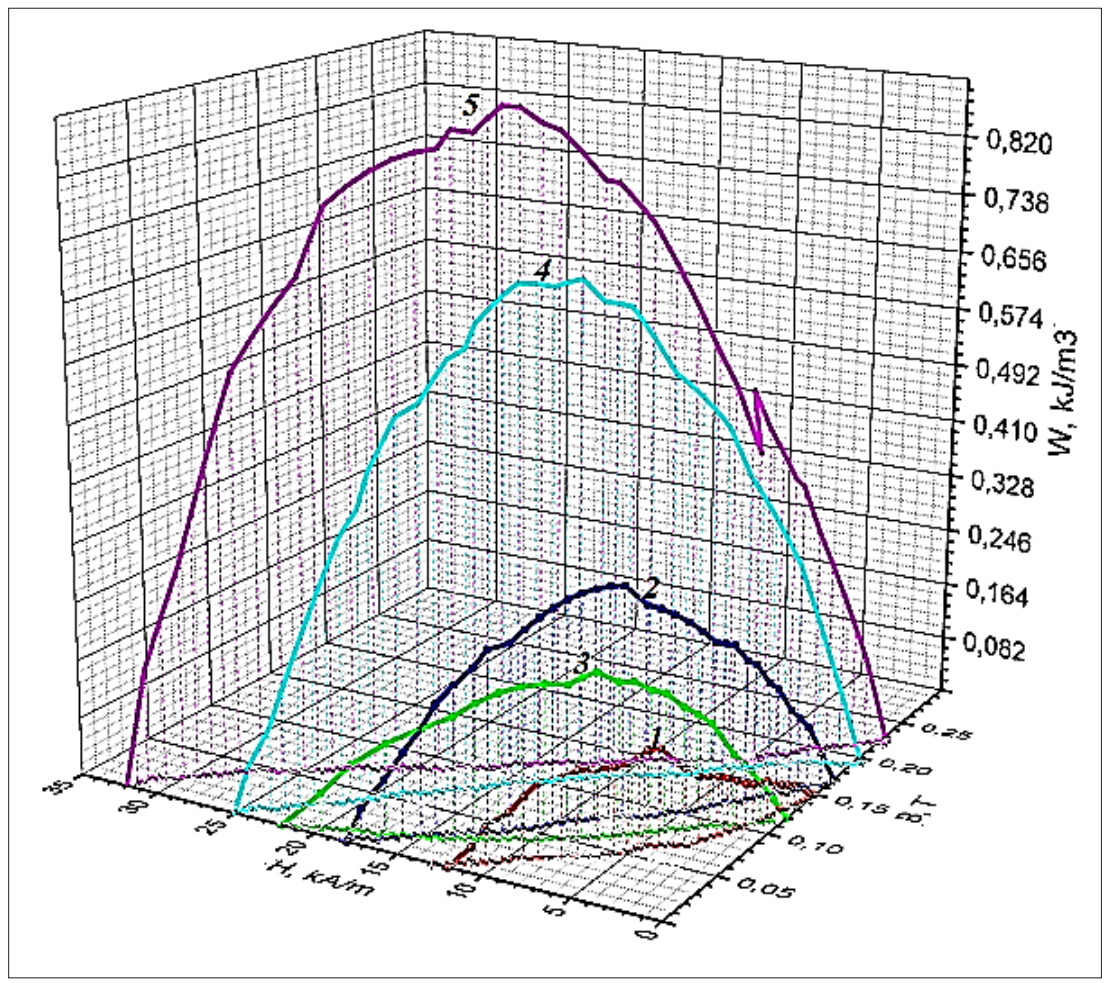

Rice. 15. Dependence of specific magnetic energy

on the sintering temperature for compacts sintered from the base alloy $\mathrm{Nd}_{20} \mathrm{Fe}_{70} \mathrm{C}_{9,5} \mathrm{~B}_{0,5}$, after annealing: $1-1023 \mathrm{~K} ; 2-1073 \mathrm{~K}$; 3 - 1123K; 4 - 1173K, 5 - 1223K

with increasing sintering temperature in the range $0,135 \ldots 0.91 \mathrm{~kJ} / \mathrm{m}^{3}$ and $12 \ldots 32 \mathrm{kA} / \mathrm{m}$, respectively.

Such differences can be explained by the fact that $\mathrm{CD}$ number 1 is not observed a clear structure, fragments of $\phi$-phase is not formed, the boundaries of the fragments are blurred. Also structure compactum present fragments of soft magnetic $\mathrm{Nd} 2 \mathrm{Fe} 17$ phase, which contribute to the emergence of stray fields. On the contrary, for sample No. 5 there is an optimal microstructure with small fragments of the $\varphi$-phase and with the least amount of Defragmenter space. 


\section{Gulyaeva Tatiana}

\section{Discussion of results}

Analyzing the obtained results, we can say that quenching from the liquid state of alloys $\mathrm{Nd}_{20} \mathrm{Fe}_{70} \mathrm{C}_{9,5} \mathrm{~B}_{0.5}$ allows to obtain the main magnetic phase $\mathrm{Nd}_{2} \mathrm{Fe}_{14} \mathrm{C}$ directly from the liquid. In addition, obtaining $\varphi$ of the metastable phase does not preclude the crystallization phase $\mathrm{Nd}_{2} \mathrm{Fe}_{17}$-type, which corresponds to the equilibrium state diagram, and participates in perfectnow the transformation of $\left(\mathrm{Fe}+\mathrm{Nd}_{2} \mathrm{Fe}_{17}+\mathrm{Nd}_{4} \mathrm{FeC}_{6} \leftrightarrow \mathrm{Nd}_{2} \mathrm{Fe}_{14} \mathrm{C}\right)$. In addition to the above fact it is also known that boron contributes to the acceleration of the transformation of the $\mathrm{Nd}_{2} \mathrm{Fe}_{17}$ phase in $\mathrm{Nd}_{2} \mathrm{Fe}_{14} \mathrm{C}[15 ; 16]$. In this work introduced another thermodynamic parameter, external and examines its influence on the process perfectooo conversion.

Changing the appearance of diffraction patterns before annealing (after sintering) and after annealing of the sintered compact, significantly reduced fluctuations of the background intensity increases the "sharpness" of the diffraction maxima, and also increases the intensity of peaks that correspond to the $\varphi$-phase. This means that after quenching from a liquid phase $\mathrm{Nd}_{2} \mathrm{Fe}_{14} \mathrm{C}$ not fully formed. The increasing sintering temperature (external heat pressure) improves spket compacts and the formation of fragments of the $\varphi$-phase. Thus the external pressure helps to seal the sample and sintering on the limits of the scales, but at the same time, diffusion processes in the volume of hard scales are accelerated [17], and on the limits of sintered flakes hampered. The result perfectone reaction at such acceleration is not complete, therefore, completion perfectooo conversion and the creation of the optimal structure to obtain high magnetic properties required to perform additional annealing after sintering without any external loading.

Increasing sintering temperature in the range $1023 \ldots 1223 \mathrm{~K}$ contributes to improving the coercive force and residual induction compacts $(\mathrm{Hc}=12 \ldots 32 \mathrm{kA} / \mathrm{m}, \mathrm{Br}=0,23 \ldots 0,15 \mathrm{~T}$, respectively $)$. With increasing sintering temperature, firstly, improving the density of the compact decreases the number of pores and Defragmenter space $(\uparrow \mathrm{Br})$, and secondly, the displacement of the points of phase equilibrium according to the equation of Clausius-Clapeyron, and getting into the temperature range of formation of hard magnetic phase $\mathrm{Nd}_{2} \mathrm{Fe}_{14} \mathrm{C}$. The increase in the coercive force of compacts after annealing are due to the conversion of almost the entire amount magnetomeco phase $\mathrm{Nd}_{2} \mathrm{Fe}_{17}$ phase in magnetogorsk $\mathrm{Nd}_{2} \mathrm{Fe}_{14} \mathrm{C}$, the decrease in grain boundary areas and number of inclusions, carbides and oxides. 
That is, we study the dependence of completeness peritectoid reactions from sintering temperature at a constant primary pressure of $0.5 \mathrm{MPa}$. From the data of Fig. 11 shows that the increase in temperature promotes a phase transformation according to peritectoid reaction at constant time of sintering and annealing, that is, increasing the number of phase $\mathrm{Nd}_{2} \mathrm{Fe}_{14} \mathrm{C}$. In model 5 the number of phase $\mathrm{Nd}_{2} \mathrm{Fe}_{14} \mathrm{C}$ exceeds $80 \%$, but is still present phase $\mathrm{Nd}_{2} \mathrm{Fe}_{17}$.

\section{Conclusions}

Thus, the paper studies the influence of external primary and additional heat of the pressure created due to the different coefficients of expansion of the mold and screws bonding, sintering temperature, doping on structure and magnetic properties of the permanent magnets, sintered products of quenching of liquid alloys of Nd-Fe-B. based On the above we can draw the following conclusions:

1. According to mathematical modeling, at the time of sintering of alloy $\mathrm{Nd}_{20} \mathrm{Fe}_{70} \mathrm{C}_{9,5} \mathrm{~B}_{0}$, you can get 5 additional "thermal" pressure up to 1 GPA.

2. Alloying boron, copper and rapid cooling of alloys in Nd-Fe-C,allows to obtain the main magnetic phase $\mathrm{Nd}_{2} \mathrm{Fe}_{14} \mathrm{C}$ directly from the liquid, including crystallization magnetomeco phase $\mathrm{Nd}_{2} \mathrm{Fe}_{17} \mathrm{C}_{\mathrm{x}}$.

3. Pressing is rapidly cooled flake under the pressure of $0.5 \mathrm{MPa}$ and sintering at a temperature of perfectooo conversion $1223 \ldots 1073 \mathrm{~K}$ gives the opportunity to obtain a compacted sample with good sintering on the limits of the scales and accelerate the process perfectooo conversion under the influence of external pressure.

4. Annealing of the compacts sintered without external pressure almost completes perfectone conversion, and also contributes to the formation of the optimal structure with the contents of the main magnetic phase $\mathrm{Nd}_{2} \mathrm{Fe}_{14} \mathrm{C}$ to $80 \%$.

5. Vstanovleno scho laguana forest that Spinna under towns the vise may pcvisit magnet characteristics VDC after VDPAU. Magnta energy, eco can dosage in these magnets sklada of $0.91 \mathrm{~kJ} / \mathrm{m}^{3}$.

In the future, complex studies of the influence of alloying $(\mathrm{Cu}, \mathrm{Ti})$, initial external pressure $(0.5 \ldots 10 \mathrm{MPa})$, time and temperature of sintering on this nd-Fe-C, b alloy are planned. 


\section{Gulyaeva Tatiana}

\section{References:}

1. Luo Y. (2004) Current Status of Global NdFeB Magnet Industry. Proceedings of the 18th Int. Workshop on HPMA, (Annecy, France September, 2004), Vol. 1, Annecy (France), pp. 28-39.

2. Brekharya G.P., Kharitonova E.A., Gulyaeva T.V. (2014) Svoystva postoyannykh magnitov sistemy $\mathrm{Nd}-\mathrm{Fe}-\mathrm{B}$, legirovannoy $\mathrm{Cu}, \mathrm{Ti}, \mathrm{C}$, poluchennykh poroshkovym metodom ili spekaniem plenok $\mathrm{v}$ usloviyakh vysokogo davleniya [Properties of the permanent magnets $\mathrm{Nd}-\mathrm{Fe}-\mathrm{B}$ alloy with $\mathrm{Cu}, \mathrm{Ti}, \mathrm{C}$, obtained by a powder method or sintering of the films at high pressure]. Progress in physics of metals, T. 15, pp. 35-53.

3. Brekharya G.P., Gulyaeva T.V., Kharitonova O.A., Gulyaev V.I., Gnezdilova V.O., Pribora T.I. Litvinenko Y.M. Pat. on corino model 92390 Ukraine, IPC H01F 1/00 H01F 1/053 H01F 1/057. Sposib oderzhannja postijnogho maghnitu na osnovi splaviv $\mathrm{Nd}-\mathrm{Fe}-\mathrm{B}$ [The method of darianna postijno magneto on snow splavu $\mathrm{Nd}-\mathrm{Fe}-\mathrm{B}]$. The applicant patentovannym Kyiv, Institute of metallic im. G. V. Kurdyumov of NAS of Ukraine. no u 201403132; stated. 28.03.2014; publ. 11.08.2014, bul. No.15.

4. Grieb B., Fritz K. (1991) As-cast magnets based on Fe-Nd-C. J. Appl.Phys., Vol. 70, pp. 6447-6449.

5. Vasyljjeva E.A., Vystavkina V.V. (2003) Vplyv termichnoji obrobky na strukturu ta vlastyvosti lytykh maghnitiv Nd-Fe-C, leghovanykh middju [Effect of heat treatment on structure and properties of cast magnets copper $\mathrm{Nd}-\mathrm{Fe}-\mathrm{C}$ alloy]. Physics and chemistry of solids, № 3, pp. 40-47.

6. Vystavkina V.V. (2006) Vplyv nerivnovazhnykh umov okholodzhennja na fazoutvorennja u leghovanykh middju maghnitotverdykh splavakh systemy Nd-Fe-C [The Influence of nonequilibrium conditions of cooling Fazotron in doped copper magnetitic alloys $\mathrm{Nd}-\mathrm{Fe}-\mathrm{C}]$ : author. dis. on competition of the Sciences. the degree candidate. Fiz.-Mat. Sciences.: spec. 01.04.07 "Solid state Physics" / V. Vistavka - Dnepropetrovsk, -19 sec. blonde.

7. Belotserkovsky O. M. (1994) Chislennoe modelirovanie $v$ mekhanike sploshnykh sred [Numerical simulation in continuum mechanics]. M.: Fizmatlit. (in Russian)

8. Brekharya G.P. (1991) Formirovanie metastabil'nykh sostoyaniy v metallicheskikh splavakh pri zakalke iz zhidkosti [Formation of metastable States in metallic alloys with quenching from the liquid]: dis. ... d-ra Fiz. -Mat. Sciences: 01.04.07. - Zaporozhye, ZSU.

9. Tumanova A.T. (ed.) (1965) Spravochnik po aviatsionnym materialam [Handbook of aviation materials] M: Mechanical engineering, T. I.

10. Bobylev A.V. (1990) Mekhanicheskie i tekhnologicheskie svoystva metallov. Spravochnik [Mechanical and technological properties of metals. Reference Book] Moscow: Metallurgy.

11. Tsimmerman R., Gyunter K. (1993) Metallurgiya i materialovedenie. Spravochnik [Metallurgy and materials science. Handbook] [per.s nem.]. Moscow: Metallurgy.

12. Solntsev Yu.P., Veselov V.A., Demyantsevich V.P. Zimmerman, R. (1996) Materialovedenie i tekhnologiya konstruktsionnykh materialov: Uchebnik dlya 
vuzov [The science and technology of structural materials: a Text.book for universities]. Moscow: Mrs.

13. Grieb B. (2001) Ternary system Fe-Nd-C. Zeitschrift für Metallkunde. Vol. 92, pp. 172-178.

14. Buschow K.H.J., de Mooij D.B., Denissen C.J.M. (1988) Note on the formation and the magnetic properties of the compound $\mathrm{Nd}_{2} \mathrm{Fe}_{14} \mathrm{C}$. Journal of the Less Common Metals. Vol. 141, pp. L15 - L18.

15. Brekharya G.P., Savin V.V., Bovda A.M. [et al.] (2006). Doslidzhennja vplyvu midi ta vughlecju na vlastyvosti postijnykh maghnitiv, vyghotovlenykh na osnovi stopu $\mathrm{Fe}_{76} \mathrm{Nd}_{16} \mathrm{~B}_{8}$ [A study of the influence of copper and carbon on the properties of permanent magnets made on the basis of the foot $\left.\mathrm{Fe}_{76} \mathrm{Nd} \mathrm{d}_{16} \mathrm{~B}_{8}\right]$. Metallophysics and newest technologies. Vol. 28, No. 3, pp. 383-395.

16. Buschow K.H.J. (1986) New permanent magnet materials. North-Holland, Amstrdam, P. 63.

17. Sh'yumon P. (1966). Diffusion in solids [Difuziya v tverdykh telakh] [per.s eng.]. Moscow: Metallurgy. 


\title{
RELEVANCE ANALYSIS OF MEASUREMENT MECHANICAL QUANTITIES IN THE COMPOSITION OF THE NETWORK "INTERNET OF THINGS" AND SYSTEMS OF PROFESSIONAL COOPERATION DURING METROLOGICAL STUDIES
}

\author{
Kvasnikov Volodymyr ${ }^{1}$ \\ Dudnik Andriy ${ }^{2}$ \\ Bondarenko Yuri ${ }^{3}$
}

DOI: http://dx.doi.org/10.30525/978-9934-571-26-8_8

Abstract. In our time, the need for separate use of measuring devices has significantly decreased.

This trend is characterized by two major changes in the world of electronic devices:

1. In modern devices, sensors have ceased to be independent systems or separate devices and are part of them (in their everyday life they are tablets and smartphones, and in the production they are sensory measuring networks).

2. Measurement systems themselves have ceased to be of interest. They are an integral part of the system, which also includes technologies for processing, measuring, storing and forecasting measurements.

An example of using such technologies is "Internet of Things", which can be considered as one of the IT-technologies that improve professional interaction, due to the shared use of this or that group of people

The research of information-measuring systems, including the research of the technologies of modeling, control and interaction of computerized systems of measuring mechanical quantities, is devoted to the work of modern scientists such as Kvasnikov V., Ornadsky D., Osmolovsky A., as well as works by Geyer D., Irwin J., Liery J., Roshan P., Stollings V., Harley D. et al.

\footnotetext{
${ }^{1}$ Doctor of Technical Sciences, Professor,

Head of the Department of Computerized Electrical Systems and Technologies,

National Aviation University, Ukraine

${ }^{2}$ Candidate of Technical Sciences, Associate Professor,

Associate Professor of the Department of Network and Internet Technologies,

Kyiv National University T. Shevchenko, Ukraine

${ }^{3}$ Postgraduate Student of the Department of Computer Multimedia Technologies, National Aviation University, Ukraine
} 
The subject of the study is the measuring sensor network "Internet of Things", as a kind of informational measuring system that is being solved as a system of professional interaction.

Research methods are the systematic method of analytical research, computer simulation, simulation modeling.

The purpose of the research is to analyze the problem of modern information measuring systems of mechanical quantities, to harmonize the basic concepts and terms, to analyze the concept of deployment of the sensory network "Internet of Things", to develop a basic simulation model of sensory measuring network of mechanical quantities as a means of professional interaction.

The article will analyze the problem of modern information measuring systems of mechanical quantities, will agree on the basic concepts and terms, will analyze the concept of deployment of the sensor network "Internet of Things", will develop a basic simulation model of sensory measuring network of mechanical quantities as a means of professional interaction.

\section{Introduction}

Today there is a decisive transition from individual measuring instruments to intelligent measurement systems of the future generation. In such systems can simultaneously provide coordinate services, weather forecast, and calorie measurement (based on what distance people overcame and at what speed).

Over time, cloud service access for historical data analysis, processing, and creation of metrics has also been added for further research (for example, Microsoft Azure Cloud Services).

Among this diversity of services one important problem is highlighted: the need for the rapid implementation of a measuring system, which will include both a monitoring system, an information flow management system, and a system that will be responsible for collecting and processing data for them in a professional interaction (shared use for better coordination of actions).

A good solution for such different requirements is the computerized measurement system. They consist of geographically distributed autonomous devices and their intelligent sensors related to them: temperature, sound, vibration, time positioning, etc., they can freely compete with existing measurement systems, and also serve as an addition to any existing measurement system with a professional interactions. 


\section{The role of professional interaction}

The category of interaction is one of the general categories of knowledge and inextricably linked with such basic categories as motion, space, time, structure; reflects the processes of the actions of various objects on each other, their mutual conditionality, state change, interconnection and is defined as the process of integration activities of subjects.

The essence of interaction consists in the continuity of direct and reciprocal action, the organic combination of changes of actors that affect each other. It is a holistic, internally differentiated, self-evolving system. This understanding of interaction involves a mutual change in managers and managed actions, convinces in the need to consider changes in interacting subjects and the process of interaction as a change in its states.

Theories of interpersonal interaction represent it as a material process accompanied by the transfer of matter, movement and information: as a collaboration, a joint activity (B. Lomov, O. Leontiev, A. Zhuravlev), empathy (J. Homans, E. Hoffman, J. Schepansky ), communication (G. Andreev).

In the structure of interaction distinguish transactions (E. Bern), interactions (J. Mead, R. Blummer), influences (A. Zhuravlev), contact, relations, actions (Ya Shchepansky); emotions and problems (R. Bails), mutual interest (G. Andreev). V. Semikin states that in the structure of interaction, different authors singled out the same components, calling them differently: practical (V. Myasishchev), behavioral (Ya. Kolominsky), regulatory (B. Lomov) - includes results of activity and deeds, facial expressions, gesticulation, pantomime and speech; the second is affective, which includes what is related to the emotional state and experiences of the individual; the third is Gnostic (V. Myasishchev), cognitive (Y. Kolominsky), informational (B. Lomov) characterizing the activity of the person receiving and processing information.

The variety of approaches to the definition and structure of interaction leads to the conclusion that interaction as a socio-psychological category is an integrative factor, which unites the parts into a holistic process of direct or indirect interaction of objects (entities) that generates their mutual conditionality and connection.

The interaction involves not only two individuals, but also some groups, groups as a whole. In categories that characterize the interaction in the general plan and reflect the peculiarities of the professional activity of a 
specialist, in particular a specialist in commercial activity, we consider it necessary to include the purpose, subject, methods, feedback.

The purpose of interaction provides purposefulness (in contrast to spontaneity) of joint activity, communication and empathy of subjects. The purpose of the interaction is to represent the intended result of the activity, which is in the general interest and contributes to the realization of the needs of each of its participants (C. Golovin); ensures controllability of the mutual actions of the subjects. Researchers G. Andreyev, A. Zhuravlev, O. Leontiev to the purpose of interaction include optimization of relations, intensification, stimulation, activation, management, development, formation, prevention, evaluation, information.

The object of interaction forms a "field", "space", in relation to which there are mutual actions of subjects. As an object of interaction act, according to R. Bayles, emotions and problems. A. Zhuravlev calls the interaction of subjects subject-oriented, emphasizing the objectivity of mutual actions. The subject of interaction are ties, relationships, co-decision, mutual interest, the commonality of emotional experiences, the formulation and solution of problems (G. Andreev, A. Harasch).

Methods of interaction are represented by methods, technologies of organization of communications; manifested as interpersonal relationships, interpersonal relationships; characterize awareness, mutual understanding, interrelation of actions of subjects in relation to the subject of interaction.

Feedback as an attribute of interaction serves as a reciprocal reaction to action, provides feedback to the action of the subject and characterizes the subjectivity of the other side of the interaction. O. Solovieva calls it a mirror image, a reaction to influence, understanding, mechanism, ensuring the existence of interaction [12, p. 103]. The feedback reveals the changes of the interacting actors, the reaction to influences, signals the state of the object of interaction, actualizes the way of interaction, approximates or removes from the purpose of interaction (Y. Harutyunyan, V. Konets'ka, L. Petrovskaya). The presence of feedback provides manageability, target orientation, reciprocity.

Feedback, according to L. Petrushenko, can be a visual observation, audio message, an electrical signal, have the form of messages, reports, written reports [11, p. 67]. L. Petrushenko points out that the cybernetic notion of feedback is not limited to the concept of reverse effect or physical feedback channel. For cybernetic systems, not all feedback is important, 
but above all, the one that regulates the reciprocal action by passing the information necessary for it to the available changes of all aspects of the interaction.

Consequently, interaction is a process of purposeful, objective, organized guided and variable-purpose methods and feedback that promotes interrelated and interdependent change of subjects. Such an understanding of the interaction corresponds to the situation of professional activity of specialists in commercial activity, since it contains an indication of the need to implement both the subject-object and the subject-subject relations.

\section{Heredity of terms and concepts}

Measuring information system (MIS) - a set of measuring instruments, control means, diagnostics and other technical means combined for the creation of signals of measurement and other types of information [12, p. 110] in order to provide it to the consumer (including ASC) in the right form.

Information-measurement system - a set of functionally combined measurement, computing and other auxiliary technical means for obtaining measurement information, its transformation, processing in order to provide the consumer (including input to the Automatic Control System) in the required form or automatic implementation of the logical functions of control, diagnostics, identification.

Internet of Things (IoT) is a network concept consisting of interconnected physical devices that have built-in sensors, as well as software that allows the transmission and exchange of data between the physical world and computer systems, using standard communication protocols. In addition to sensors, the network may have actuators built into physical objects and interconnected via wired or wireless networks. These interconnected devices have the ability to read and execute, the programming function and identification, and also eliminate the need for human involvement through the use of intelligent interfaces.

Method of measurement - a set of methods for using measuring instruments and measurement principles to create measurement information.

Based on these definitions, we can conclude that the Internet of Things network is one of the types of information measuring systems. Also, this network can be used as a measurement method based on certain rules of the interaction of measuring devices and devices that are controlled. In particular, this also applies to the mechanical quantities corresponding to the 
Relevance analysis of measurement mechanical quantities in the...

passport of the specialty "Instruments and methods of measuring mechanical quantities."

\section{Concept of "Internet of Things" network}

The basic concept of the Internet of things is the ability to connect all sorts of objects (things) that a person can use in everyday life, for example, a refrigerator, air conditioner, a car, a bike and even sneakers. All these objects (things) must be equipped with built-in sensors or sensors, which have the ability to process the information coming from the environment, exchange it and perform various actions depending on the information received. An example of implementing such a concept is the "smart home" or "smart farm" system. This system analyzes the data of the environment and, depending on the indicators, regulates the temperature in the room. In the winter, the intensity of heating is regulated, and in the case of hot weather, the house has mechanisms for opening and closing windows, which makes the house airing, and all this happens without human intervention.

Several technologies are needed to connect everyday things to the network.

- To identify each object you need a simple, compact technology. Only if there is a unique identification system can collect and accumulate information about a particular subject. Such a functionality can be provided with RFID chips (Radio-Frequency Identification). They are able to transmit information to readers without their own source of current. Each chip has an individual number. As an alternative to this technology, QR codes can be used to identify objects. To determine the exact location of the thing suitable GPS technology, which is effectively used today in smartphones and navigators.

- Objects should be equipped with sensors to monitor changes in the state of an element or the environment.

- An integrated computer (such as Raspberry Pi, Intel Edison) should be used to process and accumulate sensor data.

- Wireless technology (Wi-Fi, Bluetooth, ZigBee, 6LoWPAN) can be used to share information between devices.

Internet integration implies that devices will use the IP address as a unique identifier. However, due to limited IPv4 address space (which allows 4.3 billion unique addresses), IPs will have to use IPv6, which provides 
unique network layer addresses of at least 300 million devices per inhabitant of the Earth. Objects in the IP will be not only devices with sensory capabilities, but also devices that perform actions (for example, bulbs or locks that are controlled via the Internet). To a large extent, the future of the Internet of things will not be possible without the support of IPv6, hence the global introduction of IPv6 in the coming years will be crucial for the successful development of IP in the future.

For wireless data transmission, the following characteristics, such as efficiency, fault tolerance, adaptability, the possibility of self-organization, play a particularly important role in the construction of the Internet of things. The main interest in this sense is IEEE 802.15.4, an access control for the organization of energy efficient personal networks, and is the basis for protocols such as ZigBee, WiFi, Bluetoot, 6LoWPAN.

ZigBee is a communication technology based on the IEEE 802.15.4 protocol for the implementation of low-speed wireless private networks. ZigBee has features such as low power consumption, low data rates, low cost and high bandwidth. ZigBee is currently used mainly for transmitting information between different electronic equipment items that are within short distances and data rates are not very high. This is mainly peripherals (mouse, keyboard) and consumer electronics (TV, DVD), as well as industrial control devices (monitors, sensors and automation tools).

Many publications under the IEEE 802.15.4 standard understand ZigBee technology and vice versa under ZigBee, the IEEE 802.15.4 standard. However, this is not the case. The IEEE 802.15.4 standard defines the interaction of only two lower levels of the interaction model (Figure 1) [1, p. 22]:

- Physical level (PHY) level of access control to the radio channel for three unlicensed frequency bands: $2.4 \mathrm{GHz}, 868 \mathrm{MHz}$ and $915 \mathrm{MHz}$.

- The MAC is responsible for controlling access to the radio channel using the Carrier Sense Multi Access with Collision Avoidance (CSMA/ CA) method, as well as for controlling the connection and disconnection from the data transmission network and providing security Transmitted information by symmetric key AES-128. This protocol will be used for further research.

Wi-Fi is a local wireless technology that uses $2.4 \mathrm{GHz}$ ultra-high frequency or $5 \mathrm{GHz}$ super-high-frequency radio waves. This technology is very suitable for transmitting large volumes of data over a wireless network between devices, but it also requires a lot of power to work and has a low 
Relevance analysis of measurement mechanical quantities in the...

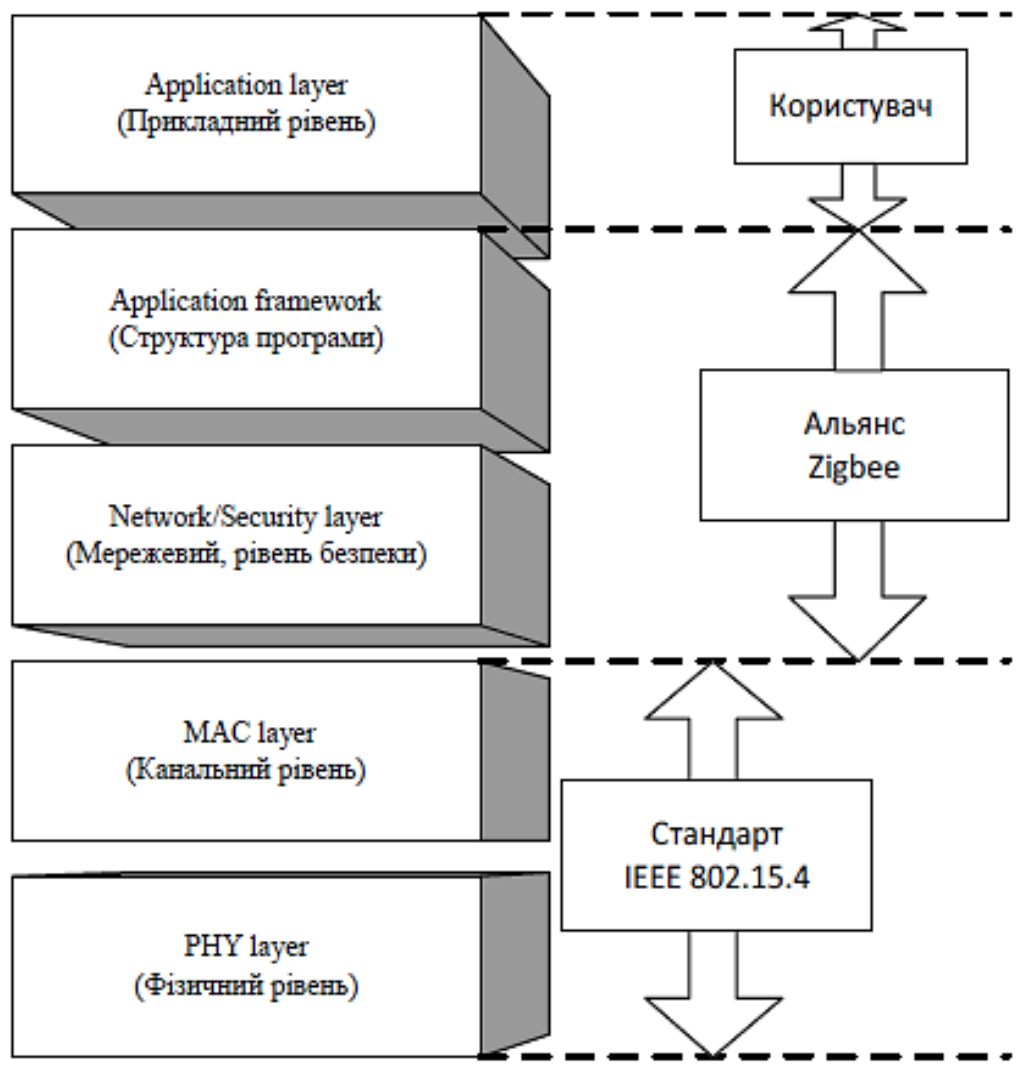

Fig. 1. ZigBee protocol decomposition model [3, p. 22]

level of data bandwidth. When using this technology, it will be necessary to replace the batteries on all devices on a regular basis.

Bluetooth is a wireless technology used to transfer data to personal networks. It transmits data over the band from 2.4 to $2.485 \mathrm{GHz}$ and operates at shorter distances than Wi-Fi. You can synchronize a couple of devices, such as phones, headphones, speakers, computers, and more. With the development of Bluetooth v4.0, it was possible to implement the low power function and increased the range of up to several tens of meters.

Among the leading technologies, the PLC solution, the technology for building data transmission networks over power lines, plays an important 
role in distributing the Internet of things, since many applications have access to power grids (for example, vending machines, ATMs, intelligent meters, lighting controllers are originally connected to the power supply network). 6LoWPAN, which implements an IPv6 layer over both IEEE 802.15.4 and above the PLC, being an open protocol, standardized by the IETF, is seen as particularly important for the development of the Internet of Things.

The Internet of things can cause tremendous changes in everyday life, giving ordinary users a whole new level of comfort. But if the elements of such a system are not adequately protected from unauthorized interference, they will use a reliable cryptographic algorithm instead of the benefit, by giving cybercriminals a loophole to undermine information security. Because things with built-in computers store a lot of information about their owner, including the exact location of their site, access to such information can help intruders commit a crime. The lack of standards for the protection of such autonomous networks is currently slowing down the implementation of the Internet of things in everyday life.

\section{Actuality of sensory networks}

The interest in automation networks grows each year due to their low cost and relative simplicity of installation. One of the most promising areas for using these WSN networks is the automation of buildings and premises [9, p. 195], for example, automated systems for temperature and illumination control. The number of incoming sensors (wired sensors) for climate control at someone and the intelligent house (Intelligent House) can be significant, which inevitably leads to high installation and installation costs, and even in some cases, even before the building is reconstructed for laying cable systems Therefore, an economical and efficient alternative to the CAN, BACnet, LonTalk, Ethernet, and TokenBus protocols is a modern wireless sensor network (WSN) in the "Internet of Things".

Sensory patrons play an increasingly important role in the automation of industrial buildings, buildings and facilities (Smart Ambiences), in the monitoring of areas used in health care, agriculture, forestry and animal husbandry, ecology, ornithology, aircraft engineering, and to the gate. But the list of applications, of course, is far from complete. The WSN wireless sensory networks with Wi-Fi and WiMAX networks, which address office communication tasks (Fig. 1), are integrated into the system. 


\section{Relevance analysis of measurement mechanical quantities in the...}

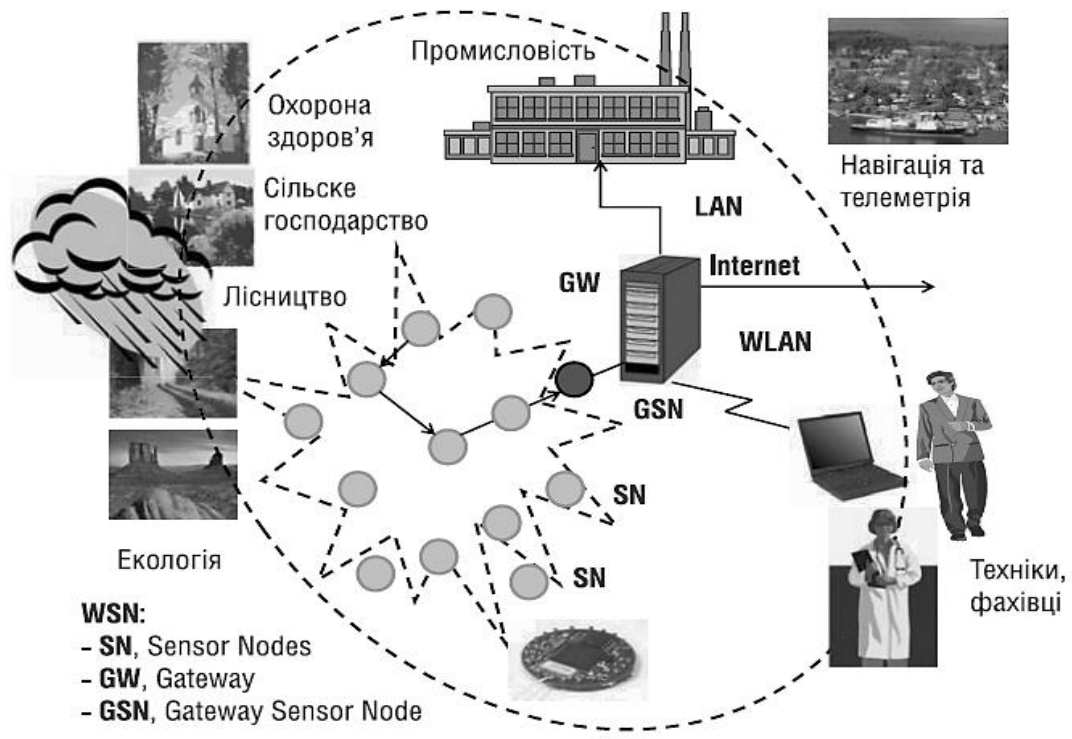

Fig. 2. Areas of application of sensory pawns WSN [9, p. 196]

On the whole, the WSN's coasts are composed of spatially-allocated autonomous units (SN, Sensor Nodes) that communicate with the purpose of joint monitoring of physical parameters or ambient conditions such as air temperature, sound, vibration, and pressure, movement of parts during structural assembly or diffusion of pollutants into the air. The model and parameters without a proximity sensor are shown in Fig. 2.

In most pockets, microcontrollers installed in nodes are implemented in 8-bit Harvard architecture with an average RAM (128-Kb) and $64 \mathrm{~kb}$ data. For the most part, the transmission frequency is in the range of $\mathrm{F}=315 \ldots 916 \mathrm{MHz}$ (Mica2, Mica2Dot) or $\mathrm{F}=2.4 \mathrm{GHz}$ (ZigBee IEEE 802.15 .4 , Imote). The data transfer speed of DR is usually small and ranges from $38 \mathrm{kBits} / \mathrm{s}$ to $0.7 \mathrm{MB} / \mathrm{s}$. The radius of the sensor is in the range of 30 to $150 \mathrm{~m}$. The energy consumption is determined by the sensor operation phase and is up to $1,000 \mathrm{~mW}$ for data transmission and reception, $100 \mathrm{~mW}$ for Idle Mode and up to $0.05 \mathrm{~mW}$ for partial mode Sleep Mode. The average transmit power is PTx $=4-10 \mathrm{dBm}$. To provide Real Time Requirements in the WSN automation outings, only short mes- 


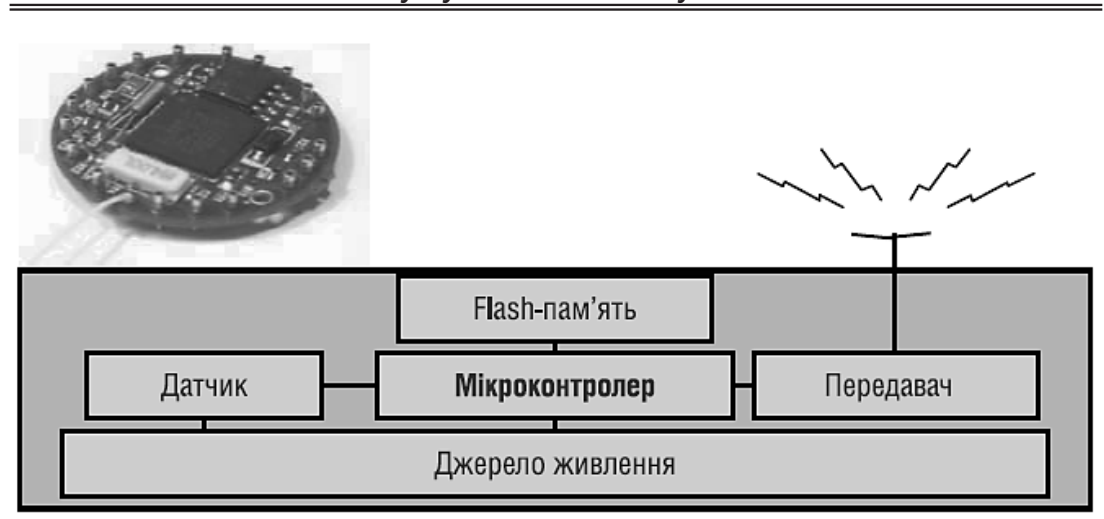

Архітектура мікроконтролера розрядністю 8 біт: Приклад CPU: Intel StrongARM

- Оперативна пам'ять програм - 128 KB;

- Оперативна пам'ять даних RAM - 64 KB;

- Flash-пам'ять - $1 \mathrm{MB}$;

- Частотний діапазон:

- швидкість передавання: $D R=38 \mathrm{k} 6 \mathrm{iT} / \mathrm{c}-0,7 \mathrm{M \sigma iT} / \mathrm{c}$;

- відстань: $D=30-150 \mathrm{~m}$;

- $F=315-916$ МГц для Мica 2, Mica2Dot;

- живлення: максимум 1000 мBт;

- потужність передавання: $P T X=4-10$ дБм;

$-F=2,4$ ГГц для ZigBee IEEE 802.15.4, Imote

- короткі повідомлення: $T L=100$ біт/1 мс;

- Операційна система: Tiny OS

Fig. 3. Model and parameters of the wireless sensor $[9$, p. 200]

sages that are called telegrams are allowed (TL $\sim 100$ bits) with relatively small headers (overhead, $\mathrm{OH}$ ).

In sensory networks, sensors can be the most diverse; they are connected via digital and analog connectors. Most often other sensors use temperature, pressure, humidity, illumination, vibration, less often - magnetoelectric, chemical (for example, measuring the content of $\mathrm{CO}, \mathrm{CO} 2$ ), sound and some others [3, p. 10]. The set of sensors depends on the functions performed by the wireless sensor networks. Node power is provided by a small battery and used only for collecting, processing and transmitting sensory data. The appearance of nodes manufactured by different manufacturers is shown in Figure 4.

\section{Improved accuracy of measurements}

When solving many practical problems arising in instrument making, as well as in conducting research, there is a shortage of information due to the nature of the measurement of the function of the state and other factors. 

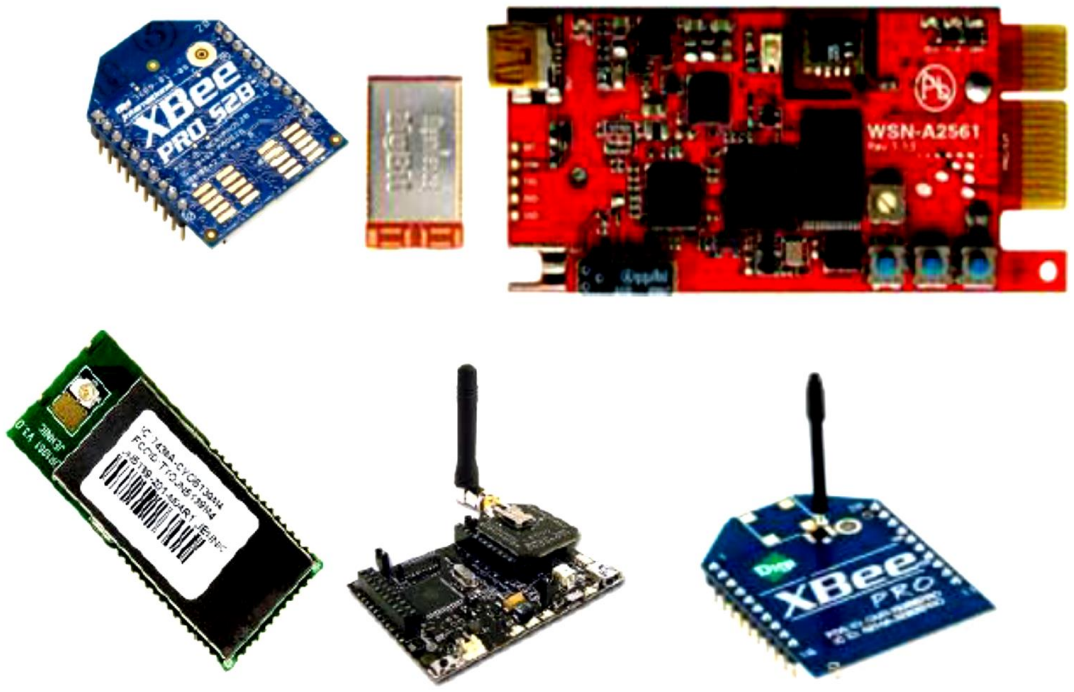

Fig. 4. ZigBee sensor network devices

The specified deficit is replenished by solving the problems of controlling distributed systems that are part of the Internet of Things network such as mathematical modeling, estimating the state and parameters of stochastic processes, minimizing the number of measuring points and optimizing their location in the spatial domain.

Formulation of the problem. Consider the case of measuring (estimating) the vector information parameter under the influence of the additive interference with the non-Gaussian probability distribution density in the "Internet of Things" sensory network based on ZigBee.

The random process selection $X_{h}=X\left(t_{h}\right), h=1, \ldots, H$, is a mixture of the useful signal $S\left(\lambda, t_{h}\right)$, that carries information about the measurement information parameters $\lambda=\left\{\lambda_{1}, \ldots, \lambda_{\mathrm{m}}\right\}$, and additive generally non-Gaussian noise $n_{h}[8$, p. 1]

$$
X\left(i_{h}\right)=S\left(\lambda, t_{h}\right)+n_{h} .
$$

We believe that the results of measurement of mechanical quantities are functions of sufficient statistics and have asymptotic properties of sufficiency, instability and normality, as well as the regularity conditions are 
fulfilled. We believe that additive interference and measurement parameters are independent.

The task of determining the optimal filtering of the random process of measuring mechanical quantities is to convert a signal $\xi$ to the target as the most accurate reproducing $S$. The distribution density $p(x / \lambda)$ depends on the vector parameter $\lambda=\left\{\lambda_{1}, \ldots, \lambda_{s}\right\}, p \geq 2$. To obtain a timetable in a power polynomial relative $x$

$$
\ln p_{s}(x / \lambda)=\int_{a}^{\lambda} \sum_{i=1}^{s} k_{i}(t)\left[x^{i}-m_{i}(t)\right] d t+c_{s}(x)
$$

where $c_{s}(x)$ - he function that does not depend on $\lambda$, and for the convergence in $x$ sequence $\left\{\ln p_{s}(x / \lambda)\right\}$ to the logarithm of the distribution density $\ln p(x / \lambda)$ at $s \rightarrow \infty$ need to $k_{i}(\lambda)$ are determined from the solution of the system of linear algebraic equations [8, p. 3]

$$
\sum_{j=1}^{s} k_{j}(\lambda) F_{i j}(\lambda)=\frac{d}{d \lambda} m_{i}(\lambda), i=\overline{1, s},
$$

де $F_{i j}(\lambda)=m_{i+j}(\lambda)-m_{i}(\lambda) m_{j}(\lambda) i, j=\overline{1, s}, m_{i}(\lambda), m_{j}(\lambda)$ - moments. According to the schedule (1), to find the vector parameter, the approximation of the compatible density distribution of independent sample values will have the form

$$
p_{s n}(x / \lambda)=\exp \left\{\sum_{i=1}^{s} h_{m i}(\lambda) \cdot t_{i n}+h_{0}(\lambda)+c_{s}\left(x, \lambda / \lambda_{m}\right)\right\}
$$

where the notation is introduced:

$$
\begin{gathered}
h_{m i}(\lambda)=\int_{a}^{\lambda} k_{i m} d t, \\
h_{0}(\lambda)=n \int_{a}^{\lambda} \sum_{i=\lambda}^{s} k_{i}(t) b_{i}(t) d t, \\
t_{i n}=\sum_{r=1}^{n} c_{s}\left(x_{r}\right),
\end{gathered}
$$

But $c_{s}\left(x, \lambda / \lambda_{m}\right)$ - function independent of the composite vector parameter.

In accordance with the Cramer-Rao theorem, the variance of any unbiased estimation is determined by the inequality [1]

$$
G_{\lambda}^{2} \geq\left[-m\left\{d^{2} \ln W_{n}(\lambda) / d \lambda^{2}\right\}\right]^{-1},
$$


Where $W_{n}(\lambda)$ - function of plausibility.

We believe that the logarithm of the probability function (LFP) exists and has the form

$$
B_{n}=\ln W_{n}\left\{X_{h}-S\left(\lambda, t_{h}\right)\right\},
$$

Where $W_{n}\{*\}$ - There is an additive interference.

To evaluate the accuracy of the measurement of the vector information parameter, we shall consider, for example, the random vibrational processes that occur when the foundation is fluctuating in flexible production systems and frequency measurement $-\omega$, frequency derivative $-\omega^{\prime}$ and phase $-\varphi$ of the useful signal of the sensors

$$
S\left(\lambda, t_{h}\right)=U_{m h} \cos \left[\left(\omega+0,2 \omega^{\prime} t_{h}\right) t_{h}+\phi\right] .
$$

Let's represent a useful signal (2) $S\left(\lambda, t_{h}\right)$ in the form

$$
S\left(\lambda, t_{h}\right)=U_{m h} \cos \left(\lambda_{1}+\lambda_{2} t_{h}+\lambda_{3} t_{h}^{2}\right),
$$

де $\lambda_{1}=\varphi ; \lambda_{2}=\omega^{\prime} ; \lambda_{3}=\omega$.

For a measuring signal we define the derivatives:

$$
S_{\lambda i}^{\prime}\left(\lambda, t_{h}\right)=U_{m h} t_{h}^{i-1} \sin \left(\hat{\lambda}_{1}+\hat{\lambda}_{2} t_{h}+\hat{\lambda}_{3} t_{h}^{2}\right) i=1,2,3 .
$$

In estimating the information parameters for the maximum of the a posteriori density of probability distribution (ASSR), three equations are fulfilled:

$$
\left.\frac{d}{d \lambda_{1}} \ln W_{y}(\lambda)\right|_{\lambda_{1}=\lambda}=0 ;\left.\frac{d}{d \lambda_{2}} \ln W_{y}(\lambda)\right|_{\lambda_{2}=\hat{\lambda}}=0 ;\left.\frac{d}{d \lambda_{3}} \ln W_{y}(\lambda)\right|_{\lambda_{3}=\lambda}=0 .
$$

The Cramér-Rao lower bound on the variance of unbiased common parameters of useful signal $\lambda=\left\{\varphi, \omega, \omega^{\prime}\right\}$, may be written as $[4$, p. 2]:

$$
G_{\lambda i j}^{2} \geq\left|I_{i j}\right| / I \mid ; i, j=1,2,3
$$

where $\left|I_{i j}\right|$ - the algebraic complement of the element $I_{\mathrm{ij}} \mathrm{s}$ the algebraic complement of the element $\|I\| ;|I|$-determinant of the matrix.

\section{Conclusions}

Thus, in this paper an attempt was made to consider the combination of metrology, computer information systems and networks, as well as psychological theory of professional interaction, to solve common problems, in order to improve the automatic exchange of information about the state of the environment between end-user devices. In order for devices connected to the Internet of things, based on the information received, could carry out control actions that are useful to consumers. 
To this end, the role of professional interaction, as a system of communication between people, and its main components that can improve the Internet of Things network, was determined.

The choice of "Internet things" technology was substantiated and proved that this technology can be one of the types of information measuring systems and can be used as a method for measuring mechanical quantities.

The basic protocols that can be used in the Internet of Things network are analyzed and the ZigBee IEEE 802.15.4 protocol is chosen which is most suitable for constructing sensor networks and describes the model of its decomposition.

The main areas of application and structure of ZigBee IEEE 802.15.4 devices are considered.

The method of increasing the accuracy of measurements of mechanical quantities for a sensor network based on the ZigBee protocol is proposed.

\section{References:}

1. Institute of Electrical and Electronics Engineers (2003) IEEE Standard for Information Technology - telecommunications and Information Exchange between Systems - Local and Metropolitan Area Networks - Specific Requirements [IEEE Standard for Information Technology - telecommunications and Information Exchange between Systems - Local and Metropolitan Area Networks - Specific Requirements], New York: IEEE Press.

2. Kvasnikov V.P., Ganeva T.I. (2015) Method of measurement of stress in loaded structures [Method of measurement of stress in loaded structures]. Scientific and technical journal "Metallurgical and Mining Industry", vol. № 7, pp. 340-343.

3. Artyushenko V.M., Solenov V.I. (1997) Otsenka tochnosti izmereniya informatsionnogo parametra signala na fone additivnoy negaussovoy pomekhi [Estimation of the accuracy of measuring the information parameter of a signal against the background of additive non-Gaussian noise], Vestnik MGTU. Seriya Priborostroyeniye, vol. 4, pp. 9-14.

4. Kvasnikov V.P., Khaeyn T.M. (2013) Kontseptsiya povirky koordynatno-vymiryuval'nykh mashyn cherez Internet [Concept of verification of coordinate-measuring machines via the Internet], Metrolohiya ta prylady, vol. 6, pp. 48-53.

5. Kvasnikov V.P., Hanyeva T.I. (2015) Nova metodyka rozrakhunku datchyka deformatsiy [New method for calculating the deformation sensor]. Vymiryuval'na ta obchyslyuval'na tekhnika $v$ tekhnolohichnykh protsesakh, vol. 3, no. 52, pp. 169-173.

6. Kvasnikov V.P., Leshchenko YU.P. Rozrobka ta doslidzhennya intelektual'noyi systemy dlya analizu ymovirnisnykh kharakterystyk vypadkovykh protsesiv mekhanichnykh velychyn [Development and research of the intellectual system for the analysis of probabilistic characteristics of random processes of mechanical quantities]. Tekhnolohycheskyy audyt y rezervy proyzvodstva, vol. 5/3, no. 100-102. 
7. Kunchenko YU.P. (2002) Stokhasticheskiye polinomy, ikh svoystva i primeneniye dlya nakhozhdeniya otsenok parametrov [Stochastic polynomials, their properties and applications for finding estimates of parameters]. Cherkassy.: CHITI. (in Ukreine)

8. Luntovs'kyy A.O., Mel'nyk I.V. (2011) Osnovy proektuvannya bezprovodovykh komp'yuternykh merezh [Fundamentals of Designing Wireless Computer Networks]. Kyyiv: Universytet "Ukrayina". (in Ukreine)

9. Ornatskiy D.P., Kvasnikov V.P., Osmolovskiy A.I. (2014) Optimizatsiya analogovogo interfeysa informatsionno-izmeritel'nykh sistem dlya distantsionnykh izmereniy mekhanicheskikh velichin [ptimization of the analog interface of information-measuring systems for remote measurements of mechanical quantities]. Vostochno-Yevropeyskiy zhurnal peredovykh tekhnologiy, vol.4, no. 70, pp. 31-37.

10. Rogov Ye.I. (2004) Psikhologiya obshcheniya [Psychology of communication]. Moscow: Vlados. (in Russian)

11. Bilen'kyy YE. A. (2003) Sotsiolohiya: slovnyk terminiv i ponyat' [Sociology: dictionary of terms and concepts]. Zhytomyr : Volyn' : Ruta (in Ukraine)

12. Stukhlyak P.D. (2011) Teoriya informatsiyi (informatsiyno-vymiryuval'ni systemy, pokhybky, identyfikatsiya) [Theory of information (information-measuring systems, errors, identification)]. Kherson: Aylant (in Ukraine)

13. Shteynvol'f A.L. (1993) Raschety i imitatsiya negaussovykh sluchaynykh vibratsiy [Calculations and imitation of non-Gaussian random vibrations]. Kiyev: Naukova dumka (in Ukraine) 


\title{
COMPLEXITY AS THE IMMUNENTAL PROPERTIES OF LOCAL SELF-GOVERNANCE PHENOMENON
}

\section{КОМПЛЕМЕНТАРНІСТЬ ЯК ІМАНЕНТНА ВЛАСТИВІСТЬ ФЕНОМЕНУ МІСЦЕВОГО САМОВРЯДУВАННЯ}

\section{Koltun Viktoriia ${ }^{1}$}

DOI: http://dx.doi.org/10.30525/978-9934-571-26-8_9

\begin{abstract}
The subject of research is complementarity as an inherent property of the phenomenon of local self-government. The purpose of the article is to determine the substantiation of approaches to the definition of the essence and specificity of complementarity in the processes of implementation of local self-government. The methodology of the research was chosen the theory of systems, the theory of organizations, a number of interdisciplinary approaches, in connection with the fact that the theoretical and methodological foundations as a science "Public Administration and Administration" in general, and its direction "Local government" are in an active development. The formation of the methodological tools of this study was based on a philosophical basis of holism, proceeding from the synergetic unity of the world. The main conclusions are as follows. It is proved that the attributive feature of the phenomenon of local self-government and, accordingly, of local self-government as its manifestations and elements, is complementarity. The complex of activities of local self-government bodies is a sequence of states realized by their essential properties, which is complementarity. Under the complementarity of local self-government, we understand their attributive ability to act as the subject of complementarity and mutual influence in the time continuum. It is substantiated that the term "complementary changes" that describes the dynamic component of the process of realization of functions of the system of local self-government, which can lead to an optimal state of interaction of the system of local self-government and its elements with other open dynamic systems and their elements, is an appropriate term for naming the activities of local
\end{abstract}

\footnotetext{
${ }^{1}$ Doctor of Science in Public Administration, Associate Professor,

Professor of the Department of Regional Government, Local Government and City Administration, National Academy of Public Administration by the President of Ukraine, Ukraine
} 
self-government bodies. The essence of institutional and functional complementarity of the system of local self-government is determined. The institutional complementarity of the system of local self-government involves the construction and consolidation in the law of the way of implementing interaction with other public administration bodies both at local and central levels. Institutional complementarity testifies to the organizational immanent unity of several relatively stable systems and does not reflect their movement in time. Attributive features of functional complementarity of the system of local self-government are as follows: it characterizes the process; can be formed and used situationally (on the basis of the principles of organizational and legal autonomy) as a mechanism of "response" to one or another "challenge" faced by any element of the system of local self-government; in contrast to the institutional, its initiators and actors can act not only legitimized control subsystem, but also any other (group of other) elements of the system of local self-government. The status of the category of complementarity as a universal and key temporal property of local self-government is determined. The principle of universality means that local self-government is always, at any point in time, complementarily open to interactions with other systems or their elements. The peculiarity of the "key" property means the presence of a number of others that are secondary and refined, detailing the general. The specific characteristic of the phenomenon of local self-government is revealed, which is the ability to constantly implement in time, the actual ability to act as the center of complementary connections, the main actor of complementary processes. It is substantiated that the effective vector of development of the system of local self-government is the implementation of the principle of complementarity through a free (based on the principles of organizational and legal autonomy) choice of the optimal complimenter - expedient for a certain period of time to the subject II, which will be the most moderate for the subject I a system of local self-government.

\section{Introduction}

Актуальність даного дослідження обумовлюється рядом факторів об'єктивного характеру. Так, зважаючи на той факт, що теоретико-методологічні основи як науки «Публічне управління та адміністрування» в цілому, так і іiі напряму «Місцеве самоврядування» знаходяться на стадії бурхливого розвитку, виникає об'єктивна потреба у розширенні 


\section{Koltun Viktoriia}

існуючого понятійно-категоріального апарату. Зважаючи на інтердисциплінарний характер сучасних методологічних підходів, та виходячи із принципів єдності світобудови, вважаємо доцільним здійснювати пошук новітнього інструментарію у ряді суміжних наук, де ефективність застосування подібних засобів аналізу вже $є$ успішно доконаним фактом. Як довів проведений аналіз, потужний гносеологічний потенціал міститься у застосуванні поняття «комплементарність».

Саме тому, предметом даного дослідження є комплементарність як іманентна властивість феномену місцевого самоврядування. Метою визначено обгрунтування підходів до визначення сутності та специфіки комплементарності у процесах здійснення місцевого самоврядування. Методологією дослідження було обрано теорію систем, теорію організацій, ряд інтердисциплінарних підходів, зважаючи на відносну (у порівнянні у традиційними науками), молодість галузі знань «Публічне управління та адміністрування». Формування методологічного інструментарію даного дослідження грунтувалось на світоглядній основі холізму, що виходить із синергетичної єдності світу і уможливлює застосування методологічних комплексів суміжних наук. У зв'язку з вищевикладеним, основними завданнями даного дослідження стали наступні: проаналізувати комплекс змістів, що відносяться до поняття «комплементарності»; визначити доцільність та методологічний потенціал залучення до наукового обігу науки «публічне управління та адміністрування» кола понять, пов'язаних 3 «комплементарністю»; виявити специфіку застосування поняття «комплементарність» для феномену місцевого самоврядування; виходячи 3 атрибутивних властивостей місцевого самоврядування, визначити його кореляцію з проявами комплементарності.

\section{2. Комплекс змістів поняття «комплементарності»}

Поняття комплементарності останнім часом починає активно використовуватись у різних галузях знань, є складовою багатьох методологічних комплексів як загальнонаукового, так спеціального спрямування: у філософії, фізиці, хімії, генетиці, біології, психології, соціології, праві, економіці і менеджменті. Представники вищенаведених наук впевнено відстоюють необхідність застосування даного терміну у термінологічному апараті своїх досліджень. 3 метою обгрунтування доцільності застосування даного терміну у розвиткові 
методології науки публічне управління та адміністрування, нами було проведено аналіз результативності використання даного інструментарію у вказаних галузях знань.

«Термін комплементарність походить від латинського “complementum" - доповнення. Комплемент (від лат. Доповнення) - додатковий засіб; комплементарний - додатковий» [23, с. 217]. Комплементарність (біохім.) - взаємна відповідність в хімічні будові двох макромолекул, яка забезпечує їх взаємодію. Комплементарні структури підходять одна одній як ключ до замку [21, с. 621].

Даний термін у різних науках застосовується з дещо відмінним змістовним навантаженням. Наприклад, у математиці комплементарним називаються кути, що утворюють у сумі прямий «правильний», ідеальний кут. Свого часу вчені називали комплементарними такі кольори, які в результаті взаємодії утворювали білий - «ідеальний» колір. Комплементарність в молекулярній біології - взаємна відповідність, що забезпечує зв'язок доповнюючих одна одну структур [22]. У межах біохімії принцип комплементарності означає таку взаємну відповідність у структурі макромолекул, що дозволяє їм взаємодіяти. Так само широко розповсюдженим є дане поняття і у біології. Вперше термін був введений у науковий обіг Н. Бором при описі статусу частинки і хвилі. В останні десятиріччя комплементарність $\epsilon$ широко застосовуваним інструментом у філософії (роботи С. Фатєєвої, А. Цофнаса, А. Шоркіна); соціології (Е.А. Афонін, С.Г. Кірдіна) та економіці.

\section{3. Аналіз методологічної результативності використання поняття «комплементарність»}

Основні проблеми сучасної системи органів місцевого самоврядування (далі-OMC), викладені у [11], свідчать про недостатню результативність вибудуваних зв'язків між елементами ряду динамічних систем, якими є комплекси ОМС населеного пункту, регіону, тощо. На наш погляд, необхідно додати ще один параметр для характеристики i існуючих, і тих, що вибудовуються, зв'язків між ОМС, а саме - часовий вимір. Неврахування на сьогоднішньому етапі параметру темпоральності позбавляє вказані надсистеми їх сутнісної риси - складнісності. B.I. Аршинов «впевнений, що суттєвим кроком у нашому просуванні до розуміння складнісності з'явилося б звернення до темпоральності (в сенсі Пригожина)» [1]. 


\section{Koltun Viktoriia}

Ми не випадково звертаємося до класичних праць I. Пригожина, оскільки фундаментальна його ідея щодо синергетики вже стала базовою для сучасної методології науки. Водночас, дослідники вказують: «Проблема часу була для Пригожина у всіх відносинах центральною. «Це книга про час. На мій погляд, їй цілком підійшла б назва «Час забутий вимір», хоча деяким читачам такий заголовок здався б дивним» [20]. Такими словами I.Р. Пригожин починає свою книгу «Від існуючого до виникаючого». Для Пригожина ця проблема перебувала за межами класичної і навіть некласичної науки, але вже на передовій лінії становлення нової науки про складність, темпоральність» [1], пише B.I. Аршинов. Таким чином, уведення до методології науки «Державне управління» парадигми темпоральності, зокрема - у діяльності ОМС, виводить її на передову лінію світових здобутків.

Термін «комплементарність» застосовується у сучасній географічній науці при формуванні методологічних підходів до обгрунтування новітніх напрямів досліджень синкретичних єдностей, якими є, наприклад, геоекосистеми [14].

С. Бір, класик кібернетики, описував неможливість розв'язати проблему кореляції керуючої і керованої підсистем в умовах постійно змінюваного середовища (як екзогенного відносно комплексу керуюча-керована підсистема, так і частково-ендогенного, що впливає на одну з двох підсистем). Наслідком його роздумів і практичних розробок став запропонований ним (вперше для $30 \mathrm{x}$ pp. XX ст.) принцип зовнішнього доповнення для подібних систем: «Для побудови істинних кібернетичних машин, призначених для вироблення стратегічних рішень, буде необхідним принцип... зовнішнього доповнення, адже він являє собою практичний метод подолання наслідків теореми неповноти» [4]. Даний принцип застосовується нами у дослідженні в якості парадигми комплементарності місцевого самоврядування.

Таким чином, можна стверджувати факт трансляції термінологічного інструментарію з природничих наук у блок гуманітарних i, більш вузько, наук, які займаються питаннями управління. Однак, як буде показано далі, у науці «публічне управління та адміністрування» термін комплементарність не є достатньо вживаним, що, на наш погляд, дещо звужує методологічний інструментарій цієї галузі.

Ідея пошуку іманентної цілісності є притаманною онтологічним науковим розвідкам. Так само, як Всесвіт і окрема особистість прагне 
довершеності у віднайдені своєї повноти (за К. Марксом і В.П. Івановим), кожен суспільний феномен об'єктивно потребує стану комплементарності, будучи потенційно відкритим для взаємодії з іншими динамічними відкритими системами. Тому на когнітивному рівні у межах спеціальних наук комплементарність також виступає окремим предметом досліджень. Так, дане поняття широко застосовується у соціології «де процес виникнення малих груп... грунтується перш за все на комплементарності індивідів» (Т. Лірі). У психології використовується у класичних працях, наприклад, Е. Берна, Тоумена, Ж. Піаже. На суміжних гранях філософії, культурології, економіки і психології - глибоко опрацьовано С.В. Фатєєвою. Дослідниця аналізує існуючі підходи до універсального розуміння принципу комплементарності і зазначає: «ще В. Гейзенберг відстоював думку, що додатковість має універсальний характер. М. Борн вважав, що ідея додатковості має всезагальне значення, оскільки існує багато сфер людської діяльності, де один і той саме факт може розглядатися у різних, але взаємодоповнюючих аспектах. Він був згоден з Н. Бором у тому, що уявлення про додатковість можливо застосовувати у інших сферах знання, зокрема, у біології, психології, філософії, політиці» [22].

Зважаючи на статус філософії як «загальної методології науки», почнемо розгляд 3 неї. Розуміння комплементарності як взаємодоповнення, що має глибинний, іманентний характер, відображено у ряді філософських публікацій як сучасних вчених, так і всесвітньовідомих класиків. Наприклад, з точки зору Г. Лейбніца, комплементарність $\epsilon$ способом представлення всезагального як процесу взаємодоповнення індивідуальних явищ до цілого [15]. На думку ряду зарубіжних вчених, «запропонований Ф. Енгельсом закон єдності і боротьби протилежностей у рамках діалектичного матеріалізму найбільш близько описує поняття комплементарності» [7]. У вітчизняних філософських дослідженнях термін «комплементарність» також починає активно застосовуватись: «Пошук зв’язності...є характерним, перш за все, прагненням встановити комплементарність явищ культури - їх синхронізовану з'єднаність в упорядковану цілісність [25]. У контексті нашого дослідження інтерпретація є доцільною як «комплементарність процесів місцевого управління у синхронізованій єдності в упорядкованій цілісності». Такий підхід вбачається обгрунтованим для побудови системи управління на місцях, реалізовуваній як комплекс 


\section{Koltun Viktoriia}

функцій та повноважень ОМС і МOBВ на основі комплементарного підходу.

На думку американського філософа Р. Бернстайна, є доцільним для відображення повноти світу застосування терміну «констелляція», який, з точки зору С.В. Фатєєвої, він запозичив з робіт Т. Адорно і В. Беньяміна. Однак, Р. Бернстайн наповнює це поняття дещо іншим змістом, потрактовуючи його як «групу сусідніх, змінних елементів, які чинять спротив приведенню до спільного знаменника, невід'ємної суті або первинному принципу, що все породжує - (переклад наш. B.K.)» [29].

У сучасних правових дослідженнях термін комплементарність також застосовується, але вже з іншим змістовним відтінком - як фактор соціальних співрегуляторів (через кореляцію норм права і моралі); як характеристика юрисдикції того чи іншого суду (наприклад, «Принцип комплементарності юрисдикції Міжнародного кримінального суду» описаний Н.В. Дрьоміною [8]. Л.О. Корчевна розглядає новітню, всеохоплюючу концепцію права на основі принципу комплементарності. Зазначена мета реалізується вченим через осмислення різноджерельного права або різних юрисдикцій в межах одного суспільного устрою [13, с. 1]. Таким чином, дослідження у галузі права увагу акцентують, головним чином, на таких аспектах комплементарності, що зумовлені іiі синтезуючими властивостями.

Сучасна психологія розглядає принцип комплементарності у контексті «обгрунтованого розподілу освітнього матеріалу за... модальностями... при проектуванні електронних підручників» У контексті «набуття знань принцип комплементарності означає таку організацію навчального матеріалу, яка забезпечує вільні взаємопереходи між загальним (абстрактним) і частковим (конкретним)» [17].

\section{4. Специфіка застосування поняття «комплементарність» для феномену місцевого самоврядування}

Зважаючи на методологічну цінність комплементарного підходу, вважаємо доцільним покласти цей принцип не тільки у феноменальну основу організації процесів управління на місцевому рівні, витлумачених як взаємодія ОМС і місцевих органів виконавчої влади (далі $M O B B)$, спрямована на розвиток територій, але і у когнітивну складову, в якості інструменту освіти і підвищення кваліфікації виборних 
і посадових осіб ОМС та державних службовців. У такий спосіб буде забезпечено принцип єдності світобудови та світосприйняття.

Є.Б. Герасимова, описуючи застосування розглядуваного нами поняття зазначає: «В управлінні персоналом, у промисловій психології комплементарність поведінки керуючого суб'єкту полягає у його прагненні максимально наблизити реальне протікання процесу до нормативного. Тут комплементарність використовується нарівні $з$ синонімічним йому поняттям процесуальної додатковості» [6]. Поняття «комплементарність» у менеджменті застосовується як принцип формулювання цілей організації і передбачає, що досягнення однієї цілі полегшує досягнення іншої [6].

Відомий методолог науки С.В. Фатєєва зазначає, що «особливого значення у сучасній економічній культурі набула ідея комплементарності, взаємодії на противагу жорстким уявленням щодо антиномій класових різниць...» [22]. На наше переконання, виглядає слушною думка щодо розповсюдження такого своєрідного «толерантного», тобто без вимоги взаємовиключення, підходу до інших, позаекономічних сфер суспільного буття.

Зважаючи на очевидну роль керуючої підсистеми суспільства, значну питому вагу функцій якої на місцях реалізує система місцевого самоврядування (далі - MC), видається доцільним розглядати категорію комплементарності в якості універсальної і ключової тенденції місцевого самоврядування. Принцип універсальності означає, що місцеве самоврядування, витлумачене і в якості феномену, і в якості системи, завжди є комплементарно відкритим до взаємовпливів 3 іншорідними системами або їх елементами. Застосовуючи поняття «ключової» тенденції ми мали на увазі наявність ряду інших, які є вторинними, похідними, залежними, такими, що уточнюють і деталізують генеральну властивість.

У [10] нами аналізуються трансформаційні процеси у системі місцевого самоврядування на основі підходів, що пропонує квантова фізика і квантова механіка. Застосування обраного інструментарію видається цілком обгрунтованим не тільки завдяки проведеній верифікації одержаних результатів та розширення традиційного кола методологічних інструментів науки державного управління, але і через наявність спільного онтологічного та гносеологічного підгрунтя принципу комплементарності, що є наскрізним атрибутом буттєвих 


\section{Koltun Viktoriia}

феноменів і когнітивних механізмів, які здатні забезпечити адекватне відображення і пізнання дійсності. Так, у роботах В.В. Налимова [18] 3 квантової механіки доведено, що однієї логічної конструкції, якою би досконалою вона не була, є недостатньо для опису складності світобудови. В результаті виникають підходи до багатозначних логік, розроблені Д. Бочвара, Я. Лукасевичем, Е. Пост і рядом інших вчених, за якими принципи класичної, аристотелівської логіки вже не мають абсолютного значення [22].

Близьким до кола досліджуваних нами проблем як практичного рівня (тенденції розвитку місцевого самоврядування), так і теоретико-методологічного (введення у науковий обіг науки публічне управління та адміністрування терміну комплементарність) є поняття «глокалізація», запропоноване британським соціологом Р. Робертсоном, яким він позначає два взаємодоповнюючих, комплементарних процеси - глобалізацію та регіоналізацію [31].

У сучасній політології до поняття комплементарності звертається К.Ф. Завершинськ, обгрунтовуючи необхідність методологічної комплементарності у дослідженні динаміки політичних інститутів [9]. На нашу думку є доцільним застосовувати когнітивний потенціал поняття комплементарності для дослідження складних відкритих динамічних систем і відповідних процесів, що відносяться до сфери публічного управління.

Серед сучасних економістів увагу поняттю комплементарності приділяють дослідники, які працюють у сфері маркетингу та менеджменту, наприклад І.А. Кораблинова, М.В. Лиходед, А.І. Цапко [12]. Концепція інституціональної комплементарності в економіці розробляється нашим сучасником і співвітчизником В.В. Ліповим. До зарубіжних класиків цієї концепції відносять Б. Амабле [27], М. Аокі [29], П. Холла і Д. Соскіса [30]. Як зауважує В.В. Ліпов, їх «об'єднує відмежовування дослідження економічної сфери від інших складових соціально-економічних систем» [16]. 3 точки зору В.В. Ліпова, «Комплементарність грунтується на зв'язках і взаємодіях, які мають впорядкований характер, об'єднаних на постійній основі і таких, що забезпечують цілісність, внутрішню диференціацію, самоідентифікацію і саморозвиток економічних систем у процесі господарювання» [16]. Принагідно зазначимо, що взаємодія як така це «вплив об'єктів один на одного, їх взаємообумовленість і породження одним об'єктом 
іншого; універсальна форму руху, розвитку, яка визначає існування і структуру будь-якої матеріальної системи» [24].

Стійкість будь-якої системи, у т. ч. системи місцевого самоврядування, є одним із аспектів, що характеризує ії ефективність, тобто здатність досягати власних цілей. Оскільки ефективність місцевого самоврядування визначено метою сучасного етапу державної політики у сфері місцевого самоврядування, видається доцільним здійснити аналіз підходів до формування та забезпечення стійкості системи МС на основі пропонованого нами у дослідженні принципу комплементарності із застосуванням окремих елементів інструментарію суміжних наук.

Стійкість ряду економічних феноменів давно перебувають у центрі уваги вчених, однак параметр стійкості як характеристика ефективних керуючих підсистем у галузі науки державне управління достатньою мірою не висвітлено. Вважаємо, що динамічний стан стійкості, iii комплексність забезпечується принциповою комплементарністю відкритої динамічної системи місцевого самоврядування. Водночас, 3 метою забезпечення відповідності когнітивного рівня феноменологічному, видається доцільним зосереджувати увагу не тільки на об'єктивній комплементарності системи МС як такої, але і комплементарному характеру чинників-процесів, які забезпечують вказані властивості, i на взаємодоповнюючому характері застосовуваного комплексу методологічних інструментів, які використовуються для аналізу вказаних явищ і процесів.

Для деталізації дослідження варто розмежовувати специфіку стійкості системи МС в широкому розумінні слова, за яким вона передбачає комплекс явищ, об'єктів і процесів, та систему ОМС того чи іншого населеного пункту, що пов'язана також із стійкістю окремого органу МС. Якщо оцінювати відповідність параметру стійкості всієї системи $\mathrm{MC}$ цілком, або навіть системи ОМС окремого населеного пункту, то є досить складним завданням забезпечити об'єктивність оціночних суджень, зважаючи на відсутність верифікованої системи критеріїв. Водночас, стійкість до зовнішніх впливів окремого ОМС може бути витлумачена як результат ефективного менеджменту. Зазначимо, що стійкість окремого ОМС характеризується через динамічний аспект, адже управлінські рішення щодо специфіки стійкості приймаються перманентно в якості реакції на постійно оновлювану інформацію, яка надходить $з$ ендогенного і екзогенного середовищ. 


\section{Koltun Viktoriia}

Однак, як показує проведений аналіз, стійкість і окремого елементу системи МС і системи в цілому, забезпечується через домірність процесів ендогенного середовища до симетричних процесів екзогенного середовища. Тому варто розглядати феномен стійкості через динамічну характеристику організації - процес, який має бути синхронним до комплексу процесів екзогенних середовищ. Вказану синхронність вбачається можливим досягнути шляхом вбудовування комплементарних процесів до керованої структури (організації чи процесу).

3 точки зору С.Б. Герасимової, «варто звернути увагу на неспівпадіння понять «стабільність» і «стійкість». Стабільність - стан матеріальних об'єктів, для яких збереження заздалегідь заданих параметрів $є$ умовою функціонування. Стійкість - стан, більш близький до рівноважного» [6]. На думку дослідниці, «якщо рівновага характеризується стійкістю, то додаткове регулювання є необов'язковим... Якщо рівновага не володіє властивістю стійкої рівноваги, то при збуреннях зовнішнього середовища, іiі регулювання є необхідним» [6].

Проведений аналіз доцільності застосування теорії стійкого розвитку до проблематики функціонування місцевого самоврядування виявив, що місцеве самоврядування, витлумачене і на рівні феномену, і на рівні системи, за рахунок синкретичної комплементарності, яка виступає його атрибутивною ознакою, здатне вибудовувати новий рівноважний стан через формування взаємодії з різноманітними елементами різнопорядкових («іншорідних» за М.Д. Кондратьєвим) середовищ.

«Особливої значущості набуває комплементарність інститутів за умов якісної різнорідності елементів системи світового господарства та багатоваріантності еволюційних трендів глобального розвитку», пише [7]. Запропоноване бачення доцільності комплементарності різнорідних інституцій дозволяє використати здійснений вказаний крок у економічній теорії для розвитку методології науки державне управління. Загальновідомо, що сьогодні відсутні єдині усталені підходи щодо розуміння іманентних зв'язків між природою феноменів місцевого самоврядування і державної влади. Відомі вітчизняні вчені О.В. Батанов і В.І. Борденюк, зокрема, дотримуються діаметрально протилежних поглядів. Якщо В.I. Борденюк стоїть на позиціях державницької концепції, то О.В. Батанов є яскравим послідовником громадівської.

Ми не випадково звернулися до таких дихотомічних підходів, адже ще Аристотелем було розроблено теорію різних видів проти- 
лежностей - від контрадикторності до контрарності, різниця між спектром яких полягає, фактично, у факті «взаємовиключності» або iii відсутності. Зважаючи на подібний за широтою спектр підходів до розуміння сутності на феноменальному рівні явищ «самоврядності» i «державності» як таких, вважаємо за доцільне аналізувати їх взаємовпливи і взаємодію через поняття комплементарності. Невипадково девізом Копенгагенської школи фізики стали слова “Contraria sunt complementa!" (Протилежності суть додатковості!).

Сучасне звучання і поглиблене розуміння слів Гегеля щодо єдності і боротьби протилежностей надав Нільс Бор, спираючись на принцип невизначеності Вернера Гейзенберга. Відомий фізик написав: «існує ... дилема щодо властивостей електронів і фотонів, де ми стикаємося 3 протиріччям, яке виявляється при порівнянні результатів спостереження над атомним об'єктом, одержуваних за допомогою різних експериментальних установок. Такі емпіричні вказівки свідчать про наявність співвідношень нового типу, що не мають аналогів в класичній фізиці, які зручно позначити терміном додатковість, щоб підкреслити ту обставину, що в суперечать один одному явищах ми маємо справу з різними, але однаково істотними аспектами єдиного чітко визначеного комплексу відомостей про об’єктах» [5]. Варто зауважити, що сучасна методологія ряду наук користується, крім терміну комплементарність, деякими його синонімами - «Принцип додатковості»; «Копенгагенська інтерпретація» квантової теорії; «Принцип комплементарності Нільса Бора», тощо.

Саме тому вбачається доцільним використовувати термін комплемен-тарність для позначення мультифакторної і поліваріантної взаємодії феномену місцевого самоврядування. Адже, як буде доведено далі, традиційне розуміння категорії комплементарності описує також поліваріантні види дихотомій - від протилежності до взаємодоповнення. Таким чином, обраний нами підхід забезпечить достатню об'єктивність щодо широкого спектру розумінь іманентного зв'язку феноменів місцевого самоврядування і державності.

Відомий методолог науки С.В. Фатєєва зазначає, що «особливого значення у сучасній економічній культурі набула ідея комплементарності, взаємодії на противагу жорстким уявленням щодо антиномій класових різниць...» [22]. На наше переконання, виглядає слушною думка щодо розповсюдження такого своєрідного «толерантного», тобто без вимоги 


\section{Koltun Viktoriia}

взаємовиключення, підходу до інших, позаекономічних сфер суспільного буття. Зважаючи на очевидну роль керуючої підсистеми суспільства, значну питому вагу функцій якої на місцях реалізує система МC, видається доцільним розглядати категорію комплементарності в якості універсальної і ключової тенденції місцевого самоврядування. Принцип універсальності означає, що місцеве самоврядування, витлумачене і в якості феномену, і в якості системи, завжди є комплементарно відкритим до взаємовпливів з іншорідними системами або їх елементами. Застосовуючи поняття «ключової» тенденції ми мали на увазі наявність ряду інших, які є вторинними, похідними, залежними, такими, що уточнюють і деталізують генеральну властивість.

Видатний дослідник проблем державного управління Г.В. Атаманчук пише: «При аналізі управління через управлінську діяльність припускаються однієї великої помилки, яка полягає у тому, що управлінська діяльність будь-якого суб'єкту влади (органу державної влади або органу місцевого самоврядування...) розглядається ізольовано від управлінської діяльності інших суб'єктів влади, як дещо автономне і самостійне. До розгляду майже не приймається той очевидний факт, що всі суб'єкти влади взаємопов'язані і взаємозалежні...» - (nереклад наш - В.К.) [2, с. 35] «тому у реальній дійсності між суб'єктами влади ...iде постійна взаємодія...тільки майстерність узгодження керуючих впливів з іншими суб'єктами влади дає можливість раціонально і глибоко впливати...не керовані об'єкти» [2, с. 35].

На наше переконання, застосування терміну «комплементарність» для визначення специфіки характеру взаємодії між ОМС і MOBВ ті іншими суб'єктами територіального розвитку цілком вирішує названу вченим проблему. «Реальна проблема полягає у чіткому, обгрунтованому визначенні місця і ролі кожного суб'єкту управління і системному узгодженні їх керуючих впливів» [2, с. 123]. Побудова системи місцевого самоврядування на феноменальному рівні з урахуванням запропонованих у даному дослідженні підходів дозволить уникнути вказаних вченим ускладнень. Під комплементарністю ОМС розуміємо їх атрибутивну властивість до взаємодоповнення та взаємовпливів в часовому континуумі.

Сучасний вітчизняний вчений В.В. Ліпов вдало використовує методологічний потенціал комплементарності для аналізу взаємодії ринку і держави [16]. Дослідник у цитованій статті розглядає вплив ринкових 
інститутів на формування інститутів державного устрою. При цьому вченим використовується поняття інституціональної комплементарності, яка відображає якість інтегративної цілісності соціально-економічних систем.

\section{5. Кореляція атрибутивних властивостей місцевого самоврядування та комплементарності}

Здійснена нами екстраполяція подібних інструментів на досліджувану сферу дозволяє сформулювати специфіку інституціональної та функціональної комплементарності, властивих системі МС. Так, інституціональна комплементарність системи МС передбачає заздалегідь вибудуваний і закріплений у законодавстві спосіб реалізації взаємодії з іншими органами публічного управління як місцевого, так і центрального рівнів. Подібні зв’язки визначено на рівні Конституції України, Законів України (у першу чергу - у Законі України «Про місцеве самоврядування в Україні» та «Про місцеві державні адміністрації»). Інституціональна комплементарність свідчить про організаційну іманентну єдність декількох відносно стабільних систем і не відображає їх рух у часі.

Натомість, функціональна комплементарність системи МС, як доводять результати проведених досліджень, суттєво відрізняється від інституціональної. Її специфічними рисами $є$ наступні: вона характеризує процес, тобто динаміку, а не статику, тому описується через «синхронізацію динамічних аспектів»; може формуватися і використовуватись ситуативно (на основі принципів організаційної і правової автономії) в якості механізму «відповіді» на той чи інший виклик, що постає перед будь-яким елементом системи МС; на відміну від інституціональної, iï ініціаторами і суб'єктами може виступати не тільки легітимізована керуюча підсистема (наприклад, місцева рада), але і будь-який інший (група інших) елементів системи МС; другою стороною комплементарності може виступати не тільки орган публічного управління, але і інша ТГ (наприклад, при реалізації функцій, передбачених Законом України «Про співробітництво територіальних громад») і громадська організація (рух) при реалізації тих чи інших функцій із забезпечення розвитку територій (наприклад, моніторингу і контролю).

На наш погляд, ключовим є поняття «кореляційного зв'язку», яке вибудовує логічну пов'язаність на когнітивному рівні між декількома об'єктами рівня феноменального. При цьому вважаємо, що кількість 


\section{Koltun Viktoriia}

об'єктів, які знаходяться у відносинах комплементарності є формально не обмеженою, адже, якщо виходити з розуміння необхідності постійного забезпечення домірності керуючої системи до керованої, система МС повинна постійно знаходитись у різних аспектах стану комплементарності, не тільки з іншими елементами системи публічного управління, але і з громадськими організаціями/рухами, з підприємницьким сектором, тощо.

Вітчизняний дослідник Д.С. Пілевич пише: «якщо говорити про комплементарні процеси, то, насамперед, необхідно виділяти основні та додаткові їх складові. Останні у свою чергу доповнюють, збагачують центральні елементи та частково, вступаючи у зв'язок з ними, створюють синергетичні ефекти для розвитку досліджуваного явища» [19]. Ми переконані, що аналіз специфіки місцевого самоврядування, витлумаченої через поняття комплементарності, виявляе його унікальну рису - постійно реалізовувану здатність, актуалізовану спроможність виступати центром комплементарних зв'язків, головним актором комплементарних процесів.

Згідно з основними положеннями теорії систем, аналіз будь-якої системи феноменів будується на використанні принципу комплементарності - «максимального наближення реального протікання процесу до ідеального. Комплементарність вивчає і вимірює синергетичний ефект, притаманний системам, що самоорганізовуються» [26]. У такому аспекті сучасну систему місцевого самоврядування варто розглядати як систему, що самоорганізовується на основі принципу комплементарності. Згідно із сучасними визначеннями, «Комплементарність - це відповідність, взаємодоповнюваність, взаємовідповідність. Комплементарність - у найбільш загальному сенсі - це філософське поняття, за допомогою якого протилежні теорії, концепції, явища і точки зору, які відображають різні погляди на дійсність, можливо представити у вигляді несуперечливої моделі» [7].

Найбільш ефективним вектором розвитку системи місцевого самоврядування можна вважати реалізацію принципу комплементарності шляхом вільного (на основі принципів організаційної та правової автономіі) вибору оптимального комплементора - доцільного та оптимального на певний період часу суб'єкту II, який у певний період часу буде найбільш домірним для суб'єкта I, який представляє систему місцевого самоврядування. 


\section{Complexity as the immunental properties of local self-governance...}

На думку [7] «концепція комплементарності виходить з того, що множина організацій, або послуг, або теорій, грунтуючись на різних системах відносин, взаємно доповнюють одна одну і можуть бути використані для побудови системи більш високого рівня. Кожна організація має власні системи цінностей, систему теоретичних і методологічних обгрунтувань реалізації власних стратегій. У цьому випадку комплементарність виявляється у внутрішній і зовнішній взаємодоповнюваності і залежності...на основі цього утворюється нова система більш високого рівня, яка забезпечує усіма необхідними параметрами обидві організації, доповнюючи або заміщуючи ті чи інші функції» [7].

Зважаючи на те, що вищенаведена думка дослідників стосується організацій комерційного сектору, для них справджується багатовекторність ідеологій, що може утруднювати формування цілісної системи. Водночас, застосування подібного підходу для забезпечення принципу комплементарності у системі МС, буде значно простішим, адже процес синхронізації елементів як самої системи МС, так і їх взаємодію з МОВВ буде відбуватись для однотипних (звісно, з урахуванням ряду відмінностей) місцевих органів публічного управління, що реалізовують як державну політику, так і власну діяльність, спрямовані на забезпечення комплексного соціально-економічного розвитку територій.

Перспективним підходом в організації здійснення системою МС своїх функцій на основі принципу комплементарності є використання аутсорсінгових технологій, описаних нами у [10] на прикладі спільного надання муніципальних адміністративних послуг ОМС і МOBВ.

Серед сучасних вчених, які займаються проблематикою менеджменту, а саме - управління підприємствами, варто виокремити А.В. Балабаниць і Д.В. Сай, праці яких присвячено актуальному як з методологічної, так і прикладної точки зору питанню - управлінню маркетингом взаємодії підприємств [3]. Вказані дослідники вибудовують технологію планування стратегічних змін в системі управління маркетингом взаємодії підприємств на основі моделі «Калейдоскоп» і матриці комплементарності стратегічних змін. У контексті нашого дослідження є вкрай важливим здобутком цитованих авторів застосування поняття «комплементарних змін», що вони застосовують при характеристиці взаємодії підприємств. 


\section{Koltun Viktoriia}

Здійснена екстраполяція подібного методологічного інструментарію на сферу місцевого самоврядування дає підстави для використання поняття «комплементарних змін» для характеристики динамічної складової процесу трансформації системи місцевого самоврядування, що здатна призвести до оптимального стану взаємодії системи МС/iї елементів з іншими відкритими динамічними системами/іх елементами.

Необхідно зазначити, що принцип комплементарності повинен забезпечити синкретичну єдність управлінських процесів, керуючих підсистем та нерозривність управління на територіальному рівні.

Conclusions. На основі методологічного підходу тлумачення діяльності як способу реалізації сутності діючого суб'єкту, здійснено пошук іманентних властивостей феномену місцевого самоврядування. Доведено, що атрибутивною ознакою феномену МC i, відповідно, органів місцевого самоврядування як його проявів та елементів, $є$ комплементарність. Комплекс діяльностей ОМС є послідовністю станів реалізовуваної сутнісної властивості ОМС, якою є комплементарність. Під комплементарністю ОМС розуміємо їх атрибутивну властивість виступати суб' єктом взаємодоповнення та взаємовпливів в часовому континуумі. Обгрунтовано, що влучним терміном для позначення діяльності органів місцевого самоврядування $є$ поняття «комплементарних змін», що описує динамічну складову процесу реалізації функцій системи місцевого самоврядування, яка здатна призвести до оптимального стану взаємодії системи місцевого самоврядування та іiі елементів 3 іншими відкритими динамічними системами та їх елементами.

Визначено сутність інституціональної та функціональної комплементарності системи МС. Інституціональна комплементарність системи МС передбачає вибудуваний і закріплений у законодавстві спосіб реалізації взаємодії з іншими органами публічного управління як місцевого, так і центрального рівнів. Інституціональна комплементарність свідчить про організаційну іманентну єдність декількох відносно стабільних систем і не відображає їх рух у часі. Атрибутивними рисами функціональної комплемен-тарності системи місцевого самоврядування є наступні: вона характеризує процес; може формуватися і використовуватись ситуативно (на основі принципів організаційної і правової автономії) в якості механізму «відповіді» на той чи інший «виклик», що постає перед будь-яким елементом системи місцевого 
самоврядування; на відміну від інституціональної, іiі ініціаторами і суб'єктами може виступати не тільки легітимізована керуюча підсистема, але і будь-який інший (група інших) елементів системи місцевого самоврядування. Визначено статус категорії комплементарності в якості універсальної і ключової темпоральної властивості місцевого самоврядування. Принцип універсальності означає, що місцеве самоврядування завжди, у будь-якій точці часу (квантовому елементі) $\epsilon$ комплементарно відкритим до взаємовпливів з іншорідними системами або їх елементами. Особливість «ключової» темпоральної властивості означає наявність ряду інших, які є вторинними та уточнюючими, що деталізують генеральну.

Виявлено специфічну властивість феномену місцевого самоврядування, якою $є$ постійно реалізовувана у часі здатність, актуалізована спроможність виступати центром комплементарних зв'язків, головним актором комплементарних процесів. Обгрунтовано, що ефективним вектором розвитку системи місцевого самоврядування є реалізація принципу комплементарності шляхом вільного (на основі принципів організаційної та правової автономії) вибору оптимального комплементора - доцільного на певний період часу суб'єкту II, який буде найбільш домірним для суб'єкта I, що представляє систему місцевого самоврядування.

Перспективи подальших наукових досліджень пов'язані із обгрунтуванням парадигмальних характеристик місцевого самоврядування.

\section{Список літератури:}

1. Аршинов В. И. Синергетика конвергирует со сложностью [Электронный ресурс] / Аршинов В. И. // Вопросы философии. - Режим доступа: http://vphil.ru/index.php?option=com_content\&task=view\&id=301\&Itemid=52

2. Атаманчук Г. В. Управление: сущность, ценность, эффективность: учеб. пособие для вузов / Г. В. Атаманчук. - М.: Академический Проект; Культура, 2006. - 544 с.

3. Балабаниць А. В. Технологія планування стратегічних змін у системі управління маркетингом взаємодії підприємств / А. В. Балабаниць, Д. В. Сай // Теория и практика управления. Экономика и управление. - 2014. № $1 .-$ C. $30-35$.

4. Бир С. Кибернетика и менеджмент: пер. с англ. / Стаффорд Бир; под ред. А. Б. Челюсткина, предисл. А. Н. Отоцкого. - Изд. 3-е. - М.: КомКнига, 2010. $-280 \mathrm{c}$.

5. Бор Н. Вибрані наукові праці / Нільс Бор // Статті 1925-1961 рр. - М.: Наука, 1971. - Т. 2. - С. 393. 


\section{Koltun Viktoriia}

6. Герасимова Е. Б. Аналитический инструментарий самооценки устойчивости банка / Е. Б. Герасимова // Вопр. современной науки и практики. 2009. - № 9 (23). - С. 124-132.

7. Глухих Л. В. Реализация комплементарной стратегии посредством конкурентного механизма ведения бизнеса [Електронний ресурс] / Л. В. Глухих, Д. Я. Родин, Е. П. Астахова // Научный журнал КубГАУ. - 2014. - № 101(07). Режим доступу: http://ej.kubagro.ru/2014/07/pdf/21.pdf

8. Дрьоміна Н. В. Юрисдикція міжнародних кримінальних судів і трибуналів: дис. ... канд. юрид. наук: спец. 12.00.11 / Дрьоміна Наталія Вікторівна. Київ, 2006. - 240 с.

9. Завершинск К. Ф. Методологическая комплементарность в исследовании символических матриц динамики политических институтов [Електронний ресурс] / К. Ф. Завершинск // Полис. Полит. исслед. - 2003. - № 1. - С. 39. Режим доступу: http://www.politstudies.ru/article/ 3153?printmode

10. Колтун В. С. Закономірності та тенденції розвитку місцевого самоврядування: комплементарний підхід: монографія / В. С. Колтун. - К.: НАДУ; Вид-во» Фенікс «, 2015. - 365 с.

11. Концепція реформування місцевого самоврядування та територіальної організації влади в Україні [Електронний ресурс]: схвалена розпорядженням Кабінету Міністрів України від 1 квіт. 2014 р. № 333-р. - Режим доступу: http://zakon2.rada.gov.ua/laws/show/333-2014-\%D1\%80

12. Кораблинова И. А. Комлементарные формы отношений между компаниями и потребителями в сфере инфокоммуникаций [Електронний ресурс] / И. А. Кораблинова, М. В. Лиходед, А. И. Цапко. - Режим доступу: http://www.rusnauka.com/19 TSN_2014/Economics/6_173439.doc.htm

13. Корчевна Л. О. Проб̆лема різноджерельного права: дослід порівняльного правознавства: дис. ... д-ра юрид. наук: спец. 12.00.01 - теорія та історія держави і права; історія політичних і правових учень / Корчевна Л. О. - Одеса, 2005. $-412 \mathrm{c}$.

14. Круглов I. Ландшафт як геоекосистема / I. Круглов // Вісн. Львів. ун-ту. - 2006. - Вип. 33. - С. 186-193. - (Серія географічна).

15. Лейбниц Г. В. Сочинения / Г. В. Лейбниц. - М., 1982-1989.

16. Липов В. В. Методологические основы исследования комплементарного взаимодействия рынка и государства [Електронний ресурс] / В.В.Липов//Теоретическаяэкономика.-№4.-2011.-С.76-80.-Режимдоступу: www.theoreticaleconomy.info

17. Назаров А. І. Принцип комплементарності у медіа-освіті / А. І. Назаров [Електронний ресурс] // Устойчивое развитие: наука и практика: междунар. 2014. - Вып. 1 (12). - Ст. 14. - Режим доступу: www.yrazvitie.ru

18. Налимов В. В. Вероятностная модель языка: о соотношении естественных и искусственных языков / В. В. Налимов. - Томск: Томск-М, 2003. - 368 с.

19. Пілевич Д. С. Сутність комплементарної інвестиційної політики держави [Електронний ресурс] / Д.С. Пілевич // Вісн. Чернігів. Нац. технолог. ун-ту. Режим доступу: http://vistnic.stu.cn.ua/index.pl?task=arcl\&l= ua\&j=31\&id=16

20. Пригожин И. Р. От существующего к возникающему: Время и сложность в физических науках / И. Р. Пригожин. - М., 1985. 


\section{Complexity as the immunental properties of local self-governance...}

21. Советский энциклопедический словарь / гл. ред. А. М. Прохоров. 4-е изд. - М.: Сов. энциклопедия, 1989. - 1632 с

22. Фатеева С. В. Комплементарность в экономической культуре: понятие, формы и механизм действия: автореф. дисс. ... д-ра филос. наук: спец. 24.00.01. / Фатеева С. В. - Ростов-н/Д., 2006. - 48 с.

23. Философский энциклопедический словарь. - М.: ИНФРА-М, 1997. $576 \mathrm{c}$.

24. Шеметов П. В. Теория организаций: учеб. пособ. / П. В. Шеметов, С. В. Петухова. - М.: Изд-во «Омега-Л», 2008. - 282 с.

25. Шоркин А. Д. Схемы универсума и генезис научной рациональности / А. Д. Шоркин // Филос. и социолог. мысль. - 1989. - № 3. - С. 22-33.

26. Шухов А. Метрологический факт и общая теория комплементарности [Электронный ресурс] / А. Шухов // Философский портал 2012: электрон. журн. - Режим доступа: http://nounivers.narod.ru/

27. Amable B. Institutional complementarity and diversity of social systems of innovation and production / B. Amable // Review of International Political Economy. - 2000. -V. 7, Issue 4. - P. 645-687.

28. Aoki M. Contingent Governance of Teams: Analysis of Institutional Complementarity / M. Aoki // International Economic Review. - 1994. Vol. 35. - P. 657-676.

29. Bernstein R. J. The New Constellation. The Ethical-Political Horizons of Modernity / R. J. Bernstein // Postmodernity. - Cambridge, 1991. - P. 8.

30. Hall P. An introduction to varieties of capitalism / P. Hall, D. Soskice // Varieties of capitalism: the institutional Foundations of Corporative Advantage. Oxford: Oxford University Press, 2001. - P. 1-68.

31. Robertson R. Glocalization: Time-space and homogeneity - heterogeneity / R. Robertson // Global Modernities. - 1995.

\section{References:}

1. Arshynov V.I. (2011). Sinergetika konvergiruet so slozhnost'ju [Synergetics converges with complexity]. Questions of Philosophy. Vol. 4, pp. 73-84.

2. Atamanchuk G. V. (2006). Upravlenie: sushhnost', cennost', jeffektivnost' [Management: essence, value, efficiency]. Moscow: Akademicheskij Proekt; Kul'tura (in Russian)

3. Balabanycj A. V., Saj D.V. (2014). Tekhnologhija planuvannja strateghichnykh zmin u systemi upravlinnja marketynghom vzajemodiji pidpryjemstv [Technology of planning of strategic changes in the system of management of marketing interaction of enterprises]. Theory and Practice of Management. Economics and Management. vol. 4, pp. 30-35.

4. Bir S. (2010). Kibernetika i menedzhment [Cybernetics and management]. Moscow: KomKniga. (in Russian).

5. Bor N. (1971). Izbrannye nauchnye trudy [Selected scientific works]. Moscow: Nauka. (in Russian)

6. Gerasimova E. B. (2009). Analiticheskij instrumentarij samoocenki ustojchivosti banka [Analytical tool for self-assessment of bank's sustainability]. Issues of modern science and practice. Vol. 9, no. 23, pp. 124-132. 


\section{Koltun Viktoriia}

7. Gluhih L. V., Rodin D. Ja., Astahova E. P. (2014). Realizacija komplementarnoj strategii posredstvom konkurentnogo mehanizma vedenija biznesa [Implementation of the complementary strategy through the competitive mechanism of doing business]. Nauchnyj zhurnal KubGAU [Scientific magazine KubGAU] (electronic journal). Vol. 07, no.107. Retrieved from: http://ej.kubagro.ru/2014/07/pdf/21.pdf/. Accessed: 08.03.2018.

8. Drjomina N. V. (2006). Jurysdykcija mizhnarodnykh kryminaljnykh sudiv $i$ trybunaliv [Jurisdiction of International Criminal Courts and Tribunals] (PhD Thesis). Kyiv: Kyjivsjkyj nacionaljnyj un-t im. Tarasa Shevchenka

9. Zavershinsk K.F. (2003). Metodologicheskaja komplementarnost' v issledovanii simvolicheskih matric dinamiki politicheskih institutov [Methodological complementarity in the study of semimonetary matrices of the dynamics of political institutes]. Polis. Polit. Issled [Polic. political research] (electronic journal). Vol.1, p. 39. Retrieved from: http://www.politstudies.ru/article/ 3153?printmode. (accessed 08.03.2018)

10. Koltun V. S. (2015). Zakonomirnosti ta tendenciji rozvytku miscevogho samovrjaduvannja: komplementarnyj pidkhid [Policies and Trends in Local SelfGovernment Development: A Complementary Approach]. Kyiv: Feniks.

11. Koncepcija reformuvannja miscevogho samovrjaduvannja ta terytorialjnoji orghanizaciji vlady v Ukrajini (2014). [The Concept of Reforming Local SelfGovernment and Terriyal Organization of Power in Ukraine]. (Electronic resource). Retrieved from: http://zakon2.rada.gov.ua/laws/show/333-2014-\%D1\%80 (accessed: 08.03.2018).

12. Korablinova I. A., Lihoded M. V., Capko A. I. (2014). Komlementarnye formy otnoshenij mezhdu kompanijami i potrebiteljami v sfere infokommunikacij [Complementary form of relations between companies and consumers in the field of infocommunications] Jekonomicheskie nauki / 6. Marketing i menedzhment [Economics Sciences / Marketing and management] (electronic journal). Odesskaja nacional'naja akademija svjazi im. A.S. Popova [Odessa National Academy of Communications named after A.S. Popov]. Retrieved from: http://www.rusnauka.com/ 19_TSN_2014/Economics/6_173439.doc.htm. (accessed: 08.03.2018).

13. Korchevna L. O. (2005). Problema riznodzhereljnogho prava: doslid porivnjaljnogho pravoznavstva [The problem of multi-source law: the test of comparative law] (PhD Thesis). Odesa: Nauka.

14. Krughlov I. (2006). Landshaft jak gheoekosystema [Landscape as a geocosystem]. Visn. Ljviv. un-tu [Bulletin of the University of Lvivs]. vol. 33, pp. 186-193.

15. Lejbnic G. V. (1989). Sochinenija [Compositions]. Moscow: Nauka. (in Russian)

16. Lipov V. V. (2011). Metodologicheskie osnovy issledovanija komplementarnogo vzaimodejstvija rynka i gosudarstva [Methodological basis is the study of complementary interaction between the market and the state]. / В. В. Липов // Teoreticheskaja jekonomik [Theoretical economics]. (electronic journal). Vol. 4., pp. 76-80. (electronic journal). Retrieved from: www.theoreticaleconomy.info (accessed: 08.03.2018).

17. Nazarov A. I. (2014). Princip komplementarnosti v mediaobrazovanii [Principle of complementarity in media education]. Ustojchivoe razvitie: nauka 


\section{Complexity as the immunental properties of local self-governance...}

$i$ praktika [Sustainable development: science and practice]. (electronic journal). Vol. 1, no. 12, p. 14. Retrieved from: www.yrazvitie.ru. Accessed: 08.03.2018.

18. Nalimov V. V. (2003). Verojatnostnaja model' jazyka: o sootnoshenii estestvennyh $i$ iskusstvennyh jazykov [Probabilistic model of language: the relationship of natural and artificial languages]. Tomsk: Tomsk-M.

19. Pilevych D. S. (2013). Sutnistj komplementarnoji investycijnoji polityky derzhavy [The Suit of the Complementary Enlightenment of Power]. Visnyk Chernighivsjkogho derzhavnogho tekhnologhichnogho universytetu. Serija "Ekonomichni nauky" [News of the Chernigiv State Power Engineering University. Серія «Економічні науки»].(electronic journal). Vol. 4, no. 70. p. 67. Retrieved from: http://vistnic.stu.cn.ua/index.pl?task=arcl\&l=ua\&j=31\&id=16. Accessed: 08.03.2018.

20. Prigozhin I. R. (1985). Ot sushhestvujushhego $k$ voznikajushhemu: Vremja $i$ slozhnost' $v$ fizicheskih naukah [From the existing to the emerging: Time and complexity in the physical sciences]. Moscow: Nauka. (in Russian)

21. Prohorov A. M. (1989). Sovetskij jenciklopedicheskij slovar' [Soviet Encyclopedic Dictionary ]. Moscow: Sov. Jenciklopedija.

22. Fateeva S. V. (2006). Komplementarnost'v jekonomicheskoj kul'ture: ponjatie, formy $i$ mehanizm dejstvija [Complementarity in economic culture: the concept, forms and mechanism of action] (PhD).

23. Filosofskij jenciklopedicheskij slovar' (1997). [Philosophical Encyclopedic Dictionary ]. Moscow: INFRA-M.

24. Shemetov P.V., Petuhova S.V. (2008). Teorija organizacij [Theory of Organizations].Moscow: Omega-L

25. Shorkin A. D. (1989). Shemy universuma i genezis nauchnoj racional'nosti [Schemes of the universe and the genesis of scientific rationality]. Filos. $i$ sociolog. mysl' [Philosophical and sociological thought]. - vol. 3., pp. 22-33.

26. Shuhov A. (2012). Metrologicheskij fakt i obshhaja teorija komplementarnosti [Meteorological fact and the general theory of complementarity]. Filosofskij portal 2012 [Philosophical portal 2012]. Philosophical portal 2012 (electronic journal). Retrieved from: http://nounivers.narod.ru/ (accessed 08.03.2018).

27. Amable B. Institutional complementarity and diversity of social systems of innovation and production / B. Amable // Review of International Political Economy. - 2000. - V. 7, Issue 4. - P. 645-687.

28. Aoki M. Contingent Governance of Teams: Analysis of Institutional Complementarity / M. Aoki // International Economic Review. - 1994. Vol. 35. - P. 657-676.

29. Bernstein R. J. The New Constellation. The Ethical-Political Horizons of Modernity / R. J. Bernstein // Postmodernity. - Cambridge, 1991. - P. 8.

30. Hall P. An introduction to varieties of capitalism / P. Hall, D. Soskice // Varieties of capitalism: the institutional Foundations of Corporative Advantage. Oxford: Oxford University Press, 2001. - P. 1-68.

31. Robertson R. Glocalization: Time-space and homogeneity - heterogeneity / R. Robertson // Global Modernities. - 1995. 
IMPACT OF PLANT BIOMETRIC CHARACTERISTICS ON SEED PRODUCTIVITY OF CASTOR-OIL PLANT AND SWITCHGRASS DEPENDING UPON WEATHER CONDITIONS OF THE VEGETATION PERIOD IN THE FOREST-STEPPE OF UKRAINE

\title{
Kulyk Maksym ${ }^{1}$ \\ Shokalo Natalia ${ }^{2}$
}

DOI: http://dx.doi.org/10.30525/978-9934-571-26-8_10

\begin{abstract}
The article has demonstrated the necessity of investigating new, alien crops such ascastor-oil plant (Ricinus communis L.) and switchgrass (Panicum virgatum L.) as a raw material for production of biofuel and by-products for different fields of industry. The detailed description of plant morphology, and practices regarding increase of seed germination ability of the studied crops have been given. Solid literature overview has been made and attention has been emphasized on the up-todate of the research of castor-oil plant and switchgrass seed productivity. Expanding of cultivation area enables to provide farmers with seed material as well as processing industry with raw material. In future this will permit to obtain seed material, plant biomass for energy purposes and technical oil of high quality in order to satisfy requirements of strategic fields of industry.

Research object is the morphological and biological peculiarities and seed productivity of castor-oil plant and switchgrass depending on quantitative indices of plants considering weather conditions of the vegetation period.

Methods. Methods of multi-year research in the forest-steppe of Ukraine are standard for the zone of these crops cultivation and special methodical recommendations have been used as well. The area of seeding plot of land was $54.0 \mathrm{~m}^{2}$, the area of accounting plot of land was $50 \mathrm{~m}^{2}$, experiment

\footnotetext{
${ }^{1}$ Candidate of Agricultural Sciences, Associate Professor,

Senior Research Assistant of the Research Department,

Poltava State Agrarian Academy, Ukraine

${ }^{2}$ Candidate of Agricultural Sciences,

Associate Professor of the Department of Selection, Seed Science and Genetics,

Poltava State Agrarian Academy, Ukraine
} 
repetition is four time. Allocation of plots of land in the field is random. Observations and analyses have been applied according to the appropriate research recommendations. Statistical processing of the research results have been done by the analysis of variance as well as correlation and regression analysis, applying licensed computer programme Statistica-6.0.

Results. Switchgrass and castor-oil plant response to the environmental conditions has been defined and this enables to allocate these crops in certain soil and climate zones of Ukraine reasonably and choose the ideal elements of the cultivation technology. This will permit to work out farm operations for the development of conditions close to favourable for plant growth and development and providing high productivity of phytomass and seed.

It has been determined that studied crops have similar responses to the weather conditions. Under optimal conditions during the vegetation period (hydrothermal coefficient near or more than 1.0) increase of biometric characteristics, seed size and seed productivity has been recorded and vice versa. Established correlation dependencies have proved this factor $(r>0,70)$. Statistically proved that castor-oil plant provides higher seed productivity (to $2.68 \mathrm{Tt} / \mathrm{ha}$ ) depending on the length and number of clusters per the plant and switchgrass provides seed productivity depending on the length and number of panicle per the plant (to $0,93 \mathrm{t} / \mathrm{ha}$ ). It has been also defined that seed productivity has close correlation connection with seed yield that is determined by biometric characteristics of the reproductive organs.

Conclusion. Considerable impact of air temperature and precipitation on the formation of crop productivity elements has been established according to the results of five-year experiment. Impact of air temperature and precipitation is determinative for switchgrass and castor-oil plants yield and productivity. It has been found that increase of precipitation as well as growth of air temperature is favourable for castor-oil plants yield but much drier weather of the vegetation period is better for switchgrass yield.

Taking into consideration research results according to biometric characteristics of plants and seed productivity depending on weather conditions, castor-oil plant can be recommended to cultivate on farms in the central forest-steppe of Ukraine in order to get technical oil of high quality and switchgrass is recommended to be used for biofuel production and energy generation. 


\section{Introduction}

Today more thorough investigation of alien crops is increasingly demanded because of weather conditions changes, increase of temperature regime, frequent droughts and necessity of introducing new crops in order to get extra profit. Castor-oil plant and switchgrass are distinguished among the new crops which have scientific and practical importance and require detailed study of seed formation peculiarities to satisfy farm producers needs.

Castor-oil plant is an oil crop that is getting incresing influence over the economy year in year out in view of science and technology advancement. Taking in the fact that at the beginning of the past century the castor oil was mostly known in medicine, and now it is in great demand in many industries - automibile, machine engineering, pait-varnish and chemical ones [1].

Castor-oil seeds depending on the variety and cultivation conditions accumulate $50-55 \%$ of oil (castor or ricin one) that belong to the group of non-drying ones. This oil is sticky, slightly dissolvable in petrol and other organic solvents, does not hardened at low temperatures $\left(12-18{ }^{\circ} \mathrm{C}\right.$ below zero) and burns at high temperatures (300-3100C above zero). These properties make castor-oil an excellent oil material crop and it is used in different fields and directions [2].

Switchgrass is a drought-resistent, long-years standing crop that has simplified cultivation technology with minimal fertilizers applied and irrigation absence. The lesser irrigation and fertilizers applied means reduction of energy consumption that in turn means the lesser costs and emission of greenhouse gases are. Moreover, the crop is not soil demanding and no competitor to food crops.

Fuel obtained out of switchgrass raw material is used for producing solid (fuel pellets, bars) and liquid biofuel-cellulose ethanol. Besides using for biofuel, the grass mentioned above has a whole lot advantages and wide range of applications.

Switchgrass is used in construction, paper production, greening, animal feeding and effective environment pollution soil purification as well (phytoremediation). Above-mentioned crop is used as good grazing weed for animals (in spring), and haymaking process (in summer). Switchgrass does have a significant influence on lowering erosion processes over worn-out clay pits, coil pits, sand dunes, dams and other man-contaminated soils. The crop is suitable for wind-resistant greenery as well [3]. 
Switchgrass betters nature biodiversity, is being a natural habitat for many species of small animals and birds, diversity of insects provided them with shelter and nutrition. Switchgrass accumulates a significant mulching layer over its long cycle of life(fallen leaves, plant stems) that in addition to moisture increases the mixture of organic substance in soils that are not enriched with useful substances [4].

\section{Morphological and biological characteristics of castor-oil plant}

Castor oil plant (Ricinus communis L.) is a species in the spurgy family. There is a great diversity of castor-oil plant forms. They differ by appearance, biological demands and farm peculiarities (figure 1).

In Ukraine castor-oil plant is an annual grass that can reach the size from 0.5 to $5 \mathrm{~m}$ with strong root system. The root system consists of thich primary root and 3-6 large lateral roots with numerous tillers which form smaller roots. Primary root of castop-oil plant penetrates into soil to 2-4 m depth and lateral roots to $1.5-2 \mathrm{~m}$ depth. However, late-ripening forms have stronger root system than early-ripening ones. Moisture deficit results in root growth into the depth. In wet years roots grow closer to the surface using rainfall moisture.

Castor-oil plant stem is hollow, geniculate, change in colour with 15-18 or more internodes. The faster ripening form the less internodes it has. The most fast-ripening forms have stem with 5-6 internods and the most late-ripening varieties have more than 18 internods. Primary branches grow from the main stem, the secondary branches grow from the primary and the third branches grow from the secondaryones. Castor-oil plant does not develop branches of other orders in Ukraine.

The number of branches changes according to the nutrition area, weather, soil and other conditions. Plants almost do not branch out on the dense crop areas, in hot summer or on low-productive soils. On the contrary, plants branch out well in humid years and on fertile soils.

Stems, leaves, petioles and unripe fruit capsules can be covered with slight or thick waxy bloom and there are forms where waxy bloom is absent.

The plant is leafy. Leaves are petioled, alternate, except two first - opposite. Petioles are of different length $(15-45 \mathrm{~cm})$, smooth with the colour of the stem. Leaf blade is peltate with 7-11 lobes and with toothed segments. Different botanical forms have different sizes of leaves. Plants are divided into large-leaved, small-leaved and middle-leaved ones according to the leaf 


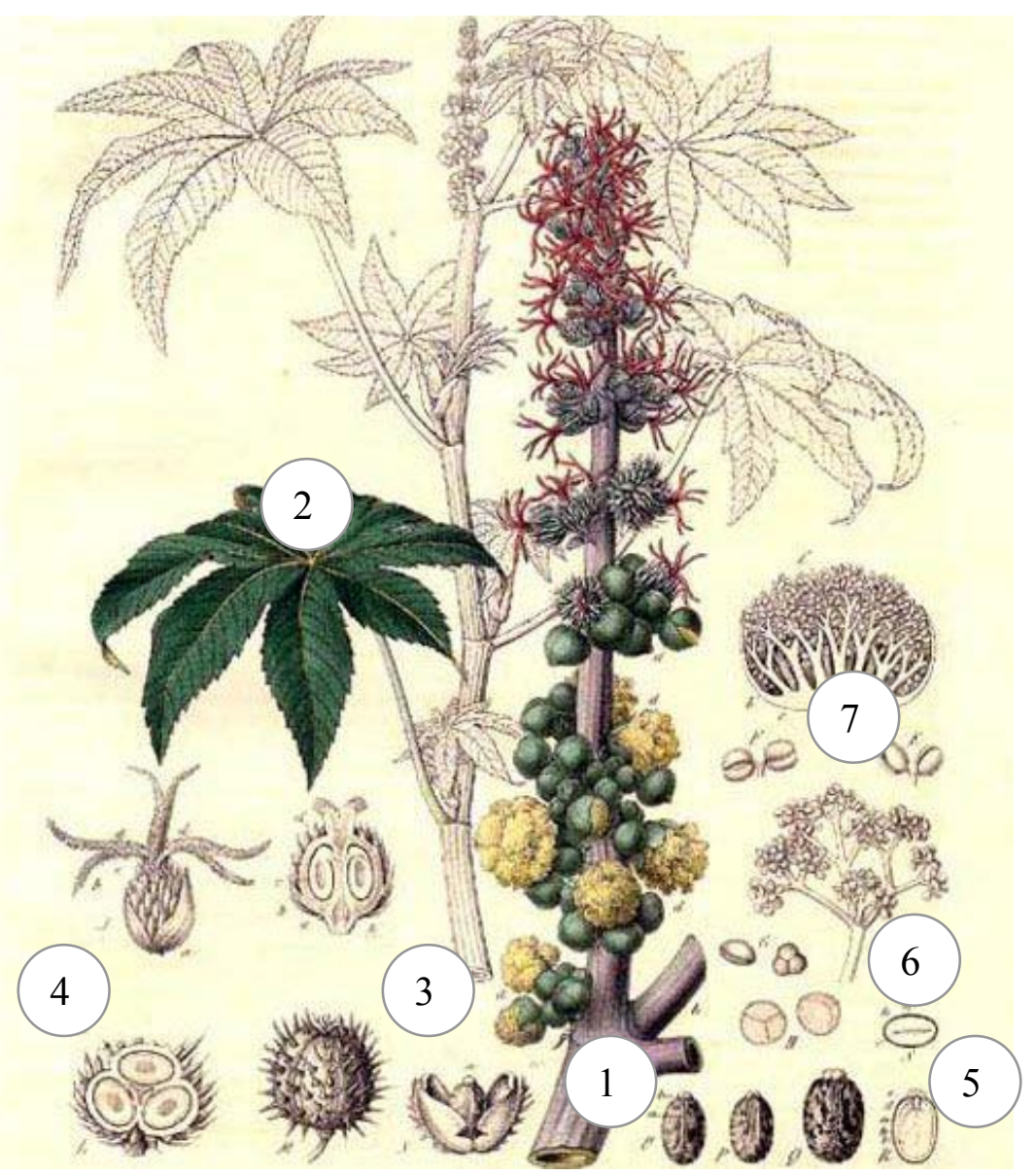

Fig. 1. Morphological structure of castor-oil plant (Ricinus communis L.).

1 - inflorescence; 2 - leaf; 3 - stem; 4 - fruit; 5 - seeds; 6 - the male flowers; 7 - the female flowers.

size of the middle layer. Green forms have green leaf blade, whereas other forms have fallow young leaf and mature leaf with green and purple ribs [5].

Castor-oil plant flowers are heterosexual, small, in terminal panicle-like inflorescences. There are clusters of the main stem (central), the first order 
and etc. Clusters of both male and female flowers are bunched in groups tsimas. They are spirally arranged on the inflorescence caudex. Each tsima has the central flower, flower of the first order and etc. Tsimas with male flowers are placed at the bottom of inflorescence and with female flowers at the top of inflorescence. There are forms providing dioecious plants not depending on weather conditions.

The fruit is a three-lobed capsule. Each lobe contains one seed. Capsules are oval, elongate, spherical and of different sizes. Capsule size depends on the botanical castor-oil form, place in inflorescence, and inflorescence place itself. Capsules are smaller at the top of the central raceme and on the lateral racemes.

The external cover of the unripe capsule can be smooth, wrinkled and spiny. The capsules are green, dark-green, yellow, pink, red, dark-red and purple.

Capsules of some forms split out forcibly ejecting seeds, whereas others do not. Splitting can be strong, moderate and weak. Varieties grown in Ukraine have capsules which do not split out or split out moderately

Forms of castor-oil plant clusters are conical, narrow-cone, cylindrical, widely cylindrical and oval. Clusters are very long when the whole fruit system is occupied by capsules, long when capsules occupy $2 / 3$ of the fruit system, of middle size when $1 / 2$ of the fruit system is occupied and short when capsules occupy $1 / 3$ or less of the fruit system length. Cluster length is measured by the distance from the bottom to the top capsule.

Castor-oil seeds are shiny beans of different colour, size and form with smooth shine surface. They are differentiated by background colouring and mosaic. Background can be grey, blue-grey, light-brown, dark-brown, lightred, dark-red. Mosaic colouring can be white, light-grey, pinkish, lightbrown [6].

Forms of seeds are egg-shaped, ellipsoid, bean-like. Some botanical forms at the end of mature seed havea warty appendage called the caruncle. The caruncle is hyghly important for corcle nutrition and turns into dry husk [7].

Large sized seeds with length from 22 to $15 \mathrm{~mm}$, middle-sized seeds with length from 14 to $9 \mathrm{~mm}$ and small-sized seeds with length from 8 to $5 \mathrm{~mm}$ are distinguished. Mass of 1000 seeds is from 70 to $1000 \mathrm{~g}$ depending on the botanical form and cultivation conditions. The mass of small seeds is $160-290 \mathrm{~g}$, mass of middle seeds is $290-350 \mathrm{~g}$ and mass of large seeds is 
$350-1000 \mathrm{~g}$. Seed kernel is white, very oil and forms $63-83 \%$ of total weight while glumes forms $17-37 \%$ [8].

Castor-oil plant tends to continuous growth and remanent development that result in different periods of harvesting affects growth and development of castor-oil plant as an annual crop. Thus, forms of chinese subvariety have rapid development rates and weak vegetative growth, Zanzibar and Communis subvarieties are characterized by strong growth and slow development rates.

Castor-oil development has the following phases: emergence, formation of the central cluster, flowering, ripening of seeds of the central and lateral primary, secondary and other clusters [9].

Castor-oil plant reproduction is by seed. Seed germination goes by fat reserve consumption and at the expense of its energy plantlet develops. In dry seed corcule part is $3-3.5 \%$, at the end of germination it is $87-88 \%$; the mass of endosperm decreases from 97 to $12 \%$.

The temperature minimum that support transition of seed from dormancy to vitality is physiological zero. Trials of Kherson Agricultural Institute proved that forms of Persydski castor-oil plant subvariety have the border of the lower physiological zero of 7.1-7.7 ${ }^{\circ} \mathrm{C}$ and forms of Sangvineus subvariety $-10.2^{\circ} \mathrm{C}$, amount of effective temperatures for germination is $59.8^{\circ} \mathrm{C}, 53.6^{\circ} \mathrm{C}$ and $56.6^{\circ} \mathrm{C}$ respectively. Different speed of water uptake, chemical seed composition, ratio of hydrophilious colloids and hydrophobic fats results in different physiological zero and amount of temperature needed for subvarities germination [10].

Minimal $\left(10^{\circ} \mathrm{C}\right)$, optimal $\left(14-15^{\circ} \mathrm{C}\right)$ amd maximal $\left(35-36^{\circ} \mathrm{C}\right)$ temperatures of castor-oil seeds germination are distinguished. Castor-oil seed has to absorb from 28 to $32 \%$ of water in order to germinate. Whereby, low oil content varieties absorb more water than seeds of high oil content varieties.

During the fruit-formation period seeds of the central clusters ripen, lateral brunches with clusters grow, fruits are formed on these branches, seeds are formed and ripened. Flowering and seed ripening of lateral primary and secondary clusters is an interphase. Ripening of seeds pods of the central clusters, which form $65-90 \%$ of total harvest of many varieties is an important development interphase.

In years with wet summer and warm autumn and under irrigation conditions the fruit formation period continues, whereas it reduces in drought.

Varieties grown in Ukraine need ammount of active temperatures $\left(>10^{\circ} \mathrm{C}\right)$ from 2000 to $3800^{\circ} \mathrm{C}$ and no frost period for $140-180$ days [11]. 
The temperature conditions for castor-oil plant can not be examined separately from irrigation conditions. In these conditions moisture deficit is formed (especially in late sowing) and as a result castor-oil plant productivity dramatically decreases. In years with rainy and cool summer castor-oil plants has warmth deficit. High warm balance should be combined with adequate moisture regime.

\section{Morphological and biological switchgrass characteristics}

Switchgrass is a perennial crop. It can grow up to $3 \mathrm{~m}$ with $12-14$ to 30-35 productive trailings per the plant. Plants can be straight and slightly curved. The number of metameres on the stem is from 3 to 7 and in some forms this number is up to 9. Diameter near stem base is 4-6 mm on average but forms with thin and thick stems are also present. Leaf blade is $50-60 \mathrm{~cm}$ long, width is $11-14 \mathrm{~mm}$. Panicle is flat, oval, pyramidical and cob-like. Panicle length is $30-40 \mathrm{~cm}$, width is $20-30 \mathrm{~cm}$. Seeds are divided into three groups according to mass of 1000 seeds. The following ones: small mass group up to $1.5 \mathrm{~g}$, average mass group up to $1.5-1.8 \mathrm{~g}$ and big mass group over $1.8 \mathrm{~g}$. Perennial rhizomes can be splitted into 8-25 (up to 80) parts, each of them is $5-7 \mathrm{~cm}$ long in vegetative reproduction.

Switchgrass plant (Panicum virgatum L.) consists of root system, stem, leaves, sheath, inflorescence in which in spikelets fruit (corn seed) is formed (figure 2).

Switchgrass goes the full development cycle (from seed to seed) throughout the first vegetation period. The crop completes intensive vegetation in October-November depending on genotype. The intensive plant regrowth begins after overwintering, in early spring. The phase of stem formation comes in the second decade of July. Flowering period lasts since the third decade of July till the first decade of August. Ripening period is late September - the middle of August. The vegetation period lasts 175-185 days [12].

Yield of above-ground plant phytomass in the period of panicle show is $42-64 \mathrm{t} / \mathrm{ha}$, in the flowering period is $42.73-70.19 \mathrm{t} / \mathrm{ha}$; dry mass is $10-15 \mathrm{t} / \mathrm{ha}$; seeds is $500-600$ (sometimes up to 1000 ) $\mathrm{kg} / \mathrm{ha}$. Plant energy productivity is $40-60$ (to 80 ) Gcal/ha [13].

Peculiarities of ontomorphogenesis of switchgrass plants have been examined during the first and the next life cycle. Depending on form and variety characteristics plants of early forms complete intensive vegetation 


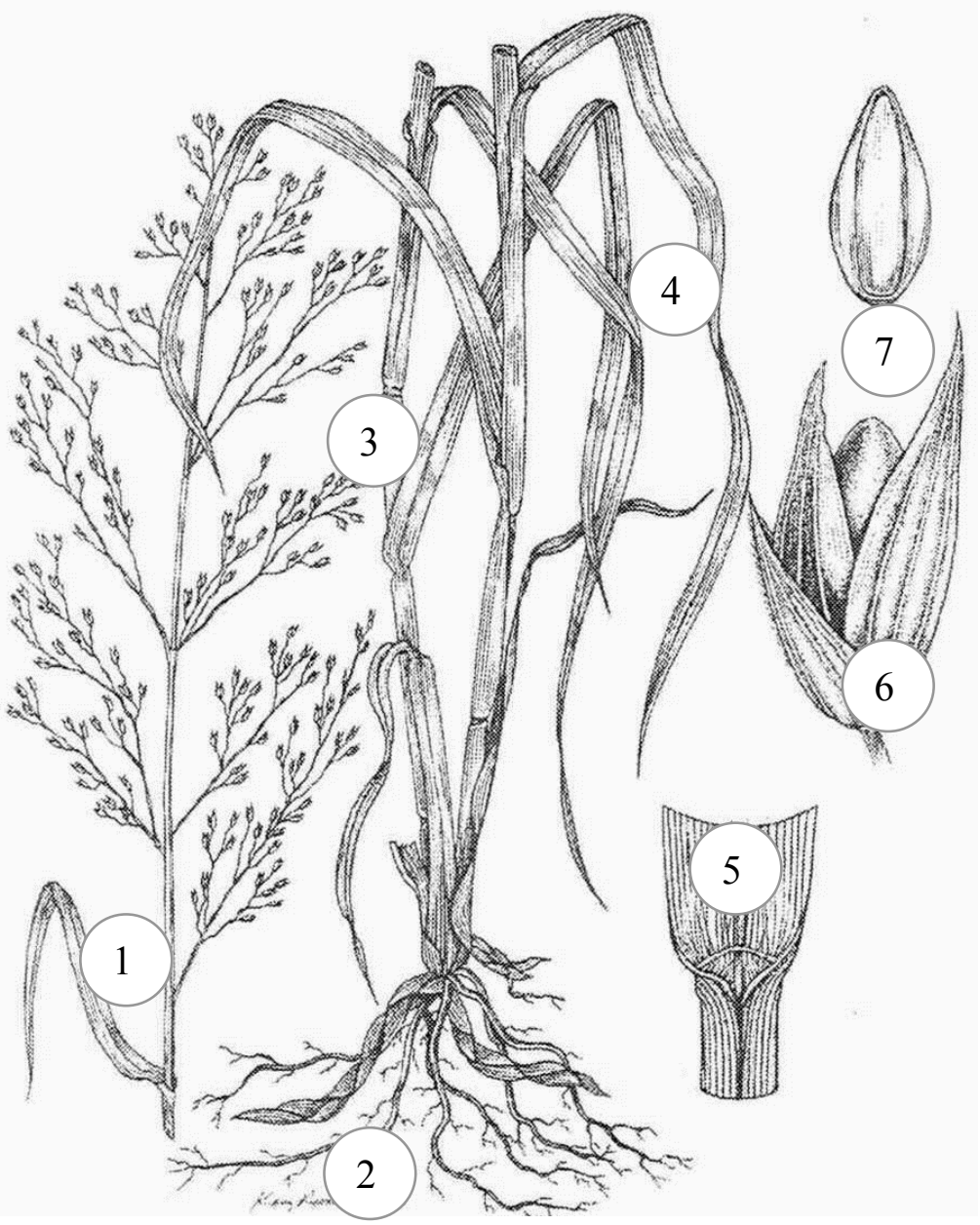

Fig. 2. Morphological structure of switchgrass plant (Panicum virgatum L.)

1 - inflorescence; 2 - root system; 3 - stem; 4 - leaves; 5 - sheath; 6 - spikelet; 7 - seeds.

in the third decade of August, the plants of middle forms complete vegetation till the end of September and the plants of late forms complete vegetation till the end of October. 
In some years plants of late and very late forms have green colour till strong frost $\left(-5 \ldots-7^{\circ} \mathrm{C}\right)$. Different autumn colouring of above-ground mass is typical for switchgrass plants of different forms and varieties and this testifies to plant vegetation completion.

In early June plant develops to the bushing out phase and formsplant density up to $50-70 \mathrm{~cm}$.

Intensive plant growth lasts to the first decade of August when they develop to flowering phase and reach up to $140-160 \mathrm{~cm}$.

Height parameters slow down till the beginning of seed ripening period. The seed ripening phase of different switchgrass forms comes in different terms and depends on the temperature regime.

During the vegetation period switchgrass goes through certain periods related to the changes of quantitative and qualitative plant characteristics. Therefore, we recommend to record the dates of the next development and growth phases after sowing, from emergence phase till the plant vegetation completion.

Planting-emergence period is rather long (to 30 days), that is linked to the structure of seed pellicle as well as demand of moisture for acceleration of biochemical changes in seed endosperm [14].

In the period of formation of the third true switchgrass leaf, secondary tillers separate from the stem node while the moisture is present for several days.

The next stages of growth and development are bushing out phase and stem formation phase.

The most intensive growth of switchgrass plants takes place in summer during flowering phase and gains nearly $75 \%$ of total plant biomass. After flowering phase completion stems grow older and stiffen as fruit-bearing seed ripening period comes.

In Ukraine growth and development cycle finishes in October-November till cold weather. During the period of vegetation completion reserve constituents pass from leaves and stems into bushing nodes and rhizome where they are stored till the next growth cycle. Renewal of spring vegetation is a start of the next stage of crop life cycle. Then phases of growth and development are repeated to the end of vegetation period. In Ukraine we have not observed senile period till 20 years. Thus, switchgrass can belong to cereal grass of very long, productive life cycle (more than 20 years) [15]. 
Investigation of switchgrass growth and development in the first and the next years will enable to study dynamics of quantitative and qualitative changes in ontogenesis, determine the duration of interphase periods during long life cycle. This will allow to define the most critical periods in organogenesis as well as work out optimization actions due to various fertilizers, biological components and land treatment.

\section{Overview of the published works related to the research}

Castor-oil plant is originated in Africa, it was grown in Egypt and gradually dispersed towards Asia, America and Europe.

The world sowing area of castor-oil plants is almost 1.5 million hectares. It is widespread in Brasil, India, Thailand and throughout other tropical countries. In Ukraine castor-oil plant sowing areas were 110-120 thousand hectares in the years of the USSR. This crop was mainly grown in Zaporizhia oblast, Mykolaiv oblast, Odessa oblast, Kherson oblast, Dnipropetrovsk oblast and Crimea [16].

Manifestation of castor-oil plant morphological characteristics depends on the environmental impact. Even slight changes of environmental factors such as humodity or temperature considerably affect vegetative organs [17].

Castor-oil plant is highly demanding to warm weather. Varieties grown in Ukraine need amount of active temperatures $\left(>10^{\circ} \mathrm{C}\right)$ from 2000 to $3800{ }^{\circ} \mathrm{C}$ and no frost period for $140-180$ days.

In the emergence period, depending on the variety, essential amount of temperature is $160-350{ }^{\circ} \mathrm{C}$, in the emergence-flowering period essential amount of temperature is $800-1200{ }^{\circ} \mathrm{C}$ and in the fruit-formation period is $1200-2000{ }^{\circ} \mathrm{C}$. Varieties of different subforms have diverse warmth demands. In the field conditions emergence begin in 20-25 days at soil temperature of $10-12{ }^{\circ} \mathrm{C}$, in $12-14$ days at soil temperature of $14-16^{\circ} \mathrm{C}$ and in 9-11 days at soil temperature of $18-20^{\circ} \mathrm{C}$ [18].

Trials of V. N. Salatenka and V. K. Ivanova (1971) have shown that full-value uptake of warm weather potential of the south of Ukraine by castor-oil plants is possible only altogether with irrigation. It has been established that water consumption throughout the vegetation is $3000-5000 \mathrm{M}^{3}$ per 1 ha. It has been proved that castor-oil plants need no less than 180-200 $\mathrm{mm}$ of rainfall in order to provide average yield. Demands of humidity differ according to the periods. Humidity excess in the first part of vegetation and in autumn is harmful as it causes intensified 
growth of vegetative organs at the expense of reproductive organs. Castor-oil plants consume the greatest amount of water during the phases of flowering and seed filling. This period is critical. In Ukraine it lasts from late July till early August. In drought during this period leaves wither away, flowers and seed capsules fall off [19].

Conditions of optimal water availability are formed at moisture of active soil layer: in the period of flowering of the central raceme and the primary racemes no less than $80 \%$, in the seed filling-ripening period no less than $65-70 \%$. Excess of moisture in the third period results in unfavourable renewal of growth processes.

Moisture index of castor-oil plant changes depending on the cultivation conditions and varies from 300 to 630 and water consumption coefficient varies from 2600 to $3020 \mathrm{~m}^{3}$ per 1 ton of seeds [20].

Switchgrass grows on eastern side of Rocky mountains at wide natural habitat, on the south along 55 degrees of northern longitude all the way down to Mexico and Central America. It is one of the main variety of north-american high grass which grows all over the prairies. The crop has been cultivated against soil erosion and natural preservation while also used for animal nutrition production. Switchgrass varieties are also populated on other continents where they are being cultivated for animal nutrition production $[21 ; 22]$.

Switchgrass seeds are usually harvested in the second and the next years of vegetation. Switchgrass seed is relatively fine, mass of 1000 seeds varied from $1.76 \mathrm{~g}$ to $1.96 \mathrm{~g}$. Average length of each seed is $2.4 \mathrm{~mm}$, width is $1.0-1.5 \mathrm{~mm}$.

It has been established that a great part of harvested seeds does not germinate the next year after being harvested and can have only $10 \%$ of germination. However, prolong after-harvesting period of ripening, storage in warm and cool places, stratification increase this index. At this time grain ripening is stimulated and it resulted in malaxation of seed pellicle layers and acceleration of biochemical process in the corcule [23].

Adaptive responses of wild plants to unfavourable soil and weather conditions explain low emergence of switchgrass seeds. That is why considerable part of seed material is in biological dormancy [24].

Factors that cause a state of natural calm are very diverse - reduced activity of the embryo or various properties of seed membranes, etc. $[25 ; 26]$. Foreign scientists found that the resting state to the vast number 
of species is controlled by the hormonal system and the presence of certain acids in seeds [27].

High dormancy level can be reduced while storing seeds at low temperatures $\left(4{ }^{\circ} \mathrm{C}\right)$ and relative humidity of $40 \%$ or at room temperatures for several years [28].

We determined that seed productivity can be $220-560 \mathrm{~kg} / \mathrm{ha}$ and sometimes switchgrass provides up to $1000 \mathrm{~kg} / \mathrm{ha}$. In the conditions of forest-steppe of Ukraine switchgrass varieties Sunburst and Cave-in-Rock of the second vegetation year provide seed productivity of 597 and $373 \mathrm{~kg} / \mathrm{ha} \mathrm{[29].}$

Switchgrass plants are able to take advantage of favourable conditions for growth and development and accumulate great amount of dry biomass during the vegetation period. However, proper requirements of cultivation conditions, especially to warm weather and humidity must be satisfied [29].

Impact of origin climate conditions resulted in switchgrass adaptability to high temperatures and sun intensity $[30 ; 31]$.

\section{Research methods}

Multi-year researches have been conducted by field and laboratory trials. Study of seed productivity of castor-oil plant and switchgrass with quantitative characteristics depending upon weather of the vegetation period has been planned according to the programs of the research.

The area of seeding plot was $54.0 \mathrm{~m}^{2}$, the area of accounting plot was $50 \mathrm{M}^{2}$, experiment repetition is four time. Plots were arranged in a randomized design.

The following observations and analyses have been used:

- planning and laying out of trials according to the methods of agronomy researches [32] and methods [33];

- phenological observations of plant growth and development have been made by the methods of state crop variety testing [34];

- quantitative characteristics of castor-oil plants have been determined by the methods [35], swithgrass characteristics by the methods [36, 37];

- seed yield has been accounted by weighing seed material of each plots followed by recalculation to $14 \%$ moisture [38];

- mass of 1000 seeds has been determined according to State Standards of Ukraine (DSTU) 4232-2003;

- statistical processing of the research results have been done by the analysis of variance (the least significant difference - $\mathrm{LSD}_{05}$ ) as well as 
Impact of plant biometric characteristics on seed productivity of castor-oil...

correlation and regression analysis, applying licensed computer programme Statistica-6.0.

\section{Research results}

Description of meteorological characteristics of the trial period (2012-2016 years) is highly important for establishing seed productivity level as castor-oil plant and switchgrass are quite sensitive to the weather changes during the vegetation period. Dynamics of daily average decade air temperature and precipitation during vegetation period (May-September) is shown in figure 3-4.

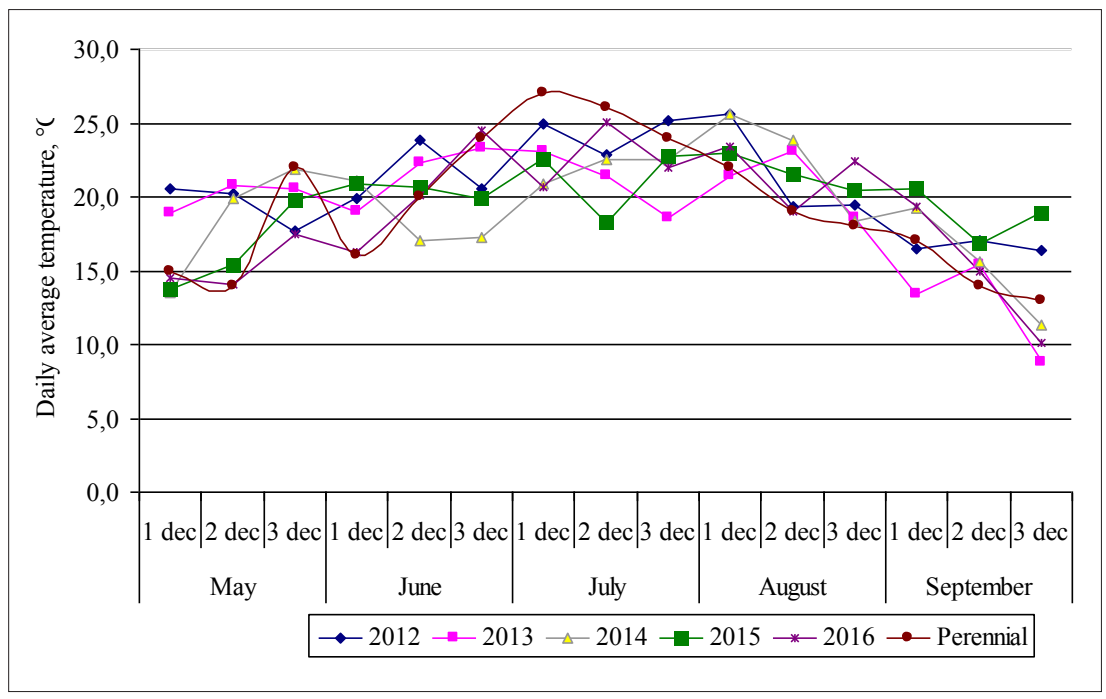

Fig. 3. Daily average and many-year average temperature during May-September period in 2012-2016 years

Daily average air temperature during May-September period shows increase of this characteristic in 2013-2014 and great decrease in 2012. Precipitation during this period of time was the highest in 2013 with decreasing to $18.9 \mathrm{~mm}$ in 2016. More reliable characteristic is hydrothermal coefficient (HTC), which varied from 0.1 (2012) to 1.2 (2015).

Having analyzed weather conditions of the vegetation period according to HTC index we have established that 2012 and 2013 year were dry, 


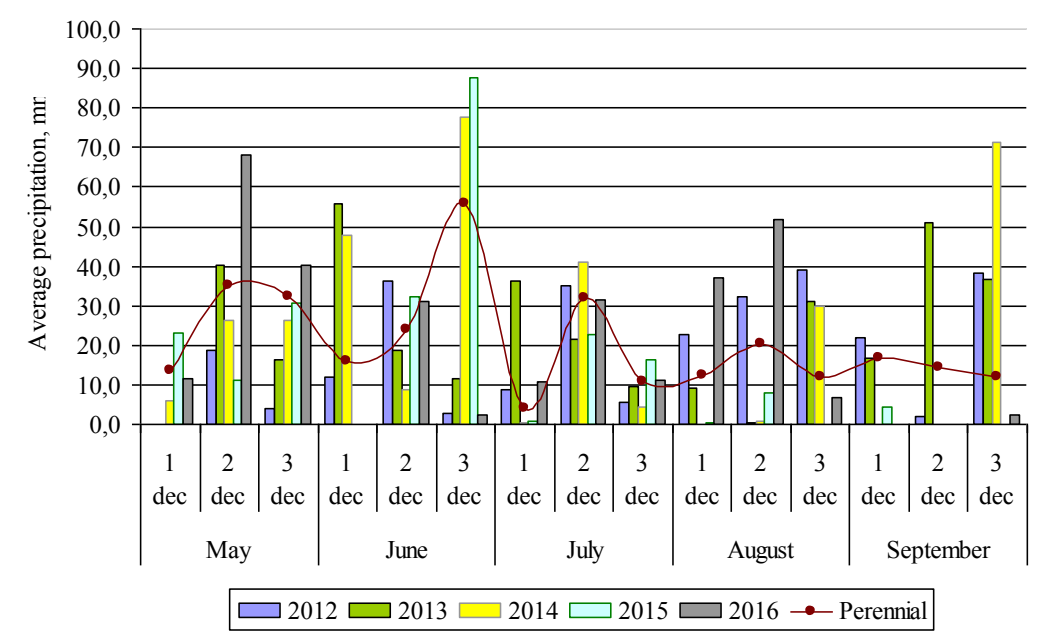

Fig. 4. Daily average and many-year average precipitation during May-September period in 2012-2016 years

2015 was subhumid, 2014 and 2016 years were characterized by average humidity.

Research results of castor-oil plant. Hydrothermal coefficient somehow affected quantitative castor-oil characteristics which by plant height, height of attachment of lower raceme, length and number of racemes, seed mass and size widely varied and depended on the conditions of the cultivation year (Table 1).

Table 1

Biometric characteristics of castor-oil plant, 2012-2016 years

\begin{tabular}{|c|c|c|c|c|c|c|}
\hline \multirow{2}{*}{ Characteristics } & \multicolumn{5}{|c|}{ Vegetation year } & \multirow{2}{*}{$\begin{array}{c}\text { Duncan } \\
\text { test, } \\
\text { p } 0,05\end{array}$} \\
\hline & 2012 & 2013 & 2014 & 2015 & 2016 & \\
\hline Plant height, $\mathrm{cm}$ & 68,8 & 175,9 & 173,5 & 179,1 & 187,0 & 9,2 \\
\hline $\begin{array}{l}\text { The height of bottom raceme } \\
\text { attachment, cm }\end{array}$ & 40 & 78,8 & 57,3 & 78 & 116,6 & 9,3 \\
\hline Length of the central raceme, $\mathrm{cm}$ & 13,9 & 25,4 & 22,9 & 36,8 & 32,6 & 4,8 \\
\hline Number of racemes & 1,0 & 5,1 & 5,3 & 3,4 & 4,8 & 0,70 \\
\hline Mass of seeds per one plant, $g$ & 23,6 & 75,2 & 117,2 & 86,8 & 67,0 & 21,7 \\
\hline Mass of 1000 seeds, $g$ & 247,8 & 270,2 & 324,0 & 336,0 & 312,5 & 1,77 \\
\hline
\end{tabular}


It has been determined that castor-oil plant height varied from 68.8 to $187.0 \mathrm{~cm}$ during the trial period. The highest plants were recorded in 2016. The weather conditions of this year were the most favourable for the last several years according to water availability and air temperature indices. In 2016 stable transition of daily average temperature from $+10^{\circ} \mathrm{C}$ to higher took place on April 5-6, 14-16 days earlier than usually. Precipitation in April-May exceeded 2-4 months means that resulted in faster crop vegetation. Summer months were quite warm and rainy. Lowering of daily average temperatures up to $+8-13{ }^{\circ} \mathrm{C}$ began in the middle of September. Such weather conditions were favourable for castor-oil seeds ripening.

The height of lower cluster attachment directly depends on water availability especially in the first part of the vegetation period. So, from 2012 to 2016 height of lower cluster attachment varied from $40.1 \mathrm{~cm}$ in 2012 to $116.6 \mathrm{~cm}$ in 2016 .

The lenth of the lower cluster was the shortest in $2012-13.9 \mathrm{~cm}$ and the longest in $2015-36.8 \mathrm{~cm}$. Castor-oil plant forms from 1 to 6-7 clusters depending on weather. Thus, in 2012 when precipitation was dramatically low during the vegetation period mostly only one cluster per plant was formed. In years with more water availability 3-6 clusters were formed. It has been established that the central cluster substantially exceeds the secondary and the third clusters by both size and number of seeds.

During the trial we recorded plants with 3-4 well-formed clusters or sometimes 5-6 clusters with small number of seeds. In early 2012 August castor-oil seeds were already ripened. However, rainfall in the second decade caused growth of the secondary branches and formation of additional inflorescences that negatively affected seed productivity.

The mass of seeds per one plant changed from $247.8 \mathrm{~g}$ in 2012 to $336.0 \mathrm{~g}$ in 2015. The wide range of this characteristic depended on both water availability of plants during the vegetation period and in which development phase rainfall and optimal temperatures were present. For example, in 2016 castor-oil plants were actively gaining vegetative mass because of excessive rainfall. But these conditions were not favourable for seed setting. Tthe mass of seeds per one plant was $67.0 \mathrm{~g}$ on average and the mass of 1000 seeds was $312.5 \mathrm{~g}$.

Quantitative characteristics of castor-oil plants which highly affect castor-oil plant productivity have been determined by correlative-regression analysis (Table 2). 
Table 2

Correlation coefficient of quantitative plant characteristics and seed productivity of castor-oil plants, 2012-2016

\begin{tabular}{|l|c|c|c|c|c|}
\hline \multirow{2}{*}{\multicolumn{1}{|c|}{ Characteristics }} & \multicolumn{5}{|c|}{ Vegetation year } \\
\cline { 2 - 6 } & $\mathbf{2 0 1 2}$ & $\mathbf{2 0 1 3}$ & $\mathbf{2 0 1 4}$ & $\mathbf{2 0 1 5}$ & $\mathbf{2 0 1 6}$ \\
\hline Plant height, cm & 0,53 & $-0,11$ & 0,42 & 0,43 & 0,22 \\
\hline Height of bottom cluster attachment, cm & 0,40 & $-0,05$ & 0,34 & $-0,02$ & 0,33 \\
\hline Length of the central cluster, cm & $0,80^{*}$ & $0,61^{*}$ & $0,37^{*}$ & $0,30^{*}$ & $0,69^{*}$ \\
\hline Number of clusters & - & $0,82^{*}$ & $0,44^{*}$ & $-0,17$ & $0,79^{*}$ \\
\hline Mass of 1000 seeds, $\mathrm{g}$ & $-0,27$ & $-0,02$ & 0,10 & 0,19 & $-0,31$ \\
\hline
\end{tabular}

* Note: $\mathrm{p}<5,0 \%$

The length of the central cluster and number of clusters per plant have the greatest impact on castor-oil plant productivity. In 2012 the length of the central cluster ( $\mathrm{r} 0.80$ ) had great impact on weight of seeds per plant. In 2015 this link lowered (r 0.30) and in 2014 number of clusters per plant had middle impact ( $\mathrm{r} 0.44)$.

In 2013 and 2016 the length of the central cluster and total number of clusters affected castor-oil seeds productivity as well as seed yield of the crop (figure 5).

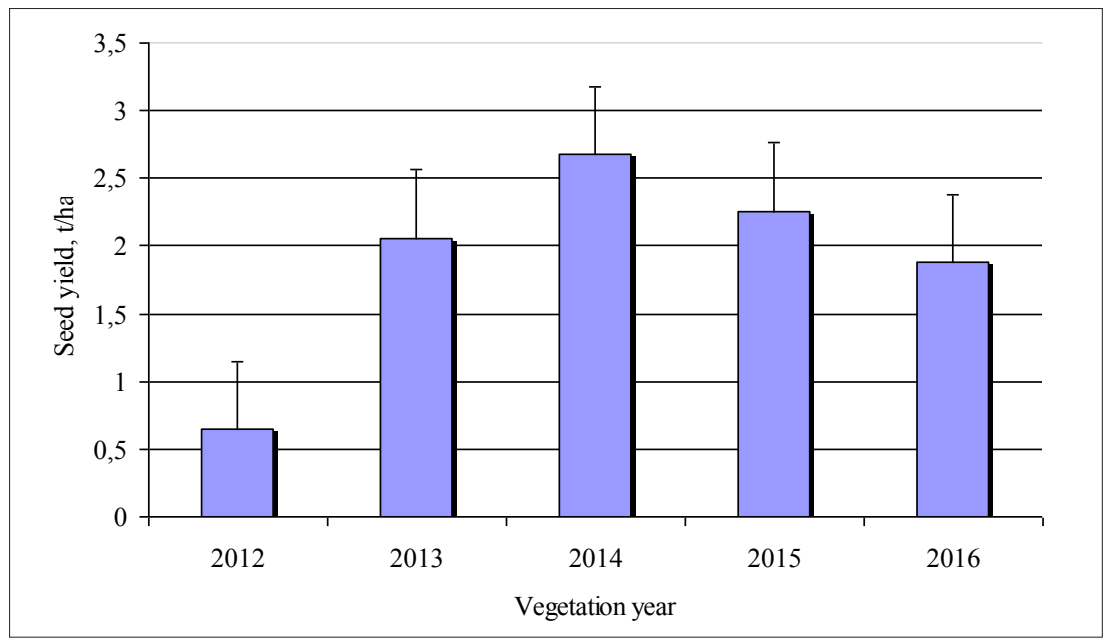

LSD 050,34

Fig. 5. Seed yield of castor-oil plants (t/ha), 2012-2016 
It has been established that both quantitative characteristics of the generative part of plant and weight of seeds per area unit (r 0.87) had considerable impact on castor-oil plant yield. Weight of seeds per area unit depends on crop density and weather conditions of the organogenesis period. Crop yield was completely different as the weather conditions of the vegetation period during research years were variable. The lowest yield $(0.65 \mathrm{t} / \mathrm{ha}) \mathrm{was}$ recorded in the driest 2012. During next years crop yield increased and it was $2.22 \mathrm{t} / \mathrm{ha}$ for 4 years on average. The highest crop yield of $2.68 \mathrm{t} / \mathrm{ha}$ was provided in 2014 as this year had the most favourable temperature regime and precipitation in critical phases of the castor-oil plant development.

Thus, castor-oil plant is highly potential crop for cultivation in the central part of forest-steppe of Ukraine. Adequate rainfall and dynamics of annual average temperature increase enable to expand cultivation area of this strategic crop.

Research results of switchgrass. Quantitative characteristics of switchgrass plants changed in the wide range (Table 3).

Table 3

Biometric switchgrass characteristics, 2012-2016

\begin{tabular}{|l|c|c|c|c|c|c|}
\hline \multirow{2}{*}{\multicolumn{1}{c|}{ Characteristics }} & \multicolumn{5}{|c|}{ Vegetation year } & $\begin{array}{c}\text { Duncan } \\
\text { test, } \\
\text { p 0,05 }\end{array}$ \\
\cline { 2 - 6 } & $\mathbf{2 0 1 2}$ & $\mathbf{2 0 1 3}$ & $\mathbf{2 0 1 4}$ & $\mathbf{2 0 1 5}$ & $\mathbf{2 0 1 6}$ & 13,2 \\
\hline Plant height, cm & 138,3 & 141,5 & 178,0 & 182,0 & 174,1 & 3,2 \\
\hline Number of stems & 198,7 & 213,5 & 309,6 & 303,5 & 310,6 & 6,5 \\
\hline Panicle length, cm & 25,2 & 27,4 & 52,0 & 51,2 & 43,4 & 2,7 \\
\hline Panicle number & 16,3 & 18,7 & 34,1 & 32,0 & 30,7 & 4,1 \\
\hline Mass of seeds per one plant, g & 157,0 & 214,4 & 288,0 & 320,7 & 252,3 & 9,8 \\
\hline Mass of 1000 seeds, g & 1,53 & 1,62 & 1,82 & 1,94 & 1,79 & 0,15 \\
\hline
\end{tabular}

Throughout two years the height of plants varied from 138.3 to $182.0 \mathrm{~cm}$. The highest plants grew in 2014 that was midhumid, lower plants grew in dry 2012-2013, and plants with middle height grew in insufficiently wet 2014 and 2016.

The highest number of switchgrass plants per area unit was in 2014 and 2016, less number was in 2012-2013 and average number was recorded in 2015.

The structural analysis of panicle revealed that total number of seeds from branches of different orders was 157.0-320.7 and depended on panicle length. Mass of 1000 seeds varied from $1.53 \mathrm{~g}$ to $1.94 \mathrm{~g}$. The biggest mass of 1000 seeds was formed in 2014-2016 (HTC near or more than1.0), less mass was in dry 2012-2013 (HTC less than 1.0). 
Connections between quantitative plant characteristics and seed productivity has been established by correlative-regression analysis (Table 4).

Table 4

\section{Correlation coefficient of quantitative plant characteristics} and seed productivity of switchgrass, 2012-2016

\begin{tabular}{|l|c|c|c|c|c|}
\hline \multirow{2}{*}{\multicolumn{1}{|c|}{ Characteristics }} & \multicolumn{5}{|c|}{ Vegetation year } \\
\cline { 2 - 6 } & $\mathbf{2 0 1 2}$ & $\mathbf{2 0 1 3}$ & $\mathbf{2 0 1 4}$ & $\mathbf{2 0 1 5}$ & $\mathbf{2 0 1 6}$ \\
\hline Plant height, cm & 0,36 & 0,31 & 0,41 & 0,30 & 0,33 \\
\hline Number of stems & $-0,12$ & $-0,04$ & $-0,11$ & $-0,07$ & 0,03 \\
\hline Panicle length, cm & $0,73^{*}$ & $0,61^{*}$ & $0,78^{*}$ & $0,60^{*}$ & $0,65^{*}$ \\
\hline Number of panicles & 0,25 & 0,32 & $0,41^{*}$ & 0,28 & $0,39^{*}$ \\
\hline Mass of 1000 seeds, $\mathrm{g}$ & 0,31 & 0,20 & 0,14 & 0,17 & 0,11 \\
\hline
\end{tabular}

* Note: $\mathrm{p}<5,0 \%$

Panicle length and in some years panicle number per one plant have the strongest impact on switchgrass seed productivity. Switchgrass seed yield closely linked to productivity ( $\mathrm{r} 0.80$ ) was the highest in the years with HTC of moderate water availability (Figure 6).

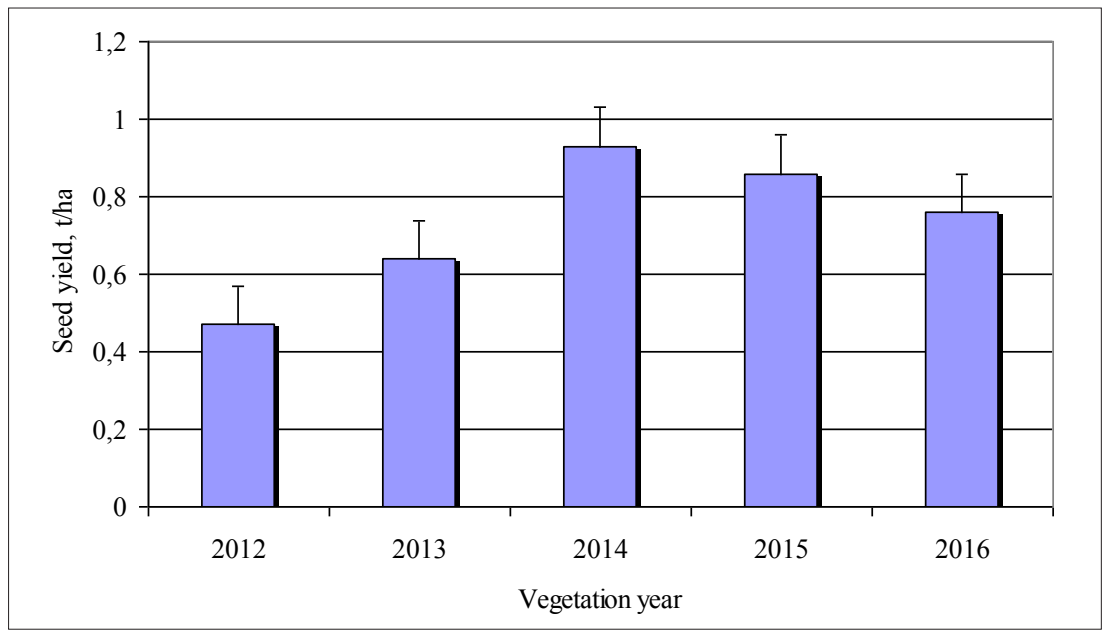

LSD 050,13

Fig. 6. Yield of switchgrass seeds (t/ha), 2012-2016 
The highest switchgrass yield was provided in 2014 and 2015 years ( 0.93 and $0.86 \mathrm{t} / \mathrm{ha}$ ) LSD05 0.13 , that is connected with morphological panicle characteristics and weather conditions during this period. Average yield was provided in $2016(0.76 \mathrm{t} / \mathrm{ha})$ and considerably less seed yield was in dry 2012-2013 (0.47 and 0.64 t/ha).

\section{Conclusions}

1. Biological peculiarities of castor-oil plant and switchgrass correspond with soil and climate conditions (temperature and water availability) in order to be cultivated in the forest-steppe of Ukraine.

2. High quantitative characteristics of castor-oil plant height, length of the central raceme and mass of 1000 seeds are formed in insufficiently wet years. Decreasing of these characteristics with simultaneous increase of raceme numbers and height of the central raceme attachment was recorded in dry conditions of the vegetation period.

3 . It has been determined that length of the central cluster and sometimes number of racemes greater affect seed productivity of castor-oil plant during the vegetation period with adequate water availability, though in dry weather conditions length of the central cluster has the greatest influence and number of racemes does not exceed 1 .

4. High biometric switchgrass characteristics (plant height, panicle length, number of panicles, mass and size of seeds) have been obtained in wetter years with HTC $>1.0$.

5. High yield of switchgrass seed is provided under influence of length and number of panicles per plant in the conditions close to optimal. In dry weather conditions influence of panicle length increases whereas mass of 1000 seeds has average influence.

6. Yield of castor-oil seeds was the highest in $2014(2.68 \mathrm{t} / \mathrm{ha})$ with $2.03 \mathrm{t} /$ ha lower in 2012, $0.65 \mathrm{t} /$ ha lower in 2013, $0.42 \mathrm{t} /$ ha lower in 2015 and $0.38 \mathrm{t} /$ ha lower in 2016 by LSD05 0.34 .

7. The highest switchgrass yield was provided in $2014(0.93 \mathrm{t} / \mathrm{ha})$, by LSD 05 - in $2015(0,86 \mathrm{t} / \mathrm{ha})$. This characteristic was $0.39 \mathrm{t} / \mathrm{ha}$ lower in 2012, $0.29 \mathrm{t} /$ ha lower in 2013 and $0.17 \mathrm{t} /$ ha lower in 2016.

Thus, taking into consideration research results according to biometric characteristics of plants and seed productivity depending on weather conditions, castor-oil plant can be recommended to be cultivated on farms in the forest-steppe of Ukraine in order to get technical oil of high quality and 
switchgrass is recommended to be cultivated for biofuel production and energy generation.

Prospects of the future researches will imply determination of impact of the cultivation technology elements on seed yield of lignocelluloses, sugar and oil crops considering weather and environmental factors.

\section{References:}

1. Nosenko Yu. (2012). Rycyna - kul'tura cinna [Ricine is a valuable culture]. Agrobiznes sogodni, vol. 7. - pp. 29-31. (in Ukrainian).

2. Mutlu H, Meier M. (2010). Castor oil as a renewable resource for the chemical industry. Sci Technol. 112(1):10-30.

3. Knight B., Westwood A. (2005). Global growhf The world biomass market: Renewable energy world. Vol. 8 : 118-128.

4. Kulyk M. I. (2015). The use of energy crops for phytoremediation. Proceedings of the Rozvytok APK na zasadax racionalnogo pryrodokorystuvannya: ekologichnyj, socialnyj ta ekonomichnyj aspekty [Development of agroindustrial complex on the basis for rational nature management: environmental, social and economic aspects]: materialy II Mizhnarod. nauk.-prakt. konf. (Poltava, 28.05.2015), Poltava : PGAA, pp. 25-29. (in Ukrainian).

5. Anjula Pandey and Radhamanji J. (2006) Studies on variability in seed longevity of castor (R. communis) in relation to seed morphological characters. Indian Journal Plant Genetic Resources: 19 (2) :253-258.

6. Hafiz Munir Ahmed1, Ghulam Sarwar and Muhammad Ahsan ul Haq (2012). Genetic variability and interdependence of morphological traits in castorbean (Ricinus communis L) mutants. Songklanakarin J. Sci. Technol. 34 (3), 279-286.

7. Gavrylyuk M.M., Salatenko V.N., Chexov A.V., Fedorchuk M.I. (2008). Olijni kul tury v Ukrayini: Navch. Posibnyk [Oil crops in Ukraine: Training Manual]; za red. V.N. Salatenka, K.: Osnova, 420 s. (in Ukrainian).

8. Kushwah Poonam, Singh K.P. (2012) Morphological variation in castor (Ricinus communis L) International Journal of Institutional Pharmacy and Life Sciences. Department of Botany, R.B.S. College, Agra (India) 2(3): 128-133.

9. Alabushev V. A. (2001). Rastenyevodstvo: uchebnoe posobye [Crop production: textbook], Rostov-na-Donu (2001), pp. 38. (in Ukrainian).

10. Salatenko V. N., Vasylenko N. Ye. (2011). Intensyvnist' procesiv rostu i rozvytku doslidzhuvanyx sortiv rycyny u zvyazku zi strokamy sivby ta gustotoyu stoyannya roslyn [Intensity the growth and development processes of investigated varieties for rice in connection with the terms of sowing and the density of plant standing] / Tavrijs kyj naukovyj visnyk, Xerson: Ajlant, Vyp. 75 : 91-97. (in Ukrainian).

11. Bewley J. D., Black M. (1994). Seeds: Physiology of Development and Germination. New York: Plenum. 367 pp.

12. Kurylo V. L, Kulyk M. I. (2017). Energetyhni kul'tury dlya vyrobnycztva biopalyva : dovidnyk [Energy crops for biofuels production: reference book], Poltava: RVV PDAA, 74 p. (in Ukrainian). 


\section{Impact of plant biometric characteristics on seed productivity of castor-oil...}

13. Rakhmetov D. B., Verhun O. M., \& Rakhmetova S. O. (2014). Panicum virgatum L. as a promising introduced species at M. M. Hryshko National Botanical Garden of the NAS of Ukraine. Introduktsiia roslyn [Plant Introduction], 3, 3-14. (in Ukrainian).

14. Kulyk M. I. (2012). Sowing preparation of seeds is an important component of seedling switchgrass (Panicum virgatum L.) / Zbirnyk naukovyx pracz' Vinnyczkogo nacionalnogo agrarnogo universytetu, Vinnycya, Vyp. 6 (68). pp. 96-104. (in Ukrainian).

15. Kulik M. I. (2016). Biologicheskie osobennosti i potencial urozhajnosti prosa prut'evidnogo - Panicum virgatum L. [Biological features and yield potential switchgrass - Panicum virgatum L.]. Aktual'nye zadachi biologii i jekologii v regional'nom kontekste: kollektivnaja monografija [Actual problems of biology and ecology in the regional context: collective monograph]; pod red. M. V. Larionova, Novosibirsk: Izd. NAS SibAK, pp. 38-64. (in Russian).

16. Kalens `ka S. M., Shevchuk O. Ya., Dmytryshak M. Ya. ta in. (2005). Roslynnycztvo: Pidruchnyk [Crop Growing: Textbook], K.: NAUU, pp. 52. (in Ukrainian).

17. Drozd I. Ocinka introdukcijnoyi zdatnosti vy`du ry`cy`na zvy`chajna (Ricinus communis L.) v umovax Peredkarpattya [Estimation of the introductive ability of the species a Ricinus communis L. in the conditions of the Carpathian region]. ACTA CARPATHICA, 21: 13-17. (in Ukrainian).

18. Shpaar D. (2006). Vozobnovljaemoe rastitel'noe syr'e (proizvodstvo i ispol'zovanie) [Renewable vegetable raw materials (production and use)], SankPeterburg-Pushkin, kniga 1. pp. 338-339. (in Russian).

19. Salatenko V., Ivanov V. (1971). Osobennosti agrotehniki kleshheviny sorta Chervonnaja [Features of agrotechnics of Ricinus communis Varieties Red]. Zernovye i maslichnye kul'tury, vol, 6: 27- 29. (in Russian).

20. Nazarenko G. I., Shokalo N. S. (2011). Introdukciya rycyny v umovax pivdenno-zaxidnoyi chastyny Poltavs koyi oblasti [Introduction a Ricinus communis in the conditions of the southwestern part of the Poltava region]. Visnyk Poltavs koyi derzhavnoyi agrarnoyi akademiyi. Poltava, 4: 36-38. (in Ukrainian).

21. Wolf D. D., Fiske D. A. (1995). Forages. Planting and managing switchgrass for forage, wildlife, and conservation. Virginia Cooperative Extension: 418-423.

22. Beaty E. R., Engel J. L., Powell D. J. (1978). Tiller development and growth in switchgrass. Range Manage, 31:361-365.

23. Kurylo V. L., Raxmetov D. B., Kulyk M. I. (2018). Biologichni osoblyvosti ta potencial urozhajnosti energetychnyx kul tur rodyny tonkonogovyx $\mathrm{v}$ umovax Ukrayiny [Biological features and potential of crop yields of energy cultures in the conditions of Ukraine], Visnyk Poltavs 'koyi derzhavnoyi agrarnoyi akademiyi. Poltava, 86: 26-35. (in Ukrainian).

24. Kulyk M. I. (2012). Botanical features and characteristics of ecotypes switchgrass (Panicum virgatum L.). Proceedings of the Materialy vosmoyi Mizhnar. nauk.-prakt. internet-konf, Ch. 3. pp. 6-7. (in Ukrainian).

25. Adkins S. W., Bellairs S. M., Loch D. S. (2002). Seed dormancy mechanisms in warm season grass species. Euphytica. V. 126, 1: 13-20.

26. Li M. [and other] (2010). Different seed dormancy levels imposed by tissues covering the Capyopsis in zoysiagrass (Zoysia japonica Steud). Seed Science and Technology. V. 38, 2: 320-331. 
27. Finch-Savage W. E., Leubner-Metzger G. (2006). Seed dormancy and the control of germination. New Phytologist. 171 (3):501-23.

28. Ray Smith S., Schwer Laura, Boyd Holly, Keene Tom (1999). Prechilling Switchgrass Seed on Farm to Break Dormancy.Lexington, KY, 40546. Retrieved from: http://www2.ca.uky.edu/agcomm/pubs/id/id199/id199.pdf (7.03.2018).

29. Moroz, O. V., Smirnykh, V. M., Kurylo, V. L., Herasymenko, Yu. P., Mos tovna, N. A., Horobets, A. M., \& Kulyk, M. I. (2011). Switchgrass as a new phytoenergy crop. Tsukr. buriaky [Sugar Beet], 3, 12-14. (in Ukrainian).

30. Kurylo V. L., Gumentyk M. Ya., Kaskiv V. V. (2013). Vplyv strokiv sivby ta glybyna zagortannya nasinnya svitchgrasu prosa lozovydnogo na polovu sxozhist' $\mathrm{v}$ umovax zaxidnoyi chastyny Lisostepu Ukrayiny [Influence of sowing dates and the depth wrapping seeds of switchgrass on field similarity in the conditions of the western part of the forest-steppe of Ukraine]. Naukovi praci Instytutu bioenergetychnyx kul'tur i czukrovyx buryakiv : zb. nauk. pr. - K. : FOP Korzun D. Yu., vol. $3: 358-361$. (in Ukrainian).

31. Kucherovs'ka S. V., Stefanovs'ka T. R. (2012). Agrojekologicheskie aspekty vyrashhivanija mnogoletnih trav dlja proizvodstva biotopliva vtorogo pokolenija [Agroecological aspects of growing perennial grasses for the production of second-generation biofuel]. Visnik KrNU, Vip. 4 : 128-131. (in Russian).

32. Ermantraut E. R., Bobro M. A., Gopcij T. I. ta in. (2008). Metodyka naukovyx doslidzhen` $\mathrm{v}$ agronomiyi: navch. Posibnyk [The Methodology of scientific research in agronomy: a manual], Xark. nacz. agrar. un-t im. V. V. Dokuchaeva, 64 p. (in Ukrainian).

33. Kurylo V. L., Gumentyk M. Ya., Goncharuk G. S., ta in. (2012). Metodychni rekomendaciyi z provedennya osnovnogo ta peredposivnogo obrobitkiv gruntu i sivby prosa lozovydnogo [The Methodical recommendations for the main and pre-planting of soil and sowing the swithgrass].Sugar Beet, 28 pp. (in Ukrainian).

34. Volkodav V. V. (2000). Metodyka derzhavnogo sortovyprobuvannya sil’s'kogospodars 'kyx kul'tur (Zagal'na chastyna) [The Method of state sorting of agricultural crops. General part], K., 100 p. (in Ukrainian).

35. Metodyka provedennya ekspertyzy sortiv roslyn grupy texnichnyx ta kormovyx na prydatnist' do poshyrennya $v$ Ukrayini (2016). [The Methods of conducting expert examination of plant varieties of the technical and fodder groups for suitability for distribution in Ukraine]. Ministerstvo agranoyi polityky ta prodovol`stva Ukrayiny, UIESR, Vyp. 540. (in Ukrainian).

36. Kulyk M. I., Raxmetov D. B., Kurylo V. L. (2017). Metodyka provedennya polovyx ta laboratornyx doslidzhen' $\mathrm{z}$ prosom prutopodibnym (Panicum virgatum L.) [The Methods of conducting field and laboratory research for switchgrass], Poltava: RVV PDAA, 24 p. (in Ukrainian).

37. Royik M. V., Raxmetov D. B., Goncharenko S. M., ta in. (2014). Metodyka provedennya ekspertyzy sortiv prosa prutopodibnogo (Panicum virgatumL.) na vidminnist', odnoridnist' i stabil 'nist' [The method of expert examination of varieties for difference, homogeneity and stability for switchgrass (Panicum virgatum L.)], K., pp. 637-651. (in Ukrainian).

38. Babych A. O. (1994). Metodyka provedennya doslidiv z kormovyrobnycztva [The Methods of experiments with forage production], Kiev, 87 p. (in Ukrainian). 
Statistical reasoning for the application of qualimetry methods to...

STATISTICAL REASONING FOR THE APPLICATION
OF QUALIMETRY METHODS TO SPEED-LOAD MATERIALS

\section{СТАТИСТИЧНЕ ОБГРУНТУВАННЯ \\ ЗАСТОСУВАННЯ МЕТОДІВ КВАЛІМЕТРІЇ \\ ДО ШВИДКІСНО-НАВАНТАЖЕНИХ МАТЕРІАЛІВ}

\section{Kurilyak Valentina ${ }^{1}$ \\ Himicheva Anna ${ }^{2}$}

DOI: http://dx.doi.org/10.30525/978-9934-571-26-8_11

Abstract. The work is statistically substantiated by the use of methods of qualimetry for assessing the quality of materials in conditions of high-speed loads. The results of theoretical and statistical researches concerning estimation of quality level of speed-loaded metal materials with the help of methods of qualimetry are given. It is established that in order to increase the reliability of their evaluation, it is necessary to propose acceptable qualitative characteristics of metal materials, which, in the case of quality evaluation in conditions of high-speed loads, are represented by dynamic parameters. The following material parameters are defined such as: loading speed, longitudinal and transverse shear rates, along with the deformation rate and the strength of the slit, are critical in assessing the quality level of loaded materials, since they are least varied in the area of loading of metal materials. The mathematical calculation of statistical data presented in the form of dynamic characteristics of loaded materials is proposed. It is established that the mean square deviation of statistical data is within the limits of the permissible variation coefficient. It is shown that increasing the reliability of the assessment of the quality of materials is permissible due to some adaptation of the methods of qualimetry due to the specific conditions in which the studied list of metal materials works.

\footnotetext{
${ }^{1}$ Postgraduate Student of the Department of Computer-Integrated Technologies and Measuring Instruments,

Kyiv National University of Technology and Design, Ukraine

${ }^{2}$ Doctor of Technical Sciences,

Professor of the Department of Computer-Integrated Technologies and Measuring Instruments,

Kyiv National University of Technology and Design, Ukraine

(C) Kurilyak Valentina, Himicheva Anna
} 


\section{1. Вступ}

В області дослідження якості матеріалів використовуються різні методи кваліметрії в залежності від самого матеріалу, специфіки його виробництва, застосування та випробування. Наприклад, в таких областях, як металургія, будівництво, використовуються статистичні методи оцінки і контролю якості, але в області високошвидкісного руйнування матеріалів проблема вибору матеріалу, в основному, вирішується методом експертних оцінок. При цьому оцінка якості матеріалу грунтується на знаннях експертів, які мають великий досвід в дослідженні матеріалів в умовах високошвидкісного навантаження. Тому поряд з експертним методом, в області навантажених матеріалів необхідно впровадження додаткових автоматизованих методів кваліметрії за допомогою яких стане можливим підвищення оцінювання рівня якості металевих матеріалів, оскільки експертний метод вимагає істотних ресурсних витрат, і в ряді випадків характеризується неузгодженістю думок експертів, саме це обумовлює актуальність даного дослідження. Також в дослідженні вперше статистично обгрунтовано кваліметричний інструмент по оцінюванню рівня якості металевих матеріалів, який на відміну від експертного, підвищує достовірність оцінювання за рахунок зменшення впливу суб'єктивного фактору на процес оцінювання. Виходячи із наукової новизни, метою роботи є статистична перевірка експериментальних значень, які є базовою основою для застосування методів кваліметрії для оцінювання рівня якості швидкісно-навантажених матеріалів. Для досягнення поставленої мети необхідно виконати наступні завдання: 1. Проаналізувати процеси, які відбуваються в металах при динамічних навантаженнях; 2. Запропонувати алгоритм застосування методів кваліметрії до швидкісно-навантажених матеріалів; 3. Статично обгрунтувати можливість застосування методів кваліметрії та виконати перевірку закону розподілу експериментальних величин за допомогою критерія Пірсона. В даній роботі використовувались теорія та методи кваліметрії на базі яких було обгрунтовано можливість їх застосування до оцінювання рівня якості навантажених матеріалів. Методи експертного оцінювання, які наряду із статистичними дозволили підвищити достовірність оцінювання якості металевих матеріалів. Методи математичної теорії та статистики, методи планування експерименту в процесі експериментального визначення динамічних характеристик матеріалів. 
Statistical reasoning for the application of qualimetry methods to...

\section{2. Аналіз процесів, які відбуваються \\ в швидкісно-навантажених металах}

Ударні навантаження матеріалів в першу чергу характеризуються процесом двійникування, яке в свою чергу є важливою характеристикою деформації металів з об'ємно-центрованою кубічною (ОЦК) та гексагональною щільно упакованою решітками (ГЩУ). В той час, як при деформації металів з гранецентрованою кубічною (ГЦК) решіткою цей процес не має великого значення, оскільки механізм двійникування діє тоді, коли його критична напруга $є$ меншою ніж критична напруга ковзання. Прогресивна тенденція до двійникування зростає зі зменшенням енергії дефектів упаковок решітки.

Механізм двійникування по своїй природі споріднений із ковзанням, але має деякі обмеженнями. На рис. 1. представлений процес двійникування. У вихідній решітці, що має характерну відстань між сусідніми атомами d, по площині ковзання аа (площина двійникування) здійснюється зрушення вправо на вектор s в кожному шарі кристалу, так що в n-му шарі зрушення дорівнює ns. Це призводить до дзеркального відображення верхньої частини кристалу щодо нижньої, а в макроскопічному відношенні до зміни форми кристалу (Хімічева i Куриляк, 2015).

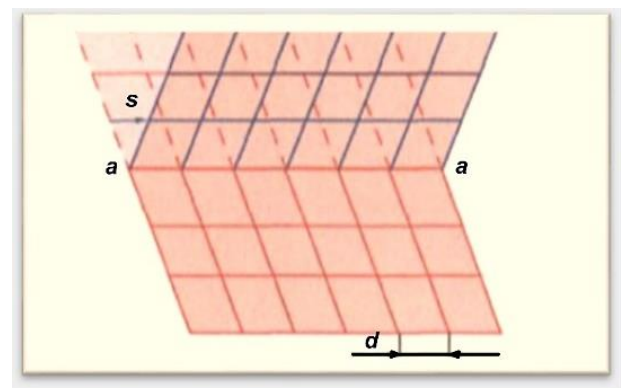

\section{Рис. 1. Схема реалізації двійникування}

Будь-який метод високошвидкісної деформації створює рівень напружень у зразку вищий, ніж в умовах квазістатичного деформування. Це дає можливість досягнути стартової напруги двійникування і збільшує роль механізму двійникування при ударному навантаженні. Метали, що не двійникуються при кімнатній температурі, здатні до 
двійникування при ударному навантаженні. Двійникування підвищує міцність матеріалів, оскільки двійники утворюються в хвилях стиснення, а не розтягування. Легкість двійникування визначається декількома факторами (Куриляк, 2016):

1) Тиском (так в нікелі двійникування виникає при тисках вище 35 ГПа) (Хімічева і Куриляк, 2016);

2) Кристалографічною орієнтацією. Двійникування здійснюється при досягненні результуючими зсувними напругами порогового значення в площині двійникування і вздовж напрямку двійникування (мідь, нікель);

3) Енергією дефектів упаковки (зменшення енергій призводить до збільшення кількості двійників);

4) Тривалістю імпульсу (кількість двійників збільшується при збільшенні тривалості імпульсу до 2 мкс);

5) Субструктура (зсувні напруження можуть релаксувати в вигляді двійникуванням, якщо дислокації відсутні, або ковзанням вже наявних в матеріалі дислокацій, якщо матеріал попередньо деформований);

6) Розміром зерна (в крупнозернистих зразках молібденова деформація двійникуванням здійснюється легше, ніж в зразках з дрібним зерном) (Куриляк і Хімічева, 2016).

Зниження температури або збільшення швидкості деформації сприяє розвитку двійникування і придушення ковзання. В ОЦК металах (перлитної стали, наприклад) (Куриляк і Хімічева, 2017) двійники утворюються при низькому тиску, і їх щільність збільшується зі зростанням тиску, при цьому підвищуються міцність металу.

3 ГЩУ металів двійники можна спостерігати у титані та титанових сплавах. Кількість площин двійникування у титані більше, ніж в інших ГЩУ металах. Мартенситні перетворення відносяться до фазових перетворень з спотворенням кристалічної решітки. Термін «мартенситне» перетворення зберігається для перетворень, що відбуваються 3 такими спотвореннями кристалічної решітки, при яких домінують девіаторні компоненти напруг. Таким чином, лише перетворення ГЦК в ОЦК і ГЦК в ГЩУ в сплавах на основі заліза і перетворення ОЦК решітки в щільно упаковані в благородних металах (сплавах з пам'яттю форми) можуть бути строго названі мартенситними (Куриляк, 2017).

На термодинаміку фазових перетворень здійснюють різний вплив тиск ударної хвилі, зсувні напруження і температура. Так фазові пере- 
творення, що відбувається зі зменшенням обсягу (щільність нової фази більше, ніж вихідної), тому термодинамічно віддається перевага високому тиску, так як цей аспект призводить до зменшення тиску в тій області, де він відбувається. Разом з тим, фазовому перетворенню, що відбувається зі зменшенням щільності та підвищенням тиску не сприяє мартенситне перетворення, котре можна розглядати як механізм деформації, конкуруючий з ковзанням і двійникуванням, а зовні прикладена напруга має збільшувати температуру початку мартенситного перетворення. Зсувні напруги в ударній хвилі повинні полегшити утворення мартенситу (Куриляк, 2016).

Смуги адіабатичного зсуву є типовим механізмом, крім ковзання і двійникування, для високошвидкісного деформування. Зростання температури, що супроводжує пластичну деформацію, в умовах обмеженого відведення тепла може вносити вклад в загальний пластичний перебіг, а саме в ідеї дестабілізуючого деформаційного розміцнення. Супутнє зазначеним процесам явище локалізації деформації, відоме під назвою «адіабатичне зрушення» рис. 2., котре грає важливу роль при динамічній пластичній деформації (Куриляк, 2016). Під час поширення пластична деформація сильно локалізується в області смуги зсуву, приводячи до істотного підвищення температури. Вона може досягати і навіть перевищувати температуру плавлення.

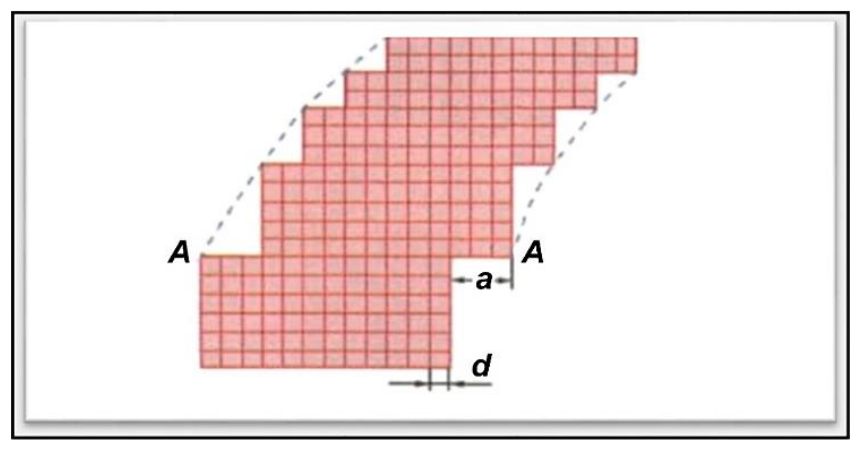

Рис. 2. Схема реалізації пластичного зсуву

При пластичному зсуві елементарний осередок не спотворюється, зміщуючись як ціле, а значить і симетрія кристала не змінюється. Схематично процес пластичного зсуву представлений на рисунку 2 , де за 
однією з площин ковзання АА стався зсув на величину а. Він дорівнює міжатомній відстані d, i може бути більшим (Куриляк, 2017).

Отже, ударні навантаження в першу чергу характеризуються динамічними характеристиками матеріалів, котрі виникають у випадку взаємодії конструкції $з$ тілами (елементами конструкцій) та в момент контакту мають ненульову швидкість (зокрема, при падінні тіл на конструкцію). Це призводить до того, що швидкість елементів конструкцій на протязі малого проміжку часу змінюється від максимальної до нульової. Високошвидкісна взаємодія співударних елементів призводить до виникнення значних сил інерції, котрі спричинені великими прискореннями та сповільненнями в моменти співударяння.

\section{3. Оцінювання рівня якості металевих матеріалів}

за допомогою методів кваліметрії

Для обгрунтування вибору методів кваліметрії, які можливо застосовувати в області високошвидкісних впливів був складений спеціальний алгоритм, який зображає покрокове виконання того як вірно визначитися до якого саме матеріалу необхідно застосовувати апробовані (в рамках швидкісних навантажень) методи кваліметрії. Підбір методів кваліметрії для оцінювання рівня якості високонавантажених матеріалів зображено за допомогою алгоритму на рис. 3 .

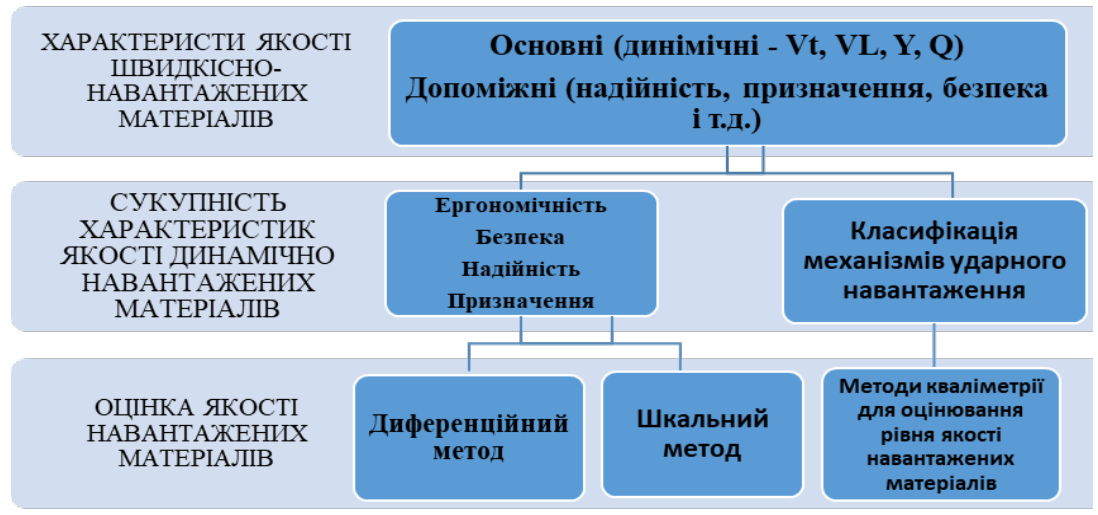

Рис. 3. Алгоритм вибору методів кваліметрії для оцінювання рівня якості навантажених матеріалів 
Відповідно до даного алгоритму, і на основі проведеного аналізу питань оцінювання рівня якості металевих матеріалів і різних об'єктів, а також аналізу поведінки матеріалів в умовах ударного навантаження зроблено висновок про те, що в подібному випадку основними і визначальними характеристиками якості $є$ динамічні характеристики. На основі цих характеристик необхідно побудувати систему показників якості навантажених матеріалів. На основі аналізу прикладів практичного застосування різних методів кваліметрії, в тому числі для оцінювання рівня якості металів, визначено перелік використовуваних в роботі кількісно-комплексних методів.

До обраних методів належить: «павутиння якості», метод секторних діаграм, функція бажаності та кореляційний аналіз. Застосування «павутиння якості» для оцінювання рівня якості зразків матеріалів здійснюється шляхом зіставлення характеристик окремих властивостей оцінюваного зразку з відповідними базовими показниками. При цьому визначають, чи досягнуто відповідність якості оцінюваного зразку, і які показники властивостей оцінюваного зразку перевершують або не відповідають показникам базового зразку, а також, наскільки відрізняються один від одного аналогічні показники властивостей.

Для визначення рівня якості динамічно-навантажених матеріалів необхідно визначити, за допомогою довідкової літератури, базові характеристиками металевих матеріалів. Використані в роботі еталонні показники досліджуваних металів представлені в таблиці 1.

Таблиця 1

Базові характеристики металевих матеріалів

\begin{tabular}{|c|l|c|c|c|c|c|}
\hline № & $\begin{array}{c}\text { Назва } \\
\text { металевого } \\
\text { зразку }\end{array}$ & $\begin{array}{c}\text { Швидкість } \\
\text { навантаження }\end{array}$ & $\begin{array}{c}\text { Поперечна } \\
\text { Швидкість } \\
\text { зсуву }\end{array}$ & $\begin{array}{c}\text { Поздовжня } \\
\text { Швидкість } \\
\text { зсуву }\end{array}$ & $\begin{array}{c}\text { Швидкість } \\
\text { зсувної } \\
\text { деформації }\end{array}$ & $\begin{array}{c}\text { Відкольна } \\
\text { міцність }\end{array}$ \\
\hline 1 & Сталь & $400 \mathrm{M} / \mathrm{c}$ & $70 \mathrm{M} / \mathrm{c}$ & $40 \mathrm{~m} / \mathrm{c}$ & $2,0 * 10^{6} \mathrm{c}^{-1}$ & $10 \mathrm{MПа}$ \\
\hline 2 & Мідь & $210 \mathrm{~m} / \mathrm{c}$ & $30 \mathrm{~m} / \mathrm{c}$ & $15 \mathrm{~m} / \mathrm{c}$ & $1,0 * 10^{6} \mathrm{c}^{-1}$ & $3 \mathrm{MПа}$ \\
\hline 3 & Титан & $700 \mathrm{M} / \mathrm{c}$ & $35 \mathrm{~m} / \mathrm{c}$ & $60 \mathrm{~m} / \mathrm{c}$ & $1,0 * 10^{6} \mathrm{c}^{-1}$ & $10 \mathrm{MПа}$ \\
\hline 4 & Алюміній & $300 \mathrm{M} / \mathrm{c}$ & $30 \mathrm{~m} / \mathrm{c}$ & $20 \mathrm{~m} / \mathrm{c}$ & $1,0 * 10^{6} \mathrm{c}^{-1}$ & $5 \mathrm{MПа}$ \\
\hline
\end{tabular}

Для нікелід титану базовими характеристиками стали товщина зразку - 1,5 мм. (Значення мінімальне, тому що товщина мішені-зразку повинна прагнути до мінімуму); товщина ударника - 2 мм; швидкість 
ударника - 700 м/с; відкольна швидкість - 300 м/с; відкольна міцність - 10 ГПа.

Розробка кваліметричних принципів при оцінці рівня якості високонавантажених матеріалів включала в себе їх адаптацію для обраних зразків матеріалів, а саме пристосування кваліметричних методів до оцінювання рівня якості динамічно-навантажених матеріалів. Тому визначення рівня якості зразків за допомогою «павутиння якості» відбувається наступним чином: відповідно до кількості оцінюваних показників (характеристик) якості в різні боки, подібно павутині, відкладається n-на кількість кваліметричних шкал у відповідному масштабі рис. 4.

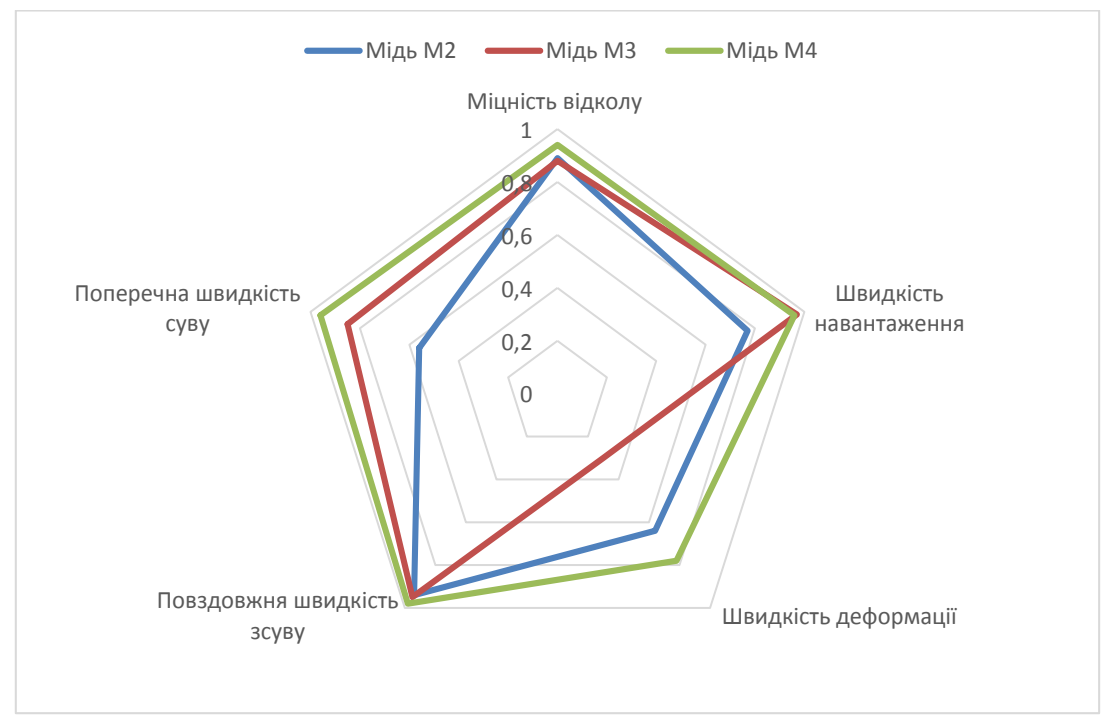

\section{Рис. 4. Приклад застосування павутиння якості} до навантажених матеріалів

На шкалах, відкладається кожне значення показників властивостей, після чого точки з'єднуються між собою і отримують число багатокутників, згідно кількості оцінюваних зразків. Площа, яку займає кожним многокутник, відповідає якості конкретного зразку і дозволяє порівняти його із іншими. 
Statistical reasoning for the application of qualimetry methods to...

\section{4. Статистичне обгрунтування застосування методів кваліметрії} до оцінювання рівня якості навантажених матеріалів

Розмір вибірки становить 200 вимірювань для кожного виду зразку при однаковій швидкості навантаження. Тобто в результаті одного випробування ми отримуємо по одному значенню кожної із динамічних характеристик. Випробування відбувалися з приблизно однаковою частотою, а значення динамічних характеристик металевих матеріалів варіювалися в певному діапазоні, а саме в тому якому відповідала швидкість навантаження та реакція кожного виду металу на ударник.

Для статистичного обрахування було обрано металевий зразок із сталі 30ХН4М та обраховані його експериментальні значення по чотирьом критеріям, таким як: поздовжня швидкость зсуву $\mathrm{V}_{\mathrm{L}}$; поперечна швидкість зсуву Vt; швидкість зсувної деформації $\gamma$; відкольна міцність $\sigma$.

В нижче приведеній таблиці відображені значення вимірювань та кількість вимірювань в яких зафіксовано певне значення. $\mathrm{X}_{\mathrm{i}}$ - випадкова величина, розмірність м/c; $\mathrm{n}_{\mathrm{i}}$ - кількість вимірювань в яких зафіксовано значення $\mathrm{X}$.

Таблиця 2

Значення експериментальних вимірювань

\begin{tabular}{|c|c|c|c|c|c|c|c|c|c|}
\hline № & $\mathbf{1}$ & $\mathbf{2}$ & $\mathbf{3}$ & $\mathbf{4}$ & $\mathbf{5}$ & $\mathbf{6}$ & $\mathbf{7}$ & $\mathbf{8}$ & $\mathbf{9}$ \\
\hline $\mathbf{X}_{\mathbf{i}}$ & 60 & 61 & 62 & 63 & 64 & 65 & 66 & 67 & 68 \\
\hline $\mathbf{n}_{\mathbf{i}}$ & 15 & 28 & 20 & 28 & 17 & 19 & 26 & 26 & 21 \\
\hline
\end{tabular}

Гіпотетично на основі значень експериментальних вимірювань зроблено висновок про те, що вибірка підпорядковується рівномірному закону розподілу, який представлений на рис. 5 .

Під час експерименту були виміряні чотири динамічні характеристики матеріалів. В табл. 3. представлений перелік випадкових величин для динамічного параметру сталі 30XH4M по характеристикам Vt, $\mathrm{V}_{\mathrm{L}}, \gamma, \sigma$.

В таблиці № 4 обраховані значення вимірювань та їх імовірності, де $\mathrm{Xi}$ - випадкова величина, а $\mathrm{P}$ - ймовірність випадання випадкової величини, яка визначається за формулою:

$$
\mathrm{P}=\mathrm{n} / \mathrm{N}(1)
$$

В нашому випадку генеральна сукупність величин дорівнює $\mathrm{N}=200$. 


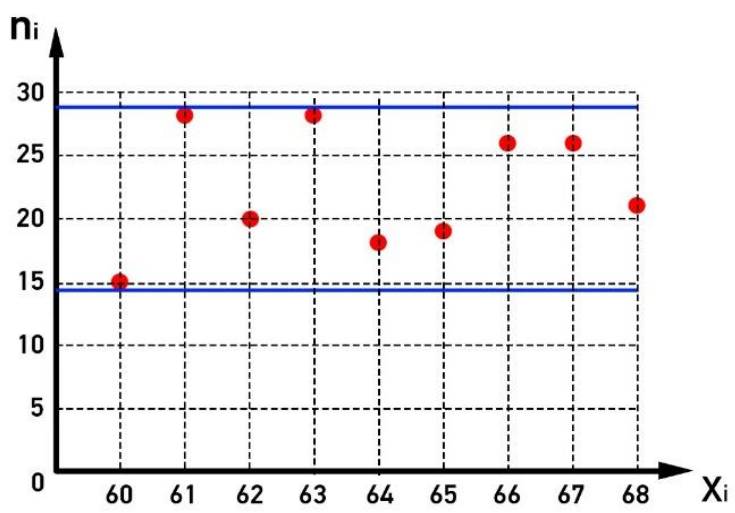

Рис. 5. Рівномірна щільність розподілу вибірки

Таблиця 3

Значення експериментальних вимірювань

\begin{tabular}{|c|c|c|c|c|c|c|c|c|c|}
\hline № & $\mathbf{1}$ & $\mathbf{2}$ & $\mathbf{3}$ & $\mathbf{4}$ & $\mathbf{5}$ & $\mathbf{6}$ & $\mathbf{7}$ & $\mathbf{8}$ & $\mathbf{9}$ \\
\hline $\mathrm{X}_{\mathrm{i}}(\mathrm{Vt}) \mathrm{M} / \mathrm{c}$ & 60 & 61 & 62 & 63 & 64 & 65 & 66 & 67 & 68 \\
\hline $\mathrm{n}_{\mathrm{i}}$ & 15 & 28 & 20 & 28 & 17 & 19 & 26 & 26 & 21 \\
\hline $\mathrm{X}_{\mathrm{i}}\left(\mathrm{V}_{\mathrm{L}}\right) \mathrm{M} / \mathrm{c}$ & 32 & 33 & 34 & 35 & 36 & 37 & 38 & 39 & 40 \\
\hline $\mathrm{n}_{\mathrm{i}}$ & 25 & 29 & 24 & 16 & 17 & 26 & 18 & 25 & 20 \\
\hline $\mathrm{X}_{\mathrm{i}}(\gamma)^{*} 10^{-6} \mathrm{c}^{-1}$ & 2,4 & 2,45 & 2,5 & 2,55 & 2,6 & 2,65 & 2,7 & 2,75 & 2,77 \\
\hline $\mathrm{n}_{\mathrm{i}}$ & 22 & 24 & 21 & 22 & 29 & 24 & 28 & 26 & 30 \\
\hline$\sigma, \mathrm{M \Pi A}$ & 8,9 & 8,95 & 9,0 & 9,05 & 9,1 & 9,15 & 9,2 & 9,3 & 9,25 \\
\hline $\mathrm{n}_{\mathrm{i}}$ & 20 & 21 & 30 & 24 & 31 & 22 & 25 & 27 & 19 \\
\hline
\end{tabular}

Таблиця 4

Значення вимірювань та їх ймовірності для $\mathrm{Vt}, \mathrm{V}_{\mathrm{L}}, \gamma, \sigma$

\begin{tabular}{|c|c|c|c|c|c|c|c|c|c|}
\hline № & $\mathbf{1}$ & $\mathbf{2}$ & $\mathbf{3}$ & $\mathbf{4}$ & $\mathbf{5}$ & $\mathbf{6}$ & $\mathbf{7}$ & $\mathbf{8}$ & $\mathbf{9}$ \\
\hline $\mathrm{X}_{\mathrm{i}}(\mathrm{Vt})$ & 60 & 61 & 62 & 63 & 64 & 65 & 66 & 67 & 68 \\
\hline $\mathrm{P}_{\mathrm{i}}$ & 0.075 & 0.14 & 0.1 & 0.14 & 0.085 & 0.095 & 0.13 & 0.13 & 0.105 \\
\hline $\mathrm{X}_{\mathrm{i}}\left(\mathrm{V}_{\mathrm{L}}\right)$ & 32 & 33 & 34 & 35 & 36 & 37 & 38 & 39 & 40 \\
\hline $\mathrm{P}_{\mathrm{i}}$ & 0,125 & 0,145 & 0,12 & 0,08 & 0,085 & 0,13 & 0,09 & 0,125 & 0,1 \\
\hline $\mathrm{Xi}(\gamma)$ & 2,4 & 2,45 & 2,5 & 2,55 & 2,6 & 2,65 & 2,7 & 2,75 & 2,8 \\
\hline $\mathrm{P}_{\mathrm{i}}$ & 0,11 & 0,12 & 0,105 & 0,11 & 0,145 & 0,12 & 0,14 & 0,15 & 0,16 \\
\hline $\mathrm{X}_{\mathrm{i}}(\sigma)$ & 8,9 & 8,95 & 9,0 & 9,05 & 9,1 & 9,15 & 9,2 & 9,25 & 9,30 \\
\hline $\mathrm{P}_{\mathrm{i}}$ & 0,1 & 0,105 & 0,15 & 0,12 & 0,155 & 0,11 & 0,125 & 0,135 & 0,140 \\
\hline
\end{tabular}


Statistical reasoning for the application of qualimetry methods to...

На основі розрахованих даних зроблено пропущення, що отримані значення розподілені згідно з законом рівномірної щільності. Для перевірки гіпотези про рівномірну щільність розподілу виконаємо наступні розрахунки (табл. 5-8).

Таблиця 5

Рахунок показників Vt

\begin{tabular}{|c|c|c|c|c|c|}
\hline $\mathbf{x}_{\mathbf{i}}$ & Частота, $\mathbf{f}_{\mathbf{i}}$ & $\mathbf{x}_{\mathbf{i}}{ }^{\mathbf{f}} \mathbf{f}_{\mathbf{i}}$ & $\begin{array}{c}\text { Накопичена } \\
\text { частота, } \mathbf{S}\end{array}$ & $\left|\mathbf{x}-\mathbf{x}_{\mathbf{c p}}\right| *_{\mathbf{f}_{\mathbf{i}}}$ & $\left(\mathbf{x}-\mathbf{x}_{\mathrm{cp}}\right)^{2 * \mathbf{f}_{\mathbf{i}}}$ \\
\hline 60 & 0.075 & 4.5 & 0.075 & 0.308 & 1.264 \\
\hline 61 & 0.14 & 8.54 & 0.215 & 0.435 & 1.35 \\
\hline 62 & 0.1 & 6.2 & 0.315 & 0.211 & 0.443 \\
\hline 63 & 0.14 & 8.82 & 0.455 & 0.155 & 0.171 \\
\hline 64 & 0.085 & 5.44 & 0.54 & 0.00893 & 0.000937 \\
\hline 65 & 0.095 & 6.175 & 0.635 & 0.085 & 0.0761 \\
\hline 66 & 0.13 & 8.58 & 0.765 & 0.246 & 0.467 \\
\hline 67 & 0.13 & 8.71 & 0.895 & 0.376 & 1.09 \\
\hline 68 & 0.105 & 7.14 & 1 & 0.409 & 1.593 \\
\hline Всього & 1 & 64.105 & & 2.233 & 6.454 \\
\hline
\end{tabular}

Таблиця 6

Розрахунок показників $V_{L}$

\begin{tabular}{|c|c|c|c|c|c|}
\hline $\mathbf{x}_{\mathbf{i}}$ & Частота, $\mathbf{f}_{\mathbf{i}}$ & $\mathbf{x}_{\mathbf{i}}{ }^{*} \mathbf{f}_{\mathbf{i}}$ & $\begin{array}{c}\text { Накопичена } \\
\text { частота, } \mathbf{S}\end{array}$ & $\left|\mathbf{x}-\mathbf{x}_{\mathbf{c p}}\right| * \mathbf{f}_{\mathbf{i}}$ & $\left(\mathbf{x}-\mathbf{x}_{\mathbf{c p}}\right)^{2 * \mathbf{f}_{\mathbf{i}}}$ \\
\hline 32 & 0.125 & 4 & 0.125 & 0.479 & 1.834 \\
\hline 33 & 0.145 & 4.785 & 0.27 & 0.41 & 1.161 \\
\hline 34 & 0.12 & 4.08 & 0.39 & 0.22 & 0.402 \\
\hline 35 & 0.08 & 2.8 & 0.47 & 0.0664 & 0.0551 \\
\hline 36 & 0.085 & 3.06 & 0.555 & 0.0145 & 0.00246 \\
\hline 37 & 0.13 & 4.81 & 0.685 & 0.152 & 0.178 \\
\hline 38 & 0.09 & 3.42 & 0.775 & 0.195 & 0.424 \\
\hline 39 & 0.125 & 4.875 & 0.9 & 0.396 & 1.256 \\
\hline 40 & 0.1 & 4 & 1 & 0.417 & 1.739 \\
\hline Всього & 1 & 35.83 & & 2.35 & 7.051 \\
\hline
\end{tabular}

Для оцінювання ряду розподілу знайдемо наступні показники: показник центру розподілу. Середньо-зважена (вибіркова середня величина).

$$
\bar{x}=\frac{\sum x_{i}^{*} f_{i}}{\sum f_{i}}
$$


Таблиця 7

Розрахунок показників $\gamma$

\begin{tabular}{|c|c|c|c|c|c|}
\hline $\mathbf{x}_{\mathbf{i}}$ & Частота, $\mathbf{f}_{\mathbf{i}}$ & $\mathbf{x}_{\mathbf{i}}{ }^{*} \mathbf{f}_{\mathbf{i}}$ & $\begin{array}{c}\text { Накопичена } \\
\text { частота, } \mathbf{S}\end{array}$ & $\left|\mathbf{x}-\mathbf{x}_{\mathbf{c p}}\right| * \mathbf{f}_{\mathbf{i}}$ & $\left(\mathbf{x}-\mathbf{x}_{\mathbf{c p}}\right)^{2 * \mathbf{f}_{\mathbf{i}}}$ \\
\hline 2.4 & 0.11 & 0.264 & 0.11 & 0.0205 & 0.00383 \\
\hline 2.45 & 0.12 & 0.294 & 0.23 & 0.0164 & 0.00224 \\
\hline 2.5 & 0.105 & 0.263 & 0.335 & 0.00908 & 0.000786 \\
\hline 2.55 & 0.11 & 0.281 & 0.445 & 0.00402 & 0.000147 \\
\hline 2.6 & 0.145 & 0.377 & 0.59 & 0.00196 & $2.60 \mathrm{E}-05$ \\
\hline 2.65 & 0.12 & 0.318 & 0.71 & 0.00762 & 0.000484 \\
\hline 2.7 & 0.14 & 0.378 & 0.85 & 0.0159 & 0.0018 \\
\hline 2.75 & 0.15 & 0.413 & 1 & 0.0245 & 0.00401 \\
\hline Всього & 1 & 2.587 & & 0.1 & 0.0133 \\
\hline
\end{tabular}

Таблиця 8

Розрахунок показників $\sigma$

\begin{tabular}{|c|c|c|c|c|c|}
\hline $\mathbf{x}_{\mathbf{i}}$ & Частота, $\mathbf{f}_{\mathbf{i}}$ & $\mathbf{x}_{\mathbf{i}} * \mathbf{f}_{\mathbf{i}}$ & $\begin{array}{c}\text { Накопичена } \\
\text { частота, } \mathbf{S}\end{array}$ & $\left|\mathbf{x}-\mathbf{x}_{\mathbf{c p}}\right| * \mathbf{f i}$ & $\left(\mathbf{x}-\mathbf{x}_{\mathbf{c p}}\right)^{2 * \mathbf{f}_{\mathbf{i}}}$ \\
\hline 8.9 & 0.1 & 0.89 & 0.1 & 0.0182 & 0.00329 \\
\hline 8.95 & 0.105 & 0.94 & 0.205 & 0.0138 & 0.00182 \\
\hline 9 & 0.15 & 1.35 & 0.355 & 0.0122 & 0.000996 \\
\hline 9.05 & 0.12 & 1.086 & 0.475 & 0.00378 & 0.000119 \\
\hline 9.1 & 0.155 & 1.411 & 0.63 & 0.00287 & $5.30 \mathrm{E}-05$ \\
\hline 9.15 & 0.11 & 1.007 & 0.74 & 0.00754 & 0.000516 \\
\hline 9.2 & 0.125 & 1.15 & 0.865 & 0.0148 & 0.00176 \\
\hline 9.25 & 0.135 & 1.249 & 1 & 0.0227 & 0.00383 \\
\hline Всього & 1 & 9.082 & & 0.0959 & 0.0124 \\
\hline
\end{tabular}

Показники варіації. Розмах варіації - різниця між максимальним і мінімальним значеннями ознаки первинного ряду.

$$
\mathrm{R}=\mathrm{x}_{\max }-\mathrm{x}_{\text {min }}
$$

Середнє лінійне відхилення - обчислюють для того, щоб врахувати відмінності всіх одиниць досліджуваної сукупності.

$$
d=\frac{\sum\left|x_{i}-\bar{x}\right|^{*} f_{i}}{\sum f_{i}}
$$

Дисперсія - характеризує міру розкиду близько іiі середнього значення (міра розсіювання, тобто відхилення від середнього). 
Statistical reasoning for the application of qualimetry methods to...

$$
D=\frac{\sum\left(x_{i}-\bar{x}\right)^{2} * f_{i}}{\sum f_{i}}
$$

Середнє квадратичне відхилення.

$$
\sigma=\sqrt{D}
$$

Таблиця 9

\section{Розрахунок показника центру розподілу та показників варіації}

\begin{tabular}{|c|c|c|c|c|}
\hline № & $\mathbf{V}_{\mathbf{t}}$ & $\mathbf{V}_{\mathbf{L}}$ & $\boldsymbol{\gamma}$ & $\boldsymbol{\Sigma}$ \\
\hline $\bar{x}$ & 64.11 & 35.83 & 2.59 & 9.08 \\
\hline $\mathrm{R}$ & 8 & 8 & 0.35 & 0.35 \\
\hline $\mathrm{d}$ & 2.23 & 2.35 & 0.1 & 0.0959 \\
\hline $\mathrm{D}$ & 6.454 & 7.051 & 0.0133 & 0.0124 \\
\hline$\sigma$ & 2.54 & 2.655 & 0.115 & 0.111 \\
\hline
\end{tabular}

Показники форми розподілу, а саме ступінь асиметрії, оскільки симетричним є розподіл, в якому частоти будь-яких двох варіантів, рівнорозподілених в обидві сторони від центру розподілу, рівні між собою. Найбільш точним і поширеним показником асиметрії $є$ моментний коефіцієнт асиметрії.

$$
A_{S}=\frac{M_{3}}{\sigma^{3}}
$$

Де, $\mathrm{M}_{3}$ - центральний момент третьего порядку. $\Sigma$ - Середньоквадратичне відхилення. Оцінка показника асиметрії дається за допомогою середньоквадратичної помилки коефіцієнта асиметрії:

$$
S_{A_{s}}=\sqrt{\frac{6(n-2)}{(n+1)(n+3)}}
$$

Якщо виконується співвідношення $\left|\mathrm{A}_{\mathrm{s}}\right| \mathrm{s}_{\mathrm{As}}<3$, то асиметрія незначна, iї наявність пояснюється впливом різних випадкових обставин. Якщо має місце співвідношення $\mid \mathrm{A}_{\mathrm{s}} / \mathrm{s}_{\mathrm{As}}>3$, то асиметрія значна i розподіл ознаки в генеральній сукупності не є симетричним.

Застосовуються також структурні показники (коефіцієнти) асиметрії, що характеризують асиметрію тільки в центральній частині розподілу, тобто основної маси одиниць, і не залежать від крайніх значень ознаки. Розрахуємо структурний коефіцієнт асиметрії Пірсона: 


$$
A_{s p}=\frac{\bar{x}-M_{o}}{\sigma}
$$

Для симетричних розподілів розраховується показник ексцесу (гостровершинності). Найчастіше ексцес оцінюється за допомогою показника:

$$
\mathrm{E}_{x}=\frac{M_{4}}{s^{4}}-3
$$

Для розподілів гостро вершиності (витягнутих), показник ексцесу -позитивний $(\mathrm{Ex}>0)$, для більш плосковершінних (сплюснених $)$ - негативний $(\mathrm{Ex}<0)$.

Таблиця 10

Розрахунок центральних моментів $\mathrm{M}_{3}$ та $\mathrm{M}_{4}$ для $\mathrm{Vt}$

\begin{tabular}{|c|c|c|}
\hline $\mathbf{X i}$ & $(\mathbf{x}-\mathbf{x c p})^{\mathbf{3} * \mathbf{f}}$ & $\mathbf{( x - \mathbf { x c p }}^{\mathbf{4} * \mathbf{f i}}$ \\
\hline 60 & -5.19 & 21.3 \\
\hline 61 & -4.19 & 13.01 \\
\hline 62 & -0.93 & 1.96 \\
\hline 63 & -0.19 & 0.21 \\
\hline 64 & $-9.80 \mathrm{E}-05$ & $1.00 \mathrm{E}-05$ \\
\hline 65 & 0.068 & 0.061 \\
\hline 66 & 0.88 & 1.68 \\
\hline 67 & 3.15 & 9.13 \\
\hline 68 & 6.2 & 24.17 \\
\hline Всього & -0.19 & 71.52 \\
\hline
\end{tabular}

Таблиця 11

\begin{tabular}{|c|c|c|}
\hline $\mathbf{X i}$ & $(x-x c p) 3 * f i$ & $(x-x c p) 4 * f i$ \\
\hline 32 & $\begin{array}{l}-7.02 \\
\end{array}$ & 26.9 \\
\hline 33 & -3.29 & 9.3 \\
\hline 34 & -0.74 & 1.35 \\
\hline 35 & -0.046 & 0.038 \\
\hline 36 & 0.000418 & $7.10 \mathrm{E}-05$ \\
\hline 37 & 0.21 & 0.24 \\
\hline 38 & 0.92 & 2 \\
\hline 39 & 3.98 & 12.62 \\
\hline 40 & 7.25 & 30.24 \\
\hline Всього & 1.27 & 82.68 \\
\hline
\end{tabular}

Розрахунок центральних моментів $\mathrm{M}_{3}$ та $\mathrm{M}_{4}$ для $\mathrm{V}_{\mathrm{L}}$ 
Statistical reasoning for the application of qualimetry methods to...

Таблиця 12

Розрахунок центральних моментів $\mathrm{M}_{3}$ та $\mathrm{M}_{4}$ для $\gamma$

\begin{tabular}{|c|c|c|}
\hline $\mathrm{Xi}$ & $(\mathrm{x}-\mathrm{xcp}) 3 * \mathrm{fi}$ & $(\mathrm{x}-\mathrm{xcp}) 4 * \mathrm{fi}$ \\
\hline 2.4 & -0.000714 & 0.000133 \\
\hline 2.45 & -0.000305 & $4.20 \mathrm{E}-05$ \\
\hline 2.5 & $-6.80 \mathrm{E}-05$ & $6.00 \mathrm{E}-06$ \\
\hline 2.55 & $-5.00 \mathrm{E}-06$ & 0 \\
\hline 2.6 & 0 & 0 \\
\hline 2.65 & $3.10 \mathrm{E}-05$ & $2.00 \mathrm{E}-06$ \\
\hline 2.7 & 0.000205 & $2.30 \mathrm{E}-05$ \\
\hline 2.75 & 0.000656 & 0.000107 \\
\hline Всього & -0.000201 & 0.000313 \\
\hline
\end{tabular}

Таблиця 13

Розрахунок центральних моментів $\mathrm{M}_{3}$ та $\mathrm{M}_{4}$ для $\sigma$

\begin{tabular}{|c|c|c|}
\hline $\mathbf{X i}$ & $(x-x c p) 3^{*}{ }^{*} i$ & $(\mathrm{x}-\mathrm{xcp}) 4^{*}$ fi \\
\hline 8.9 & -0.000598 & 0.000109 \\
\hline 8.95 & -0.000239 & $3.10 \mathrm{E}-05$ \\
\hline 9 & $-8.10 \mathrm{E}-05$ & $7.00 \mathrm{E}-06$ \\
\hline 9.05 & $-4.00 \mathrm{E}-06$ & 0 \\
\hline 9.1 & $1.00 \mathrm{E}-06$ & 0 \\
\hline 9.15 & $3.50 \mathrm{E}-05$ & $2.00 \mathrm{E}-06$ \\
\hline 9.2 & 0.000208 & $2.50 \mathrm{E}-05$ \\
\hline 9.25 & 0.000646 & 0.000109 \\
\hline Всього & $-3.10 \mathrm{E}-05$ & 0.000283 \\
\hline
\end{tabular}

Таблиця 14

Розрахунок показників форми розподілу

\begin{tabular}{|c|c|c|c|c|}
\hline $\mathbf{X i}$ & $\mathbf{V t}$ & $\mathbf{V L}$ & $\boldsymbol{\gamma}$ & $\boldsymbol{\sigma}$ \\
\hline $\mathrm{AS}$ & 0.0115 & 0.0679 & -0.13 & 0 \\
\hline$S_{A_{s}}$ & 0.592 & 0.592 & 0.603 & 0.603 \\
\hline $\mathrm{Asp}$ & 25.23 & 1.07 & -1.42 & -0.17 \\
\hline $\mathrm{Ex}$ & -1.28 & -1.34 & -1.23 & -1.16 \\
\hline
\end{tabular}

Для того щоб перевірити гіпотезу про рівномірний розподіл $\mathrm{X}$, тобто. за законом: $\mathrm{f}(\mathrm{x})=1 /$ (b-a) в інтервалі $(\mathrm{a}, \mathrm{b})$, треба:

1. Оцінити параметри a i b - кінці інтервалу, в якому спостерігалися можливі значення X, за формулами (через знак * позначені оцінки параметрів): 


$$
\begin{aligned}
& a^{*}=\bar{x}-\sqrt{3} \sigma \\
& b^{*}=\bar{x}+\sqrt{3} \sigma
\end{aligned}
$$

2. Знайти щільність ймовірності передбачуваного розподілу

$$
f_{(x)}=1 /\left(b^{*}-a^{*}\right)
$$

3. Знайти теоретичні частоти:

$$
\begin{gathered}
n_{1}=n^{*} 1 /\left(\left(b^{*}-a^{*}\right) *\left(x_{1}-a^{*}\right)\right) \\
n_{2}=n_{3}=n_{s-1}=n^{*} 1 /\left(\left(b^{*}-a^{*}\right) *\left(x_{i}-x_{i-1}\right)\right) \\
n_{1}=n^{*} 1 /\left(\left(b^{*}-a^{*}\right) *\left(b^{*}-x_{s-1}\right)\right)
\end{gathered}
$$

4. Порівняти емпіричні і теоретичні частоти за допомогою критерію Пірсона, прийнявши число ступенів свободи $\mathrm{k}=\mathrm{s}-3$, де $\mathrm{s}-$ число первинних інтервалів вибірки; якщо ж було вироблено об'єднання малочисельних частот, отже, i самих інтервалів, то s - число інтервалів, що залишилися після об'єднання.

Таблиця 15

Значення щодо: $a^{*}, b^{*}, \mathbf{f}(\mathbf{x})$

\begin{tabular}{|c|c|c|c|c|}
\hline $\mathbf{X}_{\mathbf{i}}$ & $\mathbf{V}_{\mathbf{t}}$ & $\mathbf{V}_{\mathbf{L}}$ & $\boldsymbol{\gamma}$ & $\boldsymbol{\sigma}$ \\
\hline $\mathrm{a}^{*}$ & 59.7 & 31.23 & 2.39 & 8.89 \\
\hline $\mathrm{b}^{*}$ & 68.51 & 40.43 & 2.79 & 9.27 \\
\hline $\mathrm{f}(\mathrm{x})$ & 0.114 & 0.109 & 2.501 & 2.594 \\
\hline
\end{tabular}

Визначимо границю критичної області, оскільки статистика Пірсона вимірює різницю між емпіричним і теоретичним розподілами, то чим більше ііі значення Кнабл, тим сильніше аргумент проти основної гіпотези. Тому критична область для цієї статистики завжди правобічна: $\left[\mathrm{K}_{\mathrm{kp}} ;+\infty\right)$. Ї̈̈ границя $\mathrm{K}_{\mathrm{kp}}=\chi^{2}(\mathrm{k}-\mathrm{r}-1 ; \alpha)$ знаходимо за таблицями розподілу $\chi^{2}$ і заданим значенням s, $\mathrm{k}$ (число інтервалів), $\mathrm{r}=2$ (параметри а i b).

Для всіх розрахунків вимірювань динамічних характеристик спостережувані значення статистики Пірсона не потрапляють в критичну область: $\mathrm{K}_{\text {набл }}<\mathrm{K}_{\mathrm{kp}}$, тому немає підстав відкидати основну гіпотезу. 
Statistical reasoning for the application of qualimetry methods to...

Таблиця 16

Розрахунок теоретичних частот для $V_{t}$

\begin{tabular}{|c|c|c|c|c|c|}
\hline № & $n_{i}$ & $\mathbf{n}_{*_{\mathrm{i}}}$ & $\mathbf{n}_{\mathrm{i}}-\mathbf{n}_{*_{\mathrm{i}}}$ & $\left(\mathbf{n}_{\mathrm{i}}-\mathbf{n}_{* \mathrm{i}}\right)^{2}$ & $\left(\mathbf{n}_{\mathrm{i}}-\mathbf{n}_{v_{\mathrm{i}}}\right)^{2} / \mathbf{n}_{*_{\mathrm{i}}}$ \\
\hline 1 & 0.075 & 0.03355 & 0.04145 & 0.00172 & 0.05123 \\
\hline 2 & 0.14 & 0.1136 & 0.02637 & 0.000695 & 0.00612 \\
\hline 3 & 0.1 & 0.1136 & -0.01363 & 0.000186 & 0.00164 \\
\hline 4 & 0.14 & 0.1136 & 0.02637 & 0.000695 & 0.00612 \\
\hline 5 & 0.085 & 0.1136 & -0.02863 & 0.00082 & 0.00721 \\
\hline 6 & 0.095 & 0.1136 & -0.01863 & 0.000347 & 0.00305 \\
\hline 7 & 0.13 & 0.1136 & 0.01637 & 0.000268 & 0.00236 \\
\hline 8 & 0.13 & 0.1136 & 0.01637 & 0.000268 & 0.00236 \\
\hline 9 & 0.105 & 0.05741 & 0.04759 & 0.00226 & 0.03945 \\
\hline Всього & 1 & & & & 0.1195 \\
\hline
\end{tabular}

Таблиця 17

Розрахунок теоретичних частот для $\mathrm{V}_{\mathrm{L}}$

\begin{tabular}{|c|c|c|c|c|c|}
\hline № & $\mathbf{n}_{\mathrm{i}}$ & $\mathbf{n}_{*_{\mathrm{i}}}$ & $\mathbf{n}_{\mathrm{i}}-\mathbf{n}_{*_{\mathrm{i}}}$ & $\left(\mathbf{n}_{\mathrm{i}}-\mathbf{n}_{*_{\mathrm{i}}}\right)^{2}$ & $\left(\mathbf{n}_{\mathrm{i}}-\mathbf{n}_{*_{\mathrm{i}}}\right)^{2} / \mathbf{n}_{*_{\mathrm{i}}}$ \\
\hline 1 & 0.125 & 0.08363 & 0.04137 & 0.00171 & 0.02047 \\
\hline 2 & 0.145 & 0.1087 & 0.03629 & 0.00132 & 0.01211 \\
\hline 3 & 0.12 & 0.1087 & 0.01129 & 0.000127 & 0.00117 \\
\hline 4 & 0.08 & 0.1087 & -0.02871 & 0.000824 & 0.00758 \\
\hline 5 & 0.085 & 0.1087 & -0.02371 & 0.000562 & 0.00517 \\
\hline 6 & 0.13 & 0.1087 & 0.02129 & 0.000453 & 0.00417 \\
\hline 7 & 0.09 & 0.1087 & -0.01871 & 0.00035 & 0.00322 \\
\hline 8 & 0.125 & 0.1087 & 0.01629 & 0.000265 & 0.00244 \\
\hline 9 & 0.1 & 0.04667 & 0.05333 & 0.00284 & 0.06095 \\
\hline Всього & 1 & & & & 0.1173 \\
\hline
\end{tabular}

Отже, справедливе припущення про те, що дані вибірки мають рівномірний закон розподілу.

На графіку (рис. 6) показана залежність значень випадкових величин від їхніх імовірностей (частот).

Полігон емпіричних частот і ймовірність для рівномірного закону розподілу для $\mathrm{V}_{\mathrm{t}}$. На графіку показано порівняння графіків емпіричних частот з теоретичними частотами згідно з законом рівномірного розподілу для $\mathrm{Vt}$ згідно з таблицями $\mathrm{n}$ - графік експериментальних частот. $\mathrm{n}^{*}$ - графік теоретичних частот. Значення вимірювань та їх ймовірності для Vt представлені на рис. 7. 
Розрахунок теоретичних частот для $\gamma$

\begin{tabular}{|c|c|c|c|c|c|}
\hline № & $\mathbf{n}_{\mathbf{i}}$ & $\mathbf{n}_{*_{\mathrm{i}}}$ & $\mathbf{n}_{\mathbf{i}}-\mathbf{n}_{\text {*i }_{\mathbf{i}}}$ & $\left.\mathbf{( n}_{\mathbf{i}}-\mathbf{n}_{*_{i}}\right)^{2}$ & $\left(\mathbf{n}_{\mathbf{i}}-\mathbf{n}_{*_{\mathrm{i}}}\right)^{2} / \mathbf{n}_{*_{\mathrm{i}}}$ \\
\hline 1 & 0.11 & 0.03348 & 0.07652 & 0.00586 & 0.1749 \\
\hline 2 & 0.12 & 0.1251 & -0.00507 & $2.60 \mathrm{E}-05$ & 0.000206 \\
\hline 3 & 0.105 & 0.1251 & -0.02007 & 0.000403 & 0.00322 \\
\hline 4 & 0.11 & 0.1251 & -0.01507 & 0.000227 & 0.00182 \\
\hline 5 & 0.145 & 0.1251 & 0.01993 & 0.000397 & 0.00317 \\
\hline 6 & 0.12 & 0.1251 & -0.00507 & $2.60 \mathrm{E}-05$ & 0.000206 \\
\hline 7 & 0.14 & 0.1251 & 0.01493 & 0.000223 & 0.00178 \\
\hline 8 & 0.15 & 0.09101 & 0.05899 & 0.00348 & 0.03824 \\
\hline Всього & 1 & & & & 0.2236 \\
\hline
\end{tabular}

Таблиця 19

Розрахунок теоретичних частот для б

\begin{tabular}{|c|c|c|c|c|c|}
\hline № & $n_{i}$ & $\mathbf{n}_{*_{\mathrm{i}}}$ & $\mathbf{n}_{\mathrm{i}}-\mathbf{n}_{* \mathrm{i}}$ & $\left(\mathbf{n}_{\mathrm{i}}-\mathbf{n}_{* \mathrm{i}}\right)^{2}$ & $\left(\mathbf{n}_{\mathrm{i}}-\mathbf{n}_{k_{\mathrm{i}}}\right)^{2} / \mathbf{n}_{k_{\mathrm{i}}}$ \\
\hline 1 & 0.1 & 0.02915 & 0.07085 & 0.00502 & 0.1722 \\
\hline 2 & 0.105 & 0.1297 & -0.02471 & 0.000611 & 0.00471 \\
\hline 3 & 0.15 & 0.1297 & 0.02029 & 0.000412 & 0.00317 \\
\hline 4 & 0.12 & 0.1297 & -0.00971 & $9.40 \mathrm{E}-05$ & 0.000727 \\
\hline 5 & 0.155 & 0.1297 & 0.02529 & 0.00064 & 0.00493 \\
\hline 6 & 0.11 & 0.1297 & -0.01971 & 0.000388 & 0.00299 \\
\hline 7 & 0.125 & 0.1297 & -0.00471 & $2.20 \mathrm{E}-05$ & 0.000171 \\
\hline 8 & 0.135 & 0.06288 & 0.07212 & 0.0052 & 0.08272 \\
\hline Всього & 1 & & & & 0.2716 \\
\hline
\end{tabular}

Таблиця 20

\section{Границі критичних областей}

для емпіричного і теоретичного розподілу

\begin{tabular}{|c|c|c|c|c|}
\hline $\mathbf{X}_{\mathbf{i}}$ & $\mathbf{V}_{\mathbf{t}}$ & $\mathbf{V}_{\mathbf{L}}$ & $\boldsymbol{\gamma}$ & $\boldsymbol{\sigma}$ \\
\hline $\mathrm{K}_{\text {kр }}$ & 12.59159 & 12.59159 & 11.07050 & 11.07050 \\
\hline $\mathrm{K}_{\text {спост }}$ & 0.1195 & 0.1173 & 0.22 & 0.27 \\
\hline
\end{tabular}

Полігон емпіричних частот для $\mathrm{V}_{\mathrm{L}}$. На цьому графіку показана залежність значень випадкових величин від їхніх імовірностей (частот).

Полігон емпіричних частот і ймовірність для рівномірного закону розподілу для $\mathrm{V}_{\mathrm{L}}$. На цьому графіку показано порівняння графіків 


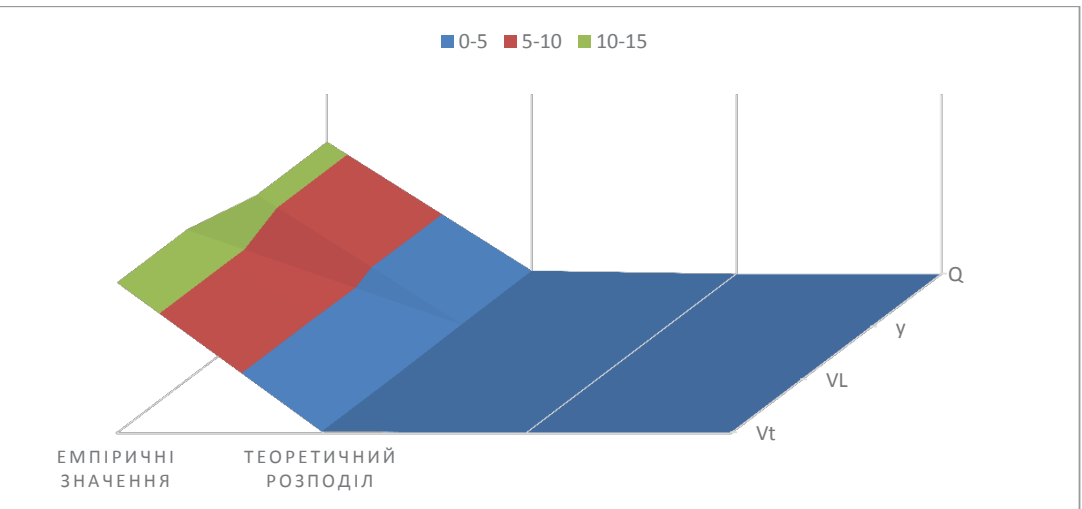

\section{Рис. 6. Границі критичних областей для емпіричного і теоретичного розподілу}

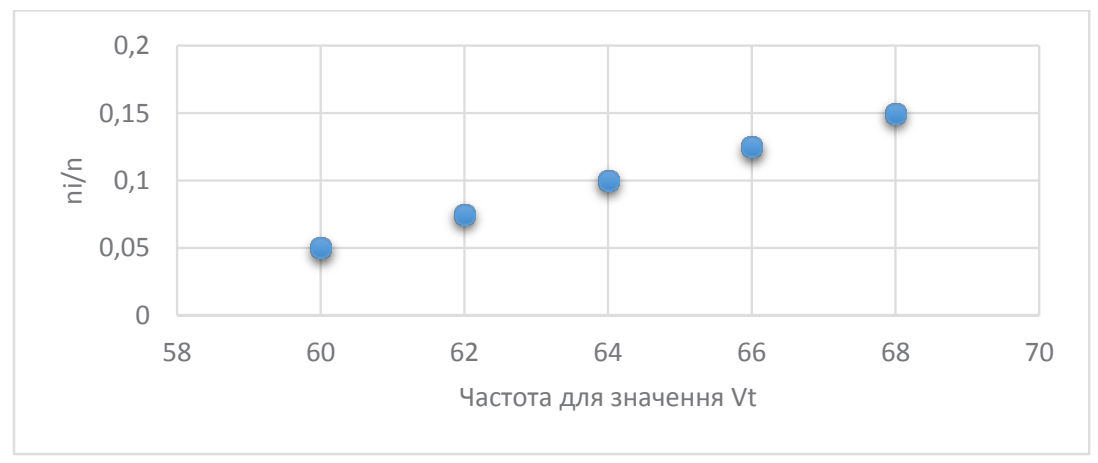

\section{Рис. 7.1. Полігон емпіричних частот для Vt}

емпіричних частот з теоретичними частотами згідно з законом рівномірного розподілу для $\mathrm{V}_{\mathrm{L}}$.

Полігон емпіричних частот для $\gamma$. Значення вимірювань та їх ймовірності для $\gamma$. На цьому графіку показана залежність значень випадкових величин від їхніх імовірностей (частот).

Полігон емпіричних частот і ймовірність для рівномірного закону розподілу для $\gamma$. На цьому графіку показано порівняння графіків емпіричних частот з теоретичними частотами згідно з законом рів- 


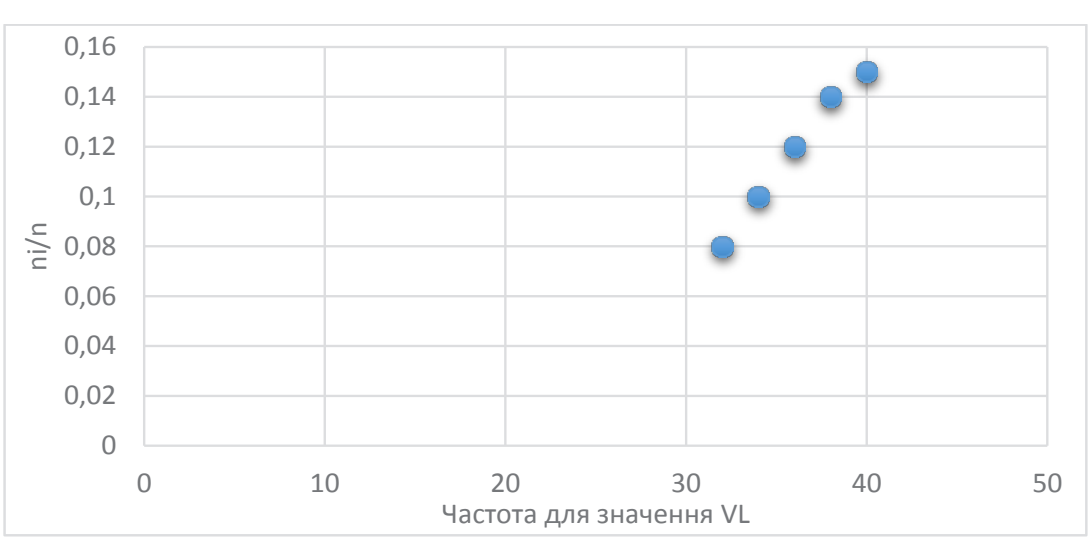

Рисунок 7.2. Полігон емпіричних частот для $\mathrm{V}_{\mathrm{L}}$

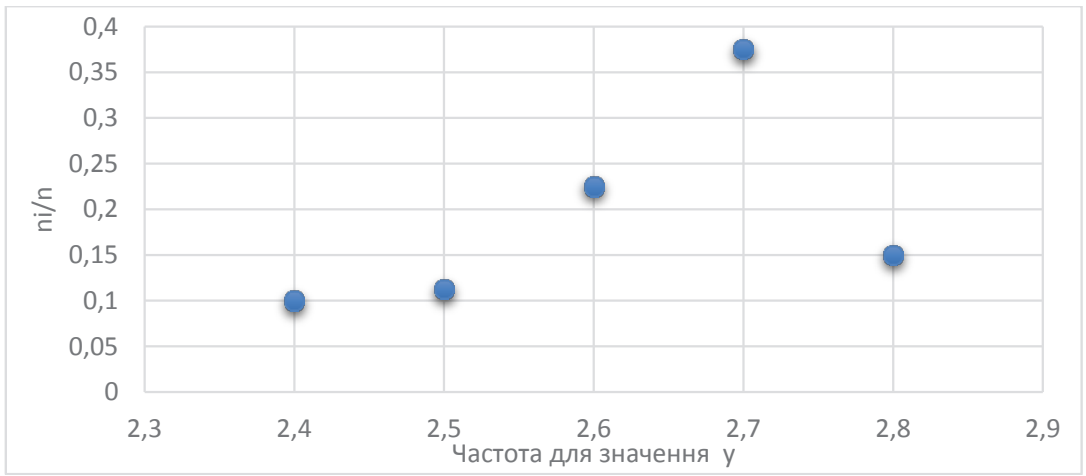

Рис. 8. Полігон емпіричних частот для $\gamma$

номірного розподілу для $\gamma$. Значення вимірювань та їх ймовірності для $\gamma, \mathrm{n}$ - графік експериментальних частот, $\mathrm{n}^{*}$ - графік теоретичних частот.

Полігон емпіричних частот і ймовірність для рівномірного закону розподілу для $\sigma$. На цьому графіку показане порівняння графіків емпіричних частот з теоретичними частотами згідно з законом рівномірного розподілу для $\sigma$ згідно з таблицями. Таблиця розрахунку теоретичних частот для $\sigma, \mathrm{n}$ - графік експериментальних частот, $\mathrm{n}^{*}$ - графік теоретичних частот (рис. 10). 
Statistical reasoning for the application of qualimetry methods to...

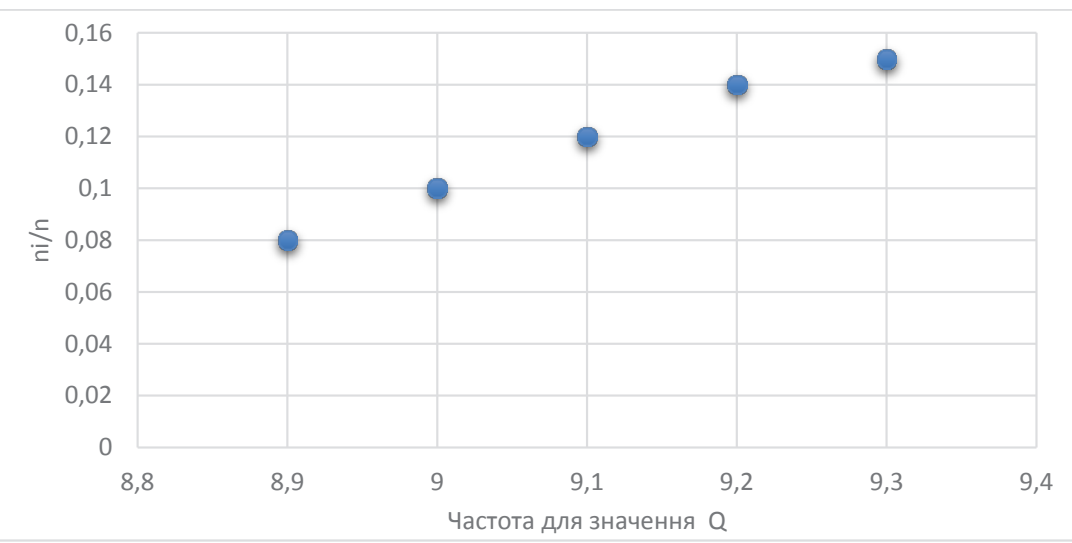

Рис. 9. Полігон емпіричних частот для $\sigma$

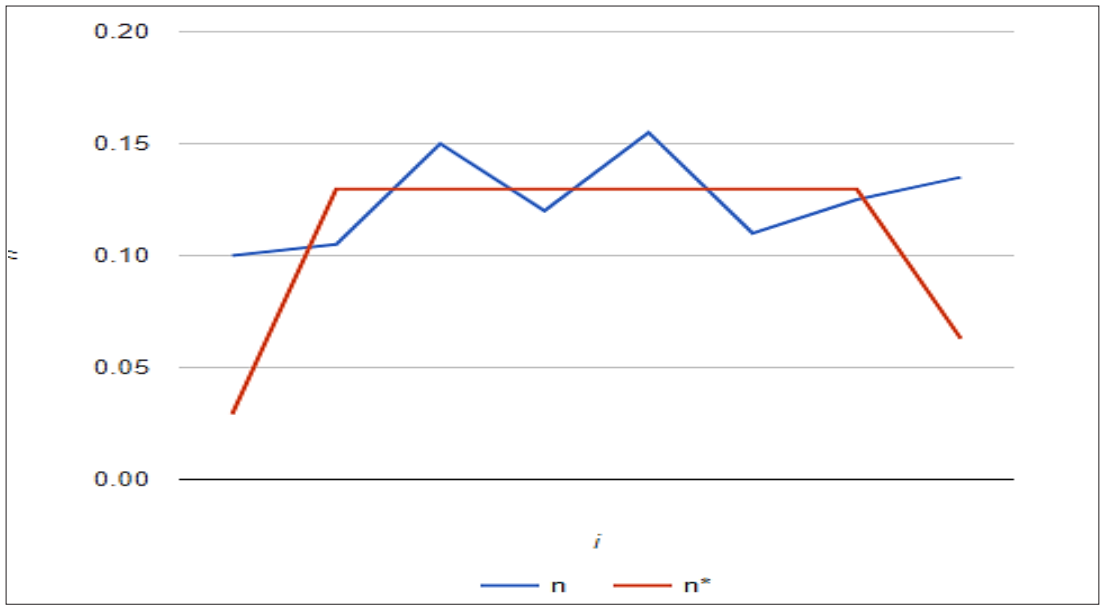

Рис. 10. Порівняння теоретичних і експериментальних частот

Отже, згідно із рисунком 10 гіпотетичний закон щодо рівномірно розподілення експериментальних величин відповідає теоретичній перевірці, котра була виконана за допомогою критерію Пірсона. Тому можна зробити висновок про те, що застосування методів кваліметрії для оцінювання рівня якості динамічно-навантажених матеріалів допустиме в якості допоміжного інструменту до існуючого експертного підходу. 


\section{5. Висновки}

В ході проведення оцінювання рівня якості металевих матеріалів в умовах високошвидкісного навантаження було враховано специфічність досліджень, оскільки характеристиками якості в даному випадку будуть параметри, котрі пов'язані з ударним навантаженням. При цьому визначальною характеристикою якості для ударно-навантажених матеріалів була встановлена відкольна міцність матеріалу.

На основі виконаного аналізу сучасного досвіду застосування комплексно-кількісних методів зроблений вибір найбільш прийнятних методів оцінювання рівня якості матеріалів в умовах високошвидкісного навантаження. Як показує представлений аналіз матеріалів - це вирішує проблему оцінки якості імпульсно навантажених матеріалів $\mathrm{i}$ створює альтернативний механізм оцінки якості навантажених матеріалів, поряд з експертним методом.

Крім того обрані методи кваліметрії найбільшою мірою підходять для використання в умовах експериментального випробування, $\epsilon$ наочними і легко відтворюваними. При наявності рекомендацій щодо застосування обраних методів, які можуть бути легко впроваджені на виробництві або в навчальному процесі.

\section{Список літератури:}

1. Хімічева Г.І. Обгрунтування можливості застосування кваліметричного підходу, щодо оцінки якості матеріалів, що знаходяться в умовах високошвидкісного навантаження / Г.І. Хімічева, В.В. Куриляк // Вісник національного технічного університету «ХПІ». - 2015. - № 62. - С. 40-45.

2. Куриляк В.В. Оцінка якості металів та сплавів в умовах високошвидкісного навантаження / В.В. Куриляк // Технологічний аудит та резерви виробництва. - 2016. - № 30. - С. 53-56.

3. Хімічева Г.І. Аналіз поведінки параметрів інтелектуальних матеріалів та полімерів в умовах високошвидкісного навантаження / Г.І. Хімічева, В. В. Куриляк // Вісник національного технічного університету «ХПІ». 2016. - № 25. - C. 125-131.

4. Куриляк В.В. Обгрунтування застосування комплексно-кількісних методів для оцінки якості матеріалів в умовах високошвидкісного навантаження / В.В. Куриляк, Г.І. Хімічева // Успехи физики металлов. - 2016. № $17 .-$ С. 343-367.

5. Куриляк В.В. Застосування кваліметричних методів для оцінки якості ударно-навантажених матеріалів / В.В. Куриляк, Г.І. Хімічева. // Успехи физики металов. - 2017. - № 2. - С. 155-175. 
6. Куриляк В.В. Программа «AQM» для оцінки рівня якості високонавантажених матеріалів / В.В. Куриляк. // Технічне регулювання, метрологія та інформаційні технології. - 2017. - № 7. - С. 136-140.

7. Куриляк В.В. Оцінка якості матеріалів в умовах високошвидкісного навантаження / В.В. Куриляк // Мехатроніка, комп'ютерні системи, метрологія та інноваційні технології в машинобудуванні. Ресурсозбереження та охорона навколишнього середовища: Тези доповідей. - Київ, 2016. - С. 137.

8. Куриляк В.В. Динамические характеристики и критерии качества нагруженных материалов / В.В. Куриляк // Экономика, технологии и право в современном мире: Материалы Международной научно-практической конференции факультета экономики и права инженерного факультета. - Барановичи, 2016. - C. 100-102.

9. Куриляк В.В. Експериментальне дослідження якісних характеристик поліметилметакрилатового матеріалу / В.В. Куриляк // Мехатронні системи: інновації та інжинірінг: Тези доповідей Міжнародної науково-практичної конференції. - Київ, 2017. - 228-229.

\section{References:}

1. Himicheva G.I., Kuryliak V.V. (2015) Obrruntuvannya mozhlivosti zastosuvannya kvalimetrichnogo pidhodu, shchodo ocinki yakosti materialiv, shcho znahodyat'sya $\mathrm{v}$ umovah visokoshvidkisnogo navantazhennya. Visnik nacional'nogo tekhnichnogo universitetu, no. 62, pp. 40-45.

2. Kurilyak V.V. (2016) Ocinka yakosti metaliv ta splaviv $v$ umovah visokoshvidkisnogo navantazhennya. Tekhnologichnij audit ta rezervi virobnictva, no. 30 , pp. $53-56$.

3. Himicheva G.I., Kuryliak V.V. Analiz povedinki parametriv intelektual'nih materialiv ta polimeriv $\mathrm{v}$ umovah visokoshvidkisnogo navantazhennya. Visnik nacional'nogo tekhnichnogo universitetu "HPI", no. 25, pp. 125-131.

4. Kurilyak V.V., Himicheva G.I. Obrruntuvannya zastosuvannya kompleksno-kil'kisnih metodiv dlya ocinki yakosti materialiv v umovah visokoshvidkisnogo navantazhennya. Uspekhi fiziki metallov, no. 17, pp. 343-367.

5. Kurilyak V. V., Himicheva G.I. Zastosuvannya kvalimetrichnih metodiv dlya ocinki yakosti udarno-navantazhenih materialiv. Uspekhi fiziki metalov, no. 2, pp. 155-175.

6. Kurilyak V. V. (2017) Programma "AQM" dlya ocinki rivnya yakosti visokonavantazhenih materialiv ["AQM" to assess the quality level of high-load materials]. Tekhnichne regulyuvannya, metrologiya ta informacijni tekhnologiy. (Ukraïna, Odesa, 22 kvitnya 2017 r.), Odesa, pp. S. 136-140.

7. Kurilyak V.V. (2016) Ocinka yakosti materialiv v umovah visokoshvidkisnogo navantazhennya [Assessment of materials quality in conditions of high-speed loading]. Mekhatronika, kom'yuterni sistemi, metrologiya ta innovacijni tekhnologii $\mathrm{v}$ mashinobuduvanni. Resursozberezhennya ta ohorona navkolishn'ogo seredovishcha: Tezi dopovidej (Ukrayna, Kiyv, 20 travnya 2016 r.), Kiyv, p. 137.

8. Kurilyak V.V. (2016) Dinamicheskie harakteristiki i kriterii kachestva nagruzhennyh materialov [Dynamic characteristics and quality criteria of loaded materials]. Ekonomika, tekhnologii i pravo v sovremennom mire: Materialy 
Mezhdunarodnoj nauchno-prakticheskoj konferencii fakul'teta ehkonomiki i prava inzhenernogo fakul'teta (Bilorusiya, Baranovichi, 22 lyutogo 2016 r.), Baranovichi, pp. 100-102.

9. Kurilyak V.V. (2017) Eksperimental'ne doslidzhennya yakisnih harakteristik polimetilmetakrilatovogo materialu [Experimental study of qualitative characteristics of polymethyl methacrylate material]. Mekhatronni sistemi: innovaciï ta inzhiniring: Tezi dopovidej Mizhnarodnoy nauvovo-praktichnoy konferenciy (Ukrayna, Kiyv, 20 travnya 2016 r.), Kiyv, pp. 228-229. 


\section{Lapkina Inna ${ }^{1}$ \\ Malaksiano Mykola ${ }^{2}$}

DOI: http://dx.doi.org/10.30525/978-9934-571-26-8_12

Abstract. Operational characteristics of equipment tend to worsen due to ageing and wear. As a result, there comes the time when it becomes appropriate to upgrade the equipment. The determining factor to make a decision concerning the equipment replacement is typically how effective its further usage could prove to be. When planning reasonable terms of replacement of sophisticated equipment, it is important to take into account not only the expected performance indicators average, but also resistance of these indicators against possible fluctuations caused by random changes in the level of equipment loading. In many cases the level of equipment loading has a tendency to fluctuate. That is why it is important to develop methods of substation for the strategies of the renewal the fleet of loading equipment, which must operate under conditions of unstable level of loading. In this chapter the dynamic model of changes in the performance indicators of sophisticated equipment is proposed. The proposed model consists of two parts. The first part concerns modeling of a random process of changes in the level of equipment loading and is described by the stochastic equation in the form of Ito. The second part concerns modeling of dynamics of equipment wear depending on changes in the levels of its loading and is described by the differ-ential equation. As a result, the stochastic dynamic model of changes in performance indicators of sophisticated equipment, which takes into account random fluctuations of equipment loading, was obtained. Using the proposed model, we analyzed dynamics of equipment total specific costs average in the case when a degree of equipment loading is subject to random changes. Quantitative ratios of equipment total specific

\footnotetext{
${ }^{1}$ Doctor of Economic Sciences, Professor,

Head of Department of Management of Logistics Systems and Projects,

Odessa National Maritime University, Ukraine

${ }^{2}$ Candidate of Physical and Mathematical Sciences, Associate Professor,

Department of Management of Logistics Systems and Projects,

Odessa National Maritime University, Ukraine

(C) Lapkina Inna, Malaksiano Mykola
} 
costs average, level of fluctuations of these costs during possible random changes in loading and terms of equipment replacement were found out. The research demonstrates that changes in equipment total specific costs average can be insignificant for a certain time. In this case, the spread range of the level of equipment total specific costs within the same time range can increase significantly. That is why it makes sense to reduce the equipment service term. This would lead to an insignificant increasing of equipment mean costs, however, their stability level will improve considerably.

\section{Introduction}

For most types of equipment, with the passage of time its performance indicators have tendency to decline due to wear and tear, exhaustion of the resource and other disruptive processes. Physical deterioration leads to increasing in the number of failures and increases in equipment current expenditures. As a result, there comes the time when it becomes appropriate to upgrade the equipment. The determining factor to make a decision concerning the equipment replacement is typically how effective its further usage could prove to be. Actually, it often happens that technical condition of the equipment would allow its further usage over a long time under conditions of proper repairs and maintenance, but, nevertheless, this equipment is replaced by new machinery for efficiency reasons. Equipment replacement may be caused by both physical and moral wear. Only physical depreciation of equipment is taken into consideration in this research. When planning reasonable terms of replacement of sophisticated equipment, it is important to take into account not only the expected perfor-mance indicators average, but also resistance of these indicators against possible fluctuations caused by random changes in the level of equipment loading. In recent years, the structure and intensity of freight flow through Ukrainian ports have undergone significant changes and tends to fluctuate in the future. Thus, it is a relevant task to substantiate strategies for the renewal and development of fleet of loading equipment, which must operate under conditions of unstable level of loading.

Planning the terms of equipment replacement due to its physical wear is a relevant and, in many cases, difficult problem, the study of which is the focus of many scientific works. There are different approaches to investigate such problem. For example, those techniques that are based on survival curves are rather effective for simple standard equipment [1, p. 139]. More sophisticated methods are typically used for complex repairable equipment. 


\section{Optimal replacement scheduling for equipment taking into account the...}

There are a number of models for technical maintenance and replacement of equipment. These models can be conventionally divided according to the types of maintenance policies: the policy of replacement due to age or service term, the policy of group changes, the policy of periodic preventive maintenance, etc. Each type of policy has its own specifics, their merits and drawbacks. In review [2], several existing maintenance policies both for one-unit and for multi-level systems are generalized, categorized, and compared. The relations between different maintenance policies are studied.

Paper [3] considered the task on choosing optimal preventive maintenance policy and a scheduled machine's sale date. It was assumed that performance of a machine did not depend on age, while a probability of failure of a machine increases over its operation period. In this case, preventive maintenance could be applied to reduce the probability of a machine's failure.

The problem of determination of the optimal repairs and retirement terms for complex port equipment was considered in [4]. The dynamic model of wear and tear growth was proposed in order to make allowance for variable loading level.

Papers $[5,6]$ explore the problems of CBM (condition-based maintenance) optimization. Thus, in article [5], authors addressed general problems of quality of the data used for analysis of CBM tasks, and proposed ways to solve them. Specifically, the article explores approaches to the estimation of data that are missing during analysis of decisions; the structure of data to control information on equipment maintenance, which is essential for making CBM-based decisions, was proposed. In paper [6], a task of finding the optimal strategy for equipment repairs and replacements was examined. The findings of research are based on using a dynamic model of equipment ageing.

Article [7] examines the issue about making decisions on the replacement of chains of machines over time employing an optimal control model, which takes into account random factors of machines' failures. The authors based their research on the known model [3]. This work also takes into consideration a possibility of technological improvements of the used equipment.

Studies [8] tackled the issues of coordination of operations on maintenance equipment with the investment strategies in the presence of possible random failures of equipment. In these works, in contrast to the traditional 
approach, which was proposed in the classic paper [3], a stochastic process of failures of machines is modeled explicitly. Thus, the task on choosing the optimal strategies for equipment replacements comes down to analysis of the model of stochastic dynamic programming. In paper [8], the task on reserving production capacities was studied also, with comparison of deterministic politics of equipment replacements and policies that depend on a machines' condition. In addition, the authors studied influence of performance deterioration, technological improvements and possible delays in the implementations of decisions, as well as the impact of a discount rate on the optimal policy of control over a fleet of machines.

The influence of wear and tear of complex port equipment on the dynamics of its performance indicators was studied in [9]. Estimations of fluctuations of average costs per unit of cargo handling equipment service time were obtained under conditions of unstable cargo flow intensity.

In [10], the authors examine a task of the replacement of one machine and reduce it to a nonlinear integral equation for a variable optimal service life of a machine.

The tasks on the optimization of equipment fleet in ports, which operates under conditions of alternating intensity of cargo flow, and the optimization of a system of cargo delivery under conditions of alternating intensity of cargo flow, are enclosed in [11\$12]. In these papers, simulation models are proposed that allow the evaluation of effectiveness of various schemes of cargo delivery and optimization of port's equipment fleet structure.

Decisions on the terms of equipment replacement depend on such factors as the level of current operating expenses and replacement costs, as well as on coefficients of discount and performance actual difference, reliability, and safety of remaining and new equipment. However, the predictions that are related to these factors are typically not fully defined and are not always easy to assess objectively. Article [13] discusses possible subjective approaches to the assessment of uncertainty, which could be used as a basis for making a decision on equipment replacement.

The issue that requires further research is the substantiation of terms of re-placement of sophisticated equipment taking into consideration the instability of its loading level. In the studies given above, various options for stating the problem on the substantiation of terms of equipment replacement are proposed, employing different methods and models aimed at resolving it. However, each of the approaches, suggested in these papers, is 


\section{Optimal replacement scheduling for equipment taking into account the...}

aimed at examining one particular case, under certain conditions and constraints. The methods, proposed in the above studies, do not make it possible to substantially enough study the task on the substantiation of terms of replacement of sophisticated equipment taking into account the instability of its loading level. Specifically, all of them fail to establish quantitative relationships between the average level of equipment efficiency indicators, the level of fluctuations in these indicators at possible random fluctuations in loading and the term of equipment replacement.

The aim of present research is to study dynamics of average indicators of equipment efficiency and fluctuations of these indicators over time, as well as to develop a procedure for the substantiation of terms of replacement of sophisticated equipment taking into account the instability of its loading intensity.

To accomplish the aim, the following tasks are considered:

- to develop a mathematical model for the estimation of dynamics of mean values and fluctuations of indicators of sophisticated equipment functioning, which would take into account random fluctuations in the loading of equipment;

- to calculate the limits of intervals for possible values of total average costs per unit of time of equipment operation in the period from the start of its operation to its disposal;

- to establish quantitative relationships between the average level of indicators of equipment efficiency, the level of fluctuations in these indicators at possible random loading fluctuations and the term of equipment replacement.

\section{Modeling of random changes in a coefficient of equipment loading}

Let a coefficient of equipment loading $s=s(t)$ change randomly, accepting values between functions $s_{t}=s_{t}(t)$ and $s_{b}=s_{b}(t),\left(s_{b}(t)<s(t)<s_{t}(t)\right)$, and the average level of coefficient of loading at every moment of time $t$ equals to $s_{c}=s_{c}(t)$. Changes in coefficient of loading will be described with the help of a diffusion process $s=s(t, \omega)$, where $\omega \in \Omega$, and $(\Omega, \mathrm{A}, \mathrm{P})$ is the probability space.

To model a random process of equipment loading, let us consider the function of displacement in the following form:

$$
a(x, t)=l \cdot\left(s_{c}(t)-x\right)+s_{c}^{\prime}(t) .
$$


Function of displacement expresses the rate of a change in the values of a random process

$$
a(x, t)=\lim _{\tau \rightarrow t} \frac{1}{\tau-t} \cdot E(s(\tau, \omega)-s(t, \omega) \mid s(t, \omega)=x) .
$$

Let us consider function of diffusion

$$
b(x, t)=q^{2} \cdot\left(s_{t}(t)-x\right) \cdot\left(x-s_{b}(t)\right) .
$$

This function expresses the rate of change in conditional variance of random process $s=s(t, \omega)$ :

$$
b(x, t)=\lim _{\tau \rightarrow t} \frac{1}{\tau-t} \cdot \mathrm{E}\left((s(\tau, \omega)-s(t, \omega))^{2} \mid s(t, \omega)=x\right) .
$$

Thus, at existing functions of displacement and diffusion, random process $s=s(t, \omega)$ can be expressed with the help of the stochastic model of the state in the form of Ito [14]:

$$
d s(t, \omega)=a(s(t, \omega), t) d t+\sqrt{b(s(t, \omega), t)} d W(t, \omega),
$$

where $W(t, \omega)$ is the Wiener process that comes from zero under initial condition $s\left(t_{0}, \omega\right)=s_{0}(\omega)$.

It is possible to show [14] that at such selection of function of displacement and function of diffusion, a random process of a change in coefficient of loading $s=s(t, \omega)$, which was obtained with the help of stochastic differential equation (5), is limited by functions $s_{t}=s_{t}(t)$ and $s_{b}=s_{b}(t)$ and has mathematical expectation $E(s(t, \omega))=s_{c}(t)$.

Indeed, mathematical expectation $m_{s}(t)=E(s(t, \omega))$ of random process $s(t, \omega)$ is the solution to the Cauchy problem

$$
\left\{\begin{array}{l}
\frac{d m_{s}(t)}{d t}=l \cdot\left(s_{c}(t)-m_{s}(t)\right)+s_{c}^{\prime}(t), \\
m_{s}\left(t_{0}\right)=s_{c}\left(t_{0}\right),
\end{array}\right.
$$

which follows form the stochastic model of the state in the form of Ito (5), if it is influenced by operators of mathematical expectation. Through the direct check, it is possible to make sure that function $s_{c}(t)$ is the solution of equation (6), so $m_{s}(t)=s_{c}(t)$.

Selection of parameters $l, q>0$ in displacement function (1) and diffusion function (3) makes it possible to take into account specifics of the process of equipment loading. Parameter $l$ expresses the rate, at which trajectories of the stochastic process $s=s(t, \omega)$ approaches mathematical expectation $E(s(t, \omega))$. Equipment loading, at which the value of coeffi- 
cient of loading after deviations tend to approach quickly their mean values correspond to higher values of parameter $l$. Parameter $q$ characterizes intensity of fluctuations of stochastic process $s=s(t, \omega)$. Higher values of $q$ correspond to greater fluctuations of the level of equipment loading.

Since the choice of functions $s_{t}=s_{t}(t), s_{b}=s_{b}(t)$ and $s_{c}=s_{c}(t)$ is not restricted, it creates wide possibilities for taking into consideration the peculiarities of the process of changes in equipment loading, for example, like seasonal fluctuations and other specific factors, associated with the given cargo flow.

\section{Dynamics of wear of equipment depending on its loading level}

For the quantitative estimation of costs per unit of time of equipment operation from the beginning of its operation to its disposal at various scenarios of the change in coefficient of loading, we will consider wear indicator $u=u(t),(0 \leq u \leq 1)$. This indicator characterizes intensity of operating costs at moment $t$ at full loading of equipment.

To model changes in the indicator of wear and tear, we will consider a dynamic model [9] that is described by differential equation

$$
u^{\prime}=(1-u)^{q} \cdot(u-L)^{r} \cdot(a \cdot s(t)+b)
$$

under initial condition $u(0)=u_{0}$, where $r$ is the parameter that determines intensity of an increase in wear of equipment at the initial stage of ageing; $q$ is the parameter that determines intensity of an increase in wear of equipment at the final stage of ageing; $s(t)$ is the coefficient of equipment loading at moment $t(0 \leq s(t) \leq 1) ; L$ is the parameter that determines the lower asymptote of the curve of wear indicator $(0 \leq L<1) ; u_{0}$ is the initial value of wear indicator $\left(u_{0}>L\right) ; a$ and $b$ are the parameters that determine the total rate of an increase in wear within all time of operation equipment and influence of the level of equipment loading on the rate of its equipment.

We will discount all costs to the moment the operation of equipment starts. We will consider a year as the unit of time measurement by default. Average operating costs per unit of time of a machine's operation over the period from the beginning of operation till moment $t$ can be found from formula

$$
R_{o p e r}(t)=\frac{1}{t} \cdot \int_{0}^{t}\left(\frac{R_{v a r} \cdot u(\tau)}{u(0)} \cdot s(\tau)+R_{\text {const }}\right) \cdot e^{\frac{-\delta \tau}{100}} d \tau
$$


where $u(t)$ is the indicator of total wear at moment $t, R_{\text {const }}$ is the constant operation costs of equipment per unit of time; $R_{v a r}$ is the variable operation costs of the new equipment per unit of time at complete loading; $\delta$ is the annual interest rate at continuous accrual. The expression that is in brackets in formula (8) determines intensity of current costs for equipment per unit of time. Thus, expression (8) is the result of application of the known formula for finding present value of costs at continuous accrual:

$$
V(t)=\int_{0}^{t} f(\tau) \cdot e^{\frac{-\delta \tau}{100}} d \tau
$$

Formula (8) is often used when studying efficiency indicators of equipment operation.

Average capital costs per unit of time of operation of a machine in the period from the start of operation until the moment $t$ will be derived from formula

$$
R_{\text {cap }}(t)=\frac{R_{0}}{t},
$$

where $R_{0}$ is the price of new equipment.

Then total average costs per unit of time of equipment operation in the period from the start of operation till moment $t$ will be equal to

$$
R(t)=R_{\text {cap }}(t)+R_{\text {oper }}(t) .
$$

Following [9], the optimal term of equipment service will be considered time $t$, which minimizes mathematical expectation of total average costs per unit of time of equipment operation in the period from the start of operation till disposal, i.e. minimizes the expression

$$
E(R(s(t, \omega), t))=\int_{\Omega} R(s(t, \omega), t) P(d \omega),
$$

where $R(s, t)$ is the total average costs per unit of time of the given equipment operation in the period from the beginning of its operation till moment $t$ at the function of a change in coefficient of loading $s=s(t)$. For statistic evaluation of the specific value $E(R(s(t, \omega), t))$ at every moment $t$, using (5), we will generate a sample of functions of equipment loading $s_{1}(t)$, $s_{2}(t), \ldots, s_{N}(t)$ and use equation

$$
E(R(s(t, \omega), t)) \sim \hat{R}(t)=\frac{1}{N} \sum_{k=1}^{N} R\left(s_{k}(t), t\right)
$$

We will accept such value $t$ that minimized function $\hat{R}(t)$ as the optimal time for replacement of equipment. 


\section{Optimal replacement scheduling for equipment taking into account the...}

Prediction of the average level of costs of equipment at different possible trajectories of a change in loading volumes is of great importance. However, in many cases it is also important to estimate how much actual costs can deviate from their predicted mean. Standard deviation of total average costs per unit of time of equipment operation in the period from the beginning of its operation to disposal will be found from formula

$$
\sigma(R(s(t, \omega), t))=\left(\int_{\Omega}(R(s(t, \omega), t)-E(R(s(t, \omega), t)))^{2} P(d \omega)\right)^{1 / 2}
$$

or by the statistical estimation

$$
\sigma(R(s(t, \omega), t)) \sim \hat{\sigma}(t)=\left(\frac{1}{N-1}\left(\sum_{k=1}^{N} R^{2}\left(s_{k}(t), t\right)-\frac{1}{N}\left(\sum_{k=1}^{N} R\left(s_{k}(t), t\right)\right)^{2}\right)\right)^{1 / 2} .
$$

It is of practical interest to determine for every moment $t$ the interval $\left(x_{(1-\alpha) / 2}, x_{(1+\alpha) / 2}\right)$, within which values $R(s(t, \omega), t)$ will be found with the assigned probability $\alpha$. Results of numerical calculations of the intervals within which indicators of the total average costs per unit of operation time of equipment are given in the next chapter.

\section{Study of performance indicators of equipment at random fluctuations in loading level}

Generation of a random sample from implementations of the random process, which is the solution of the stochastic differential equation (5), was implemented in the package of applied programs for engineering calculations Matlab. Using Matlab, we performed calculation of indicators from formulas (8)-(15) and numerical calculations of trajectories of a change of coefficient of equipment wear, which are assigned by the dynamic model (7).

Fig. 1 shows a random sample of 100 trajectories of a change in average costs per unit of time of equipment operation $R(s(t, \omega), t)$. Numeric values of input parameters for the dynamic model (1)-(15), which were used, were obtained basing on statistical data of operation of port container loaders [9]. In this work, results of point estimations of parameters for the proposed dynamic model of equipment ageing (1)-(15) are used. This can be substantiated by the fact of using dynamic models as an approach that is widely and successfully used for modeling of various technical systems. The problem of statistical estimation of parameters of stochastic dynamic 
models is the focus of many studies. It should also be noted that the method of maximum likelihood is effective for the estimation of input parameters of dynamic models.

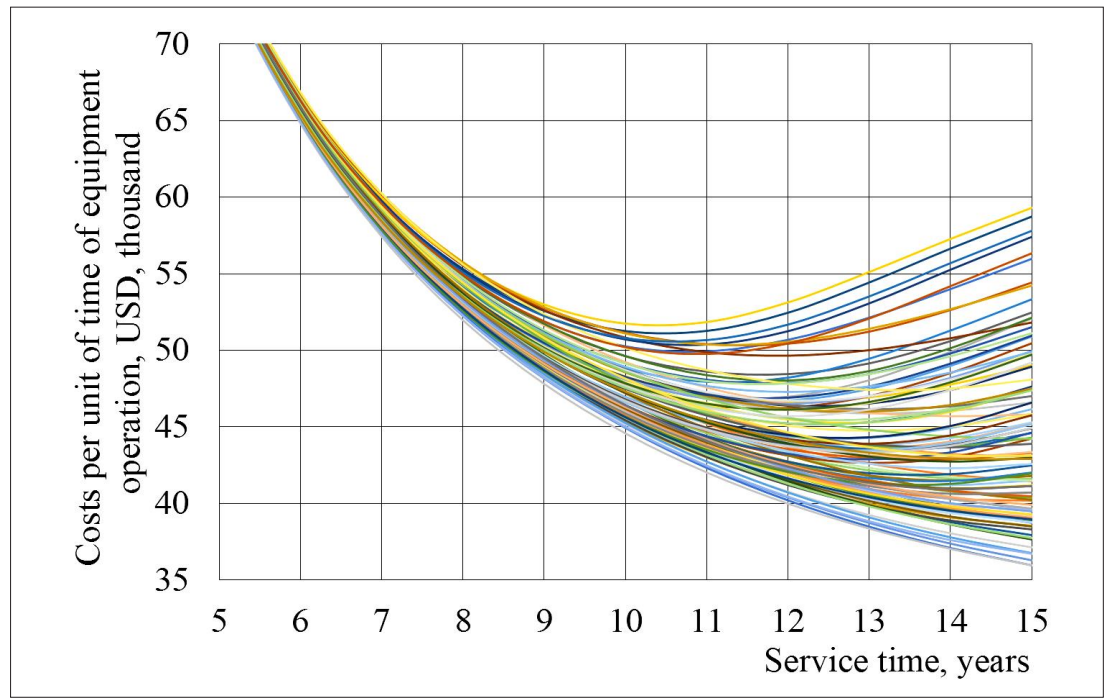

Fig. 1. Random sample of 100 trajectories of a change in average costs per unit of time of equipment service

The curves, shown in Fig. 1, are different trajectories of random process $R(s(t, \omega), t)$. When calculating, it was considered that the curve of a change in wear $u(t)$ is described with the help of a dynamic model (7) with initial conditions $u(0)=0,1$ and parameters $q=1, r=2.01, L=0, a=1.4, b=0.3$. This shape of the curve of a change in wear is typical for port container loaders. It was accepted that $R_{\mathrm{var}}=200, R_{\text {const }}=8, R_{0}=240, \delta=10$. When modeling a stochastic process of a change in the coefficient of loading with the help of differential equation (5), it was assumed that $s_{b}=0.1, s_{c}=0.4$ and $s_{t}=0.9$. Function of wear and function of diffusion are, respectively, equal to $a(t)=0.1 \cdot(0.4-x)$ and $b(t)=0.09 \cdot(0.9-x) \cdot(x-0.1)$.

Table 1 gives estimations of indicators of average costs per unit of time of equipment operation, obtained by random sample of function $\left\{R\left(s\left(t, \omega_{k}\right), t\right)\right\}_{k=1}^{400}$. Estimations of quantiles of distributions of average costs per unit of time of equipment operation for different terms of equipment 
service at random trajectories of intensities of equipment loading are shown in Table 2. It is possible to follow more visually the changes in the law of distribution of average costs per unit of time of equipment operation over time in Fig. 2, 3.

Table 1

Estimations of indicators of average costs per unit of time of equipment operation at random changes in intensity of loading

\begin{tabular}{|c|c|c|c|}
\hline $\begin{array}{c}\text { Service } \\
\text { term, years }\end{array}$ & $\begin{array}{c}\text { Estimation of } \\
\text { mathematical expectation } \\
\text { of average costs per unit } \\
\text { of time of equipment } \\
\text { operation, USD, thousands }\end{array}$ & $\begin{array}{c}\text { Estimation of } \\
\text { variance of average } \\
\text { costs per unit of } \\
\text { time of equipment } \\
\text { operation }\end{array}$ & $\begin{array}{c}\text { Confidence } \\
\text { interval for } \\
\text { estimation of } \\
\text { mathematical } \\
\text { expectation }\end{array}$ \\
\hline 1 & 330.12 & 0.02 & 0.002 \\
\hline 2 & 170.54 & 0.07 & 0.007 \\
\hline 3 & 117.59 & 0.13 & 0.013 \\
\hline 4 & 91.35 & 0.22 & 0.021 \\
\hline 5 & 75.80 & 0.32 & 0.032 \\
\hline 6 & 65.65 & 0.46 & 0.045 \\
\hline 7 & 58.61 & 0.65 & 0.063 \\
\hline 8 & 53.58 & 0.89 & 0.087 \\
\hline 9 & 49.92 & 1.21 & 0.119 \\
\hline 10 & 47.31 & 1.64 & 0.161 \\
\hline 11 & 45.53 & 2.22 & 0.218 \\
\hline 12 & 44.47 & 2.97 & 0.292 \\
\hline 13 & 44.02 & 3.86 & 0.379 \\
\hline 14 & 44.11 & 4.82 & 0.474 \\
\hline 15 & 44.64 & 5.76 & 0.567 \\
\hline
\end{tabular}

The data in Tables 1, 2 and diagrams in Fig. 1-4 were obtained based on calculations of trajectories of random process $R(s(t, \omega), t)$, which was determined from formulas (1)-(12). For Fig. 1, the sample of 100 trajectories of random process $R(s(t, \omega), t)$ was used. From statistical estimations in Tables 1, 2, the sample of 400 implementations was used. Confidence intervals for assessment of mathematical expectations of cross-sections of the random process, which are presented in the last column of Table 1, were calculated based on the sample of 400 implementations of process $R(s(t, \omega), t)$ with the use of Student's distribution. 
It is possible to observe the way the shape of the law of distribution of indicators of average costs per unit of time of equipment operation changes at replacement of equipment after 3, 7 or 11 years, in Fig. 2-4, which represent histograms of distributions of values of cross sections of random process $R(s(t, \omega), t)$ at the specified moment. Fig. 2-4 were plotted using the software Statistica based on the sample of 400 implementations of random process $R(s(t, \omega), t)$.

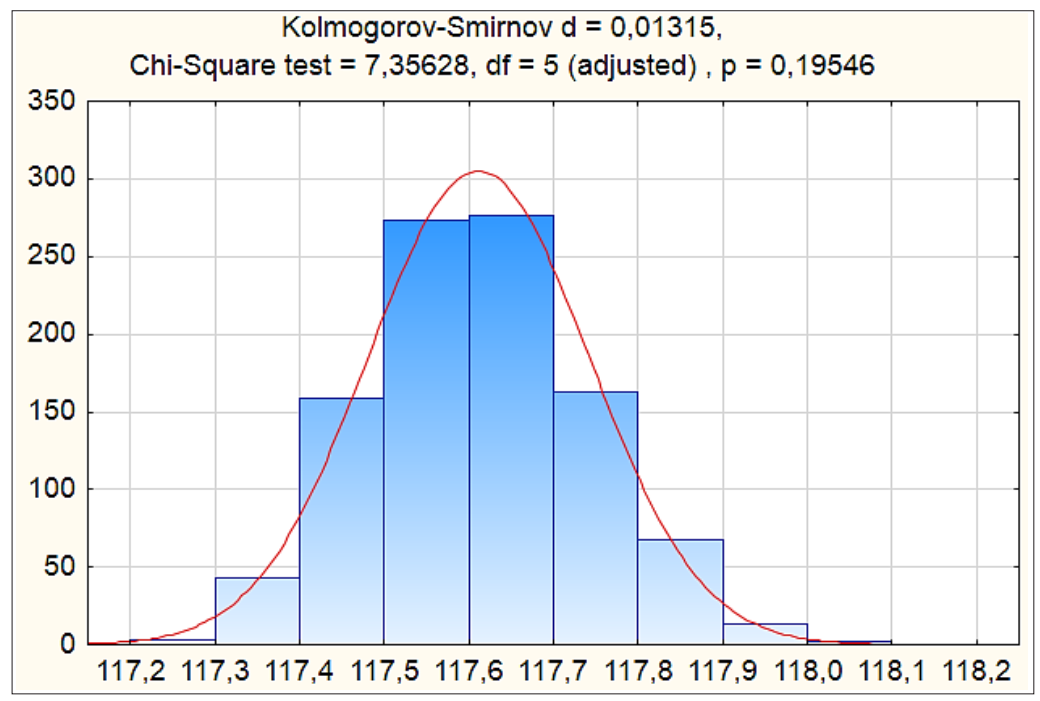

Fig. 2. Histogram of distribution of values of cross-section of random process $R\left(s\left(t, E^{\prime}\right), t\right)$ at $t=3$

In these figures, densities of normal distributions, mathematical expectation and standard deviations of which correspond to the indicators of the sample are shown in red color, in addition, results of verification of the Kolmogorov-Smirnov test and $\chi^{2}$ test for normality of distribution are specified. Thus, at small $t$, the law of distribution of average costs per unit of time of equipment operation almost does not differ from the normal (Fig. 2, 3), but over time, deviation from the normal law of distribution is becoming more noticeable (Fig. 4).

It can be noted that the degree of scattering of values of average costs per unit of time of equipment operation substantially increases over time, 


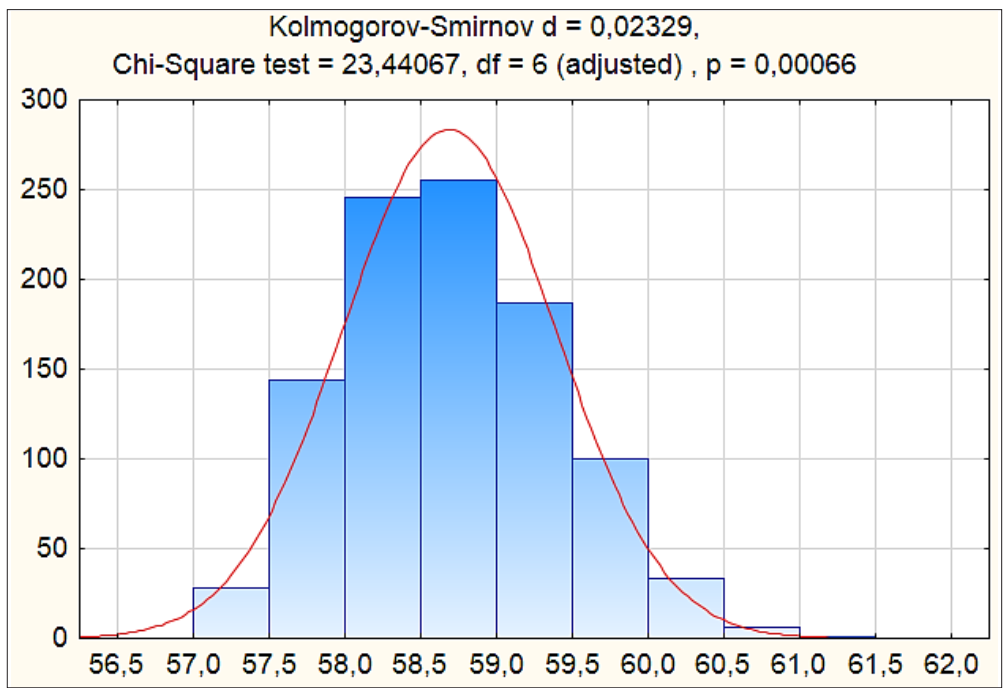

Fig. 3. Histogram of distribution of values of cross-section of random process $R(s(t, w), t)$ at $t=7$

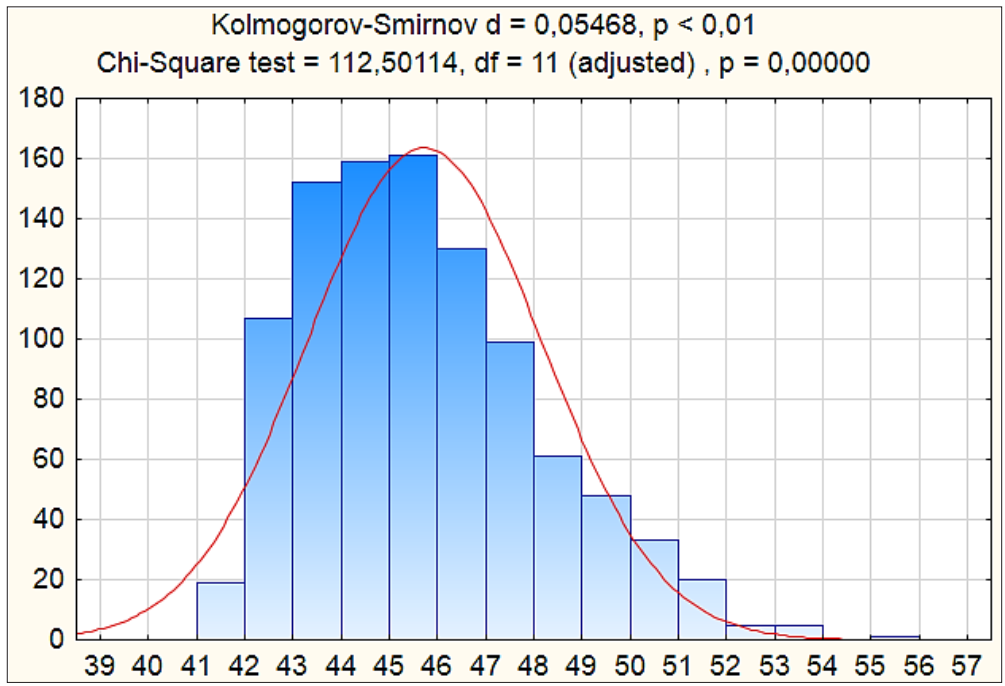

Fig. 4. Histogram of distribution of values of cross-section of a random process $R(s(t, w), t)$ at $t=11$ 
Table 2

Estimations of quantiles of distributions of average costs per unit of time of equipment operation for various terms of equipment operation at random functions of equipment loading intensity

\begin{tabular}{|c|c|c|c|c|c|}
\hline $\begin{array}{c}\text { Service } \\
\text { time, years }\end{array}$ & $\mathbf{x}_{\mathbf{0 . 0 5}}$ & $\mathbf{x}_{\mathbf{0 . 2 5}}$ & $\mathbf{x}_{\mathbf{0 . 5 0}}$ & $\mathbf{x}_{\mathbf{0 . 7 5}}$ & $\mathbf{x}_{\mathbf{0 . 9 5}}$ \\
\hline 1 & 330.10 & 330.11 & 330.12 & 330.14 & 330.16 \\
\hline 2 & 170.45 & 170.49 & 170.52 & 170.57 & 170.66 \\
\hline 3 & 117.40 & 117.51 & 117.57 & 117.69 & 117.86 \\
\hline 4 & 91.04 & 91.21 & 91.29 & 91.52 & 91.75 \\
\hline 5 & 75.34 & 75.59 & 75.72 & 76.05 & 76.43 \\
\hline 6 & 64.98 & 65.31 & 65.56 & 65.97 & 66.49 \\
\hline 7 & 57.73 & 58.15 & 58.49 & 58.98 & 59.79 \\
\hline 8 & 52.37 & 52.90 & 53.42 & 54.03 & 55.31 \\
\hline 9 & 48.37 & 49.08 & 49.60 & 50.53 & 52.34 \\
\hline 10 & 45.24 & 46.15 & 46.81 & 48.15 & 50.79 \\
\hline 11 & 42.72 & 43.95 & 44.93 & 46.85 & 50.35 \\
\hline 12 & 40.75 & 42.23 & 43.80 & 46.29 & 50.57 \\
\hline 13 & 39.22 & 41.06 & 43.30 & 46.54 & 52.07 \\
\hline 14 & 38.02 & 40.28 & 43.18 & 47.43 & 54.00 \\
\hline 15 & 37.10 & 39.65 & 43.63 & 48.95 & 55.99 \\
\hline
\end{tabular}

and function $\hat{R}(t)$ takes the smallest value approximately in 13.5 years after the beginning of equipment operation (Fig. 5, 6).

The boundaries of the color areas, which are shown in Fig. 6, are the curves of a change in quantiles $x_{0.05}, x_{0.25}, x_{0.75}, x_{0.95}$ depending on the time of equipment operation. These curves are plotted according to data given in Table 2.

Thus, the blue color area determines the boundaries of the intervals, within which with probability of 0.5 there will be total average costs per unit of time of the equipment operation. The upper and the lower boundaries of the red color areas determine the limits of the intervals, within which there are total average costs per unit of time of equipment operation with probability of 0.9 . Given a significant increase in fluctuations of total average costs, there is a need to substantiate the measures, aimed at an increase in the level of stability of average costs of equipment. 


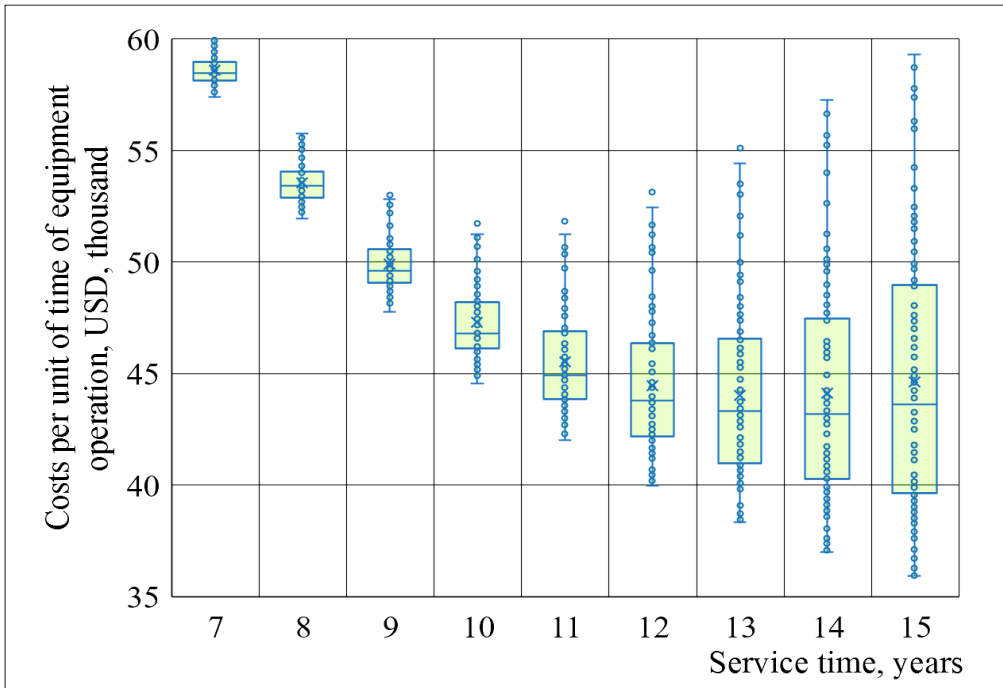

Fig. 5. "Box and whisker" diagram, constructed by the sample of 100 random trajectories of a change in average costs per unit of time of equipment service

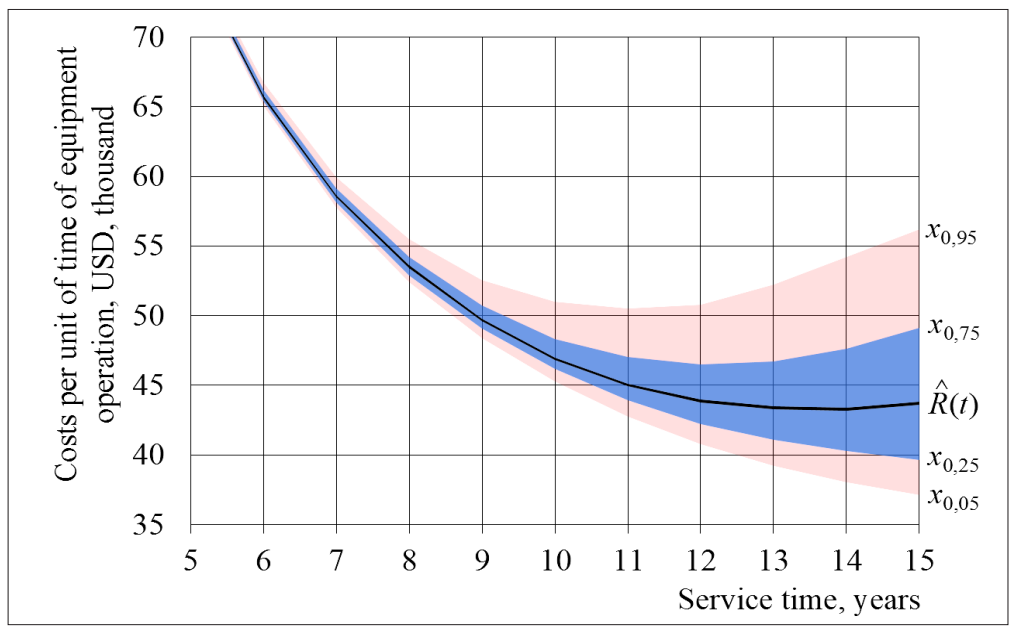

Fig. 6. Estimations of a change in mathematical expectation and quantiles for total average costs per unit of time of equipment operation 


\section{Dynamics of stability level of equipment performance indicators}

In Fig. 7, a continuous bold line shows the curve of values of estimation of mathematical expectation of total average costs per unit of time of equipment operation $\hat{R}(t)$

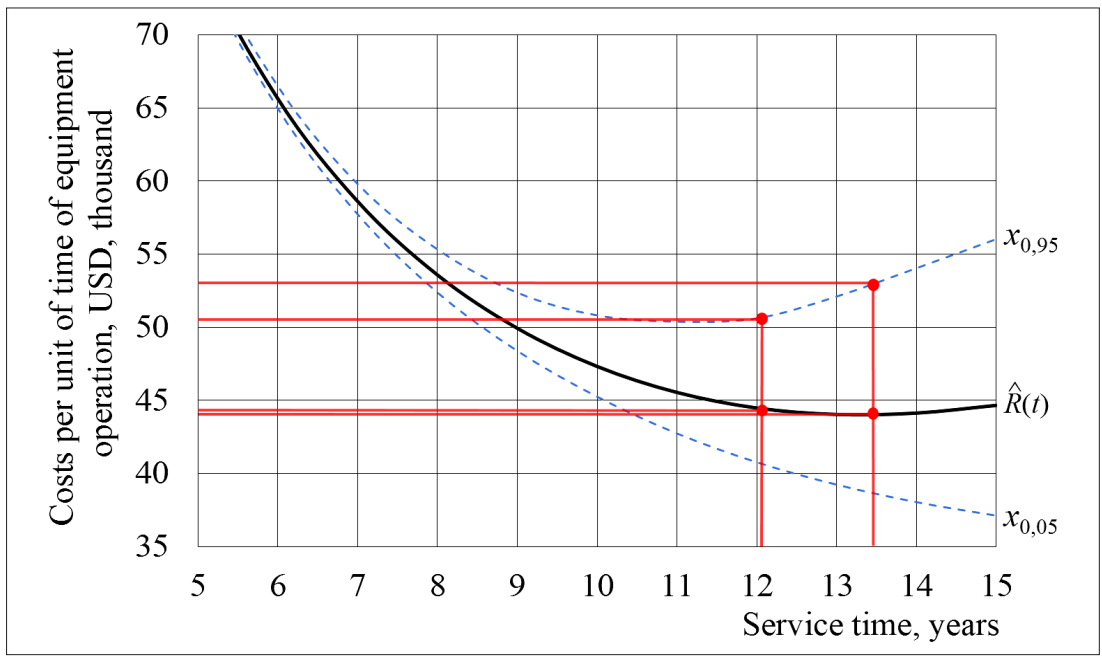

Fig. 7. Change in mathematical expectation and boundaries of the interval, within which there are values of total average costs per unit of time of equipment operation with a probability of 0.9

The diagrams in Fig. 5-7 are plotted based on data given in Table 1 and 2. Dotted lines in Fig. 7 represent the boundaries of the intervals, within which there are the values of total average costs per unit of time of equipment operation with probability of $\alpha=0.9$. Fig. 7 shows that in terms of minimizing mathematical expectation of total average costs per unit of time of equipment operation, the optimal service time of equipment is approximately 13.5 years. At equipment replacement at any time in the interval between 12 and 13.5 years, mathematical expectation of average costs is almost minimal. Along with this, over time, there is a noticeable increase in degree of dispersion and, consequently, an increase in risks of getting excessive costs.

Thus, in this case it is advisable to reduce the planned service time of equipment from approximately 13.5 years to about 12 years and even 


\section{Optimal replacement scheduling for equipment taking into account the...}

less. Then expected total average costs per unit of time of operation equipment almost do not change, but in this case, the level of their stability will increase significantly.

Most of the research, devoted to planning of terms of equipment replacements, consider the level of loading to be permanent (for example, [1-5]). But in some cases, this assumption is not true. A change in the level of equipment loading significantly affects the rate of physical deterioration and, as a result, equipment performance indicators. The advantage of the method for determining the terms of equipment replacements, proposed in this paper, is the fact that it takes into account possible fluctuations of the level of equipment loading. This makes it possible to determine the terms of equipment replacement, based not only on mean values of equipment performance indicators, but also taking into consideration the level of stability of these indicators. Specifically, the applied aspect of the use of the obtained scientific outcome is the possibility of operation efficiency of the port equipment that operates under conditions of unstable cargo traffic.

Assume that there are data about results of the use of a certain number of machines, in addition, the history of changing in intensity of the loading level for each of these machines is individual. Then using standard statistical methods, it is possible to determine the values of parameters of the proposed dynamic model by these statistical data. Subsequently, it is possible to use this model for prediction of changes in performance indicators of operation of these new machines. Moreover, this model enables us to make predictions even in the case, where dynamics of the intensity of loading of new machines will be significantly different from the level of loading of machines that were studied before.

However, it should be noted that the proposed model does not take into account the impact of obsolescence on planning the terms of replacement of sophisticated equipment. Sophisticated equipment usually has a long term of service. That is why during its operation, new and more efficient models can appear on the market. The appearance of new models of equipment is also a factor that determines the terms of replacement of obsolete equipment. Thus, it is advisable to continue research, directed at studying the joint influence of physical and moral depreciation on determining of the optimal terms of replacement of sophisticated equipment that operates under conditions of unstable loading. 


\section{Conclusions}

The dynamic model of a change in performance indicators of operation of sophisticated equipment was proposed. The structure of the proposed model consists of two parts. The first part concerns modeling of a random process of changes in the level of equipment loading and is described by the stochastic equation in the form of Ito (5), and by formulas (1)-(4). The second part concerns modeling of dynamics of equipment wear depending on changing in the levels of its loading and is described by differential equation (7) and formulas (8)-(11). As a result, we obtained the stochastic dynamic model of a change in performance indicators of sophisticated equipment (1)-(15), which takes into account random fluctuations in the level of equipment loading. This model makes it possible to calculate the limits of the intervals of possible values of total average costs per unit of time of equipment operation in the period from the beginning of its operation to disposal. It was proposed to determine a random process of changing the level of equipment loading, described by the stochastic model of state in the form of Ito (5), with the use of displacement function (1) and diffusion function (3). This approach created wide possibilities for taking into account the specific features of the process of changing in the level of equipment loading through selection of values of parameters in functions of displacement and diffusion. Numeric values of input parameters for the dynamic model (1)-(15), which were used in this article, and verification of adequacy of the model, were obtained based on statistical data of port container loaders operation.

We established quantitative ratios of the average level of equipment perfor-mance indicators, the level of fluctuations in these indicators at possible random fluctuations in loading and the term of equipment replacement. Specifically, studies showed that changes in average total specific costs of equipment could be insignificant over a certain period, whereas the range of variability in the level of costs of equipment during the same period could significantly increase.

Based on analysis of the developed mathematical model, a procedure for planning the terms of replacement of sophisticated equipment taking into account instability of loading intensity level was proposed. The given procedure makes it possible to substantiate the terms of equipment replacement, taking into consideration both expected average indicators of equipment performance efficiency and the level of possible fluctuations in these indicators. 


\section{Optimal replacement scheduling for equipment taking into account the...}

\section{References:}

1. Marston, A., Winfrey, R., \& Hempstead, J. C. (1975). Engineering valuation and depreciation. Iowa State University Press: 508.

2. Wang, H. (2002). A survey of maintenance policies of deteriorating systems. European Journal of Operational Research, 139 (3): 469-489.

3. Kamien, M. I., \& Schwartz, N. L. (1971). Optimal Maintenance and Sale Age for a Machine Subject to Failure. Management Science, 17 (8): B-495-B-504.

4. Malaksiano, N. A. (2012). Ob optimal'nykh srokakh remontov slozhnogo portovogo oborudovaniya. Visnyk Dnipropetrovs'koho universytetu. Seriya: Ekonomika, 6(3): $186-195$.

5. Tsang, A. H. C., Yeung, W. K., Jardine, A. K. S., \& Leung, B. P. K. (2006). Data management for CBM optimization. Journal of Quality in Maintenance Engineering, 12 (1): 37-51.

6. Malaksiano, N. A. (2012). On the stability of economic indicators of complex port equipment usage. Actual Problems of Economics, 12(138): 226-233.

7. Dogramaci, A., \& Fraiman, N. M. (2004). Replacement Decisions with Maintenance Under Uncertainty: An Imbedded Optimal Control Model. Operations Research, 52 (5): 785-794.

8. Bensoussan, A., Feng, \& Q., Sethi, S. P. (2015). Integrating equipment investment strategy with maintenance operations under uncertain failures. Annals of Operations Research: 1-34. doi: 10.1007/s10479-015-1862-0

9. Lapkina, I., \& Malaksiano, M. (2018). Estimation of fluctuations in the performance indicators of equipment that operates under conditions of unstable loading. Eastern-European Journal of Enterprise Technologies, 1(3(91)): 22-29.

10. Yatsenko, Y., \& Hritonenko, N. (2008). Properties of optimal service life under technological change. International Journal of Production Economics, 114 (1): 230-238.

11. Lapkina, I. O., Malaksiano, M. O., \& Malaksiano, M. O. (2016). Optimization of the structure of sea port equipment fleet under unbalanced load. Actual Problems of Economics, 9(183): 364-371.

12. Lapkina, I. O., \& Malaksiano, M. O. (2016). Modelling and optimization of perishable cargo delivery system through Odesa port. Actual Problems of Economics, 3(177): 353-365.

13. Apeland, S., \& Scarf, P. A. (2003). A fully subjective approach to capital equipment replacement. Journal of the Operational Research Society, 54 (4): 371-378.

14. Malaksiano, M. O. (2012). On the optimal repairs and retirement terms planning for complex port equipment when forecast level of employment is uncertain. Economic Cybernetics, 4-6 (76-78): 49-56. 


\title{
HOP-PLANT DRUG USING ON TREATMENT \\ OF THE COMPLICATE ACNE FORMS
}

\section{ЗАСТОСУВАННЯ ПРЕПАРАТІВ ХМЕЛЮ \\ У ЛІКУВАННІ УСКЛАДНЕНИХ ФОРМ АКНЕ}

\author{
Moiseienko Tetiana ${ }^{1}$ \\ Torianyk Inna ${ }^{2}$ \\ Kazmirchuk Viktor ${ }^{3}$
}

DOI: http://dx.doi.org/10.30525/978-9934-571-26-8_13

\begin{abstract}
This publication contains information on modern diagnostic and treatment concepts of acne. Authors analyze the state of problem abroad, point to the continuing importance of epidemiological surveillance and concepts of modern complicate acne forms, critically assess the possibility of their accelerated diagnosis. Report notes the diagnostic significance of morphological markers of acne vulgaris is a chronic obstructive and inflammative dermatosis in pilosebasea unit. Authors focuses attention on generalized nature of process development, on gross damage of the main structural and functional units of targeted organs. It was established that acne is a polymorphic dermatosis and has polygenetic influence. Pathogenesis of acne are follicular hyperproliferation, excessive sebum production, inflammation, and P. acnes activities. Clinical manifestation of acne are noninflammative (open and closed comedones) or inflammatory (papules and pustules). Based on type and number of lesions, acne classified as mild, moderate, severe, and very severe acne. Androgen has important role but acne severity is not correlated with serum androgen level (K. Bhate \& H.C. Williams, 2013 [1, p. 479-497]). Choice of treatment, topical and/or oral treatment, depends on acne severity, distribution of lesions, inflmma-
\end{abstract}

\footnotetext{
${ }^{1}$ Research Scientist at Laboratory of Antimicrobial Agent's,

State Institution "I. Mechnikov Institute of Microbiology and Immunology

National Academy of Medical Sciences of Ukraine", Ukraine

${ }^{2} \mathrm{PhD}$, Leader Research Scientists at Laboratory of Viral Infection,

State Institution "I. Mechnikov Institute of Microbiology and Immunology

National Academy of Medical Sciences of Ukraine", Ukraine

${ }^{3} \mathrm{PhD}$, Head of Laboratory Antimicrobial, Laboratory of Antimicrobial Agent's,

State Institution "I. Mechnikov Institute of Microbiology and Immunology

National Academy of Medical Sciences of Ukraine", Ukraine
} 
tion severity, duration of illness, previous treatment respons, and psychosocial effect. Howere seborrhoea, or grease production, is also a feature. The pathological events occurring in acne are also relatively well studied. Lesions start when keratinocytes lining the hair follicle desquamate creating a microcomedone. At puberty increased sebum production creates an environment that can sustain the colonization of Propionibacterium acnes. As P. acnes proliferates, inflammatory and chemotactic mediators are produced, which in turn drive inflammatory processes. The purpose of the planned study hop-plant drug using on treatment of the complicate acne forms, detected level of influence microorganisms on clinical course acne, its stages and characteristic. The research methodology was based on a unified algorithm of a complex of clinical, microbiological, morphological and epidemiological methods. The scientific novelty of the obtained results consists in the use of the hop-plant drug for the increasing effectivity of the complicate acne forms treatment. As a result of the study a high antimicrobial activity of hop-plant drug (application, ointment, powder, lotion) was proved.

\section{1. Вступ}

Історія дослідження акне нараховує не одне століття [1, p. 479-481]. Вченими -лікарями за доступними їм методами та засобами діагностики, що видавались найпередовішими для кожного із етапів становлення медицини як системи наукових знань, по краплині накопичувалась інформація з питань розпізнання та лікування акне $[4$, p. 5-11, p. 23-37, p. 78-90]. На той час широкого розповсюдження находили описові трактати щодо характеру акне, його морфології, форм, клінічних проявів. Розповсюдження цієї нозології було настільки широким, що у 1903 році вийшов і швидко розбігся по особистим бібліотекам практикуючих лікарів кольоровий ілюстрований збірник атлас з клінічної дерматології за авторством фон Якобі- Прінгла. На його воскових муляжах було продемонстровано декілька форм акне, а також наведені дані, які тільки були відомі спеціалістам 3 акне на той час та стосувались проявів та перебігу цієї патології. Тривалий час вважали, що причини акне - одне із найзагадковіших питань дерматології [1, p. 480-497]. Одні із дослідників схилялись до думок відносно поліморфного спектру та широкої структури етіологічних факторів зазначеної нозології. Інші відстоювали тезис щодо специфічної 
схильності до себореї у осіб, хворих на акне (саме цей факт вважали незаперечним фактором сприяння розвитку комедонів). Були й такі, хто мав великі сумніви відносно ролі бактерій, віднайдених у гнійному ексудаті пустул, у розвитку акне, його хронізації та ускладненнях. Однак близько 100 років тому палкі наукові дискусії в певній мірі надали змогу поставити на деякий час крапку у розв'язанні етіопатогенетичної проблематики акне та 3'ясувати головні причини виникнення цього захворювання. Серед них називали тотальну обструкцію (закупорку) шкіряних пор, гіперпродукцію шкіряного сала та як результат останнього - бактеріальну колонізацію сальних залоз [5, р. 562-568]. Дана концепція витримала 40-річну перевірку часом, на іiї головних принципах трималась діагностика акне, ку рація хворих, терапевтична тактика та стратегія попередження виникнення як ускладнень, так i хронічних форм запалення шкірних покровів. Підтвердженням останнім фактам залишались відпрацьовані лікарські підходи, пропоновані визнаними фахівцями дерматологами Клігмана, Шаліти, Лей дена, що спирались на дані щодо взаємозв'язків між себореєю, закупоркою пор та формуванням комедонів, бактеріальними факторами, акне та антибактеріальною терапією хвороби. Суттєвому поглибленню нашого розуміння цього питання сприяли розробки Тібутота, Зубуліса щодо морбідного процесу/ патогенезу акне. Якщо зазначене вище розглянути у порівняльному аспекті, то стане цілком прозорим такий момент: вульгарне акне тривалий час характеризували як результат фолікулярного гіперкератозу, який обов'язковим чином призводив до утворення та розвитку комедонів і не мав до того примітних причин (Вебстер). Згодом за результатами експериментальних та клінічних спостережень Мельника (3'ясування молекулярних механізмів акне) став цілком зрозумілим патогенез цього захворювання. Існують повідомлення згідно яких, акне залишається найбільш затребуваним дерматологічним захворюванням у США (за частотою звернень серед пацієнтів та рівнем фінансових затрат на його лікування у цій країні). Дослідники акне в Україні, Російській Федерації також вважають його - однією 3 найпопулярніших нозологій у косметологічній та дерматологічній сферах. На лікування цього захворювання витрачаються мільйони грошових одиниць навіть у розвинутих країнах Європи, на його хірургічному лікування спеціалізуються фахові спеціалісти з різних куточків світу. Акне залишається актуальним питанням для подальших науко- 
во-теоретичних розробок, патентних впроваджень, клінічних удосконалень. Ця хвороба навіть отримала фразеологічну назву - синонім «друг молоді» і не збирається здавати позицій з огляду на еволюційні зміни макро та мікро соціуму [2, р. 424-432]. Певного зацікавлення набувають питання ефективної профілактики акне, його ранньої діагностики, унеможливлення ускладнень (ранової патології, правця, тощо). Відомо, що до традиційно відомих первинної (загальнопопуляційний, вибірковий, вузькоспе-ціалізований рівні), вторинної (попередження морфологічних ушкоджень, психологічних травм) та третинної (корекція існуючих розладів) приєдналась четвертинна профілактика, націлена на попередження проведення непотрібних та зайвих лікувальних заходів. Фахівцями проводиться превентивна робота щодо вибіркових верств населення, груп ризику та осіб з обтяженим сімейним анамнезом. Активно здійснюється екологічна діяльність 3 регулювання попереджувальних заходів у відношенні до певних причин захворювання. Що стосується загальних принципів лікування таких пацієнтів, то вони обов'язковим чином повинні бути орієнтованими на постулати доказової медицини. Тоді лікар стикається $з$ проблемою відсутності перспектив доведення наявності офіційних розробок. Застосовані клінічні спостереження набувають нерандомізованого характеру навіть $з$ огляду на те, що вони виконуються досвідченими фахівцями з багаторічним досвідом роботи. Таким чином, з одного боку, маємо позитивні результати клінічних започаткувань: орієнтація на пацієнта, індивідуальний підхід, високий лікувальний ефект, незначний рівень ускладнень або їхня цілковита відсутність. 3 іншого боку, отриманий в певному сенсі новий /оновлений алгоритм лікування не має права на долучення до стандартних шаблонів лікування. Курація хворих з акне вимагає розвинутого клінічного мислення, кмітливості та великого лікарського досвіду. Іноді у власній практичній діяльності фахівцю доводиться витримувати неймовірний тиск існуючих фармакологічних стереотипів, що здійснюється за рахунок суворих нормативів, штучно створюються умови для складення списків рекомендованих препаратів, дійсно корисних для пацієнтів, хворих на акне, обмежується чи навіть унеможливлюється спектр ліків, що не схвалені FDA. Створюються урізані корисливі протоколи, закуповуються брендові, вкрай дорогі дженерики, запускаються малоефективні державні програми [4, p. 2-7, p. 12-31]. Вкрай шкідливим може стати так 
зване «поетапне лікування», що унеможливлює проводити відповідну терапію до того часу, доки не буде доведена їі низька ефективність. Окрему проблему становить попереднє лікування пацієнтів, а саме, його алгоритми та схеми. Воно спонукає іноді системні зміни, що викликають зрозумілий гнів та незадоволення у самих хворих, їхніх близьких та родичів. Адже ними були здійснені серйозні інвестиції у попередній курс лікування, що не дав жодних помітних результатів. Тоді у відповідь на відчай можлива пропозиція відпрацьованих паттернів - «лікар - пацієнт» із обов'язковим дотриманням коректованої лікувальної тактики-політики або повернення до попереднього лікаря 3 повторенням курсу застосованої терапії. Останнє, у решті решт, призводить до очікуваного результату. Отже, підсумовуючи наведені вище факти, стає зрозумілим значення всебічного дослідження акне як нозологічної одиниці, цілковитого з'ясування їі етіопатогенезу, основних етапів ускладненого клінічного перебігу, засобів ефективної діагностики, що гарантують успіх застосованих терапевтичних алгоритмів. Метою започаткованого дослідження було вивчити етногенез та сучасні фітотерапевтичні (у тому числі, на основі хмелю та його похідних) засоби лікування ускладненого акне. Серед завдань дослідження було з'ясувати поширеність та роль мікробних чинників, провокуючих факторів у генезі ускладненого акне, умови та джерела виникнення супутньої ранової інфекції, іiї провідні нозологічні складові, сучасні фітотерапевтичні та антибактеріальні стратегії лікування. Значимість започаткованого дослідження полягає у створенні оптимальних терапевтичних алгоритмів ускладненого акне, досягнення завдяки цьому високого лікувального ефекту, зниження собівартості та тривалості заподіяної терапії. 3 огляду на все викладене вище, безсумнівну перспективність розробки, актуальність заявленої проблеми не викликає жодних сумнівів.

\section{2. Поширеність та мікробні чинники в генезі ускладненого акне}

За спостереженнями фахівців, існує чимало шляхів та джерел виникнення ускладненого рановою інфекцією акне [1, р. 479-496]. Основні з них це прямий, контактний, повітряно-крапельний, ендогенний способи інфікування шкіри. Однак найголовнішими були й залишаються закупорка шкіряних пор, підвищена екскреція сальних залоз, ендокринні розлади та збої у харчуванні осіб із такими захворюван- 


\section{Hop-plant drug using on treatment of the complicate acne forms}

нями. Акне, ускладнене рановою інфекцією можна розділити на дві великі групи - нозологія, що виникає на тлі позалікарняного зараження i нозокоміального [2, p. 424-430]. 3 огляду на це, остаточне з'ясування провідних аспектів розвитку ускладненого акне, неможливе без всебічного розуміння його нозологічних складових. Отже, першим постулатом залишається тезис щодо ролі нозокоміальних ранових інфекцій як гострої проблеми сьогодення, яка постає перед всіма без виключення фахівцями хірургічних стаціонарів. 3 іншого боку, особливістю нозокоміальних ранових інфекцій є висока частота резистентних до багатьох антибіотиків збудників, що, в свою чергу, визначає специфіку лікувальної тактики [5, р. 562-567].

У цілому, головними провокуючими факторами заявленої патології залишаються грампозитивні коки, серед них - S. aureus i коагулазонегативні стафілококи. Джерелом інфекції можуть бути як шкіра самого хворого (транзіторная - S. aureus і облігатна флора), так і екзогенні джерела (наприклад, резервуаром S. aureus або S. pyogenes є медичні працівники або хворі). До останніх складових вагомою складовою $€$ внутрішньогоспітальне зараження $S$. aureus, яким пояснюється, зокрема, колонізації верхніх дихальних шляхів i, отже, аерогенна дисемінацію. Не менш актуальним залишається широке поширення ранових інфекцій, особливо серед опікових хворих комбустіологічних стаціонарів (коли нозологічних процес запускається шляхом дійового патологічного впливу MRSA) [2, р. 435-429].

Примітно, що серед всіх нозокоміальних інфекцій, викликаних грамнегативними збудниками, на частку інфекцій шкіри і м'яких тканин приходиться 33\%. Грамнегативні бактерії - найважливіші збудники ранової інфекції в абдомінальній хірургії, гінекології, онкології i акушерстві; увагу заслуговують представники Enterobacteriaceae E. coli, Enterobacter spp., Proteus spp., Acinetobacter spp., а також неспороутворюючі грамнегативні анаероби - Pseudomonas aeruginosa, Klebsiella spp. i. Резервуари полірезістентних грамнегативних бактерий - опікові відділення, відділення гнійної хірургії, відділення реанімації та інтенсивної терапії. Особливе ставлення склалося до представників Bacteroides spp., а саме до Bacteroides fragilis. Ці анаеробні грамнегативні бактерії виявляють порівняно низьку вірулентність, але, будучи складовою полімікробної флори, разом з аеробними бактеріями демонструють виражений синергізм. 
У цілому, для етіології нозокоміальної ранової інфекції, якою суттєво посилюється агресивність перебігу відомого навіть за матеріалами класичних підручників акне, характерний певний взаємозв'язок між спровокованою поверхнею шкіри та мікробною флорою відділення, де знаходиться хворий. Сутність такого феномена полягає у тому, що ймовірним чином, будь-який мікроорганізм, потрапляючи до травмованої шкіри чи рани, стає потенційним збудником захворювання та ініціатором ускладнень.

Етіологія інфекційних ускладнень акне, що розповсюджені у побуті, на виробництві (згадаємо професійні акне: a. chlorici, a. borici, тощо), у межах оточуючого природного середовища чи наразі за умов бойової обстановки, різноманітна. Етіопатогенез залежить від вихідного стану шкіри, характеру харчового стереотипу, стану ендокринної системи, можливих механізмів попереднього травмування, його обставин, тривалості впливу чинників. Одними із чинників, що сприяють неодмінному ускладненню акне є також види, обсяги, ступень негайності надання хірургічної допомоги. За умов первинної обробки вогнища у біоматеріалах, що становлять посіви із locus morbi у переважній більшості випадків отримують коки (головним чином, Staphylococcus spp.). Достовірно встановлено, що під час лікування відбувається значна зміна характеру мікрофлори зі зміщенням спектру від домінування грампозитивних коків до грамнегативних аеробів [1, р. 479-496]. Таким чином, збудниками гнійної інфекції травматичних ран $\epsilon$ не «вулична» флора, що потрапила в рану при бактеріальному забрудненні, а госпітальна, яка проникає у разі недотриманні правил асептики під час хірургічної обробки вогнищ акне, виконання перев'язок тощо.

Не можна недооцінювати роль грампозитивних коків і, перш за все, S. aureus, $з$ огляду на те, що останнім часом позалікарняних випадків інфекцій, викликаних метіціллінрезістентним стафілококком, зустрічається все більше [5,p. 564-568]. У зв'язку із цим основними дієвими антибіотиками (анти - MRSA препаратами), що становлять прерогативи спеціалізованих стаціонарів, в поза лікарняних умовах залишається екологічна ніша, яка сприяє широкому поширенню таких штамів. Отже з урахуванням існуючої загрози періодичних спалахів інфекцій м'яких тканин, викликаних MRSA, слід приділяти увагу і перебігу ускладнень ранової інфекції, і їі першопричині, - акне. За наявністю у рані некротичних тканин і порожнин, заповнених кров'ю або гній- 


\section{Hop-plant drug using on treatment of the complicate acne forms}

ним ексудатом, в асоціаціях бактерій виділяються анаероби, головним чином, Bacteroides fragilis i Bacteroides spp., а також Fusobacterium spp., грампозитивні анаеробні коки, в основному Peptostreptococcus spp. і Peptococcus spp. Саме вони і призводять у разі затримки відповідної хірургічної допомоги до серйозних ускладнень. Переважна роль серед застосовуваних препаратів належить, як водиться препаратам хімічної природи. Як наслідок цього. в організмі людини пригнічується нормальна мікрофлора, знижується імунологічний статус, зростає кількість алергічних реакцій та ускладнень перебігу захворювань. Застосування антибіотиків та антисептиків без визначення чутливості до збудника хвороби призводить до утворення полірезистентних форм. Недотримання або нехтування головними принципами системи мікробіологічного моніторингу та постулатами ефективної служби інфекційного контролю в лікувально-профілактичних закладах унеможливлює раціональне використання протимікробних засобів. У результаті нераціональної хіміотерапії відмічається підвищення темпів еволюції патогенних і умовно патогенних для людини мікроорганізмів, змінюється етіологічна структура збудників інфекційних і гнійно-запальних захворювань зі зниженням частки облігатних патогенів та розширенням спектру чи навіть підвищення питомої ваги умовно патогенних мікроорганізмів [3, р. 136-141].

Слід також відмітити той факт, що сама по собі гнійна інфекція, яка супроводжує акне, різноманітна за генезом та є однією із самих складних проблем хірургії. Розвиток та перебіг ранової інфекції визначається станом захисних реакцій організму, з одного боку, вірулентністю мікроорганізмів, що впровадилися, i наявністю сприятливих умов для їхньої життєдіяльності - 3 іншого. Найбільш ускладненим типом ранова інфекція ускладнення, обумовлене розвитком патогенної мікрофлори кратерів чи порожнин акне. Всі рани, у тому числі і операційні, вважаються первинно забрудненими, оскільки певна кількість мікробів потрапляє на поверхню ураженої шкіри 3 повітря, навіть при бездоганному дотриманні правил асептики і антисептики. Як не дивно, випадкові рани забруднюються сильніше, тому в таких випадках джерелом інфекції, зазвичай, стає первинне мікробне забруднення. За умов залучення, як методу хірургічного втручання, локальних операцій у разі ускладненого акне, на перший план виступає ендогенне (з внутрішнього середовища організму) або внутрішньогоспітальне (вто- 
ринне) інфікування. У більшості випадків збудником інфекції у випадкових ранах стає стафілокок. Час від часу у якості основного збудника виступає протей, кишкова і синьогнійна паличка. У $0,1 \%$ випадків зустрічається анаеробна інфекція. Через кілька днів перебування у стаціонарі флора змінюється, у рані починають переважати стійкі до антибактеріальної терапії грамнегативні бактерії, які зазвичай, стають причиною розвитку ранової інфекції за умов вторинного інфікування як випадкових, так і операційних ран. У разі зазначеного тактичного ходу як найяскравіше проявляється здатність мікробів щодо обумовлення характерної хірургічної (як безумовне ускладнення процесу) інфекції, з кількісними і якісними особливостями бактеріальної активності з урахуванням дози і індексу патогенності. Доведено, що наявність у locus morbi до 1 млн. мікробних одиниць на один грам тканини, спричиняє розвиток місцевого гнійного процесу. Слід також пам'ятати про те, що серед ускладнень акне в спеціальній літературі описані приєднання специфічної ранової інфекції: правця, анаеробної інфекції, сказу, навіть дифтерії ран. 3 огляду на спостереження фахівців, частота інфекційних ускладнень у хірургії мирного часу зростає у разі нагноєння «чистих» операційних ран до $5 \%$, забруднених - 10-15\%. Причиною смерті післяопераційного періоду за умов інфекційних ускладнень становить $15 \%$ хворих.

\section{3. Протимікробні властивості хмелю та його похідних}

Хміль звичайний (Humulus Lupulus L.) і його лікарська сировина $€$ офіціальними в Україні і Росії, а також в Німеччині, Франції, Іспанії, Португалії, Греції, Румунії, Мексиці, США. Лупулін увійшов до фармакопей Німеччини, Португалії, Швейцарії, Італії, Австрії, Голландії, Бразилії, США.

Сучасна фармакологічна промисловість використовує цю рослину у складі чисельних медичних препаратів. Особливо корисними для медичних потреб та лікувальними вважаються використовують суцвіття хмелю звичайного, які помилково називають супліддями, жіночі «шишки» (Strobuli Humuli lupuli, або Strobuli Lupuli), а також залозки хмелю (Glandulae Lupuli), або лупулін (Lupulinum).

Фітопрепарат лупулін існує у вигляді яскраво-жовтого велико зернистого порошку, який містяться на внутрішній поверхні жіночих суцвіть «шишок». Готовий продукт має вигляд нерівномірно крупнозер- 
нистої клейкої речовини зеленкувато-жовтого кольору, яка на повітрі поступово набуває червонуватого відтінку. Для потреб фармацевтичної промисловості суцвіття хмелю заготовляють у середині серпня, коли вони набувають зеленкувато-жовтого забарвлення (пізніше вони стають коричневого забарвлення, сухими і після сушіння легко розсипаються). Суцвіття зривають руками разом з плодоніжками. Зібрану сировину швидко сушать у затінку на свіжому повітрі, розстеляючи тонким шаром на папері чи тканині. Зберігати шишки краще в не подрібненому вигляді, оскільки у разі подрібнення вони втрачають активність. До основних біологічно активних речовин, які визначають фармакологічну активність шишок хмелю відносять гіркоти, поліфенольні сполуки, а також ефірну олію. Перелічені біологічно активні речовини є найбільш важливими сполуками хмелю, вміст яких має суттєве значення у фармацевтичному виробництві та використанні лікувальних засобів із хмелю у науково-практичній медицині (шишки хмелю містять 0,2-1,8 \% ефірної олії, 2-5 \% поліфенольних сполук і від 5 до $26 \%$ гіркот).

На сьогодні достеменно не встановлено, коли хміль почали використовувати як лікувальний засіб. У єврейських талмудах та коментарях до Біблії стверджується, що євреї, які знаходилися в полоні у Вавилоні, рятувалися від прокази (лепри) і не хворіли цією хворобою лише тому, що вживали виготовлене із хмелю пиво. Ще до початку нашої ери пиво із хмелю вважалось популярним напоєм у багатьох племен. 3 найдревніших фінських рунічних письмен надійшли свідчення, що фіни для виробництва пива використовували хміль більше 1200 років тому, так само як естонці та латвійці.

Перша згадка про хміль як лікарську рослину зустрічається в працях арабського лікаря IX ст. Мезе (Mezue), який використовував сироп хмелю для очищення крові і як жовчогінний засіб. Дані про хміль як лікарську рослину містяться у середньовічних травниках та медичних трактатах. На початку XII ст. німецька абатиса ордену бенедиктинців св. Гільдегарда з Бінгена (1098-1178) у своєму медичному записнику рекомендувала вживати пиво, виготовлене 3 хмелю, як лікувальний засіб. Пізніше середньовічні травники рекомендували використовувати хмільне пиво проти подагри і різних урологічних захворювань, шкірних хвороб. Автори старовинних книг радили пити пиво навіть матерям-годувальницям і у невеликій кількості немовлятам, серйозно 
вважаючи, що після материнського молока, пиво є найбільш придатною їжею для немовлят. Середньовічні лікарі рекомендували вживати пиво 3 хмелю при зниженні апетиту, розладах травлення, хворобах нирок і сечового міхура. Вони радили прикладати компреси з теплого пива до ніг людям, втомленим після далекої подорожі. Симон Сиренський (1540-1611) у своєму травнику (1613) рекомендував шишки хмелю при хворобах шкіри, а лупулін - при потінні ніг. Польський лікар пізнього ренесансу Христофор Клук (1739-1790) у своєму "Dykcyonarzu" вказував на застосування шишок хмелю як сечогінного і сокогінного засобу, а листків - як протизапального засобу при подагрі та набряках нижніх кінцівок, вугрових висипах, гнійних ранах. Карловарські пивовари із Західної Чехії і сьогодні виготовляють лікувальне пиво «Доктор Бір» на основі шишок хмелю і лікувальної мінеральної води. Це пиво дає позитивний ефект при хворобах шлунку, печінки і нирок [3, p. 136-141]. Завдяки антисептичним, протизапальним і знеболюючим властивостям відвари шишок хмелю застосовують у вигляді примочок і мазей для лікування радикуліту, захворювань суглобів, забоїв, опіків, обморожень, корости, грибкових уражень шкіри, інфікованих ран і виразок.

Для зовнішнього застосування з хмелю використовують мазь на основі його шишок, де на 1 ст. л. сировини надається 1 склянка окропу. За умов упарювання до розчину додають 4 ст. л. вазеліну, добре перемішують і застосовують при ранах, наривах, вугровій хворобі.

Широкого застосування при ускладненнях вугровою хвороби, синцях набули настої, виготовлені із його шишок. Ці фітопрепарати використовують переважно для місцевого призначення у вигляді ванн, компресів, кашоподібних обмотувань уражених зон 2 рази на день. Ефект рекомендованих лік забезпечується широким спектром та різнобічністю їхніх фармакологічних властивостей - заспокійливим, знеболюючим, снодійним, протизапальною активністю. Хміль сприяє підвищенню репараційної активності шкіри чи слизових оболонок, потенціює захисні резерви шкіри. Він інтенсивно посилює локальний кровообіг, трофіку, здатен до попередження тромбоутворення, формування емболів [2, р. 425-434]. Доведено, що біологічну активність хмелю визначають чисельні гіркоти, фенольні сполуки, ефірна олія. Нейротропні властивості галенових препаратів 3 шишок хмелю пов'язують 3 присутністю в них лупуліну, який проявляє заспокійливу дію 
не лише на периферичні нервові волокна, але й головний мозок. Ще 3 середніх віків відомо, що у переважної більшості людей, які збирали хміль руками, з часом спостерігали появу відчуття втоми, сонливість, помірне зниження працездатності. Такі особи скаржились на загальмованність, зниження реакцій на подразники різного природного походження (світло, тиск, температура), приголомшуючу психогенну дію легких речовин (емоційно - вольова сфера, когнітивні функції). 3 хмелем пов'язували інкункурентну пластичну болевтамовуючу дію. Тривалий зовнішній контакт (навіть на поверхні неушкодженої шкіри) iз препаратами хмелю, їхнє випадкове передозування призводили до перевтоми, головного болю, нудоти, розладів у діяльності шлунково-кишкового тракту, появи локальних чи зональних парестезій. Його не бажано застосовувати вагітним жінкам, а породіллям чи жінкам, що годують груддю. 3-за наявності в шишках хмелю токсичних речовин не варто застосовувати їх більше 30 днів поспіль. За цим продовження прийому краще повторити не раніше, ніж через 1 місяць (за соматичними параметрами та призначенням лікаря). Шишки хмелю часто використовують у комплексі з іншими лікарськими рослинами при дизурії, захворюваннях нирок, сечовивідних шляхів, сечового міхура. Він ефективний як протизапальний, гіпосенсибілізуючий, сечогінний та регулюючий мінеральний обмін засіб.

Протизапальні, знеболюючі, бактерицидні і антиалергічні властивості галенових препаратів хмелю зумовлюють їх терапевтичну ефективність при захворюваннях шкіри і слизових оболонок, які супроводжуються запальними ураженнями, з ознаками ексудативних реакцій, наявністю проліферативного компоненту, розвитку алергічних реакцій, відповідно пов'язаних із цим когнітивними проявами, свербінням. Особливо помітні результати лікуваня хмелем отримані за умов розвитку алергічних реакцій і професійних дерматитах, акне. Доволі високий ефект застосування хмелю було встановлено при дистрофічних процесах в слизових оболонках, покровному епітелію. Зовнішньо настій суцвіть хмелю використовують для компресів, при забоях, інфільтратах, ним промивають рани, виразки, влаштовують ванни при ревматизмі кінцівок, подагрі. Порошок з шишок хмелю місцево застосовують як знеболюючий, антисептичний засіб. Вважають, що сприятлива дія препаратів хмелю на шкіру визначається присутністю речовин 3 естрогенною активністю, рослинних анестетиків. Найчастіше в меди- 
цині із сучасних галенових препаратів хмелю використовують суміші, порошки із його суцвіття, так звані, супліддя, жіночі «шишки» (Strobuli Humuli lupuli, або Strobuli Lupuli), а також залозки хмелю (Glandulae Lupuli), або лупулін (Lupulinum). Застосовують ці препарати у вигляді настоїв (з розрахунку: 1 столова ложка на 200 мл окропу) при шкірних хворобах запального характеру, знову ж таки, вугровій хворобі, iii інфекційних ускладненнях стафілококами. Доволі успішною видавалась терапія хмелепрепаратами хронічних виразок гомілки, стопи, передпліччя. Із зазначеною метою locus morbid інтенсивно змочують настоєм марлеву пов'язку та у вигляді компресу накладають на уражену ділянку на термін від 30 хвилин до 1-2 годин. Смолисті речовини, що містить хміль (50-70 \% від загальної кількості активної речовини), у комплексі із рослинним воском, специфічним жовтим пігментом, холіном, гіпоксантином, аденіном, цератиновою та ізопропілакриловою кислотою, а також гумуліном (хопеїн) - алкалоїдоподібною речовиною призводять до виразної наркотичної дії. Помічено, що високого ефекту препарати із суцвіття хмелю набувають за умов правильного збору та збереження. У зазначеному сенсі велике значення мають біологічні часи початку збору (середина серпня), ступень дозрівання рослин (зеленкувато-жовтого забарвлення), морфологія зібраної сировини (суцвіття $з$ цілими плодоніжками). Важливим є підтримання умов та параметрів сушки (простора площина, тонкий шар, затінок, свіже повітря, натуральне волокно тканини чи сушильного паперу). Збереження зазначеної схеми відпрацьованого алгоритму сприяє активній взаємодії найбільш цінних речовин, належних хмелю як корисній лікарській рослині: суміші кислих та смолистих складових, гіркот (понад 90 хімічних сполук). На тепер згідно до міжнародної номенклатури їх називають «загальними смолами». Особливостями цих речовин (гіркот хмелю 3 групи гумулону, дезоксигумулону і лупулону) є схильність до розчинення у холодному метанолі та діетиловому ефірі, нестійка формула та утруднене вивчення. На сьогодні достеменно відомо, що фармакологічна активність препаратів хмелю забезпечується 230 сполуками моно- і сесквітерпенового ряду. Відомо також, що у екстрактах хмелю $\epsilon$ наявними естрогенні (типу естрону, естрадіолу і естріолу) та андрогенні (типу андростерону) гормоноподібні сполуки. Найбільша кількість сумарних естрогенів (34,8 мг\%) і андрогенів (0,96 мг\%) міститься у вуглекислих екстрактах хмелю. Дослідження останніх років вказу- 
ють на те, що естрогенна активність хмелю пов'язана із ізопренільованими флавоноїдами. Наявність у шишках хмелю та пиві 8-ізопренілнарінгеніну забезпечує один із найактивніших фітоестрогенів. Варто зауважити, що в народній медицині за звичай застосовують водні чи спиртові витяжки хмелю. Оскільки токофероли розчинні в жирах, то фармакологічну дію більшості вживаних в даний час препаратів хмелю навряд чи можна пов'язати з наявністю в них токоферолів.

Вищезазначені властивості хмелю пояснюють ефективність його мазевих препаратів при гострих суглобових болях, їх ускладненнях (артрити, артрози, ревматизм, подагра), розтягненнях та ударах. Для приготування такої мазі розтирають в порошок сухі шишки хмелю, змішують 3 жировою основою до отримання сметаноподібної консистенції та застосовують протягом місяця. В якості основи використовують нутряний жир, вершкове масло.

Смоли хмелю містять речовини, які є природними рослинними антибіотиками. Протимікробну і протигрибкову дію їм забезпечує ефірне масло, яке входить до складу шишок. Цікавим фактом є застосування препаратів на основі хмелю у пацієнтів з хронічними гастритами, активованій секреторній діяльності шлунка (за рахунок цього зростає виділення шлункового соку, підвищується апетит, покращується травлення). Отже, враховуючи все зазначене вище, розробка i впровадження в медичну практику нових високоефективних лікарських засобів вітчизняного виробництва на основі хмелю та хмелепродуктів для лікування акне та його ускладнень, у тому числі, ранового генезу є завданням надзвичайно актуальним і своєчасним.

\section{4. Висновки}

Питання щодо всебічного обгрунтування та використання у практичній діяльності лікаря найбільш ефективних способів діагностики та лікування ускладнених форм акне на сьогодні далеке від свого остаточного розв'язання. Орієнтуючись на отримані результати, стає зрозумілим значення всебічного дослідження акне як нозологічної одиниці, цілковитого з'ясування іiі етіопатогенезу, основних етапів ускладненого клінічного перебігу (інфікована рана, правець, дифтерія, тощо), засобів визначення та всього того, що у цілому гарантує успіх застосованих терапевтичних алгоритмів (як традиційно відомих, так i новаторських). 
До шляхів та джерел, що сприяють виникненню ускладнень акне рановою інфекцією відносять: прямий, контактний, повітряно-крапельний, ендогенний способи інфікування шкіри. Однак найголовнішими з них залишаються закупорка шкіряних пор, підвищена екскреція сальних залоз, ендокринні розлади та збої у харчуванні осіб із клінічно встановленим акне. Власне ускладнене акне диференціюють на дві великі групи - нозологія, що виникає на тлі позалікарняного зараження та нозокоміального.

Головними провокуючими факторами заявленої патології залишаються грампозитивні коки, серед них - S. aureus і коагулазонегативні стафілококи. Джерелом інфекції можуть бути як шкіра самого хворого (транзіторная - S. aureus і облігатна флора), так і екзогенні джерела (наприклад, резервуаром $S$. aureus або $S$. pyogenes є медичні працівники або хворі).

Протизапальні, знеболюючі, бактерицидні і антиалергічні властивості галенових препаратів хмелю зумовлюють їх терапевтичну ефективність при захворюваннях шкіри (акне) і слизових оболонок, які супроводжуються запальними ураженнями, з ознаками ексудативних реакцій, наявністю проліферативного компоненту, розвитку алергічних реакцій, відповідно пов'язаних із цим когнітивними проявами, свербінням. Хміль сприяє підвищенню репараційної активності шкіри чи слизових, потенціює захисні резерви шкіри. Він інтенсивно посилює локальний кровообіг, трофіку, здатен до попередження тромбоутворення, формування емболів. Доволі високий ефект застосування хмелю було встановлено при дистрофічних процесах у епітелії, різкому зниженні локального імунітету шкіри.

\section{Список літератури:}

1. Basak S. A. \& Zaenglein A. L. (2013) Acne and its management. Pediatrical Review, 34(11), 479-497.

2. Hori, K., \& Matsumoto, S. (2010). Bacterial adhesion: from mechanism to control. Biochemical Engineering Journal, 48(3), 424-434.

3. Kapczynski D., Meinersmann R., Lee M. Adherence of Lactobacillus to intestinal cells in culture correlates with fi bronectin binding. // Current microbiology. - 2000. - 41. - P. 136-141.

4. Paulson D. S. Biostatistics and microbiology: a survival manual / D. S. Paulson // Springer Science \& Business Media. - 2008. - 100 p.

5. Sadava, E. E., Krpata, D. M., Gao, Y., Novitsky, Y. W., \& Rosen, M. J. (2013). Does presoaking synthetic mesh in antibiotic solution reduce mesh infections? An experimental study. Journal of Gastrointestinal Surgery, 17(3), 562-568. 


\section{References:}

1. Basak S. A. \& Zaenglein A. L. (2013) Acne and its management. Pediatrical Review, 34(11), 479-497.

2. Hori, K., \& Matsumoto, S. (2010). Bacterial adhesion: from mechanism to control. Biochemical Engineering Journal, 48(3), 424-434.

3. Kapczynski D., Meinersmann R., Lee M. Adherence of Lactobacillus to intestinal cells in culture correlates with fi bronectin binding. // Current microbiology. $-2000 .-41$. - P. 136-141.

4. Paulson D. S. Biostatistics and microbiology: a survival manual / D. S. Paulson // Springer Science \& Business Media. - 2008. - 100 p.

5. Sadava, E. E., Krpata, D. M., Gao, Y., Novitsky, Y. W., \& Rosen, M. J. (2013). Does presoaking synthetic mesh in antibiotic solution reduce mesh infections? An experimental study. Journal of Gastrointestinal Surgery, 17(3), 562-568. 


\title{
MODERNIZATION HOUSING TERRITORIES \\ OF UKRAINE'S MILITARY CITIES. BACKGROUND AND CONCEPT
}

\section{МОДЕРНІЗАЦІЯ ЖИТЛОВИХ ТЕРИТОРІЙ ВІЙСЬКОВИХ МІСТЕЧОК УКРАЇНИ. ПЕРЕДУМОВИ ТА КОНЦЕПЦІї}

\section{Morozik Alina ${ }^{1}$ \\ Vasylenko Lyudmila ${ }^{2}$}

DOI: http://dx.doi.org/10.30525/978-9934-571-26-8_14

\begin{abstract}
The presented scientific material concerns the modernization of planning decisions and architectural environment military towns of Ukraine. Especially this problem is relevant for small cities, where the military town is a city forming element. The article describes the preconditions and main directions modernization of the architectural environment of the residential part the Ukrainian military towns, outlines the purpose of the study, which is to develop theoretical, methodological and practical approaches to the modernization of the architectural and planning structure of residential areas of military towns. To achieve the goal, the following tasks need to be addressed: the search for and analysis of modern scientific research, in which different approaches are proposed both in designing and practical activities, identifying the principal deficiencies of existing military settlements; development of a methodology for modernizing the planning structure of the residential zone of military towns.

Principles of modernization of the architectural and planning structure residential areas of military towns are the subject of studying modern scientific approaches to the development military towns. At different stages of research, we use the following methods: search monographic and compar-
\end{abstract}

\footnotetext{
${ }^{1}$ Postgraduate Student of the Department of Urban Development, Kyiv National University of Construction and Architecture, Ukraine ORCID 0000-0002-9325-3837

${ }^{2}$ Candidate of Architecture, Associate Professor the Department of Urban Development, Kyiv National University of Construction and Architecture, Ukraine ORCID 0000-0002-3122-0917
} 
ative. The historical and comparative methods are used to study historical types of military territorial objects and determine their development. Analysis, synthesis, methods of synthesis and comparison are used to reveal the characteristics of the architectural and planning and functional structure of military towns. The method of forecasting and experimental designing is used by us in developing project proposals for the modernization planning structure of military towns.

Consequently, the urgent need to address the issues of improving the living environment of servicemen and ensuring their housing are topical issues, as evidenced by state programs aimed at modernizing and developing these facilities. Principles of modernization of military towns are determined in accordance with the existing problems of modern Ukrainian military territorial objects and taking into account the shortcomings of the architectural and urban environment. Analysis of diverse city-planning situations, architectural-planning and spatial decision-making features contributed to the formation principles of modernization, the application of which can be more effective, the combination use of multi-dimensional principles will determine the direction of modernization in each particular case, find rational solutions, methods and techniques modernization. The use of the principles proposed by us allowed us to experimentally verify the results research on specific objects located in Ukrainian small cities. The search for effective ways to modernize the architectural, planning, functional structure, the system cultural and domestic services and the infrastructure of military towns refers to the most urgent tasks of our time.

\section{1. Вступ}

Окреслена нами мета дослідження, яка полягає в розробці теоретичних та практичних підходів модернізації архітектурно-планувальної структури житлової частини військових містечок в малих містах України, потребує рішення наступних задач: дослідити та проаналізувати сучасні наукові розробки та напрямки дослідження в галузі проектування військових територіальних об’ єктів; визначити види військових територіальних об'єктів на певних історичних етапах (таборів, міст-фортець, військових поселень); виявити основні недоліки існуючих військових містечок та окреслити фактори та передумови, що впливають на їх архітектурно-планувальну організацію та функціональне зонування; дослідити практичний вітчизняний та закордон- 


\section{Morozik Alina, Vasylenko Lyudmila}

ний досвід територіальної організації об'єктів; визначити типологічні групи сучасних військових містечок та виявити особливості їх формування; розробити методику модернізації планувальної структури військових містечок; перевірити експериментально виявлені принципи осучаснення.

В досліджені сучасних наукових напрямків вивчення військових містечок використовується пошуковий, монографічний та порівняльний методи. У вивченні історичних видів військових територіальних об'єктів та визначенні їх розвитку використовується пошуковий історичний та порівняльний методи. Для виявлення характеристик планувальної та функціональної структури військових містечок застосовані аналіз, синтез, методи узагальнення та порівняння. Метод прогнозування, експериментального проектування використовуються в розробці проектних пропозицій модернізації планувальної структури військових містечок. Отже, розробка теоретичних принципів модернізації $\epsilon$ основою для проектних пропозицій осучаснення існуючих військових містечок України, а основні положення, висновки та результати наукової роботи використанні в проектуванні.

\section{2. Актуальність теми}

Питання безпеки країн відноситься до числа давніх, в той же час, завжди актуальних проблем. Зважаючи на останні події в геополітичному просторі України 2014-2018 року, питанням цілісності та національної безпеки надається велике значення. Існує потреба в модернізації та осучасненні військових територіальних об'єктів, зокрема військових містечок, які є однією з складових обороноздатності країни та виконують стратегічні функції. Це відносить проблему пошуку ефективних способів та принципів осучаснення архітектурно-планувальної структури, системи культурно-побутового обслуговування та інфраструктури військових містечок до сучасних та найактуальніших завдань, які потребують першочергового вирішення і визначаються програмами державного розвитку, як перспективні напрямки. Сучасні соціокультурні потреби жителів військових містечок диктують необхідність розробки нових підходів, принципів та методів модернізації житлових територій військових містечок. Пошук ефективних шляхів удосконалення житлового середовища військовослужбовців засобами містобудування та архітектури відноситься до сучасних проблем. 
Напрям дослідження модернізації військових містечок пов'язаний 3 державними програмами та стратегіями. Основними з них є «Стратегія воєнної безпеки», «Стратегія національної безпеки» та «Державна програма розвитку Збройних Сил України» [4; 7]. Положення щодо реформування та розвитку Збройних Сил України викладені в плані заходів Міністерства оборони України з виконання «Програми діяльності Кабінету Міністрів України» та «Стратегії сталого розвитку України - 2020 року» від 12 січня 2015 року № 5/2015 [4]. Дана концепція передбачає розвиток військових містечок, формування на їх основі системи автономних військових баз з необхідною інфраструктурою для розташування військових частин із фондом службового житла, соціально-побутовою інфраструктурою для військовослужбовців та членів їх сімей [4; 7]. Державна програма розвитку Збройних Сил України на період до 2020 року передбачає: будівництво та відновлення казармено-житлового фонду, їдалень, інженерних мереж; реконструкція та капітальний ремонт військових об'єктів із впровадженням сучасних технологій із швидкозбірних конструкцій; розквартирування військових частин.

Наказ Міністерства Оборони України від 30.11.2011 року № 737 «Про затвердження Інструкції про організацію забезпечення військовослужбовців Збройних Сил України та членів їх сімей жилими приміщеннями». Постанова Кабінету Міністрів України від 03.08.2006 року № 1081 «Про затвердження Порядку забезпечення військовослужбовців та членів їх сімей житловими приміщеннями«, Постанова Кабінету Міністрів України від 2 вересня 2015 року № 728 «Деякі питання забезпечення житлом військовослужбовців та інших громадян», Рішення Ради національної безпеки і оборони України від 29 грудня 2016 року «Про Державну програму розвитку Збройних Сил України на період до 2020 року» свідчать про актуальність теми дослідження та необхідність розробки сучасних підходів вирішення проблематики забезпечення військовослужбовців та членів їх сімей житлом та модернізації житлових територій військових містечок.

\section{3. Сучасний стан наукових досліджень}

Протягом ХХ століття, групою дослідників було розроблено нормативну документацію «Планировка и застройка военных городков»: Ю. Зайцев, В. Башков, Г. Усенко, В. Звєрьков, А. Соков, А. Харкевич, 
С. Корягін $[8,9]$. Над розробкою відомчих будівельних норм «Загальновійськові споруди» працювали науковці, архітектори, проектувальники: Е. Андронова, П. Афонін, В. Башаков, Ю. Зайцев, А. Козаков, І. Кончева, С. Корягин, Г. Лутошкін, Г. Маленкін, С. Пекарская, Л. Подолян, С. Топорков, Г. Усенко, А. Хрюкін, В. Чернова Б. Шиляєв [8]. Кожен розділ вищезазначеного документу присвячений певному типу будівель військового призначення, до яких відносяться: казарми, об'єкти громадського харчування, клуби, будівлі медичних пунктів, адміністративні службові будівлі, споруди зони парку техніки, будівлі побутового обслуговування, складські споруди та учбові заклади військових частин.

На початку XXI ст. дослідження, що стосуються проблематики військових територіальних об'єктів висвітлюються в роботах: М. Буніна, Ю. Затикіна, М. Максименко, В. Мухіна [2; 5; 6]. В. І. Мухін спільно з М. А. Буніним працювали над розробкою принципів архітектурно-планувальної організації територій спеціального призначення. Питання організації системи культурно-побутового обслуговування військових містечок висвітлює Максименко О. О., в роботах автора докладно проаналізовано архітектурно-планувальна організація центрів обслуговування військових містечок, визначені принципи їх формування з врахуванням соціальних та економічних факторів [5]. Вагомий внесок у розробку методики осучаснення міських територій зробили: М. В. Биваліна, І. І. Гонгало, В. Ф. Касьянов, О. Ф. Осипов, А. М. Плешкановська, М. В. Сисойлов, В. К. Соколов, А. В. Степанюк $[1 ; 2 ; 3]$.

Огляд наукових робіт, різнобічних актуальних гіпотез мають значення для розробки функціональної та архітектурно-планувальної структури військових об'єктів та їх раціональної організації території. При всій широті розгляду наукових аспектів, в роботах вищезазначених вчених не розглянуті, зокрема, питання осучаснення вітчизняних існуючих військових містечок, які розташовані в малих містах України. Не вирішені проблеми удосконалення архітектурно-планувальної, функціональної структури, системи культурно-побутового обслуговування та об'єктів соціальної сфери військових містечок. Існує потреба в дослідженні окреслених питань та містобудівних аспектів знаходження оптимальних рішень для осучаснення вітчизняних військових містечок. Важливо, що проблема модернізації архітектурно-плану- 
вальної структури військових містечок потребує поглибленого аналізу праць низки науковців, що вивчали загальні питання знаходження раціональних підходів до реконструкції міст, міських територій, житлових районів.

Результати наукових досліджень, що пов'язані з військовими об'єктами широко не викладені для загального користування, що є об'єктивним та логічним з міркувань безпеки. Проте, питання архітектурно-планувальної та функціональної організації, реконструкції та осучаснення житлових та громадських територій військових форм територіальної організації все ж залишаються актуальними питаннями і не суперечать проблемам безпеки.

\section{4. Недоліки житлових територій військових містечок}

Основні недоліки військових містечок можна поділити на: містобудівні, функціональні, середовищні та об’єктні. До містобудівних недоліків можна віднести: нефукціональність планувальних рішень військових містечок та нераціональне використання територій. Аналіз архітектурного середовища дозволяє визначити рівень амортизації житлового фонду військових містечок, тому очевидною є необхідність проведення комплексу заходів модернізації елементів містобудівного та архітектурного середовища. В процесі модернізації житлових територій необхідне вирішення ряду питань: соціальних - забезпечення населення комплексом установ та підприємств культурно-побутового обслуговування; санітарно-гігієнічних - забезпечення належного санітарного стану території, нормативної інсоляції території і будинків, зниження рівня шуму, які перевищують нормативні показники, зменшення санітарно-захисних зон за умови спеціальних заходів, протипожежних та цивільної оборони; інженерно-технічних - реконструкції транспортної та інженерної інфраструктури; естетичних $[11 ; 12 ; 13]$.

Військові містечка, які розташовані в малих містах мають функціональну структуру, яка не відповідає сучасним потребам. Відомо, що особливості функціонального зонування, в значній мірі, залежать від типологічної групи військових містечок, розміри території функціональних зон залежать від соціально-демографічних умов. Відповідно планування військових містечок визначається, як формування поліфункціональної структури. Аналіз існуючого стану військових містечок України свідчить про недостатній розвиток соціальної та культур- 
но-побутової інфраструктури. Несформовані громадські території та забудова, які призначені для забезпечення потреб військовослужбовців та членів їх сімей.

Однією з основних проблем сучасних військових містечок $є$ недостатнє житлове забезпечення військовослужбовців. Ця проблема набула значних масштабів, станом на 01.01.2017 р. в черзі на житло перебувають понад 44 тисячі сімей військовослужбовців [4]. Існує потреба збільшення житлового фонду та норми проживання на одну людину. Основний документ, що підтверджує дану необхідність $є$ Наказ Міністерства оборони України від 03.07.2013 № 448 «Положення про організацію квартирно-експлуатаційного забезпечення Збройних Сил України» [4]. Організація квартирно-експлуатаційного забезпечення Збройних Сил України - це комплекс заходів, спрямованих на безпечну експлуатацію, утримання казармено-житлового фонду, об'єктів соціально-культурного призначення, комунальних споруд та інженерних мереж військових містечок, забезпечення військових частин квартирним майном. Загальновійськове планування, що включає в себе комплексне проектування військових містечок і всіх елементів їх інфраструктури - будівель і споруд, що забезпечують повсякденний побут, бойове навчання, зберігання та експлуатацію військової техніки [7].

Найпростіша типова житлова забудова, яка є застарілою і не відповідає сучасним функціональним та естетичним потребам населення, існуючі багатоквартирні будинки є вітхими та застарілими. Особливо незадовільний стан мають будівлі казарм, їх фізичний та моральний знос не відповідає задоволенню сучасних потреб. Зазначені недоліки, дають підстави для покращенням умов проживання шляхом реконструкції та модернізації існуючих будівель. Недоліки архітектурного середовища житлової зони виражається також в занедбаних, неорганізованих прибудинкових територіях з низьким рівнем благоустрою та озеленення. Разом з тим, недостатньо розвинені спортивні та рекреаційні зони. На території військових містечок недостатня кількість відкритих майданчики для оздоровчих та спортивних комплексів, разом 3 тим, існує необхідність створення місць рекреації [12; 13].

Архітектурне середовище житлових зон військових містечок справляє похмуре та неестетичне враження на жителів. Тому, існує необхідність гармонізації середовища та підвищення естетичних якостей 
військових містечок шляхом використання архітектурних та композиційних прийомів, що відповідають сучасним стильовим тенденціям. Гармонізації середовища об'ємно-просторової та архітектурно-планувальної структур військових містечок набуває особливого значення в умовах сталого розвитку [13].

На основі аналізу вітчизняного та закордонного досвіду територіальної організації військових об' єктів, що складаються з цивільної та військової частини, були визначені особливості містобудівних рішень та їх проблематика. Вивчення характеристик планування вищезазначених об'єктів дозволило виявити основні причини, що визначили необхідність та доцільність їх модернізації, а саме: невідповідність сформованої планувальної структури діючим будівельним нормам та соціально-культурним потребам, недостатня ефективність використання територій; дефіцит забезпеченості військовослужбовців житлом; низький рівень соціального та культурно-побутового обслуговування; відсутність рекреаційних зон; моральний і фізичний знос забудови.

\section{5. Напрямки модернізації житлових територій військових містечок}

Як свідчить аналіз, проблема осучаснення архітектурно-планувальної структури житлових територій військових містечок на сьогодні не отримала глибокого дослідження в наукових джерелах. Ще й досі існує потреба розробки сучасних підходів у вивченні даної тематики. Теоретичні питання модернізації охоплюють широке коло проблем. Загальні питання реконструкції та модернізації міст та міських територій висвітлені в роботах: А. М. Плешкановської, М. В. Сисойлова, В. К. Соколова, М. В. Биваліна, В. Ф. Касьянова, І. І. Гонгало, О. Ф. Осипова, А. В. Степанюка $[1 ; 2 ; 10 ; 11]$. Військове містечко є містобудівним об'єктом, тому найбільш грунтовними для даного дослідження є наукові розробки А. М. Плешкановської. В наукових працях автора викладені методи та прийоми реконструкції, розглядається функціонально-планувальна оптимізація міських територій, які зокрема стосуються і наших проблем. Докладно висвітлені основні напрямки реконструкції житлової забудови, що є корисними для розробки методики модернізації вітчизняних військових містечок. Низка сучасних науковців сконцентровані, в своїх працях, на дослідження певної проблематики пов'язаної з функціональним зонуванням, пла- 
нуванням, забудовою, організацією архітектурних комплексів та окремих будівель. Для даного дослідження є цінними наукові праці та доробки сучасних вчених, які діднімають основні актуальні проблеми реконструкції та модернізації [10; 11].

Існуючі недоліки архітектурного та містобудівного середовища військових містечок диктують необхідність розробки сучасних принципів та методів модернізації. Пошук ефективних шляхів осучаснення архітектурно-планувальної та функціональної структури, системи культурно-побутового обслуговування та інфраструктури військових містечок відноситься до сучасних завдань, які потребують більш детального дослідження та розробки сучасних підходів до вирішення проблематики їх модернізації.

Державними цільовими програмами та стратегіями розвитку передбачається ряд заходів спрямованих на будівництво та відновлення казармено-житлового фонду, їдалень, інженерних мереж; розквартирування (розміщення) військових частин у районах виконання завдань; відновлення та нарощування аеродромної мережі; будівництво, реконструкція та капітальний ремонт, насамперед у східному та південному регіонах; будівництво та реконструкція військових об'єктів із впровадженням сучасних технологій із швидкозбірних конструкцій; забезпечення підрозділів сучасними малогабаритними, малопомітними польовими модулями, захищеними спорудами та іншими об'єктами польової інфраструктури; забезпечення потреб у розквартируванні особового складу та частково оновлена інфраструктура військових містечок та інших військових територіальних об'єктів [5].

Будівництво житлових комплексів для контрактників здійснюватиметься здебільшого на територіях існуючих військових містечок майже по всій території України в 21 області. Планується побудувати 184 житлових комплексів для військовослужбовців Збройних Сил України. Таке рішення $є$ оптимальним з точки зору збереження та максимально ефективного використання комунікацій і мережі, елементи інженерної інфраструктури [5].

Вивчений досвід став основою для виявлення принципів модернізації військових територіальних об'єктів, а саме: територіального розвитку, інтеграції, адаптації та трансформації. Вони в своїй структурі поділяються на три рівні: архітектурно-планувальний, функціональний та об’єктний. Завдяки диференціації містобудівного середовища 
визначається раціональний підхід до вирішення проблематики осучаснення необхідних структурних елементів в залежності від потреб. Зміст принципу територіального розвитку військових містечок полягає в можливості розширення військових територіальних об'єктів за рахунок вільних прилеглих територій. Даний принцип реалізується за рахунок включення та освоєння незабудованих територій для розквартирування та забезпечення соціальних та культурно-побутових потреб населення, що працює та проживає у військовому містечку. Основною метою є створення нових осередків військового, житлового та громадського будівництва.

Принцип інтеграції полягає у доповненні елементів містобудування, до існуючої архітектурно-планувальної структури, додаються нові утворення, що забезпечують створення нових об'єктів, сучасних складових містобудівного простору. Принцип інтеграції на об'єктному рівні передбачає включення необхідних будівель та споруд, закладів та об'єктів освіти, спорту, торгівлі, громадського харчування та медицини, що забезпечується вибірковим будівництвом, в умовах обмеженого територіального розвитку військового містечка. Відповідність структурних елементів містобудівного середовища сучасним будівельним нормам та соціально-культурним потребам визначаються принципом адаптації. Під час модернізації необхідно перепланувати простори під новий зміст надавши архітектурному середовищу новий імпульс для розвитку. Принцип трансформації та адаптації заключається у перетворенні територій, зон та будівель 3 певних функціональним призначенням під інше цільове використання [7].

Зазначенні принципи модернізації військових містечок поєднують планувальні, функціональні та об'єктні напрямки сучасного розвитку, шляхи їх реалізації зумовлені застосуванням методів та прийомів осучаснення військових територіальних об'єктів. Для реалізації принципів застосовуються методи: екстенсивного розвитку, ущільнення забудови, ускладнення архітектурного середовища, перепланування, реорганізація, пристосування, функціональної відповідності та оновлення. Нами виявлені відповідні прийоми розвитку архітектурного простору: освоєння нових територій, вибіркове будівництво, надбудова, прибудова, зміна функціонального призначення території, реорганізація. Принципи, методи та прийоми модернізації військових містечок визначені у відповідності до існуючої проблематики сучасних 


\section{Morozik Alina, Vasylenko Lyudmila}

військових територіальних об'єктів України та з врахуванням недоліків архітектурного середовища. Різноплановість містобудівних ситуацій, особливості архітектурно-планувальних та об'ємно-просторових рішень визначили необхідність комплексного використання методів та прийомів. Варіативність принципів дозволять визначати доцільний напрям осучаснення для конкретного містобудівного об'єкту з врахуванням їх особливостей.

Представлений в теорії містобудування принцип територіального розширення $\epsilon$ прикладом екстенсивного розвитку військових містечок і початковим рівнем модернізації. Його зміст полягає в можливості розширення військових територіальних об'єктів за рахунок вільних прилеглих територій. Осучаснення військових містечок має низку можливих шляхів поліпшення, одним із яких може бути реалізація за рахунок включення та освоєння незабудованих територій для розквартирування та забезпечення соціальних та культурно-побутових потреб населення. Основною метою є створення нових осередків житлового та громадського будівництва $[10 ; 11]$.

Одним з найпоширеніших базових принципів в теорії містобудування є принцип функціональної інтеграції (функціонального насичення). Наступні принципи осучаснення військових містечок $€$ прикладами інтенсивного розвитку, де є можливості трансформації показників від кількісних до якісних. Визначена у відомчих нормативних документах функціональна структура відкритих військових містечок України має сталу базову модель зонування [7]. Спираючись на проведене нами дослідження, існує можливість насичення функціонального зонування за рахунок інтеграції нових функціональних зон в існуючу структуру, що сприятиме покращенню комфортних умов соціального та культурно-побутового обслуговування, задоволення соціально-культурних потреб мешканців. В осучасненні військових містечок України виникає необхідність розширення функціональної структури за рахунок включення додаткових зон: спортивно-рекреаційної, науково-просвітницької, навчально-тренувальної, адміністративної та медично-реабілітаційної [5].

Інтеграція на об'єктному рівні передбачає включення додаткових будівель та споруд. Інтегрування закладів та об'єктів освіти, спорту, торгівлі, громадського харчування та медицини забезпечується вибірковим будівництвом, в умовах неможливого територіального розвитку 
архітектурно-планувальної та функціональної структури військового містечка. Принцип об'єктної інтеграції є одним 3 найефективніших принципів модернізації військових містечок України, оскільки він може бути застосований в умовах забудови, що склалася без радикальних змін архітектурно-планувальної та інженерно-транспортної структури. Локальне доповнення до вже існуючої забудови є раціональною можливістю осучаснення в умовах обмежених територіальних ресурсів військового містечка, де визначені вузькі межі модернізації архітектурного простору [10].

Зміст принципу функціональної трансформації, який полягає у перетворенні територій з певним функціональним призначенням на інше цільове використання. Під час модернізації необхідно перепланувати простори під новий зміст надавши архітектурному середовищу новий імпульс для розвитку. Завдання модернізації полягає у створенні по можливості гнучкої планувальної структури для зниження необхідності радикальних трансформацій під час подальшого осучаснення містобудівного та архітектурного середовища $[8,9]$. Аналіз допомагає визначити території з функціональним призначенням, які використовуються не ефективно 3 точки зору параметрів щільності забудов. Даний принцип дозволяє переорганізувати існуючу функціональну структуру, що дозволяє раціонально використати містобудівний простір військового містечка і забезпечує його осучаснення.

Більшість об'єктів військової інфраструктури внаслідок змін соціальної політичної та економічної ситуації у країні, втратили своє початкове призначення. Конструктивні схеми, задовільний технічний стан будівель (казарм, штабів, їдалень, медичних закладів тощо) та вдале розташування на території колишніх військових містечок з розвинутою інфраструктурою дозволяє розглядати їх як перспективні об'єкти 3 метою створення фондів житла різних категорій, у тому числі і соціального. Реконструкція цих об'єктів супроводжується модернізацією інженерного обладнання, утепленням огороджувальних конструкцій та благоустроєм прибудинкової території.

Принципи архітектурно-планувальної інтеграції, трансформації та адаптації включають в себе більший спектр можливих методів та прийомів модернізації військових містечок і $є$ більш широким поняттям, що вміщує в себе функціональну структуру та транспортно-інженерну мережу [10]. Принцип архітектурно-планувального доповнення 


\section{Morozik Alina, Vasylenko Lyudmila}

полягає у формуванні нових архітектурно-планувальних утворень: житлових кварталів та громадських осередків, центрів (територій). До існуючої архітектурно-планувальної структури доповнюються нові містобудівні утворення, що забезпечує створення нових об' єктів, сучасних елементів містобудівного простору та забезпечує модернізацію військового містечка. Архітектурно-планувальна трансформація полягає в перетворенні територій під нові архітектурно-планувальні утворення. Перепланування та створення нових структур, використання територій для розвитку містобудівного та архітектурно простору за рахунок реорганізації. Території, що використовуються малоефективно потребують перепланування з можливістю організації сучасного простору. Принцип архітектурно-планувальної та функціональної адаптації полягає в перетворенні середовища зі збереженням елементів вже сформованої системи архітектурно-планувальної або функціональної структури. Надає можливість підпорядкувати містобудівне та архітектурне середовище найбільш ефективними засобами за рахунок використання існуючих елементів та доповнення необхідними [11]. Завдання модернізації на містобудівному рівні $є$ раціональне використання земель та територій для містобудівних потреб, підвищення ефективності забудови та іншого використання земельних ділянок.

Прийоми модернізації способи здійснення осучаснення середовища проживання військовослужбовців. Ущільнення забудови (прибудова, надбудова). В умовах існуючої забудови основними 3 можливих способів реалізації осучаснення архітектурного середовища на містобудівному рівні включаючи архітектурно-планувальну та функціональну структуру $є$ таки прийоми модернізації як прибудова та надбудова. Раціональним і економічно ефективним є підвищення щільності забудови шляхом надбудови і прибудови, влаштування багатоповерхових вставок між будинками і зведення окремих житлових корпусів, створення об'єктів інфраструктури, більш продуктивного використання підземного простору [3; 10; 11].

Комплексне вирішення модернізації квартальної забудови дозволяє створити комфортні умови проживання, що відповідають сучасним вимогам міського середовища, врахувати вимоги до формування соціальної сфери, необхідної для нормальної життєдіяльності громадян. Модернізація житлової забудови не повинна супроводжуватися 
погіршенням інсоляції та аерації i, як наслідок, має бути спрямована на поліпшення мікроклімату житлової забудови, підвищення комфортності проживання та оздоровлення умов проживання населення [12]. Ускладнення архітектурно-планувальної та функціональної структури. (насичення, інтеграція, додавання планувальних та функціональних елементів, вибіркове будівництво). Ускладнення та насичення функціонального зонування. Додавання нових функціональних зон для забезпечення покращення соціального та культурно-побутового обслуговування.

Локальна модернізація передбачає застосування певного принципу на окремому рівні містобудівного середовища. Комплексна модернізація передбачає застосування сукупності принципів: територіального розвитку, функціональної інтеграції, трансформації та адаптації, принципи архітектурно-планувального доповнення (інтеграції) та трансформації, а також принципу інтеграції для найповнішого осучаснення існуючих військових містечок України. Принципи модернізації військових містечок визначені у відповідності до існуючої проблематики сучасних військових територіальних об'єктів України та $з$ врахуванням недоліків архітектурного та містобудівного середовища. Модернізація військових містечок спрямована на осучаснення містобудівного середовища та його елементів, що обумовлено недоліками планування та забудови. Різноплановість містобудівних ситуацій, особливості архітектурно-планувальних та об'ємно-просторових рішень визначили необхідність створення принципів модернізації, які в поєднанні можуть надати ефективніший результат. Комбінації використання принципів дозволять визначати напрям осучаснення в конкретному випадку, знаходячи раціональні рішення, методи та прийоми модернізації.

\section{6. Впровадження принципів модернізації військових містечок}

Теоретичні принципи модернізації були апробовані в експериментальному проектуванні та при розрозробці містобудівної документації. Основні результати досліджень модернізації житлової частини військових містечок були використані при виконанні дипломної роботи на тему: «Детальний план території військового містечка відкритого типу в м. Чугуєві». Проектними рішеннями передбачено розвиток військового містечка за рахунок освоєння вільних територій та осучаснення 


\section{Morozik Alina, Vasylenko Lyudmila}

існуючої планувальної і функціональної структури. Запроектовано житлові квартали з об’єктами щоденного (первинного) культурно-побутового обслуговування, а також створення військової частини, що відповідає сучасним потребам.

Також, одним із завданням було поєднання існуючої забудови 3 проектною та удосконалення архітектурного середовища в цілому. Тому, застосовані принципи модернізації для осучаснення існуючого планування та забудови вищезазначеного військового містечка, а саме: принцип функціональної інтеграції та трансформації, а також об'єктної (локальної) інтеграції. Одним з найпоширеніших принципів в теорії містобудування $є$ принцип функціональної інтеграції.

Також, в проекті визначений напрямки функціонального переосвоєння територій військового містечка. Аналіз допомагає визначити території 3 функціональним призначенням, які використовуються неефективно 3 точки зору параметрів щільності забудов, кількості постійно перебуваючого населення та відвідування. Даний принцип дозволяє переорганізувати існуючу функціональну структуру, що дозволяє раціонально використати містобудівний простір військового містечка і забезпечує його осучаснення. Спираючись на проведене нами дослідження, існує можливість насичення функціонального зонування за рахунок додавання нових функціональних зон в існуючу функціональну структуру, що сприяють покращенню умов соціального та культурно-побутового обслуговування для задоволення соціально-культурних потреб жителів [8].

Для локального осучаснення існуючого планування військового містечка був застосований принцип інтеграції, який на об'єктному рівні передбачає включення додаткових будівель та споруд, закладів та об'єктів, а саме: освіти, спорту, торгівлі, громадського харчування та медицини, які забезпечується вибірковим будівництвом, в умовах неможливого територіального розвитку архітектурно-планувальної та функціональної структури військового містечка. Локальне доповнення до вже існуючої забудови $є$ раціональною можливість осучаснення в умовах обмежених територіальних ресурсів військового містечка, де визначені незначні можливості модернізації архітектурного простору. Принцип об'єктної інтеграції є супутнім принципом до вищезазначених, оскільки є доповненням в більш широких процесах модернізації [13]. 
Разом з принципами модернізації військових містечок, також були застосовані планувальні принципи міського середовища: розділення потоків транспорту та пішоходів; створення озеленених просторів, які створюють єдину структуру; організація розвиненої системи культурно-побутового обслуговування. В існуючій житловій частині були розміщені заклади культурно-побутового обслуговування, передбачено покращення транспортної інфраструктури та благоустрій озеленених територій. Проектна сельбищна зона представлена житловими квартали багатоквартирної забудови, які сформовані з секційних будинків середньої поверховості (3-5 поверхи). Центр військового містечка складається 3 громадських будівель. Всі функціональні зони військових містечок поєднуються пішохідними зв'язками з врахуванням дисперсії пішоходів. Основний пішохідний бульвар є комунікаційним сполученням, що поєднує громадський центр, житлові квартали та паркову зону. Ландшафтно-рекреаційна зона запроектована 3 врахуванням навантаження на ландшафт та враховує розподілення потоків пішоходів. Планувальна організація військової частини виконана у відповідності до відомчих планувальних норм «Планування та забудова військових містечок». В цілому планування військового містечка регулярне з чітко визначеними планувальними осями.

Наступним прикладом модернізації військових територіальних об'єктів є військове містечко розташоване в місті Старокостянтинів Хмельницької області. Згідно проекту генерального плану м. Старокостянтинів, ділянка проектування передбачена під квартал багатоквартирної багатоповерхової житлової забудови з об'єктами громадського обслуговування. Ділянка, що проектується, знаходиться в північно-західному напрямку від центру міста Старокостянтинів в межах населеного пункту на території військового містнчка, що належать Міністерству Оборони України. На ділянці проектування частково розташовуються існуючі будівлі військової частини, які мають високих рівень амортизації. Натомість перенесення їх заплановане на територію військової частини в рамках іiї реконструкції та модернізації. Основні фактори, які впливають на проектну архітектурно-планувальну та об'ємно-просторову організацію: особливості планування існуючої забудови міста; планувальні обмеження; матеріали історико-архітектурного плану, врахування наявного територіального розподілу території; забезпечення санітарно-гігієнічних, протипожежних та інших 
містобудівних умов. В осучасненні військового містечка в м. Старокостянтинові були використані принципи архітектурно-планувальної трансформації та адаптації. Для забезпечення соціальних потреб застосовується принцип функціональної та об’єктної інтеграції [12].

Також, при розробці детального плану території житлової частини військового містечка були враховані: взаємозв'язки планувальної структури військового містечка 3 існуючою планувальною структурою; забезпечення проектного кварталу об'єктами соціального, громадського, побутового та культурного обслуговування та нормативною кількістю автостоянок. На території площею біля 15 га, проектом передбачається розміщення секційних середньоповерхових житлових багатоквартирних будинків, що формують компактну планувальну структуру кварталу військового містечка. Біля будинків передбачено розміщення дитячих майданчиків, облаштованих місць тихого відпочинку, майданчиків для занять фізкультурою, господарських майданчиків та гостьових стоянок. Проектом модернізації військового містечка намічається будівництво житлової забудови 3 закладами повсякденного обслуговування. 3 метою забезпечення оптимальних умов перебування населення на території цивільної частині військового містечка в проекті передбачено площі озеленених територій загального користування житлових районів згідно нормативних показників 3 подальшою організацією благоустрою [3; 12; 13$]$.

Крім апробації результатів дослідження в експериментальному проектуванні, виконані впровадження основних принципів методів та приймів модернізації цивільної частини військових містечок України відкритого типу при виконанні містобудівної документації, проектів генеральних планів та пану зонування. При розробці генерального плану м. Гайсин впроваджені принципи модернізації, а саме: функціональної інтеграції та трансформації цивільної частини військового містечка на прикладі м. Гайсин з метою функціонального насичення, ефективного розвитку житлової зони та удосконалення територій спеціального призначення. Комплексний аналіз архітектурно-планувальної та функціональної структури військових містечок та територій спеціального призначення дозволяє розробити наукові пропозиції їх осучаснення та розвитку з урахуванням містобудівних, екологічних, соціально-демографічних та економічних вимог при розроблені містобудівної документації. 
Дослідження планування та забудови військового містечка відкритого типу диктують необхідність застосування принципів та методів ïx модернізації. Визначені актуальні напрямки осучаснення функціональної структури та системи культурно-побутового обслуговування. На прикладі міста Чортків 3 метою функціонального насичення та ефективного використання територій військового містечка впроваджені принципи модернізації, а саме: функціональної та архітектурно-планувальної адаптації житлової частини військового містечка. Різноплановий підхід з можливими варіаціями осучаснення від локальної до комплексної модернізації визначає адаптивні можливості запропонованих компонентів осучаснення. Апробація принципів модернізації житлових територій військових містечок визначає можливість подальшого застосування принципів методів та прийомів на подальших стадіях проектування (детальний план території, робоча документація та проекти благоустрою прибудинкових територій).

\section{7. Висновки}

Першочергова потреба вирішення проблематики модернізації житлових територій військових містечок, удосконалення середовища проживання військовослужбовців та забезпечення їх житлом, розквартирування є актуальними питаннями, про що свідчать державні програми спрямовані на розвиток військових об'єктів. Принципи модернізації військових містечок визначені у відповідності до існуючої проблематики сучасних військових територіальних об'єктів України та $з$ врахуванням недоліків архітектурного та містобудівного середовища. Варіативність використання принципів дозволять визначати напрям осучаснення в конкретному випадку знаходячи раціональні рішення, методи та прийоми. Розроблені пропозиції щодо модернізації військових містечок з урахуванням особливостей діючої законодавчої та нормативної баз. Експериментально та теоретично підтверджена ефективність основних принципів модернізації військових містечок: територіального розвитку, інтеграції, адаптації та трансформації. Здійсненні проектні впровадження принципів, методів та прийомів модернізації житлових територій військових містечок України відкритого типу при виконанні містобудівної документації проектів генеральних планів та плану зонування. Крім того, розроблені теоретичні та методичні основи осучаснення військових містечок були застосо- 
вані у дипломному та курсовому проектуванні для студентів п'ятого та шостого курсів $з$ напрямку підготовки «містобудування» та «архітектура». Вищезазначені роботи підтверджують результативність виявлених підходів осучаснення архітектурно-планувальної структури цивільної частини відкритих військових містечок.

\section{Список літератури:}

1. Биваліна М. В. Проблеми та методи модернізації районів масової житлової забудови 1960 - 1970-х років (на прикладі м. Києва) : Автореф. дис... канд. техн. наук / М. В. Биваліна; Київ. нац. ун-т буд-ва і архіт. - К.: КНУБА, 2003. $-19 \mathrm{c}$.

2. Дьомін М. М. Проблеми та методи модернізації районів масової житлової забудови 1960-1970-х років (на прикладі м. Києва) / М. М. Дьомін, М. В. Биваліна // Містобудування та територіальне планування: Наук.-техн. збірник / Відпов. ред. М. М. Осєтрін. - К. : КНУБА, 2005. - Вип. 21. - С. 67-75.

3. Волкова Т. Ф. реабилитация городской жилой среды. Социальноградостроительный аспект: учеб. пособие / Т. Ф. Волкова. - Пенза: ПГУАС, 2014. $-116 \mathrm{c}$.

4. Закон України: «Про державні цільові програми» // Відомості Верховної Ради України (ВВР). - 2004, N 25. - 352 с.

5. Максименко О. А., Архитектурно-планировочная организация центров обслуживания военных городков: автореферат дис. ... кандидата архитектуры: 05.23.21 / Максименко Ольга Александровна, Москва, 2013. - 26 с.

6. Мухин В. И. Социально-демографические основы совершенствования организации жилых территорий постоянного населения военных городков / В. И. Мухин. - Л., ЛВВИСКУ, 1985. - 355 с.

7. Наказ Міністра оборони України «Про затвердження Положення про організацію квартирно-експлуатаційного забезпечення Збройних Сил України». - 2011, № 215.

8. Планировка и застройка военных городков // Нормы проектирования: ВСН 34-94. М.: МО РФ, 1994. - 102 c.

9. Планировка и застройка военных городков: Нормы проектирования. BCH 34-89. / MO СССР М., 1989. - 88 c.

10. Плешкановська А. М. Методологія комплексної реконструкції міста : автореф. дис. ... д-ра техн. наук / А. М. Плешкановська; К.: КНУБА. - Київ, 2013. $-40 \mathrm{c}$.

11. Плешкановська А. М. Проблеми реновації забудови міських територій / А. М. Плешкановська // Містобудування та територіальне планування: Наук.-техн. збірник / Відпов. ред. М. М. Осєтрін. - К. : КНУБА, 2006. Вип. 25. - С. 183-191.

12. Методика реконструкции городов / ЦНИИП градостроительства. - М.: Стройиздат, 1975. - 197 с.

13. Шепелев Н. П. Реконструкция городской застройки: Учеб. для строит. спец. вузов. / Н. П. Шепелев, М. С. Шумилов - М.: Высш. шк., 2000. -271 с. 


\section{Modernization housing territories of Ukraine's military cities. Background...}

\section{References:}

1. Byvalina M. V. Problems and methods of modernization of areas of mass housing development of the 1960s - 1970s (for example, Kyiv) : Author's abstract. Kiev.: KNUBA, 2003. -19 p.

2. Djomin M. M. Problems and methods of modernization of areas of mass housing development of the 1960-1970s (for example, Kyiv). Urban Planning and Territorial Planning: Scientific Collection (electronic journal). Kiev.: KNUBA, 2005. - Vol. 21. - pp. 67-75.

3. Volkova T. F. Rehabilitation of urban living environment. Social-townplanning aspect. Penza, 2014. -116 p.

4. Law of Ukraine: "On State Target Programs". - 2004, n. 25. - 352 p.

5. Maksymenko O. A. Architectural and planning organization of service centers for military towns. 2013. $-26 \mathrm{p}$.

6. Mukhin V. I. Socio-demographic fundamentals of improving the organization of residential areas of the permanent population of military towns. LVVISKU.1985. $-355 \mathrm{p}$.

7. Order of the Minister of Defense of Ukraine "On Approval of the Regulation on the Organization of Apartment Maintenance of the Armed Forces of Ukraine". 2011, № 215.

8. Planning and building of military camps. VSN 34-94. Moscow: Ministry of Defense of the Russian Federation, 1994. - 102 p.

9. Planning and building of military camps. Design standards. VSN 34-89. I USSR Moscow: 1989. $-88 \mathrm{p}$.

10. Pleshkanovsjka A. M. Methodology of the complex reconstruction of the city, Kiev.: KNUBA, 2013. -40 p.

11. Pleshkanovsjka A. M. Problems of renovation of urban areas / Kiev.: KNUBA, 2006. - vol. 25. - 183-191 pp.

12. Methods of urban reconstruction. Central Research Institute of Urban Planning. - Moscow: Stroyizdat. - 1975. - 197 p.

13. Shepelev N. P. Reconstruction of urban development. Moscow.: ext. shock, 2000. $-271 \mathrm{p}$. 
NATIONAL LIBERATION MOVEMENT IN WESTERN UKRAINE IN THE INTERWAR PERIOD (1918-1939)

\section{Pylypenko Lilia ${ }^{1}$ \\ Bilan Serhii $^{2}$}

DOI: http://dx.doi.org/10.30525/978-9934-571-26-8_15

Abstract. The paper attempts to investigate the peculiarities of the national liberation movement of Western Ukrainians during the interwar period, when several social movements emerged, represented both as democratic unions and parties that carried out the legal struggle, as well as by two illegal political forces. Leading political forces tried to influence the national liberation, which did not lead to the consolidation of the community and further contradictions. Instead, the struggle of the Polish national chauvinists and Ukrainian patriotic forces did not allow Ukrainians to defend the sovereignty of their state, since this was affected by the military-political situation in the region, the position of the Entente countries, as well as the ethnic relations of the region. The development of the Ukrainian national liberation movement was perceived as antistate activity by the Polish society, and the unresolved political, economic, cultural, educational, and social problems - as an attempt to "steal" these lands. The Polish community considered the "Ukrainian question" through the prism of its own struggle for state independence and "groundless claims of Rusyns" to these territories. The consistent assimilation policy of the Polish authorities, the actual lack of unity of Ukrainian political forces pushed part of the Ukrainian youth to the use of more radical forms of struggle. In January 1929, the Organization of Ukrainian Nationalists (OUN) was created in Vienna. The prevalence of national interests over individual ones was proclaimed, the supreme goal of the struggle was asserted by the achievement of state independence. Methods of struggle - propaganda, propaganda, sabotage and terrorist.

\footnotetext{
${ }^{1} \mathrm{PhD}$ student of Department of History and Political Sciences,

National University of Life and Environmental Sciences of Ukraine, Ukraine

${ }^{2}$ Doctor of Historical Sciences, Professor,

Professor of Department of History and Political Sciences,

National University of Life and Environmental Sciences of Ukraine, Ukraine
} 
Not only representatives of the occupation authorities, but also Ukrainians who did not share the ideology and methods of struggle of the OUN, were subjected to terror. Despite ideological sympathies or antipathies to the Ukrainian national idea, objectivity requires that the activities of legal parties and illegal influences significantly on the historical events of the twentieth century.

\section{Introduction}

Ukrainian-Polish relations and their problems have a long-lasting and controversial history. Territorial neighborhood, several centuries of common history, similar signs of development of the Ukrainian and Polish peoples cause the interest of the scientific community to various aspects of relations between the two countries.

The relations between the Polish and Ukrainian states in 1918-1939 were not the most promising, and later, tragic for Ukrainians.

The Ukrainian issue on the eve of the Second World War was even more complicated than in 1914. It's solution affected the fate of at least four states, which included Ukrainian ethnic lands in the interwar period. Germany chose to destabilize the internal situation in countries that were supposed to be conquered in the future, as the main way of achieving the goal.

The first goal was Poland, which found itself in the situation between the hammer and the anvil - Germany's support for the Ukrainian movement was threatening the loss of Western Ukraine, and the idea of cooperation with the USSR was unacceptable.

Ultimately, as a result of external aggression and under the influence of the domestic political and economic crisis, national statehood was eliminated, and Ukrainian lands were once again divided between neighboring states. In particular, the lands of Western Ukraine were divided between several states:

- Eastern Halychyna, Polissya, Volyn and Podlyaschcha joined the territory of Poland;

- Romania Bucovina and Northern Bessarabia entered;

- Transcarpathia moved to Czechoslovakia.

The situation of Ukrainians in these states was not the same, within each of them, Ukrainians demonstrated different levels of self-awareness and political activity, but the national liberation movement began to emerge in the occupied territories. 


\section{Aim of the research}

The relevance of the topic of research in the stated chronological boundaries is that, despite a large number of published sources and scientific literature, there are many gaps in its study. In particular, there is a need to find out how specific forms and methods of counteracting state assimilation and the preservation of national identity appeared in Ukrainian society.

The main results of research in this area belong to Western Ukrainian researchers, in particular M. Kugutyak [1], O. Krasovsky [2], M. Lytvyn and K. Naumenko [3], V. Marchuk [4] and many other domestic researchers who, with the use of a broad source base, in a comprehensive way highlighted the state-political, cultural and educational, socio-economic, spiritual life of Western Ukrainians.

A separate place in the study of leading political forces in the struggle for Ukrainian statehood was occupied by L. Zashkilnyak [5], V. Khodak [6], S. Vidyansky [7], M. Mandryk, and others. The research of scientists accumulated the best traditions of both domestic and foreign historical science.

The purpose of the work is to analyze the components of the course of the national liberation struggle of the Ukrainian people in the period 1918-1939.

\section{Emergence of the liberation movement}

In the 1920's, the ideological face of the Ukrainian liberation movement was still rather vague, so at this time it is impossible to talk about nationalist ideology, but only about the formation of a nationalist outlook.

In the 20-30's, Western-Ukrainian society witnessed radicalization of the national liberation movement with the use of terrorist acts.

Gradually, the most prominent factor in the social and political life of Western Ukraine was Ukrainian nationalism, whose birth is associated with a radical position in the struggle for Ukraine's state independence of the Ukrainian Military Organization (UMO), which in the future served as an "army in the underground". The UMO was a military patriotic, not a nationalist organization: it aimed to liberate Ukrainian lands from invaders by military means. Corresponding was its organizational structure like the army. According to its organizers, the main task of the UMO was to prepare a nationwide uprising of the Ukrainian people against the invaders. 
Starting from the spring of 1922, activists of the UMO began to carry out acts of sabotage in Galicia, burned bread storages, conducted armed attacks on gendarmes, blew up trains and bridges. In the 1920 's, the UMO organized several assassinations of state officials.

In 1923-1924, UMO experienced a crisis, many activists and militants were in prison, a plan to spread sabotage and propaganda activities on the territory of the Ukrainian SSR failed, and the influence of the Communist Party of Western Ukraine increased. All these events somewhat undermined the credibility of the UMO. In order to consolidate nationalist and patriotic forces, the I Congress of Ukrainian Nationalists took place in Berlin in November 1927, which was attended by representatives of the UMO from the "Ukrainian Nationalist Youth Group" from Czechoslovakia (leader M. Konovalets), "The Union of Ukrainian Nationalist Youth" (Lviv), "The Legions of Ukrainian Nationalists" of Czechoslovakia under the leadership of M. Sziborski. In Prague, on April 8-9, 1928, the II Congress of Ukrainian Nationalists took place. Discussing the problem of consolidation of the movement, its participants emphasized that it was necessary to form a unified organization on the basis of all-nation, supra-partisanship, monocracy and national dictatorship.

The nature of the UMO's activity, which positioned itself as a suprapartisanship secret non-mass military organization, whose main task was to continue the armed struggle with the occupier, did not contribute to the development of ideology. A certain role here was played by the disappointment of the military with all sorts of political programs and ideological platforms. Sufficient was the presence of a member of the organization's desire to fight for the liberation of Ukraine.

A clear ideological positioning of the UHF took place in the second half of the 1920's. It was accelerated by an acute discussion in the organization's rocks, caused by the emergence of Soviet-Philippine tendencies in it. In the end, this crisis was overcome: the Soviet -Filly membership of the UBO broke up, creating the Western-Ukrainian People's Revolutionary Organization, which advocated the expansion of the partisan movement in Poland, so that part of the youth joined the ranks. The rest of its members gradually leaned to a new one for Ukrainian politics and a popular nationalist ideology.

Then this ideology was just born - in numerous discussions in various youth circles, literary and cultural clubs. Therefore, it can be argued that the 
ideological platform of the liberation movement in this period was formed outside the clear organizational framework - at the level of personal outlook. The focus on the development of certain psychological features also determined the specifics of the ideological works of that time - most of them, filled with emotions, rather resemble religious sermons than political documents.

Among the causes of the defeat of the liberation struggle were also the psychological unwillingness of the Ukrainians to defend their freedom under the brutal conditions of the struggle. Therefore, in order to realize their state-building aspirations, Ukrainians would have to reburse: from the "soft, sentimental" to become "fanatically loyal soldiers". The radicalism of this requirement was sometimes even denied by the universal values inherent to people - compassion, morality, and the like. Obviously, these maximalist demands have never been fulfilled, but they have played an important role in shaping the psychological face of the movement's participants. For the first time in the Ukrainian history a generation of true revolutionaries people separated from everyday life, whose life was entirely devoted to the struggle, arose.

\section{Ukrainian National Democratic Union}

In 1923-1927 there were significant changes in the social and political movement of Western Ukraine. Political parties reflected three orientations that dominated the then Polish society: pro-Soviet, pro-Polish, and self-determinant.

The most influential political association of Ukrainians was the Ukrainian National-Democratic Union (UNDU), the most massive legal Ukrainian party, formed in Lviv on July 11, 1925, with the Ukrainian People's Labor Party with all its factions, the Ukrainian National Work Party and the National a group of Ukrainian Parliamentary Representations with their associates from Volyn, Kholmshchyna, Polissya and Pidljashya. The head of the union was D. Levytsky, and from 1935 - V. Wise.

The association was based on Ukraine's self-determination without the use of terrorist methods. An agreement was reached between UNDU and the Polish government, where UNDU refused to fight for the autonomy of the Western Ukraine. At first, some of the members of the party relied on the peaceful evolution of the Ukrainian SSR to a national state, which was the result of a compromise between Soviet forces and supporters of the 


\section{National liberation movement in Western Ukraine in the interwar period...}

"orientation to their own forces". Until 1927, the UNDU considered the Ukrainian SSR as a sovereign state, which eventually would become completely independent, however, the struggle against the "national-deflection" in the Communist Party of Ukraine, the repression against the intelligentsia, and forced collectivization became an obstacle. From the late 20's, UNDU took hostile positions regarding the Soviet regime and laid the foundations for its overthrow through a revolutionary way. In the 1930's, the UNDU believed that the Ukrainian state would emerge from war due to the intervention of the Western powers. According to the leaders of UNDU, Western Ukraine should have become the base for the liberation of the Transdniestrian Ukraine from the power of Bolshevik Moscow. The search for a compromise with the Polish government on the anti-Soviet platform began. In 1932, the leadership of UNDU decided to temporarily refuse from the slogans of independence, replacing them at the request of the national-territorial autonomy for all Ukrainian lands in the Polish state. The anti-Ukrainian position of the Sejm leadership finally convinced Ukrainian parliamentarians of the futility of further attempts to settle themselves with the Polish circles. UNDU became an opposition to the Polish government. This led to the collapse of the UNDU and other legal parties.

\section{Organization of Ukrainian Nationalists}

The successive assimilation policies of Polish authorities, the lack of unity of Ukrainian political forces pushed part of the youth to the use of more radical forms of struggle. In January 1929, an Organization of Ukrainian Nationalists was created in Vinnytsia. Its leader became E. Konovalets, and the main ideologist for a long time was D. Dontsov. On the eve of the Second World OUN had around 20 thousand members. Using tactics of terror and government sabotage, defining itself as a movement, and not as a party, the OUN condemned all the legitimate Ukrainian parties of Galicia as colloquialist. The OUN has committed dozens of state fund expropriations, over 60 attempts and assassinations.

As a matter of fact, among all political parties and organizations operating on the lands of subordinated Poland, it was the OUN's most active influence on the actual course of events and eventually left behind the most significant result in the history. Obviously, this was the response to the demands of the time when it became necessary to unite disparate nationalist organizations into a single structure based on a clear ideology. The OUN, 
unlike the UMO, from the outset acted as a political organization, and therefore had to ideologically oppose the existing political forces in order to prove its necessity.

OUN members carried out sabotage actions, attacked banks and mail. The political doctrine of the OUN was formulated in its program documents in 1929, and finally - in the program adopted by its Grand Meeting in 1939. The concept of "creative violence and the active minority as a leading force" was an integral part of ideology. The OUN's state concept was based on the assumption that the Ukrainian lands were occupied by Poland and the USSR. Therefore, Ukrainian nationalists did not recognize all those international acts, treaties and agreements, which separated the Ukrainian lands and endorsed Ukrainian statehood. The building of independent Ukraine should end with the complete expulsion of all occupiers from the Ukrainian lands. The first commandment of the OUN called: "You will win the Ukrainian state or you will die in the struggle for it". The attacks on Polish officials were particularly popular.

Student youth, students of higher and secondary educational establishments, were most fond of this movement. They began to unite, to create youth organizations standing on self-styled attitudes. The youth was disappointed in the older generation, which could not stand up to Ukrainian statehood. In addition, she suffered constant oppression by the Polish authorities, suffered from unemployment.

The OUN was a subsidiary organization. It issued legal and illegal newspapers and magazines ("National Development", "Surma", "Young"), adhered to military methods of leadership, had a rigidly centralized structure. At the same time, the OUN did not refuse to participate in political, economic, cultural and educational associations. It was because of them that it hoped to lead a massive national-liberation movement.

Accordingly, at this stage, the professionalization of ideologists takes place - in the structure of the OUN one of the leading places occupies a special ideological reference, a specialized edition "Building the Nation" appears (coming out in 1928), which became a platform for discussion of ideology issues. Since one of the main tasks of the liberation movement was the creation of a powerful consolidated organization as an instrument of the liberation struggle, considerable attention was paid to the education of membership. There were a number of specially designed requirements for members of the OUN (Decalogue, 12 attributes, 44 rules), which, in their 
form and content, somewhat resemble the codes of religious organizations. Incidentally, at this stage, the desire of the ideologues of the OUN to transform the ideology of Ukrainian nationalism into a kind of secular religion has led to an escalation of the OUN's relationship with the church and clerical organizations. In general, at this stage, the OUN leadership recognized the formation and popularization of the ideology of Ukrainian nationalism as one of the priority areas - along with the continuation of armed struggle against the invaders. Ideological and military schools become the basis of membership training. As in the previous period, a significant imprint on ideology left the fashion on authoritarian models of governance, a critical attitude to democratic principles both in ideology and in practice. The worldwide fashion for charismatic leaders was reflected in the Ukrainian leaders (Konovalets, later Bandera), in the creation of the cult of the heroic past.

The final chord for this stage was the split of the OUN in two, which, on the one hand, completed a long conflict within the organization, and on the other hand, it was the beginning of a new stage in the development of the ideological platform of a dynamic youth wing that took shape in 1940 under the leadership of Stepan Bandera.

Consequently, the conflict, in essence, has become an important catalyst for the development of nationalist ideology and its transition to a political program format. "Splitters", in order to gain membership support, to legitimize their actions, had to oppose the leadership of the then one organization more than personal claims to specific figures. In addition to the OUN, the emergence of a new organization, a new leadership opened the way for the younger generation of ideologists who could not be realized under the pressure of senior authorities.

The split also seriously affected authoritarian tendencies, which for a long time dominated the nationalist movement. Confrontation with a concrete manifestation of authoritarianism soon transformed into a confrontation with authoritarianism as a principle.

\section{Legal Liberation Organizations in Western Ukraine}

In addition to the OUN, less radical organizations acted on the territory of Western Ukraine, for example, the pro-Ukrainian political direction, which supported the idea of the unity of the Transcarpathians with the entire Ukrainian people. This course was headed by the leader of the Christian People's Party, the priest Augustine Voloshin, brothers Michael and Yuriy 
Braschayky. The Ukrainian people used the support of the Galician Intelligentsia. With their help, the centers of "Enlightenment", Scout organization "Plast", cooperatives, newspapers and magazines were created in the region.

An important link in the "legal sector" activity was the support and development of a network of Ukrainian public organizations: cultural, educational, economic, youth, sports, etc. their significance in the conditions of Polish occupation is difficult to reassess. Thus, the Society "Enlightenment", having rallied about half a million members, supported the activity of readers, published educational materials, conducted a number of courses. The "Union of Ukrainians", uniting 45 thousand Ukrainian women, carried out extensive philanthropy, education and cultural activities.

The Ridna School, with up to 100 thousand members, in contrast to the polonization of state education, has built up its own network of private Ukrainian schools, which in 1938 accounted for about 40 gymnasiums, lyceums and vocational schools. The youth organizations "Sokil", "Lug" (formerly "Sich"), "Plast" and others, which raised patriotism among their members and aspirations for state independence.

The Ukrainian cooperative movement, the essence of which was determined by the slogan "Stand on its own strength", achieved significant results. The largest of the cooperatives - "Butter Union", "Central Bank", "Peoples Trading", and others have deployed their branches throughout Galicia. Co-operation has given impetus to the introduction of new ways of managing among the Ukrainian peasantry, and has created conditions for the centralized sale of agricultural products, including abroad, ending the usurious debts of the Galician village, and contributed to the gradual improvement of the economic situation of its inhabitants. Taking into account 4000 cooperatives with a total of more than 700 thousand members in Galicia, the Ukrainian cooperative movement successfully competed with Polish, but also became a means of economic self-defense and self-government of the Western Ukrainian society.

An important factor in the liberation movement of the Galician Ukrainians was the Greek Catholic Church, whose national character was finally crystallized due to its head Metropolit A. Sheptytsky.

Protecting the interests of the oppressed people, he used his own strength, authority, and personal finances. He built high school, provided material assistance to private schools, was a generous philanthropist and a good connoisseur of Ukrainian art. 
Thus, the "legal sector" of the Ukrainian liberation movement essentially covered all areas of national life - from the production of agricultural products to the development of scientific and cultural values.

Thanks to it, they managed to rebuild, first of all, the Halychyna territory, a strong civil society, which turned into a kind of "state in the state". Ukrainians, in spite of the discriminatory policy of the Polish authorities, managed not only to preserve the previous national conquests, but to some extent to multiply them.

\section{Polish-Ukrainian confrontation in Volynia}

The public-political life of pre-war Volynia was characterized by an intensification of inter-ethnic confrontation. The Polish government's implementation of a militant course aimed at assimilating Ukrainians led to a new breakthrough of the Polish-Ukrainian confrontation in the province. The most complete anti-Ukrainian views were formulated in the program of the Volynia governor G. Yuzevsky, whose main provisions were announced at the congress of governors in Lutsk on December 2-3, 1929, and agreed with Y. Pilsudski. An important element of this program was an attempt by the Polish government to artificially separate the ethnic Ukrainian lands in the Second Commonwealth. For this purpose, in the late 1920s and early 1930 s, a complex of measures was taken to strengthen the artificial boundary, which separated the Volynia from the Galicia. During the first half of the 1930 's, as a result of the implementation of government plans, the internal situation in Volynia became more acute, and Polish-Ukrainian relations became more complicated. This was due to the fact that during the specified period in the province the Polish authorities closed all branches of Prosvita, eliminated almost all Ukrainian cooperatives that were subject to the Revision Union of Ukrainian Cooperatives in Lviv, and instead they formed mixed Polish-Ukrainian economic structures subordinated to Warsaw, the activities of most Ukrainian schools were discontinued. Instead, the authorities tried to open Polish or mixed (Polish-Ukrainian) schools. As a result of such domestic policy, the Ukrainian majority of Volynia in the mid-1930's was virtually without national education. Another factor that negatively affected the Polish-Ukrainian relations was the government's policy of distributing lands to Polish colonists.

All this led to the fact that on the eve of the Second World War, the Polish-Ukrainian confrontation in the province intensified, and anti-Ukrainian 
accents in the domestic policy of the Polish governments strengthened. This activity of the Polish government set against itself not only the representatives of the Ukrainian political environment, the opposition to power, but also the part of those Ukrainian politicians who stood at the position of Polish-Ukrainian cooperation.

In declaring the need for Polish-Ukrainian understanding and covering behind the slogans of "cohabitation" and "cooperation", practically did everything in order to separate the Ukrainian ethnic territory within Poland and to implement the policy of colonization of Western Ukrainian lands. The government attached importance to the implementation of Poland's domestic policy in the occupied lands by combating Orthodoxy as the basis of the national consciousness of Ukrainians.

Thus, the government's policy of distributing lands to Polish colonists, which lasted in Volynia and during the 1930s, has become one of the factors that has aggravated inter-ethnic confrontation. An important factor in the colonization of Ukrainian lands by the Polish governments was not only the desire to grant the former Polish military land plots: the Polish colonists were also assigned the task of promoting the assimilation of the local population. Taking into account that in the rural areas of Volynia the predominance of Ukrainians was evident, the increase in the number of Polish settlers created the conditions under which the Poles were able to reserve their posts in local self-government bodies and thus control the activities of rural communities.

To autonomize the political and social life in Volynia, Polish officials, tried to prevent the distribution of Ukrainian periodicals among the Ukrainian population. The first of these bans fell on Ukrainian calendars, at that time very popular among the Ukrainian population. During 1936-1937, in some provinces of Volynia, the police arrested the distributors of Ukrainian calendars and confiscated their calendars without any reason. A little later, having not achieved the desired result, the Polish administrative authorities decided to prevent the release of Volyn Ukrainian periodicals published in Galicia.

According to the documents of the Polish security forces, this was done on the initiative of the Volyn governor, who thus tried to protect the land from the "harmful" influences of Galicia.

However, despite attempts by Poland to take measures aimed at the information blockade of Volynia, anti-colonial publications disseminated 
by activists of Ukrainian political structures remained a form of counteraction to the policy of colonizing Ukrainian lands by Poles.

Against such activists, the Polish authorities often used force methods, arresting and imprisoning them. For example, April 13, 1937, the case of M. Vashchyshyn was considered at the Rivne District Court, whщ circulated anti-colonial publications of UNDГ. Rivne city court accused him of spreading "false" information about the implementation of the Polish government colonization plans, according to which during the colonization, the authorities took the land from Ukrainian peasants and gave the Polish settlers. At the time of the conviction in this case, the judge did not pay attention to the fact that all confiscated publications were legal and were subject to appropriate censorship. Consequently, when making sentences to distributors of Ukrainian newspapers, magazines and other literature issued outside of the province, the Volyn judges used laws that were not in force in the country, and the orders of the local administration, which tried to discourage the Ukrainian people from any desire to distribute "unnecessary" and "harmful" information.

During 1938-1939, control over the proliferation of Ukrainian periodicals intensified and the magazines stopped coming not only to kiosks or to individual citizens but also to party structures, in particular to the legal Ukrainian parties, with the exception of the pro-government Volyn Ukrainian Association (VUA).

Consequently, the internal policy of Polish government, aimed at the autonomy of public life in the land and the cessation of the activities of oppositional political groups, has not only failed to achieve its goal, but rather had a reciprocal effect. According to documents of that time, the Ukrainian population of Volynia did not reconcile with such a policy of power, on the contrary, the inter-ethnic confrontation in the province intensified.

Another factor that led to a new revolt of the Polish-Ukrainian confrontation in Volynia was the policy of forcible conversion of Orthodox to Catholics. Increasing pressure on Ukrainian society by the Polish government, and not only the civilian administration, was due to the fact that in the second half of the 1930s, Polish militaries played an increasingly important role in the political life of Volyn. Special hatred for Ukrainians was revealed by the Border Guard Corps (BGC). It was the BGC who destroyed the Ukrainian temples, and converted Orthodox Ukrainians to Catholics, often evicted them from the border strip. 
In the beginning of 1938 B. Kozubsky, a member of the Central Committee of the UNU, received a request from the party's leadership to gather information about the compulsory conversion of the Orthodox to Catholics, which was carried out by the BGC in the border counties. The data obtained was planned to be used in the country's parliament, as such actions contradicted the constitutional rights of Polish citizens.

In addition to the conversion of Orthodox to Catholics, in the border counties the BGC set various restrictions for Ukrainians that concerned not only the possibilities of free movement, but also the activities of Ukrainian structures. Public life in these lands was managed not so much by the representatives of the local administration, but by the Polish military.

Consequently, representatives of Ukrainian political structures tried to counteract the reverberative action of the Polish authorities and opposed the restrictions on the Ukrainian national movement that existed in the border regions with the USSR through the domination of the representatives of the BGC who terrorized Ukrainians in the border counties of Volynia. Representatives of the Polish military played a major role in the life of the frontier counties and had much more levers of influence on all spheres of public life than representatives of the local civilian administration. In this regard, the border counties acted not depending on national laws, but on the orders of the command of the BGC. Protests by members of the Ukrainian Parliamentary Representation (UPR) against this situation in the border zone did not produce the desired result.

The authorities continued to encourage anti-Ukrainian military activities, giving the latter more and more powers. At the same time, in the middle of the 1920's, Polish border troops settled mainly in the border counties, whose task was not only to promote polonization of the region but also to counteract the illegal crossing of the Polish-Soviet border.

In the military plans of "Strengthening the Polish character" of the eastern provinces of the state, it was emphasized that in Volynia the national policy towards the Ukrainians of the region should be aimed at their state assimilation.

This activity of the Polish government caused a harsh confrontation between radical Ukrainian political groups. Taking G. Yuzevsky's direct blame for discrimination against the Ukrainian population of Volyn, members of the underground Organization of Ukrainian Nationalists 


\section{National liberation movement in Western Ukraine in the interwar period...}

(OUN) in the mid-1930's began preparing an assassination attempt on the Volyn governor G. Yuzevsky, which they planned to carry out in 1936. But the plan was not implemented by the members of the organization, as the police arrested many members of the OUN. The case of preparing an assassination attempt on the Volyn governor received a broad resonance.

As the investigation revealed, preparations for an assassination commenced in 1934, and O. Kutz, a student of the Ukrainian grammar school in Lutsk, a member of the county executive office of the OUN, was responsible for its execution. O. Kuts explained the reasons for joining the OUN in 1933 by the fact that he wanted to fight communism, which was spreading among Ukrainian youth. The lawyer of the defendant S. Shukhevych tried to draw the attention of the judges to the point that O. Kuts attempted, by belonging to the OUN, to oppose himself to communism, and by way of passive resistance, it was impossible to carry out an assassination attempt on the governor. O. Kuts was sentenced to 9 years imprisonment and 10 years deprivation of his rights. The fact that the assassination attempt on G. Yuzevsky was planned by the OUN was confirmed in the Lviv process against the leadership of the OUN in the 1936 where O. Kuts acted as a witness. In this process of the planned assassination attempt on G. Yuzevsky, $\mathrm{S}$. Bandera, referring to the reasons for the preparation of the assassination, explained that it was stimulated by the assimilation policy of the Volyn governor G. Yuzevsky. This position of the members of the nationalist underground was dictated by the fact that the activity of the governors, in their opinion, hurt the Ukrainian population of the region, and its internal policy was directed at the separation of Volyn from Galicia because G. Yuzevsky prohibited the distribution of Ukrainian periodicals even legally issued in Galicia in Volynia.

Therefore, part of the right-wing radical-minded Ukrainian politicians planned to use force methods in the struggle against Polish chauvinistic politics, not excluding the acts of political terror against prominent figures of the Polish administration.

Thus, during the second half of the 1930's, Ukrainian-Polish relations in the Volhynia were in a state of confrontation. Their complication was caused by the domestic policy of Polish governments aimed at discriminating against Ukrainians in all spheres of socio-political, religious and economic life. 


\section{Conclusions}

The national liberation movement of Ukrainians against the policy of the Polish authorities was manifested both in legal and illegal forms of struggle for their rights.

In 1925, Ukrainians in Poland had 12 political parties that represented a very broad political spectrum. Among them, the most influential are:

1) The Ukrainian National Democratic Union (UNDU) is a centrist-oriented party that was oriented towards Ukraine's independence and democratic development.

2) Ukrainian Social-Radical Party (USRP), which sought to combine the principles of democratic socialism with the national revival of Ukraine.

At the opposite pole, there were political associations of the Ukrainian Catholic Party type that were weak and inclined to cooperate with the Polish government. Ukrainian parties fought unsuccessfully for seats in the Polish parliament: if in November 1927 the representation of Ukrainians in the Sejm consisted of 25 ambassadors and 6 senators, then in July 1930 it increased to 50 ambassadors and 14 senators. Although there was no unity among Ukrainian parliamentarians, the Ukrainian parliamentary representation was an important and influential factor in political life.

In the economy, the opposition to the official line to inhibition of the development of Ukrainian lands was carried out through a cooperative movement. At this time, the expansion of the functions of cooperatives took place, the cooperative movement began to consider itself as an instrument of self-government and economic self-defense. Obviously, this is precisely why Ukrainian co-operation is intensively developing under severe economic pressure.

The Greek Catholic Church had a significant influence on the activity of the Ukrainian population. Her head, Metropolitan A. Sheptytsky, opposed the annexation of Ukrainian lands to Poland. In 1923 A. Sheptytsky was arrested.

The consistent assimilation policy of the Polish authorities, the actual lack of unity of Ukrainian political forces pushed part of the Ukrainian youth to the use of more radical forms of struggle. In January 1929, the Organization of Ukrainian Nationalists (OUN) was created in Vienna. Its leader became E. Konovalets. The prevalence of national interests over individual ones was proclaimed, the supreme goal of the struggle was asserted by the achievement of state independence. Methods of struggle - propaganda, sab- 
otage and terrorist. Not only representatives of the occupation authorities, but also Ukrainians who did not share the ideology and methods of struggle of the OUN, were subjected to terror.

All this led to the fact that on the eve of the Second World War, the Polish-Ukrainian confrontation in the province intensified, and anti-Ukrainian accents in the domestic policy of the Polish governments strengthened. This activity of the Polish government set against itself not only the representatives of the Ukrainian political environment, the opposition to power, but also the part of those Ukrainian politicians who stood at the position of Polish-Ukrainian cooperation.

In declaring the need for Polish-Ukrainian understanding and covering behind the slogans of "cohabitation" and "cooperation", practically did everything in order to separate the Ukrainian ethnic territory within Poland and to implement the policy of colonization of Western Ukrainian lands. The government attached importance to the implementation of Poland's domestic policy in the occupied lands by combating Orthodoxy as the basis of the national consciousness of Ukrainians.

Thus, the government's policy of distributing lands to Polish colonists, which lasted in Volynia and during the 1930s, has become one of the factors that has aggravated inter-ethnic confrontation. An important factor in the colonization of Ukrainian lands by the Polish governments was not only the desire to grant the former Polish military land plots: the Polish colonists were also assigned the task of promoting the assimilation of the local population. Taking into account that in the rural areas of Volynia the predominance of Ukrainians was evident, the increase in the number of Polish settlers created the conditions under which the Poles were able to reserve their posts in local self-government bodies and thus control the activities of rural communities.

The authorities continued to encourage anti-Ukrainian military activities, giving the latter more and more powers. At the same time, in the middle of the 1920's, Polish border troops settled mainly in the border counties, whose task was not only to promote polonization of the region but also to counteract the illegal crossing of the Polish-Soviet border.

In the military plans of "Strengthening the Polish character" of the eastern provinces of the state, it was emphasized that in Volynia the national policy towards the Ukrainians of the region should be aimed at their state assimilation. 


\section{References:}

1. Kugutyak M. (1993) Halychyna: storinky istorii. Narys suspilno-politychnoho rukhu (XIX st. - 1939 r.) [Galicia: History pages. Essay on the socio-political movement (nineteenth century - 1939)]. Ivano Frankivsk. (in Ukrainian)

2. Krasivsky O. (2000) Halychyna u pershii chverti XX st.: Problemy polsko-ukrainskykh stosunkiv [Galicia in the first quarter of the twentieth century: Problems of Polish-Ukrainian relations]. Lviv (in Ukrainian)

3. Lytvyn M., K. Naumenko. (1995) Istoriia ZUNR [History of the ZUNR]. Lviv: "OLIR" (in Ukrainian)

4. Marchuk V. (2004) Tserkva, dukhovnist, natsiia. Ukrainska hrekokatolytska tserkva v suspilnomu zhytti Ukrainy XX st. [Church, spirituality, nation. Ukrainian Greek Catholic Church in the public life of Ukraine of the twentieth century]. Ivano-Frankivsk: Play (in Ukrainian)

5. Zashkilnyak L. (2005) Ukrainsko-polski stosunky v XX stolitti: istoriohrafichni aspekty [Ukrainian-Polish relations in the twentieth century: historiographical aspects]. Ukraine: cultural heritage, national consciousness, statehood, vol. 13, pp. 3-22.

6. Khodak V. (2005) Suspilno-politychna diialnist Orhanizatsii ukrainskykh natsionalistiv (1929-1934 rr.) [Social-political activity of the Organization of Ukrainian Nationalists (1929-1934)] (PhD Thesis). Ivano-Frankivsk.

7. Vynnyansky S.V. (2003) Ukrainske pytannia v mizhvoiennii Polshchi: osnovni problemy y napriamky naukovykh doslidzhen u suchasnii vitchyznianii istorychnii nautsi [The Ukrainian Question in Interwar Poland: The main Problems and Directions of Scientific Research in Modern Native Historical Science]. Ukrainian historical journal, no. 2, pp. 39-55.

8. Mandryk M. (2006) Ukrainskyi natsionalizm: stanovlennia v mizhvoiennu dobu [Ukrainian nationalism: emergence in the interwar period]. Kyiv: Eleni Teligi. 
The cyber physical principle management of capriciousness of landscape...

THE CYBER PHYSICAL PRINCIPLE MANAGEMENT

OF CAPRICIOUSNESS OF LANDSCAPE COMPLEXES

\title{
КІБЕРФІЗИЧНИЙ ПРИНЦИП УПРАВЛІННЯ КОПРОЄМНІСТЮ СКЛАДНИХ ЛАНДШАФТНИХ КОМПЛЕКСІВ
}

\author{
Ruda Mariya ${ }^{1}$ \\ Taras Ulyana ${ }^{2}$
}

DOI: http://dx.doi.org/10.30525/978-9934-571-26-8_16

Abstract. The concept of the cyberphysical system of the CPE functioning on the railway lines is proposed, which will allow increasing: (1) the level of adequacy of the actual ecological state on the railway transport lines to its information model; (2) efficiency of obtaining and authenticity of primary data on the quality of CPEs on the railway; (3) the level and quality of information services for consumers of eco-information on the basis of network access to databases. The general algorithm for the use of the defined indicators combines the establishment and assessment of the relevant factors of CPE by means of direct or indirect determination of the quantitative indicators, as well as the creation of a spatial basis based on the multispectral data for assessing the impact of the railway facilities on the state of the Environment. The general algorithm for the use of the defined indicators combines the establishment and assessment of the relevant factors of CPE by means of direct or indirect determination of the quantitative indicators, as well as the creation of a spatial basis based on the multispectral data for assessing the impact of the railway facilities on the state of the Environment. The creation of quality control system for PCE functioning on the basis of the CFS allows you to solve a number of problems, namely: the possibility of combining a large number of heterogeneous components, high performance, intellectualization of means of interaction with the physical environment, interacting with the person, online information collecting, structural adjustment of measuring and computing tasks, high level

\footnotetext{
${ }^{1}$ Assistant Lecturer at Department of Environmental Safety and Environmental Activities, Lviv Polytechnic National University, Ukraine

${ }^{2}$ Candidate of Agricultural Sciences,

Acting Director of Regional Landscape Park "Znesinnia"

(C) Ruda Mariya, Taras Ulyana
} 
of service. The proposed CFS contains a network of intelligent measuring-computing nodes united into commutating environment and supported by high-performance computing means and means of information protection that are connected to the information center, among which the central place is occupied by three modules: environmental analysis, design, and ecosystem monitoring and control of PCE. Implementation of the research results will make a significant contribution to the process of bringing the railways to a higher level of competitiveness among carriers and will create better conditions for transportation. Ecosystem problems are extremely diverse. The proposed concept of quality control of PCE functioning allows us to consider management as a holistic process in which it is not difficult to identify the actual specific tasks, and in particular, the study of wind-protective and snow-retaining properties of PCEs provided a limited pollution of the natural environment - the issues which we will further deal with in the future.

\section{1. Вступ}

Складність процесів, які відбуваються на залізничних шляхах породжує необхідність вирішення значної кількості задач, які виникають при проектуванні та створенні системи контролю якості захисту довкілля. На нашу думку, за основу створення системи контролю якості захисту довкілля доцільно прийняти загальну структуру кіберфізичних систем [1]. Остання містить такі рівні:

- засоби взаємодії з фізичним світом;

- засоби збирання та доставлення інформації;

- засоби опрацювання інформації;

- засоби прийняття рішень;

- засоби персонального сервісу.

Особливістю, що вирізняє кіберфізичні системи серед інформаційних систем, є поява інтелектуальних комп'ютерних засобів, які в реальному часі забезпечують збір просторово-координатної та іншої інформації з фізичного світу, їі доставлення та інформаційний зворотній зв'язок від кібернетичного простору і кібернетичний простір, який забезпечує інтелектуальне управління даними, надає обчислювальні потужності та математичні сервіси для виділення 3 даних корисної інформації, забезпечує аналітику та прийняття рішень. Система допускає розпаралелювання вимірювально-обчислювальних процесів 
та процесів відслідковування змін контрольованих параметрів, що дозволяє, взявши за базу незначну кількість контрольованих параметрів, нарощувати систему в міру одержання нових знань та проектування більш досконалих засобів контролю окремих характеристик.

Розглянемо для прикладу задачу забезпечення екологічної безпеки на шляхах залізничного транспорту за допомогою складних ландшафтних комплесів, на прикладі консорційних екотонів захисного типу (тут і далі КЕЗТ). При цьому, КЕЗТ виступаються частиною складного інженерного комплексу колійного господарства і повинні бути біологічно стійкими, довговічними та постійно виконувати свої захисні функції, забезпечувати нормальний, безперебійний рух поїздів у будь-яку пору року.

\section{2. Сутність складних природних комплексів}

Фундаментальним поняттям системного аналізу $є$ поняття «система». Системи мають зовсім нові якості, які відсутні у їі елементів. Ці якості виникають завдяки наявності зв'язків між елементами. Саме за допомогою зв'язків здійснюється перенесення властивостей кожного елемента системи до інших елементів. Головним системоутворювальним фактором є іiї функція. Існує кілька поглядів з приводу того, що являє собою функція системи. Так, під функцією системи можна розуміти перетворення іiі входів у виходи. 3 іншого погляду функція системи може полягати у збереженні іiі існування, підтримці іiі структури та впорядкованості. Іноді функцію системи ототожнюють із функціонуванням цієї ж системи, визначаючи іiі як спосіб, засіб або як дії для досягнення цілі системи.

Системи функціонують у певному зовнішньому середовищі. Зовнішнє середовище - це все те, що знаходиться зовні системи, включаючи необхідні умови для існування та розвитку системи. Зовнішнє середовище складається із ряду природних, суспільних, інформаційних, економічних, виробничих та інших факторів, що впливають на систему та самі певною мірою перебувають під впливом цієї системи.

Взаємодія між системою та зовнішнім середовищем здійснюється за допомогою входів та виходів. Вхід системи - це дія на неї зовнішнього середовища. Вихід системи - результат функціонування системи для досягнення певної мети або іiі реакція на вплив зовнішнього середовища. Отже, у загальному вигляді систему (з контуром зворотного зв’язку) можна зобразити графічно у такий спосіб (рисунок 1): 
Ruda Mariya, Taras Ulyana

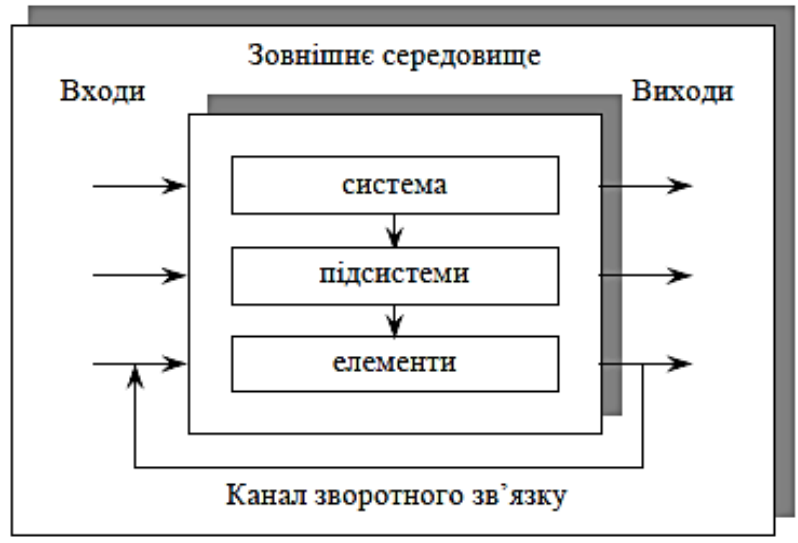

Рис. 1. Графічне зображення системи

Явище самоорганізації складних систем було відкрите у другій половині XX століття. Один з основоположників синергетики Хакен визначив їі як науку «про колективну поведінку підсистем, що утворюють систему». Феномен синергії або синергетизму має кілька моментів: насамперед, йдеться про явища, що виникають внаслідок спільної дії кількох різних факторів, у той час, коли кожний фактор окремо до подібного явища не приводить.

У процесі взаємодії і взаємообумовленості трьох сутнісних начал формуються природні сутності. Природні сутності - це побудовані за типом відкритих стаціонарних систем матеріально-інформаційні утворення, що несуть у собі закріплені пам'яттю стійко повторювані ознаки даного типу систем, що дозволяють відтворювати їх багаторазово в просторі і часі.

Сама належність складних ландшафтних комплексів до класу відкритих стаціонарних систем обумовлює єдині закономірності їх існування і трансформації. Усі вони можуть існувати лише підтримуючи гомеостаз, що досягається здійсненням метаболізму, тобто обміну із зовнішнім середовищем і всередині самих систем. А процеси, що забезпечують динамічну стійкість і трасформації систем, досягається двома видами механізмів зворотного зв'язку - відповідно негативним і позитивним, а також двома видами трансформаційних механізмів - адаптаційним та біфуркаційним. Будь-яка відкрита стаціонарна 
система є одночасно і матеріально-інформаційною, i інформаційно-матеріальною сутністю.

\section{3. Визначення екологічного індексу}

КЕЗТ є замкненою системою матеріальних потоків (на противагу енергетичним потокам). Переходячи з одного продукту в інший та змінюючи форми свого стану, матерія циклічно циркулює в цій системі. Саме тому загальна маса матерії не змінюється, незалежно від того що відбувається на шляхах залізничного транспорту.

У сучасному соціально-економічному середовищі матеріальні потоки і процеси відбуваються за лінійною схемою. Але, на нескінченному відрізку часу матеріали, що пройшли через техносферу, заново повертаються у навколишнє середовище як сировина. Концепція життєвого циклу розглядає продукти/послуги з початку їх фізичного виникнення і до моменту припинення їх функціонування. Вихідні потоки енергії можуть бути як відходами досліджуваної системи, так і слугувати ресурсами (вхідними потоками) в іншу систему. На всіх стадіях життєвого циклу КЕЗТ має місце певне забруднення, використовуються енергія та матеріали.

Для визначеня екологічного індексу КЕЗТ необхідно здійснити три частини аналізу: інвентаризаційну $\rightarrow$ екологічного впливу $\rightarrow$ можливостей поліпшення. Всі три частини дослідження взаємопов'язані через етап формулювання задачі та встановлення меж досліджуваної системи. Формулювання завдання є важливим етапом, що становлять основу всього аналізу.

Формулювання завдання - це особливо важлива стадія аналізу, так як на ній визначається зміст і порядок виконання всіх подальших стадій. Для формулювання завдання необхідно відповісти на питання «для якої мети проводиться аналіз?». Для цього необхідно: знати, яка саме система аналізується; переконатися, чи можна порівняти систему за іiі функціями; знати, хто і як буде користуватися отриманими результатами аналізу; чітко визначити, за якими параметрами буде проводитися аналіз; встановити причини, за якими для порівняння були обрані саме ці параметри (параметри повинні бути репрезентабельними, тобто відповідати цілям аналізу); визначити призначення системи і функціональну одиницю, використану для аналізу; визначити масштаб і глибину проведеного аналізу або, іншими словами, визначити межі 
аналізованої системи. Останній аспект найбільш важливий, тому що вибір меж системи визначає тривалість, складність, точність і повноту результатів аналізу.

Межі системи - це стадії та елементи енергетичного балансу, які розглядаються в аналізі життєвого циклу продукту/послуги [2]. Межі також включають відповідний проміжок часу, географічні координати системи, тип технології, яка використовується на даний момент, а також набір аналізованих параметрів впливу на довкілля [3]. Вибрані межі системи продукту не повинні бути ні надто вузькими, ні надто широкими. Приклад можливого вибору меж системи зображений на рисунку 2.

Важливо обмежувати межі системи для забезпечення прийнятного рівня точності результатів. По-перше, обмежувати аналізовану систему потрібно тому, що система без обмеження може розростися до неймовірних розмірів. По-друге, аналізована система не може бути занадто простою, тому що можливе упущення окремих складових життєвого циклу, що здійснюють істотні екологічні впливи. У такому випадку результат аналізу буде неточним.

Якість функціонування багато в чому визначає функціональну одиницю, яка є одним 3 найголовніших аспектів, що впливають на якісні

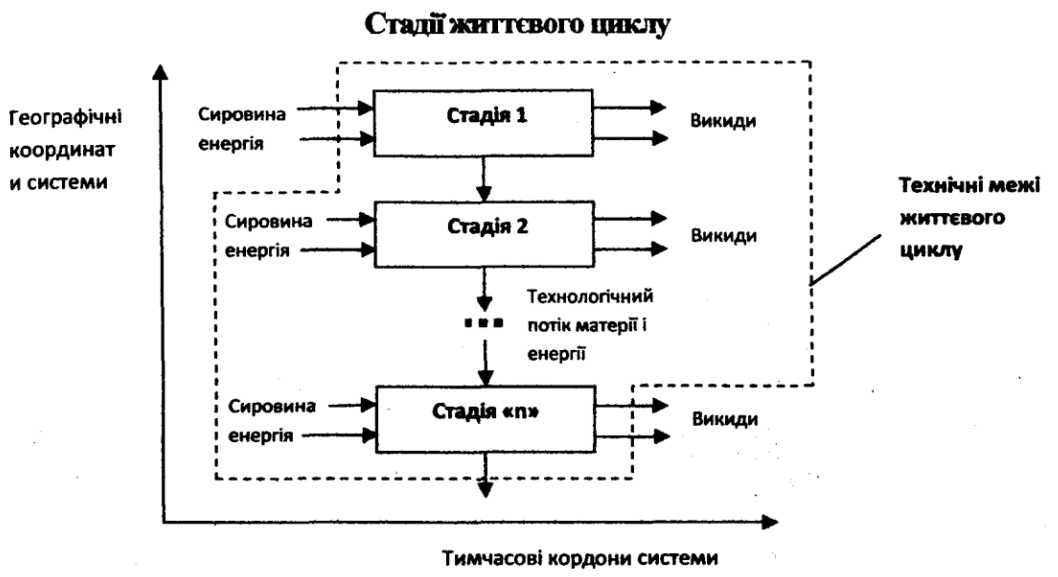

Рис. 2. Приклад аналізованої системи та обраних для дослідження меж 
розрахунки. Під функціональною одиницею ми розуміємо кількісний вираз функції ситсеми, яка відображає характеристики аналізованих систем. Функціональна одиниця - це основа для всіх наступних розрахунків, вся інформація, зібрана на стадіях інвентаризації та оцінки впливів, відноситься до функціональної одиниці.

Після збору кількісної інформації про матеріальні та енергетичні потоки системи останні оцінюють з екологічної точки зору. Оцінювання екологічного впливу - це стадія, на якій дані про різні викиди у довкілля, зібрані на стадії інвентаризації, характеризуються і оцінюються в різних групах і за різними параметрами. Іншими словами, встановлену кількість викидів інтерпретують у вигляді нанесеного екологічного збитку.

Створення мінімальної моделі для КЕЗТ - такої, що агрегує в невеликому числі змінних інформацію про захисні насадження і піддається чисельно-аналітичному дослідженню $є$ актуальним та важливим завданням в умовах антропогенної трансформації навколишнього природного середовища з боку залізниці. Одним з підходів, що реалізують цю концепцію, є компартментальний аналіз. КЕЗТ розбивається на блоки, що містять певні запаси речовини і енргії та здатні здійснювати обмін та перенесення не лише між собою, але й з навколишньою природою. На основі біологічної інформації задаються швидкості обміну, а також швидкості вхідних і вихідних потоків. Модель, яку ми отримуємо називається компартментальною, а блоки - компартментами (compartment - відділення, розділ).

Перевага такого підходу полягає в тому, що, по-перше, немає потреби ретельно збирати дані про взаємодію сотень або тисяч видів, що мешкають у КЕЗТ, а по-друге, дослідник відносно вільний у виборі змінних і предмету обміну (замість біомаси можна оцінювати концентрацію будь-якого важливого для живих організмів хімічної речовини, в тому числі полютантів та седиментів).

\section{4. Визначення копроємності природного середовища}

Під копроємністю природного середовища розуміють величину максимального навантаження, яку може витримати i переносити протягом тривалого часу КЕЗТ без серйозних порушень їі структурно-функціональних характеристик [4]. Для практичного визначення цього показника ще не існує достатньо надійних кількісних методів. 
Застосування енергетичного підходу дає можливість представити копроємність як гранично допустиму зміну загального потоку біологічного перетворення енергії на даній території.

Другий спрощений спосіб оцінки копроємності може грунтуватися на кількісних результатах біоіндикації та використанні гігієнічних і токсикометричних нормативів. Так, приймають, що гранично допустимий ступінь зміни функції стану КЕЗТ досягається тоді, коли інтегрована по площі земельного угіддя приведена концентрація домішок наближається до одиниці. При цьому важливо, щоб критичні концентрації відповідали найсуворішим еколого-нормативним вимогам, наприклад, мінімальній фітотоксичності і нульовій мутагенності та канцерогенності, тобто були менші від нинішніх стандартних ГДК. Використання гігієнічних нормативів слід розглядати як тимчасовий захід, викликаний відсутністю комплексу екологічних нормативів.

Для підтримання еколого-енергетичного балансу та вибору варіанту подальшого розвитку КЕЗТ у моделі вводяться блоки-компартмени, які є критеріями збалансованості природоємкості і копроємності насаджень. Оптимізаційна модель еколого-енергетичного балансу $є$ верхньою в ієрархії основних оптимізаційних моделей та базується на компартментному аналізі.

Схему функціонування КЕЗТ подамо у вигляді чотирьох взаємопов'язаних компартментів:

- компартмент залізничного господарства (3Т), де біологічні та технологічні фактори мають визначальний вплив на величину антропогенного навантаження на КЕЗТ;

- компартмент шляхів залізничного транспорту (ШЗТ), яка функціонує, як постійне джерело антропогенного впливу на стан навколишнього природного серидовища;

- власне КЕЗТ, як екологічного компартмента (Е), який охоплює природні об'єкти і процеси приодокористування;

- компартмент управління (У) - алгоритми управління, математичне забезпечення, програми.

Для аналізу якості функціонування КЕЗТ на шляхах залізничного транспорту були згруповані необхідні дані, а саме: основні ресурси, що необхідні для функціонування КЕЗТ та залізничних шляхів, комплектуючі кожної складової сировини та матеріалу, які розглядаються як входи; процеси, такі як транспортування людей та вантажів, в тому 
числі і небезпечних, природно-кліматичні умови (виходи). Для зручності з роботою складові частини процесу були згруповані у дві групи:

- необхідні природні ресурси;

- технічні та технологічні засоби.

Таким чином функціонування КЕЗТ на шляхах залізниного транспорту утворює цілісну систему, об'єк управління якої включає сукупність технологічних і біологічних чинників, що взаємодіють в єдиному еколого-технологічному виробничому процесі і задовольняють як виробничо-екологічним, так і екологічним вимогам $[5,6]$.

Розробку загальної математичної моделі визначення копроємності КЕЗТ здійснено на основі потоків речовини та енергії. Нехай, КЕЗТ на шляхах залізничного транспорту задано:

- структурою взаємозв'язків між елементами екологічної, технологічної та керуючої частин.

- потоками речовин та енергії, що включають: множину вхідних потоків $-x^{3 T}, x^{Ш 3 T}, x^{E}$; множину вихідних потоків: $y^{3 T}, y^{Ш 3 T}, y^{E}$; винесення і розсіювання енергії та речовин - ЕЗТ, ЕШЗТ, ЕЕ; $v^{3 T}, v^{\amalg 3 T}, v^{E}-$ генерування відходів на шляхах залізничного транспорту, трансформація екосистеми;

- властивостями, відношеннями і алгоритмом взаємодії компартментів 3Т, ШЗТ, Е, У;

- метою КЕЗТ та ії кампартментів, яка полягає у перевезенні пасажирів та вантажів при мінімальних витратах речовини та енергії із забезпеченням максимальної екологічної безпеки.

Характер взаємодії людини з середовищем визначають потоки речовин, енергій та інформації. Змінюючи величину будь-якого потоку маси, енергії, інформації, дій людини від мінімально значущої до максимально можливої, можна пройти ряд характерних станів взаємодії в системі «людина - середовище функціонування залізниці». Поняття якості КЕЗТ тісно пов'язане з поняттям якості навколишнього природного середовища.

Якість насадження оцінюється за двома показниками: життєздатність (таблиця 1) та захисна ефективність.

Захисна ефективність КЕЗТ оцінюється за наступними класами: добрий - коли насадження не пошкоджені, або слабо пошкоджені анторопогенними чинниками залізниці; задовільний - коли несприятливі чинники частково призвели до істотного ослаблення; пога- 
ний - коли будь-який 3 несприятливих чинників значно вплинули на насадження; дуже поганий - коли насадження значно пошкоджені багатьма чинниками.

Таблиця 1

Життєздатність КЕЗТ

\begin{tabular}{|l|l|c|}
\hline \multicolumn{1}{c|}{$\begin{array}{c}\text { Категорія } \\
\text { життсзатності }\end{array}$} & \multicolumn{1}{|c|}{ Зовнішні ознаки верхнього ярусі насаджень } & Клас \\
\hline 1 & \multicolumn{1}{|c|}{2} & 3 \\
\hline Висока (ЖВ) & $\begin{array}{l}\text { Складається переважно зі здорових гостроверхих } \\
\text { дерев, всихаючі екземпляри одиничні. Санітарний } \\
\text { стан добрий, грунти покриті опалим листям, трав’я- } \\
\text { ний покрив або відсутній, або рідкий (ТО) }\end{array}$ & 1 \\
\hline Понижена (ЖП) & $\begin{array}{l}\text { Складається переважно зі здорових дерев, але пере- } \\
\text { важають туповерхі екземпляри, кількість всихаючи } \\
\text { дерев не перевищує 25\%. Санітарний стан добрий або } \\
\text { задовільний, грунт пухкий або затверділий, трав’яний } \\
\text { покрив не більший середньої густоти (ТС) }\end{array}$ & 2 \\
\hline Низька (ЖН) & $\begin{array}{l}\text { Складається із суховерхих і сухихи дерев (до 75\%), } \\
\text { супутні породи в більшості не всихають). Санітарний } \\
\text { стан поганий, грунти затверділі або тверді, трав'яний } \\
\text { покрив середній (ТС) або великої густоти (ТГ) }\end{array}$ & 3 \\
\hline Дуже низька & $\begin{array}{l}\text { У складі насадження переважають сухостійні низькі } \\
\text { екземпляри. } \\
\text { Санітарний стан поганий або дуже поганий, грунти } \\
\text { затверділі, трав’яний покрив густий з великою кількі- } \\
\text { стю прикореневих рослин (ТОГ) }\end{array}$ & 4 \\
\hline
\end{tabular}

Для розв'язання задач управління необхідне чітке розуміння структури КЕЗТ керуючими параметрами в яких, зокрема, є:

- вертикальна структура, яка задається ярусами (ярус домінуючих дерев; середній ярус; чагарниковий ярус; мохово-трав'яний ярус; ярус залягання кореневищ і коренів трав'янистих рослин, що укореняються у верхньому шарі грунту- 15-20 см; ярус трав'янистих рослин 3 глибшим розташуванням коренів - 50-70 см; ярус коренів чагарників - 1-3 м; ярус коренів деревних порід (Н - до 5-6 м), лісова підстилка (Н - 1-3 см); гумусовий горизонт (Н - 20 см-1,5м); горизонт вимивання, або накопичення (Н - 0-20 см); перехідний горизонт (Н - до 180 см;).

- горизонтальна структура: кількість рядів, ширина рядів, розміщення дерев у рядах та кулісах, кількість куліс тощо. 
Життєздатність КЕЗТ зобразимо вектором $\mathrm{S}$, компоненти якого $є$ функціями часу $t$ і протстору $R$. Зміна стану відбувається в результаті певних дій $£(t, R)$ та управлінських рішень $u$ :

$$
\mathrm{u}=(\mathrm{g}, \lambda),
$$

де $g \in H^{K}$ - схема технологічних процесів, що належать простору $H^{\kappa}$ (електрофіковані і неелектрофіковані залізничні шляхи, інтероперабельність, інтенсифікація пасажиро та вантажопотоку і т.д.)

$\lambda \in H^{m}$ - сукупність елементів технологічних процесів, що входять у простір $H^{m}$ (машини, механізми, тощо).

Формально систему зобразимо у вигляді:

$$
S(t)=A(S(\tau), u),
$$

де $A$ - визначення життєздатності та захисної ефективності в момент часу $t \in\left[t_{0,}, T\right]$ за значенням вектора $S(\tau), \tau \in\left[t, t_{0^{0}}\right]$.

Необхідно на множині $M$ визначити невідповідність у швидкостях обороту енергії і речовин у виробничій та природній підсистемах, що зумовлює виникненння непогоджених еколого-біотехнічних відносин, знайти таку стратегію управляння $u_{0} \in M$, яка б при екосистемному моніторингу КЕЗТ забезпечувала копроємність $H_{c}$ максимально функціональним:

$$
\Phi_{\text {КЕзТ }}=\varphi\left\{\eta_{i}{ }^{E E}\left(u_{i}\right), \eta_{i}^{E E}\left(u_{n}\right)\right\} \rightarrow \max ,
$$

де $\eta_{i}{ }^{5 E}\left(\mathrm{u}_{\mathrm{i}}\right)$ - показник біоенергетичної ефективності;

$\eta_{i}^{E B}\left(u_{n}\right)$ - показник екологічної безпеки;

$\varphi$ - показник зворотних критеріїв.

Запишемо у скалярному вигляді три системи рівнянь, що визнаяають відповідно, три системи обмежень у компартментах ЕЗТ, ЕШЗТ та EE.

Компартмент залізничного господарства (3Т):

$$
\begin{gathered}
\sum_{\lambda \in H^{m}} x_{i \lambda}^{3 T}(t)-\sum_{j=1} \sum_{\lambda \in \mathrm{H}^{\mathrm{m}}} a_{\mathrm{ij} \lambda} x_{i}^{3 T}(t)-v_{i}^{3 T}(t)=y_{i}^{3 T}(t) \geq y_{0}^{3 T}(t) ; \\
\left\{\begin{array}{l}
\sum_{\mathrm{j} \in 3^{\mathrm{T}}} \sum_{\lambda \in \mathrm{H}^{\mathrm{m}}} \mathrm{v}_{\mathrm{i} \lambda}^{b e} 3 T \\
\sum_{\mathrm{j} \in 3^{3 \mathrm{~T}}} \sum_{\lambda \in \mathrm{H}^{\mathrm{m}}} \mathrm{v}_{\mathrm{i} \lambda}^{3 T^{\mathrm{be}}}(\mathrm{t})=v_{\mathrm{i}}^{b 3 T}(t)+v_{i}^{\mathrm{e}} 3 \mathrm{~T}(t) \\
\sum_{i=1^{k}} \beta_{i y}^{3 T} x_{\mathrm{i}}^{3 T}(t)-v_{\mathrm{y}}^{3 T^{\mathrm{b}}}(t)+v_{y}^{3 \mathrm{~T}^{\mathrm{e}}}(t) ;
\end{array}\right.
\end{gathered}
$$


де $y_{0}{ }^{3 T}$ - обмеження для залізничного транспорту;

$\mathrm{a}_{\mathrm{ij \lambda}}$ - коефіцієжнт витрат $j$-го виду ресурсів на функціонування $i$-го виду залізничного транспорту на $\lambda$-дій дистанції колії;

$\mathrm{v}_{\mathrm{i} \lambda}^{\text {beз }}$ - питомий коефіцієнт споживання ресурсів;

$\mathrm{v}_{\mathrm{i} \lambda}^{3 T^{\mathrm{be}}}$ - питомий коефіцієнт утворення $y$-тих відходів при виробництві та експлуатації $i$-го стаціонарного джерела забруднення на $\lambda$-му підприємстві залізничного транспорту;

$\beta_{i y}^{3 T}-$ коефіцієнт витрат виробничих потужностей $\lambda$-го агрегату під час експлуатації $i$-го об'єкту залізничного транспорту;

$N_{\lambda}^{3 T}$ - приріст виробничих та експлуатаційних потужностей залізничного транспорту;

$N_{\lambda 0}$ - виробничі та експлуатаційні потужності залізничного транспорту.

Компартмент шляхів залізничного транспорту (ШЗТ):

$$
\begin{aligned}
& \sum_{g \in H^{k}} x_{y \lambda}^{\amalg I 3 T}(t)-\sum_{y \in H^{n}} \sum_{\lambda \in \mathrm{H}^{k}} a_{\mathrm{ylg}} x_{i}^{\amalg I 3 T}(t)-v_{i}^{\amalg I 3 T}(t)=y_{i}^{\amalg I 3 T}(t) \geq y_{0}^{\amalg I 3 T}(t) ;
\end{aligned}
$$

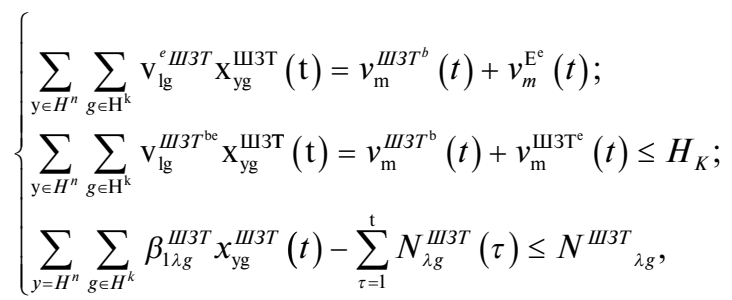

де $y_{0}^{\text {шззт }}$ - обмеження для надання $l$-того виду послуг/продукції;

$a_{\mathrm{ylg}}-$ коефіцієнт витрат у-го ресурсу для надання $l$-того виду послуг/продукції на $g$-тому технологічному модулі (рухомому складі залізниці);

$\mathrm{v}_{\mathrm{lg}}^{\text {IIIт⿻) }}$ - питомий коефіцієнт забруднення під час експлуатації / споживання під час будівництва $i$-тої діялнки колії на $g$-тій території;

$\mathrm{v}_{\mathrm{lg}}^{\text {eшзт }}$ - питомий коефіцієнт утворення $m$-их транспортних відходів;

$H_{K}$ - копроємність навколишнього природного середовища;

$\beta_{1 \lambda g}^{\text {шзт }}$ - коефіцієнт витрат виробничих потужностей $\lambda$-го рухомого складу при перевезенні $i$-го пасажиру чи вантажу;

$N_{\lambda g}^{\amalg з}-$ збільшення потужностей $\lambda$-го рухомого складу на $g$-тій дистанції колії i/або технологічному модулі.

Екологічний компартмент (Е): 


$$
\begin{gathered}
\sum x_{i}^{E}(t)-\sum_{r \in H^{p}} \sum_{\lambda \in \mathrm{H}^{\mathrm{m}}} a_{\mathrm{rg} \lambda} x_{i}^{E}(t)-\sum_{q} v_{i}^{E}(t)=y_{i}^{E}(t) \geq y_{0}^{E}(t) ; \\
y_{o}^{E}(t)=y_{o}^{E-1}(t)+\sum_{r \in H^{p}} \sum_{\lambda \in H^{m}} a_{r g \lambda} x_{i}^{E}(t) \leq L_{r}^{E} \\
\sum_{g \in H^{p}} \beta_{q \lambda} x_{\mathrm{i}}^{E}(t)-\sum_{\tau=1}^{\mathrm{t}} N_{\lambda g}^{E}(\tau) \leq N_{\lambda q},
\end{gathered}
$$

де $a_{r g \lambda}-$ коефіцієнт витрат $r$-го виду ресурсів при експлуатації $q$-го рухомого складу на $\lambda$-дій дистанції колії;

$L_{r}^{E}$ - гранично допустима доза токсиканта.

Системний біоенергетичний аналіздає змогу врахувати не тільки прямі витрати енергії, речовини та ресурсів, але й витрати живої праці робітників та службовців. В основі пропонованого аналізу лежить визначення коефіцієнта біоенергетичної ефективності, кількісним виразом якого є відношення енергії. акумульованої в продукції чи послузі (енерговміст), до сумарних витрат енергії та іiі виробництва (енергоємність):

$$
\eta=\frac{E_{\Pi}}{\sum_{\mathrm{i}=1} \sum_{\mathrm{j}=1} C_{i j}^{k} x_{i j}^{k}},
$$

де $E_{\Pi}$ - енерговміст залізничного транспорту, ГДж/ц;

$C_{i j}^{k}-$ енергетичний еквівалент $k$-го елемента $i$-го виду витрат для кожного технологычного процесу $j$, ГДж/(ц, $\mathrm{M}^{2}$, люд.год);

$x_{i j}^{k}$ - величина $k$-го елемента $i$-го виду витрат для кожного технологычного процесу $j$, ц, м², люд.год;

$i, k$ - види витрат та їх елементів: прямі (електроенергії, палива, природних комплесів і т.д.), непрямі (вплив з боку залізничної інфраструктури: механічний, фізичний, хімічний, біологічний, естетичний вигляд);

$j$ - технологічні процеси.

\section{5. Кіберфізична суть консорційних екотонів захисного типу}

Структура і склад інформаційних потоків системи погодження антропогенної дії повинні відповідати стуруктурі та функціональним особливостям КЕЗТ і узгоджуватися з режимами природокористування. Діагностику об'єктів КЕЗТ слід проводити на основі відношення копроємності оточуючого середовища до природоємкості КЕЗТ.

Особливої уваги й аналізу заслуговує кібернетична суть запропонованого підходу. На відміну від цілком біотичних систем, які, за В.I. Вер- 
надським [7, 8], виникли спонтанно, стихійно, природним шляхом, формувалися впродовж тривалого часу органічної еволюції і мають такого самого походження генетичні механізми саморегуляції, КЕЗТ є наслідком потужної роботи людського розуму і керованої ним праці [9]. Їхнє зародження також було спонтанним, стихійним і природним, але їхні механізми саморегуляції за своєю суттю - соціального походження і генезисно пов'язані з вищою від біотичної формою організації, оскільки будучи за своєю суттю біологічними об' єктами виконують функції інженерних споруд на шляхах залізничного транспорту.

Після того, як виробнича діяльність охопила цілу біосферу, вона (біосфера) разом з іншими блоками соціосфери опинилася в єдиому кібернетичному контурі управління [10] - інтелектуальному, перетворившись в трофічну, ресурсну і середовищну базу соціосфери, а ії стан з часом потрапив у залежність від ефективності роботи регуляторних механізмів останньої.

Кіберфізична система (КФС) являє собою складну систему, яка об'єднує обчислення, комунікації та фізичні процеси. Інформаційна система (IC) КФС має ієрархічний рівень структури, потоки інформації та систему прямих і зворотних зв'язків і грунтується на гіпотезі про те, що зміни у системі зумовлені цими зв'язками. Отримання кінцевого результату - $є$ функцією параметрів окремих блоків системи, якими необхідно керуватися при обгрунтуванні та прийнятті управлінських рішень щодо еколого-економічного розвитку КЕЗТ на шляхах залізничного транспорту.

На рисунку 3 наведено модуль екологічного аналізу КЕЗТ. Екологічний аналіз включає ідентифікацію КЕЗТ - це процес розпізнавання системою показників і параметрів, що визначають лісове насадження, як КЕЗТ; оцінка використання потенціалу КЕЗТ - застосування запасів та засобів компонентів КЕЗТ, що можуть бути використані для виконання захисних функцій на шляхах залізничного транспорту; виділення повнопрофільних та неповнопрофільних КЕЗТ - класифікація КЕЗТ за ознаками профільності, тобто чітко простежуваною структура смуг; встановлення екологічної ємності - узагальнена характеристика, що кількісно відповідає максимальному техногенному навантаженню, яке може витримувати впродовж тривалого періоду сукупність реципієнтів та екологічних систем КЕЗТ без порушення їхніх структурних і функціональних властивостей. 
The cyber physical principle management of capriciousness of landscape...

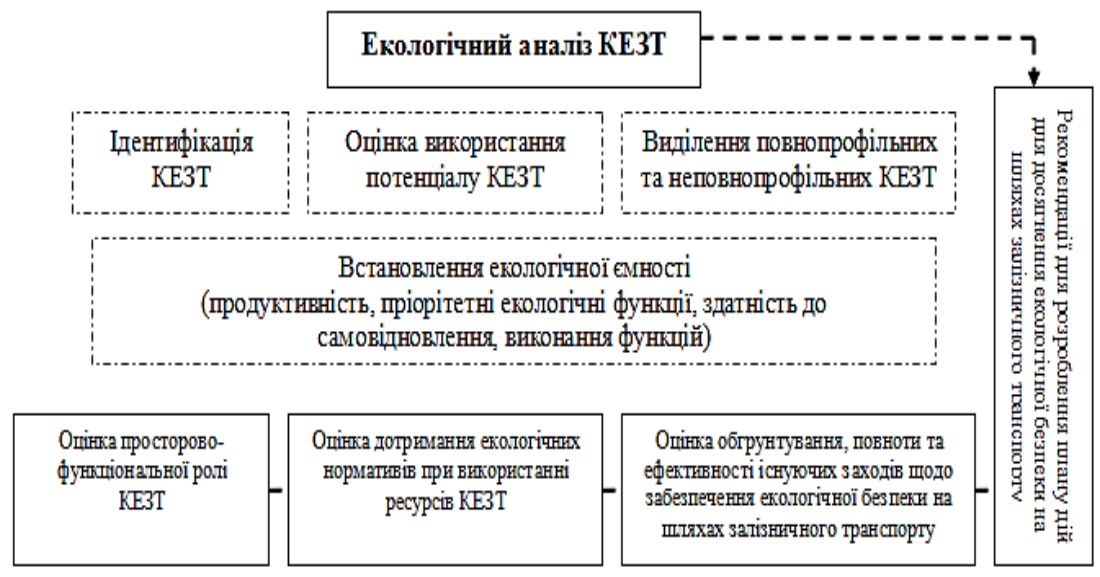

Рис. 3. Модуль екологічного аналізу КЕЗТ

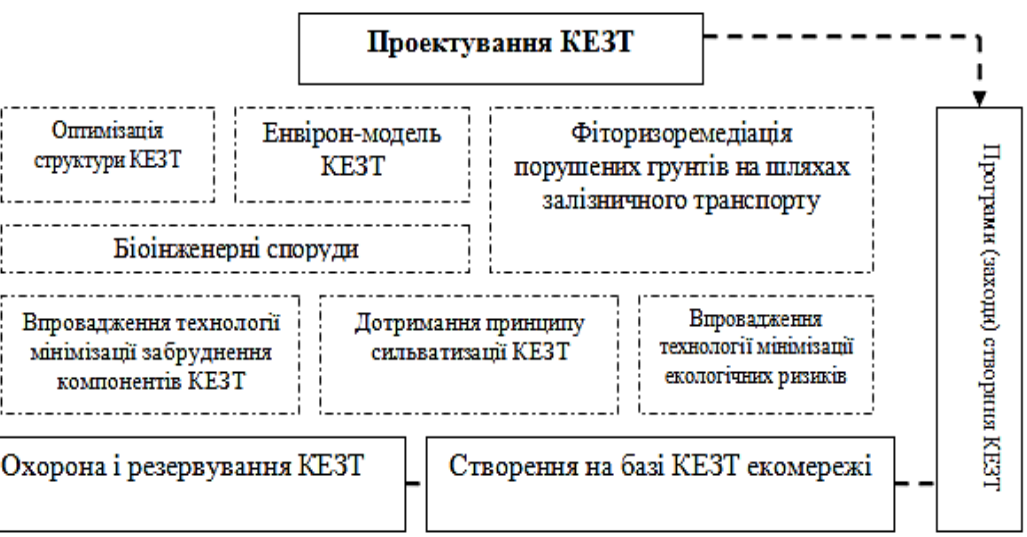

Рис. 4. Модуль проектування КЕЗТ

На рисунку 4 наведено модуль проектування КЕЗТ. Алгоритм застосування показників передбачає:

- оптимізацію структури КЕЗТ - знаходження екстремуму певної функції або вибору найкращого (оптимального) варіанту з безлічі можливих - найбільш надійним способом знаходження найкращого варіанту є порівняльна оцінка всіх можливих варіантів (альтернатив); 
- компртмент-модель КЕЗТ - метод аналізу статистичних даних КЕЗТ, як сукупності блоків, повязаних між собою вхідними і вихідними потоками речовини і енергії;

- фіторизоремедіація грунту - в основу методу поставлено задачу розробки нового ефективного, універсального, доступного, екологічно та економічно обгрунтованого спосібу ремедіації спрямованого на культивування комплексу ремедіатів: мікоризні гриби та асоційовані 3 ними рослинні мікроорганізми, що володіють потенціалом до високої ризосферної біоремедіації грунту in situ;

- біоінженерні споруди - склад і структура насаджень, які за умови інтенсифікації залізниці здатне зберігаєти/відновлювати біотичне та ландшафтне різноманіття, підвищувати продуктивність КЕЗТ і здатність їх до самовідновлення, забезпечувати екологічну безпеку теритоpiї - такий стан, за якого не виникають екологічні ризики, зберігається здатність КЕЗТ виконувати тепер і в майбутньому економічні, екологічні і соціальні функції на шляхах залізничного транспорту.

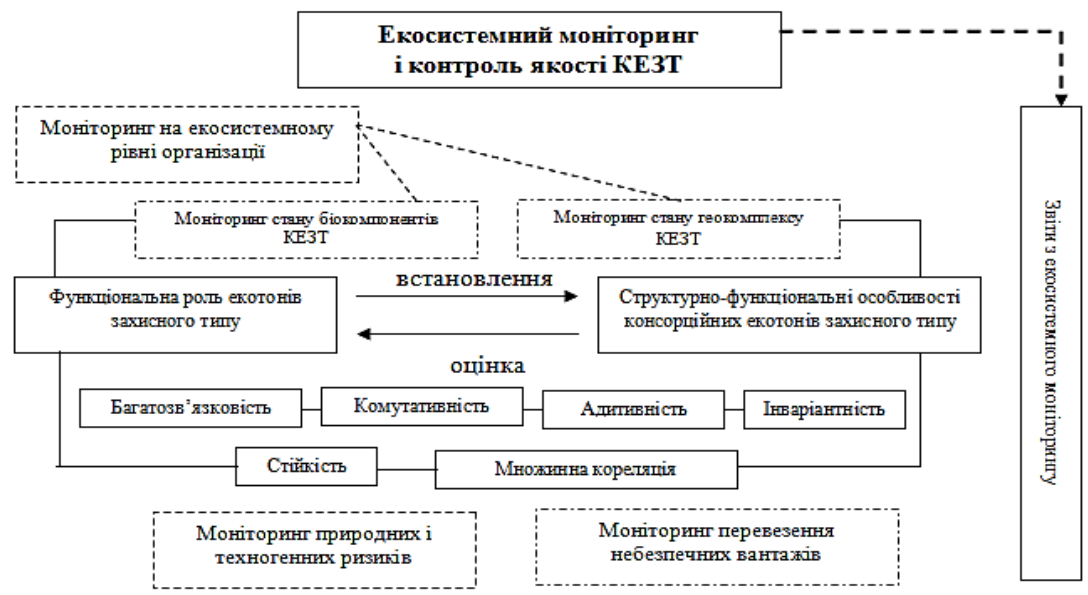

Рис. 5. Модуль екосистемного моніторингу і контролю якості КЕЗТ

На рисунку 5 наведено модуль екосистемного моніторингу і контролю якості КЕЗТ. Екосистемний моніторинг і контроль якості КЕЗТ доцільно проводити за наступними показниками: функціональна роль ЕЗТ; структурно-функціональні особливості КЕЗ. 
Для ефективного обліку необхідно мати достовірну, своєчасну і повну інформацію про головні параметри поточних станів компонентів КЕЗТ і техногенних факторів, що впливають на них. До інформації, яка формує основу науково обгрунтованих рішень, необхідно висувати такі вимоги:

- повнота і збалансованість, отримані показники повинні дозволяти використовувати обрану стратегію оцінки і відповідати поставленим цілям проведення екологічного моніторингу: визначати ступінь емісії забруднювачів, характеризувати проблеми якості навколишнього природного середовища;

- чутливість - доцільно було б встановити для кожної змінної відповідний діапазон значень, в межах якого вона може змінюватися, i відповідно до цього відібрати коректні методики їі визначення;

- статистична залежність між станом консорції та екотоном вцілому;

- можливість інтерпретації отриманої інформації;

- доступність і надійність даних;

- принцип біоіндикації, як напрямок підвищення обсягів отримання екологічної інформації при збереженні витрат на реалізацію програм.

Екосистемний принцип моніторингу і контролю якості КЕЗТ дозволить підвищити: рівень адекватності дійсному екологічному стану на шляхах залізничного транспорту його інформаційної моделі; оперативність отримання та достовірність первинних даних за якістю КЕЗТ на залізниці; рівень і якість інформаційного обслуговування споживачів екоінформаціі на основі мережевого доступу до банків та баз даних.

\section{6. Висновки}

Для отримання достовірної інформації необхідно запропонований підхід реалізовувати в таких напрямах:

- застосування не тільки методів математичної статистики, а й інформації про механізми реакції екотонів на зовнішній вплив;

- виявлення ступеня впливу конкретних зовнішніх факторів на стан НПС;

- встановлення впливу взаємозв'язків різних параметрів;

- вивчення періодичності часової і просторової мінливості аналізованих параметрів у консорціях; 
- отримання можливості роздільної оцінки кількісних параметрів розвитку природних і антропогенних процесів в консорціях і прогнозування тенденцій в екотонах при сукупному впливі природних і антропогенних факторів;

- визначення оптимального числа натурних вимірювань одного параметра в екотоні і рівня достатньої точності інструментальних засобів екологічного моніторингу.

Загальний алгоритм використання визначених показників поєднує встановлення і оцінку відповідних факторів НПС шляхом прямого або непрямого визначення за матеріалами моніторингу їх кількісних показників, а також створення на основі багатоспектральних даних просторової основи для оцінки впливу об'єкті залізниці на стан НПС.

Запропонований підхід враховує властивості природних комплексів: багатозв'язковість, стійкість, комутативности, адитивність, інваріантність, а також багатофакторна кореляція компонентів природи:

- багатозв'язковість виражається в різнохарактерній дії транспорту на природу, яке може викликати в ній зміни, які складно врахувати. Якщо виразити об'єкти залізничного транспорту $x_{1}, x_{2}, x_{3}, \ldots, x_{n}$, КЕЗТ $y_{1}, y_{2}, y_{3}, \ldots, y_{n}$, а зв'язки, що виникають між ними $k_{1}, k_{2}, k_{3}, \ldots, k_{n}$, тоді якість стану НПС на ШЗТ $(N)$ в будь-який момент часу $(t)$ можна виразити функціональною залежністю:

$$
N t=\Phi[x(t), y(t), k(t)]
$$

- адитивність - це можливість багатопараметричного складання різних джерел техногенної і антропогенної дії на природу, що може привести до непередбачуваних змін у ній. Надходження забруднень в КЕЗТ від об'єктів залізничного транспорту $d P_{M з T} / d t$ та інших об'єктів регіону $d P_{\text {фон }} / d t$ обмежується самоочищувальною здатністю НПС $d P_{\text {самооч }} / d t$, що виражається формулою:

$$
d P_{\text {фон }} / d t+d P_{\text {Mзт }} / d t \leq d P_{\text {самооч }} / d t
$$

- інваріантність $\epsilon$ властивістю екосистем зберігати стабільність у межах регламентованих техногенних і антропогенних дій.

$$
d P_{\text {зкд }} / d t \leq d P_{\text {відновл }} / d t
$$

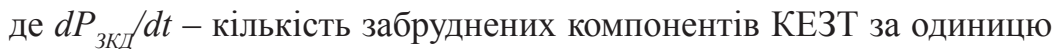
часу; $d P_{\text {віднол }} / d t-$ відновлювальні можливості КЕЗТ за компоненто.

- стійкість - це здатність екосистем зберігати початкові параметри до природної, техногенної і антропогенної дії. 
- Багатофакторна кореляція характеризує КЕЗТ з позицій їх зумовленості до випадкових і невипадкових подій з аналітичним зв'язком між ними:

$$
d \Pi_{к о р} / d t>d V_{\text {зм }} / d t
$$

де $d \Pi_{\text {кор }} / d t$ - стан КЕЗТ за методикою есо-індикатора 99; $d Y_{\text {зm }} / d t-$ вплив на стан КЕЗТ, що може виражатись в еко-балах.

\section{Список літератури:}

1. Мельник А.О. Кіберфізичні системи: проблеми створення та напрями розвитку // Вісник Національного університету «Львівська політехніка» Комп’ютерні системи та мережі. - 2014. - № 806. С. 154-161.

2. Дейлі Г. Поза зростанням. Економічна теорія сталого розвитку. - К.: Інтелсфера, 2002. 246 с.

3. Мирцхулава Ц.Е. Количественная оценка предельно допустимых нагрузок на ландшафт // Известия АН. Серия географическая. - № 3. 2001. - C. $68-74$.

4. Чміль А.І. Дослідження енергетичної досконалості біотехнічних систем у тваринництві // Науковий вісник НУБіП України. Серія «Техніка та енергетика АПК» - 2015 - 209/2 - С. 58-63. «Енергетика і автоматика», № 1, 2015 p. 29.

5. Чміль А.І. Обгрунтування оптимальної структури сільськогосподарської еколого-біотехнічної системи // Актуальні питання фізіології рослин в аспекті екологічних проблем. - Чернівці, 1995. - С. 64-65.

6. Економічна безпека: навч.посіб. / О. Є. Користін, О. І. Барановський, Л. В. Герасименко та ін. // За ред. О. М. Джужі. - К. : Алерта ; КНТ ; Центр навчальної літератури, 2010. - 368 с.

7. Борисенков Е.П. Идеи Вернадского В.И. о ноосфере и биогеохимических циклах и их современное звучание при изучении процессов, происходящих в климатической Системе и в обществе // «Академия Трипитаризма». М.: Эл. № 77-6567. публ. 10464, 10.06.2003. http://www.Trinitas.ru|rus|doc|0203|001a| 02030016.htm.(-7c).

8. Вернадский В. И. Биосфера и ноосфера. - М.: Наука, 1989. 263 с.

9. Бачинкський Г.А. Социоэкология: теоретические и прикладные аспекты. - К.: Наук. думка, 1991. 153 с.

10. Бокарев В.А. Понятие управления и оптимизации биосферы // Методологические аспекты исследования биосферы. - М.: Наука, 1975. - C. 268-282.

\section{References:}

1. Meljnyk, A.O. (2014). Kiberfizychni systemy: problemy stvorennja ta naprjamy rozvytku [Cyberphysical systems: problems of creation and directions of development]. Visnyk Nacionaljnogho universytetu "Ljvivsjka politekhnika" Komp'juterni systemy ta merezhi, (806): 154-161. 
2. Dejli Gh. (2002). Poza zrostannjam. Ekonomichna teorija stalogho rozvytku [Out of growth. Economic Theory of Sustainable Development]. K.: Intelsfera, p. 246.

3. Myrckhulava, C.E. \& Yzvestyja, A.N. (2001). Kolychestvennaja ocenka predeljno dopustymbkh naghruzok na landshaft [The Quantitative estimate of the maximum allowable loads on the landscape]. Seryja gheoghrafycheskaj, (3): 68-74.

4. Chmilj, A.I. (2015). Doslidzhennja energhetychnoji doskonalosti biotexnichnyx system u tvarynnyctvi [The Research of energy perfection of biotechnical systems in livestock breeding]. Naukovyj visnyk NUBiP Ukrajiny. Serija "Texnika ta energhetyka APK”, (209/2): 58-63.

5. Chmilj, A.I. (1995). Obghruntuvannja optymaljnoji struktury siljsjkoghospodarsjkoji ekologho-biotekhnichnoji systemy [The Justification of the optimal structure of the agricultural ecological and biotechnical system]. Aktualjni pytannja fiziologhiji roslyn $v$ aspekti ekologhichnykh problem. Chernivci: pp. 64-65. (in Ukrainian).

6. Korystin O.Je., Baranovsjkyj O.I., Gherasymenko L.V. ta in. (2010)/ Ekonomichna bezpeka [Economic security ]: navch.posib. K.: Alerta ; KNT; Centr navchaljnoji literatury, 368. (in Ukrainian).

7. Kompleksna derzhavna proghrama energhozbere-zhennja Ukrajiny [Integrated state-of-the-art programma energhozbere-zhennja Ukrajiny]: zatverdzhena Postanovoju Kabinetu Ministriv Ukrajiny vid 05.02.1997 № 148 (zizminamy ta dopovnennjamy) Retrieved from: http://www.zakon.rada.gov.ua/.

8. Borisenkov, E.P. (2003). Idei Vernadskogo V.I. o noosfere i biogeokhimicheskikh tsiklakh i ikh sovremennoe zvuchanie pri izuchenii protsessov, proiskhodyashchikh $\mathrm{v}$ klimaticheskoy Sisteme i v obshchestve [The Ideas of Vernadsky V.I. about the noosphere and biogeochemical cycles and their contemporary sound when studying processes occurring in the climate system and in society]. "Akademiya Tripitarizma". - M.: El. № 77-6567. Retrieved from: http://www.Trinitas.ru|rus|doc|0203|001a|02030016.htm.(-7c).

10. Vernadskyj, V.Y. (1989). Byosfera y noosfera [Biosfera i noosfera]. M.: Nauka, 263. (in Ukrainian).

12. Bachynksjkyj, Gh.A. (1991). Sotsioekologiya: teoreticheskie i prikladnye aspekty [Socioecology: theoretical and applied aspects]. K.: Nauk. dumka. 153. (in Ukrainian).

13. Bokarev, V.A. (1975). Ponyatie upravleniya i optimizatsii biosfery [The concept of management and optimization of the biosphere]. Metodologicheskie aspekty issledovaniya biosfery. M.: Nauka, pp. 268-282. (in Russian) 
Comprehensive pedagogical diagnosis of the quality of the training of future...

COMPREHENSIVE PEDAGOGICAL DIAGNOSIS

OF THE QUALITY OF THE TRAINING OF FUTURE TEACHERS

\section{Savchenko Larysa ${ }^{1}$ \\ Savchenko Karyna²}

DOI: http://dx.doi.org/10.30525/978-9934-571-26-8_17

Abstract. The tidy of problem of the complex pedagogical diagnostician of quality of preparation of future teachers of labor studies and technologies. On results the questionnaire of teachers and students, analysis of educational documentation and row of publications from the investigated problem, and also own supervisions, it is found out, that on the modern stage many models of organization of pedagogical diagnostics are offered; verification takes place with the use of different scales of evaluation, criteria and going near the calculation of rating of students; the methodical providing failing on issue of organization of diagnostic control from pedagogical disciplines in the conditions of higher pedagogical school; tasks of professionally-pedagogical orientation in the complexes of control tasks and tasks for the independent working; methodical advices for working of educational information and implementation of diagnostic tasks students. The all-round comprehension of results of success of students, id est level of quality of knowledge of students, relation of them to the courses of professionally-subject orientation and display of the personal interest to the studies on establishment and to forming the stages of experiment, induced to the conclusion that the use of reasonable methodologies of diagnostic control strengthened interest and improved attitude of students toward studies, and also assisted the increase of level of quality of knowledge, and thus, internals of pedagogical education. Thus, preparation of future teachers of labor studies and technologies to pedagogical diagnostics of quality of education is a process, during that comprehend, optimize studies, care of objective analysis of educational results, control, verification, evaluation, accumulations of statistical data, their reflection, study a dynamics,

\footnotetext{
${ }^{1}$ Doctor of Pedagogical Sciences, Assistant Professor,

Kryvyi Rih State Pedagogical University, Ukraine

${ }^{2}$ Candidate of Pedagogical Sciences, Senior Lecturer,

Kryvyi Rih State Pedagogical University, Ukraine

(C) Savchenko Larysa, Savchenko Karyna
} 
tendencies, prognoses in relation to further development of events. The analysis of pedagogical theories devoted to the problem of the quality of education confirms the constant increase in the number of scientific facts and key concepts that mark this process and reflect its essence, deepen their content. Clarification of the content of the main concepts and categories, which nominated investigated phenomena, their ratio has allowed fixing the presence of various scientific-theoretical and methodological approaches to their interpretation. The concept of "quality of education" applies to the designation of the results of learning, upbringing and development of the individual as the ultimate goal and product of the educational process. The quality of education in the broadest sense is the result and the process of functioning of the educational system, which shows the effectiveness of the actions of the participants in the educational process with regard to the implementation of goals, conditions, social and educational standards, capable of meeting consumers, their requirements and the actual needs of society.

In the narrow sense, the quality of education manifests itself as an integrated set of properties that characterizes the adaptability of education to the realization of the social goal of the formation and development of personality in aspects of its teaching, parenting, mental and physical capabilities. Tasks of the article in the first place: to define methodological support for the problem of the organization of diagnostics of pedagogical disciplines in the conditions of higher pedagogical school; the second task is to determine the professionally-pedagogical orientation in complex control tasks and tasks for self-study; the third task tips for the study of educational information and perform diagnostic tasks.

\section{Introduction}

The world pedagogical thought is in search of new priorities in education being at the present stage of development of society, marked by globalization processes, operating of information technology. The quality of the education becomes the main benchmark in determining the credibility and competitiveness of educational institutions on regional, national levels and international arena. The analysis of the scientific literature of the preparation of future teachers of vocational training institutions to the professional activity and the content of the syllabus shows that this problem is not adequately addressed in the context of their professional preparation to the 
pedagogic diagnostics of the quality of students' education, which caused a number of contradictions between: the challenges of modernization of higher education, aimed at improving the quality and existing system of preparation of future teachers of vocational training in higher pedagogical institutions; the need to overcome the fragmentation and inconsistency of some scientific data in the national pedagogy about the nature, structure and functioning of the pedagogical diagnostics of the quality of education and the negative attitude of teachers to use it in practical activities with the students of vocational educational institutions.

The analysis of the recent researches and publications (A. Binet, Bitinas) of the nature of pedagogical diagnostics, its history and development regarding (O. Andriyenko, A. Belkin) the quality control of the professional-pedagogical preparation of future teacher and lecturer (I. Podlasie, N. Rosenberg, D. Chernilevskiy, C. Sandrock, A. Shatalov).

The purpose of the monograph. The study of the problem of the comprehensive pedagogical diagnostics of the quality of the training of future teachers of vocational training in the field of "food technology" and "services". According to the results of the survey of teachers and students, the analysis of educational documentation and several publications on the studied issue, as well as my own observations, it appears that at the present stage many models of the organization of pedagogical diagnostics are offered; the validation is done using different scales of evaluation, criteria and approaches to the calculation of the students' rating; the methodological support for the problem of the organization of the diagnostics of the pedagogical disciplines in the conditions of higher pedagogical school is not enough; tasks of professional-pedagogical orientation in complex control tasks and tasks for self-study; methodological advice for the development of educational information and perform diagnostic tasks.

\section{Study of methodological approaches to the training of future specialists}

The National Education Development Strategy in Ukraine for the period up to 2021 and other state documents, the tasks and vectors of education reform are related to the establishment of a system for evaluating its quality, systematic monitoring and analysis of the state of actual educational problems and their solution. In order to ensure the quality of education, the material, financial, human resources and scientific resources of the society 
are directed, it becomes the basis for evaluation by the state and the public of educational services, guaranteeing the access of citizens to obtaining a thorough and publicly-requested education.

Under these conditions, the quality of higher pedagogical education has become the principle and the main criterion for the effectiveness of the modern system of training pedagogical personnel. In the most widespread sense, pedagogical diagnosis is a set of methods of control and evaluation aimed at identifying the effectiveness of solving the tasks of the educational process, differentiating the learners, as well as improving the curricula and pedagogical methods for further optimization of the educational process.It is important that pedagogical diagnostics does not replace teaching aids, but helps to identify the conditions, achievements and disadvantages of their use in the organization of this process, outline ways to increase its efficiency and improve the activities of teachers in accordance with the stated goal.

Note that pedagogical diagnosis is a specific type of diagnosis that has features that are distinct from psychological and sociological diagnostics, as well as from the diagnostics used in scientific research.

For pedagogical diagnostics is characterized by the presence of inherent only her functions and principles; special structure and a number of specific stages. Pedagogical diagnostics is a system of methods, procedures, methods, methods for clarifying the circumstances, conditions and factors of the functioning of pedagogical processes, studying their effectiveness and results regarding the measures that are envisaged or happen. By its intended purpose pedagogical diagnostics determines a method of recognition of a state of a certain object or system by means of the rapid registration of its essential parameters and the subsequent relation to a certain diagnostic category in order to make a prediction of the actions, behavior or development of the subject to diagnosis in the desired direction.

In its content pedagogical diagnostics - this is an analytical cut and evaluation of the state of the pedagogical phenomenon according to the statistical data in accordance with certain, predetermined parameters. In this regard, the diagnosis of the results of the professional activity of the teacher involves the knowledge and ability to use parametric data characterizing the state of these results at different levels of implementation.

The analysis of pedagogical theories devoted to the problem of the quality of education confirms the constant increase in the number of scientific 


\section{Comprehensive pedagogical diagnosis of the quality of the training of future...}

facts and key concepts that mark this process and reflect its essence, deepen their content. Clarification of the content of the main concepts and categories, which nominated investigated phenomena, their ratio made it possible to fix the presence of various scientific-theoretical and methodological approaches to their interpretation. The concept of "quality of education" applies to the designation of the results of learning, upbringing and development of the individual as the ultimate goal and product of the educational process. The quality of education in the broadest sense is the result and the process of functioning of the educational system, which shows the effectiveness of the actions of the participants in the educational process with regard to the implementation of goals, conditions, social and educational standards, capable of meeting consumers, their requirements and the actual needs of society. In the narrow sense, the quality of education manifests itself as an integrated set of properties that characterizes the adaptability of education to the realization of the social goal of the formation and development of personality in aspects of its teaching, parenting, mental and physical capabilities.

It is proved that the study of the effectiveness of training future teachers for pedagogical diagnosis should be carried out in accordance with the laws of dialectics and principles of consciousness, personality and activity. The practical cut of the methodological basis of the study of the training of future teachers for pedagogical diagnostics of the quality of education includes: axiological (the value of education and its results as universal value), systemic (a set of tools for managing the process of teacher training to meet the educational services of society), competence (professional level of development of the personality of the future teacher and his readiness to perform the tasks of professional activity) and personality-activity (goals of educational activities of future teachers, knowledge, skills, learning skills, which determine the implementation of their personality in their professional activities) approaches.

In the context $f$ the study of the training of future teachers for pedagogical diagnostics of the quality of education, the axiological approach is aimed at identifying value benchmarks and ideological positions, according to which they are able to isolate the parameters of the achieved learning outcomes and upbringing of students, the criteria for their evaluation and forecasting with a view to their further improvement. Such value orientations reflect the semantic core of preparation for pedagogical diagnostics of 
the quality of education as the ultimate product of student socialization in the system of professional training and pedagogical activity.

Competency approach reveals the essence of social requirements regarding the final results of the professional training of the future teacher, his general and pedagogical erudition, and pedagogical skills in accordance with the state standards recognized in the society for the recognition of higher and general secondary education recognized in the society. According to its purpose in the study, it was used to outline the content of the process of professional training of future teachers for pedagogical diagnostics of the quality of students' education in the framework of current curricula and nomenclature of normative educational disciplines. Pedagogical diagnostics in line with the competence approach is considered as a complex system of internal mental states and personality traits of the future teacher, which ensures his ability to diagnose the results of his own professional activity and the activities of his colleagues through a variety of methods in the educational process of the school. From the point of view of the competence approach, the preparation of the future teacher for pedagogical diagnostics of the quality of education is considered as a multi-faceted phenomenon, which depends on the professional basic knowledge and skills, value orientations, motives of the future teacher's activity, understanding of themselves and the world around, the style of relationships with people, general culture, ability before developing its educational potential.

Personality-activity approach in the study of the training of future teachers for pedagogical diagnostics of the quality of education characterizes the actions of each student in this process as a source of their own activity, which largely determines the learning outcomes. The analysis of the personality of the future teacher as a subject of educational activity with individual cognitive and professional motives and needs, special cognitive strategies (analytical, spatial-synthetic, verbal) of comprehension of educational material, experience of pedagogical activity and their consideration in the educational process is the key to the success of his professional training. in general, and to pedagogical diagnostics of the quality of education of students, in particular.

From the point of view of the system approach, vocational and pedagogical training of future teachers for pedagogical diagnostics is considered as an open, dynamic socially oriented system, functioning of which is provided by appropriate pedagogical subsystems (content, forms, methods, 
means of learning), the integral interaction of which is aimed at achieving the intended result. The professional training of future teachers for pedagogical diagnostics of the quality of education is a systemic multidimensional phenomenon that determines the cognitive activity of its subjects, their self-development and self-organization, which in the future determine the results of professional-pedagogical activity, which is mastered in higher education.

Recently, in connection with the modernization of higher education, there are significant changes in the content and methodology of preparing a future teacher, which intensifies the problem of identifying the potential of teaching and special disciplines in the preparation of the future teacher of technology and drawing to pedagogical diagnostics of the quality of education.

It is proved that in pedagogical diagnostics it is important not only to fix the result, but also to construct the dynamics of its change. Diagnosis and assessment of the effectiveness of the teacher includes: a comprehensive study of the individual; self-analysis of own activity; analysis of the effectiveness of the educational process as a cumulative result of many teachers.

The qualitative and quantitative indicator of evaluation of the results of pedagogical activity is to achieve the desired result. It is a norm or a state educational standard that serves as a prerequisite and the basis for diagnosis in education, since it compares actual results with them, after which the evaluation and correction are carried out.

The effectiveness of the professional and pedagogical activity of the future teacher of technology and drawing is to a certain extent determined by his ability to correlate his conceptual position regarding the teaching of students with a certain model of the organization of the educational process, the ability to correlate the selected learning technologies with the age-old characteristics of students, taking into account their interests during the design of the content of each lesson; the ability to diagnose and monitor the quality of the students' learning tasks, and to simulate, on this basis, the likely development of their creative abilities in technological activities.

Preparation of future technology teachers and drawing for pedagogical diagnostics of quality of education is considered as a holistic educational process aimed at forming the system of knowledge, skills and skills necessary for the students to identify the achievements of pupils in a secondary school in the formation of skills and skills in a particular type of labor edu- 
cation. The concrete result of mastering the methods and methods of diagnosing, monitoring and evaluating the results is manifested in the formation of a professionally directed creative personality of the future teacher, his psychological willingness and practical preparedness for the implementation of pedagogical diagnostics of the quality of students' education.

Preparedness of students for pedagogical diagnostics of the quality of education of students is a complex personal formation, which shows the effectiveness of their professional preparation for pedagogical activities in higher education, the degree of orientation in the requirements for the quality of teaching students in a school on a certain subject in accordance with current state standards, theoretical knowledge of pedagogical diagnostics of this quality, practical skills to solve diagnostic tasks, to evaluate the results of work, to control the quality of students' activity, to forecast and project pull out the results of your own professional activities and other teachers.

The preparation of the future teacher of technology and drawing to the pedagogical diagnostics of the quality of education of students may turn into a personal formation provided that the process of vocational and pedagogical training is organized as an independent cognitive activity of students, during which each of them during the whole study systematically and consistently acquires the experience of the decision diagnostic tasks that are constantly complicated. At the same time, an important component of preparation is awareness and mastering of the tools of pedagogical diagnostics by the teacher of the quality of education of students.

In scientific studies of diagnosing the quality of education of subjects of the educational process, various methods are classified in three groups: empirical, theoretical and mathematical-statistical. Among the modern methods of pedagogical diagnosis of the quality of education, the most appropriate are the following: test control (integrated system, which is a subsystem of pedagogical control, an organic part of the educational process in general); monitoring control (a complex of repeated repeating control procedures in the given time parameters in order to find out the trends and deviations in the results obtained and make adjustments in the adoption of management decisions); expert control with the involvement of professional experts (dean's office, administration, accreditation) for assessing the effectiveness of educational processes.

It is concluded that control over the quality achieved in the educational process of the results is an integral part of pedagogical diagnostics, which 
covers the theoretical determination of diagnostic parameters; visual and practical substantive demonstration of the results of the diagnosis; Instrumental control of planned control (with the help of a computer, practical control, self-control, tests and tests, "portfolio", analysis of products, scaling, rating, pair comparison, etc.)

The diagnostic function of teacher control based on the results of the educational process involves a systematic analysis of the final training products, obtaining objective and reliable information about the reasons for the students' failure in the educational activity. This allows to correct not only the actual content of teacher's teaching activity, but also the system of control, evaluation and quality management of education that he uses.

\section{Study the problem of complex pedagogical diagnostics of future professionals in vocational education}

From the analyzed training plans for students' training at the technological and pedagogical departments of higher educational institutions of Ukraine, it became clear that there are significant differences in the number of hours allocated to normative disciplines within the framework of professional and practical training of future technology teachers and drawing. It is established that according to the content of educational programs their vocational training does not foresee purposeful training of pedagogical diagnostics of the quality of students' education. As a result, according to the results of the survey, it was found that $55 \%$ of teachers, and $36 \%$ of graduate students do not understand the essence of the concept of "quality of education", "pedagogical diagnosis" or identify them with the concepts of "assessment", "analysis", "control". At the same time, they do not consider it advisable to use pedagogical diagnostics in the professional activity of the teacher in the educational process of the school. The lack of methodological developments in pedagogical diagnostics of the quality of education of students from educational subjects "Theory and Technique of Technological Education" and "Methodology of teaching drawings" were indicated by $81 \%$ of practicing teachers and graduate students; the inability to apply the latest information technologies in the pedagogical diagnosis of the quality of education of students is noted by $69 \%$ of the teachers and students questioned.

The following structural components have been identified for assessing the degree of preparedness of future technology teachers and the drawing 
of the quality of the students' education: motivational (attitude to professional activity, activity in mastering the knowledge on pedagogical diagnostics of the quality of education, the desire to constantly increase the level of professional and diagnostic preparation, professional knowledge in the field of the subject, attitude towards the implementation of pedagogical diagnostics of the quality of education); operational-activity (mastering of knowledge about goals and methods of pedagogical diagnostics, ways of evaluating academic achievements of students by units of educational information; ability to design future results of educational activity on a subject and analyze results), creative (presence of creative abilities of future technology teachers and drawing on professional training, mastering of skills of pedagogical improvisation) and diagnostic (ability to identify and analyze difficulties of students, search of optimal ways of using pedagogical results diagnostics objectification of its results in diagnostic conclusions, recommendations and prognostic models of professional development activities to improve the quality of education of students).

On the basis of isolated structural components, criteria and indicators of the preparedness of future technology teachers and the drawing for pedagogical diagnostics of the quality of education are developed: value-orientation (the presence of interest in the profession of technology teacher and drawing; positive attitude to the constant implementation of pedagogical diagnostics of the quality of education; the desire to deepen their knowledge of techniques pedagogical diagnostics of education quality); imperative-setting (awareness of the methods of pedagogical diagnostics of the quality of education of students from the subject, the ability to select and apply diagnostic methods of quality education of students in the field of technology and drawing; ability to predict, project future design and technical activities of students and analyze their results); constructive (ability to develop abstracts of lessons from labor studies; independently develop diagnostic tasks for identifying the quality of students' education in technology and drawing; in the ability to assess the quality of technological education of students according to certain criteria).

As a result of the qualifying phase, the level of preparedness of future technology teachers and drawing to pedagogical diagnostics of quality of education was revealed: high, satisfactory and low. It turned out that most of the students were at a satisfactory level (52.08\%). At the low level of preparedness for pedagogical diagnostics $34.42 \%$ of graduate students were found; high $-13.50 \%$. 


\section{Comprehensive pedagogical diagnosis of the quality of the training of future...}

Thus, the analysis of the results of the search experiment showed that the training of future technology teachers and drawing to pedagogical diagnostics of the quality of education in the educational process of the higher pedagogical school needs to improve the content of learning, finding more effective forms and methods for its awareness.

The developed model of preparation of future teachers of technologies and drawing for pedagogical diagnostics of the quality of education was carried out preparatory-cognitive, practical-constructive, analytical, technological, reflexive-evaluation stages; pedagogical conditions, content components and methods of their implementation.

The existence of a unified system of criteria and indicators of pedagogical diagnostics of the quality of education in the methodology for implementing the model of training future technology teachers and drawing provided reproduction in the content of individual sections and topics of normative academic disciplines "General Pedagogy", "School of Science", "Methodology of technological education", "Artwork" information that reveals the essence of the manifestation of the quality of education of students in technology and drawing. For the selection and discussion with students of the system of criteria and indicators of the quality of education of students, the state standards of general secondary education, the data of age psychology, requirements of school programs were used. According to the requirements of the second pedagogical condition (interaction of innovative, productive, informational and communicative, interactive methods and technologies) implementation of all stages of the proposed model was carried out using various forms of organization of the educational process in which the traditional classroom and independent work stud Entities were supplemented or completely replaced by innovations. So, lectures were conducted using multimedia support (lectures-visualization, problem presentations); seminars (interdisciplinary, gaming) took place in disputes, conferences or organizational-activity games using an interactive multimedia board; Laboratory and practical classes provided for step-by-step development, discussion and protection of students of multimedia educational projects, reflexive analysis of products of activity. Independent work of students contained individual research tasks, which included the preparation of information projects, the development and selection of various tests for students, schemes for monitoring and analysis of lessons; preparation of 
presentations on the results of pedagogical diagnosis of achievements of pupils, their various ratings and self-evaluation.

Students gain experience of independent professional and pedagogical activity in developing pedagogical diagnostics of quality of education of students, which was the third pedagogical condition, took place in the process of pedagogical practice. For this purpose, in the program of pedagogical practice, it was included the task of preparing students for the detailed description of individual students, groups or class as a whole according to the criteria and indicators important for the quality of their training in technology and drawing. In particular, the compilation of such a characteristic required the ability to test students from the peculiarities of their thinking (logical, figurative, spatial), imagination and attention, ability to creativity, aesthetic perception, and others like that.

In the modern educational system of Ukraine the scientific level of testing (test development, testing, processing, presentation, pedagogical analysis of the results and their interpretation) is not consistent with international standards in this area. In the libraries of the universities there is not enough literature that reflects the current state of the global theory and the practice of educational measurement. Today, in the pedagogical universities of Ukraine the systematic work of preparation and retraining of personnel, who are capable to develop and use the educational tests in educational-professional programs of preparation of future teachers of vocational training in many fields is not organized, there are no training courses of the educational assessment, the didactic testology or of the educational qualimetry. The pedagogical diagnostics of the education quality of professional training of future teachers of vocational training in the field of "food technology" and "services" includes examination, observation and analysis of the learning process, provides an opportunity to obtain and use information on the adequacy of pedagogical technologies, forms, methods and tools; to improve the learning process.

The quality of students' education is influenced by the level and quality of students, the quality of educational standards, the quality of education, contents of curricula and programmes, the quality of the educational process and scientific-methodical maintenance of pedagogical competence and pedagogical skills of the teaching staff, logistics, morale and psychological climate, etc.

The pedagogical diagnostics is a process during which the analysis of the learning process is happen, the providing of the objective determination 
of its results, the monitoring, the review, the evaluation, the accumulation of statistical data, their analysis, the identification of the dynamics, the trends, t5he forecasting of further improvement in the quality of education.

The pedagogical diagnosis is an important factor of organizational forms that affect the quality of education in the training of students in higher education. The complex pedagogical diagnostics of the quality of the training of future teachers of technologies was based on the system studies, which were implemented at the university:

- the carrying out of the large-scale teaching experiments to identify the parameters of the learning process of students and formation on this basis of the strategies of the quality management system of educational process;

- the study of the nature of the formation of residual knowledge and development of methods of integrated monitoring of quality residual knowledge as one of the most important indicators of the quality of the educational process in general;

- the formation of the bank of the diagnostic tasks of the core subjects, the development of diagnostic technologies;

- the creation of the information technology of a continuous system-complex diagnostics of the quality of the training of future teachers.

The results of complex pedagogical diagnostics of the training of future teachers of technology in $2015-2017$ is presented in Fig. 1.

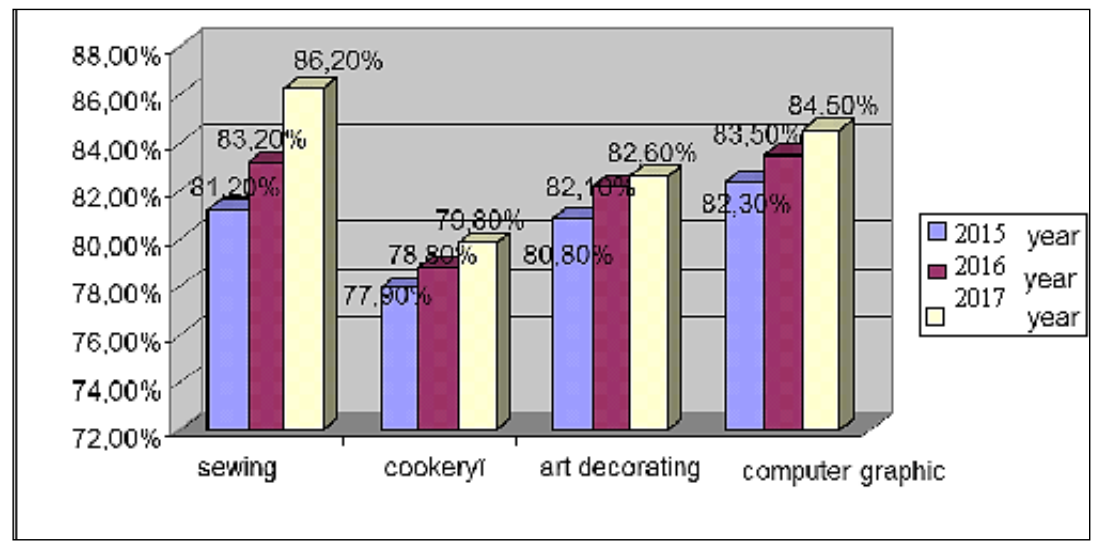

Fig. 1. The average index of the quality of the training of future teachers 
The average index of the quality of the training has gradually changed in the course of the year. These results are related to the fact that in 2015, the traditional aspects of the diagnostics of the quality of the knowledge of students are applied. In 2016 - 2017 years in the educational process, in addition to the described types of control, a portfolio of students, individual-group work, technology web quest, group work, simulations etc are introduced.

The repeated questioning was done to determine the significance of the use of diagnostic techniques in the learning process and the levels were differentiated: high, medium, low. The results of the study according the criterion "The importance of the use of the diagnostic techniques in the learning process" at the ascertaining and the forming stages of the experiment are mapped in the table. 1.

It is summarized that the parameters have changed in the control and experimental groups by comparing the results of studies according the criterion "The importance of the use of the diagnostic techniques in the learning process".

Table 1

The comparative table of the results according the criterion "The importance of the use of the pedagogical diagnostics in the learning process"

\begin{tabular}{|c|c|c|c|c|}
\hline \multirow{3}{*}{ Levels } & \multicolumn{2}{|c|}{ The ascertaining stage } & \multicolumn{2}{|c|}{ The forming stage } \\
\hline & $\begin{array}{l}\text { The control } \\
\text { group }\end{array}$ & $\begin{array}{c}\text { The } \\
\text { experimental } \\
\text { group }\end{array}$ & $\begin{array}{l}\text { The control } \\
\text { group }\end{array}$ & $\begin{array}{c}\text { The } \\
\text { experimental } \\
\text { group }\end{array}$ \\
\hline & $\%$ & $\%$ & $\%$ & $\%$ \\
\hline High & 16 & 15 & 16 & 38 \\
\hline Medium & 42 & 38 & 16 & 54 \\
\hline Low & 42 & 47 & 34 & 8 \\
\hline
\end{tabular}

In the control group there is a marked increase in the number of students with average level (8\%), decreasing with low (6\%), and the number of respondents with a high level remained unchanged. In the experimental group the number of students with high (23\%) and secondary (16\%) levels increased, with low (39\%) level decreased, but these figures are significantly higher than in the control group, which gives reason to believe the experimental work is efficient and effective. 


\section{Comprehensive pedagogical diagnosis of the quality of the training of future...}

The experimental method, which includes: the first - the preparatory-cognitive stage, was foreseen to provide the future teachers with knowledge, skills and skills in pedagogical diagnostics of the quality of education; practical and constructive - directed and intensified the students on the positive attitude and use of the system of pedagogical diagnostics of the quality of education of students, stimulated the development of the need for the study of the theory of pedagogical diagnostics; analytical - tracking the causes of weak links (problems); analysis and systematization of received information, development of recommendations and proposals for further correction of work, preparation of conclusions; technological - correction by means of introduction of technologies, feedback, selection of methods of pedagogical diagnosis of quality of education; Reflective and evaluation students' training on their own to develop innovative methods of pedagogical diagnostics of the quality of education of students on the development of self-assessment of their preparation for the implementation of pedagogical diagnostics in modern school

The developed method of the diagnostic control of the students' knowledge was embedded at the stage of the formative experiment in the experimental group, but the control group continued to study according to the traditional method. After the experiment, the control pedagogical diagnostics with using the same research methods as during the ascertaining experiment.

The smart tasks were specially designed that related to the diagnostic methods should be constructed in such a way that during their implementation the intellectual skills will be used: analysis, synthesis, distillation, comparison, classification and generalization. With their help, students penetrate into the problem that confronts them, they describe the properties of the components affected by the issue, pick a solution to the problems. The process of the solving intellectual tasks consists of several steps: the analysis of the conditions of the problem, the search a solution plan, the solution, the validation and investigation, the analysis of the fulfilled work.

The variety of conditions was used, here is an example:

Situation 1. You are the head of the methodical bloc. You need to re-pack the department according to the staff schedule after the reorganization. The task is to describe which path you would choose and why:

a) Undertake the work themselves, examine all the lists and personal files of the teachers, submit your project at the meeting of the bloc; 
b) Offer to resolve this issue to the personnel office, because that's its job;

c) In order to avoid conflicts, suggest to express the wishes of all interested parties, establish a commission of the acquisition of a new bloc;

d) Ask the teachers to submit their proposals concerning the composition of the bloc.

Situation 2. You have recently started to work as a teacher of technology, having come to this position from another school. Not everybody has known you personally yet. Walking down the hallway during the class you see three high school students who are talking about something animatedly and do not pay attention to you. Returning 20 minutes later, you see the same picture. The task is to tell us how you will behave:

a) You will stop, make it clear to students that you are a new teacher of technology, you will say that their conversation is too long and it's time to go to the class;

b) You will ask who their direct teacher of technology is;

c) You will first ask about the conversation, then introduce yourself and ask whether there are any claims to the teacher of technology, then offer to go in the workshops for the class;

g) First of all you will ask how they study, what they don't like at the technology classes, you will take these students into consideration.

Situation 3. There is a list of 24 qualities below, which the teachers must have in varying degrees to solve any problems that interfere with normal teaching activities: persistence, endurance, freedom, sociability, diligence, variability, sensitivity, knowledge of their capabilities, respect for family traditions, ability to imagine, arrogance, skill, thrift, self-discipline, resourcefulness, initiative, purposefulness, persistence, ability to listen, sincerity, independence, erudition, the desire for success, efficiency. The task is to form the teaching staff. The methodical instructions are: you should give a prepared list of qualities to all students and ask each to choose five qualities which, in their opinion, are essential for solving problems that interfere with the normal work of the teaching staff. Each student will be able to do it using the method of pair wise comparisons.

\section{Conclusion}

According to the results of the final section of the training of future technology teachers and the drawing for the pedagogical diagnosis of the quality of education of students, positive qualitative changes were identified in the 
formation of the preparedness of future technology teachers and drawing to pedagogical diagnostics of the quality of education. The number of students of the experimental group, which showed high level of preparedness, grew by $8.54 \%$, satisfactory - by $8.33 \%$, at the low - it decreased by $16.87 \%$.

Pedagogical diagnostics is a process in which an analysis of the learning process is carried out, an objective definition of its results, control, verification, evaluation, accumulation of statistical data, their analysis, revealing of dynamics, tendencies, forecasting of further improvement of educational quality.

A comprehensive understanding of the results of student performance, i.e. the quality level of students ' knowledge, their attitude towards the vocational subject nature and interest in learning at the ascertaining and forming stages of the experiment, led to the conclusion that the use of reasonable methods of diagnostics increased interest and improved attitude of the students to the learning, and also contributed to the increase in the level of quality of knowledge, and consequently, the quality of teacher education. Thus, the preparation of future teachers of vocational training in the field of "food technology" and "services" to the pedagogical diagnostics of the quality of education is a process in which comprehend, optimize learning, care about the objective analysis of educational outcomes, the monitoring, inspection, evaluation, accumulation of statistical data, reflection, and study the dynamics, trends, predictions about future developments. Further his work we see the development of gaming diagnostic situations.

\section{References:}

1. Bespalko V.P. (2006) Parameters and crater for diagnostical purposes. School technologies, No. 1, p. 118-128.

2. Bodnar A. (2010) Innovative technologies in the form of a monitoring and evaluation activity. School number 1, p. 5-6.

3. Viktorov V.G. (2004) Certification and accreditation of educational institutions in the quality management system. Multiversum. Philosophical Almanac. K.: Center of spiritual culture, No. 43, R. 23.

4. Podlasie I.P. (1998) Diagnostics and expertise of the pedagogical project: [textbook], K.: Ukraine, 343 p.

5. Bloom B.S., Madaus, G.F. \& Hasting, J.T. (1971) Handbook on Formative and Summative Evaluation of Student Lerning. - N.Y.: McGraw-Hill.

6. Carol Taylor Fitz-Gibbon. (1996) Monitoring Education: Indicators, Quality and Effectiveness / Taylor Fitz - Gibbon Carol. - Cassel, 259 p.

7. UniTest System - software for computer testing automation [Electronic resource]: Web page. - Access mode: http://sight2k.com/rus/unitest/ 


\section{ELABORATION OF THE METHOD OF OBTAINING THE PRODUCTS FOR THE CULTIVATION OF FLOWER PRODUCTION WITH ANTIMICROBIAL COVERING}

\section{Sorokina Svetlana ${ }^{1}$ \\ Akmen Vyktorya ${ }^{2}$}

DOI: http://dx.doi.org/10.30525/978-9934-571-26-8_18

Abstract. The purpose of the research paper is the elaboration of the method of obtaining products for the cultivation of flower products with antimicrobial covering. The method of obtaining the developed components of glutinous mixtures for antimicrobial fungal covering allows offering the way of their applying and obtaining new products which can be used for diseases prevention and treating in hothouses plants during their cultivation. Methodology. Since significant proportion of pathogens can enter the root system of in hothouses plants precisely when they are transplanted, the working hypothesis is advanced; it is in the providing of accessories and flowerpots with the ability to show prophylactic and therapeutic action against pathogens of fungal and microbial diseases of potted plants by treating their surface with disinfectant mixture. The implementation of the hypothesis is carried out by selecting of the mixture components, which have an effective action, don't have significant affect on the product price increasing and can be used in the technological process of flower and decorative goods producing without significant changes. It is facilitated by a wide range of systemic disinfectants which are presented on the market and own researches about their actions.

We have formed and scientifically grounded new ways of improving the consumer properties of products belonging to the group of flower and decorative products on the base of the theoretical and experimental researches of the study physical and mechanical and aesthetic indices of flower pots and accessories quality. Proposed ways are based on the technology of manufacturing ceramic pots and accessories for flowers with additional con-

${ }^{1}$ Candidate of Technical Sciences, Associate Professor,

Kharkiv State University of Food Technology and Trade, Ukraine

${ }^{2}$ Candidate of Technical Sciences, Associate Professor,

Kharkiv State University of Food Technology and Trade, Ukraine 
sumer properties, which are exhibited by the application of antimicrobial covering - a glutinous mixture which contains glue (on the base of flour, starch, etc.) and solution of substances which provide prophylaxis and plant protection against microbial and fungal diseases. The composition of the antimicrobial covering, the concentration of components and the duration of its action were experimentally determined. Methods of applying antimicrobial covering to a number of products for cultivating and decorating in hothouses plants (solid and striped) are proposed depending on the type of glue substance. It is established that antimicrobial covering does not affect on the processed products quality indices which were defined according to the normative standards.

The absence of microbiological damage of the covering membrane is proved; the dynamics of microbiological contamination of the soil, the inhibition of fungal diseases development and the plants decorative properties improvement were experimentally confirmed on the example of flowering plants - Cyclamen and Begonia x elatior due to the microbiological research.

Thus, the composition of the antimicrobial glutinous mixture and its method of application to the products which are used for cultivating of flower products were developed and proposed; it allowed the consumer properties increasing and obtaining new products with antimicrobial covering.

\section{Introduction}

Floriculture and design with use of flowers and flower accessories are the most developed sectors of the national economy, which bring significant profit, in most countries of the world. Recently, this trend is developing at a rapid pace, especially in Europe.

Exterior design of houses, private plots, parks, interiors of habitable and office premises with souvenirs, natural and artificial flowers, which are placed in bright pots and decorated with a number of accessories, serving as separate complement and design accent is traditional for Ukraine as a European country, and also based on national habits of the population. Now practically all companies and trading networks offer to decorate flower compositions or gift sets with bright and colorful accessories which are suitable for seasonal subjects or human nature. That is why they became good sources of income for various Ukrainian and foreign companies. However, with the development of market economy, there is an intensification of the struggle for the consumer both in the Ukrainian 
and foreign markets in this sector; it requires the intensification of scientific research, the implementation of new ideas and developments into the production and the use of new competitive products. In this regard, the formation and improvement of consumer properties of floral and decorative goods allow creation of new opportunities for their application and preservation of quality during operation, and accordingly provide increasing of competitive advantages over analogues.

New tendencies of improvement of the consumer properties of products which belong to the group of flower and decorative products are formed and scientifically substantiated on the base of theoretical and experimental researches of physical and mechanical and aesthetic indices study of flower pots and accessories quality. The proposed tendencies are related to the technology of manufacturing ceramic pots for flowers with additional consumer properties, which are manifested by the application of antimicrobial covering - glutinous mixture with the content of substances which promote the prevention and protection of plants from microbial and fungal diseases. The composition of the antimicrobial covering, the concentration of components and the duration of its action were experimentally determined. Methods of applying antimicrobial covering to a number of products for cultivating and decorating in hothouses plants are proposed depending on the type of glue substance. It is established that antimicrobial covering does not affect on the processed products quality indices which were defined according to the normative standards.

The absence of microbiological damage of the covering membrane is proved; the dynamics of microbiological contamination of the soil, the inhibition of fungal diseases development and the plants decorative properties improvement were experimentally confirmed on the example of flowering plants - Cyclamen and Begonia x elatior due to the microbiological research.

\section{Market trends and consumer properties improving of flower and decorative goods (products)}

In the 21 st century, new wave of growing interest in flower pots and accessories was appeared in Europe and America as a serious complementing and emphasizing means for flower composition. The largest flower shops began to actively engage in the cooperation small things enterprises; it would emphasize the beauty of indoor plants and the appearance of pri- 
vate plots. At the same time, the Ukrainian market of flower products annually grows by $20-25 \%$ [1-3].

The local production of accessories is not sufficiently developed in our country, therefore, this market largely depends on imports, where significant proportion is counterfeit products, its share can reach one third of the total market volume. Official importers are mostly Western European countries (France, Czech Republic, Germany, and Italy); their share is under 28\%. However, Ukrainian enterprises try to win their place on the market every year and equalize the shares of Ukrainian, Russian, European and "Eastern" products in the sales volumes of flower accessories in Ukraine [4].

In general, over the past few years, there were three main trends in the market of ceramic pots and other decorative ceramic products. First, cheap products are still in high demand and in 2016 its share has decreased slightly. Secondly, despite the rather low demand for local products in Ukraine, the Ukrainian producer continued to increase production volumes by expanding the range and developing chamotte raw materials. Thirdly, Ukraine continues to increase the volume of imports of these goods from virtually all countries-producers and in all price segments. Fourth, the Ukrainian consumer is ready to introduce new developments for increasing the competitiveness of their products. Thus, the assortment of the Ukrainian market of flower and decorative products and accessories for their cultivation is not saturated yet and will continue to increase.

At the same time, the development of the market is impossible under the presence of goods which don't meet the quality and a number of consumer properties such as functional, ergonomic, aesthetic characteristics of the copyright model, the ceramics properties and compliance with the technological process [5-8]. An important index is the microbiological stability of pottery materials and other flower accessories. That is, it is the new introduction to the formation of quality and a number of consumer properties will provide the competitiveness of local producers in the market of flower and decorative products.

The developments of scientists V. Ignatenko, V. Vohmyanina, G. Ivanova, brothers Makarov in the field of increasing the consumer properties of accessories and flower pots are known, where much attention is paid to constructive devices to pots for setting up and automation of plants watering and nutrition [9-16]. Flowers pots with design which allows preventing injury or poisoning of children and animals as a result of contact 
with plants are elaborated [17]. At present, there are a number of developments which concern new constructions, raw materials cost reducing, equipping with automatic fertilizer and irrigation devices, and other methods for improving the quality and properties of ceramic products [18-20]. The pots with improved container-devices are suggested for facilitating the formation of the plant during its growth [21] or where flowers are planted in the openings between the upper and lower parts [22; 23]. A number of works are devoted to conducting studies of assortment and quality indices of flower and decorative ceramic pots of local and foreign producers is known [24; 25]. According to the results of these works, it is established that a large proportion of the products fully corresponds to the standardized quality parameters, but they are usual means for cultivating and decorating in hothouses plants, it indicates the necessity to continue the researches for providing products with new properties.

The analysis shows that in conditions of fierce competition, the actual task for scientists is not only to control the quality of ceramic pots for flowers, but also to develop new solutions for improving the consumer properties of ceramic pots for flowers by providing them with additional functional potential and it will provide the competitiveness increasing of products of this group.

\section{Effect of diseases on the formation of potted plants properties}

Pests and pathogens, as well as diseases of physiological (non-parasitic) and infectious (fungi, bacteria, viruses, nematodes) origin, which significantly affect on general state of plants, sometimes cause their death, damage considerably of flower and decorative products. The development of harmful and pathogenic organisms is facilitated by the environmental conditions of the premises: light and temperature conditions are not always optimal and excessive air dryness is often observed. Insufficient or excessive watering, improperly selected earth mixtures, unbalanced nutrition, draughts, gas pollution and other conditions increase the influence of negative factors. Plants under proper care differ not only in high decorative, but also show increased resistance to disease, less susceptible to pest attacks [26]. It should be noted that the pathogenic fungi are the causative agents of most of the diseases of the in hothouses plants, only some of them affect on plants leaves; others cause the extinction of branches and trunks [27].

Anthracnose is quite widespread disease of indoor plants, causative agents of which are pathogenic fungi of deuteromycetes - Phylosticta, Col- 
letotrichum, Ceratocystis, Septoria, Kabatiella, Gloeosporium and many others. The reason of rotting and/or roots and root necks wilt (for rosettelike plants such as African violets) is affection by soil fungi such as Cylindrocladium, Fusarium, Phytophtora, Pythium, Rhizoctonia and many others. Among the fungi Fusarium oxesporum should be marked out, it causes vascular wilt, is one of the most common diseases of potted plants. Yellowing of leaves, their twisting and drying are signs of this disease [28; 29].

For today, systems of measures for the protection of plants against pests and diseases are developed for various types of open ground and in hothouses plants, these measures include preventive (agrotechnical, selective, quarantine) and exterminative (chemical, biological, mechanical) methods of control, which mutually complement each other [30]. Fungicides and bactericides are main among chemical agents for the protection of potted flowers in closed premises, they completely (fungicidal) or partially (fungistatic) inhibit the development of pathogens of plant diseases and now they are actively used for pest control $[31 ; 32]$.

The necessity of use the measures for prevention and prophylaxis of plant infections by fungal and microbial diseases during their growth is conditioned by the fact that significant percentage of soil mixtures which are presented in the Ukrainian market may contain fungal germs of certain diseases at the time of their selling because of non-compliance with storage conditions. The young plants which are firstly planted in pot with soil the most sensitive to the infection contamination. It is difficult for an inexperienced consumer to choose necessary disinfectant, in addition, there is not always time for its purchasing and preparation for use, and sometimes just careless attitude causes the plant death. Therefore, the development of such products and means of control and prevention of diseases, where system addition to the soil of disinfectants occurs mediated indirectly from the actions of plant owner and provides neutralization the fungi germs of the most common diseases becomes topical problem.

\section{Hypothesis of antimicrobial covering elaboration on products for flower products cultivating}

The studies of consumer properties of floral and decorative products, namely, pots for their cultivation show that although local producers' products meet the requirements of regulatory documentation on organoleptic and physical and chemical indices for this type of product, but are inferior 
to imported products of the same name on the decorative design quality. Foreign producers also win due to the availability of larger material base, which updates the need to develop and implement new scientific advances for solving the problem of the industry. Thus, the problem of improving the consumer properties of goods for cultivating and decorating in hothouses plants arises in conditions of fierce competition.

According to scientific research and a number of literary sources significant factor in the formation of new consumer properties and, accordingly, the quality of pots for the cultivation in hothouses plants is the possibility of creating medium which provides protection or prevents the emergence and reproduction of fungal and microbial diseases. Under this condition the important factor is the lack of influence on the organoleptic and physical and chemical indices of quality as of new products and on the growth and development of decorative properties of the plant directly.

Since significant proportion of pathogens can fall into the root system of in hothouses plants precisely under their transplanting, the working hypothesis is advanced, it is in the possibility to provide pots for flowers cultivation with ability to exhibit prophylactic and therapeutic action for controlling pathogens of fungal and microbial diseases of potted plants by treating their surface with disinfectant mixture. Implementation of the hypothesis is possible in the conditions of selection of mixture components, which will have an effective action, not significantly affect the product price increasing and can be used in the technological process of producing flower and decorative goods without significant changes. It is facilitated by a wide range of systemic disinfectants which are available on the market and the results of own researches about their action.

The proposed working hypothesis with taking into account the above mentioned can be transformed into an innovative strategy for the introduction of the final technological operation for the processing of flower accessories and containers for the cultivation of in hothouses plants with specially prepared disinfectant mixtures in the solution of astringent which provide the prevention of fungal diseases. And from the goal achieving standpoint the implementation of the components of the innovation strategy is, mainly, for obtaining the plants with good decorative properties under the lack of their cultivation experience.

The ways and methods by which the application of the disinfecting mixture is possible: covering the inside surface of boxes for bulbous flowering 
plants cultivation; covering the surface of flowers accessories which have contact with the soil; covering the inside surface of ceramic pots for flowers cultivation are proposed on the base of assortment of flower and decorative goods which are directly interconnected with the soil or parts of the plants during their cultivation.

It is assumed on the base of the theory of gradual solubility of certain types of glutinous solutions that the applied on flower and decorative product membrane which contains the decontamination solution gradually dissolves and the solution substrate gradually passes to the soil with each plant watering. In this way, the gradual decontamination and protection of the soil will occur.

The tasks of the presented in this paper research include the substantiation and selection of components for the disinfection mixture, the choose of the method of applying it to selected research objects and confirming of the pots' consumer properties increasing for the cultivation of plants obtained with the application of the proposed technological stage; confirmation of the effectiveness of the action and the gradual transition of disinfectants into the soil by conducting its microbiological research and observing the change in the aesthetic properties of the experimental plants.

\section{Elaboration of the antimicrobial covering composition and methods of its use}

The research is aimed at developing the composition of the antimicrobial covering and studying the ways of its applying to ceramic products for proving the hypothesis of the possibility of manufacturing the pots, which apart from their main purpose, would have additional consumer properties, namely the ability to neutralize pests in the soil and prevent fungal diseases. Samples of ceramic pots, water soluble glue substances and decontamination solutions were selected as objects for further research [33]. The studies were conducted in several stages. At the first stage, work was devoted to the development of an antimicrobial mixture of fungicide and water soluble astringent, which was applied to the walls of ceramic pots, and exhibited after placing in pots of soil and plants its neutralization effect under plants' watering for a long time. At the second stage, the absence of changes in the quality of the pots with antimicrobial covering and their shelf life were determined. At the third stage, the effectiveness of the selected mixture was checked through microbiological analysis. 
At the beginning, water solution of potatoes starch paste was chosen as glue agent, because of its ability to gradual dissolution in water, starch safety for plants and low cost. Systemic fungicide "Phytosporin-M" was chosen as a solution for treating pots for prevention microbiological and fungal diseases of plants [34]. The preparation "Phytosporin-M" was prepared by dissolving 0,5 liters of water at $20^{\circ} \mathrm{C}$ according to the instructions; then starch paste was prepared by dissolving it in the prepared solution "Phytosporin-M", with its further brewing, in three concentrations: liquid 2: 1 , medium cream-like 7:1, ointment-like 10:1. The ratio of starch and water 7:1 was chosen experimentally as the optimum consistency, which made it possible to obtain cream-like consistency of paste. Such paste under drying firmly fixes on the surface without cracking and splashing. The layer of astringent $-1.5 \ldots 2 \mathrm{~mm}$ is experimentally determined; it quickly hardens, minimizes the appearance of cracks and provides good adhesion with pot's crock. In addition, such thickness should be resistant to swelling and not provide significant nutrient medium for the development of microbes, molds, etc., but it required experimental confirmation.

The experimental samples of the pots were treated by applying of glutinous mixture (potato starch paste and fungicide "Phytosporin-M") along the entire interior surface of the walls (fig. 1) and left for gelling with a periodic (every $10-15 \mathrm{~min}$ ) drying at temperature of $150 \ldots 180^{\circ} \mathrm{C}$.
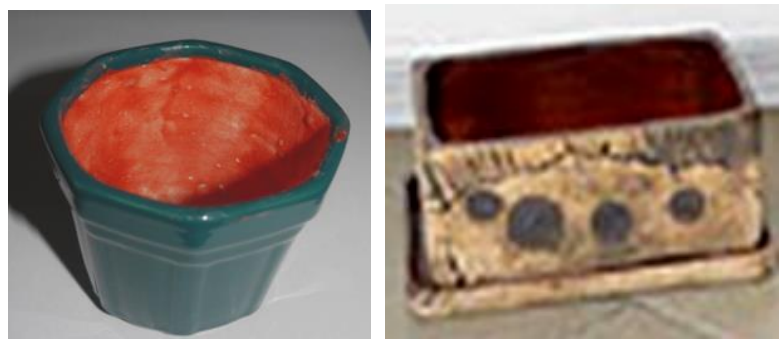

\section{Fig. 1. Ceramic pots with antimicrobial covering of the interior surface}

The pots samples were filled up with usual soil for flowers and it was watered with settled water during 6 months for determining the ability and time of gradual dissolution of the astringent. The quantity of water was selected 
according to known literature data $[35 ; 36]$ about standard watering of in hothouses plants. At the same time, the possibility of dissolving and the presence of astringent on the walls of the pot were determined due to the available color of water, which passed through the thickness of the soil and went through hole at the bottom of the pot. Studies show that glutinous mixture of potato starch paste and fungicide can gradually dissolve under watering the soil during the whole study period, although the color gradually lightens as the paste concentration decreases on the walls of the pot and, consequently, in water.

Since potato starch paste is nutrient medium for the propagation of fungi and yeast spores, and also may be contaminated with potato bacillus spores, a number of studies have been conducted on the development of microbial contamination in the prepared glutinous mixture (the solution of "Phytosporin-M" and starch). The research sample was taken in 12 hours, in a day and in 36 hours after its preparing. The microbiological analysis included standard operations [37]. Studies have shown that after 7 days characteristic colonies formed on the medium of MPA, and they were considered on the dishes with small magnification $(10 \times 10)$ of microscope. The results of the studies were compared with Sanitary Rules and Standards 2.3.21078-01 [38] (table 1).

Table 1

\section{Microbiological indices of potato starch paste and fungicide "Phytosporin-M" during storage $(n=5, P \geq 0,95)$}

\begin{tabular}{|l|l|l|l|l|}
\hline \multirow{2}{*}{\multicolumn{1}{|c|}{ Indices }} & \multicolumn{2}{c|}{$\begin{array}{c}\text { The paste mixture from potato } \\
\text { starch and fungicide }\end{array}$} & \multicolumn{1}{|c|}{$\begin{array}{c}\text { Norms } \\
\text { according to } \\
\text { Sanitary Rules } \\
\text { and Standards }\end{array}$} \\
\cline { 2 - 5 } & $\begin{array}{c}\text { after } \\
\text { 12 hours }\end{array}$ & $\begin{array}{c}\text { after } \\
\mathbf{2 4} \text { hours }\end{array}$ & $\begin{array}{c}\text { after } \\
\mathbf{3 6} \text { hours }\end{array}$ & $\begin{array}{l}\text { not found } \\
\text { not found } \\
\text { allowed }\end{array}$ \\
\hline Escherichia coli & not found & not \\
\hline $\begin{array}{l}\text { Number of mesophilic } \\
\text { aerobic and facultative } \\
\text { anaerobic microorganisms, } \\
\text { CFU/g }\end{array}$ & $4,1 \times 10^{3}$ & $4,7 \times 10^{3}$ & $5 \times 10^{3}$ & $\begin{array}{l}5 \times 10^{3} \mathrm{CFU} / \mathrm{g}, \\
\text { not more }\end{array}$ \\
\hline $\begin{array}{l}\text { Number of fungi spores, } \\
\text { CFU/g }\end{array}$ & 170 & 180 & 195 & $\begin{array}{l}200 \mathrm{CFU} / \mathrm{g}, \\
\text { not more }\end{array}$ \\
\hline $\begin{array}{l}\text { Number of yeast spores, } \\
\text { CFU/g }\end{array}$ & 55 & 100 & 120 & $\begin{array}{l}100 \mathrm{CFU} / \mathrm{g}, \\
\text { not more }\end{array}$ \\
\hline $\begin{array}{l}\text { Number of Bacillus } \\
\text { mesentericus spores, CFU/g }\end{array}$ & $100 \mathrm{CFU/g}$ & $120 \mathrm{CFU} / \mathrm{g}$ & 150 & $\begin{array}{l}\text { Not more than } \\
200 \mathrm{CFU} / \mathrm{g}\end{array}$ \\
\hline
\end{tabular}


As it can be seen from the data of table values of all indices after 12 hours after preparation of suspension from potato starch paste and fungicide are lower than it is allowed by Sanitary Rules and Standards. Moderate increasing of microbiological contamination is observed after 24 hours, but it is within the norm limits, which allows recommending of this term for storage the prepared glutinous mixture of potato starch paste and fungicide "Phytosporin-M", before applying it on the pot surface.

Determining of the pot quality with an antimicrobial covering during storage is the task of further studies. Since the starch and, accordingly, the mixture on its base has high sorption properties, the study of antimicrobial covering humidity was carried out during pots storage. It allows to prove that under thickness of $1,5-2 \mathrm{~mm}$, the humidity of the covering for 9 months is within the recommended limits.

The effect of the antimicrobial mixture (potato starch paste and fungicide "Phytosporin-M") on pot crock porous corking is further studied, it in some way effect on the moisture absorption index (it should be $14-19 \%$ for majolica and pottery products), and according to the index of air permeability, which are important for the development and function of the root system of in hothouses plants. Studies show that the porosity of the crock (according to State Standard 473.3 [39]) of both samples is standard (within $14-19 \%)$ and the use of antimicrobial covering affects on its index insignificantly. Moreover the study showed that after 6 months, the index returns to the previous level, it indicates the washout antimicrobial covering particles. Investigation of the water resistance index of the crock showed that after the application of the antimicrobial covering, the time of the appearance of the wet trace on the side wall of the pot was within the experimental error compared with the control sample. That is, the covering is well soluble in water and does not provide clogging of the crock's natural pores.

Studies of the heat resistance of new pots were carried out in accordance with State Standard 53546-2009 [40] with use of drying oven and thermostat. Studies show that there are hardly noticeable cracks on the surface of the antimicrobial covering in the corner of the products after 6 months of storage which appear at increasing of temperature to $150{ }^{\circ} \mathrm{C}$ and they are permissible for non-food products using.

The microbiological study of pots crock with an antimicrobial covering (from potato starch paste and fungicide "Phytosporin-M") during storage at $18{ }^{\circ} \mathrm{C}$ and humidity of $70 \ldots 75 \%$ determine that all microbiological indices 
after 6 months are within the limits allowed by Sanitary Rules and Standards, which is facilitated by the small thickness of the covering and the low humidity of the pot's crock and the covering membrane (samples were prepared similarly to the above mentioned).

Thus, it is established that pots with antimicrobial covering during 6 months of storage (under air humidity of $70-75 \%$, temperature $18 \pm 2{ }^{\circ} \mathrm{C}$ ) meet the requirements for ordinary ceramic pots.

At the third stage, studies were conducted for proving the effectiveness of the proposed development. For this purpose, the research of the growth and development of the widespread potted plant Begonia $\mathrm{x}$ elatior, which is transplanted into antimicrobial pot (transplantation of the diseased plant together with the soil), was carried out. The choice of plant Begonia x elatior is occurred on the base of the presence of symptoms of powdery mildew (Peronospora parasitica) which is caused by lower fungus Peronospora (the presence of savoyed leaves on one side of the plant, and yellow-green round shape oily spots which are limited by veins on the leaves and gray-violet coat on the underside of leaves) for visualizing the results of external changes under plant cultivation and identifying of the decontamination effect action. The studies were conducted during 16 weeks, with ordinary care and standard watering. The visual observation of plants was accompanied by the sampling of soil for studying the degree of its contamination with fungal diseases, through microbiological research. Selection of soil samples for research was carried out by quartization method with further sifting through sieve with diameter of $3 \mathrm{~mm}$; Then $10 \mathrm{~g}$ of soil was taken, small amount of distilled water was added and it was rubbed to the pastelike state. The dilution 1:10 was done. The grant suspension was treated with use of ultrasound apparatus during 3 minutes, for good dispersion providing before microbiological seeding. Preparation of vivifying medium and sowing were carried out according to the standard method. Surface seeding was carried out on Petri dishes (it is possible to use one method for studying different groups of microorganisms). Sown dishes were incubated during 7 days at temperature of $26^{\circ} \mathrm{C}$ and further studied under microscope magnification $10 \times 10$.

The calculation of isolated Peronospora fungal germs number in the soil was carried out according to the following formula:

$$
a=\frac{b c d}{e}
$$


де $a$ - number of fungal germs in $1 \mathrm{~g}$ of soil; $b$ - the average number of colonies per dishes; $c$ - cultivation from which the inoculation was made; $d$-number of drops in $1 \mathrm{ml}$ of suspension; $e$ - mass of soil taken for analysis, $g$.

The described above microbiological studies were repeated 4 times with periodicity of 3 weeks. Decreasing of Peronospora fungal germs in the soil was observed during that period. The data from fig. 2 confirmed that fact [41].

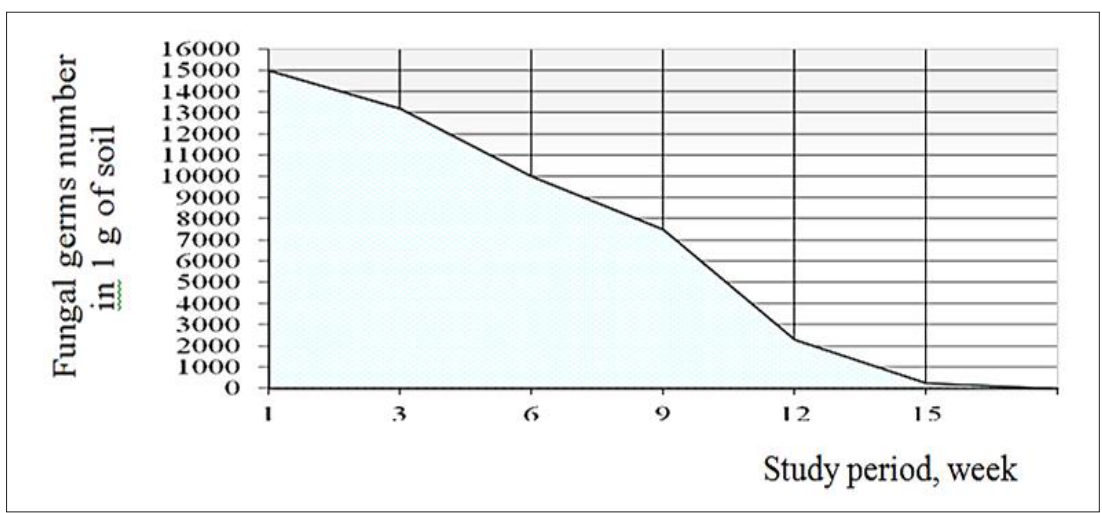

Fig. 2. The dynamics of Peronospora fungal germs number decreasing in the soil

Fig. 2 data show that number of fungal germs decreases after three weeks of watering, then gradual decreasing of fungal contamination was observed every 3 weeks of soil intake and microbiological studies showed that Peronospora fungal germs were almost not identified in $1 \mathrm{~g}$ of soil after 16 weeks. It is satisfactory index for the normal plant development.

The visual observation of the aesthetic and decorative characteristics of the plant Begonia x elatior shows significant improvement of the plant state after ten weeks: gray-violet coat on the underside of leaves disappeared; savoyed leaves had to be removed, but the new shoots of the leaves were healthy, without disease's symptoms.

The conducted studies show the effectiveness of the proposed development and the expedience of use the mixture, which includes potato starch paste and "Phytosporin-M" for application to the walls of ceramic pots for 
obtaining new products with improved consumer properties - pots with antimicrobial covering. New products are able to carry out not only preventive action against the pathogens of plant diseases, but also help to neutralize fungal diseases.

Thus, glue solution with mixture of potato starch paste and fungicide "Phytosporin-M" in ratio of 1:7 is proposed, it is expedient for use as antimicrobial covering for application to the interior surface of flower pots (with layer of $1,5-2 \mathrm{~cm}$ ) and the production of pots with antimicrobial covering with stable consumer properties (microbiological parameters are within the limits allowed by Sanitary Rules and Standards, crock's porosity is at the level of $16-18 \%$, absence of crock's water penetration, humidity of the covering membrane is at the level of $12 \%$ ) during 6 months of storage under conditions of air humidity $70-75 \%$ and temperature of $18 \pm 2{ }^{\circ} \mathrm{C}$.

Series of experiments were carried out for further proving the validity of the hypothesis under conditions of selection of other components for the antimicrobial covering mixture after obtaining positive result of studies the stability of the quality and efficacy of the proposed antimicrobial covering on the base of potato starch and "Phytosporin-M" on the interior surface of ceramic flower pots.

Therefore, the following samples were selected in the further work, as the water-soluble astringent for the development of antimicrobial mixture: 1 - carboxymethylcellulose (CMC), 2 - polyvinyl acetate, 3 - styrene acrylate [29]. The choice of these substances is conditioned by their ecological safety and the ability to form glue astringent solutions which are water soluble, but more resistant to water action compared with starch based paste, and therefore, able to give disinfectant to the soil with plants more longer, which is more rational. Preparation "Fundazol" is selected as solution for prevention microbiological and fungal diseases of plants. The sequence of the main stages of work was similar to the previous one.

Three samples of antifungal action glue mixture with optimal concentration of astringent substance (100 g of CMC per $250 \mathrm{ml}$ of the solution of the preparation "Fundazol", $50 \mathrm{~g}$ of polyvinyl acetate per $25 \mathrm{ml}$ of solution of the preparation "Fundazol" and $30 \mathrm{ml}$ of sterol acrylic per $250 \mathrm{ml}$ of solution of the preparation "Fundazol") were prepared for the research. Water-soluble paint of certain color was added to each sample, which was used as indicator for checking the solubility of used mixture. 
The assumption (hypothesis) about the effectiveness of the antifungal action glue mixtures are prepared on the base of water-soluble astringents under using them on the walls of the pots with non-solid layer, but in the form of strips (fig. 3) arises since the samples of water-soluble astringents are quite expensive. For the realization of the hypothesis, Obtained three samples of the glutinous mixture of antifungal activity were applied to the interior walls of the pots in the form of closed strips with width of $1,5 \mathrm{~cm}$ and thickness of1,5 $-2 \mathrm{~cm}$. The pots were left after application for solidification for 2 days with periodic (every 6 hours) drying at temperature of $150-180{ }^{\circ} \mathrm{C}$ [42]. The thickness of the layer of $1,5-2 \mathrm{~mm}$ was chosen on the base of previous studies, resistance to swelling, index of crack resistance and adhesive properties of the mixture. The index of resistance to microorganisms in the layer of the glue mixture was not taken into account on the base of the absence in the mixture composition of natural nutrient substrate.

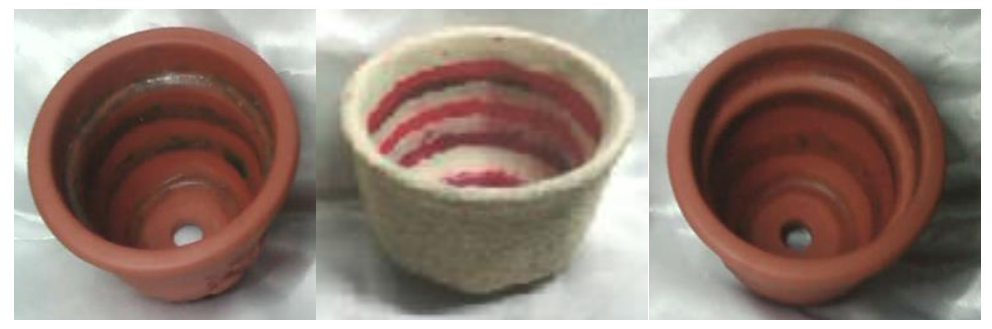

\section{Fig. 3. Ceramic pots with use of antifungal action glutinous mixture}

Soil which was watered by settled water during 6 months, similar to the previous research was introduced into studied pots. Conducted studies ascertain that the glutinous mixture of CMC with "Fundazol" is able to gradually dissolution under watering the soil with water which releases the antifungal preparation "Fundazol". The glue mixture of polyvinyl acetate with "Fundazol" shows weak solubility: the water solution after watering had much lighter color and was coloured for more than 12 months. The third sample of the glutinous mixture remained on the walls of the pot; water under watering was not coloured during the whole study period, it was explained by the formation of membrane which prevented transition of the antifungal agent into the soil. That is why the samples number 2 and 3 were excluded from further researches. 
Further studies were aimed at determining the quality of pots with antifungal covering which was applied according to the economical technology and determination the terms of new products storage. As in previous studies, the effect of antifungal covering on the porosity of the crock has been investigated. It is found that the porosity of the crock after antifungal covering application decreases, but it remains within the normal range $-16.2 \%$, which indicates the effect of the astringent CMC on the possibility of clogging the pores of pots' crock because of the dense membrane formation; this membrane has good adhesion and doesn't dissolve rapidly in water. Investigation of the water inpermeability index of pots' crock shows that wet trace on the side wall appears after 23 hours in pot sample without applying antifungal covering; wet trace on the side wall appears after 25 hours in pot sample with antifungal covering on the base of CMC with "Fundazol". It indicates that the antifungal covering forms membrane which protects the porous walls of the ceramic pot from water infiltration, but this membrane has the ability to gradually dissolving.

After research the compliance of the pots with antifungal covering on the base of CMC with "Fundazol" with the requirements of the normative documentation on heat resistance [40] it is noted that the sample with antifungal covering has high resistance to high temperatures: noticeable cracks in the antimicrobial covering appear only after the temperature increasing to $150{ }^{\circ} \mathrm{C}$ on samples which were stored during 12 months. The rational storage period of pots with antifungal covering is 9 months on the based of obtained results.

The effectiveness of glue mixtures samples was checked at the next stage of the work. For this purpose, the soil is infected with vascular wilt (Fusarium oxesporum), was placed in the test pot, after which the contaminated soil was watered with settling water during 6 months and the changes of Fusarium oxesporum fungal germs in the soil were observed by microbiological researches (similar to the previous one). Decreasing of Fusarium oxesporum fungal germs number in the soil was observed during the experiment. The data are presented in fig. 4 prove this fact [43].

As it can be seen from data of fig. 4 the number of fungal germs in the soil was the largest during the first study. The number of fungal germs began to decrease three weeks later. The number of fungal germs significantly decreased after 12 weeks (more than in four times as compared to the 


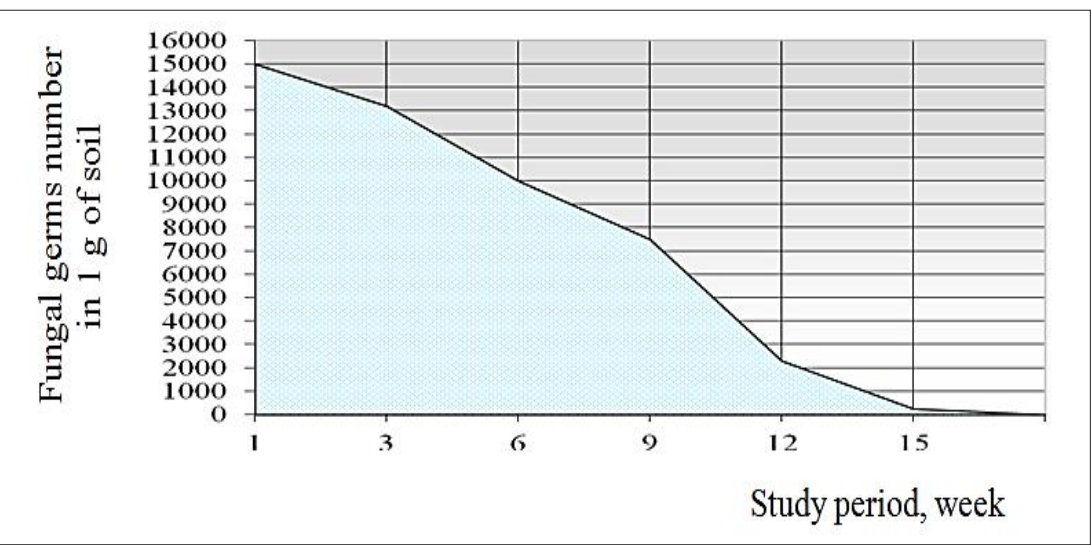

Fig. 4. The study of dynamics of Fusarium oxesporum fungal germs number decreasing in the soil

initial contamination). Fusarium oxesporum fungal germs were not almost identified during the last study.

The visual observation of pots with antifungal action ability to neutralize pathogens of fungal diseases of potted plants is conducted along with microbiological studies. Cyclamen is affected by fungus Fusarium oxesporum was chosen for the research. It has such disease symptoms: the yellowing of leaves, which begins with the tops, is external onset of the disease. Yellowing and fading were observed on one side of the plant. The other side of Cyclamen continued its growth, but without flowering. The affected plant with the above-described symptoms of fusariosis was planted in pot treated with antifungal covering on the base of glutinous mixture of CMC and "Fundazol", after which periodic watering of the plant was carried out. Three months later, significant improvement in the state of the plant was noted. The affected side of the plant could not be saved. Since fusariosis is treated at the initial stages, but yellowing and fading of new leaves were not observed; the growth of the poor crop side increased. The plant almost completely renewed its state after 15 weeks.

It is established that treating of the interior surface of ceramic pots with glutinous mixtures of antifungal action on the base of antifungal preparation "Fundazol" and CMC, in the form of closed strips of $1,5 \mathrm{~cm}$ wide and thickness of $1,5-2 \mathrm{~cm}$, provides obtaining pots for flowers with antifun- 
gal covering, which promotes not only the implementation of preventive action against the soil causative agents of diseases of potted plants, but also the neutralization of contaminated by vascular wilt (Fusarium oxesporum) causative agents soils; which is proved by microbiology studies on the example of Cyclamen house plant. It is determined that pots with antifungal covering which is economically applied meet the quality standards (crock porosity is $16,2 \%$, heat resistance is up to $150{ }^{\circ} \mathrm{C}$ without covering cracking) and have recommended shelf life of 9 months at humidity of 70-75\% and temperature of $18 \pm 2{ }^{\circ} \mathrm{C}$.

\section{Conclusions}

1. The method of obtaining products for cultivation of floral products with antimicrobial covering is proposed and the possibility of realizing the hypothesis of antimicrobial medium creating, which helps protecting or preventing the emergence and reproduction of fungal and microbial diseases is proved.

2. The principle of formation of such medium as new antimicrobial covering on the base of mixture of water-soluble substance and preparations with prophylactic and therapeutic effects on pathogens of fungal and microbial potted plants diseases is developed and proved.

3. The selection of mixture components which have effective action, don't significantly affect on the product's price increasing and can be used in the technological process of producing flower and decorative goods without significant changes is carried out.

4. The method of applying of new antimicrobial covering to the interior surface of flower pots in the form of solid layer or closed strips of $1,5 \mathrm{~cm}$ wide and 1,5-2 cm thickness is presented.

5. It is shown that pots with developed antimicrobial and antifungal covering meet the standards according to quality indices (crock porosity, water absorption, heat resistance) and have the recommended shelf life of 6 and 9 months, respectively, at humidity of $70-75 \%$ and temperature of $18 \pm 2{ }^{\circ} \mathrm{C}$.

6. It is experimentally proved (on the example of plants (Cyclamen and Begonia $x$ elatior) cultivation and microbiological studies of the soil) that the treatment of the interior surface of ceramic pots with antimicrobial covering provides not only the implementation of preventive action against the soil causative agents of plant diseases, but also the neutralization of 
pathogens of fungal diseases in contaminated soils and gradual renewal of the decorative state of plants.

The next stage of experimental research is planned to be carried out in the field of proving the possibility of treatment with antimicrobial mixtures of a number of other products for cultivation and decorating of in hothouses plants.

\section{References:}

1. Vysotskyi A.L., Bodnar A.V., Dzelendziak Yu.A. (2012) Lohistyka kvitiv v Ukraini [Logistics of flowers in Ukraine]. Lviv Polytechnic National University Institutional Repository. Retrieved from http://ena.lp.edu.ua:8080/bitstream/ ntb/16007/1/6-Vysotsky-34-37.pdf

2. Shvahuliak-Shostak O. (2007) Mystetstvo ne potrebuie zhertv [Art doesn't demand the victims]. Magazine Contacts, no. 37, pp. 23-25.

3. Solomakha I.V. (2012) Osoblyvosti funktsionuvannia vitchyznianoho rynku produktsii kvitnykarstva [Features of functioning of the domestic market of production of floriculture]. Bulletin of the Ternopil national economic university, no. 3 , pp. 33-41.

4. Moroz I.I. (1984) Tekhnologiya farforo-fayansovikh izdeliy. [Technology farforo-fayansovikh of products]. Moscow: Stroyizdat. (in Russian)

5. Khodykin A.P., Liashko A.A., Voloshko N.I., Snytko A.P. (2006) Tovaroznavstvo neprodovolchykh tovariv [Merchandizing of nonfoods]. Moscow: Dashkov and K. (in Russian)

6. Kardash V.Ya., Pavlenko I.A. (2002) Tovarna innovatsiina polityka [Commodity innovative policy]. Kiev: Kiev national economic university. (in Ukrainian)

7. Sorokina S.V., Zakharenko V.O., Diakov O.H. (2013) Patent 84961 Ukraine, A01G 9/01. Syhnalizator dlia pidtrymky optymalnoi volohosti gruntu v kvitkovykh horshchykakh [Signaling device for maintenance of optimum humidity of the soil in flowerpots], No u201304254; stated 20.08.2013; posted. 11.11.2013; bulletin No. 20.

8. Chuchkin V.G., Legkov S.E., Fedotova L.V., Iordan A.G. (1996) Patent $2070782 \mathrm{RF}, \mathrm{A} 01 \mathrm{G}$ 9/02. Ustroystvo dlya vyrashchivaniya rasteniy s avtomaticheskim uvlazhneniem pochvy [The device for cultivation of plants with automatic moistening of the soil], stated 30.05.1994; posted. 27.12.1996.

9. Ignatenko V.V, Sel'kov V.K. (1992) Patent 1706461 SSSR, A01G 9/02. Gorshok dlya tsvetov [Flower pot], No 4311631/15; stated 25.08.1987; posted. 23.01.1992; bulletin No. 3 .

10. Shchepochkina Yu.A. (2008) Patent 2327340 RU, A01G 9/02. Gorshok dlya tsvetov [Flower pot], stated 27.10.2006; posted. 27.06.2008. Retrieved from http://www.findpatent.ru/patent/232/2327340.html

11. Akhmedov Yu. (1986) Patent 1454311 SSSR, A01G 9/02. Sposob izgotovleniya korneobitaemogo pologo gorshochka [Way of production of a korneobitayemy hollow pot], No 4073491/30-15; stated 16.04.86; posted. 30.01.86; bulletin No. 4. 
12. Vinogradov A.V. Patent 2086102 RU, A01G 9/02, A01G31. Sposob vyrashchivaniya rasteniy i ustroystvo dlya vyrashchivaniya rasteniy [Way of cultivation of plants and the device for cultivation of plants]. Retrieved from http://www.findpatent.ru/patent/208/2086102.html

13. Sevelev N.V., Konovich A.Ya., Dragunov I.A. (1986) Patent 961174 SSSR, A01G 9/02. Ustroystvo dlya proizvodstva gorshochkov [The device for production of pots], No 2938821/30-15; stated 06.06.80; posted. 07.10.86; bulletin No. 37.

14. Makarov A.N., Makarov A.A. (1994) Patent 2010492 RF, A01G 9/02. Gorshok dlya vyrashchivaniya rasteniy [Pot for cultivation of plants], No 4937927/15; stated 28.03.91; posted. 15.04.94; bulletin No. 7.

15. Vokhmyanin V.G. (1994) Patent 2011335 RF, A01G 9/02. Tsvetochnyy gorshok [Flowerpot], No 5028935/15; stated 25.02.92; posted. 30.04.94; bulletin No. 8 .

16. Ivanova G.A. (1991) Patent 1692383 SSSR, A01G 9/02. Razbornoy tsvetochnyy gorshok [Folding flowerpot], No 47110799/15; stated 28.06.89; posted. 23.11.91; bulletin No. 43.

17. Anokhina O.O., Sorokina S.V. (2007) Doslidzhennia spozhyvchykh vlastyvostei keramichnykh vyrobiv [Research of consumer properties of pottery]. Proceedings of the Sotsium. Nauka. Kultura: II Vseukrainska naukovo-praktychna Internet-konferentsiia (Ukraine, Kiev, on January 29-31, 2007), Kiev: Meganom, part 2, pp. 61-63.

18. Musiienko M.M. (2001) Fiziolohiia roslyn [Phytophysiology]. Kiev: Fitosotsiocentre. (in Ukrainian)

19. Kefeli V.I. (1991) Fiziologiya rasteniy s osnovami mikrobiologii [Physiology of plants with fundamentals of microbiology]. Moscow: Agropromizdat. (in Russian)

20. A. Yousser, K.A. El-Tarabily, A.M. Hussen (2001) Pletosporium tabacium root rot disease of white lupiand its biological control by Streptomyces spicies. Phytopathol Journal, vol. 1, no. 149, pp. 29-33.

21. Rukavitsina I.V. Nechay N.L., Karamshuk Z.P. (2008) Fungitsidnoe deystvie vodnykh vytyazhek vysshikh rasteniy na morfologiyu gribov roda fusarium [Fungicide action of water extracts of the higher plants on morphology of mushrooms of the sort fusarium]. Proceedings of the Sovremennaya mikologiya v Rossii: II s"ezd mikologov Rossii (Russia, Moscow, on April 18, 2008), Moscow: National academy of a mikotologiya, pp. 299-300.

22. Trybel S.O. Stryhun O.O. (2013) Zakhyst roslyn - realnyi napriam zbilshennia vyrobnytstva roslynnytskoi produktsii [Protection of plants - the real direction of increase in production of crop production]. Zakhyst $i$ karantyn roslyn, mizhvidomchyi tematychnyi naukovyi zbirnyk [Protection and quarantine of plants, interdepartmental thematic scientific collection]. Kiev: Institute of protection of plants of National academy of agrarian sciences of Ukraine, no. 59, pp. 324-336.

23. Primenenie fungitsidov [Use of fungicides]. Retrieved February 20, 2018, from https://iplants.ru/preparats3.htm

24. Sorokina S.V, Talaieva O.V. (2012) Doslidzhennia orhanoleptychnykh pokaznykiv ta pokaznykiv bezpechnosti keramichnykh vyrobiv dlia kvitiv [Research of organoleptic indicators and indicators of safety of pottery for flowers]. Proceedings 
of the Aktualni problemy rozvytku kharchovykh vyrobnytstv, hotelnoho, restorannoho hospodarstv i torhivli: vseukrainska naukovo-praktychna konferentsiia molodykh vchenykh i studentiv (Ukraine, Kharkiv, on April 25, 2012), Kharkiv: Kharkiv state university of food and trade, part 2, pp. 24.

25. Shuvalov V.N. (2018) Fungitsidy dlya komnatnykh rasteniy: vidy i nazvaniya [Fungicides for houseplants: types and names]. Retrieved February 20, 2018, from https://klumba.guru/uhod-za-rasteniyami/fungicidy-dlya-komnatnyh-rasteniy-vidy-i-nazvaniya.html\#hcq=NmGzmJq

26. Ganichkina O. (ed.) (2001) Bol'shaya kniga sadovoda i ogorodnika [Big book by the gardener and gardener]. Moscow: New wave. (in Russian)

27. Tabolkin D., Vasil'eva E., Pernat'ev Yu. (2010) Komnatnoe tsvetovodstvo [Room floriculture]. Kiev, Folio. (in Ukrainian)

28. Mudretsova-Viss K.A., Kudryashova A.A., Dedyukhina V.P. (2001) Mikrobiologiya, sanitariya $i$ gigiena [Microbiology, sanitation and hygiene]. Moscow: Business literature. (in Russian)

29. Cherkes F.K., Bel'skaya N.A., Bogoyavlenskaya L.B. (1986) Sanitarnobakteriologicheskoe issledovanie pochvy [Sanitary and bacteriological research of the soil]. Mikrobiologiya [Microbiology]. Moscow: Medicine, pp. 385-402.

30. Sorokina S.V., Horbenko O.O. (2008) Rozrobka dodatkovykh vlastyvostei keramichnykh horshchykiv dlia kvitiv [Development of additional properties of ceramic flower pots]. Visnyk Natsionalnoho tekhnichnoho universytetu "Kharkivskyi politekhnichnyi instytut": Zburnyk naukovykh prats. Tematychnyi vypusk "Khimiia, khimichna tekhnolohiia ta ekolohiia" [Bulletin of the National technical university "Kharkiv Polytechnical Institute": Collection of scientific works. Thematic release "Chemistry, chemical technology and ecology"]. Kharkiv: National technical university "Kharkiv Polytechnical Institute", no. 10, pp. 82-84.

31. Sorokina S.V., Karpenko Z.P., Ivanova A.A. (2007) Do pytannia nadannia keramichnym horshchykam dlia kvitiv dodatkovykh spozhyvchykh vlastyvostei [To a question of providing additional consumer properties to ceramic flower pots]. Proceedings of the Rozvytok naukovykh doslidzhen - 2007: mizhnarodna naukovo-praktychna konferentsiia (Ukraine, Poltava, on November 26-28, 2007), Poltava: Inter-graphics, no. 10, pp. 103-105.

32. Tarasenko O.S., Sorokina S.V. (2010) Ekspertyza yakosti ta napriamy polipshennia pozhyvnykh vlastyvostei keramichnykh horshchykiv dlia kvitiv [Examination of quality and direction of improvement of consumer properties of ceramic flower pots]. Proceedings of the Ekspertna diialnist v mytnii spravi: problemy ta perspektyvy: Vseukrainska konferentsiia studentiv i molodykh vchenykh (Ukraine, Donetsk, on April 6, 2010), Donetsk: Donetsk national university of economy and trade, pp. 282-284. 


\section{ORGANOSOLV PULPING OF WHEAT STRAW}

\section{Trembus Iryna ${ }^{1}$ \\ Halysh Vita ${ }^{2}$}

DOI: http://dx.doi.org/10.30525/978-9934-571-26-8_19

Abstract. The aim of the study was the development of scientifically grounded technological modes for the production of pulp from wheat straw by more environmentally friendly organosolv methods of delignification and its application in the composition of cardboard and paper products. The influence of the temperature mode, cooking time and the consumption of chemicals on the quality indices of organosolv straw pulp was studied in details. The influence of the catalytic action of anthraquinone on the quality indices of straw pulp obtained by ammonia sulfite-alcohol and twostage alkaline-alcohol methods of cooking was studied. It was established that the use of anthraquinone with the consumption of $0.1 \%$ of oven dry material contributes to an increase in yield by $2-6 \%$ in the case of twostage alkaline-alcohol delignification, a decrease in the content of lignin by $0.4-1.0$ and $0.3-1.9 \%$, respectively, and an increase in physical and mechanical properties on average by $25-30 \%$, compared with similar pulping without catalyst. The regression equations of the processes of obtaining straw pulp using the method of a full factorial design were obtained. Optimization methods using a generalized Harrington's desirability function were applied to obtain optimal parameters for organosolv delignification of wheat straw. The indices of the selectivity of lignin dissolution from wheat straw during pulping and the kinetic characteristics of the investigated methods of delignification were calculated. It was established that the highest selectivity correspond to ammonia-sulfite-alcohol and alkaline-sulphite-alcohol methods of delignification of wheat straw. It was proved that organosolv delignification is described by kinetic equations of the second order and is characterized by lower values of activation energy in comparison with wood delignification. The possibility of bleaching of organosolv straw pulp

\footnotetext{
${ }^{1} \mathrm{PhD}$, Associate Professor of the Department of Ecology and Plant Polymer Technologies, National Technical University of Ukraine "Igor Sikorsky Kyiv Polytechnic Institute", Ukraine ${ }^{2} \mathrm{PhD}$, Senior Lecturer of the Department of Ecology and Plant Polymer Technologies,

National Technical University of Ukraine "Igor Sikorsky Kyiv Polytechnic Institute", Ukraine

(C) Trembus Iryna, Halysh Vita
} 
without use of molecular chlorine was investigated. It was found out that for organosolv pulp bleaching the scheme C-P-A can be recommended, with the consumption of hydrogen peroxide of 3-5\%, which allows one to obtain pulp with brightness up to $80 \%$. The papermaking properties of the obtained pulps were investigated and its practical suitability for the production of cardboard and paper products was shown. It was found out that ammonia sulfite-alcohol and alkaline-sulfite-alcohol straw unbleached pulps can be used in a composition with recycling paper for the production of packaging paper, and bleached alkali-sulphite-alcohol unbleached pulp from straw in a composition with bleached sulfate softwood pulp for the production of writing paper.

\section{Introduction}

Nowadays, the products of the pulp and paper industry (PPI) are extremely important for the development of culture, education and scientific, also for technological progress. In the production of paper and cardboard, such fibrous products as cellulose pulp, waste paper and wood pulp can be used. In world practice, the dominant methods of obtaining cellulose pulp are sulfate and sulfite methods, which are the main source of environmental pollution due to the pollution of air with mercaptans, hydrogen sulfide, dioxins, furans and water with lignin derivatives. The amount of organic wastes from these types of cooking of plant material is 2-3 million tons per year [1, p. 37].

In the world PPI, in order to obtain pulp bisulfite and neutral sulfite methods of delignification are also can be used [2, p. 2127]. Pulp from plant material with an yield of 50-53\% was obtained by acid-bisulfite cooking on the magnesium base; such pulp was characterized by high content of lignin due to the presence of unpulped particles and with gray color, therefore it did not find a wide industrial application in the unbleached form.

For obtaining pulp from non-woods, neutral sulfite method of delignification is the most widely used [2, p. 2127]. The yield of unbleached neutral-sulfite pulp from straw is $53-55 \%$ and $47-48 \%$ is for bleached. Tthe industrial application of this method of delignification is connected with a strong problem of the regeneration of monosulfite from the spent liquor.

In order to reduce the environmental problem, scientists develop alternative methods of cooking: organosolv, hydrotropic, biotechnological, etc. [3, p. 67]. Among such methods, organosolv pulping of plant material is 
the most developed and implemented in production. The application of organosolv cooking [3, p. 67] allows one to reduce the use of fresh water (5-10 $\mathrm{m}^{3}$ per 1 ton of cellulose instead of $50-100 \mathrm{~m}^{3}$, which is typical for traditional technologies) and investments by $20-30 \%$, as compared to the production of sulfate hardwood pulp. The technology of organosolv cooking involves the complex processing of raw materials, the utilization of waste and by-products with the receiving of valuable materials and substances (plastics, furfural, etc.) [3, p. 67].

In the world PPI, wood is the main raw material for the production of pulp. For countries that have short stocks of wood, the search for alternative sources of fibrous products is an urgent problem. Different representatives of non-wood plant material (NWPM), in particular, stems of cereal crops, can be regarded as source of pulp.

An attractive aspect in the production of pulp from wheat straw stems is its availability and lower cost in comparison with wood. Fibers of agricultural plants can be processing into fibrous product more economically advantageously, mainly in small volumes and using simple technologies, which require much less investments than wood processing.

According to the chemical composition, wheat straw has a lower content of lignin and a higher content of low molecular weight fractions of polysaccharides such as hemicelluloses (pentosans and hexoses) than those in wood. The hemicelluloses are characterized with hydrophilicity and high ability to swell, they can plasticized fibers, promote hydration, facilitate their fibrillation, thereby contributing to the formation of a dance paper sheet. Therefore, the development of new environmentally safe technologies for the production of pulp from wheat straw by organosolv methods of delignification and their use in the composition of cardboard and paper products is an important scientific and technical issue.

In this study, different methods of analysis were used to determine the quality indices of organosolv pulp from wheat straw, as well as cardboard and paper based on obtained straw pulp.

\section{Organosolv methods of delignification}

Organic solvents, which are used to delignify plant material, can belong to one or more classes of organic compounds (monoatomic and polyhydric alcohols, phenols and carboxylic acids, ethers and esters, ketones and amines). Classification of organosolv methods of cooking is shown in Fig. 1. 
To choose an organic solvent and to develop organosolv technology for the production of pulp from plant raw materials, it is necessary to consider the technological process and the characteristics of the quality of the obtained fibrous products, also the possibility of multi-tonnage solvent production, the possibility of using a simple regeneration of the solvent, its consumption must be taking into account too.

The solvent should not increase the corrosion activity of the cooking solution and excessively increase the fire and explosion hazard of the production. From an environmental point of view, the solvent must be suitable for biological degradation and must be non-toxic. Taking into account these factors, the range of solvents for pulping was narrowed to ethanol, methanol, acetone, acetic acid and monoethyl ether of ethylene glycol.

For organosolv delignification of plant material, binary hydrogen-organic solutions are widely used, that increase the efficiency of lignin removal and the process of regeneration of the solvent can be applied.

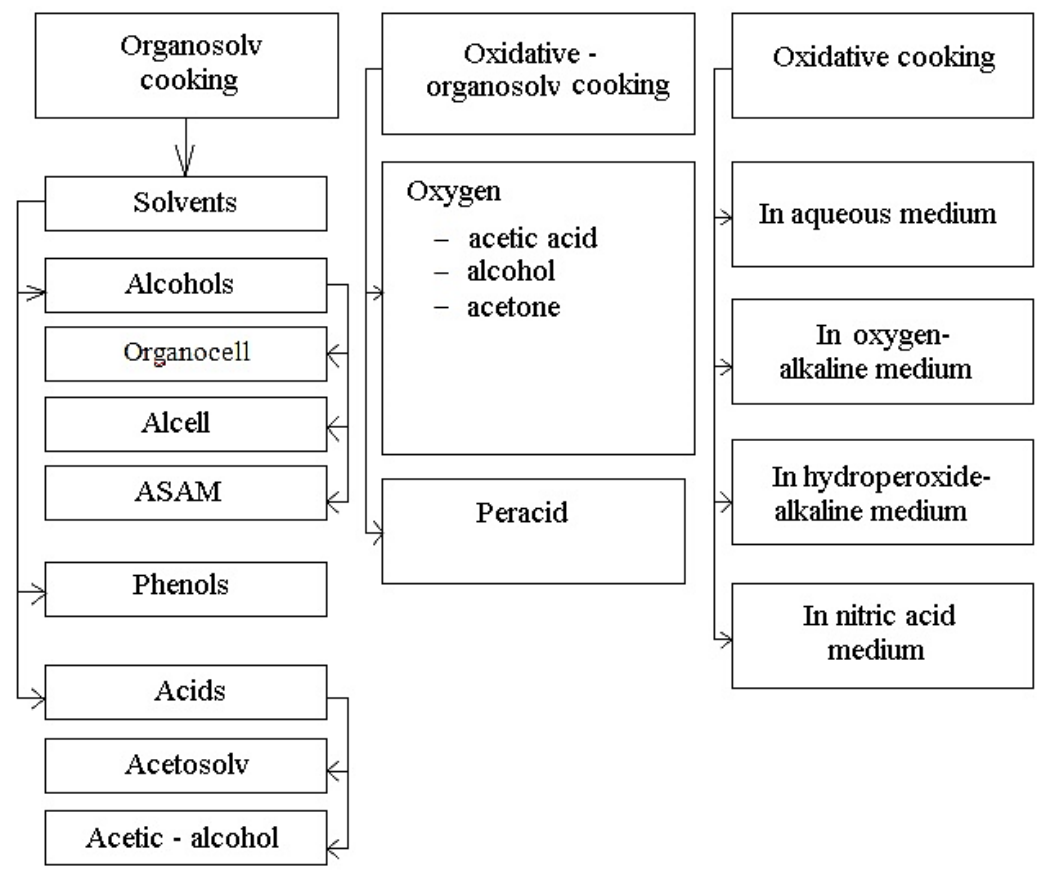

Fig. 1. Classification of organosolv methods of cooking 
For theoretical substantiation of the investigated methods of obtaining straw fibrous products, it is necessary to consider the chemistry of the basic processes of organosolv cooking.

\section{Chemistry of delignification in organosolv pulping}

The process of organosolv delignification is characterized not only by the reactions of hydrolytic degradation of lignin, but also by the influence of the components of cooking solution on carbohydrates, primarily on hemicelluloses, which determines the yield and quality of the fibrous products. The degree of such influence depends on the composition of the organosolv cooking solution and the conditions of the process.

Organic solvents used in organosolv methods of delignification, differ in the chemistry of interaction with the components of plant material and technological parameters of the process of cooking. Thus, they can be used as chemical reagent, as well as the medium, in which the process of delignification takes place. As a chemical reagent, organic solvents interact with reactive groups of lignin, which leads to the destruction of lignin or the blockage of reactive hydroxyl groups of benzyl alcohol (to prevent lignin condensation reactions). As a medium, organic solvents can positively influence the physical and chemical processes that occur during cooking: impregnation, swelling, solubility of lignin degradation products.

The absence of strong nucleophiles that are used in traditional cooking solutions, as well as the ability of the solvent to affect the acid-alkali balance and the rate of chemical reactions, add some features to the characterization of organosolv solutions [4, p. 186]. The nature of the process of organosolv delignification depends on the $\mathrm{pH}$ of the cooking solution. In the acidic medium $(\mathrm{pH}=2-4)$, the destruction of the mesh structure of lignin occurs as a result of the acid splitting of the $\alpha$-etheric bonds of lignin with the formation of intermediate carbocations (Fig. 2) [5, p. 813].

As it known, in the hardwood species the fraction of non-cyclic structures of the $\alpha$-aryl ether, that responsible for the destruction of lignin, is almost 2 times higher than that in softwood species. Therefore, delignification of hardwood and non-wood materials in the acidic medium occurs easier unlike softwood species. In this case, the organic solvent, like a weak nucleophile, blocks the active centers of lignin and prevents the process of its condensation

During organosolv cooking in the acid medium, the $\beta$-ether bonds of lignin (especially $\beta-\mathrm{O}-4$ bond) are also degraded, unlike to chemical trans- 


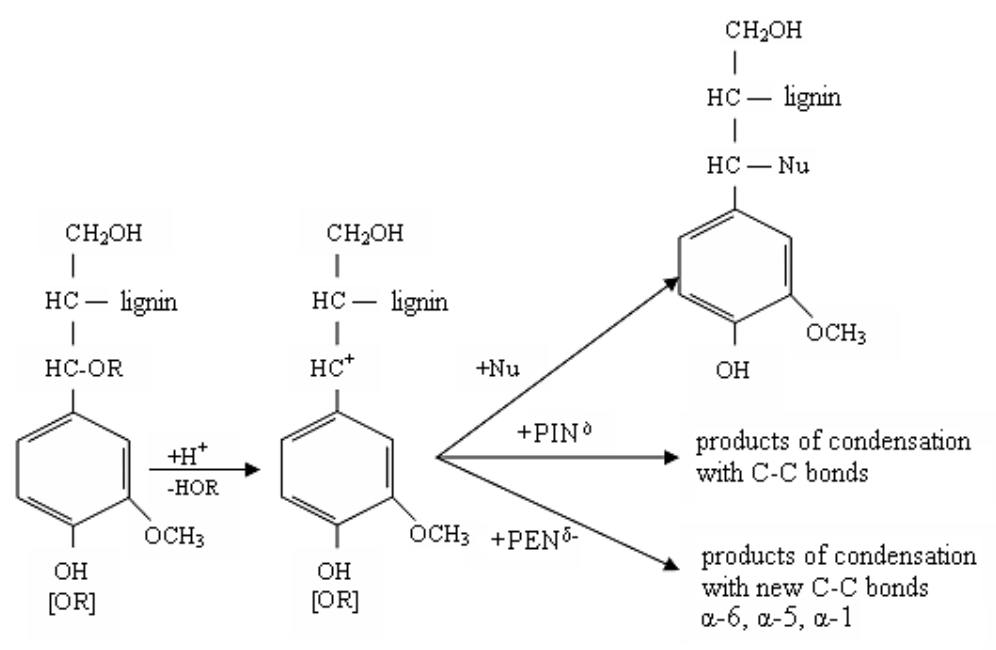

Fig. 2. Splitting of $\alpha$-etheric bonds of lignin during organosolv cooking of plant material in acid medium:

$\mathrm{Nu}$ - external nucleophile ( $\mathrm{HOH}, \mathrm{C}_{2} \mathrm{H}_{5} \mathrm{OH}, \mathrm{CH}_{3} \mathrm{OH}$, etc.); $\mathrm{PIN}^{\delta-}-$ internal nucleophile (phenilpropane unit of lignin); $\mathrm{PEN}^{\delta-}$ - external nucleophile of phenolic type (phenol, cresols, etc).

formations that occur during traditional acidic sulfite pulping of plant material (Fig. 3).

At the same time, the degradation of the $\beta-\mathrm{O}-4$ bond leads to the splitting of the $\gamma$-methyl group in the form of formaldehyde and the formation of ketones. Reduction of dielectric permittivity of the cooking solution with the use of organic solvent and raising the temperature of cooking, promotes hemolytic degradation of $\beta$-etheric bonds of lignin and the freely radical reactions that lead to the process of condensation of lignin take place.

In an alkali medium, the destruction of lignin takes place through the splitting of $\alpha$-etheric bonds through to the intermediate structure - quinone-methyl (Fig. 4, 5), which is blocked by an organic solvent and prevents the process of condensation of lignin.

Alkylation of hydroxyl $\mathrm{OH}$ group in $\alpha$-position with an alcohol promotes the fragmentation of lignin due to improving its dissolution in an 


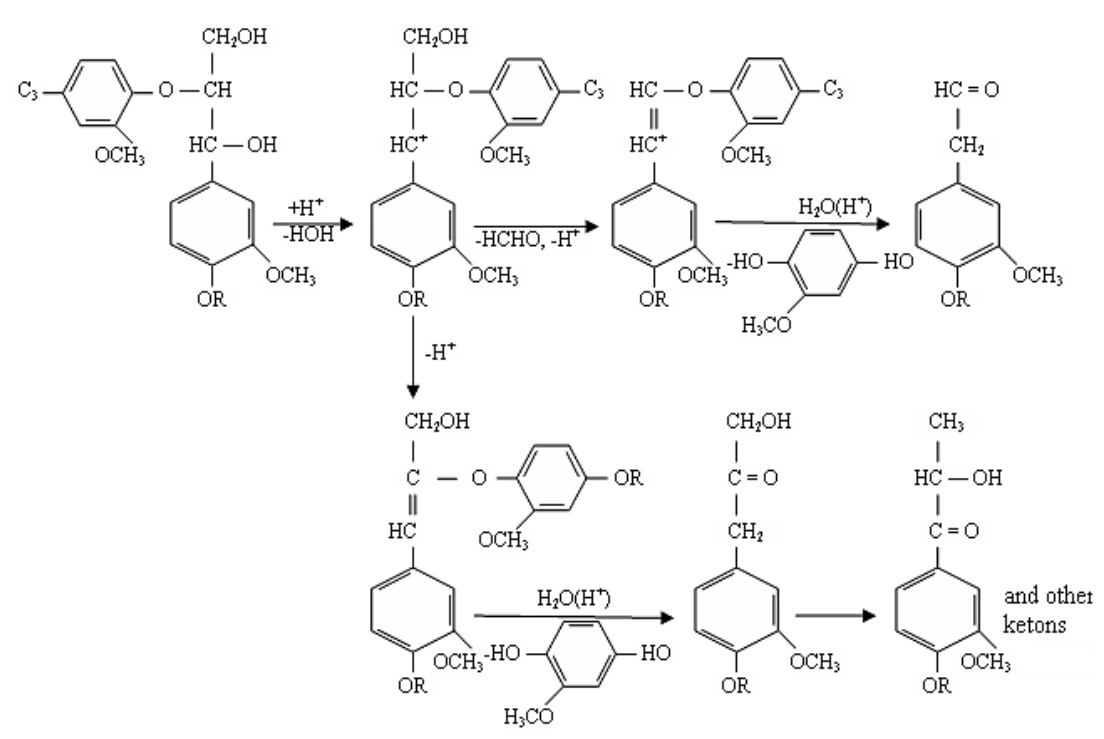

Fig. 3. Splitting of $\beta$-etheric bonds of lignin during organosolv cooking of plant material in acid medium

organic solvent. In addition, in the alkali medium, condensation processes are less developed than at $\mathrm{pH}<7$. All this leads to a greater selectivity of the lignin dissolution process (obtaining a larger yield of cellulose at 3 to $5 \%$ with the same content of lignin) compared with organosolv cooking in acid medium.

Physical and mechanical properties of organosolv pups also depend on the $\mathrm{pH}$ of organic solutions. Thus, fibrous products obtained in an acid medium are generally characterized by lower parameters than those obtained in an alkali medium. This is especially true in the case of tear index, the value of which is depended on the content of hemicelluloses in pulp, on the structure of the resulting fibrous product, on the surface properties of the fibers.

It also should be noted that the process of organosolv delignification in an alkali medium is characterized by a greater selectivity of the lignin removal from plant raw materials in comparison with organosolv cooking methods that take place in an acid medium. 


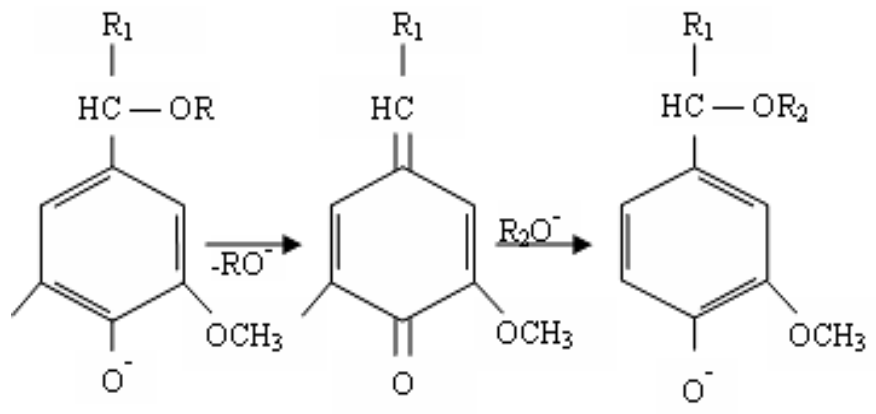

Fig. 4. Splitting of $\alpha$-ether bonds of lignin during organosolv cooking of plant material in alkali medium: $\mathrm{R}=\mathrm{H}, \mathrm{Ar}, \mathrm{Alk} ; \mathrm{R}_{1}=\mathrm{HC}<\underset{\mathrm{OAr}}{\mathrm{CH}_{2} \mathrm{OH}} ; \mathrm{R}_{2}=\mathrm{Me}$, Et, etc.

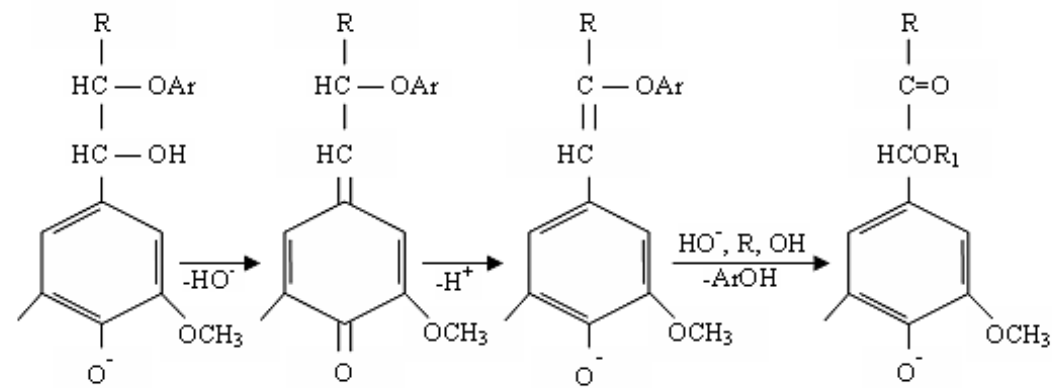

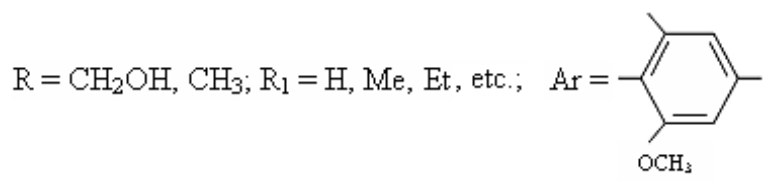

Fig. 5. Splitting of $\beta-O-4$ ether bonds of lignin during organosolv cooking of plant material in alkali medium

\section{Obtaining of straw pulp}

Organosolv methods of delignification of wheat straw that were investigated are: acetic (As), etheric (ES), two-stage alkaline-alcoholic (2AS), ammonia sulfite-alcoholic (ACC) and alkaline sulfite-alcohol (ASAE). 
Anthraquinone was used as a catalyst for the intensification of some of these methods. The comparative characteristic of organosolv pulping of wheat straw is given in Table. 1.

During cooking wheat straw with acetic acid it was possible to obtain pulp with the degree of delignification from 42.7 to 95.4 Kappa number and low mechanical strength. In addition, the increased corrosion of such cooking solution leads to additional investments, and indicates the inappropriate of industrial application of this method.

The equal parts of acetic acid, ethyl acetate and water as delignify solution can be used. The choice of acetic ester is done due to the fact that, in its presence, the spent liquor can be easily divided into two layers - aqueous with hemicelluloses sugars and organic with lignin compounds, that simplifies the regeneration of chemicals.

The high content of residual lignin, relatively low mechanical properties of the obtained straw pulp (Table 1), gives grounds for arguing about low industrial use of this method of delignification for the production of fibrous products suitable for the production of paper and cardboard.

Cooking of wheat straw in hydrogen-alcohol solutions allows one to produce pulp of high yield and with low content of residual lignin in comparison with sulfate and sulfite methods of delignification of plant material. Delignification of wheat straw in water-alcohol solutions, for example, according to the 2 AS method, as well as hydrogen-alcohol solutions of ammonia and sulfur dioxide (ACC method), allows to receive straw pulp with an yield of 58.8 to $86.1 \%$ and the content of lignin from 1.8 to $11 \%$ (Table 1).

The use of anthraquinone as the catalyst reduces the yield of 2AS organosolv straw pulp due to reducing the content of lignin in it and increases the mechanical properties of obtained fibrous product. The proposed delignification of plant material can be considered as an alternative way of obtaining pulp suitable for the production of paper and cardboard products.

The use of anthraquinone as the catalyst during ACC cooking of wheat straw helps increase the yield of cellulose, its mechanical characteristics and reduces lignin content in it by $0,3-1,9 \%$ compared to cooking without catalyst. Pulp, obtained in this way, can be bleached without the use of molecular chlorine and its mechanical parameters are comparable to the similar characteristics of sulfate wood pulp [6, p. 345]. 
Trembus Iryna, Halysh Vita

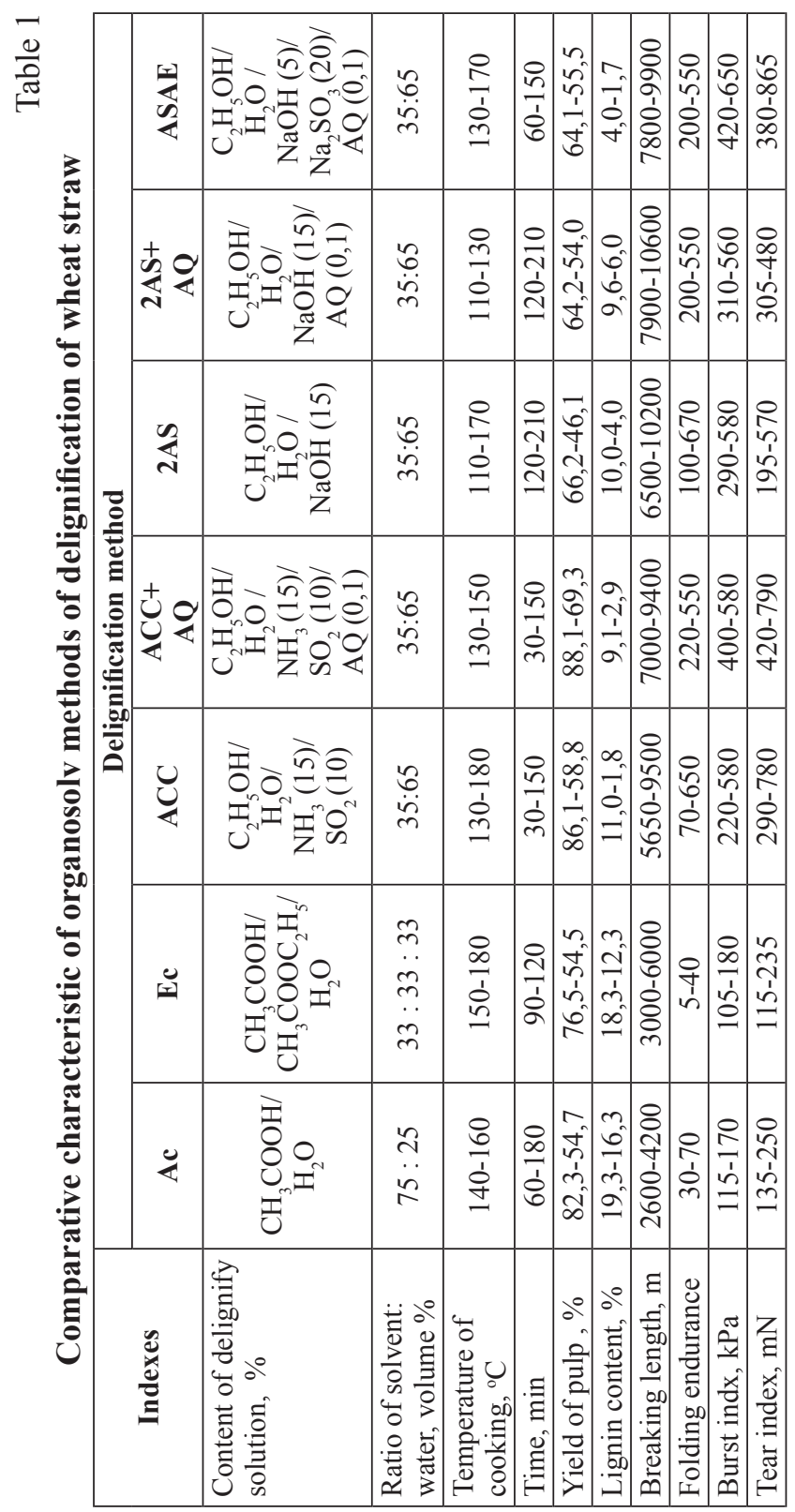


Ammonia-sulfite-alcohol, alkaline-sulphite-alcohol and two-stage alkaline-alcohol cooking of wheat straw are characterized by better straw pulp quality indices (yield, lignin content and mechanical parameters) among investigated organsolv methods of delignification, so they can be considered as alternative methods obtaining of fibrous products suitable for the production of paper and cardboard.

Bleaching of organosolv straw pulp

One of the problems of the modern PPI is the development of environmentally friendly pulp bleaching technologies, since, as it known, the use molecular chlorine for bleaching pulp is accompanied by the formation of highly toxic organochlorine compounds: chlorophenols, dioxins, furans [7, p. 30]. Therefore, the general direction of the development of pulp bleaching technologies is the development of bleaching methods without the use of molecular chlorine or completely without chloric reagents.

Bleaching of straw pulp was carried out using an environmentally friendly chemical - hydrogen peroxide with a pre-treatment stage with trilon $\mathrm{B}$ application. For comparison of the effectiveness of bleaching of ASAE and ACC straw pulp, the chlorination process with different consumption of active chlorine from 1 to $10 \%$ was carried out. The treatment of $\mathrm{t}$ pulp only with chlorine water leads to large losses of cellulose, \%: 7.2-23.5 for ASAE pulp; 6.3-11.9 for ACS pulp. After the chlorination stage, lignin in cellulose is still in a large quantity. Further alkali treatment contributes to the transfer to the solution of lignin, which precipitated on fibers of pulp, that allows one to remove $10-20 \%$ of lignin at a decrease in the yield of straw pulp by $1-2 \%$. Removal up to $50 \%$ of the lignin from organosolv straw pulp occurs at the active chlorine consumption of $3 \%$ and followed by alkaline treatment. A further increase in the consumption of active chlorine leads to a slight increase in brightnes, therefore, it is inappropriate. Thus, it can be argued that bleaching organosolv pulp with chlorine water organic is not sufficiently effective.

The process of bleaching of straw pulp with hydrogen peroxide was carried out with the consumption of chemical reagent from 1 to $10 \%$ (Table 2). More effective removal of lignin occurs during treatment of organosolv pulp with hydrogen peroxide. The removal of 50\% of lignin from pulp is achieved at a consumption of $\mathrm{H}_{2} \mathrm{O}_{2}-2 \%$. Bleaching of organosolv straw pulp with hydrogen peroxide makes it possible to increase its brightness in 
twice at $\mathrm{H}_{2} \mathrm{O}_{2}$ consumption $1-2 \%$ by weight of absolutely dry pulp, while the brightness of straw pulp after chlorination with the consumption of active chlorine of $5 \%$ of oven dry pulp increases only in 1,5 times. Further alkaline treatment reduces the brightness of organosolv straw pulp by another $2-3 \%$. It must be noted that the brightness of ASAE pulp is $7-8 \%$ higher than for ACC pulp.

To remove cations of variable valence and stabilization of the solution of hydrogen peroxide during the bleaching process, it was suggested to proceed chelating treatment of organosolv straw pulp with trilon $\mathrm{B}$, that increases the brightness of fibrous product by $8.1-10.6 \%$ (Table 3 ).

Table 2

Indicators of quality of bleaching straw pulp with hydrogen peroxide

\begin{tabular}{|c|c|c|c|c|c|c|}
\hline Consumption & \multicolumn{2}{|c|}{ Yield of pulp, \% } & \multicolumn{2}{c|}{ Lignin content, \% } & \multicolumn{2}{c|}{ Brightness, \% } \\
\cline { 2 - 7 } $\mathbf{H}_{2} \mathbf{O}_{2}, \mathbf{\%}$ & ASAE & ACC & ASAE & ACC & ASAE & ACC \\
\hline 1 & 85,6 & 74,5 & 1,39 & 1,57 & 58,8 & 73,9 \\
\hline 2 & 75,1 & 70,4 & 1,26 & 1,31 & 60,7 & 74,6 \\
\hline 3 & 71,1 & 65,5 & 1,13 & 0,99 & 62,7 & 75,7 \\
\hline 5 & 69,5 & 64,9 & 0,89 & 0,82 & 65,9 & 77,1 \\
\hline 7 & 68,8 & 61,1 & 0,84 & 0,68 & 70,6 & 78,9 \\
\hline 10 & 63,7 & 57,7 & 0,81 & 0,47 & 74,3 & 80,1 \\
\hline
\end{tabular}

Table 3

\section{Indices of quality of bleached alkaline-sulphite-alcohol straw pulp}

\begin{tabular}{|c|c|c|c|c|}
\hline \multirow{2}{*}{ Indices of pilp } & \multirow{2}{*}{$\begin{array}{c}\text { Consumption } \\
\mathrm{H}_{2} \mathrm{O}_{2} \%\end{array}$} & \multicolumn{3}{|c|}{ Scheme of bleaching } \\
\hline & & $\mathbf{P}-\mathbf{A}$ & $\mathbf{C}-\mathbf{P}$ & $\mathbf{C}-\mathbf{P}-\mathbf{A}$ \\
\hline \multirow{2}{*}{$\begin{array}{l}\text { Yield, \% from } \\
\text { unbleached pulp }\end{array}$} & 3 & 97,2 & 97,5 & 96,5 \\
\hline & 5 & 96,8 & 97,1 & 96,1 \\
\hline \multirow{2}{*}{$\begin{array}{l}\text { Content of residual } \\
\text { lignin, } \%\end{array}$} & 3 & 0,85 & 0,89 & 0,71 \\
\hline & 5 & 0,72 & 0,76 & 0,62 \\
\hline \multirow[t]{2}{*}{ Brightness, $\%$} & 3 & 68,5 & 77,6 & 79,1 \\
\hline & 5 & 72,7 & 78,1 & 80,8 \\
\hline
\end{tabular}

Bleaching of organosolv straw pulp with hydrogen peroxide makes it possible to increase its brightness in twice at $\mathrm{H}_{2} \mathrm{O}_{2}$ consumption $1-2 \%$ of oven dry pulp, while the brightness of straw pulp after chlorination with the consumption of active chlorine $5 \%$ of oven dry pulp increases only in 1,5 times. Further alkaline treatment reduces the brightness of organosolv 
straw pulp by another $2-3 \%$. It should be noted that the brightness of ASAE straw pulp is $7-8 \%$ higher than those for ACC straw pulp.

Investigation of papermaking properties of pulps showed that organosolv straw pulp obtained by alkaline-sulfite-alcohol and ammonia-sulfite alcohol methods of delignification are easy to bit, with a lower energy consumption compared to sulfate and sulfite wood pulp.

The use of unbleached ASAE and ACC straw pulp, instead of wood pulp in the composition with the recycling paper, allows one to receipt packaging cardboard, and the use of alkaline-sulphite-alcohol straw pulp in a bleached form in the writing paper can replace up to $75 \%$ sulfate softwood pulp, and, thus, substantially reduce the cost of final products.

\section{Optimization of organosolv methods for the obtaining straw pulp}

The experimental studies allows to assert that fibrous products obtained by such organosolvent methods of cooking wheat straw, as ASAE, ACC+AQ and $2 \mathrm{AS}+\mathrm{AQ}$, are characterized with the highest physical and mechanical parameters. To obtain the mathematical dependences of the quality indices of straw pulp $\left(Y_{i}\right)$ from the main technological factors $\left(x_{i}\right)$ of proposed organosolv cooking of wheat straw, a full factor design of 22 was used [8, p. 207]. The temperature of cooking $\left(x_{1}\right)$ and the cooking time $\left(x_{2}\right)$ were chosen as factors $x_{i}$ that affect the quality indices of organosolv straw pulp and were studied. For the initial indices of straw pulp $Y_{i}$, which determine the quality of organosolv straw pulp, were selected: yield of fibrous product $\left(Y_{1}\right)$, degree of delignification $\left(Y_{2}\right)$, content of residual lignin $\left(Y_{3}\right)$, breaking length $\left(Y_{4}\right)$, folding endurance $\left(Y_{5}\right)$, burst index $\left(Y_{6}\right)$ and tear index $\left(Y_{7}\right)$. The statistical mathematical model of the process of obtaining pulp for two independent variables has the following form:

$$
y_{i}=b_{0}+b_{1} \cdot x_{1}+b_{2} \cdot x_{2}+b_{3} \cdot x_{1} \cdot x_{2}+b_{4} \cdot x_{1}^{2}+b_{5} \cdot x_{2}^{2},
$$

where $y_{i}$-indicator of the quality of straw pulp;

$b_{0}, b_{1}, b_{2}, b_{3}, b_{4}, b_{5}$ - coefficients of the mathematical model;

$x_{1}$ i $x_{2}$ - value of cooking factors in coded form.

As a result of the mathematical treatment of the experimental data of organosolv pulping of wheat straw, regression equations, which adequately describe the dependence of the indicators $Y_{i}$ on the technological factors $x_{i}$, were obtained. The values of the obtained coefficients of the regression equations are given in Table 4. 
Table 4

Values of coefficients of mathematical models of cooking processes of straw pulp by organosolv methods of delignification

\begin{tabular}{|c|c|c|c|c|c|c|c|c|}
\hline \multirow{2}{*}{ Coefficients } & \multicolumn{7}{|c|}{ Organosolv pulp quality indices $\left(\boldsymbol{V}_{i}\right)$} \\
\cline { 2 - 8 } & $\boldsymbol{V}_{1}$ & $\boldsymbol{y}_{2}$ & $\boldsymbol{y}_{3}$ & $\boldsymbol{y}_{4}$ & $\boldsymbol{y}_{5}$ & $\boldsymbol{V}_{6}$ & $\boldsymbol{y}_{7}$ \\
\hline \multicolumn{7}{|c|}{ ASAE } \\
\hline$b_{0}$ & 60.606 & 16.727 & 3.104 & 9123.1 & 363.53 & 640.16 & 552.44 \\
\hline$b_{1}$ & -3.971 & -4.150 & -1.103 & -586.51 & -76.39 & -157.53 & -70.37 \\
\hline$b_{2}$ & -1.269 & -2.503 & -0.375 & 604.99 & 113.67 & 120.66 & 44.19 \\
\hline$b_{3}$ & 0.009 & -0.214 & 0.123 & 161.89 & -75.43 & 9.05 & -3.76 \\
\hline$b_{4}$ & -0.227 & -0.520 & -0.111 & -441.12 & -53.48 & -35.71 & -32.23 \\
\hline$b_{5}$ & -0.195 & 0.031 & 0.011 & 48.80 & -2.61 & -12.62 & 7.88 \\
\hline \multicolumn{7}{|c|}{ ACC+AQ } & & \\
\hline$b_{0}$ & 77.005 & 31.542 & 5.176 & 8880.7 & 401.16 & 603.30 & 515.63 \\
\hline$b_{1}$ & -3.512 & -6.038 & -1.407 & -259.23 & -56.45 & 0.88 & -8.79 \\
\hline$b_{2}$ & -5.189 & -10.210 & -1.443 & 1590.1 & 200.88 & 209.27 & 108.86 \\
\hline$b_{3}$ & -0.744 & 0.885 & 0.445 & 95.18 & -26.68 & -13.44 & 10.98 \\
\hline$b_{4}$ & -0.862 & -0.463 & -0.623 & 253.27 & 48.54 & 56.23 & 7.45 \\
\hline$b_{5}$ & 2.231 & 5.213 & 1.037 & -809.15 & -45.85 & 33.48 & -20.21 \\
\hline \multicolumn{7}{|c|}{$\mathbf{2 A S + A Q}$} \\
\hline$b_{0}$ & 59,765 & 30,596 & 7,612 & 8734,4 & 297,63 & 370,74 & 537,75 \\
\hline$b_{1}$ & $-2,012$ & $-3,525$ & $-0,712$ & 831,25 & 54,50 & 73,70 & 73,87 \\
\hline$b_{2}$ & $-3,215$ & $-4,000$ & $-0,940$ & 612,50 & 108,50 & 37,89 & 47,90 \\
\hline$b_{3}$ & 0,082 & 0,075 & 0,172 & 78,75 & 29,40 & 11,85 & $-26,62$ \\
\hline$b_{4}$ & $-0,762$ & $-1,050$ & $-0,062$ & 381,25 & 41,00 & 7,20 & $-72,12$ \\
\hline$b_{5}$ & 0,243 & $-0,712$ & 0,112 & 28,12 & 12,37 & $-9,21$ & $-9,00$ \\
\hline
\end{tabular}

Different methods of optimization for finding the optimal values for the parameters of the technological process are known [8, p. 207]. One of the most common ways of solving the problem of optimizing the parameters of technological processes for several quality indices is the union of criteria (quality indices) using the generalized Harrington's desirability function $(D)$. In this method the natural values of individual quality indices $\left(y_{i}\right)$ converted into a dimensionless scale of desirability of $d$ in the interval of desirsbility from 0 to 1 . A higher numerical value on the scale of desirability corresponds to a greater desirability - from very bad $(\mathrm{d}=0,20-0,00)$ to very good $(d=1,00-0,80)[8, p .207]$. Graphic dependences of the gen- 
eralized function of desirability $D$, as an average geometric for individual desires of $d$, on the plane of technological factors $X_{1}-X_{2}$ show good coordination between all quality indicators $\left(\boldsymbol{y}_{i}\right)$.

To determine the optimal values of the technological parameters for obtaining the corresponding organosolv straw pulp by the generalized Harrington's desirable function, the limitations for each of the quality indices $\left(y_{i}\right)$ were chosen and the results are given in Table 5.

Table 5

Limitation of the quality of pulp $\left(y_{i}\right)$

for different organosolv methods of delignification of wheat straw

\begin{tabular}{|l|c|c|c|c|c|c|}
\hline \multirow{2}{*}{$\begin{array}{c}\text { Organosolv straw pulp } \\
\text { quality indices }\end{array}$} & \multicolumn{3}{|c|}{ The best value } & \multicolumn{3}{c|}{ The worst value } \\
\cline { 2 - 7 } & ASAE & ACC+AQ & 2AS+AQ & ASAE & ACC+AQ & 2AS+AQ \\
\hline Yield of pulp $\left(\boldsymbol{y}_{i}\right), \%$ & 70 & 85 & 65 & 50 & 70 & 55 \\
\hline Kappa number $\left(\boldsymbol{y}_{2}\right)$ & 8 & 20 & 22 & 25 & 55 & 36 \\
\hline $\begin{array}{l}\text { Content of residual lignin } \\
\left(\boldsymbol{y}_{3}\right), \%\end{array}$ & 1 & 3 & 6 & 5 & 9 & 10 \\
\hline Breaking length $\left(\boldsymbol{y}_{4}\right), \mathrm{m}$ & 10000 & 10000 & 11000 & 7000 & 7000 & 8000 \\
\hline Folding endurance $\left(\boldsymbol{y}_{5}\right)$, & 600 & 700 & 550 & 200 & 200 & 200 \\
\hline Burst index $\left(\boldsymbol{y}_{6}\right), \mathrm{mN}$ & 1000 & 900 & 500 & 300 & 400 & 270 \\
\hline Tear index $\left(\boldsymbol{y}_{7}\right), \mathrm{kPa}$ & 700 & 600 & 570 & 300 & 350 & 310 \\
\hline
\end{tabular}

The calculated optimal parameters of the parameters $X_{i}$ in coded form for each organosolv method are: for ASAE $X_{1}=-0,48$ i $X_{2}=1$; for ACC $X_{1}=-1 \mathrm{i} X_{2}=1$; for $2 \mathrm{AS} X_{1}=1 \mathrm{i} X_{2}=0,55$. Optimal values $X_{i}$ in encoded form and the values of quality indicators $\left(y_{i}\right)$ for each pulp at the optimum points are presented in Table 6.

Optimal values $X_{i}$ and $y_{i}$ and the results of calculations of the value of the generalized desirability function $\mathrm{D}$ indicate that the best consistency of the quality indices of organosolv pulp $\left(\boldsymbol{y}_{i}\right)$ at the determined optimal values of the technological factors $\left(X_{i}\right)$ belong to an alkali-sulfite alcohol method of wheat straw delignification (the function of desirability $\mathrm{D}$ for this method cooking of raw materials is characterized by the greatest value).

In addition to the task of multicriteria optimization, the task of finding compromise conditions for organosolv cooking of wheat straw, which 
Table 6

Optimal technological parameters of organosolv cooking and straw pulp quality indices at the optimum point

\begin{tabular}{|c|c|c|c|}
\hline Indexes & ASAE & $\mathrm{ACC}+\mathrm{AQ}$ & $2 A S+A Q$ \\
\hline $\begin{array}{l}\text { Parameters }\left(X_{i}\right): \\
\text { temperature of cooking, }{ }^{\circ} \mathrm{C}\left(X_{1}\right) \\
\text { time of cooking, } \min \left(X_{2}\right)\end{array}$ & $\begin{array}{l}140 \\
150 \\
\end{array}$ & $\begin{array}{l}130 \\
150 \\
\end{array}$ & $\begin{array}{l}130 \\
190 \\
\end{array}$ \\
\hline $\begin{array}{l}\quad \text { Variable functions }\left(\boldsymbol{Y}_{i}\right) \text { : } \\
\text { yield of pulp, \% }\left(\boldsymbol{y}_{1}\right) \\
\text { Kappa number }\left(\boldsymbol{y}_{2}\right) \\
\text { content of residual lignin, \% }\left(\boldsymbol{Y}_{3}\right) \\
\text { breaking length, } \mathrm{m}\left(\boldsymbol{y}_{4}\right) \\
\text { folding endurance }\left(\boldsymbol{y}_{5}\right) \\
\text { burst index, } \mathrm{mN}\left(\boldsymbol{y}_{6}\right) \\
\text { tear index, } \mathrm{kPa}\left(\boldsymbol{y}_{7}\right)\end{array}$ & $\begin{array}{c}61 \\
16,2 \\
3,2 \\
9880 \\
535 \\
810 \\
632 \\
\end{array}$ & $\begin{array}{c}77 \\
31,2 \\
5,1 \\
10080 \\
685 \\
915 \\
610 \\
\end{array}$ & $\begin{array}{c}55 \\
23,6 \\
6,5 \\
10330 \\
470 \\
475 \\
580 \\
\end{array}$ \\
\hline Desirability function (D) & 0,6495 & 0,6365 & 0,6248 \\
\hline
\end{tabular}

ensure high quality of the obtained straw pulp for all quality indicators $\left(\boldsymbol{y}_{i}\right)$, was also considered. Such a task was solved by constructing a compromise area on the plane of technological factors $X_{1}-X_{2}$.

In Fig. 6 the compromise areas for the studied organosolv systems are represented by shaded segments formed by the lines of quality indicators of pulp at the numerical values indicated on them.

a)

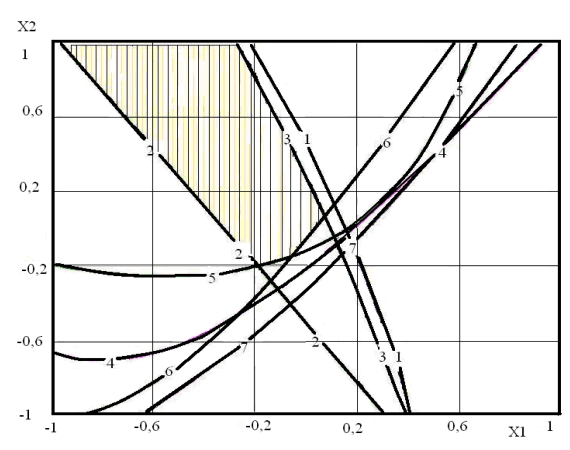

$1-y_{1}=60 \% ; 2-Y_{2}=18.0$ Kappa number; $3-Y_{3}=3 \% ; 4-Y_{4}=9000 \mathrm{~m}$; $5-y_{5}=350 ; 6-y_{6}=600 \mathrm{mN} ; 7-y_{7}=550 \mathrm{kPa}$. 
b)

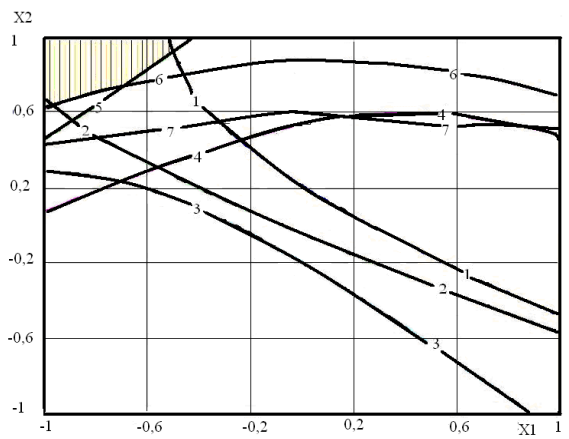

$1-Y_{1}=76 \% ; 2-Y_{2}=32.0$ Kappa number; $3-Y_{3}=5,5 \% ; 4-Y_{4}=9500 \mathrm{~m}$; $5-y_{5}=600 ; 6-Y_{6}=570 \mathrm{mN} ; 7-y_{7}=810 \mathrm{kPa}$.

c)

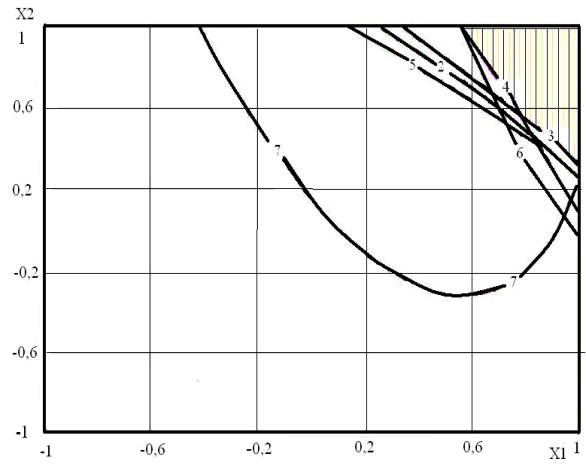

$1-y_{1}=56 \% ; 2-y_{2}=25.0$ Kappa number; $3-y_{3}=6,6 \% ; 4-y_{4}=10000 \mathrm{~m}$; $5-y_{5}=430 ; 6-Y_{6}=450 \mathrm{mN} ; 7-Y_{7}=545 \mathrm{kPa}$.

Fig. 6. Compromise areas of processes of alkaline-sulfite-alcohol (a); ammonia-sulfite-alcoholic (b); two-stage alkaline-alcoholic (c) cooking of wheat straw

Alkaline-sulfite-alcoholic cooking of straw pulp in accordance with calculated optimal values of technological parameters allows to obtain pulp, which has mechanical parameters close to those shown in Table 6 (error $+/-10 \%)$. 


\section{Selectivity and kinetic characteristics of the solvolytic delignification of wheat straw}

In order to compare the selectivity of the dissolution of lignin by investigated organosolv methods of delignification of wheat straw, calculations of such parameters as: selectivity (S1, \%), degree of removal of carbohydrates (DRC, \%) and degree of delignification (DD, \%) by the following equations were performed $[9$, p. 34]:

$$
\begin{gathered}
S l=\left(\frac{Y}{100}-\frac{L \cdot D D}{100}\right) \cdot 100 ; \\
D R C=100-Y \cdot \frac{100-L_{f}}{100-L_{i}} ; \\
D D=100-\frac{Y \cdot L_{f}}{L_{i}},
\end{gathered}
$$

where $\mathrm{L}_{\mathrm{i}}$-content of lignin in initial raw material, $\%$;

$\mathrm{Y}-$ yield of pulp, \%;

$\mathrm{L}_{\mathrm{f}}$ - content of lignin in final pulp, $\%$.

In table 7 the range of changes in the indices of selectivity of organosolv processes of wheat straw delignification for separate temperature-time intervals are given.

Table 7

\section{Indicators of selectivity of organosolv processes of delignification of wheat straw}

\begin{tabular}{|c|c|c|c|c|c|}
\hline $\begin{array}{c}\text { Method of } \\
\text { delignification }\end{array}$ & Temperature, ${ }^{\circ} \mathbf{C}$ & Time, $\mathbf{m i n}$ & $\begin{array}{c}\text { SI, } \\
\mathbf{\%}\end{array}$ & $\begin{array}{c}\text { DRC, } \\
\mathbf{\%}\end{array}$ & $\begin{array}{c}\text { DD, } \\
\mathbf{\%}\end{array}$ \\
\hline \multirow{2}{*}{ Ac } & 140 & $60 \ldots 180$ & $98 \ldots 75$ & $0,5 \ldots 30$ & $21 \ldots 49$ \\
& 160 & $60 \ldots 180$ & $94 \ldots 68$ & $5 \ldots 38$ & $34 \ldots 58$ \\
\hline \multirow{2}{*}{ Ec } & 150 & $60 \ldots 310$ & $98 \ldots 85$ & $0,6 \ldots 12$ & $11 \ldots 41$ \\
& 170 & $60 \ldots 180$ & $97 . .63$ & $6 \ldots 38$ & $28 \ldots 68$ \\
\hline \multirow{2}{*}{ ACC } & 130 & $30 \ldots 150$ & $96 \ldots 90$ & $2 \ldots 3$ & $61 \ldots 81$ \\
& 150 & $30 \ldots 120$ & $91 \ldots 82$ & $11 \ldots 15$ & $81 \ldots 90$ \\
\hline \multirow{2}{*}{ ACC+AQ } & 130 & $30 \ldots 150$ & $98 \ldots 96$ & $0,5 \ldots 1,9$ & $68 \ldots 84$ \\
& 150 & $30 \ldots 120$ & $96 \ldots 92$ & $3 \ldots 6$ & $84 \ldots 92$ \\
\hline \multirow{2}{*}{$\mathbf{2 A S}$} & 110 & $120 \ldots 210$ & $77 \ldots 71$ & $24 \ldots 29$ & $70 \ldots 77$ \\
& 130 & $120 \ldots 210$ & $74 \ldots 70$ & $27 \ldots 31$ & $74 \ldots 83$ \\
\hline \multirow{2}{*}{$\mathbf{2 A S}+\mathbf{A Q}$} & 110 & $120 \ldots 210$ & $79 \ldots 74$ & $22 \ldots 26$ & $75 \ldots 82$ \\
& 130 & $120 \ldots 210$ & $76 \ldots 68$ & $31 \ldots .35$ & $81 \ldots 86$ \\
\hline \multirow{2}{*}{ ASAE } & 130 & $60 \ldots 120$ & $97 \ldots 82$ & $17 \ldots 20$ & $89 \ldots 91$ \\
& 150 & $90 \ldots 150$ & $80 \ldots 78$ & $20 \ldots 22,5$ & $90 \ldots 93$ \\
\hline
\end{tabular}


The increase in temperature and cooking time leads to an increase in such indicators as the DRC and the DD, and the rate of selectivity decreases. Reduced selectivity connected with the predominant removal of carbohydrates in comparison with the removal of lignin and is confirmed by an increase in the DRC index in the studied temperature-time intervals. The use in 2AS, ACC and ASAE of cooking of ethanol, which play the role of a buffer, prevents the process of condensation of lignin and stabilizes the hydrocarbon part of the plant material, thereby, promoting the softly delignification process and increasing the selectivity in comparison with the selectivity of the Ac and Ec of wheat straw. Thus, the process of delignification of wheat straw by 2AS, ACC and ASAE methods is characterized by a higher selectivity of lignin removal in comparison with acetic and etheric cooking.

On the example of ACC and 2AS pulping it is shown that the application of anthraquinone improves the selectivity of the process of removal of lignin from wheat straw. In this case, the SL and the DD increase, and the DRC decreases.

Among all investigated organosolv methods of cooking of wheat straw, the highest CL and DD were reached by ammonia-sulfite-alcohol and alkaline-sulphite-alcohol methods of delignification of plant material. Therefore, they are most suitable for practical use in the pulp and paper industry.

In order to obtain deep knowledge about the essence of reactions occurring during the process of delignification of plant material and itsr optimal conditions, it is also necessary to know its kinetic characteristics. The kinetic characteristics are calculated for the following topochemical levels: Kolmogorov-Erofeev, Praut-Thompkinson, Histling-Braunstein, equations of the first and second order for which the corresponding kinetic curves of wheat straw delignification were constructed (dependence of the content of lignin on the time of cooking). The analysis of the obtained kinetic curves allows us to conclude that the organosolv delignification of wheat straw is more accurately characterized by the second-order kinetic equation, since the kinetic curves obtained by this equation have less curvature and are described by linear dependencies with correlation coefficient close to one. Calculated by analytical and by graphical methods the value of the rate constant $(\mathrm{k})$ and activation energy $(\Delta \mathrm{Ea})$ of the investigated organosolv methods of wheat straw delignification is shown in Table 8. 
Table 8

Kinetic characteristics of organosolv delignification of wheat straw

\begin{tabular}{|c|c|c|c|c|c|}
\hline \multirow{2}{*}{ 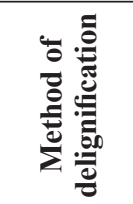 } & \multirow{2}{*}{ 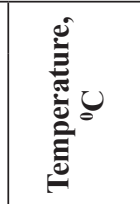 } & \multicolumn{2}{|c|}{ Analytical method } & \multicolumn{2}{|c|}{ Graphical method } \\
\hline & & $\begin{array}{c}\text { Rate constant } \\
\mathbf{k}, \mathbf{m}^{3} / \text { molecule } \cdot \mathbf{c}\end{array}$ & $\begin{array}{c}\text { Activation } \\
\text { energy } \mathbf{E}_{\mathrm{a}}, \\
\mathrm{kJ} / \mathbf{m o l}\end{array}$ & $\begin{array}{c}\text { Rate constant } \\
\mathbf{k}, \mathbf{m}^{3} / \text { molecule·c }\end{array}$ & $\begin{array}{c}\text { Activation } \\
\text { energy } \mathbf{E}_{\mathrm{a}}, \\
\mathbf{k J} / \mathbf{m o l}\end{array}$ \\
\hline Ac & $140-160$ & $7,91 \cdot 10^{-5}-1,06 \cdot 10^{-4}$ & 24,3 & $8,33 \cdot 10^{-5}-1,36 \cdot 10^{-4}$ & 35,3 \\
\hline Ec & $140-180$ & $8,11 \cdot 10^{-5}-1,87 \cdot 10^{-4}$ & 54,3 & $5,00 \cdot 10^{-5}-5,91 \cdot 10^{-4}$ & 76,2 \\
\hline ACC & $130-180$ & $7,61 \cdot 10^{-4}-2,27 \cdot 10^{-3}$ & 45,5 & $6,67 \cdot 10^{-4}-2,51 \cdot 10^{-3}$ & 41,5 \\
\hline $\mathrm{ACC}+\mathrm{AQ}$ & $130-150$ & $9,24 \cdot 10^{-4}-1,25 \cdot 10^{-3}$ & 25,1 & $7,12 \cdot 10^{-4}-1,33 \cdot 10^{-3}$ & 24,7 \\
\hline $2 \mathrm{AS}$ & $110-170$ & $7,00 \cdot 10^{-4}-1,19 \cdot 10^{-3}$ & 17,2 & $5,00 \cdot 10^{-4}-7,19 \cdot 10^{-4}$ & 16,6 \\
\hline $2 \mathrm{AS}+\mathrm{AQ}$ & $110-130$ & $8,24 \cdot 10^{-4}-9,98 \cdot 10^{-4}$ & 15,9 & $3,15 \cdot 10^{-4}-3,89 \cdot 10^{-4}$ & 13,4 \\
\hline ASAE & $130-170$ & $6,12 \cdot 10^{-4}-2,68 \cdot 10^{-3}$ & 52,3 & $7,22 \cdot 10^{-4}-2,83 \cdot 10^{-3}$ & 50,6 \\
\hline
\end{tabular}

The increase in the cooking temperature leads to an increase in the rate constants of organosolv delignification of wheat straw by various cooking solutions. In this case, organosolv delignification of wheat straw is characterized by lower values of activation energy in comparison with organosolv delignification of wood, for which it is in the range of $63-117 \mathrm{~kJ} / \mathrm{mol}$ [10, p. 541]. Lignin of annual plants is less polymerised, and therefore requires less energy for degradation.

The low values of the activation energy of wheat straw delignification of ASAE, ACC, ACC+AQ, $2 \mathrm{AS}$ and $2 \mathrm{AS}+\mathrm{AQ}$ methods indicate that these delignification processes are in the diffusion region. The high activation energy of the etheric cooking indicates that the delignification process takes place in the kinetic region, where the process rate is limited with the stage of a chemical reaction, which requires high energy consumption.

The application of anthraquinone during pulping leads to a decrease in the activation energy by $16.8-20.4 \mathrm{~kJ} / \mathrm{mol}$ for the ACC method of delignification, and by $1.3-3.2 \mathrm{~kJ} / \mathrm{mol}$ for the $2 \mathrm{AC}$ method.

\section{Conclusions}

Based on the experimental results obtained, technologies for the production of pulp from wheat straw by organosolv methods of delignification and conditions for their use in the composition of mass types of cardboard and paper products were developed. The higher yield and mechanical indices of 
straw pulp were obtained by delignification of the plant material with ACC, 2AS and ASAE methods. The application of anthraquinone with the consumption of $0.1 \%$ during $2 \mathrm{AC}$ and $\mathrm{ACC}$ methods of delignification of wheat straw helps to reduce the content of residual lignin and increase the mechanical characteristics of the obtained fibrous products. Straw alkali-sulfite-alcoholic pulp, according to its quality indicators, exceeds not only similar indicators for straw and reed pulp, obtained by traditional cooking methods, but also characteristics of the strength of sulfite wood pulp. Organosolv straw pulp is well bleached with the application of short bleaching schemes and non-chlorinated reagents of low costs. The scheme of bleaching such pulp using trilon $\mathrm{B}$, hydrogen peroxide and acid at low hydrogen peroxide consumption (3-5\%) allows to obtain organosolv straw pulp with a brightness of $80 \%$. The regression equations, which adequately describe the experimental data and can be used as a mathematical model of organosolv cooking of straw fibrous products with certain quality indices, were calculated. The method of multicriteria optimization of the parameters of organosolv cooking were used to defined compromise areas of the processes of delignification of wheat straw. It was shown that ammonia-sulfite-alcohol and alkaline-sulphite-alcohol methods of delignification of wheat straw are characterized with the most selectively and can be recommended for industrial application. Organosolv delignification of wheat straw is described by a second-order kinetic equation. Low values of activation energy indicate the occurrence of organosolv delignification of wheat straw in the diffusion region.

In further research, the technology for the practical use of waste solutions, which are formed during the process of organosolv delignification of plant material will be developed.

\section{References:}

1. Oral J., Sikula J., Puchy R., Hajny Z., Stehlik P., \& Bebar L. (2005). Processing of waste from pulp and paper plant. Journal of Cleaner Production, 22(13): 37-42.

2. Safdaril V., Reza V., Sigarodyl N., \& Moinuddin A. (2011). Identification of fibers of woody and non-woody plant. Species in pulp and papers. Pak. J. Bot., 43(14): 2127-2133.

3. Saberikha E., Rovshandeh J., \& Rezayati-Charani P. (2011). Organosolv pulping of wheat straw by glycerol. Cellulose Chemistry And Technology, 45(1-2): $67-75$.

4. McDonough T. J. (1993). The chemistry of organosolv delignification. Tappi Jurnal, 8(76): 186-193. 
5. Sano Y. (1989). Reactivity of $\beta-O-4$ linkages in lignin during Solvolysis Pulping. Degradation of $\beta-O-4$ lignin model compounds. Mokuzai Gakkaishi, 9(3): 813-819.

6. Barbash V., Trembus I., \& Shevchenko V. (2014). Ammonia-sulfite-ethanol pulp from wheat straw. Cellulose Chem. and Technol., 48(3-4): 345-353.

7. Fedorova E.I., Smoleva L.L. \& Zakharova A.V. (2001). Ob al'ternativakh i problemakh ECF-otbelki sul'fatnoy tsellyulozy. Tsellyuloza. Bumaga. Karton., 5-6: $30-31$.

8. Trautmann H., \& Weihs C. (2006) On the distribution of the desirability index using Harrington's desirability function. Metrika, 63(2): 207-213.

9. Simkovich B.S., Zilbergleyt M.A., Rezkov V.M. (1986). Issledovaniye protsessa delignimosti drevesiny vodnimi rastvorami uksusnoy kisloty. Khimiya drevesiny, 3: 34-38.

10. Kuznetsov B.N., Taraban'ko V.Ye., \& Kuznetsova S.A. (2008). Novyye kataliticheskiye metody $\mathrm{v}$ poluchenii tsellyulozy i drugikh khimicheskikh produktov iz rastitel'noy biomassy. Kinetiki i kataliz, 49 (4): 541-551. 


\title{
ПІДТЕКСТ ЛІТЕРАТУРНО-ХУДОЖНЬОГО ТВОРУ ЯК ЛІТЕРАТУРОЗНАВЧА ПРОБЛЕМА
}

\section{Foka Mariia ${ }^{1}$}

DOI: http://dx.doi.org/10.30525/978-9934-571-26-8_20

\begin{abstract}
Lately the term "subtext", which is the subject of this research, is often used in the literary criticism. Regular references to the subtext and its active study emphasize the need to clarify the meaning of this term, its definition, and to determine the correlation between subtext and adjacent phenomena, especially implicit meaning, implications, etc. The developing of the most effective methodology and methods for the analysis the subtext plan of a literary work and the specifying of the tools for its creating require a special investigation. This paper aims at examining the peculiarities of the subtext of a fictional work as a literary problem. The research methods include analysis and generalization, the systemic approach that are most appropriate for answering the questions relating the subtext phenomenon in the literary text. The subtext is one of the most complicated and vague categories in the poetics, according to the various understanding the nature of a literary text, the importance of an author and a reader, their correlation in the text interpretation process, the specific of building the implicit plan of a literary work, it is interpreted in different way. The review and the analysis of the various approaches to the subtext in the literary criticism have let to define the peculiarities and specific of its nature and to determine that subtext is an implicit meaning of a piece of fiction that consciously or uncon-sciously created by an author and re-created by a reader, giving a literary work a special artistic energy. The subtext plan creates with the varied literary tools that generate an extra, deeper sense of a text. Intertextuality is one of the tools for its forming, it conveys an extra hidden meaning, referring a reader to the other literary works to find and decode the information. The effective method for analysis of the subtext is systematic approach, that identifies the tools, used by an
\end{abstract}

\footnotetext{
${ }^{1}$ Candidate of Philology,

Postdoctoral Student of Ukrainian and Foreign Literature Chair,

Volodymyr Vynnychenko Central Ukrainian State Pedagogical University, Ukraine

(C) Foka Mariia
} 


\section{Foka Mariia}

author for creating hidden meanings. The receptive poetics has been claimed to be an essential component of the analysis of the implicit meanings in a literary work. The strategy of slow reading allows to deeply specify every artistic tool and significant detail, and the analysis of their functionality allows readers to understand the mechanism of the main message creation. The study of the subtext from these perspectives allows to analyze a literary work more deeply and detailed and understand its real meaning.

\section{1. Вступ}

Термін «підтекст» $є$ часто вживаним у мовознавстві [10], перекладознавстві [23], психології [17], мистецтвознавстві [20], філософії [40], політології [36] тощо. Останнім часом ним активно оперують також у сфері літературознавства [42; 51; 62], а про його надзвичайну функціональність свідчать іномовні аналоги: англійський - implied meaning, німецький - subtext, французький - non-dit, італійський senso nascosto, польський - podtekst [52, с. 330].

Постійнезвернення до підтекстута його активне вивчення (I. Арнольд, I. Баженова, О. Брудний, О. Вейзе, І. Гальперін, Л. Голякова, К. Долинін, Є. Срмакова, Л. Ісаєва, Л. Кайда, О. Камчатнов, Є. Квятковський, В. Кикоть, Г. Колшанський, Н. Копистянська, 3. Кулікова, В. Кухаренко, Є. Леліс, Е. Магазанік, А. Матчук, В. Миркін, Н. Муравйова, Т. Сільман, I. Солоділова, Н. Тимків, Д. Урнов та ін.) актуалізують потребу уточнити зміст цього терміна, його дефініцію, установити співвідношення підтексту та суміжних з ним явищ, зокрема імпліцитного смислу, імплікації тощо. Окремої уваги потребує вироблення найбільш адекватної методології та методів виявлення й аналізу підтекстової сфери літературного твору, способів ії̈ формування. У цьому полягає актуальність теми.

Мета - дослідити особливості підтексту літературно-художнього твору як літературознавчу проблему. Сформульована мета передбачає вирішення низки завдань: 1) проаналізувати та систематизувати наявні дефініції підтексту з метою конкретизувати та поглибити уявлення та знання про його природу; 2) розкрити інтертекстуальність як один із способів формування підтекстового плану твору; 3) розробити методологічні та методичні принципи аналізу підтексту літературно-художнього твору.

Методологія дослідження включає аналіз, узагальнення, систематичний підхід, що дозволяють усебічно та глибоко вивчити феномен підтексту літературно-художнього твору. 
Сформульовані мета та завдання статті зумовлюють таку іiі структуру: по-перше, спроба визначити природу підтексту, зокрема через аналіз дефініцій; по-друге, розкриття інтертекстуальності як одного зі способів творення підтексту; по-третє, розробка методологічних і методичних принципів аналізу підтексту, що дозволять виявити істинні смисли твору. Тож перейдімо до розгляду визначених питань.

\section{2. Підтекст: спроба дефініції}

Розгляньмо найуживаніші визначення терміна «підтекст», водночас акцентуючи увагу на розумінні сутності цього поняття.

Насамперед підтекст осмислюють як прихований смисл (внутрішній зміст):

- «прихований смисл висловлення, що випливає зі співвідношення словесного значення з контекстом та особливо - мовною ситуацією» [43, с. 755];

- «прихований, неявний смисл висловлювання або тексту» [46, с. 277];

- «...прихований, неявний смисл, що не збігається з прямим смислом тексту» [30, с. 284];

- «прихований внутрішній зміст висловлювання, пов'язаний зі словесним формулюванням, наявність якого підтверджують жести, міміка, паузи» [29, с. 216].

При цьому підтекст ототожнюють з прихованим змістом:

- «внутрішній, прихований зміст якого-небудь тексту, висловлення...» [39, с. 315];

- «...прихований, внутрішній зміст висловлювання» [12, с. 548];

- «...додатковий смисловий або емоційний зміст, який реалізується за рахунок нелінійних зв'язків між одиницями тексту» [35, с. 72].

Існує інший підхід, згідно з яким підтекст осмислюють в якості інформациї:

- «...імпліцитна інформація, яка існує на рівні глибинної структури тексту, що експлікується у вигляді прирощення смислу окремих одиниць тексту на рівні поверхневої структури» [61, с. 49];

- «...естетична інформація, яка не виражена сукупністю значень мовних одиниць, тобто безпосереднім змістом художнього тексту» [52, с. 173]. 


\section{Foka Mariia}

Натрапляємо на випадки осмислення підтексту як прямо невисловлені думки чи почуття автора:

- «думка, яку автор прямо не висловив, але ми про неї здогадуємося, відчуваючи іiї ніби «між рядками»; це внутрішній, прихований зміст тексту, він доповнює, уточнює текст» [13, с. 160];

- «...думки та почуття, які висловлені в тексті твору не прямо, а не-мовби самі по собі випливають із сюжетних ситуацій, взаємостосунків і зітк-нень персонажів, ставлення до них автора, окремих реплік у діалогах тощо» [38, с. 157-158].

Такий багатоаспектний підхід до тлумачення підтексту можна пояснити неоднаковим розумінням його сутності, яке залежить від сприйняття природи тексту. Зокрема, один 3 поширених підходів до підтексту базується на думці, що художній текст є естетичним цілим, у якому підтекст декодується читачем у процесі його сприйняття. Таке розуміння художнього тексту прив'язане до герменевтики, а саме до герменевтичного кола (Ф. Шляєрмахер), де ціле трактують через частини, а частини інтерпретують крізь призму цілого [64, с. 292-293]. У свою чергу, аналіз твору з герменевтичних позицій, де важливу роль відіграє сам текст, спрямовано на розкриття авторської ідеї. Тож у плані підтексту ідеться про відновлення авторського смислу. У такий спосіб підтекст трактують як закладену інформацію, внутрішній зміст або думки й почуття автора.

Не менш поширеною є думка, яка перевагу в тлумаченні підтексту надає читачеві. Ідеться про теорію феноменолога Р. Інгардена, відповідно до якої читач відіграє визначальну роль у процесі інтерпретації тексту. «Твір художньої літератури не $\epsilon$, власне кажучи, конкретним об'єктом естетичного сприйняття, - переконаний Р. Інгарден. - Сам по собі він репрезентує лише каркас, який у низці відношень доповнюється чи заповнюється читачем, а подекуди набуває також змін або викривлень» [21, с. 12]. Згідно з цим підходом підтекст творить читач, а отже, підтекст інтерпретують насамперед як прихований смисл (внутрішній зміст).

Збалансованим поглядом на підтекст можна уважати онтологічне розу-міння смислу, що базується на філософському вченні М. Гайдеггера [58] та на герменевтичних працях Г.-Г. Гадамера [7]. Так, Г.-Г. Гадамер зазначає, що «діапазон осмислення не може обмежуватися ні тим, що автор насамперед мав на увазі, ні кругозором людини, якій від 
самого початку був адресований» [7, с. 85]. У такий спосіб читач не лише відтворює авторську інтенцію, а й формує смисл заново. Відповідно до цього погляду підтекст становить і закладену автором приховану інформацію, і сформований читачем смисл.

Тож можемо розрізняти авторський і читацький підтексти. Як зауважує Є. Леліс, ці два види підтексту «можуть відрізнятися, оскільки вбирають у себе суб'єктивний особистісний потенціал кожного з учасників художньої комунікації. При цьому ні авторський, ні читацький підтекст не варто уважати вичерпним, оскільки свідомість окремої людини не здатна охопити все безкінечне розмаїття смислів» [37, с. 34].

Разом $з$ тим важливо наголосити, що думка про можливість творення підтексту читачем є досить поширеною в літературознавстві. К. Долінін констатує: «Ми самі приписуємо висловлюванню підтекст, видобуваючи елементи його з нашого тезаурусу» [14, с. 38]. Дослідники дедалі частіше приходять до думки, що саме читач є творцем підтексту. Так, Л. Кайда відзначає, що «читач здатен прочитати текст глибше, ніж його задумав автор» [22, с. 4].

Як видно, визначення підтексту як неявного / прихованого / iмnліциитного смислу є більш точним, адже водночас уміщує авторську інтенцію та сприймання читача, що становлять тріаду системи автор твір - читач. Розуміння ж підтексту як інформації (до речі, як і думки чи почуття автора), як влучно зауважує С. Леліс, «знерухомлює» його, «цементує», перетворює в даність» [37, с. 31], залишаючи лише дві складові системи автор - текст.

Варто відзначити, що часто підтекст уважають не лише прихованим смислом, але й емоцією. Це вповні відображено ще в санскритській теорії раса-дхвані, суть якої полягає в навіюванні емоції (поетичного настрою) імпліцитним смислом. Ця думка набула розвитку в сучасному літературознавстві. Зокрема, Д. Затонський зауважує, що настрій «не стільки виражається словами, скільки стоїть за ними, що незмірно поглиблює картину відтворюваної дійсності» [18, с. 120].

Поняття «смисл» та «емоція» тісно пов'язані між собою. Справа в тому, що художній смисл високохудожнього твору завжди породжує емоцію. Про це дуже точно сказав теоретик мистецтва 3 написання кіносценаріїв Р. Маккі таке: «Якби я міг надіслати телеграму творцям фільмів з усього світу, у ній були би ці три слова: «Смисл породжує емоцію» [67, с. 309]. 


\section{Foka Mariia}

Увагу привертає ще один важливий аспект вивчення підтексту як явища: на якому рівні - свідомому чи підсвідомому - автор закладає підтекст у свій твір? Літературознавчій науці відомі абсолютно протилежні погляди на проблему: одні дослідники уважають, що підтекст автор вибудовує свідомо, інші схильні думати, що приховані смисли можуть виникати інтуїтивно, тобто підсвідомо. Варто зіставити такі визначення підтексту:

- «...це тип художнього образу, у якому конкретно-чуттєва даність предмета зображення, крім власного, має значення зумисне прихованого натяку (виділення наше. - М.Ф.) на якусь іншу ідею чи образ, що прямо не називається, але мається на увазі й суттєво переоцінює зміст того, про що йдеться відкрито, у прямій формі» [8, с. 112];

- другий рівень дії або змісту сцени, не вказаний відкрито, тобто не усвідомлений персонажами, а іноді навіть не усвідомлений автором [70].

Очевидно, що підтекст автор може створювати як свідомо (зумисне, спеціально), так і підсвідомо (незумисне, неспеціально). У разі свідомого створення підтексту автор залишає читачеві певні, за визначенням В. Кухаренко, «віхи» [34, с. 192] чи, як їх називає Л. Безугла, «індикатори» [5, с. 120] для декодування прихованого смислу. Наприклад, так писали А. Чехов («нова драма») чи Е. Гемінгвей (принцип айсберга). Ось як пояснював Е. Гемінгвей свій метод: «...можу сказати, що я завжди намагаюся писати за принципом айсберга. Сім восьмих його перебуває під водою, і лише одна восьма на поверхні. Ви можете пропустити що завгодно з того, що знаєте, і від цього ваш айсберг стане лише міцнішим. Ваші знання залишаються в підводній його частині» [59, c. 689-690].

Разом $з$ тим натрапляємо на випадки, коли письменники вдаються до підтексту тоді, коли не знають, як висловити думку. У такому разі маємо справу з псевдопідтекстом, або, за словами Е. Гемінгвея, 3 «дірками» («...якщо письменник обминає те, чого він не знає, але повинен знати, у його творах з'являються дірки» [59, с. 690]). Про це свого часу Д. Урнов писав так: «...у підтекст ховаються від власних проблем. Домислювати простіше, ніж писати. [...] Достатньо зробити незначне зусилля й поєднати начебто «прихованим смислом» декілька реплік, як на сторінці з'явиться гримаса глибокої думки, яку за бажанням чи наївністю можна сприйняти за саму думку» [55, с. 68]. 
Іноді читач прочитує підтекст, хоча автор зумисне не вкладав його у твір, тоді маємо несвідоме творення підтексту. Яскравою ілюстрацією такого підходу слугує влучне зауваження відомого американського сценариста Е. Сарджента: «Підтекст: я не писав його, але там він є. Підтекст у нашому власному житті» [69, с. 149].

Розмірковуючи про творення підтексту в цілому, маємо звертатися до таких понять, як талант чи творча інтуїиія, що корелюють 3 несвідомим (підсвідомим) і навіть надсвідомим. «У талановитих творах виявлясться безліч «нерукотворних», «нетиражованих» прийомів, більшість з яких просто не зафіксовані в реєстрах «шкільної» поетики, - зазначає Г. Клочек. - Це авторські прийоми. Думається, що багато з них створені несвідомо» [27, с. 31-32]. Відповідно, такі неусвідомлені авторські прийоми можуть вибудовувати прихований план твору.

До того ж у літературознавстві є визначення підтексту, які концентрують у собі суто літературознавчі підходи, що водночас спрощує розуміння цього явища в літературній сфері та значно ускладнює його функціонування в інших царинах (музиці, живописі тощо). Наприклад:

- «...прихована сюжетна лінія, яка нагадує про себе лише непрямим чином, причому найчастіше в найбільш відповідальні, психологічно важливі й поворотні, «ударні» моменти сюжетного розвитку» [50, c. 89-90];

- «...не що інше, як роззосереджений, дистанційний повтор, усі ланки якого вступають одна 3 одною в складні взаємовідношення, звідки й народжується їх новий, більш глибокий смисл» [50, с. 94];

- «...це тип художнього образу, у якому конкретно-чуттєва даність предмета зображення, окрім власного, має значення зумисне прихованого натяку на якусь іншу ідею чи образ, що прямо не називається, але мається на увазі й суттєво переоцінює зміст того, про що йдеться відкрито, у прямій формі» [8, с. 112].

У літературознавчій сфері визначення підтексту як типу художнього образу репрезентує широкий погляд на проблему, а розгляд підтексту як прихованої сюжетної лінії чи дистанційного повтору - вузький. Наприклад, підтекст Наприклад, підтекст може виникати також «внаслідок використання багатозначних слів, тропів (метафори, порівняння, перифрази, іронії, алегорії та ін.), фігур (різні види повтору, умовчання, парцеляція, еліпс, інверсія та ін.), виводиться із структур- 


\section{Foka Mariia}

них особливостей речень, своєрідності їх сполучуваності, символіки мовних фактів, графічних засобів (різних шрифтових виділень тексту, розділових знаків тощо), інтонації, з усієї текстової організації, з їі композиційно-стилістичної фактури» [31, с. 59]. Тобто підтекст формується шляхом використання прийомів, що створюють смислову двочи навіть багатоплановість.

Деякі дослідники намагаються відмежовувати підтекст від інших спосо-бів творення додаткової змістової щільності й глибини художнього тексту, як-от: символу, деталі, алегорії чи тропу. Так, В. Кухаренко наголошує, що визначальною характеристикою підтексту є наявність двох смислових потоків у художньому творі [34, с. 190]. У свою чергу, автори підручника «Теорія літератури» О. Галич, В. Назарець i $€$. Васильєв уточнюють, що підтекстовий образ має глибші ознаки конкретизованості, «сталості»; на відміну від символу чи алегорії, він конкретно й навіть персонально адресований, містить у собі натяк на цілком певні історичні події або реальних (чи умовно-реальних, якщо йдеться про літературний образ) людей [8, с. 112-113]. Проте такі спроби диференціювати підтекст не знайшли широкої підтримки в науці, бо є досить умовними.

Часто підтекст ототожнюють 3 поняттям глибина твору:

- «...глибинна частина твору, яка схована від очей читача та яку він має побачити скрізь товщу тексту, щоб повніше й глибше зрозуміти закладену в ньому думку» [33, с. 85];

- «імпліцитна інформація, яка існує на рівні глибинної структури тексту, що експлікується у вигляді прирощеного смислу окремих одиниць тексту на рівні поверхневої структури» [50, с. 49];

- «...глибина тексту» $[45$, с. 81$]$.

Точними й вичерпними є визначення підтексту, пов'язані з глибиною, бо словом «глибина» увиразнюється як інформативне й багатопланове багатство тексту (його об'єм, насиченість), так і його загадковість і таємничість, що створює враження «безодні смислу» (Г. Клочек) [28, с. 170].

Подібний ефект загадковості й таємничості мають і такі метафоричні визначення підтексту, як «вищий зміст» (Леся Українка), «задня» / «закутана» думка (В. Бєлінський), «розмитий текст» (Ф. Гарсіа Лорка), «підводна течія» (В. Немирович-Данченко), «підводна частина айсберга» (Е. Гемінгвей) тощо. I хоч ці визначення не конкретизують 
природу підтексту, вони, безумовно, акцентують на таких його домінантних рисах, як смисл і прихованість.

Важливою ознакою підтексту є також здатність наділяти твір художньою енергією. Пояснюючи феномен енергії художнього слова, Г. Клочек зазначає: «Те, що слово художнє наділене енергією, не викликає сумніву. У цьому легко переконуєшся, якщо подумаєш про здатність «вічних» творів, тобто творів, які пройшли випробування часом i набули статусу класичних, вступати в іскристий контакт із читачем, заряджаючи його своєю енергією» [26, с. 5]. У створенні такої енергії підтекст відіграє важливу, а може, навіть визначальну роль. У процесі декодування й відтворення реципієнтом прихованих смислів виникає емоційна реакція, яка досягає свого найвищого ступеня в момент їх розпізнавання. Саме тоді відбувається зарядження реципієнта смислами, що, як відомо, є кінцевою метою будь-якого мистецтва.

Розглянувши важливі аспекти природи підтексту можемо дійти висновку, що підтекст - це прихований смисл художнього твору, який свідомо чи підсвідомо створюється автором і відтворюється читачем, наділяючи твір особливою художньою енергією.

У вітчизняній філологічній літературі поруч з терміном «підтекст» активно функціонує термін «імплікація», перший з яких (підтекст), за зауваженням В. Кухаренко, є питомим і традиційним, а другий (імплікація) - запозиченим [34, с. 189]. Спостерігається тенденція до розмежування цих понять. Так, І. Арнольд зазначає: «Як імплікація, так і підтекст створюють додаткову глибину змісту, але в різних масштабах. [...] Підтекст та імплікацію часто важко розмежовувати, оскільки вони представляють собою варіанти додумування й часто зустрічаються разом, будучи присутніми в тексті одночасно, вони взаємодіють один 3 одним» $[1$, с. 85$]$. Відповідно, підтекст співвідноситься з художнім текстом у цілому, а імплікація - 3 окремим епізодом. Проте термін «імплікація» в значенні «прихований смисл окремого епізоду» не знайшов широкої підтримки в науці, бо фактично дублює термін «підтекст» і вживається як його синонім.

Варто зауважити, що досить широке синонімічне поле терміна «під-текст», як і спроби відокремити його від суміжних понять, значно ускладнюють «діалог» між різними видами мистецтва та науки. Розгляд функціонування імпліцитних смислів у літературі, театрі, кіно, живописі та музиці відкриває нові горизонти компаративного аналізу. 


\section{Foka Mariia}

Наприклад, у наш час феномен підтексту детально вивчається спеціалістами $з$ написання кіносценаріїв [див.: 69], і ці оригінальні здобутки стануть у пригоді для становлення теорії підтексту, яка формується на стику двох наук - літературознавства й мистецтвознавства.

Учення про підтекст не є цілісним без поняття пресупозиція, під якою розуміємо «частину «уведених в обіг» неусвідомлених знань, необхідних для розуміння смислу висловлення, а також для породження висловлень» [16, с. 18]. Є. Леліс до поняття пресупозиція уводить фонові знання та мовну компетенцію [37, с. 16], без яких не можливе адекватне декодування підтексту. «Головна цінність проблеми пресупозиції полягає якраз у тому, що вона робить можливою експлікацію [...] підтексту» [19, с. 221]. Саме це надає твору життєздатності, що, безумовно, пов'язана зі спроможністю по-новому прочитуватися, адже будь-який художній твір, за влучним зауваженням Л. Новикова, має тенденцію «до трансформації в сприйняті читачів і дослідників у залежності від епохи, різних соціальних і культурних умов, особистості читача й дослідника, цільової настанови тощо» [44, с. 20]. Відповідно, змінюються й підтексти, набуваючи ефекту актуальності, багатоплановості й навіть невловимості.

Таким чином, огляд різноманітних підходів до феномену підтексту, узагальнення та осмислення їх дали змогу встановити особливості й специфіку природи цього явища та визначити підтекст як прихований смисл художнього твору, що свідомо чи підсвідомо створюється автором і відтворюється читачем, наділяючи твір особливою художньою енергією.

\section{3. Інтертекстуальність як спосіб формування підтексту}

Як ми зазначали раніше, підтекст може створюватися різними засобами, що формують другий змістовий план, серед них: багатозначні слова, окремі тропи (метафора, порівняння, іронія, алегорія, перифрази тощо), стилістичні фігури (повтори, замовчування тощо), структурні особливості речень, специфіка їхнього зв'язку, символіка мовних фактів, графічні засоби, інтонація тощо. Якщо відштовхуватися від думки про творення другого смислового плану, то до перерахованих засобів також можна додати й інтертекстуальність. Проте інтертекстуальність як засіб створення підтексту є чи не найбільш суперечливою й неоднозначно трактованою в науці. Одні дослідники пов'язують чи 
подекуди навіть ототожнюють інтертекст з підтекстом, інші ж учені схильні розрізняти ці поняття. Наприклад, К. Тарановський тлумачить підтекст як «уже існуючий текст, відображений у наступному, новому тексті» [54, с. 31], що зближує поняття «підтекст» та «інтертекст». У свою чергу, С. Муратова уважає, що на сучасному етапі розвитку теорії інтертекстуальності терміни «підтекст» та «інтертекст» не можуть бути тотожними через неоднозначність терміна підтексту й традиційно широке коло його семантичних відтінків, якими оперує літературознавство [41, с. 67].

У рамках питань про інтертекстуальність у літературі та підтекст у художньому творі співвідношення понять «інтертекст» і «підтекст» більшою чи меншою мірою піддавалося розгляду (Є. Леліс [37], Є. Муратова [41], I. Рикун [48], П. Таммі [53] та ін.), проте питання інтертекстуальності як одного зі способів формування підтексту досі залишається актуальним, тож потребує наукового уточнення та узагальнення.

Основною ідейною базою, на якій формувалася сучасна теорія інтертекстуальності, є теорія анаграм Ф. де Сосюра; концепції М. Бахтіна про жанрову пам'ять, діалогічний характер художніх творів і «чуже слово»; уявлення Ю. Тинянова про конструктивну функцію мови та природну двоплановість пародії; міркування Ю. Лотмана про полілогічний характер поетичного тексту тощо.

Явище інтертекстуальності насамперед пов'язується 3 поняттям «чужого слова» М. Бахтіна. «Під чужим словом (висловленням, мовленнєвим твором) я розумію будь-яке слово будь-якої іншої людини, сказане чи написане своєю (тобто моєю рідною) чи будь-якою іншою мовою, тобто будь-яке не моє слово, - пояснює літературознавець і додає: - У цьому сенсі всі слова (висловлення, мовленнєві чи літературні твори), окрім власних слів, є чужим словом. Я живу у світі чужих слів. I все моє життя є орієнтацією в цьому світі, реакцією на чужі слова (безкінечно різноманітною реакцією), починаючи від засвоєння ïx (у процесі початкового оволодіння мовленням) і закінчуючи засвоєнням багатств людської культури (виражених у слові або в інших знакових матеріалах)» [4, с. 347-348].

Слово вплітається в діалогічне середовище «чужих слів», вступаючи з ними в складні взаємозв'язки, асимілюючись чи дисонуючи 3 ними: «...будь-яке конкретне слово (висловлення) знаходить той пред- 


\section{Foka Mariia}

мет, на який воно направлене, завжди є, так би мовити, уже оговореним, оскарженим, оціненим, окутаним серпанком, що затемняє його, чи, навпаки, світлом уже сказаних чужих слів про нього. Воно обплетене й пронизане загальними думками, поглядами, чужими оцінками, акцентами. Направлене на свій предмет слово входить у це діалогічне схвильоване й напружене середовище чужих слів, оцінок й акцентів, уплітається в їх складні взаємовідношення, зливається з одними, відштовхується від інших, перетинається з третіми; і все це може істотно впливати на формування слова, відкладатись у всіх його смислових пластах, ускладнювати його експресію, впливати на весь стилістичний вигляд» [3, с. 89-90].

На думку М. Бахтіна, будь-який текст є діалогічним, містить у собі багато інших текстів, «чужих слів», які співвідносяться та взаємодіють у певному контексті, утворюючи імпліцитні смислові плани.

Опираючись на концептуальні положення М. Бахтіна, у кінці 60-х років XX століття Ю. Крістева формулює власну теорію, уводить у літературознавчий тезаурус терміни «інтертекст» та «інтертекстуальність» (уперше під час своєї доповіді про творчість російського літературознавця на семінарі Р. Барта (1966), а згодом у статті «Бахтін, слово, діалог і роман» (1967).

Осмислюючи теоретичні концепти М. Бахтіна, дослідниця акцентувала на тому, що російський мислитель «одним 3 перших замість статичного членування текстів запропонував таку модель, у якій літературна структура не присутня, але виробляється по відношенню до іншої структури» [32, с. 428]. При цьому, як зауважує Ю. Крістева, це можливо лише тоді, коли літературне слово розглядати «не як певну точку (стійкий смисл), але як місце перетину текстових площин, як діалог різного виду письма - самого письменника, отримувача (або персонажа) i, нарешті, письма, створеного теперішнім або попереднім контекстом» [32, с. 428].

Беручи за основу бахтінську ідею діалогічної моделі мови, Ю. Крістева розмірковує над діалогами між художніми текстами: «Ми назвемо інтертекстуальністю ту текстуальну інтеракцію, яка відбувається всередині окремого тексту, - пояснює дослідниця. - Для суб'єкта пізнання інтертекстуальність - це поняття, яке буде ознакою того способу, яким текст прочитує історію та вписується в неї» [66, с. 443]. Тож, на думку Ю. Крістевої, художній текст є відображенням іншого тексту, 
адже «будь-який текст будується як мозаїка цитацій, будь-який текст це вбирання й трансформації якогось іншого тексту» [32, с. 429].

Концепція Ю. Крістевої отримала широке визнання й продовження в роботах таких літературознавців, як Р. Барт [2], М. Грессе [11], У. Еко [15], М. Ріффатер [49], Ф. Соллерс [71] та ін.

Зокрема, Р. Барт подає своє визначення інтертекстуальності, яке стало класичним і хрестоматійним у сучасному літературознавстві: «...він [Текст. - М.Ф.] може бути собою тільки у своїх неподібностях (що, зрештою, не говорить про якусь його індивідуальність); прочитання Тексту - акт одноразовий (отже, ілюзорна будь-яка індуктивно-дедуктивна наука про тексти - у текстах немає «граматики»), і разом з тим текст суцільно зітканий із цитат, посилань, відгомонів; усе це мови культури (а яка мова не є такою?), старі й нові, що проходять крізь текст і створюють потужну стереофонію. Будь-який текст $є$ між-текстом по відношенню до якогось іншого тексту, але цю інтретекстуальність не варто розуміти так, що текст має якесь походження; будь-які пошуки «джерел» і «впливів» відповідають міфу про філіацію творів, текст же утворюється з анонімних, невловимих і разом 3 тим уже прочитаних цитат - із цитат без лапок» [2, с. 418]. За таким розумінням дослідника, інтертекстуальність - явище, характерне для будь-якого тексту.

У свою чергу, Ж. Женетт тлумачить інтертекстуальність як «не першое-лемент літератури, а лише один 3 типів взаємозв'язків, які існують у ній» [47, с. 54].

Поступово в літературознавстві виокремилися два основні підходи до інтертексту та інтертекстуальності, де в широкому сенсі інтертекстуальність постає як теорія безмежного тексту, де будь-який текст $\epsilon$ інтертекстом, а у вужчому сенсі інтертекстуальністю наділені тільки ті тексти, що мають конкретні відсилання до попередніх текстів, тобто автор цілком свідомо уводить у свій текст фрагменти інших текстів, розраховуючи на те, що читач зрозуміє його.

Очевидно, розгляд інтертекстуальності як способу, до якого свідомо вдається автор з метою розширення й збагачення змісту твору шляхом міжтекстової взаємодії, є більш точним у плані осягнення справжнього авторського задуму та більш продуктивним з наукового погляду. «Говорити про функціонування інтертекстуальності у творах художньої літератури слід, насамперед, відмежувавшись від бартів- 


\section{Foka Mariia}

ського широкого трактування цього явища, від його концепції «інтертекстуальності без берегів», оскільки за такого підходу передбачається вільна гра текстів та ігнорується авторська інтенція, тобто в постструктуралістських теоріях інтертекст «не функціонує», а розчиняється в нескінченності текстового простору, - зазначає М. Шаповал. - Якщо ж розглядати це явище і з боку автора, і з боку читача, у його креативних та рецептивних компетенціях, то відкриваються ширші можливості для цікавих спостережень над міжтекстовими взаємодіями, які збагачують твір новими смислами й сприяють глибокому розкриттю творчого задуму, що, на нашу думку, є вагомою підставою для ви-користання інтертекстуального підходу в літературознавстві» [63, с. 13].

Відсилання автора до попереднього тексту може відбуватися трьома основними способами: 1) цитати, де автор прямо наводить чужі (або навіть і свої!) слова або цілі речення, які здебільшого зберігають своє вихідне значення; 2) алюзії, де автор свідомо натякає на сюжет, образ чи історичну подію, часто не завжди дослівно передаючи попереднє літературне джерело; 3) ремінісценції, де автор неусвідомлено та цілковито непередбачувано нагадує читачеві про більш ранні літературні факти та їх текстові компоненти (це, наприклад, відбувається внаслідок впливу інших письменників).

У такому разі авторські відсилання (цитати, алюзії та ремінісценції) утворюють додатковий змістовий пласт, декодування якого дасть змогу глибше зрозуміти твір. У свою чергу, підтекст є прихованим смислом художнього твору, що свідомо чи підсвідомо створюється автором i відтворюється читачем, наділяючи твір особливою художньою енергією. Подібно до цитат, алюзії і ремінісценції є носіями додаткового, імпліцитного смислу, тому вони стають засобами створення підтексту.

Наприклад, цитування хоралів Й. С. Бахом у «Добре темперованому клавірі» дозволяє композитору увести в музичний твір образи й сюжети Святого письма [див.: 57], а звернення В. Шевчука у формі алюзії до причорноморської легенди про Геракла та змієногу діву в оповіданні «Жінка-змія» поглиблює ідею про демонічність жінки [див.: 56].

Уводячи цитати, алюзії чи ремінісценції у твір, письменник так чи інакше розраховує на те, що вони будуть декодовані читачем і справжній смисл буде осягнений. Дуже влучно про це говорить У. Еко: «Щоб організувати текст, його автор повинен покладатися на низку кодів, 
що надають певного змісту висловлюванням, які він використовує. Щоб зробити свій текст комунікативним, автор повинен уважати, що ансамбль кодів, на які він покладається, є такий самий, як ансамбль кодів, що їх поділяє його можливий читач. Отже, автор мусить передбачати зразок можливого читача (надалі Зразковий Читач), здатного інтерпретаційно трактувати висловлення так само, як генеративно трактує їх автор» $[15$, с. 28$]$.

Таким чином, інтертекстуальність, що відсилає читача до попереднього тексту, несучи в собі додатковий смисл і становлячи прихований смисл, є од-ним із засобів формування підтексту. Декодування інтертекстуальних зв'язків дає змогу глибше прочитати той чи той художній твір.

\section{4. Методологічні та методичні проблеми вивчення підтекстових смислів}

Розглядаючи підтекст як прихований смисл художнього твору, що свідомо чи підсвідомо створюється автором і відтворюється читачем, доходимо думки, що в процесі декодування прихованих смислів слід відштовхуватися від двох основних позицій: по-перше, якими засобами автор створює підтекст; по-друге, яким чином відтворює підтекстові смисли читач.

Беручи за основу аксіоматичне твердження, що будь-який високохудожній літературний твір є системно організованою цілісністю, уважаємо підтекст одним з важливих системотворчих чинників, вибудовування якого потребує від письменника системного й цілісного підходу. Для створення підтекстового плану митцю необхідно продумати прийоми, що є елементами художньої системи, творчі принципи, які, перебуваючи в системних зв'язках та узгоджуючись між собою, приводять «механізм» системи в дію та «працюють» на досягнення кінцевого результату. Так через осмислення імпліцитної інформації проступає істинний смисл художнього твору.

Тож поетика підтексту - це система прийомів чи творчих принципів, за-вдяки яким утворюється другий (підтекстовий, імпліцитний) смисловий план. Саме тому розкриття підтексту твору, тобто його істинного смислу, потребує системного підходу, методологія якого полягає в тому, щоб визначити художні прийоми (творчі принципи), які сприяють вираженню цього смислу. Сам же смисл, процес форму- 


\section{Foka Mariia}

вання якого вдається виявити в ході вивчення функції цих прийомів, $\epsilon$ головним системоутворювальним чинником твору. У такий спосіб відбувається експлікація підтекстового смислу, унаслідок чого здійснюється вивільнення художньої енергії та заряджання нею реципієнта.

3 огляду на те, що спектр засобів створення імпліцитного плану, які формують смислову дво- чи багатоплановість, широкий і різноманітний, аби осягнути істинний смисл, потрібно виявити задіяні автором літературні прийоми, зрозуміти їхню функцію. Одним з ефективних підходів до експлікації функції літературного прийому є змоделювати процес породження прихованих художніх смислів та результат їхнього впливу на читача, тобто задіяти рецептивну поетику.

Процес формування підтексту у свідомості читача насамперед пов'язаний з пробудженням образного ряду. Це пояснюється художньо-інформаційною щільністю літературно-художніх образів, які при цьому наділені високою інформативністю, а отже, здатні викликати низку візій, думок і почуттів у читачів. І. Гальперін зазначає: «Текст може викликати образи - зорові, слухові, тактильні, смакові. Ці образи виявляються небайдужими до самого змісту літературно-художніх творів» [9, с. 20].

Розкриттю механізму створення цих образів в уяві читача сприяють базові терміни рецептивної естетики - актуалізація, конкретизація й візуалізація. Так, механізм актуалізащії полягає в тому, що «читач, «наштовхнувшись» у тексті на які-небудь згадування про певну ситуацію чи іiі деталі, про жести, пейзаж, вираз облич персонажів, подробиці інтер'єру тощо, починає чути, бачити, вдихати й сприймати звуки, кольори, запахи, тіла, речі» [60, с. 30]. Уточнює процес створення зорових образів в уяві реципієнта термін візуалізація. Суть цього явища полягає в механізмі відтворення зорових образів під час сприймання художнього твору, тобто в уяві читача образ зринає в кольорі та об'ємі. Не менш важливим у формуванні додаткових вражень у реципієнта $\epsilon$ процес конкретизації, який полягає в заповненні ним «порожніх місць» і «ділянок невизначеності» [60, с. 190] своїми уявленнями й емоціями з урахуванням власного «горизонту очікування» [60, с. 190].

Процес моделювання збудження й породження асоціацій читача в процесі сприймання художнього твору не можливий без залучення психологічного інструментарію. Зокрема, ідеться про так званий ефект оберненої лійки [25, с. 166]. Відомо, що людина на тлі навколишнього 


\section{Subtext of a fictional work as a literary problem}

середовища усвідомлено сприймає тільки те, на чому сфокусована іiі увага в конкретний момент. Тож не всі сигнали, отримані від дійсності, доходять до вищих відділів центральної нервової системи, тобто усвідомлюються. Л. Виготський пояснює цей процес так: «Шеррінгтон порівнював нашу (людську. $-M . \Phi$.) нервову систему з воронкою, повернутою широким отвором до дії. Світ вливається в людину через широкий отвір лійки тисячею покликів, потягів, роздратуваннями, мізерна їх частина здійснюється й ніби витікає назовні крізь вузький отвір» [6, с. 313-314]. Проте інформація, яка потрапила, умовно кажучи, через широкий отвір лійки та не витекла через вузький, хоч i несвідомо, але сприймається людиною. Таким чином, психологія розглядає інформацію свідому, тобто таку, що «зберігає все, що пройшло горнило мислення, почуттів, уяви та психомоторних дій», і несвідому, тобто таку, що «зберігає те, що оминуло фокус свідомості й мимовільно залягло в сховищах за порогом свідомості» [24, с. 325].

Високохудожній текст здатний активізувати ефект оберненої лійки, що пробуджує в читача свідому та несвідому інформацію. Д. Урнов зазначає: «У кожному істинно художньому творі відображаються «вікові накопичення», вантаж традиційних уявлень, що спричинилися до простоти прийнятного, природного. Уміщуючись десь між рядками, за текстом, у підтексті, ці уявлення, неначе противага, приводять у рух механізм простих дій персонажів» [55, с. 56].

В ефективності рецептивної поетики для аналізу творів, де головне явно не виражене, переконуємося, звертаючись до робіт Г. Клочека, зокрема монографій «Душа моя сонця намріяла»: Поетика «Сонячних кларнетів» Павла Тичини» (1986), «Поетика Бориса Олійника: Літ.-критичний нарис» (1989), «Поезія Тараса Шевченка: сучасна інтерпретація» (1998) тощо. Використовуючи інструментарій рецептивної поетики, передусім ефект оберненої лійки, літературознавець максимально наблизився до відтворення того, що залишається несказаним, але є носієм прихованого смислу в тексті. Наприклад, у такий спосіб дослідник точно змоделював процес розгортання мініатюри П. Тичини «Дощ» до повномасштабної картини [25, с. 166-177].

Повнота відтворення підтекстової інформації читачем буде повністю за-лежати від його асоціативного фонду, тезаурусу, уміння критично підходити до художнього тексту. Ідеться про імпліцитного читача, тобто «ідеального» читача, який має певні погляди (моральні, 


\section{Foka Mariia}

культурні тощо), відповідні цьому тексту, для того, щоб він справив повний ефект» [65, с. 123], а отже, який здатний адекватно декодувати прихований змістовий план твору.

Розкрити підтекстові смисли уможливлює метод повільного читання твору, або інтенсивного читання, названий Г. Клочеком аналізом «під мікроскопом» [26, с. 33], що дає змогу зупинитися на кожній деталі 3 метою зрозуміти процес відтворення підтексту, аби, у свою чергу, зрозуміти істинні смисли. Т. Ньюкерт дуже точно пояснює явище повільного читання (slow reading): «Повільно читати означає встановити глибокий зв'язок з письменником. Якщо ми маємо рефлексувати до письменника, ми повинні бути відповідальними. Ми зобов'язуємося стежити за ланцюгом думок, внутрішнім творенням образів, стежити за розкриттям ідеї, чути текст, бути уважними до мови, питань, візуалізації сцен. Це означає надавати увагу рішенням, які робить письменник» $[68$, с. 2].

Моделювання процесу сприймання тексту та відновлення підтексту роблять можливим відчути художню енергію, яка виникає в процесі декодування й творення імпліцитних смислів читачем. Художня енергія є тією важливою ознакою, що являє собою сутність підтексту як мистецького явища, адже в процесі декодування прихованих смислів наступає момент «радості відкриття» (В. Сухомлинський), що становить і естетичний вплив на читача, і осягнення справжнього художнього смислу. Саме в цій єдності постає кінцевий художній результат.

Таким чином, основними методологічними та методичними підходами до вивчення художніх творів, у яких існують підтексти, $є$ повільне прочитання тексту шляхом застосування рецептивної поетики та системного підходу.

\section{5. Висновки}

Підтекст є однією з найскладніших і нечітко окреслених категорій поетики літературного твору, адже залежно від особливостей розуміння природи художнього тексту, розподілу ролі автора й читача, специфіки творення прихованого смислу це явище по-різному тлумачиться. Розгляд важливих аспектів природи підтексту в літературознавстві дав змогу визначити, що підтекст - це прихований смисл художнього твору, який свідомо чи підсвідомо створюється автором і відтворюється читачем, наділяючи твір особливою художньою енергією. 
У свою чергу, підтекстовий план може створюватися багатьма різноманітними художніми засобами, які генерують додатковий смисл. Так, інтертекстуальність, що відсилає читача до попереднього тексту, несучи в собі додатковий смисл і становлячи прихований смисл, є одним із засобів формування підтексту.

Підтекст як один 3 важливих системотворчих чинників зумовлює використання прийомів, які внаслідок узгодження та взаємодії створюють багатоплановий художній смисл. Дослідження функцій цих прийомів та аналіз їхнього впливу на реципієнта дають змогу розкрити приховані смисли.

Ефективною методикою аналізу підтексту є системний підхід, завдяки якому визначаються прийоми створення прихованих смислових планів художнього тексту. Процес виявлення та увиразнення невисловлених прямо смислів потребує моделювання сприймання твору читачем, що доцільно робити на засадах рецептивної поетики, методологічний апарат якої зараз активно розвивається. Аналіз виражальних засобів з позицій художнього сприймання стає можливим лише за умови, що інтерпретатор приділяє належну увагу кожному прийому, який породжує художні смисли. У цьому разі актуальним є метод повільного читання художнього тексту.

Вивчення підтексту літературно-художнього твору в літературознавчій сфері, зокрема розуміння його сутності та природи, визначення засобів і способів творення підтекстового плану, а також розробка методологічних і методичних підходів до його аналізу, дозволить глибше аналізувати приховані плани твору, що уможливить осягнути справжні, істинні смисли твору.

\section{Список літератури:}

1. Арнольд, И. В. (1982) Импликация как прием построения текста и предмет филологического изучения. Вопросы языкознания, № 4, С. 83-91.

2. Барт, Р. (1989) От произведения к тексту. Барт, Р. Избранные работы: Семиотика. Поэтика. Москва: Прогресс, С. 413-423.

3. Бахтин, М. М. (1975) Вопросы литературы и эстетики. Москва: Худож. лит.

4. Бахтин, М. М. (1979) Эстетика словесного творчества. Москва: Искусство.

5. Безугла, Л. Р. (2007) Вербалізація імпліцитних смислів у німецькому діалогічному дискурсі. Харків: ХНУ ім. В. Н. Каразіна.

6. Выготский, Л. С. (1968) Психология искусства. Москва: Искусство.

7. Гадамер, Х.-Г. (1991) Актуальность прекрасного. Москва: Искусство. 


\section{Foka Mariia}

8. Галич, О., Назарець, В., Васильєв, Є. (2001) Теорія літератури. Київ: Либідь.

9. Гальперин, И. Р. (2007) Текст как объект лигвистического исследования. Москва: КомКнига.

10. Голякова, Л. А. (2006) Онтология подтекста и его объективация в художественном произведении: дис. ... д-ра наук. Пермь.

11. Грессе, М. (2009) Интертекстуальность. Новосибирск: Краус и ко.

12. Гром'як, Р. Т., Ковалів, Ю. І. та ін. (1997) Літературознавчий словник-довідник. Київ: Академія.

13. Данильцова, У. Д. (2004) Літературознавчі терміни. Київ: А.С.К.

14. Долинин, К. А. (2007) Интерпретация текста. Французский язык. М.: URSS.

15. Еко, У. (2004) Роль читача. Львів: Літопис.

16. Ермакова, Е. В. (2010) Имплицитность в художественном тексте (на материале русскоязычной и англоязычной прозы психологического и фантастического реализма). Саратов: Изд-во Сарат. ун-та.

17. Заморина, О. В. (2005) Восприятие подтекста речевого произведения: На примере научных текстов: дис. ... канд. наук. Пермь.

18. Затонский, Д. В. (1988) Художественные ориентиры XX века. Москва: Сов. писатель.

19. Звегинцев, Д. В. (1976) Предложение и его отношение к языку и речи. Москва: Изд-во Моск. ун-та.

20. Зеленіна, Н. В. (2004) Підтекст музичного твору: формування і функціонування: дис. ... канд. Київ.

21. Ингарден, Р. (1962) Исследования по эстетике. Москва: Изд-во иностр. лит.

22. Кайда, Л. Г. (2005) Стилистика текста: от теории композиции - к декодированию. Москва: Флинта.

23. Кикоть, В. (2013) Суть підтексту і суміжних понять, релевантних для перекладу. Вісник Черкаського університету, № 5, С. 12-35.

24. Клименко, В. (2006) Психологія творчості. Київ: Центр навч. л-ри.

25. Клочек, Г. (1986) «Душа моя сонця намріяла...»: Поетика «Сонячних кларнетів» Павла Тичини. Київ: Дніпро.

26. Клочек, Г. (2007) Енергія художнього слова. Кіровоград: РВВ КДПУ ім. В. Винниченка.

27. Клочек, Г. (1990) Поетика і психологія. Київ: Знання.

28. Клочек, Г. (1989) У світлі вічних критеріїв: Про систему критеріїв оцінки літературного твору. Київ: Дніпро.

29. Ковалів, Ю. І. (2007) Літературознавча енциклопедія (Т. 2). Київ: Академія.

30. Кожевников В. М., Николаев П. А. (ред.) (1987) Литературный энциклопедический словарь. Москва: Сов. энцикл.

31. Кравець, Л. (2004) Явище підтексту та засоби його вираження в художньому творі. Українська мова і література в школі, № 1, С. 58-61.

32. Кристева, Ю. (2000) Бахтин, слово, диалог и роман. Французская семиотика: От структурализма к постструктурализму. Москва: ИГ Прогресс, С. 427-457. 


\section{Subtext of a fictional work as a literary problem}

33. Крылова, И. Н. (1982) Подтекстовые значения в рассказе Э. Хемингуэя «На Биг-Ривер». Анализ стилей зарубежной художественной и научной литературы. Ленинград: Изд-во ЛГУ, С. 84-88.

34. Кухаренко, В. А. (2004) Інтерпретація тексту. Вінниця: НОВА КНИГА.

35. Кухаренко, В. А. (1974) Типы и средства выражения импликации в английской художественной речи (на материале прозы Э. Хемингуэя). Филологические науки, № 1, С. 72-80.

36. Куц, Г. М. (2009) Конституційні бар'єри української демократії: ліберальний підтекст. Вісник Харківського національного університету iм. B. Н. Каразіна, Сер. «Питання політології», № 861, Вип. 15, С. 180-186.

37. Лелис, Е. И. (2013) Подтекст как лингвоэстетическая категория в прозе А. П. Чехова. Ижевск: Удмурт. ун-т.

38. Лесин, В. М. (1985) Літературознавчі терміни. Київ: Рад. шк.

39. Лесин, В. М., Пулинець, О. С. (1971) Словник літературознавчих термінів. Київ: Рад. шк.

40. Мозгова, Н. Г. (2001) Гносеологічний підтекст однієї дискусії про місце філософії в системі освіти. Практична філософія, № 1, С. 219-226.

41. Муратова, Е. Ю. (2006) Терминологический проблемы в теории интертекстуальности. Веснік Віиебскага дзяржаўнага ўніверсітэта, № 3, С. 65-70.

42. Назарець, В. М. (1994) Підтекст як смисловий феномен та художнє явище: дис. ... канд. наук. Рівне.

43. Николюкин, А. Н. (ред.) (2001) Литературная энциклопедия терминов и понятий. Москва: Интелвак.

44. Новиков, Л. А. (2003) Художественный текст и его анализ. Москва: Едиториал УРСС.

45. Озеров, Л. (1968) В мастерской стиха. Москва: Знание.

46. Оліфіренко, С. М., Оліфіренко, В. В., Оліфіренко, Л. В. (2007) Універсальний літературний словник-довідник. Донецьк: БАО. ЛКИ.

47. Пьеге-Гро, Н. (2008) Введение в теорию интертекстуальнсти. Москва:

48. Рикун, І. П. (2002) Підтекст як форма вираження «чужого слова». Питання літературознавства, Вип. 9, С. 47-52.

49. Риффатерр, М. (1998) Ансамбль Текстов. СПб.: Троммит.

50. Сильман, Т. (1969) «Подтекст - это глубина текста». Bопросы языкознания, № 1, С. 89-102.

51. Степаненко, А. А. (2007) Подтекст в прозе А. П. Чехова 1890-х-1900-х гг.: дис. ... канд. наук. Сургут.

52. Тамарченко, Н. Д. (2008) Поэтика: словарь актуальных терминов и понятий. Москва: Изд-во Кулагиной; Intrada.

53. Тамми, П. (1992) Заметки о полигенетичности в прозе Набокова. Там-ми, П. Проблемы русской литературы и культуры. Хельсинки, С. 181-194.

54. Тарановский, К. (2000) О поэзии и поэтике. Москва: Яз. рус. культ.

55. Урнов, Д. (1971) Мысль изреченная и скрытая (о подтексте в современной прозе). Вопросы литературы, № 7, С. 52-72.

56. Фока, М. В. (2017) Підтексти в химерному оповіданні В. Шевчука «Жінка-змія». Вісник Дніпропетровського університету імені Альфреда 


\section{Foka Mariia}

Нобеля. Дніпро: Вид-во Дніпр. ун-ту ім. А. Нобеля, Сер.: Філологічні науки, № 2 (14), C. 174-180.

57. Фока, М. В. (2015) Підтекстові смисли в музиці (на матеріалі «Добре темперованого клавіру» Й. С. Баха). Вісник КНУКіМ. К.: КНУКіМ, Сер. «Мистецтвознавство», Вип. 32, С. 107-113.

58. Хайдеггер, М. (2006) Бытие и время. СПб.: Наука.

59. Хемінгуей, Е. (1981) Твори (Т. 4). Київ: Дніпро.

60. Цурганова, Е. А. (ред.) (2004) Западное литературоведение XX века. Москва: Intrada.

61. Чулкова, В. С. (1978) Многочленный стилистический прием как одно из средств интеграции текста: дис. ... канд. наук. Москва.

62. Чунева, Л. Ю. (2006) Смыслообразующая функция подтекста в литературном произведении: дис. ... канд. наук. Тверь.

63. Шаповал, М. О. (2010) Стратегії інтертекстуальності та гра свідомостей у сучасній українській драмі: автореф. дис. ... д-ра наук. Київ.

64. Шлейермахер, Ф. Д. (1967) Лекции по эстетике. История эстетики: памятники мировой эстетической мысли (Т. 3). Москва: Искусство.

65. Baldick, Ch. (2001) The Concise Oxford Dictionary of Literary Terms. N.Y.: Oxford University Press.

66. Kristeva, J. (1974) La Révolution du langage poétique. L'avant-garde à la fin du XIXe siècle: Lautréamont et Mallarmé. P.: Éditions du Seuil.

67. McKee, R. (1997) Story: Substance, Structure, Style, and the Principles of Screenwriting. USA: ReganBooks, HarperCollins Publishers.

68. Newkirt, T. (2012) The Art of Slow Reading: Six Time-Honored Practices for Engagement. Portsmouth, NH: Heinemann.

69. Seger, L. (2011) Writing Subtext: What Lies Beneath. Studio City, CA: Mi-chael Wiese Productions.

70. Smith, D. Being a Glossary of Terms Useful in Critiquing Science Fiction // SFWA: Science Fiction \& Fantasy Writers of America. Available at: www.sfwa.org/2009/06/being-a-glossary-of-terms-useful-in-critiquing-science-fiction/ (Accessed 21.05.2015).

71. Sollers, Ph. (1968) Ecriture et revolution. Théorie d'ensemble. P.: Seuil.

\section{References:}

1. Arnol'd, I. V. (1985) Implikatsiya kak priem postroeniya teksta i predmet filologicheskogo izucheniya [Implication as a method for text building and a subject matter for philological study]. Voprosy yazykoznaniya [Issues in linguistics], no. 4, pp. 83-91. (in Russian)

2. Bart, R. (1989) Ot proizvedeniya k tekstu [From a literary work to a text]. Bart, R. Izbrannye raboty: Semiotika. Poetika [Selected texts: Semiotics. Poetics]. Moscow: Progress, pp. 419-423. (in Russian)

3. Bakhtin, M. M. (1975) Voprosy literatury i estetiki [Issues in literature and aesthetics]. Moscow: Khudozh. lit. (in Russian)

4. Bakhtin, M. M. (1979) Estetika slovesnogo tvorchestva [Aesthetics of a written word]. Moscow: Iskusstvo. (in Russian) 
5. Bezuhla, L. R. (2007) Verbalizatsiia implitsytnykh smysliv u nimetskomu di-alohichnomu dyskursi [Verbalization of implicit meanings in the German discourse]. Kharkiv: KhNU im. V. N. Karazina. (in Ukrainian)

6. Vygotskiy, L. S. (1968) Psikhologiya iskusstva [Art psychology]. Moscow: Iskusstvo. (in Russian)

7. Gadamer, Kh. -G. (1991) Aktual'nost' prekrasnogo [Topicality of beautiful]. Moscow: Iskusstvo. (in Russian)

8. Halych, O., Nazarets, V., Vasyliev, Ye. (2001) Teoriia literatury [Literary theory]. Kyiv: Lybid. (in Ukrainian)

9. Gal'perin, I. R. (2007) Tekst kak ob"ekt ligvisticheskogo issledovaniya [Text as a subject matter of linguistic study]. Moscow: KomKniga. (in Russian)

10. Golyakova, L. A. (2006) Ontologiya podteksta i ego ob"ektivatsiya v khudozhestvennom proizvedenii [Ontology of subtext and its objectification in a fictional work] (Grand PhD Thesis), Perm. (in Russian)

11. Gresse, M. (2009) Intertekstual'nost' [Intertextuality]. Novosibirsk: Kraus i ko. (in Russian)

12. Hromiak, R. T., Kovaliv, Yu. I., etc. (1997) Literaturoznavchyi slovnyk-dovidnyk [Literary dictionary and reference book]. Kyiv: Akademiia. (in Ukrainian)

13. Danyltsova, U. D. (2004) Literaturoznavchi terminy [Literary terms]. Kyiv: A.S.K. (in Ukrainian)

14. Dolinin, K. A. (2007) Interpretatsiya teksta. Frantsuzskiy yazyk [Text interpretation. The French language]. Moscow: URSS. (in Russian)

15. Eko, U. (2004) Rol chytacha [Reader's function]. Lviv: Litopys. (in Ukrainian)

16. Ermakova, E. V. (2010) Implitsitnost'v khudozhestvennom tekste (na materiale russkoyazychnoy i angloyazychnoy prozy psikhologicheskogo i fantasticheskogo realizma) [Implicitness in a fictional work (on the material of the Russianlanguage and English-language prose of psychological and fantastic realism)]. Saratov: Izd-vo Sarat. un-ta. (in Russian)

17. Zamorina, O. V. (2005) Vospriyatie podteksta rechevogo proizvedeniya: $\mathrm{Na}$ primere nauchnykh tekstov [Reception of subtext of a verbal work: Through the example of the scientific texts] (PhD Thesis), Perm. (in Russian)

18. Zatonskiy, D. V. (1988) Khudozhestvennye orientiry XX veka [Artistic orienting points of XX century]. Moscow: Sov. pisatel'. (in Russian)

19. Zvegintsev, D. V. (1976) Predlozhenie $i$ ego otnoshenie $k$ yazyku i rechi [Sentence and its relative to language and discourse]. Moscow: Izd-vo Mosk. un-ta. (in Russian)

20. Zelenina, N. V. (2004) Pidtekst muzychnoho tvoru: formuvannia i funktsionuvannia [Subtext of a musical work: formation and function] (PhD Thesis), Kyiv. (in Ukrainian)

21. Ingarden, R. (1962) Issledovaniya po estetike [Essays on aesthetics]. Moscow: Izd-vo inostr. lit. (in Russian)

22. Kayda, L. G. (2005) Stilistika teksta: ot teorii kompozitsii $-k$ dekodirovaniyu [Text stylistics: from the theory of composition - to the decoding]. Moscow: Flinta. (in Russian)

23. Kykot, V. (2013) Sut pidtekstu i sumizhnykh poniat, relevantnykh dlia perekladu [Essence of implied sense and adjacent translation relevant phenomena]. 


\section{Foka Mariia}

Visnyk Cherkaskoho universytetu [Cherkasy university journal], no. 5, pp. 12-35. (in Ukrainian)

24. Klymenko, V. (2006). Psykholohiia tvorchosti [Psychology of art]. Kyiv, Tsentr navch. 1-ry. (in Ukrainian)

25. Klochek, H. (1986). "Dusha moia sontsia namriiala...»: poetyka «Soniachnykh klarnetiv» Pavla Tychyny [«My Soul has dreamed the Sun»: poetics of «Clarinets of the Sun» by Pavlo Tychyna]. Kyiv: Dnipro. (in Ukrainian)

26. Klochek, H. (2007) Enerhiia khudozhnoho slova [Energy of an artistic word]. Kirovohrad: RVV KDPU im. V. Vynnychenka. (in Ukrainian)

27. Klochek, H. (1990) Poetyka i psykholohiia [Poetics and psychology]. Kyiv: Znannia. (in Ukrainian)

28. Klochek, H. (1989) U svitli vichnykh kryteriiv: Pro systemu kryteriiv otsinky literaturnoho tvoru [In relation to the perpetual criteria: about the criterion system of the evaluation of a literary work]. Kyiv: Dnipro. (in Ukrainian)

29. Kovaliv,Yu. I. (2007) Literaturoznavcha entsyklopediia [Literary encyclopedia] (Vol. 2.). Kyiv: Akademiia. (in Ukrainian)

30. Kozhevnikov, V. M., Nikolaev, P. A. (ed.) (1987) Literaturnyy entsiklopedicheskiy slovar' [Literary encyclopedic dictionary]. Moscow: Sov. entsikl. (in Russian)

31. Kravets, L. (2004) Yavyshche pidtekstu ta zasoby yoho vyrazhennia v khudozhnomu tvori [Subtext phenomenon and methods for its expression in a fictional work]. Ukrainska mova i literatura $v$ shkoli [The Ukrainian language and literature in school], no. 1, pp. 58-61. (in Ukrainian)

32. Kristeva, Yu. (2000) Bakhtin, slovo, dialog i roman. Frantsuzskaya semiotika: Ot strukturalizma k poststrukturalizmu [Bakhtin, word, dialogue and novel. French semiotics: from structuralism to post-structuralism]. Moscow: Progress, pp. 427-457. (in Russian)

33. Krylova, I. N. (1982) Podtekstovye znacheniya v rasskaze E. Khemingueya "Na Big-River». Analiz stiley zarubezhnoy khudozhestvennoy i nauchnoy literatury [Subtext meanings in the short story "Big Two-Hearted River" by E. Hemingway. Style analysis of the foreign fictional and scientifical literature]. Leningrad: Izd-vo LGU, pp. 84-88. (in Russian)

34. Kukharenko, V. A. (2004) Interpretatsiia tekstu [Text interpretation]. Vinnytsia: NOVA KNYHA. (in Ukrainian)

35. Kukharenko, V. A. (1974) Tipy i sredstva vyrazheniya implikatsii v angliyskoy khudozhestvennoy rechi (na materiale prozy E. Khemingueya) [Types and methods for implication expression in the English artistic word (on the material of E. Hemingway's prose)]. Filologicheskie nauki [Philological sciences], no. 1, pp. 72-80. (in Russian)

36. Kuts, H. M. (2009) Konstytutsiini bariery ukrainskoi demokratii: liberalnyi pidtekst [Constitutional barriers of Ukrainian democracy: liberal implication]. Visnyk Kharkivskoho natsionalnoho universytetu im. V. N. Karazina [V. N. Karazin Kharkiv national university journal], Ser. «Politology issues », no. 861, issue 15, pp. 180-186. (in Ukrainian)

37. Lelis, E. I. (2013) Podtekst kak lingvoesteticheskaya kategoriya v proze A. P. Chekhova [Subtext as a linguistic and aesthetic category in A. P. Chekhov's prose]. Izhevsk: Udmurt. un-t. (in Russian) 


\section{Subtext of a fictional work as a literary problem}

38. Lesyn, V. M. (1985) Literaturoznavchi terminy [Literary terms]. Kyiv: Rad. shk. (in Ukrainian)

39. Lesyn, V. M., Pulynecj, O. S. (1971) Slovnyk literaturoznavchykh terminiv [Dictionary of literary terms]. Kyiv: Rad. shk. (in Ukrainian)

40. Mozhova, N. Gh. (2001) Ghnoseologhichnyj pidtekst odnijeji dyskusiji pro misce filosofiji v systemi osvity [Gnosiological subtext of one discussion about the place of philosophy in the educational system]. Praktychna filosofija [Practical philosophy], no. 1, pp. 219-226. (in Ukrainian)

41. Muratova, E. Yu. (2006) Terminologicheskiy problemy v teorii intertekstual'nosti [Term problem in the theory of intertextuality]. Vesnik Vitsebskaga dzyarzhaỹnaga yniversiteta [Journal Vitsebsk state university], no. 3, pp. 65-70. (in Russian)

42. Nazarets, V. M. (1994) Pidtekst yak smyslovyi fenomen ta khudozhnie yavyshche [Subtext as a sense phenomenon and an artistic thing] (PhD Thesis), Rivne. (in Ukrainian)

43. Nikolyukin, A. N. (ed.) (2001) Literaturnaya entsiklopediya terminov i ponyatiy [Literary encyclopedia of terms and concepts]. Moscow: Intelvak. (in Russian)

44. Novikov, L. A. (2003) Khudozhestvennyy tekst i ego analiz [Literary text and its analysis]. Moscow: Editorial URSS. (in Russian)

45. Ozerov, L. (1968) V masterskoy stikha [In the studio of a poem]. Moscow: Znanie. (in Russian)

46. Olifirenko, S. M., Olifirenko, V. V., Olifirenko, L. V. (2007) Universalnyi literaturnyi slovnyk-dovidnyk [Universal literary dictionary and reference book]. Donetsk: BAO. (in Ukrainian)

47. P'ege-Gro, N. (2008) Vvedenie v teoriyu intertekstual'nsti [Introduction to the theory of intertextuality]. Moscow: LKI. (in Russian)

48. Rykun, I. P. (2002) Pidtekst yak forma vyrazhennia «chuzhoho slova» [Subtext as an expression form of other's word]. Pytannia literaturoznavstva [Issues in literature studies], no. 9, pp. 47-52. (in Ukrainian)

49. Riffaterr, M. (1998) Ansambl' Tekstov [Harmony of Texts]. Saint Petersburg: Trommit. (in Russian)

50. Sil'man, T. (1969) «Podtekst - eto glubina teksta» [Subtext is a depth of a text]. Voprosy yazykoznaniya [Issues in linguistics], no. 1, pp. 89-102. (in Russian) 51. Stepanenko, A. A. (2007) Podtekst v proze A. P. Chekhova 1890-kh-1900-kh gg. [Subtext in A. Chekhov's prose of 1890-1900 yrs] (PhD Thesis), Surgut. (in Russian)

52. Tamarchenko, N. D. (2008) Poetika: slovar' aktual'nykh terminov i ponyatiy [Poetics: dictionary of important terms and concepts]. Moscow: Izd-vo Kulaginoy; Intrada. (in Russian)

53. Tammi, P. (1992) Zametki o poligenetichnosti v proze Nabokova [Notes about polygeneticity in Nabokov's prose]. In Tammi, P. Problemy russkoy literatury $i$ kul'tury [Problems of the Russian literature and culture]. Helsinki, pp. 181-194. (in Russian)

54. Taranovskiy, K. (2000) O poezii $i$ poetike [About poetry and poetics]. Moscow: Yaz. rus. kul't. (in Russian)

55. Urnov, D. (1971) Mysl' izrechennaya i skrytaya (o podtekste v sovremennoy proze) [Said and unsaid thought (about subtext in the modern prose)]. Voprosy literatury [Issues in literature], no. 7, pp. 52-72. (in Russian) 


\section{Foka Mariia}

56. Foka, M. V. (2017) Pidteksty v khymernomu opovidanni V. Shevchuka «Zhinka-zmiia» [Subtext in V. Shevchuk's fantastic short story «The Womansnake»]. Visnyk Dnipropetrovskoho universytetu imeni Alfreda Nobelia [Alfred Nobel Dnipropetrovsk University Journal]. Dnipro: Vyd-vo Dnipr. un-tu im. A. Nobelia, Ser.: Philological sciences, no. 2 (14), pp. 174-180. (in Ukrainian)

57. Foka, M. V. (2015) Pidtekstovi smysly v muzytsi (na materiali «Dobre temperovanoho klaviru» Y. S. Bakha) [Subtext meanings in music (on the material of J. S. Bach's «The Well-Tempered Clavier»)]. Visnyk KNUKiM [Kyiv National University of Culture and Arts Journal]. Kyiv: KNUKiM, Ser. «Art studies», issue 32, pp. 107-113. (in Ukrainian)

58. Khaydegger, M. (2006) Bytie i vremya [Life and time]. Saint Petersburg: Nauka. (in Russian)

59. Kheminhuei, E. (1981) Tvory [Works] (Vol. 4). Kyiv: Dnipro. (in Ukrainian)

60. Tsurganova, E. A. (ed.) (2004) Zapadnoe literaturovedenie XX veka [West literarture studies of XX century]. Moscow: Intrada. (in Russian)

61. Chulkova, V. S. (1978) Mnogochlennyy stilisticheskiy priem kak odno iz sredstv integratsii teksta [Polymeric stylistic mark as one of the methods for text integration] (PhD Thesis), Moscow. (in Russian)

62. Chuneva, L. Yu. (2006) Smysloobrazuyushchaya funktsiya podteksta v literaturnom proizvedenii [Sense-making function of subtext in a literary work] $(\mathrm{PhD}$ Thesis), Tver. (in Russian)

63. Shapoval, M. O. (2010) Stratehii intertekstualnosti ta hra svidomostei u suchasnii ukrainskii drami [Intertextuality Strategies and Consciousnesses' Games in Contemporary Ukrainian Drama] (Abstract of Grand PhD Thesis) Kyiv. (in Ukrainian)

64. Shleyermakher, F. D. (1967) Lektsii po estetike. Istoriya estetiki: pamyatniki mirovoy esteticheskoy mysli [Lectures on aesthetics. History of aesthetics: significant records of the world aesthetic thought] (Vol. 3). Moscow: Iskusstvo. (in Russian)

65. Baldick, Ch. (2001) The Concise Oxford Dictionary of Literary Terms. N.Y.: Oxford University Press. (in English)

66. Kristeva, J. (1974) La Révolution du langage poétique. L'avant-garde à la fin du XIXe siècle: Lautréamont et Mallarmé [Revolution in poetic language. The avant-garde at the end of the 19th century: Lautréamont and Mallarmé]. Paris: Éditions du Seuil. (in French)

67. McKee, R. (1997) Story: Substance, Structure, Style, and the Principles of Screenwriting. USA: ReganBooks, HarperCollins Publishers. (in English)

68. Newkirt, T. (2012) The Art of Slow Reading: Six Time-Honored Practices for Engagement. Portsmouth, NH: Heinemann. (in English)

69. Seger, L. (2011) Writing Subtext: What Lies Beneath. Studio City, CA: Michael Wiese Productions. (in English)

70. Smith, D. Being a Glossary of Terms Useful in Critiquing Science Fiction. SFWA: Science Fiction \& Fantasy Writers of America. Available at: www.sfwa.org/ 2009/06/being-a-glossary-of-terms-useful-in-critiquing-science-fiction/ (Accessed 21.05.2015). (in English)

71. Sollers, Ph. (1968) Ecriture et revolution. Théorie d'ensemble [Scripture and revolution. General theory]. Paris: Seuil. (in French) 
ORGANIZATIONAL STRUCTURE

OF THE CHURCH OF THE ADVISERS OF THE DAY

TO THE HISTORICAL RETROSPECTIVE

\section{ОРГАНІЗАЦІЙНА СТРУКТУРА ЦЕРКВИ АДВЕНТИСТІВ СЬОМОГО ДНЯ В ІСТОРИЧНІЙ РЕТРОСПЕКТИВІ}

\section{Shevchuk Valentin ${ }^{1}$ \\ Fedorenko Mikhail ${ }^{2}$}

DOI: http://dx.doi.org/10.30525/978-9934-571-26-8_21

Abstract. The purpose of the work is to analyze the formation and development of the administrative structure of the Seventh-day Adventist Church and find out its effectiveness and prospects. The realization of the goal involves the consistent solution of such tasks: 1) A schematic outline of the current state of the Adventist Church; 2) Selection of the main stages of the formation of the organizational structure of the confession; 3) Clarification of the effectiveness of the functioning of the structure and prospects of the organization as a whole. Using the methods of analysis and synthesis, we succeeded in identifying a number of problems that arose when the first Adventists tried to create a legally established organization. In addition, the use of the method of generalization allowed to explore historical events associated with the organizational design of the confessional movement. The analysis shows the involvement of pioneers of adventism, as well as their differential attitude to the idea of James Wyatt to create an effective organization. Considered the financial sources through which managed to administrate the Adventist cell. Four levels of structure are shown on the basis of which all activities in the Church of the Seventh-day Adventists are being built. It is proved that the current state of the administrative structure of the denomination is an effective unifying tool that fully satisfies the needs of the church and promotes the Church to successfully disseminate its

\footnotetext{
${ }^{1}$ Postgraduate Student, Ancient History of Ukraine and Archival Studies Department, Ivan Franko Lviv National University, Ukraine

${ }^{2}$ Candidate of Historical Sciences,

Associate Professor of the Department of Social and Humanitarian Sciences,

Admiral Makarov National University of Shipbuilding, Ukraine

(C) Shevchuk Valentin, Fedorenko Mikhail
} 


\section{Shevchuk Valentin, Fedorenko Mikhail}

ideas around the world. The prospects for further research, the author links with an assessment of the psychological aspects of church administrators who have held positions in the Church of the Adventists for four years.

\section{1. Вступ}

Церква Адвентистів сьомого дня в сучасному релігійному світі посідає важливе місце серед інших християнських конфесій. Кількість послідовників даної конфесії на 2018 рік становить більше 20 млн. осіб. Адвентистські представництва розташовані майже 200 країнах світу. Завдяки великій кількості медичних, навчальних та видавничих закладів адвентисти відомі по всьому світу [1, с. 409]. На думку дослідників активний поступ в соціально-місіонерській діяльності та швидкий розвиток церкви АСД насамперед залежить від іiі адміністративної структури. Завдяки централізованій системі управління церква змогла більше століття виконувати поставлені завдання та цілі. На сьогоднішній день адвентистська управлінська модель є багаторівневим, представницьким та демократичним врядуванням, формування якого тривало впродовж 20 років, початком відліку вказаного періоду вважається 1844 рік.

Цікаво відмітити, що паралельно 3 появою церкви адвентистів виникли схожі деномінації такі як: «Церква Христа Александера Кемпбелла», «Церква Ісуса Христа Святих Останніх Днів» (СОД) і т.д., утворили кардинально інші структури, незважаючи на подібність доктринальних поглядів. Наприклад, система управління СОД передбачає колективне апостольське керівництво за участю всіх активних членів церкви, тобто, ця організація керована одкровеннями, які отримують апостоли, пророки і місцеві провідники, які діють відповідно до принципів одноголосності, консультацій і спільної згоди за участю всіх активних членів церкви, яким більше 12 років. В той час, яка «Церква Христа» немає будь-яких всесвітніх керівників-єпископів або інших органів влади, а також не має формальної структури над окремими громадами. Місцеві пастори обираються за побажаннями кожної із місцевих громад [2, с. 36].

Відмінність різноманітних форм управління пояснюється тим, що в основі кожної релігійної організаційної структури покладено її унікальні теологічні бачення власної релігійної сутності, ідеології, місії та задач, які породжують іiі організаційну форму. Адвентистка цер- 
ковна структура остаточно оформилась в результаті тривалих пошуків та дискусій iіi засновників, а також зазнала впливу ідей демократії, поширених в американському суспільстві в сер. XIX ст.

\section{2. Причини виникнення адміністративної структури в церкві АСД}

Потребу в організації адвентисти гостро відчули на початку 60-х років XIX ст. у зв'язку із збільшенням кількості однодумців та розрізнених груп в різних штатах Америки. Окрім того була велика кількість «блукаючих» проповідників, які називали себе адвентистами, проте поширювали різноманітні фанатичні ідеї. Засновники адвентистського руху, такі як, Вільям Уайт, Йосиф Бейтс та інші піонери усвідомлювали той факт, що активне поширення адвентистського вчення та координація діяльності груп віруючих можлива лише за умови наявності структурованої організації, в тому числі і контролі за нерукопокладеними проповідниками. Елена Вайт (одна із засновниць ЦАСД) у книзі «Ранні твори» писала про таку групу випадкових проповідників: «Люди, чиє життя не характеризується святістю, і які непридатні для того, щоб проповідувати істину для теперішнього часу, приходять на духовну роботу, не отримавши визнання церкви та іiі керівників. В результаті руйнують єдність і наступає хаос» [3, с. 102].

Проте на шляху до організаційного оформлення церкви виникало чимало проблем. Майже усі учасники мілеритсьського руху вийшли 3 багатьох церков, і кожен мав своє доктринальне розуміння, що ускладнювало їх об'єднання. Інші стверджували, що Христос незабаром повернеться на землю і необхідності в організації немає. Окрім того, ситуацію ускладнювало те, що більша частина мілеритських проповідників взагалі була проти створення будь якої організації, рахуючи, що це буде поверненням назад до «Вавилону». Того часу, ініціатор організації Джеймс Вайт писав: «Ми, здавалося, продиралися крізь хащі невизначеності в питаннях організації. Як належало очікувати у багатьох виникли побоювання, начебто я ратую за щось страшне» [3, с. 112].

Дехто вважав, що організація у любому випадку посягає на релігійну свободу особи і регламентує іiі стосунки з Богом, що вкрай є недопустимим. Джордж Сторрз стверджував, що віруючим необхідно відмовлятися від організованих церков, оскільки ми не повинні дозволяти кому б то не було окремим особам чи організаціям командувати нами» [4, с. 97]. 


\section{Shevchuk Valentin, Fedorenko Mikhail}

Розвиток і становлення церковної організації АСД мав декілька етапів. Насамперед, першим кроком, який сприяв об'єднанню адвентистських груп було проведення спільних табірних богослужінь, або їх ще називали конференціями. Такі адвентистські лідери, як: Дж. Лафборо, Джон Андрюс, Джеймс Вайт збирали сотні слухачів під відкритим небом, лише частина 3 яких могла розміститися у наметі. В журналі «Рев’ю енд Геральд» за 4 липня 1854 р. було написано, що в неділю на вечірнє богослужіння прийшла тисяча слухачів, а через тиждень в Гренд-Репідсі відбулося чергове наметове зібрання, про яка основний доповідач Джейс Вайт писав: «Було встановлено на вільному місці в центрі міста палатку, куди прийшло більше 500 осіб. Люди слухали 3 особливою увагою, і коли їм пропонували публікації, вони тіснилися, щоб їх отримати. Здається, що для розповсюдження істини відкритий безперешкодний шлях» [3, с. 86].

Таким чином спільні конференції, які проводилися у 50-ті роки XIX ст. в багатьох штатах Америки організаційно об'єднували адвентистів і були платформою, де формувалися їх основні пункти віровчення. Адвентиський рух поширювався, на нових територіях виникали громади однодумців і одночасно потреба в служителях. Для здійснення місіонерської праці необхідні були кошти, які б регулярно могли поступати від членів церкви з метою утримання їх служителів. Особливо критичними у фінансовому плані стали 1857 i 1858 роки. Не було ні церковної організації, ні церковної скарбниці. $\mathrm{Ti}$ що посвятили себе церковним справам цілком залежали від дарів, які вони отримували від людей. Подружжя Вайт також боролися зі злиднями [5, с. 358].

У цій ситуації необхідний був довготривалий план фінансового забезпечення потреб церковних служителів. На чолі із Дж. Анрюсом групою дослідників вивчалась біблійна система фінансування церкви. На основі Святого Письма був запропонований план відомий як «регулярні пожертвування», маючи на увазі десятини і добровільні пожертвування. Джеймс Вайт через журнал «Рев'ю» запросив усіх адвентистів відвідати конференцію в Батл-Крик з третього по шосте червня 1859 року з метою затвердження плану систематичних пожертвувань. Делегатами рішення було підтримано одноголосно. Отож, утворення єдиної фінансової системи в 1859 році стало важливим кроком до формування церковної організації. 


\section{Organizational structure of the church of the advisers of the day to the...}

Для зміни негативного погляду членів церкви на створення організації, необхідно було закласти теологічний фундамент, оснований на Біблії. Ще в 1853 році Елена Вайт написала статтю з приводу організації, посилаючись в основному на своє видіння і Біблію: «Господь, показав мені, що багато братів відносяться до євангельського порядку із страхом і зневагою. Порядок царить на небесах. Він царював в церкві, коли Христос жив на землі, а після його вознесіння за цим строго слідкували апостоли. I сьогодні, в ці останні дні, коли Бог приводить своїх дітей в єдність віри, порядок потрібний як ніколи раніше» [6, с. 97].

У грудні 1853 році Джеймс Вайт на сторінках «Рев’ю енд Геральд» також звернувся до своїх читачів в чотирьох редакційних статтях, яким дав однакову назву «Євангельський порядок». Тут він зазначав, що ми прагнемо до порядку і суворої дисципліни в церкві Христа. I хоча ми відкидаємо усі людські платформи і переконання, Біблія буде нашою основою, нашим кредо і порядком [5, с. 403]. Джеймс і Елена Вайт у своїх зверненнях заклали теологічний фундамент, на якому з часом буде побудована струнка організаційна структура церкви АСД.

\section{3. Розвиток організаційної структури: проблеми та вирішення}

Наступним важливим кроком, який спонукав до формування організації була видавнича діяльність. Літом 1849 року подружжя Вайт виходячи із власної ініціативи почали випускати перший адвентистський журнал «Справжня істина», перший випуск якого мав лише одну тисячу екземплярів. Через рік тираж суттєво збільшився і отримав нову назву «Секонд Адвент Рев'ю енд Саббат Геральд», в 1851 р. вийшла перша книга Е. Вайт - «Досвіди і видіння Е. Вайт». В 1852 р. типографія винаймає орендований дім у місті Рочестер штат Нью-Йорк.

Найпереконливішим переломним моментом у становленні організації взагалі, і видавництва зокрема був переїзд в 1855 р. подружжя Вайт в Батл-Крік штат Мічіган, де було збудоване приміщення під типографію, а саме місто стало центром керівництва адвентистського руху. Тут видавнича справа зібрала навколо себе групу ведучих лідерів, які регулярно почали проводити щорічні зустрічі видавничої асоціації. Згодом виникла серйозна проблема пов'язана із реєстрацією майна видавництва. Згідно нового закону штату Мічіган володіти церковним майном могла лише юридична особа. Дж. Лафборо, який працював 
разом з Дж. Вайтом своїм супротивникам писав: «Говорять, що якщо створити організацію і володіти власністю по закону, то можна стати частиною Вавилона. Нi, я розумію це зовсім інакше. Якщо не можна захищати церковну власність, то нащо людям взагалі утримувати будьяку власність на законній основі?» [3, с. 105].

30 вересня 1860 р. на черговій конференції в Батл-Крік в результаті тривалих диспутів між лідерами АСД була прийнята резолюція в якій була винесена пропозиція про створення видавничої асоціації, яка на законній основі буде володіти видавництвом «Рев’ю». На наступний день виникла перед учасниками конференції наступна проблема. Щоб володіти майном на законній основі, групі адвентистів, які були розкидані на великий території Нової Англії і на Середньому Заході, необхідно було дати назву. Джеймс Вайт заявив про те, що ми не можемо рухатися вперед, не маючи назви, більш того, вони без назви не можуть володіти майном [3, с. 107].

Того ж дня група майбутніх членів офіційної церкви за згодою усіх присутніх отримали назву - Адвентисти сьомого дня [7, с. 184]. Проте ця назва була отримана шляхом тривалих дискусій і необхідна була для реєстрації видавництва «Рев’ю». Попереду необхідно було здійснити ще декілька кроків. Тому наступним логічним кроком у формуванні організації було утворення іiї первинної ланки - громади. Оскільки перші кроки до упорядкування видавничої справи і прийняття рішення стосовно назви церкви були зроблені лідерами адвентистського руху в Батл-Крик, то і наступний був ними здійснений саме тут.

Під час проведення річної зустрічі видавничої асоціації 4 жовтня 1861 р. учасники прийшли до висновку, що настав час покласти першу цеглину в організаційну будову церкви: на місцевих рівнях утворити громади. Була прийнята наступна резолюція: «Вирішено, що ця конференція рекомендує наступну церковну угоду: Ми, що нижче підписалися, цією угодою об'єднуємося разом як церква, що носить ім'я адвентисти сьомого дня і обіцяємо зберігати Божий заповіт і віру в Ісуса Христа» [3, с. 114]. На цій же конференції було запропоновано громадам штату Мічіган об'єднатися в одну конференцію під назвою «Мічиганська конференція Адвентистів сьомого дня». Тут же були затверджені служителі і рада конференції. Голова Джозеф Бейтс і секретар Урія Сміт відповідно до результатів голосування стали керівниками конференції на майбутній рік. Було вирішено важливе питання щодо 
пастирського посвідчення, яке би давало право на служіння. До особистих документів пастора належали: свідоцтво про рукопокладання, а також посвідчення, підписане головою і секретарем конференції, причому посвідчення має щорічно поновлюватися.

Важливо зазначити, що на першій Мічиганській Конференції іiі організатори розмежовували статус рядових служителів на рівні громади, які ніколи не залишали свою місцевість і тих, хто працював в церковній організації на постійній основі і переїжджали за рішенням керівництва конференції. На основі дослідження Біблії на сторінках журналу «Рев’ю» вони до першої категорії місцевих служителів віднесли пресвітера і диякона. Пресвітер у відсутність пастора міг завершувати хрещення та Вечерю Господню, а в обов'язки диякона входило турбуватися про матеріальну сторону життя церкви. Ні пресвітер, ні диякон церковної платні не отримували. Штатні служителі - пастори отримували регулярну платню, і в кінці кожного місяця надавали регулярні звіти про свою діяльність [4, с. 111].

Таким чином в штаті Мічиган був закладений фундамент церковної організації який мав би встати взірцем для віруючих адвентистів інших Штатів. Місцеві служителі несли відповідальність за організацію місцевих громад і конференцій своїх Штатів. Організаційна хвиля швидко прокотилася по Сполученим Штатах Америки. Спочатку Джон Андрюс в штаті Мінісота організував конференцію, згодом пастор М. Корнела у штаті Огайо, і так по всім штатах, де знаходилися громади АСД.

В країні тривала громадянська війна, яка відволікала адвентистів від їх церковних питань, проте в травні 1863 р. був здійснений останній крок у створенні центральної влади церкви АСД - Генеральної конференції Адвентистів сьомого дня. Заздалегідь делегати з'їзду були запрошені на 20 травня прибути до Батл-Крік для участі на сесії Генеральної конференції [7, с. 184]. 20 делегатів, які представляли громади із шести штатів, обрали керівництво новоствореного вищого керівного органу адвентистів сьомого дня. Головою чи президентом був обраний Джон Батлер, секретарем - Урія Сміт, а Е. Уолкер - скарбником. Три перші головні особи Генеральної конференції утворювали «комітет трьох». Прийнятий статут передбачав пряму відповідальність трьох головних осіб, а також виконавчого комітету за рівномірний розподіл штатних служителів по церковним органі- 


\section{Shevchuk Valentin, Fedorenko Mikhail}

заціям, сприяння місіонерській роботі та санкціонування загальних зборів пожертвувань.

Отже, на цей час церковна організація мала трьох рівневу модель: перший рівень - помістна церква, другий рівень - конференція штату чи округу, у який повинні були увійти усі церкви на території того чи іншого штату, і на кінець - Генеральна Конференція, яка представляла усі церкви і діяла в їх інтересах [8, с. 266].

Таким чином цей останній організаційний крок зробив церкву адвентистів сьомого дня єдиною конфесійною структурою, надав мандат своїм служителям для місіонерської діяльності, об'єднав адвентистський рух в одну систему віровизнання, що сприяло швидкому поширенню адвентистських ідей по цілому світу. Цікаво зазначити, що станом на 1863 рік громада адвентистів у Сполучених Штатах нараховувала лише 3500 членів церкви, що у порівняні з іншими конфесіями вона виглядала бідно, а кількість служителів була не більше 30. У такому випадку лише централізація організації могла забезпечити їм розвиток і функціонування.

В наступні роки новостворена церква розвивались достатньо динамічно. За перші 25 років свого існування чисельність ії послідовників збільшилася в сім разів. В 1888 році вона нараховувала 26 тисяч членів церкви. 900 громад були організовані в 32 місцевих конференції і шість місіонерських полів. Окрім того, адвентисти організували цілий ряд інститутів і організацій, направлених на більш ефективне виконання своєї місії. Серед них Західний інститут реформи способу життя, адвентистське товариство освіти, адвентистське товариство взаємодопомоги, трактатне і місіонерське товариство [8, с. 268].

Одночасно церква не могла уникнути різноманітних адміністративних проблем, які часто виникали, беручи до уваги людський фактор. Період історії церкви АСД від 1863 до1888 років інколи називається періодом «централізації влади». Виконавчий комітет у своєму складі мав лише 5 членів комітету Генеральної конференції, при тому, що лише двоє із них проживали неподалік офісу, а решта знаходилися далеко від центру. Усі ці керівники багато часу проводили в поїздках, зустрічалися вони між собою досить рідко, координувати різні напрямки церковної діяльності приходилось по переписці. При тому, багаторічні і досвідчені керівники церкви, такі як Джеймс Уайт, Джон Батлер, О. Олсен виявляли особливу стурбованість за майбутнє цер- 


\section{Organizational structure of the church of the advisers of the day to the...}

кви, не довіряючи молодим служителям, що інколи приводило до протистояння.

Так наприклад, Джордж Батлер в 1873 році, на посаді президента ГК опублікував статтю під назвою «Керівники». У ній він намагався поставити на високий рівень значимість керівної ролі Джеймса Вайта i його дружини. По словам Батлера, обов'язок церкви полягає в тому, щоб віддавати перевагу позиції Джеймса Вайта в усіх питаннях церковної політики. Відмову від цього правила Батлер розглядав як зазіхання на особливу позицію, яку Бог визначив для Джеймса Вайта. Подібні тенденції були негативними для розвитку церкви, хоча теоретично Джеймс Вайт не поділяв цю думку. В журналі «Знаки часу» Джеймс Вайт писав, що Христос ніколи не доручав одній конкретній людині все керівництво церквою [4, с. 121].

Через два роки після опублікування статті «Керівники» Генеральна конференція офіційно проголосувала за те, щоб оголосити недійсними ті положення статті Батлера, які стверджували одноосібне правління в церкві. На тому з'їді була прийнята резолюція про те, що «найвищим авторитетом серед адвентистів сьомого дня є воля всієї спільноти, вираженої в рішеннях Генеральної конференції, діючої в рамках відповідної юрисдикції. Усі без винятку повинні підкорятися цим рішенням, якщо тільки вони не вступають в протиріччя зі словом Божим і совістю кожної людини.

В адміністративній політиці церкви адвентистів ніколи ні теоретично, ні з богословської позиції не сприймалося бачення одноосібного управління церквою. Навіть Елена Вайт, якій церква приписувала особливий дар пророцтва, ніколи не була керівником церкви, а лише могла давати корисні духовні поради. 3 цього приводу вона писала про те, «як би радів сатана, якщо би йому вдалося встановити одноосібний контроль зі сторони одного керівника над розумами і серцями людей» [9, с. 39].

В усі часи і тепер на всіх рівнях управління адвентистською церквою діють принципи демократичного волевиявлення. Під час звітно-виборних з'їздів на різних рівнях, обираючи на посаду президента Генеральної конференції чи пресвітера місцевої громади, завжди зберігався демократичний дух і враховувався голос кожної людини зокрема. Адвентисти вірять, що їх модель управління основується на парадигмі «теократія за допомогою демократії». Це означає, що вся духовна влада на церковному рівні повинна бути делегованою. Це 


\section{Shevchuk Valentin, Fedorenko Mikhail}

передбачало реалізацію такої формули: керівники церкви володіють владою служити, в той час Святий дух використовує їх для втілення божого принципу на землі. Таким бачить адвентисти церковне управління в апостольські часи, коли церквою керував Святий дух. Адвентисти вважають що тоді церква не була ні структурно - центричною, ні особистісно центричною, а концентрувала всю увагу на богоуправлінні [2, с. 35]. На сесії Генеральної конференції 1886 року з метою більшої колегіальності було прийняте рішення про розширення виконавчого комітету ГК до семи чоловік. Тоді ж було прийняте рішення про створення асоціації генеральної конференції, у відповідальність якої перейшло усе майно всесвітньої церкви.

Повертаючись до історії становлення організації, необхідно сказати, що з самого початку церква адвентистів мала лише трьох рівневу модель: громада, конференція, Генеральна конференція. Таке підпорядкування влаштовувало громади, що знаходилися у Сполучених Штатах Америки, оскільки їх число було невеликим і територія знаходження громад поширювалася лише на одну країну. Проте з часом була виявлена необхідність створення проміжкової структурної одиниці між Генеральною конференцією і місцевою конференцією - союз церков чи уніон. Подібні моделі чотирьох рівневого управління почали практикуватися у Європі в середині 80 -х років XIX ст. і особливо ці адміністративні зміни малий позитивний результат в громадах Австралії, які входили до складу Австрало-Азіатського уніону [3, с. 336].

Успіх інших уніонів спонукав керівників на сесії генеральної конференції 1888 року вийти з пропозицією про розподіл усієї території Сполучених Штатів і Канади на територіальні сегменти чи уніони, які б складається із декількох конференцій чи місіонерських полів. Поставлена задача не була приведена до виконання у зв'язку з теологічними дебатами, пов'язаними з доктриною праведності по вірі. Лише на наступній сесії генеральної конференції, яка проходила у 1889 році делегати офіційно утвердили нову адміністративно-територіальну одиницю, назвавши іiі дистриктом. Територія США і Канади нараховувала шість таких одиниць. Ще одним ново введенням була пропозиція проводити з'їзди ГК один раз у два роки, на відміну від щорічних з'їздів. На сесії генеральної конференції 1897 року, яка проходила у штаті Небраска делегати розширили виконавчий комітет Генеральної конференції, який тепер нараховував 13 осіб. 


\section{Organizational structure of the church of the advisers of the day to the...}

На з’їзді ГК 1899 року не одноразово лунали висловлювання про недосконалість існуючої організаційної структури церкви. Багато делегатів виступали із різкою критикою, але мало хто пропонував конструктивні рішення. Так, наприклад, Уільям Прескотт, направлений на місіонерську роботу в Англію, скаржився на нераціональне використання фінансів, передбачених для зарубіжної місії. Він досить критично відгукувався про організацію, яка перетворилася у перешкоду, яка заважає місіонерам виконувати свою місію. Назрівала необхідність адміністративних змін у церковній структурі [4, с. 130].

Багато керівників з не терпінням очікували наступної сесії Генеральної конференції, проведення якої планувалося у 1901 році, а особливі надії покладали на присутність Елени Вайт, яка 1900 році повернулися із Австралії в Сполучені Штати Америки і Артура Данієльса, досвідченого адміністратора і пастора. Більше 200 делегатів, які зібралися весною 1901 року на черговий з'їзд Генеральної конференції в Батл-Крик, очікували серйозних перемін. За день до з'їзду Елена Вайт в неформальній обстановці зустрілася з керівниками церкви. В продовж півтора годин семидесяти трьох річна жінка чесно і відкрито говорила з делегатами з'їзду про необхідність перемін в організаційній структури церкви і про потребу у нових підходах в управлінні життям церкви. Вона сказала, що не потрібно чекати доки закінчиться цей з'їзд, а потім збиратися з силами. Представники всіх напрямків церковної діяльності повинні тепер активно бути задіяні у плануванні [5, с. 363].

Так і трапилося. На з'їзді був створений дорадчий чи консультативний комітет, який нараховував 75 осіб. Усі вони впродовж декількох днів розв'язували непросту задачу реорганізації усієї церковної структури. Перше рішення, яке було запропоноване комітетом і підтримане делегатами - усі дистрикти перетворити в унійні конференції. Другою пропозицією з'їзду було збільшення виконавчого комітету до 25 осіб, серед яких були б президенти уніонів.

Новим і важливими рішенням з'їзду була передача раніше незалежних різноманітних асоціацій ГК у розпорядження виконавчого комітету і перетворення їх у спеціальні відділи. Новообраний президент Даніельс був переконаний, що проведені переміни значно спростять церковну структуру і виправлять перекоси в управлінні, які мали місце в минулому, коли адвентисти множили організації, асоціації і заклади, 


\section{Shevchuk Valentin, Fedorenko Mikhail}

забираючи з передової найбільше талановитих служителів і поповнюючи ними і без того роздутий управлінський апарат [4, с. 136].

Отже, серйозні організаційні акти на з'їзді ГК 1901 року були покликані з одної сторони об'єднати церкву і основні напрямки ії діяльності в єдину структуру. Цьому сприяло створення відділів на різних рівнях церковної організації, починаючи з Генеральної конференції. 3 іншого боку необхідною була децентралізація керівництва з метою подолання авторитарного стилю управління, яке склалося в останні роки. Це було досягнуто організацією унійних конференцій, до яких переходила вся відповідальність за служіння на їх територіях. Усі освітянські і інші заклади, які знаходилися на цих територіях переходили під керівництво унійних конференцій.

Розширення кількості членів виконавчого комітета ГК і залучення у його склад президентів уніонів сприяло з одного боку децентралізації церковного керівництва, а з іншого - зміцненню її структури по вертикалі, що забезпечило іiі ефективне функціювання у наступні роки. Час насправді показав ефективність цих організаційних перетворень, які мали місце в 1901 році. Церква швидко зростала і динамічно розвивалася [5, с. 364].

Новий з'їзд у 1903 році додав деякі нові поправки, які не були враховані раніше. Насамперед, це вибори президента, скарбника і інших працівників Генеральної конференції безпосередньо на з'їзді, а не у вузькому колі виконавчого комітету. Наступна зміна стосувалося ведення справ у випадку, коли неможливо було зібрати повний склад виконавчого комітету. Делегати погодилися з тим, що президент разом із чотирьома віце-президентами наділяються повноваженнями вести справи всесвітньої церкви в згоді із генеральними планами комітету. На з'їзді 1905 року було прийнято рішення про скликання з'їздів раз в 4 роки. Проводити з'їзди кожні 2 роки було великим фінансовим ярмом для церкви, притому проводити такі з'їзди кожні 2 роки не було ніякої необхідності [5, с. 419].

Впродовж багатьох уроків Батл-Крик був центром адвентизму, де знаходився головний офіс генеральний конференції, центральне видавництво, великий медичний центр, навчальний заклад. Надлишкова концентрація адвентистів у місті давно турбувало керівництво церквою зокрема і Елену Вайт. Не одноразово вона писала про місіологічний перекіс, пов'язаний з такою ситуацією, і закликала членів цер- 
кви переїжджати в інше місце проживання, щоб активного розповсюджувати адвентизм на нових територіях. Що стосується видавництва i офісу Генеральної конференції, керівники церкви отримали конкретну пропозицію від Елени Вайт переїхати ближче до столиці сполучених Штатів Америки. Ця пропозиція, враховуючи міжнародний характер адвентистської церкви була насправді виправданою [4, с. 139].

У приміській території Вашингтона, Такома-Парк була придбана земельна ділянка для будівництва будинків під видавництво і офіс Генеральної конференції. Артур Даніельс діяв рішуче, оскільки він і його команда охоче прагнули покинути Батл-Крік. В 1908 році міжнародна медико-місіонерська і благодійна асоціація остаточно вийшла 3 під церковного контролю. Доктор Келлог не тільки увійшов у конфлікт 3 керівництвом церкви, але встав на хибний шлях пантеїзму.

Останні зміни у церковній структурі були затверджені на сесії генеральної конференції в 1913 році і стосувалися утворення адміністративної одиниці, яка отримала назву дивізіон чи відділення. Цьому рішенню в 1903 році передувала подія, яка наштовхнула керівництво на необхідність створення п'ятого рівня організації. Для того, щоб забезпечити більш ефективне керівництво церквою у Європі на з'їзді Генеральної конференції 1903 року був вибраний другий віце-президент ГК, який мав відповідати за розвиток церкви на європейському континенті. Ним став відомий діяч європейського адвентизму, який був також причетний до організації церкви в Російській імперії, Луїс Конраді. В обов'язок Конраді входило збирати президентів унійних організацій і здійснювати консультативну адміністративну допомогу. Фактично Конраді став першим керівником новоствореного дивізіону. На з’їзді в 1913 році делегати підтвердили необхідність створення європейського відділення Генеральної конференції. Одночасно вони виступили із пропозицією про організацію Північно-Американського дивізіону [10, с. 34].

Кінцеве рішення про дивізіону структуру церковної організації було прописано у новому статуті, який був прийнятий делегатами з'їзду ГК в 1922 році. П'яти ступенева модель церковної організації церкви адвентистів сьомого дня залишається актуальною до теперішнього часу і служить потребам прихожан і місії міжнародної церкви.

Паралельно із організацією унійних конференцій по всьому світу і формуванням дивізіонної моделі Генеральної конференції, відбувалося 


\section{Shevchuk Valentin, Fedorenko Mikhail}

створення відділів ГК, які відповідали за окремі напрямки церковної діяльності. Ще в 1902 році існуючі незалежні асоціації були заміщені 4 відділами: відділом освіти, видавничим відділом, відділом релігійної свободи і відділом суботньої школи. Значно більше часу пішло на організацію відділу здоров'я, оскільки довелось достатньо довго вирішувати проблеми медико-місіонерської і благодійної асоціації.

\section{4. Чотирьох рівнева структура в церкві Адвентистів сьомого дня}

Структура Генеральної конференції, представлена різними відділами, довела свою ефективність. 3 часом до існуючих чотирьох відділів стали додаватися нові. Так в 1905 році був створений закордонний відділ, в 1907 -молодіжний відділ місіонерів добровольців, в 1909 році - відділ по роботі з чорношкірими, в 1912 році - відділ громадських зв'язків, в 1913 році - місіонерський відділ. На з'їзді 1922 році було прийнято рішення про створення пасторської асоціації, яку очолив колишній президент Генеральної конференції Артур Даніельс [4, с. 144].

Важливо сказати, що до 20 років XX-го століття фактично завершився процес формування церковною організації адвентистів сьомого дня. Їм вдалося сформувати достатньо ефективну і працездатну церковну організацію, яка відповідає місіологічному баченню церкви i основним іiі задачам. Пізніше лише відбувався ріст церковних організацій і формування нових відділів, які відповідали на виникаючі потреби церкви.

Розглянемо сучасну модель адміністративного устрою із певними деталями кожного рівня: місцева громада - конференція - унійна конференція - Генеральна конференція [8, с. 266].

Місцева громада адвентистів сьомого дня являє собою добровільне об'єднання віруючих осіб, які своє релігійне світобачення відображають у 28 пунктах віровчення чи догматів. Керівництво громадою здійснює обраний і рукопокладений пресвітер чи група пресвітерів у випадку великої кількості членів церкви без оплати на добровільних засадах у вільний від роботи час. У його обов'язки входить турбота про членів церкви, виголошення духовно повчальних проповідей, здійснення таких церковних обрядів, як водне хрещення, причастя чи похорон. Один пресвітер відповідає приблизно за 50 членів церкви. Пресвітера та інших служителів громади обирають на служіння під 


\section{Organizational structure of the church of the advisers of the day to the...}

час церковних виборів, які відбуваються один раз на рік. Виборчий комітет пропонує для членських зборів список кандидатів на служіння заздалегідь, з інтервалом не менше одного тижня до голосування, 3 метою виявлення не згоди щодо запропонованих кандидатів. Голосування може бути відкритим, або таємним. Рішення приймається більшістю голосів, присутніх на членському зібранні. Виборчим процесом керує штатний служитель конференції, офіційно направлений у громаду [11, с. 33].

Інститут дияконату містить в собі обов'язки про турботу за матеріальний стан членів церкви. Як правило, дияконат у своєму складі поділяється на старшого диякона, старшу дияконісу і рядових дияконів. Рядовий диякон в середньому опікується 5-6 членами церкви. Старший диякон рукопокладається на служіння і під час причастя може допомагати пресвітеру чи пастору розносити хліб і вино. Служіння дияконів не оплачується.

Різноманітна діяльність церкви здійснюється через відділи. Кожен відділ має керівника і заступника, при потребі свою раду. Список відділів громади відповідає переліку відділів на рівні Генеральної конференції, уніону і конференції. Ось перелік основних відділів громади: дитячий відділ, молодіжний, суботня школа, клуб слідопитів, дияконський відділ, відділ здоров'я, релігійної свободи і громадських контактів, жіночий відділ, сімейний, відділ управління ресурсами, відділ інформації. Усі керівники відділів обираються під час церковних виборів $[12$, с. 400$]$.

Члени церкви приймають участь у фінансовому служінні, яке виражається у принесенні добровільних пожертвувань та десятин. Усі десятини 100\% повертаються у скарбницю конференції, 60\% добровільних пожертвувань залишаються для потреб громади, а 40\% також повертаються у конференцію. Громада може володіти різним майном, в тому числі і нерухомістю. Поточні задачі і місіонерська діяльність планується церковною радою, проте затверджуються на членських зборах, які є вищим керівним органом. Відповідальність за духовне життя церкви і їі місіонерську діяльність несе, призначений конференцією штатний працівник - пастор.

Конференція - це добровільне об'єднання громад певного регіону чи декількох областей. Керівним органом є Рада конференції, яка в середньому складається від 12 до 20 радників на чолі $з$ президентом. 
Керівництво конференції в особі президента, секретаря та скарбника обирається на звітному виборному з'їзді, який відбувається один на раз на чотири роки. У штаті конференції знаходяться усі штатні служителі, починаючи від книгонош, місіонерів добровольців, початкуючих пасторів, помічників пастора та рукопокладених пасторів $[8$, c. 266].

Вищим керівним органом конференції є з'їзд, а у між з'їзд ний період - Рада конференції. Делегатами на з'їзд обираються представники від кожної громади, а також усі штатні духовні працівники згідно свого положення. Керівництво конференції опікується духовним життям усіх громад, скеровуючи туди своїх штатних працівників, які знаходяться на повному фінансовому забезпечені. Оплата праці відбувається згідно штатного розкладу, в якому визначається \% оплати в залежності від стажу роботи. Один штатний працівник може відповідати за декілька громад. Вищий сан служителя - це рукопокладений пастор-проповідник. Рукопокладення надається тим, хто має богословську освіту, стаж не менше восьми років, бездоганну репутацію і хороші результати у пасторській та місіонерській діяльності. Лише рукопокладений пастор має право здійснювати обряд вінчання та рукопокладання. Початкуючий пастор, помічник пастора може отримати пресвітерське рукопокладання і здійснювати такі обряди, як хрещення та причастя [11, с. 31].

Пастор, як представник конференції є підлеглою одиницею конференції і знаходиться в їі розпорядженні. Таке підпорядкування дає можливість координувати усю діяльність пасторів, направляючи їх на нові місіонерські поля, у відповідності до їх можливостей та досвіду. Така система також дозволяла запроваджувати єдину програму освіти пасторів відповідно до їх статусу і здійснювати регулярну їх переатестацію.

Конференція отримує десятини і пожертвування від громад. 30\% від десятини конференція повертає у скарбницю уніону, а решту використовує згідно бюджету, затвердженого на річній пасторській нараді за участю представників уніону. Конференція може володіти любим майном, в тому числі і нерухомістю. У більшості випадків молитовні будинки громад знаходяться у власності конференції з метою гарантійного збереження майна. У штаті конференції серед служителів знаходяться керівники різноманітних відділів, вище перерахованих у 


\section{Organizational structure of the church of the advisers of the day to the...}

списку громади. Задача керівників координувати служіння свого відділу на рівні громад конференції [8, с. 266].

Уніон (союз) - це добровільне об'єднання конференцій чи місіонерских полів на рівні країни чи великого регіону. Зокрема, на території України знаходиться вісім конференцій і одне місіонерське поле, які входять у склад українського уніону. Керівництво уніону назагал турбується про духовний стан громад в Україні і координує діяльність президента конференції. Керівний орган уніону - Рада уніону, у склад якої входять президенти конференції, керівники відділів уніону та рядові пастори та члени церкви. Звітного виборні з’їзди уніону відбуваються один раз на 5 років. Вищий керівний орган уніону - з'їзд уніону. Делегатами на з'їзд по положенню скеровуються президенти конференцій, а також інші пастори згідно квоти для кожної конференції. Вибори президента та інших керівників відбуваються на демократичних засадах шляхом голосування.

Із 30\% десятин, які поступають в уніон від конференцій, у них залишається лише $10 \%$, інші 20\% направляються в скарбницю дивізіону. На рівні уніону також функціонують вищезазначені відділи. Обов'язок керівника відділу співпрацювати, координувати і допомагати керівнику відповідного відділу на рівні конференції. Президент уніону є членом Ради дивізіону і двічі на рік приймає участь на нарадах Генеральної конференції. Керівництво уніону представляє інтереси конференції перед дивізіоном [11, с. 173].

Дивізіон (відділення) - це відділення Генеральної конференції і частина їі складової. У складі дивізіону знаходяться уніони, територіально які охоплюють до десятка різних держав. Президент дивізіону і його команда обирається на з'їзді Генеральної конференції, який відбувається один раз на п'ять років. Керівництво дивізіону турбується про духовне життя громад на їх території. 20\% десятин, які надходять від уніону дивізіон частину залишає для своїх потреб, а більшість скеровує на всесвітне місіонерське поле. Таким чином кошти рядових членів церкви послуговуються інтересам всесвітньої адвентистської церкви. Лідери дивізіону двічі на рік приймають участь у піврічних та річних нарадах Генеральної конференції.

Генеральна конференція - вищий духовний орган всесвітньої адвентистиської церкви. На даний час у складі Генеральної конференції знаходиться 13 дивізіонів, територіально які охоплюють весь світ. 
Кожні 5 років відбуваються з'їзди генеральної конференції, делегатами якої є представники від конференцій і рядових членів церкви. Під час сесії Генеральної конференції шляхом голосування приймаються важливі рішення щодо вчення церкви, способу життя та обрядовості. Кожного разу переглядається церковний порядок, зміна якого затверджуються під час голосування [11, с. 24]. Генеральна конференція двічі на рік обирає виконавчий комітет, який складається із президентів уніонів та рядових членів церква для вирішення поточних питань життя церкви. Вибори керівника Генеральної конференції відбуваються шляхом демократичних виборів і голосування делегатів з'їзду.

\section{5. Висновки}

Отже, підводячи підсумки вище викладеному зазначимо, що:

1. Організаційне оформлення сучасної адміністративної структури церкви Адвентистів сьомого дня тривало майже 20 років;

2. Система управління АСД має багаторівневий характер, проте по вертикалі чітко підпорядкована і централізована;

3. Адвентистська система управління - представницька, оскільки дає можливість кожному рядовому члену церкви мало відомої громади через свого представника-делегата висловити свою думку;

4. Адвентистська система управління - демократична, тому що передбачає спільне управління церквою і пропонує демократичні шляхи щодо виборів лідерів;

5. Церква АСД була організована так, що не мала затвердженого інституалізованого апостольського або пророчого керівництва, а кожен член церкви мав право голосу на рівні із будь-яким представником організації;

Крім того, система централізованого управління в адвентистській церкві має ряд позитивних рис. Централізація, насамперед, об'єднує адвентистів в одну єдину всесвітню християнську сім'ю, що породжує відчуття глобальної присутності церкви і причетності кожного до всесвітнього руху, а єдине вчення і спільне вирішення церковних проблем на з'їздах Генеральної конференції має особливу значимість для кожного члена зокрема. Спільна програма дій через уніфіковане служіння різних відділів церкви збагачує кожного так, що здобутки i духовні дари стають надбанням кожного. Почерговий всесвітній збір коштів на різноманітні потреби допомагає вирішувати проблеми дале- 


\section{Organizational structure of the church of the advisers of the day to the...}

ких і близьких та приймати участь у допомозі в різних куточках світу. До негативних особливостей централізованої системи управління церквою можна віднести психологічні відчуття такі, як втрата особистої неповторності і індивідуальності. У цьому випадку ти можеш відчувати себе маленьким гвинтиком у великій системі, у якій ти втратив своє лице. Наступне, у випадку твоєї малої обізнаності в проблемах, які вирішуються на сесія ГК може з'явитися відчуття, що ти є зайвим, за якого подумали і вирішили інші. В загальному адміністративна структура АСД дозволила церкви завоювати популярність в середовищі інших протестантських конфесій, які спостерігаючи за успішною злагодженою діяльністю та єдиною доктринальною системою адвентистів неодноразово зауважували, що їм такого порядку в церквах не вистачає.

\section{Список літератури:}

1. Робинсон Д.А. История нашей вести о здоровье / Д.А. Робинсон. Киев: Джерело життя, 2015. - 448 с.

2. Біддулф Г. Відновлення стародавньої християнської церкви: чотири американські концепції / Біддулф Г. - Київ: Інтерсервіс, 2017. - 54 с.

3. Уайт А. Женщина, ведомая Богом / А. Уайт. - Заокский: Источник жизни. $-2010 .-832$ с.

4. Зайцев Е. Без прошлого нет будущего / Е. Зайцев. - Заокский: Источник жизни, 2013. -384 с.

5. Настольная книга служителя. Т. № 1. Учение и принципы жизни адвентистов седьмого дня, пасторское богословие, жизнь и труды Е. Уайт. - Москва: Издание Церкви христиан-адвентистов седьмого дня, 1989. - С. 415.

6. Уайт Е. Ранние произведения / Е. Уайт. - Заокский: Источник жизни, 1998. $-352 \mathrm{c}$.

7. Douglass H. Posłaniec Pana / H. Douglass. - Warszawa: Znaki Czasu, 2010. $-587 \mathrm{~s}$.

8. Пізній протестантизм в Україні, том 6 (п'ятидесятники, адвентисти, свідки Єгови). Історія релігії в Україні: у 10-ти томах, за ред. Анатолія Колодного та Петра Яроцького. - Київ: Видавець С. Сурма, - 2008. - 268 с.

9. Найт Д. Знакомство с Еленой Уайт / Д. Найт. - Заокский: Источник жизни, - 2002. -160 с.

10. Koziróg B. L.R. Conradi - misjonarz pięciu kontynentów / B. Koziróg. Warszawa: Znaki Czasu, -1994. - 58 s.

11. Церковное Руководство Церкви Адвентистов Седьмого дня, Заокский: Источник жизни, $-2010 .-243$ с.

12. Дедерен Р. Церковь / Р. Дедерен, Настольная книга по теологии // Библейский комментарий АСД. Том 12, Заокский: Источник жизни, 2010. - C. 390-419. 


\section{References:}

1. Robinson D.A. (2015) Istoriya nashej vesti o zdorov'e [The story of our news about health]. Kiev: Dzherelo zhittya. (in Ukraine)

2. Biddulf G. (2017) Vidnovlennya starodavn'oï hristiyans'koï cerkvi: chotiri amerikans'ki koncepciï [Restoration of an ancient Christian church: four American concepts]. Kiïv: Interservis. (in Ukraine)

3. Uajt A. (2010) ZHenshchina vedomaya Bogom [Woman guided by God]. Zaokskij: Istochnik zhizni. (in Russian)

4. Zajcev E. (2013) Bez proshlogo net budushchego [Without the past there is no future]. Zaokskij: Istochnik zhizni. (in Russian)

5. Uajt E. (1989) Uchenie i principy zhizni adventistov sed'mogo dnya, pastorskoe bogoslovie, zhizn' i trudy [The doctrine and principles of the life of the Seventh-day Adventists, pastoral theology, life and works E. White]. Nastol'naya kniga sluzhitelya [The servant's desk book]. Moskva: Izdanie Cerkvi hristianadventistov sed'mogo dnya, (pp. 415).

6. Uajt E. (1989) Rannie proizvedeniya [Early works]. Zaokskij: Istochnik zhizni. (in Russian)

7. Douglass H. (2010) Postaniec Pana [Last dad]. Warszawa: Znaki Czasu. (in Poland)

8. Kolodnogo A., Yaroc'kogo P. (2008) Piznij protestantizm v Ukraïni, (p'yatidesyatniki, adventisti, svidki Ggovi) [Late Protestantism in Ukraine, Volume 6 (Pentecostals, Adventists, Jehovah's Witnesses)]. Istoriya religiï v Ukraïni: u 10-ti tomah [The history of religion in Ukraine: in 10 volumes]. Kiïv: Vidavec' S. Surma, (pp. 268).

9. Najt D. (2002) Znakomstvo s Elenoj Uajt [Getting to know Elena White]. Zaokskij: Istochnik zhizni. (in Russian)

10. Koziróg B. L. (1994) Conradi - misjonarz pięciu kontynentów [Conradi Missionaries of the Contignus]. Warszawa: Znaki Czasu. (in Poland)

11. Cerkva adventistiv s'omogo dnya (2010) Cerkovnoe Rukovodstvo Cerkvi Adventistov Sed'mogo dnya [The Seventh-day Adventist Church Church Authority, Zaoxi], Zaokskij: Istochnik zhizni.

12. Dederen R. (2010) Cerkov' [The Table Book of Theology]. Zaokskij: Istochnik zhizni. (in Russian) 

Izdevniecība "Baltija Publishing"

Valdeķu iela 62 - 156, Rīga, LV-1058

Iespiests tipogrāfijā SIA "Izdevniecība "Baltija Publishing"

Parakstīts iespiešanai: 2018. gada 29. Aprīlis

Tirāža 300 eks. 